DANMARKS GEOLOGISKE UNDERSØGELSE

I. RAEKKE NR. 24

Geological Survey of Denmark I. Series No. 24

\title{
Beskrivelse til
}

\section{Geologisk Kort over Færøerne}

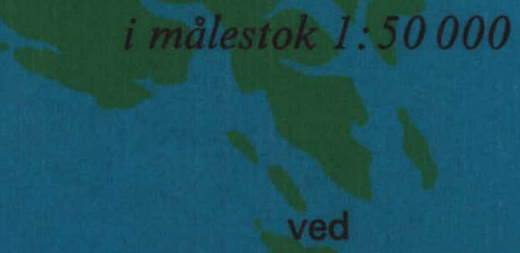

Jóannes Rasmussen og Arne Noe-Nygaard

KØBENHAVN 1969 


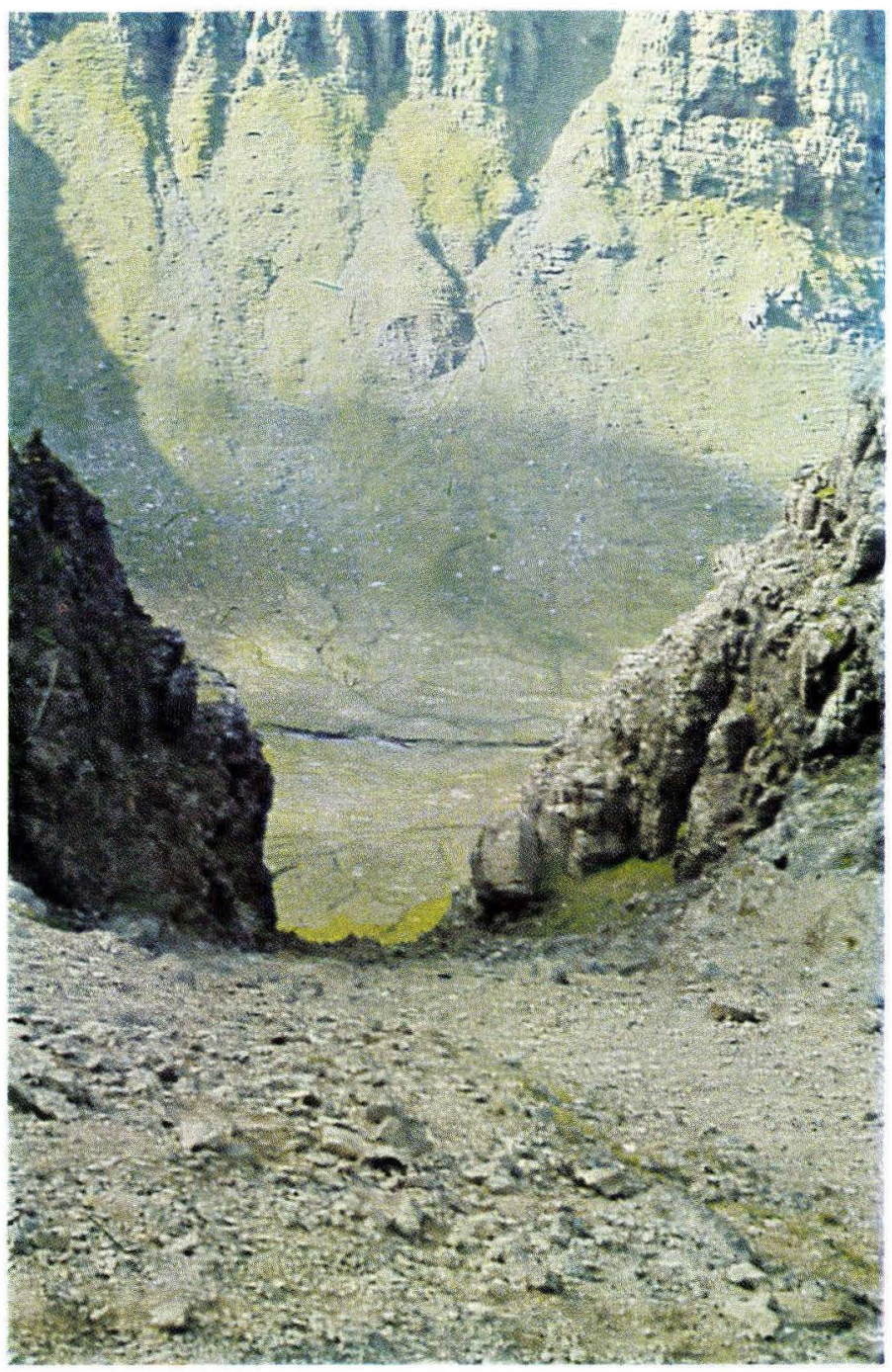


DANMARKS GEOLOGISKE UNDERSØGELSE

I. RÆKKE NR. 24

Geological Survey of Denmark I. Series No. 24

\section{Beskrivelse til \\ geologisk kort over Færøerne \\ i målestok 1:50.000 \\ ved}

Jóannes Rasmussen og Arne Noe-Nygaard

Úrtak á foroyskum

English Summary

I kommission hos

C. A. REITZELS FORLAG (JØRGEN SANDAL)

Kø BENHAVN 1969 
Forste farvebillede:

Parti fra Hvannhagi, Suðuroy.

Andet farvebillede:

Bíggjarurơ, Vágar (sml. fig. 49). 


\section{Forord}

Da Danmarks geologiske Unders $\varnothing$ gelse i 1938 iværksatte en geologisk recognoscering af Færøerne med efterfølgende systematisk kortlægning for $\varnothing \mathrm{je}$, blev dette arbejde overdraget daværende afdelingsgeolog, nuværende professor Arne Noe-Nygaard med assistance af stud. mag., nuværende afdelingsgeolog Jóannes Rasmussen. Den anden verdenskrigs udbrud i 1939 lagde sig imidlertid hindrende i vejen for de fortsatte undersøgelser, som først kunne genoptages i årene efter krigen.

I 1951 blev Jóannes Rasmussen overflyttet til Færøerne med fast station i Tórshavn (Føroya Jarðfrøðisavn), og i de følgende år blev karteringsarbejdet ledet herfra, medens laboratoriearbejdet stadig delvis foregik på Mineralogisk Museum i København.

Den endelige bearbejdelse af det indsamlede materiale og det afsluttende manuskriptarbejde er foregået som et samarbejde mellem de to forfattere, dels i Tórshavn, dels i København.

Egentlig kartering »i fladen « af plateaubasalter har næppe været praktiseret tidligere i nævneværdigt omfang; vi havde derfor meget lidt at gå efter til løsning af vor opgave på forhånd. Under arbejdet i marken kom vi hurtigt til at anse det for at være en hovedopgave at give et kortmæssigt udtryk for en holdbar stratigrafisk inddeling af den færøske lagserie. Denne inddeling opnåede vi ved at indføre lede- eller korrelationshorisonter. Disse niveauer hjalp os videre til at kunne opnå et sammenhængende hovedprofil (idealprofil) gennem hele lagserien samt et stort antal hermed korrelerede støtteeller kontrolprofiler til areal dækning af den laterale lavatypeforandring i eet og samme stratigrafiske niveau.

Korrelationshorisonterne er indtegnet på det geologiske kort, hvor de er forsynet med kote-tal. For at lette fremtidigt geologisk feltarbejde og $\mathrm{i}$ det hele taget for at gøre kortet så anvendeligt som muligt til praktiske formål, er de geologiske koter sat op i tabelform i teksten - med angivelse af lokalitet - og hvor det har været anset for formålstjenligt med en kortfattet beskrivelse af forholdene på stedet.

Det færøske plateau er gennemsat af basaltgange, og kortet rummer adskillige hundrede angivelser af disse. For at lette oversigten 
over dem, er deres data ligeledes sat op i tabellarisk form i teksten med henvisning til det gangnummer, der findes angivet på kortet, idet det i mange tilfælde - også til ekskursionsbrug - vil være $\emptyset$ skeligt til enhver tid at kunne finde frem til de observationer, der er gjort og noteret op i felten. Disse kan uden tvivl forekomme noget variable og spredte, men man må huske på, at det langtfra i alle tilfælde har været muligt at få alle $\emptyset$ nskelige data med på grund af vanskelige terrænforhold eller sparsom blotningsgrad, og at iagttagelserne ofte er gjort fra søsiden, hvilket i sig selv indebærer et betydeligt usikkerhedsmoment.

Der har under karteringsarbejdet ikke kunnet lægges speciel vægt på de tektoniske forhold; en mere indgående behandling af disse betragter vi som en kommende opgave. I den foreliggende tekst er de derfor kun ret kortfattet behandlet. De forkastninger og brudlinjer, der under markarbejdet er noteret af de enkelte medarbejdere, er løbende blevet indtegnet på kortet; siden er de blevet suppleret med de tydeligste lineamenter fra Geodætisk Instituts luftbilleder.

Heller ikke de interbasaltiske bjergarter er blevet gjort til genstand for nogen dybtgående behandling, og omtalen af dem st $\varnothing$ tter sig alene til feltiagttagelserne og den makroskopiske bedømmelse. Betegnelsen »tuf « omfatter således tuflignende bjergarter, uden at disse har været gjort til genstand for en nærmere unders $\emptyset$ gelse i laboratoriet.

De geologiske koter på kortet er alle målt med barometer (Paulin) eller med håndniveau, udgående fra en nærliggende topografisk kote, og kan derfor kun forventes at have en tilnærmet nøjagtighed.

Det vil naturligvis altid ved et karteringsarbejde være af betydning at have en fast medarbejderstab, men i ganske særlig grad gælder det, hvor det drejer sig om et plateaubasaltområde, som der her er tale om. Det har vi ifølge sagens natur ikke haft, og derfor har det ikke kunnet undgås, at der med stadig skiftende hjælpere er tilkommet en vis uensartethed i karakteristik og bedømmelse af bjergarter i marken, afhængig af de enkeltes subjektive sk $\emptyset n$. Denne uensartethed kan også gøre sig gældende ved indtegningen af det linjestykke på kortet, der markerer en gang eller et lineament; det vil dog næppe forekomme i en sådan grad, at det er virkeligt misvisende.

Bortset fra navnene på фer, bygder, fjorde og bugter er stednavnene på det geologiske kort begrænset til de navne, der direkte 
forekommer i teksten. Dog er ikke alle stednavne fra den tabellarisk opsatte tekst for korrelationshorisonter og gange medtaget; her må vi henvise til det topografiske kort i 1 : 20.000. Af praktiske grunde har vi også foretrukket at anvende de stednavneformer, som findes på dette topografiske kort, selvom de i mange tilfælde ikke stemmer overens med de nu autoriserede former. Undtagelsesvis er der dog ikke fuld overensstemmelse mellem stednavneformerne på kortet og i teksten, idet visse former på kortet vil virke unaturlige i daglig tale og i skrevet tekst, f. eks. vil Sunnbøur således findes i teksten som Sunnba eller Sumba, Hvalbøur som Hvalba og Froðbøur som Froðba. Bogstavet $\varnothing$ findes i stednavnene på det geologiske kort som ö, idet denne tidligere skriveform konsekvent er anvendt på det geodætiske kort 1:20.000.

Arbejdet i marken er gennem årene blevet udført med hjælp af efternævnte sommerassistenter: Viggo Münther, Eva la Cour, Andr. Højgaard, Asger Berthelsen, Harry Micheelsen, Bent Kraul Jensen, Erik Rasmussen, Jóhs. Jóhansen, Ib Marcussen, Sólbjørn Jacobsen, J. Mich. Matras, Jørgen Jensen, P. Milan Petersen, K. J. Damsholt, Rolf Guttesen samt midlertidigt engageret arbejdshjælp på Fær$\varnothing$ erne. De fleste af deltagerne har deltaget en enkelt sommer eller to, Jóhs. Jóhansen og Andr. Højgaard dog flere; Højgaard, der har holdt længst ud, har dels deltaget i karteringsarbejdet og dels i laboratoriearbejdet i Tórshavn med det forberedende tegnearbejde, af hvilken grund vi udover at udtale vor tak til de mange ovenfor nævnte $\varnothing$ nsker at bringe ham en særlig tak.

Vi skylder tillige efternæunte tak for deres hjælp. Ragna Larsen har tegnet kort, kurver og diagrammer, Gunni J $\varnothing$ rgensen skitser i naturen og tegninger af mikroskopiske snit, Rolf Guttesen har gennemlæst kort og tekst og udskrevet stednavne og fru A. Panning og fru Ingrid Lassen har bistået med manuskript- og korrekturlæsning.

Vi retter tak til Dansk-Færøsk Kulturfond for bidrag til trykningen af kortet; og en speciel tak $\varnothing$ nsker vi at fremføre til Færøernes Landsstyre for værdifuld støtte og $\varnothing$ konomisk bidrag til arbejdets fremkomst.

JóANNES RASMUSSEN, Tórshavn
ARne NoE-NyGAARD,

København 


\section{Indholdsfor tegnelse}

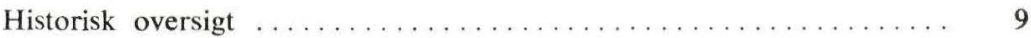

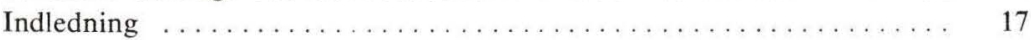

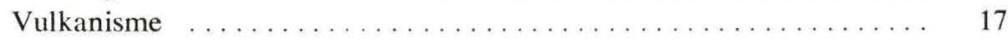

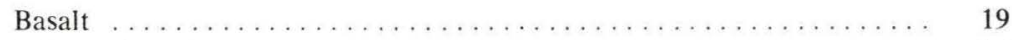

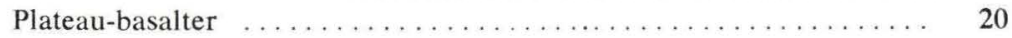

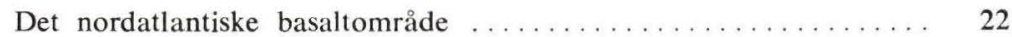

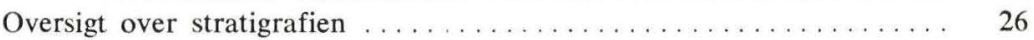

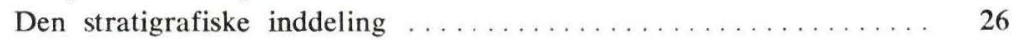

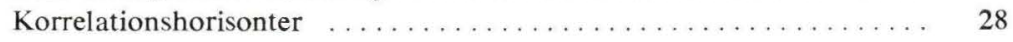

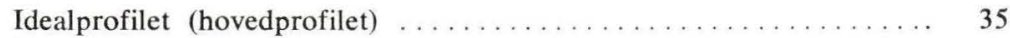

Profiler .................................... 71

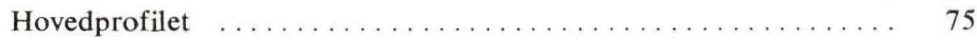

Kemiske analyser af hovedprofilets bjergarter .......... 81

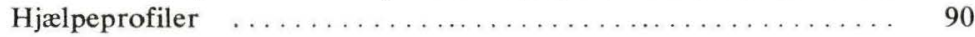

Nederste basaltserie . . . . . . . . . . . . . . . . . . . . . . . 114

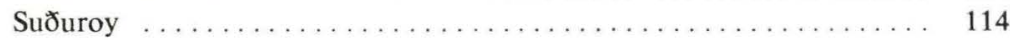

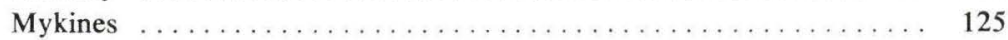

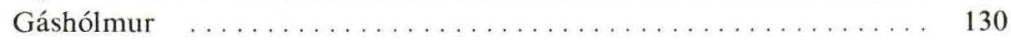

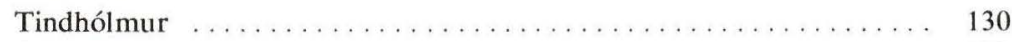

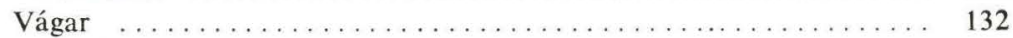

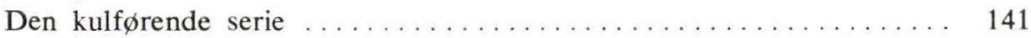

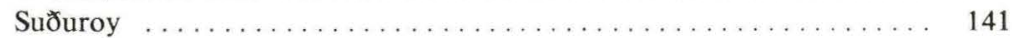

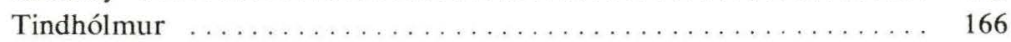

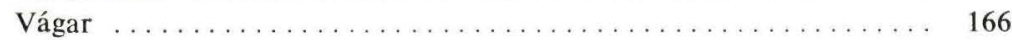

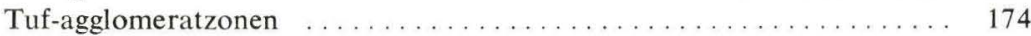

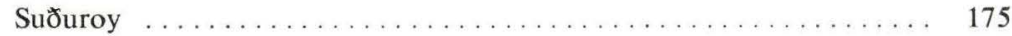

Tindhólmur og Vágar . . . . . . . . . . . . . . . . . . . 182

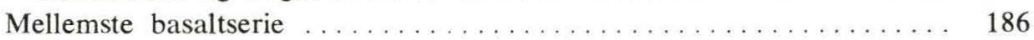

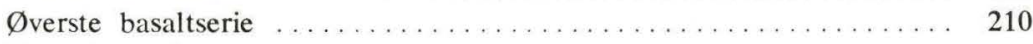

Extrusiv vulkanisme ............................ 228

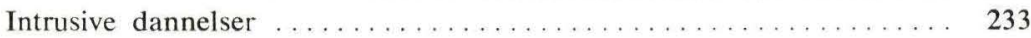

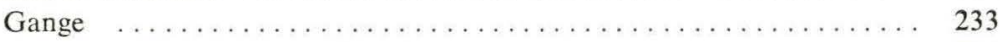

Uregelmæssige intrusive dannelser .................... 294

Sưuroy . . . . . . . . . . . . . . . . . . . . . . . . . . . . 294

Tindhólmur og Vágar . . . . . . . . . . . . . . . . . . . . 299

Sills ................................... 303

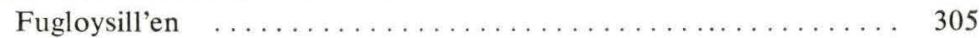

Svínoysill'en ............................ 307

Den store Eysturoysill ...................... 307

Den store Streymoysill ....................... 313

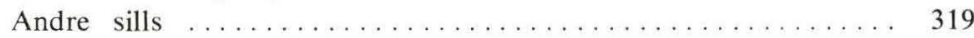

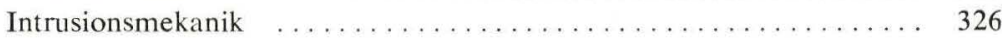


Lamelzoner, gjógv'er og forkastninger . . . . . . . . . . . . . . 329

Lamelzoner . . . . . . . . . . . . . . . . . . . . . . . . . . . . . . . . . 329

Gjógv'er .............................. 329

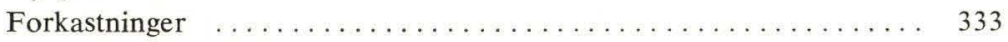

Træk af den tektoniske udvikling og geofysiske målinger ........ 335

Træk af den tektoniske udvikling ................. 335

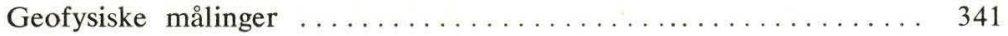

Anvendte bjergarter $\operatorname{og}$ mineraler .................... 343

Urtak á føroyskum . . . . . . . . . . . . . . . . . . . . . . 346

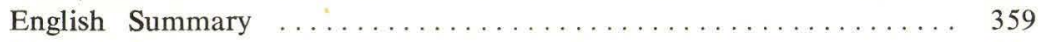

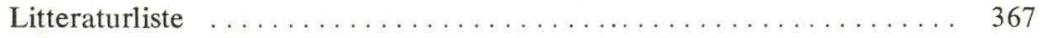




\section{Historisk oversigt}

I det følgende skal der gives en kortfattet oversigt over Færøernes geologiske udforskning. De talrige unders $\emptyset$ gelser af kulforekomsterne vil ikke blive medtaget her, da de er omtalt under den kulførende serie (s. 167); rent mineralogiske arbejder vil heller ikke blive omtalt. En samlet oversigt over den geologiske litteratur indtil 1946, også omfattende forfattere, der ikke ses selv at have besøgt øerne, findes i Medd. fra Dansk Geol. Forening (RASMussen 1946).

Såvel i ældre arkivalier som i den trykte litteratur om Færøerne finder vi spredte oplysninger om stenarter, erts og kul helt tilbage til det 17. århundrede. Meddelelser om egentlige geologiske iagttagelser eller beskrivelser af geologiske fænomener dukker dog først op henimod slutningen af det 18. århundrede.

LUCAS JACOBS $\varnothing$ N DeBES, der var præst og rektor på Færøerne fra 1651 til 1675, nævner i sin bog »Færoæ et Færoa Reserata « (1673) kullene på Suðuroy, muligheden for at finde kobber- og jernerts på Færøerne samt tilstedeværelsen af enkelte mineraler. Spredte oplysninger i hans bog, som f. eks. om havbrændingen, der er i stand til at flytte store klippeblokke, og om stenenes magnetiske egenskaber, er af mere almen end af speciel geologisk interesse.

En for sin tid mere udførlig beskrivelse af de færøske basalter finder vi hos C. L. U. von BorN i hans 3 småafhandlinger 》Om Basalt-Bierge på Færøerne« $(1792,1793,1797)$. Kaptajn Born var kommandant paa Færøerne fra 1781 til 1796; han havde et indgående kendskab til øerne fra sine mange opmålingsrejser i embeds medfør. De nævnte afhandlinger, der er skrevet i fortsættelse af hinanden i brevform til etatsråd Tyge Rothe, er publiceret $\mathrm{i} \gg$ Skrivter af Naturhistorieselskabet «. I sin første afhandling oplyser Born, at Færøerne består af basalter, og han antager, at øerne har været sammenhængende og senere er adskilt, formentlig ved jordskælv. Han omtaler søjlebasalterne, basalt »buer « ved Froðba og desuden »lodrette «, »kantede« basalter på Eysturoy (den store Eysturoysill). Desuden nævner han kort gjógv'erne. I sin anden afhandling besvarer Born 12 spørgsmål angående de færøske basalter, stillet af Tyge Rothe. Han kommer her bl. a. nærmere ind på gjógv'ernes natur, han 
påpeger deres retlinjede forløb og gør opmærksom på de i gjógv'erne forekommende $\gg$ Vægge og Vægstykker af sammensatte christalliserte Basalter « (gange). Han antager, at Færøerne er af vulkansk oprindelse, men tilføjer dog senere »at Basalterne kunde såvel skylde Vulkan, som Neptun, deres Oprindelse «. I sin sidste afhandling giver Born bl. a. en nærmere beskrivelse med ledsagende tegninger af » $\mathrm{Ba}-$ saltstøtter « (sills) på Eysturoy og Streymoy.

I sin bog »Fors $\varnothing \mathrm{g}$ til en Beskrivelse over Færøerne « (1800) ber $\varnothing-$ rer J $\varnothing$ RGEN LANDT de almindelige geologiske forhold i kapitlet $\gg \mathrm{Om}$ Bjergene «. Jørgen Landt var præst på Færøerne fra 1791 til 1798. Under sit 7-årige ophold foretog han, for at opfylde et løfte til Naturhistorieselskabet i København, talrige indsamlingsrejser og gjorde optegnelser om øernes fysiske og $\varnothing$ konomiske beskaffenhed. I Bjergene « refererer han til kapt. Born, og kapitlet er for en væsentlig del af samme indhold som kapt. Borns afhandlinger. Landt påviser, at laghældningen på Suðuroy og Sandoy er NØ, på Streymoy og Eysturoy $S \varnothing$. På de nordlige $\varnothing$ er og på Vágar forekommer lagene ham at være mere vandrette, og nord for Vestmanna mener han, at laghældningen er NV. Foruden de almindelige geologiske forhold omtaler Landt »Steenkul-Bruddet «, »Jordarterne «, » Leerarterne «, » Sandarterne $\ll$ og $\gg$ Steenarterne $\ll$.

Såvel i Borns som i Landts meditationer over basalternes og fjeldenes oprindelse, om de er dannet »ved vulkanske Explosioner « eller » ved Bundfældning under Havet «, sporer vi dønningerne fra den stående diskussion mellem neptunister og plutonister.

De første rent faglige skrifter om Færøernes geologi skyldes de to britiske geologer Sir George Steuart Mackenzie og Thomas Allan, som sammen besøgte Færøerne i 1812. Formålet med deres rejse var at drage sammenligninger mellem de geologiske forhold på Færøerne og på Island, som Sir George Mackenzie havde besøgt i 1810. Mackenzie refererer i sin afhandling »An Account of some geological Facts observed in the Faroe Islands « (1813) til Landt og beskæftiger sig derefter med basaltlagenes slagge- og »ropy-lava«overflader, og han slutter udfra disse, at den færøske lagserie er dannet ved submarin vulkanisme. Han nævner, at laghældningen er $4^{\circ}-5^{\circ}$, men tilføjer, at han på Mykines har iagttaget betydelig større hældning. Han omtaler gjógv'erne og mener, at deres oprindelse skyldes, at de vandretliggende basaltsøjler (gangene) bliver skyllet væk af rindende vand. Ligeledes er han tilbøjelig til at mene, at фerne er blevet adskilt ved destruktion af store gange, efter at landet er 
hævet over havoverfladen. Mackenzie omtaler, foruden basalt»trap«lagene, de mellemlejrede tuflag og hæfter sig særligt ved en tufforekomst på Tindhólmur (tuf-agglomeratzonen) og en ved Dalsnípa på Streymoy (agglomeratudfyldning i en vent).

Allan beskæftiger sig i sin afhandling »An Account of the Mineralogy of the Faroe Islands (1813) særlig med øernes mineraler. I en geologisk efterskrift fremsætter han dog sine egne spredte geologiske iagttagelser. Disse stemmer i det store og hele med Mackenzies også med hensyn til фernes vulkanske oprindelse, men Allan er dog betænkelig ved at dele Mackenzies opfattelse med hensyn til submarin eruption. Allan giver en ret udf $\varnothing r l i g$ beskrivelse af gangene; bemærkelsesværdige er hans iagttagelser af skurestriber, bl. a. hans bemærkning »the rock appears to have been worn down by the friction of heavy bodies « pa et tidspunkt, hvor istidsteorien endnu ikke var almindelig anerkendt.

I sommeren 1821 foretog J. G. Forchhammer en rejse til Færфerne ledsaget af den britiske videnskabsmand SIR Walther C. Trevelyan. Opholdet på Færøerne strakte sig over tidsrummet fra 6. juni til 16. oktober, og i løbet af denne tid bes $\varnothing$ gte Forchhammer snart sagt alle фerne, både de større og de mindre. De geologiske resultater af hans rejse er offentliggjort $\mathrm{i}$ afhandlingen $\gg \mathrm{Om} \mathrm{Fær-}$ фernes geognostiske Beskaffenhed « (1824); desuden indeholder hans dagbog » Rejse til Færøerne « talrige iagttagelser af geologisk interesse. Forchhammers $\varnothing$ vrige publikationer er for en væsentlig del af mineralogisk art. Forchhammer er den første, der fors $\emptyset$ ger at foretage en stratigrafisk inddeling af den færøske lagserie. Han inddeler bjergarterne i 4 grupper, som svarer til lagseriens aldersmæssige rækkefølge: 1. Trap uden glasagtig feldspat, 2. kulformationen, 3. porfyritiske dannelser og 4. den uregelmæssige trap. Forchhammer angiver laghældningen på de forskellige фer. Han antyder, at basaltlagene har en bassinformet lejring, hvor den endnu eksisterende del af Færøerne muligvis udgør halvdelen af det fuldkomne bassin. Forchhammers afhandling er ledsaget af et lille geologisk oversigtskort.

Da den franske korvet $\gg$ Recherche « i 1839 gjorde et kort ophold på Færøerne, besøgte den franske geolog og ingeniør JosePH DuROCHER den sydlige del af Streymoy, den $\varnothing$ stlige del af Sandoy og Nólsoy. Resultaterne af hans unders $\varnothing$ gelser indeholdes i beretningen fra »Recherche «s rejse »Voyages en Scandinavie, en Laponie, en Spitzberg et aux Feröe« (1840) og omfatter et geologisk afsnit 
»Description Geologique « og et petrografisk-mineralogisk afsnit »Recherches sur les Roches et les Mineraux des Iles Feröe«.

Det særlige formål med Amund Hellands og James Geikies rejse til Færøerne i 1879 var at udforske фernes glaciale geologi, som hidtil havde været så godt som ukendt. Thomas Allan havde i 1812 bemærket skuringsmærker og sammenlignet dem med lignende fænomener i Skotland, og RoBerT CHAMBERs (1855), der i »Tracings of Iceland and the Faröe Islands « beskriver skurestriber bl. a. fra Eiði og Vestmanna, forestiller sig, at фerne har ligget under et stort arktisk isdække; men bortset fra dette findes der i litteraturen intet om Færøernes glaciation. Udfra skurestribernes retning og den fuldstændige mangel på fremmede blokke slutter Helland og Geikie, at фerne har haft en egen lokal nedisning. Hellands og Geikies unders $\varnothing$ gelser strakte sig imidlertid langt videre end til deres egentlige formål, og såvel Hellands »Om Færøernes Geologi« (1880) som Geikies »On the Geology of the Færöe Islands « (1880) har lige til de senere år været de eneste fuldstændige fremstillinger af фernes geologi, som man har kunnet bygge videre på. Både Helland og Geikie bibeholder Forchhammers stratigrafiske og petrografiske inddeling af lagserien og bjergarterne. Helland indfører dog betegnelserne anamesitbænke i stedet for trap uden glasagtig feldspat, doleritbænke i stedet for porfyritiske dannelser og basaltgange i stedet for den uregelmæssige trap, og han sætter ikke grænsen mellem anamesitbænke og doleritbænke ved kulformationen, men ca. $100 \mathrm{~m}$ over denne. Såvel Hellands som Geikies afhandlinger er ledsaget af Forchhammers oversigtskort suppleret med deres egne iagttagelser.

R. BRÉON's afhandling »Notes pour servir a l'étude de la geologie de l'Islande et des Iles Faeroe « (1884) indeholder kun et mindre afsnit om de geologiske forhold på Færøerne. Bréon ses kun at have aflagt фerne et ganske kort besøg på gennemrejse til Island i juni 1880 .

Godt en halv snes år senere, i årene 1892, 1894 og 1895 besøger Karl Grossmann og i 1894 Joseph Lomas Færøerne, ligeledes i glaciologisk $\varnothing$ jemed. Den væsentlige del af deres resultater, som er nedlagt $\mathrm{i}$ afhandlingerne »Geology of the Faroe Islands « (1895) og $\gg$ Glaciated Valleys in the Faroes (1899) af J. Lomas samt "On the glaciation of the Faroe Islands (1895) af Grossmann og Lomas, er i det store og hele samstemmende med Helland og Geikie. Som led i sine undersøgelser af det nordatlantiske basaltområde 
foretog ARchibald Geikie to på hinanden følgende år rejser til Færøerne med dampyachten »Aster«. Hans iagttagelser af lavastrømme, vents og sills findes som sammenlignings- og illustrationsmateriale $\mathrm{i}$ » The Tertiary Basalt-plateaux of North-Western Europe « (1896).

Bortset fra forskellige diskussionsindlæg om landbro-hypotesen, bl. a. C. H. Ostenfeld (1901), H. G. Simmons (1905) og Тн. Thoroddsen $(1901,1906,1906)$ finder vi i de to første decennier af det 20. århundrede kun mindre arbejder vedrørende Færфernes geologi af forskere, der ved egne iagttagelser har gjort sig bekendt med forholdene på stedet, således HaNs v. Post, der i »Om Färöarnas uppkomst « 1902 mener, at basalten under kulformationen er af submarin oprindelse, F. CORNU og R. GöRGEY »Zur Geologie der Färöer« (1908), Hans RudolPHI »Die Färöer « (1913), »Die Seen der Färöer« (1914/15) og »Die Gjoven der Färöer« (1930). F. CORNU og R. GörGEY, hvis særlige formål med rejsen var af mineralogisk art, besøgte фerne i 1907, og H. Rudolphi, hvis afhandlinger er af geografisk-geologisk indhold, var på Færøerne i 1912 og 1913.

Fra O. B. BøGGILDs rejser i 1903 og 1904 foreligger der de to oversigter »Geologiske Forhold « (1922) og »Oversigt over Danmarks Geologi (Færøerne) « (1928).

De to eneste på Færøerne og på færøsk publicerede artikler om Færøernes geologi er på dette tidspunkt R. Rasmussens »Um upphav Føroya lands« (1921), der dels bygger på ældre forfattere som Forchhammer, Helland og Geikie, dels på egne iagttagelser og »Um skógir í Føroyum « (1925) af samme forfatter.

En opmåling af et profil gennem en tørvemose i Tórshavn foretaget af R. Rasmussen og senere publiceret af Kn. Jessen og R. Rasmussen i fællesskab »Et Profil gennem en Tørvemose på FærØerne (1922) gav anledning til, at KN. Jessen og Hilmar Ødum tog til Færøerne i 1922 for at unders $\varnothing$ ge de fær $\varnothing$ ske tørvemosers geologi. Resultaterne er delvis publiceret i Kn. Jessens »De fær$\emptyset$ ske Mosers Stratigrafi« (1923). Fra Ødums hånd foreligger et par mindre artikler bl. a. »Træk af Færøernes Morfologi« (1923).

Fra 1930 foreligger en lille publikation »Aimantation permanente de basaltes des Feroe « af Raymond Chevallier. Prøvematerialet er indsamlet på Suđuroy (Tvøroyri, Froðba) under anl $ø b$ af Færøerne med »Pourquoi-pas« i 1925.

Martin A. Peacock, der gjorde et kort ophold på Færøerne i 
sommeren 1925, beskæftiger sig i sin afhandling » Recent Lines of Fracture in the Faroes ...« (1928) hovedsagelig med gjógv'ernes og fjordsystemets alder og oprindelse, og han påviser en tektonisk baggrund for deres dannelse. Han mener således, at gjógv'ernes dannelse kan føres tilbage til postglaciale brudlinjer (master joints), og at fjordsystemet er dannet ved lignende processer som gjógv'erne af et ældre, pliocænt brudlinjesystem.

J. B. Simpsons besøg på Færøerne i 1920erne var af ganske kort varighed og begrænsede sig til фerne Streymoy og Suðuroy. Indholdet $\mathrm{i}$ »Notes on the Geology of the Faröe Islands « (1928) er for den væsentlige del petrografisk.

Det mest omfattende geologiske arbejde i første halvdel af dette århundrede er Frederick Walker og Charles F. Davidsons »A Contribution to the Geology of the Faeroes « (1936). Walker og Davidson besøgte øerne sammen i 1936. De omtaler i afhandlingen de sedimentære bjergarter, vulkanske vents, sills og gange, men hovedvægten er dog lagt på de petrografiske forhold. De fors $\varnothing$ ger en inddeling af de færøske basalter i 5 typer: 1. Trangisvaag type, 2. Torshavn type, 3. Velbestad type, 4. Froðbiarkambur type, 5. Ejde type.

Da den af Danmarks Geologiske Unders $\varnothing$ Gelse foranstaltede systematiske kartering af Færøerne blev afbrudt af krigen 1939-45 allerede inden den rigtig var kommet i gang, foreligger der fra dette tidsrum kun mindre meddelelser fra det indledende recognosceringsstadium.

Nedenfor følger en supplerende liste til den forannævnte oversigt over den geologiske litteratur indtil 1946 omfattende arbejder efter 1946.

Abrahamsen, N., 1964: se Saxov, S.

Abrahamsen, N., 1966: se Saxov, S.

Abrahamsen, N., 1967: Some paleomagnetic investigations in the Faroe Islands. - Medd. Dansk Geol. Foren. Bd. 17, s. 371-384.

Dahl, Sv. \& Rasmussen, J., 1953: Nólsoyarfundurin. - Fróðskaparrit, 2. bd. Tórshavn.

Dahl, Sv. \& Rasmussen, J., 1956: Víkingaaldargrøv í Tjørnuvík. - Fróðskaparrit, 5. bd. Tórshavn.

Harvey, John, 1965: The topography of the South-Western Faroe Channel. Deep-Sea Research. Vol. 12. p. 121-127.

Koch, B. Eske, 1963: se Rasmussen, J.

Lass, G. M., 1965: se Lewis, C. A. 
Laufeld, O., 1965: Sporomorphs in Tertiary coal from the Faeroe Islands. Geol. Fören. Förhan. Stockholm. Vol. 87. p. 231-238.

Lewis, C. A. \& Lass, G. M., 1965: The drift terraces of Slaettaratindur the Faeroes. - Geogr. Jour. London. p. 247-253.

Lewis, C. A., 1966: The nivational landforms and the reconstructed snowline of Slaettaratindur, Faeroe Islands. - Biul. Peryglacjalny. No. 15. Lodz. p. 293-302.

Noe-Nygaard, A., 1946: Some petrogenetic aspects of the northern basalt plateaux. - Medd. Dansk Geol. Foren. Bd. 11. s. 55-65.

Noe-Nygaard, A., 1949: Samples of volcanic rocks from the sea bottom between the Faroes and Iceland. - Glaciers and Climates. Geogr. Ann. Stockholm. p. 348-356.

Noe-Nygaard, A., 1951: Den geologiske kortlægning af Færøerne 1938-50. Medd. Dansk Geol. Foren. Bd. 12. s. 163.

Noe-Nygaard, A. \& Rasmussen, J., 1957: The making of the basalt plateau of the Faröes. - Int. Geol. Congr. 20. Ses. Secc. I., 2. T. p. 399-407.

Noe-Nygaard, A., 1958: se Rasmussen, J.

Noe-Nygaard, A. \& Rasmussen, J., 1958: Geologi. - Færøerne Bd. 1. s. 21. København.

Noe-Nygaard, A., 1962: The geology of the Faroes. - Quart. Jour. Geol. Soc. London. Vol. 118. p. 375-383.

Noe-Nygaard, A.,1966: The invisible part of the Faroes. - Medd. Dansk Geol. Foren. Bd. 16. s. 191-195.

Noe-Nygaard, A., 1966: Chemical composition of tholeiitic basalts from the Wyville Thompson Ridge belt. - Nature. Vol. 212. London. p. 272-273.

Noe-Nygaard, A., 1966: se Rasmussen, J.

Noe-Nygaard, A., 1967: Variation in titania and alumina content through a three kilometres thick basaltic lava pile in the Faroes. - Medd. Dansk Geol. Foren. Bd. 17. s. 125-128.

Noe-Nygaard, A. \& Rasmussen, J., 1968: Petrology of a 3000 metre sequence of basaltic lavas in the Faeroe IsIands. - Lithos. Vol. 1. Oslo. p. 286-304.

Pálmason, G., 1965: Seismic refraction measurements of the basalt lavas of the Faeroe Islands. - Tectonophysics. Vol. 2. Amsterdam. p. 475-482.

Persson, Chr., 1968: Försök till tefrokronologisk datering i fyra färöiska myrar. - Geol. Fören. Förhandl. Stockholm. Vol. 90. p. 241-266.

Rasmussen, J., 1946: Oversigt over den geologiske litteratur vedrørende Færфerne. - Medd. Dansk Geol. Foren. Bd. 11. s. 66-96.

Rasmussen, J., 1947: Nyere iagttagelser over laghældningen og de kulførende dannelser på Mykines (Færøerne). - Medd. Dansk Geol. Foren. Bd. 11. s. 179-188.

Rasmussen, J., 1948: Nøkur orð̋ um fornan gróður í Føroyum. - Varđin Bd. 26. Tórshavn, s. 109-116.

Rasmussen, J., 1951: Transgressive sillintrusioner i Fær $\varnothing$ plateauet. - Medd. Dansk Geol. Foren. Bd. 12. s. 164.

Rasmussen, J., 1951: Nyere synspunkter vedrørende de færøske kullags stratigrafi. - Medd. Dansk Geol. Foren. Bd. 12. s. 164.

Rasmussen, J., 1951: Kol i Mykinesi og í Vágum. - Varđin Bd. 29. Tórshavn, s. 97-116. 
Rasmussen, J., 1952: Um Kolarannsóknir í Hvalba. - Fróđskaparrit, Bd. 1. Tórshavn. s. 131-147.

Rasmussen, J., 1952: Bidrag til forståelse af den færøske lagseries opbygning. - Medd. Dansk Geol. Foren. Bd. 12. s. 275-283.

Rasmussen, J., 1953: se Dahl, Sv.

Rasmussen, J., 1955: Nøkur orð um gjáir í Føroyum - uppruna teirra og aldur. - Fróðskaparrit. Bd. 4. Tórshavn. s. 108-124.

Rasmussen, J., 1956: Iles Faeröe. - Lexique Stratigraphique International. Vol. 1. fasc. Ic. Paris. s. 13-17.

Rasmussen, J., 1956: se Dahl, Sv.

Rasmussen, J., 1957: se Noe-Nygaard, A.

Rasmussen, J., 1957: Yvirlit yvir innskotin grótsløg í Føroyum. - Fróðskaparrit. Bd. 6. Tórshavn. s. 61-96.

Rasmussen, J., 1958: Kolanøgdin í Suðuroy. - Fróðskaparrit. Bd. 7. Tórshavn. s. $102-144$.

Rasmussen, J. \& Noe-Nygaard, A., 1958: Føroyar I. Jarðfrøði. København. Rasmussen, J., 1958: se Noe-Nygaard, A.

Rasmussen, J., 1959: De færøske kulforekomster og deres kortlægning. Medd. Dansk Geol. Foren. Bd. 14. s. 184-188.

Rasmussen, J., 1962: Um goshálsar i Føroyum. - Fróðskaparrit. Bd. 11, Tórshavn.

Rasmussen, J., 1963: Recent studies on the geology of the Faeroes. - North Atlantic biota and their history. - A. Löve \& D. Löve (eds.) Pergamon Press, Oxford. p. 29-44.

Rasmussen, J. \& Koch, B. Eske, 1963: Fossil Metasequoia from Mikines, Faroe Islands. - Fróðskaparrit. Bd. 12. Tórshavn. s. 83-96.

Rasmussen, J. \& Noe-Nygaard, A., 1966: New data on the geological age of the Faeroes. - Nature. Vol. 209. London. p. 1229-1230.

Rasmussen, J., 1968: se Noe-Nygaard, A.

Rasmussen, J., 1968: Den geologiske opbygning og landskabet. - Trap Danmark (Færøerne). s. 5-23.

Saxov, S. \& Abrahamsen, N., 1964: A note on some gravity and density measurings in the Faroe Islands. - Boll. di geofis Teor. ed Appl. Vol. 4. p. 249-260.

Saxov, S. \& Abrahamsen, N., 1966: Some geophysical investigations in the Faroe Islands. - Zeitschrift für Geophysik. Würzburg.

Schou, Axel, 1949: Landskabsformerne. (i: Niels Nielsen: Atlas over Danmark. I). København. s. 111-120.

Schou, Axel, 1968: Landskabsudviklingen. Trap Danmark (Færöerne). s. 23-28.

Thomsen, Bruno, 1952: En tungmineralanalyse af nogle sandprøver fra de nordlige Færøer. - Medd. Dansk Geol. Foren. Bd. 12. s. 205-210.

Bibliografien afsluttet 1. september 1968. 


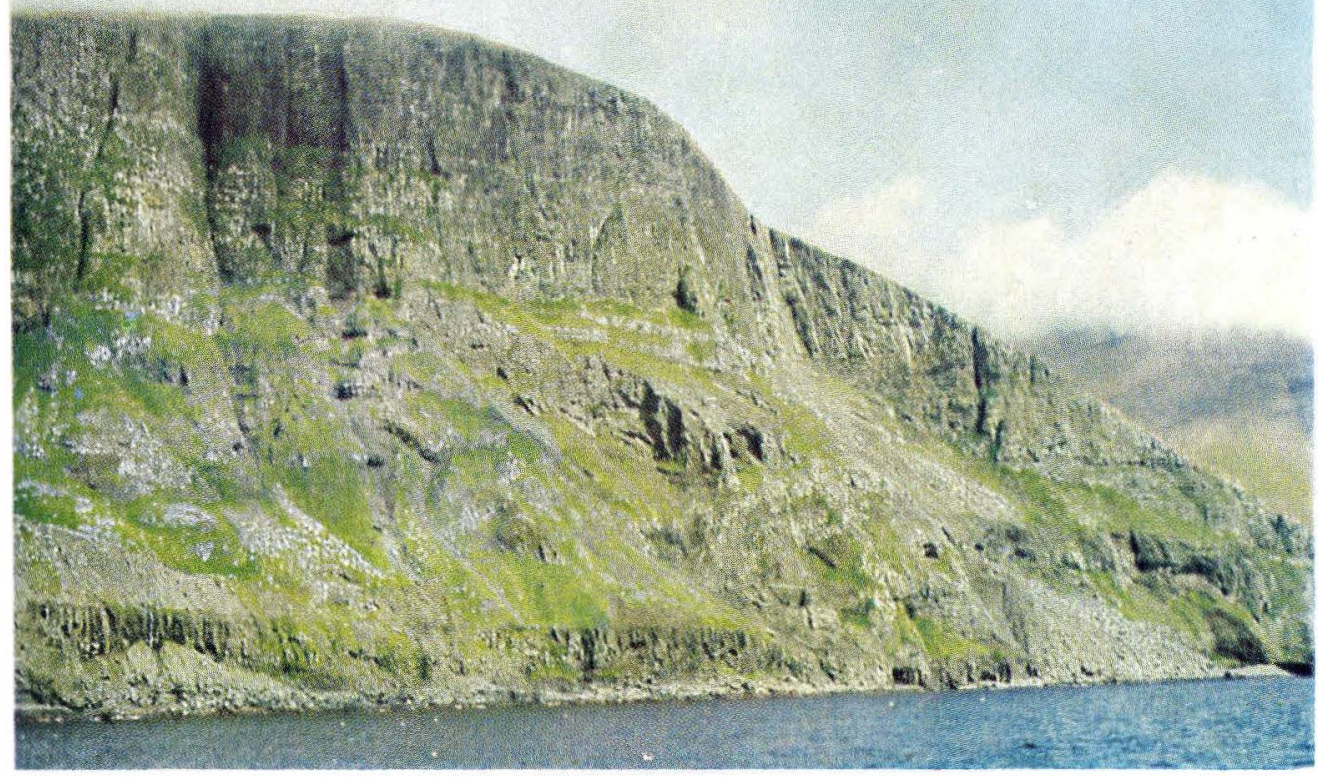




\section{Indledning}

Med det færdige geologiske kort over Færøernes prækvartære dannelser foran os skal vi i lag med at skildre den geologiske udvikling af et rent vulkansk område, kort og godt ét, der så at sige i alle måder adskiller sig fra dem, DANMARKs GEOLOGISKE UNDERS $\varnothing$ GELSE plejer at belyse med sine kort.

Vi vil derfor indlede vor kortbladsbeskrivelse med nogle korte afsnit, der omtaler 1. vulkanismen som fænomen, 2. den vigtigste blandt lavabjergarterne: basalt, 3. den særlige udformning basalten har i plateaubasaltområder og endelig 4 . Færøernes placering i det nordatlantiske basaltområde.

\section{Vulkanisme}

Taget $\mathrm{i}$ sin helhed finder vulkansk aktivitet ganske overvejende afl $\varnothing \mathrm{b}$ gennem spalter i jordskorpen. På Island er lange retlinjede og undertiden endnu gabende vulkanspalter umiddelbart synlige (f. eks. Eldgjá) i den ungvulkanske zone, der med et knækket forløb gennemskærer dette land fra sydvesthalvøen til midt på nordkysten. I Andesbjergene, i Mellemamerika, på Aleuterne, i Japan og på Sundaøerne (Java) røber bueformede spalter i jordskorpen deres tilstedeværelse derved, at de mange enkelte vulkaner, der findes her i stort mål, ligger på linje som guirlander eller perlerækker.

Hvor to systemer af spalter skærer hinanden, er der særlig mulighed for, at større enkeltliggende vulkaner kan opstå. Når man undertiden får det indtryk, at den kraftigste vulkanisme er den, der udløses gennem enkeltvulkaner (punktvulkaner), skyldes det nok, at nogle af de bedst kendte vulkaner, som Vesuv, Etna og Fujiiyama, er af denne type.

Afgørende for dannelsen af en vulkan, uanset om dens tilførselskanal har form som en spalte eller en cylinder, er tilstedeværelsen af et magma. Herved forstår vi en silikatsmeltemasse, som indeholder opløste vulkanske gasser.

Et basaltisk magma, som det, der i sin tid har dannet Færøerne, kan indeholde strøkorn af plagioklas og/eller olivin og/eller pyroxen, 
såfremt disse mineralers størkningstemperatur ligger inden for magmaets smelteinterval. Dersom temperaturen har været så høj, at hele magmaet var flydende og således uden strøkorn, taler vi om et overophedet magma; strøkornsfri basaltlavaer er fremgået ved størkning af sådanne overophedede magmaer.

Få steder er basaltisk vulkanisme af $\mathrm{i}$ dag blevet studeret mere indgående end på Hawaii, hvor et moderne geologisk-geofysisk laboratorium har været $\mathrm{i}$ arbejde gennem en række år. Vi skal nedenfor kort referere nogle af de her gjorte observationer, der har betydning for vor vurdering af de vulkanske begivenheder på Fær$\emptyset$ erne.

På Hawaii har man kunnet iagttage, at der flyder lava ovenud af en spalte i samme $\varnothing$ jeblik, den dannes, på jordoverfladen. Det må betyde, at spalten åbner sig nedefra og åbenbart $\emptyset$ jeblikkelig er blevet fyldt med magma, med andre ord at de kræfter, der har ført til dannelsen af spalten, først må have angrebet undersiden af jordskorpen; revnedannelsen er indledt subkrustalt.

Den subkrustale zone, »Jordens Kappe «, opf $\varnothing$ rer sig i seismisk henseende normalt som et fast stof, men til trods for dette, finder der temperaturbevægelser og masseforflytninger sted i den, som på visse særlig udsatte steder kan blive stærke nok til at fremkalde kraftige spændinger i den overliggende jordskorpe; til sidst vil dennes brudgrænse kunne blive overskredet med det resultat, at en gennemslående spalte dannes.

Når en spalte begynder at åbne sig, medfører det en lokal trykaflastning, som bevirker, at det indtil da faste materiale i kappen, hvis sammensætning antages at være granatperidotitisk*, delvis begynder at smelte; man taler ved denne proces om, at hypomagma afgiver pyromagma. Den magmamængde, der på denne måde bliver flydende, det andrager kun en mindre, letsmeltelig del af hypomagmaet, bevæger sig nu mod spalteområdet med lavere tryk. Hvor stor en procent, denne »selektive opsmeltning « andrager, bestemmes af trykket og temperaturen.

Pyromagmaet, der fra siderne trænger ind i spalten, holder straks fra begyndelsen denne åben og vil derefter på grund af det hydrostatiske tryk, det udøver, kunne udvide den. Pyromagmaet indeholder opløste gasser; disse er oprindelig dannet under stort tryk dybt i Jorden, men vil ved trykaflastningen udvide sig og begynde

* Granatperidotit er en feldspatfri, granatholdig ultrabasisk bjergart. 
at danne bobler i magmaet. Når boblerne bevæger sig opad, udsættes de for lavere tryk og bliver derved større; dette betyder igen, at magmaet bliver lettere og lettere på vejen opad mod overfladen. Til sidst kan gasboblerne blive så mange og store, at pyromagmaet »skummer op « og endelig i form af en lavastrøm flyder ovenud af spalten. Magmaet i spalten står under tryk og virker som en kile, der selv presser opad med »æggen «.

Efter seismiske målinger og direkte iagttagelser på Hawaii at dømme, varer oprivningen af en spalte og den dermed sammenhængende pyromagmaopstigning til jordoverfladen oftest nogle uger, under alle omstændigheder flere dage.

Det er på Hawaii ved flere lejligheder lykkedes, ved hjælp af lokalseismografer, at bestemme dybden af et vulkanudbruds indledningsfase til omkring $30 \mathrm{~km}$. Da man i samme område har bestemt jordskorpens tykkelse til at være mellem 5 og $10 \mathrm{~km}$, kan man med sikkerhed slutte, at basaltmagmaet dannes under denne.

\section{Basalt}

Basalt er den mest udbredte lavabjergart i dag og har været det så langt tilbage i tiden, som vi har geologiske oplysninger fra. En basalt-lava er dannet ved størkning af et basaltisk magma, der som nævnt er udskilt i den ydre del af Jordens Kappe.

Man har konstateret, at der i oceanisk miljø findes to hovedtyper af basaltiske magmaer, én der er forholdsvis rig på kiselsyre og fattig på alkalimetaller - der er i basalten først og fremmest tale om natrium - og én, der har et ringere kiselsyreindhold, men et større alkalimetalindhold. Disse to basaltmagma-typer kaldes i dag oftest henholdsvis den tholeiitiske og den alkali-olivinbasaltiske, eller blot den alkali-basaltiske.

Nye eksperimentelle unders $\varnothing$ gelser, som især er udført af T. H. Green, D. H. Green og A. E. Ringwood (1966) synes at godtgøre, at de to basaltiske magmatyper i virkeligheden kan stamme fra ét og samme udgangsmateriale, fordi sammensætningen af den smeltemasse, der først dannes, bestemmes af det herskende tryk på dannelsesstedet, og dermed forandrer sin sammensætning med dette. Et basaltisk pyromagmas kemiske sammensætning må derfor i virkeligheden afhænge af, i hvilken dybde dets segregation er foregået. 
Efter det vi nu ved, segregeres det tholeiitiske basaltmagma i dybder omkring $15 \mathrm{~km}$ eller mindre, medens det alkalibasaltiske dannes i dybder på mellem $35 \mathrm{og} 60 \mathrm{~km}$. I intervallet mellem 15 og $35 \mathrm{~km}$ dannes basaltiske magmaer, der er kendetegnet ved et højt aluminiumindhold (bl. a. de såkaldte høj-aluminium basalter). Basaltlavaer af denne type forekommer f. eks. udbredt i Japan; de indtager med hensyn til kiselsyre- og alkalimetalindhold en mellemstilling mellem de to hovedtyper.

Den almindelige erfaring går ud på, at et bestemt vulkansk område $\mathrm{i}$ regelen tilhører enten den tholeiitiske eller den alkali-basaltiske magmatype, selvom blandede provinser kendes; Fær $\varnothing$ erne tilhører den tholeiitiske.

Basaltlava består helt overvejende $(80-90 \%)$ af mineralerne plagioklas og pyroxen, hertil kommer magnetit og/eller ilmenit samt en ringe mængde apatit. Adskillige basalter indeholder desuden olivin, oftest som strøkorn. Plagioklasens sammensætning varierer fra bytownit til labrador, labrador overvejer; pyroxenerne kan være orthopyroxener og/eller clinopyroxener; for Færøernes vedkommende drejer det sig om clinopyroxener, der dels er til stede som augit, dels som den jernrigere pigeonit. Basaltiske lavabjergarter indeholder i regelen nogle procent ikke-krystalliseret materiale $\mathrm{i}$ form af glas.

\section{Plateau-basalter}

Lavadækker sammensættes af lavastrømme, der har meget stor udbredelse i fladen, og meget tyder på, at de overvejende er bragt frem gennem spalteformede udbrudssteder. Mere end 2 millioner kvadratkilometer af Jordens overflade består i dag af udbrudsmaterialer af denne art. Lavadække-områder sammensættes af mange efter hinanden frembragte lavastrømme, der tilsammen opbygger en serie af lavabænke, som i lodret snit lader sig se som omtrent planparallelle lag.

Erosionens indflydelse på et sådant område vil meget let føre til, at de enkelte lavastrømme kommer til at stå frem som stejlvægge (»hamre«), medens deres oprindelige, overfladenære del, der gerne er porøs og slagget og derfor meget uholdbar, antager karakteren af en skråflade (en »li«) ved foden af den næste bænk. Den typiske terrænform med en trinvis opbygning af stejlvæggene i lavadækkeområderne har allerede fra gammel tid givet ophav til betegnelsen »trap«. 
De enkelte lavabænke varierer gerne mellem knap 10 og godt 20 meter i tykkelse, og kun meget sjældent når de over 50 meter. Hovedbjergarten er altid basalt.

Lavadækkerne ligger oftest vandret eller med ganske svag hældning over meget store strækninger, de vil derfor ofte landskabeligt komme til at fremtræde som plateauer, hvorfor også Gregory indførte betegnelsen plateau-basalter for dem.

Senere har Tyrrell kaldt dem flod-basalter, dels fordi lavastrømmene har været særdeles letbevægelige, altså næsten flodagtigt tyndtflydende, så de kunne nå at dække store arealer i et jævntykt lag, dels fordi der foruden plateauerne også findes store strækninger, der oprindelig har haft bassinform, som nu er fyldt ud med serier af lavastrømme.

I vor beskrivelse af Færøerne vil vi dog anvende den ældre betegnelse, plateau-basalt, dels fordi Færøerne selv har karakteren af et plateau, der ganske vist er stærkt sønderskåret af erosionen, men også fordi de tilsvarende dannelser i Øst- og Vestisland samt i Østog Vestgrønland har en ganske lignende landskabelig udformning.

Det almindelige er, at de egentlige lavadækkeområder er bygget op af mange, efter hinanden f $\varnothing$ lgende lavastr $\varnothing m m e$, men man kender enkelte tilfælde, hvor det er muligt at studere én enkelt strøm for sig; vi skal nævne et sådant eksempel fra William Cañon i Arizona. Her ligger en lavastrøm ganske fladt hen over en sandog grusaflejring; den er $22 \mathrm{~km}$ lang og $14 \mathrm{~km}$ bred og er trængt frem gennem en $120 \mathrm{~m}$ bred spalte, lokalt når den en tykkelse på $240 \mathrm{~m}$ ! Dens dimensioner overstiger nok dem, vi skal møde på Færøerne; men nogle af disse kan alligevel tåle at sammenlignes med den.

De plateau-basalter, der endnu i dag dækker store områder af Jorden, stammer næsten alle fra Jura-, Kridt- eller Tertiær-perioderne.

Det siger næsten sig selv, at de store endnu velbevarede, sammenhængende plateau-basaltområder må stamme fra de yngste jordperioder, men der kan ikke være tvivl om, at mindre partier af samme art, stammende fra endnu ældre perioder, skal opfattes som levn af fortidige basalt-plateauer, der engang havde langt st $\varnothing$ rre areal-udbredelse; selv fra Prækambrium kender vi tydelige rester af basalt-plateauer.

Fra adskillige steder i verden er unge plateau-basalter i litteraturen opgivet til at kunne blive ca. $3 \mathrm{~km}$ tykke; både fra Øst- 
grønland (WAGER 1934) og fra Vestgrønland (NOE-NyGAARD 1942) opgives endnu st $\varnothing$ rre tykkelser, helt op til 8-10 km.

Blandt de unge plateau-basalter er Stormberg basaltlavaerne i Sydafrika og Deccan trap i Forindien betydningsfulde, men særlig omtale værd er de yngste plateau-basalter fra Columbia plateauet i U.S.A., fordi de bedst belyser karakteren af de tyndtflydende plateau-basalter og en af de måder, de optræder på i terrænet.

Columbia området var oprindelig en bjergegn, men i Miocæntiden blev den fyldt ud med, og udjævnet af store lavastrømme af basalt. De oprindelige bjerge findes nu som små øer og halvøer, der rager op over en ensartet lavaslette. Columbia River og Snake River har derefter udskåret kløfter i denne, og derved bliver vi nu i stand til at studere næsten hele lavaserien i dybe, flodnedskårne kløfter og cañons. Plateauet opbygges af et stort antal tynde lavastrømme med slaggede overflader, nu og da dækket af tynde askelag og af gamle søaflejringer. Den vulkanske aktivitet har fortsat næsten til nutiden, især i Idaho og Oregon, hvor der endnu findes små, velbevarede slaggekegler og kratere samt lavastrømme med friske, slaggestrøede overflader. Den gennemsnitlige tykkelse af hele lavafølgen er ca. $1 \mathrm{~km}$, men lokalt er der målt tykkelser på $17-1800 \mathrm{~m}$. Af næsten samme alder er store plateau-basaltområder i Syrien og Arabien.

Det nordatlantiske basaltområde

(= den brito-arktiske basaltprovins)

Gennem to-tre slægtled har geologerne været på det rene med, at der lå et plateau-basalt område i Nordatlanten, eller rettere sagt stykker af det. Det har længe været opfattelsen, at disse af havet adskilte dele udgjorde brudstykker, som engang tilbage i tiden havde været sammenhængende land af vulkansk oprindelse, samt at dette land senere for st $\varnothing$ rstedelen var sunket i havet.

Det længst i sydøst forekommende tegn på en geologisk set ung basalt-vulkanisme finder vi i form af et antal små vulkanruiner langs den fenno-skandiske randzone i Skåne, samt i form af vulkanske askelag i moleret fra Eocæn i Danmark (BöGGILD 1918) måske hidrørende fra vulkanisme i Norske Rende i Skagerak. (Sml. bl. a. NoE-NYGAARD 1967).

Egentlige plateaubasalter forekommer i Nordirland (Antrim), samtidige vulkanruiner og plutoniske centre forekommer især langs 


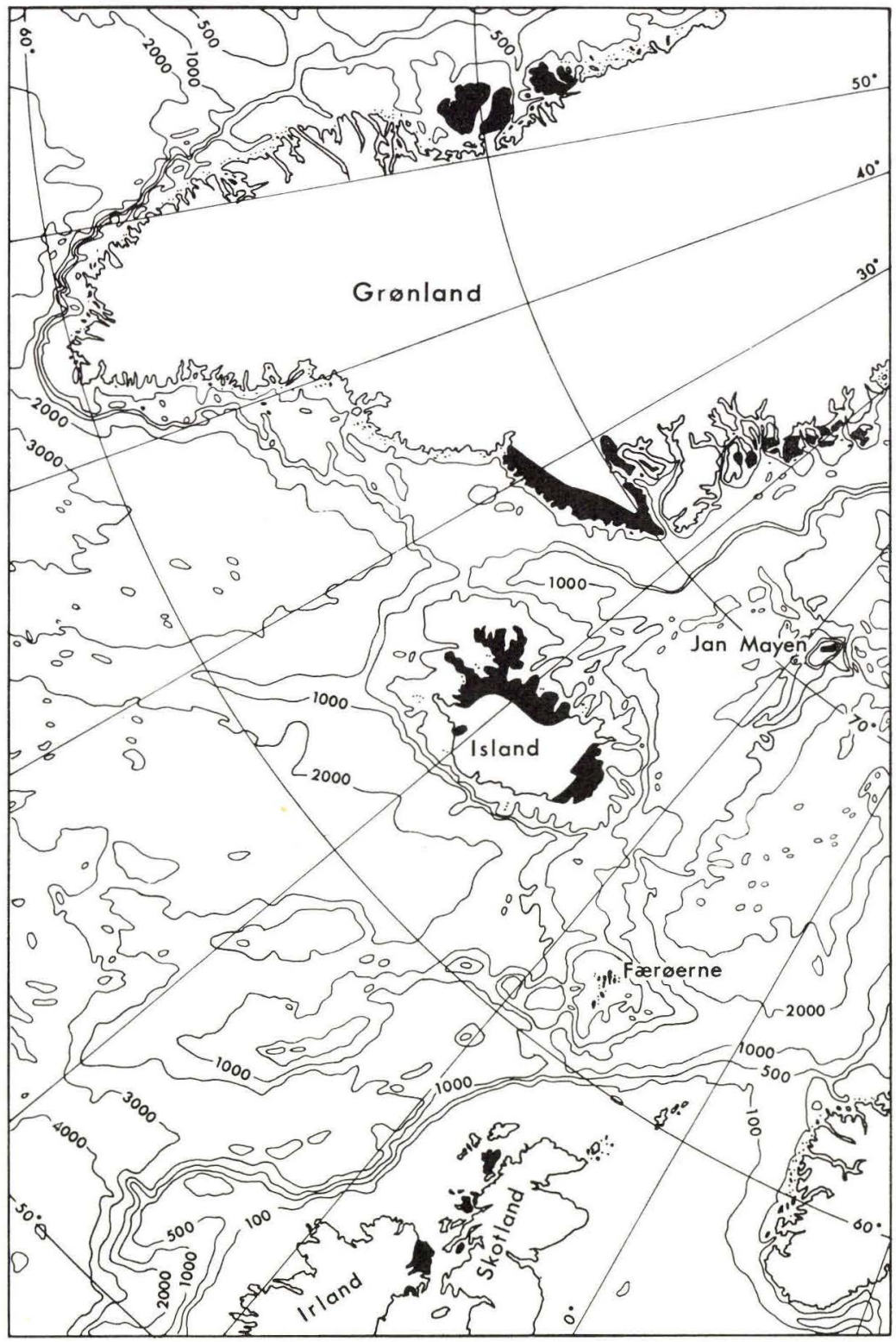

Fig. 1. Det nordatlantiske basaltområde. Dybdeangivelse i m.

Norđuratlantska basaltøkið (dýpi î $m$ ).

The North Atlantic basalt province. (Depths in $\mathrm{m}$ ). 
Skotlands vestkyst og på фerne udenfor. Går vi herfra mod nordvest, følger Færøerne og Island og videre det centrale Øst- og Vestgrønland med en udløber til Baffinland. Bevæger vi os fra Island mod nord, møder vi Jan Mayen, og går vi endelig mod nordøst, kommer vi til Spitzbergen. Disse områder er helt eller delvis præget af basaltisk vulkanisme, mest udpræget gælder det Færøerne og Island.

Om basaltvulkanismen i Vestgrønland ved vi, at den blev indledt i Danien, fortsatte gennem Paleocæn og tog fart i Eocæn; på Island ser det efter nye aldersbestemmelser ud til, at den vulkanske aktivitet først er indledt en del senere, nemlig i Miocæn. På Spitzbergen kendes der vulkansk aktivitet allerede fra Jura, men endnu til efter Istiden har aktiv vulkanisme holdt sig. Såvel Jan Mayen som Island har som bekendt den dag i dag levende vulkanvirksomhed.

Alderen af den vulkanske virksomhed på Færøerne må sandsynligvis sættes til ældre Tertiær (Paleocæn-Eocæn), herpå tyder de paleobotaniske vidnesbyrd (RASMUSSEN og KocH 1963 og LAUFELD 1965). Radioaktive aldersbestemmelser (K/Ar), foretaget af The Geochron Laboratories, Cambridge, Massachusetts (RASMUSSEN og Noe-NygaARd 1966) viser efter senere målinger at dømme for $h \varnothing j$ alder. De sidste tal angiver 50-60 mill. år (TARLING, D. H. and N. H. Gale, 1968).

Om Færøernes oprindelse har vi dannet os den opfattelse, at de udg $\varnothing \mathrm{r}$ et højtliggende parti af Wyville-Thompson ryggen, der danner et lavvandet strøg gående fra sydøst mod nordvest gennem Nordatlanten formentlig i hovedsagen bygget op gennem vulkansk spaltevirksomhed. Det er sandsynligt, at der lokalt og gennem visse tidsrum på den samme ryg har eksisteret landområder i form af фer, måske som фrækker på lignende måde som Hawaiiørækken, der i dag rager op som de højeste dele af en submarin vulkansk ryg i det nordlige Stillehav, også opbygget over et NV-S $\varnothing$ strygende system af spalter; men det betyder ikke, at sådanne фer eller $\emptyset$ grupper beh $\emptyset$ ver at have eksisteret på én og samme tid.

Når man betragter søkortet, er det et iøjnefaldende træk, at Wyville-Thompson ryggens længdeudstrækning S $\emptyset-\mathrm{NV}$ genspejles i det færøske fjordsystems retning og i den retning, de druknede fjorde udfor Sydøstisland har. Dette strukturtræk har, som det senere vil fremgå, haft betydelig indflydelse på de geologiske hændelser på Færøerne.

Efter tyngdemålinger og bundprøver at dømme, består Wyville- 
Thompson ryggen af basalt, det samme er tilfældet med Færøbanke og med Rockall- og Porcupinebankerne vest for Skotland.

Dersom de nys nævnte, i dag adskilte plateaubasaltområder, der tilsammen dækker ca. $250000 \mathrm{~km}^{2}$, en gang i tiden skulle have udgjort én samlet landmasse, måtte denne have været på 2-3 mill. $\mathrm{km}^{2}$.

Færøerne af i dag udgør kun resten af et engang større landområde. 


\section{Oversigt over stratigrafien}

\section{Den stratigrafiske inddeling}

Medens de første skrifter om Færøernes geologi kun er rent beskrivende og ikke kan siges at have haft væsentlig betydning for senere geologisk forskning, fors $\emptyset$ ger Forchhammer som nævnt (s. 11) at indføre en stratigrafisk inddeling af den færøske lagserie på et petrografisk grundlag.

Ved det foreliggende karteringsarbejde blev det også oprindelig fors $\varnothing$ gt at lægge et rent petrografisk synspunkt til grund for karteringen, men det viste sig hurtigt at være vanskeligt gennemførligt i enkeltheder. De karteringsmæssige vanskeligheder, man særlig stødte på, var: 1. den horisontale forandring i samme lavabænk som følge af nedsynkning af tungere mineralkorn, 2. det ofte store antal efter hinanden følgende meget tynde lavastr $\varnothing m m e$ med varierende sammensætning og 3. den ret hyppigt forekommende udtynding og overgribning af lagene, som er karakteristisk for plateaubasalter.

I stedet har vi derfor under karteringsarbejdet lagt vægt på at udtrykke den geologiske udvikling i landets opbygningshistorie, og karteringsmæssigt at afgrænse de forskellige stadier i vulkanismens forløb. Ved denne fremgangsmåde har det været muligt at opnå en stratigrafisk inddeling som vist i nedenstående rent skematiske snit gennem hele lagserien. (Fig. 2).*

Den nederste basaltserie. Vulkanismen indledes med rytmisk aktivitet gennem spalteeruptioner, hvorved der er blevet dannet en tykbænket lavaserie med en samlet mægtighed på ca. $900 \mathrm{~m}$, afbrudt af hvileperioder med aflejring af interbasaltiske tuf-lersedimenter.

Den kulfфrende serie. Et langvarigt ophold i den vulkanske aktivitet, der repræsenteres af en op til $15 \mathrm{~m}$ mægtig kulførende skiferlerserie.

* Der er ikke korrigeret for fald, + ca. $125 \mathrm{~m}$ i den mellemste basaltserie. 


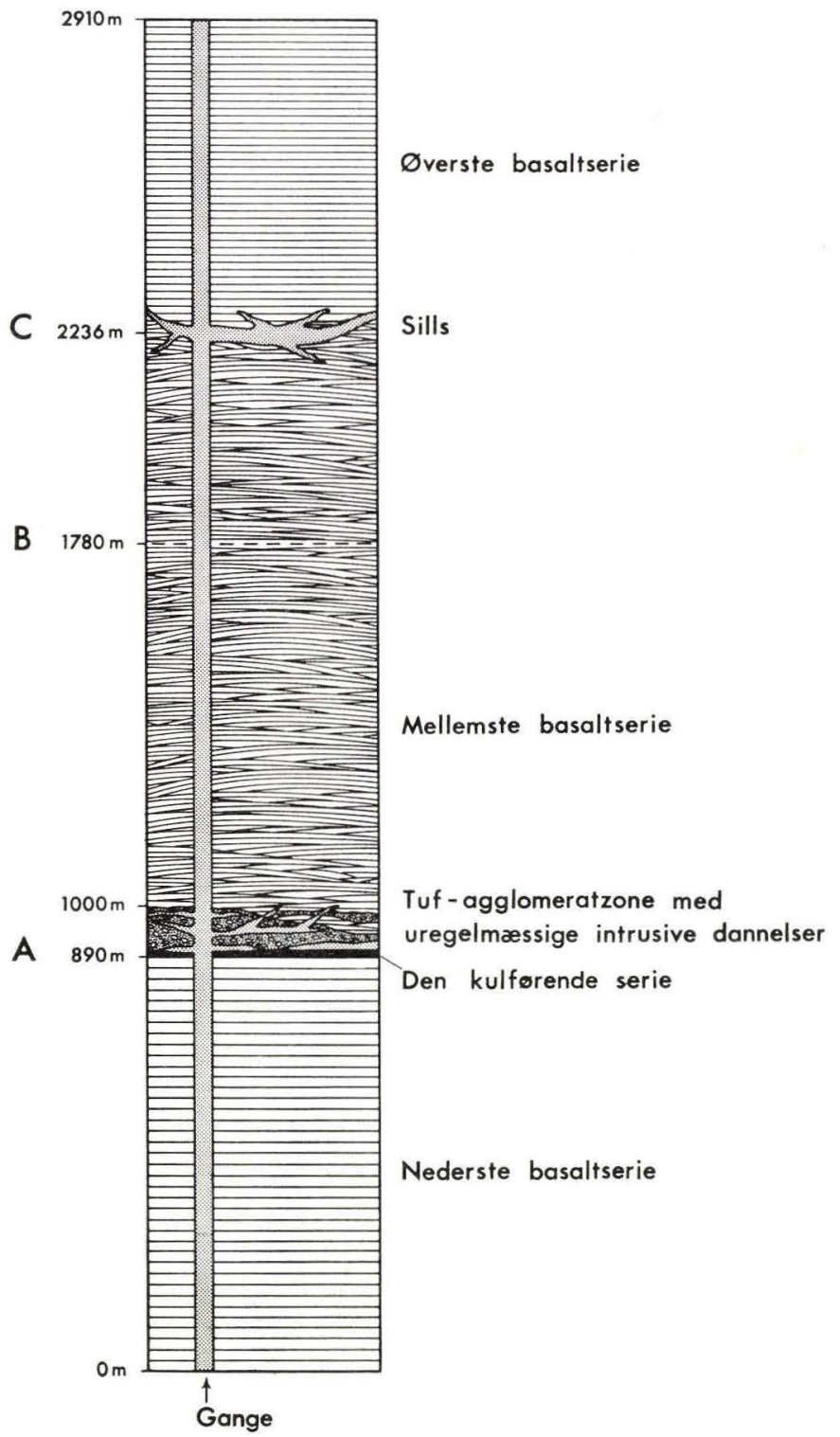

Fig. 2. Skematisk snit gennem den færøske lagserie.

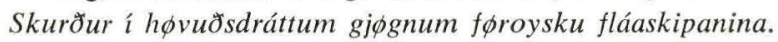
Schematic section through the lava sequence of the Faeroe Islands. 
Tuf-agglomeratzonen. Den genoptagne vulkanske aktivitet indledes med kraftig eksplosivitet næsten uden lavaproduktion. Store mængder af pyroklastisk materiale ophobes langs og i nærheden af udbrudsstederne.

Den mellemste basaltserie. Vulkanismen fortsætter umiddelbart efter med en kontinuerlig lavaproduktion fra talrige mindre udbrudssteder langs det nordvest-sydøst forløbende fjordsystem, først i tynde strømme, opad i serien med noget tiltagende mægtighed af disse. De enkelte lavastrømme adskilles almindeligvis af pore- og slaggezoner. Tuflag er ubetydelige, men er dog noget tiltagende i hyppighed opad i serien, hvis samlede mægtighed andrager ca. $1350 \mathrm{~m}$.

Den $\phi$ verste basaltserie. Efter et ophold - kendetegnet ved en mindre diskordans, et stort indhold af pyroklastisk materiale og brudstykker af basalt fra lavere niveau i de nederste lavastrømme i denne serie - indledes en ny fase i den vulkanske aktivitet, hvorunder vi får dannet den $\varnothing$ verste basaltserie med en samlet mægtighed på ca. $675 \mathrm{~m}$. Vi genfinder her den samme rytmiske aktivitet som i den nederste basaltserie. Bænktykkelsen når dog meget sjældent samme mægtighed. Ligesom i nederste basaltserie skifter lavabænkene med tuf-lersedimenter ofte indeholdende aftryk af ubestemmelige planterester.

Intrusiver udgøres af gange, uregelmæssige intrusive dannelser og sills. Disse tilhører stort set alle samme eruptionsfase. Gangene gennemsætter hele lagserien; de uregelmæssige intrusive dannelser er intruderet i den kulførende serie og i tuf-agglomeratzonen, af hvilken de stedvis udgør en væsentlig del; alle større sills ligger i grænseområdet mellem den mellemste og den $\emptyset$ verste basaltserie.

\section{Korrelationshorisonter}

For at kunne gennemføre en sikker korrelation af forskellige enkelt- eller delprofiler og en sammenstilling af disse til et idealprofil gennem hele lagserien, har det været nødvendigt at indf $\varnothing$ re begrebet korrelationslinjer, eller rettere korrelationshorisonter som faste ophængningsniveauer for profiler, der er opmålt på vilkårlige, men for profiltagning gunstige steder på de forskellige фer.

Som korrelationshorisonter er dels benyttet de stratigrafiske grænseniveauer: Nederste basaltserie - kulførende serie, A-horisonten, 


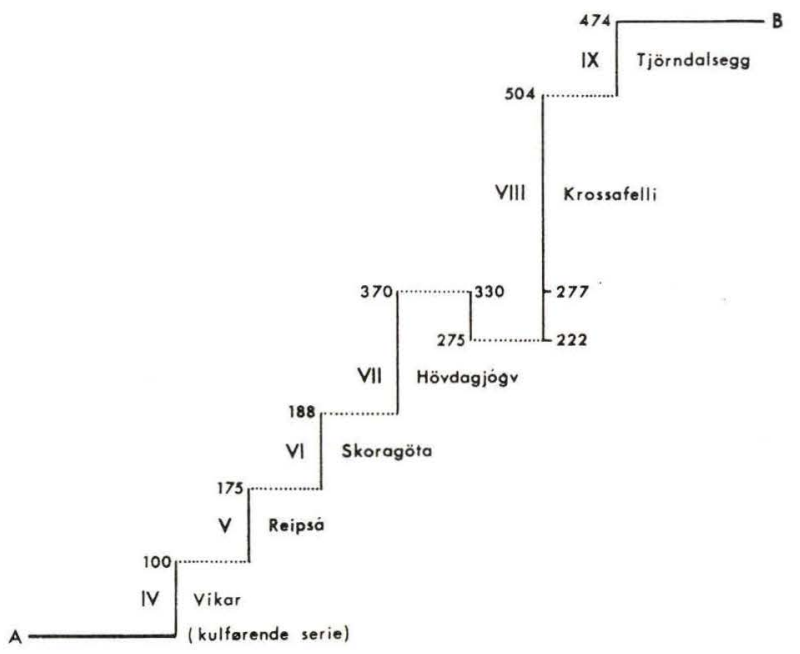

Fig. 3. Vágaprofilet (IV-IX i hoved- eller idealprofilet).

Vágaskurđurin (IV-IX í meginskurđinum).

The Vága section (IV to IX of the main profile).

(Suðuroy, Tindhólmur, Vágar), mellemste basaltserie - фverste basaltserie, C-horisonten, (Ll. Dímun, St. Dímun, Skúvoy, Sandoy, Hestur, Koltur, Streymoy, Eysturoy, Kallsoy, Kunoy, Borðoy, Viðoy) og dels en til formålet udvalgt og ligeledes på kortet indtegnet horisont indenfor den mellemste basaltserie, B-horisonten, (Vágar, Streymoy, Eysturoy). Hvor det har været ønskeligt, men ikke muligt at opnå et længere sammenhængende profil på samme sted og i samme profillinje, har det været nødvendigt at forskyde delprofiler langs lignende, ligeledes på kortet indtegnede hjælpehorisonter (f. eks. Vágaprofilet IV-IX og Sandoyprofilet 31-35), således at de enkelte delprofiler tilsammen kommer til at udgøre et lateralt forskudt, men kronologisk korrekt helprofil. (Fig. 3).

Til praktisk brug, som til beregning af strøg og fald, og i det hele taget for at kunne styre lagserien, er der med passende mellemrum indtegnet »geologiske « koter på kortet.

Nedenfor (s. 34) skal gives en kortfattet karakteristik af de omtalte horisonter, idet en nærmere beskrivelse følger under de respektive afsnit.

Her og i det følgende har vi til karakteristik af de fær $\varnothing$ ske basalter anvendt en række bjergartsbetegnelser, som først efterhånden har taget fast form. 
Generelt set lader lavaerne sig dele i følgende 3 store grupper: (Fig. 4).

1. Afyriske basalter $=$ basalter uden makroskopisk synlige str $\varnothing$ korn.

2. Porfyritiske basalter (plagioklasporfyritiske basalter) $=$ basalter med større eller mindre strøkorn af plagioklas.

3. Olivinholdige basalter $=$ basalter med tydelig olivin, helt overvejende som strøkorn.

Vi har imidlertid fundet det praktisk under arbejdets gang atter at underafdele hver af disse, især de porfyritiske, og har fortsat dermed i den efterfølgende lokalitetsbeskrivelse. Også i profilerne (s. 71) og gangskemaerne (s. 253) er disse betegnelser blevet opretholdt. Når vi således anvender udtryk som storfeldspatbasalt (eng: big feldspar basalt), storkornet feldspatbasalt, grovkornet feldspatbasalt (fær: kandisgrót) eller stjernefeldspatbasalt, småkornet feldspatbasalt, småprikket feldspatbasalt, finprikket feldspatbasalt, er disse betegnelser den enkelte medarbejders subjektive bed $\varnothing \mathrm{m}-$ melse af een bjergart med store plagioklasstrøkorn eller een med små plagioklasstrøkorn med noget forskellig udformning, der er blevet bibeholdt. Når udtrykket feldspatbasalt står alene, betegner det den almindeligste type med strøkorn af mellemstørrelse. I enkelte tilfælde er den tydeliggjorte betegnelse plagioklasporfyritisk kommet $\mathrm{i}$ anvendelse for de samme bjergarter; dette er f $\varnothing$ rst og fremmest sket, hvor bjergarter med strøkorn af forskellige mineraler (olivin henholdsvis plagioklas) veksler med hinanden i hurtig følge i et profil.

I hovedprofilerne, hvor en petrografisk og kemisk analyse er blevet gennemført, er samlebetegnelsen porfyritisk basalt anvendt for alle bjergarter, der fører strøkorn af plagioklas. I de profiler, som er mærket med arabertal, hvor feltbeskrivelsen alene eller i hovedsagen er lagt til grund, er feltnavnene brugt i beskrivelsen. Denne fremgangsmåde er ikke konsekvent, men giver til gengæld besked om fremgangsmåden ved profilets tilvejebringelse og en orienterende oplysning om forholdene i marken.

Medens prøveudtagningen i hovedprofilet først og fremmest er sket med det formål at muliggøre en petrografisk karakteristik (og kemisk analyse) af bjergarterne, har støtteprofilernes opgave dels været at belyse lagfølgen nogenlunde repræsentativt over hele det færøske område, dels den at tjene som støtte for en orientering om forholdene på stedet for eventuelle fremtidige brugere af kortet, i 


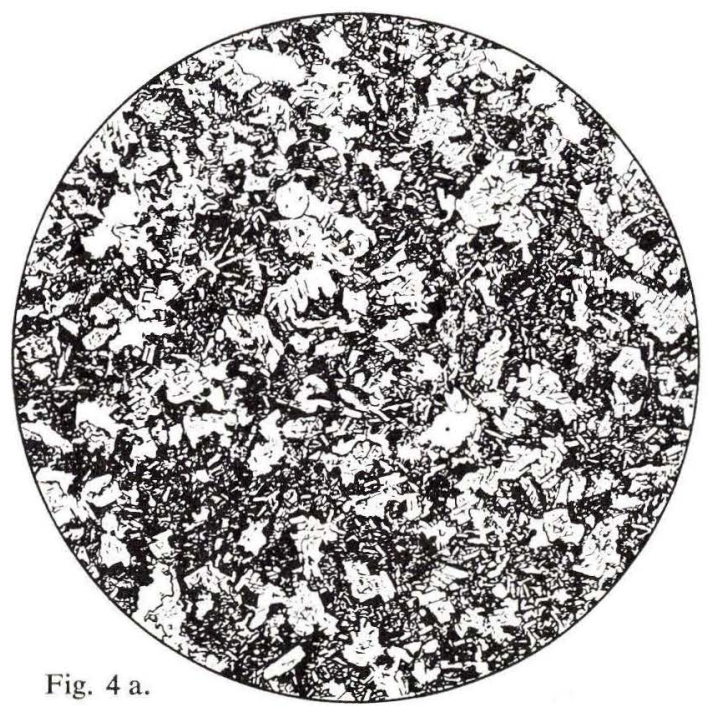

$15 \times$ forst. Strøkornsfri basalt, nederste basaltserie. Aphyric basalt, lower basalt series. $\times 15$.

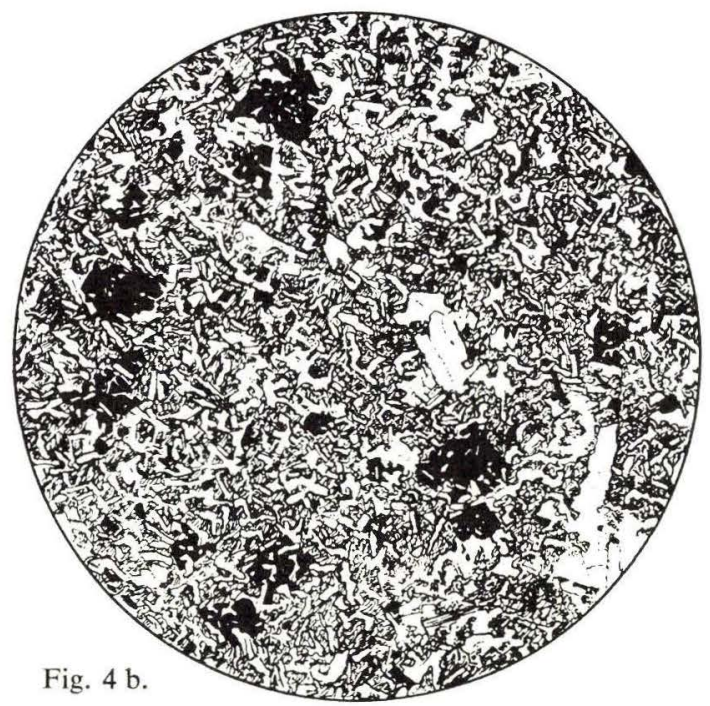

$15 \times$ Makroskopisk betragtet er basalten strøkornsfri. I tyndsnittet ses halvstrøkorn af sort malm med uregelmæssige omrids (sorte) samt enkelte halvstrøkorn af plagioklas (hvide) til højre for midten. Nederste basaltserie.

Basalt which is aphyric to the naked eye, but which in thin section is seen to contain semiphenocrysts of black ore with irregular boundaries (black) and a few semiphenocrysts of plagioclase (white, right of centre).

Lower basalt series. $\times 15$.

Sjóneykumyndir av blágrýti. 


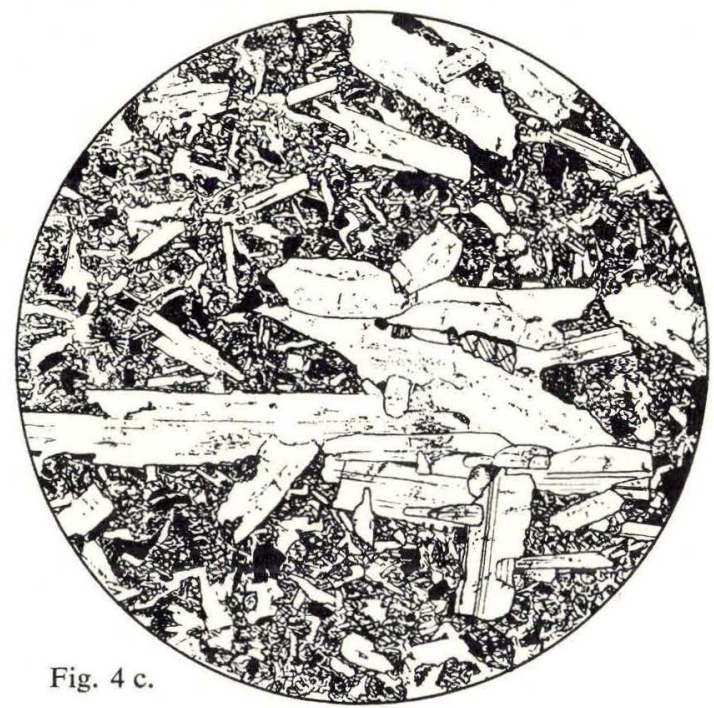

$14 \times$ forst. Plagioklasporfyritisk basalt med gruppe af plagioklasstrøkorn. Mellemste basaltserie.

Porphyritic basalt with a group of plagioclase phenocrysts. Middle basalt series. $\times 14$.

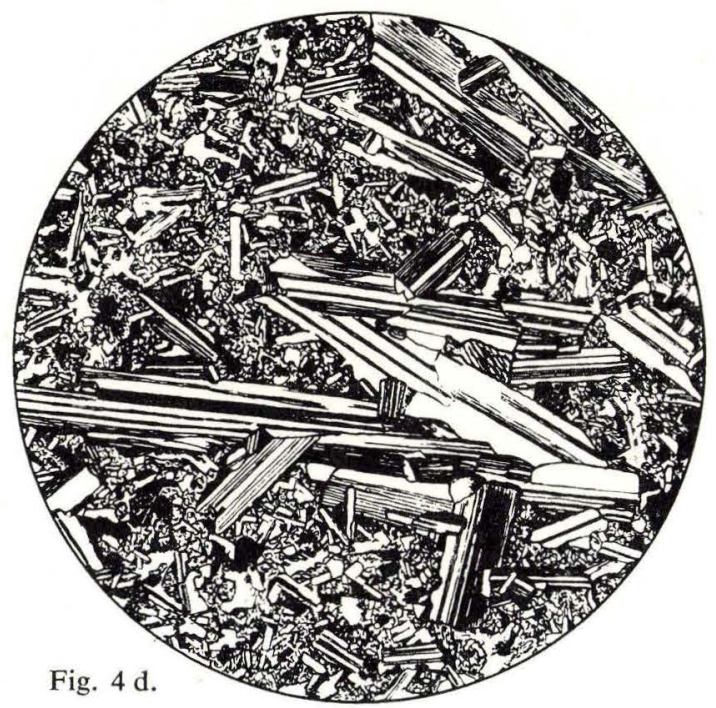

$14 \times$ forst. Samme tyndsnit betragtet med krydsede nicoller, hvorved plagioklasens tvillingstribning træder tydeligt frem. Same section with crossed nicols. $\times 14$.

Sjóneykumyndir av feldspattinnutum (plagioklas) basalti. 


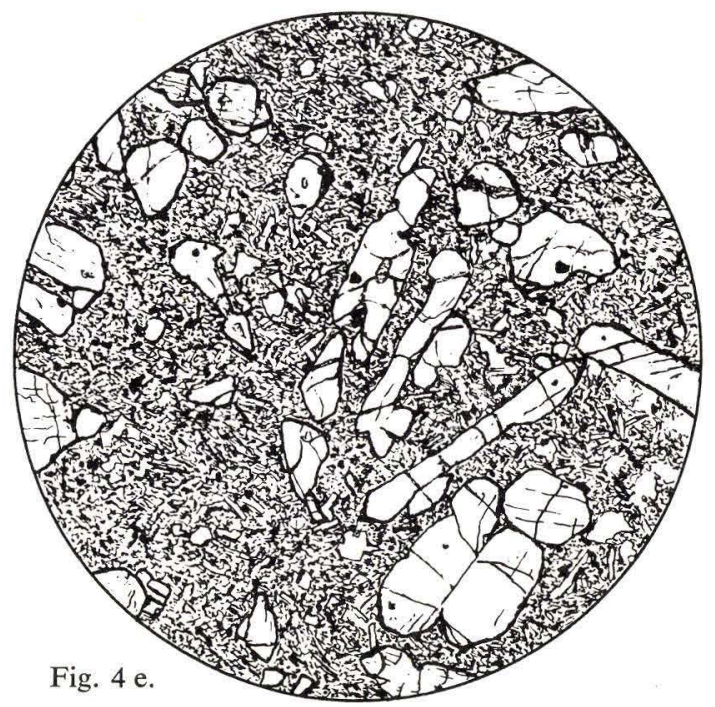

$13 \times$ forst. Olivintholeiitisk basalt med stavformede strøkorn af olivin.

"Blandede serie « ved basis af mellemste basaltserie, Vágar.

Olivine tholeiitic basalt with rod-shaped phenocrysts of olivine. From the mixed sequence at the base of the middle basalt series. Vágar. $\times 13$.

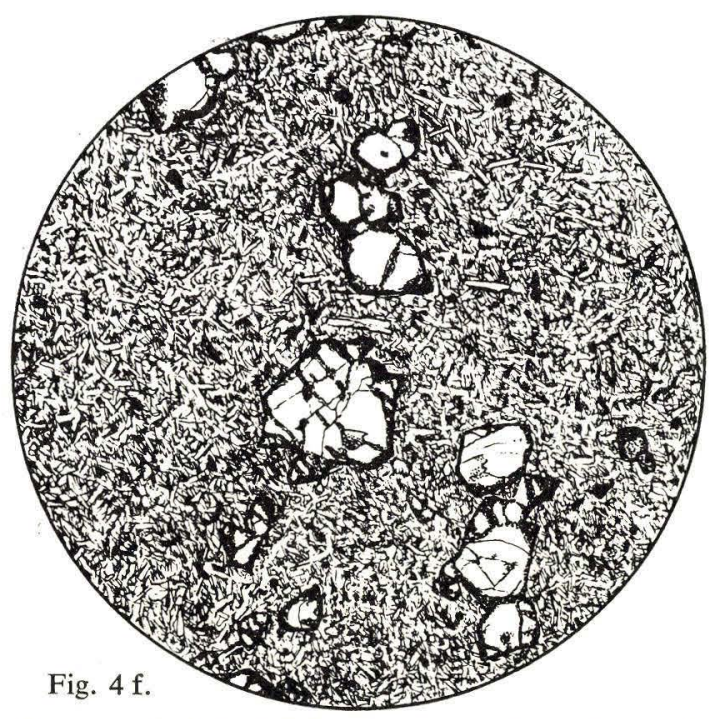

$14 \times$ forst. Olivintholeiitisk basalt med brede strøkorn af olivin.

$\emptyset$ verste basaltserie.

Olivine tholeiitic basalt with stout phenocrysts of olivine.

Upper basalt series. $\times 14$.

Sjóneykumyndir av olivinbasalti. 
lighed med beskrivelserne af forholdene ved de geologiske koter i skemaet (s. 38 til 70).

A-horisonten falder sammen med grænsen mellem den nederste basaltserie og den kulførende serie. De indmålte koter svarer til underkanten af den kulførende serie. I terrænet ses grænseområdet ved foden af en vegetationsklædt skråning mellem den landskabsform, der er karakteriseret af »brede trapper «, som hersker i den nederste basaltserie og den mere stejltstående, ofte nøgne fjeldvæg, der kendetegner overgangen til den mellemste basaltserie. Selve grænsen er næsten overalt ras- og vegetationsdækket. Naturlige blotninger ses kun i stejle fjeldvægge ud mod havet. Inde i landet kan grænsen dog erkendes i miner, hvor der foregår kulbrydning og i enkelte endnu åbne indslag, hvor den er blevet blottet ved søgning efter kul. (S. 38).

$B$-horisonten danner ikke nogen naturlig grænsehorisont. Den er udelukkende indført i korrelations $\varnothing$ jemed og svarer til underkanten af en til formålet udvalgt karakteristisk række basaltbænke med stor areal udbredelse og en vis »trap «dannende natur.

Den typiske lagfølge er over det meste af udbredelsesområdet således. Liggende: storkornet feldspatbasalt, ofte, men ikke altid dækket af en rød tuf. Horisontbasalten: Et varierende antal af ret tynde strømme eller bænke af tæt, hård, blå basalt adskilt af zeolitfyldte porezoner; fluidalstruktur er almindelig. Hængende: Småprikket feldspatbasalt.

Afgrænsningen af horisontbasalten er på kortet indtegnet som en tætprikket linje, der svarer til dennes underkant. Den er beliggende ca. $2 / 3$ oppe i mellemste basaltserie. Hvor horisontbasalten lokalt mangler, er niveauet betegnet med dobbelt prikafstand. (S. 40).

$C-$ horisonten falder sammen med grænsen mellem den mellemste og den $\emptyset$ verste basaltserie og vil derfor blive nærmere omtalt under afsnittet $\gg \emptyset$ verste basaltserie $\ll$. Her skal kun den typiske lagfølge ved overgangen mellem de to serier angives. Liggende: Storkornet feldspatbasalt, plagioklasstrøkornene har ofte listeform. $\emptyset$ verst r $\varnothing \mathrm{d}$ tuf (ikke sjældent med ubestemmelige aftryk af planter). Horisontbasalten: Tæt, blå basalt, tit med fluidalstruktur. Almindeligt ses en serie på 2-3 eller flere bænke adskilte af zeolitfyldte blærehorisonter, undertiden tynd tuf. På overfladen, undertiden også forneden, fremtræder horisontbasalten næsten overalt som et slaggeagglutinat med let blåviolet farve. Hængende: Småprikket feldspatbasalt. Bortset fra farvegrænsen på kortet (mellemste ba- 
saltserie - $\emptyset$ verste basaltserie) er C-horisonten betegnet med sort streg (underkanten af horisontbasalten). Hvor horisontbasalten er usikker på grund af dårlige iagttagelsesforhold er linjen stiplet, og hvor den helt mangler eller er meget usikker, er horisontniveauet bibeholdt som en prikket linje. (S. 47).

Hjcelpehorisonter. Som foran nævnt (s. 29) er der ved lateral forskydning og korrelation af delprofiler indført hjælpehorisonter. Disse har på kortet samme signatur som B-horisonten.

\section{Idealprofilet (hovedprofilet)}

Ved at benytte de omtalte korrelationshorisonter, A-, B- og Chorisonterne samt de nævnte hjælpehorisonter til konnektering af enkelt- eller delprofiler har det været muligt at opnå et kontinuerligt hovedprofil - et idealprofil - op gennem hele lagserien.

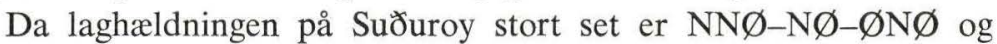
på de nordlige $\varnothing$ er stort set $\emptyset \mathrm{S} \emptyset-S \varnothing$, repræsenterer enkeltprofilerne, der på kortet er mærket I (den sydvestlige del af Suðuroy) XI (den nordlige del af Viðoy) dog ikke tilsammen et lodret profil på samme sted i lagserien, men et for hver enkelt- eller delprofil i nord- og фstlig retning lateralt forskudt vertikalprofil.

Konnekteringen af de enkelte profiler, der tilsammen danner idealprofilet, fremgår af profilskitsen (fig. 5). De vil i den følgende tekst blive omtalt med tilføjede stednavne og romertal således:

I Sunnbaprofilet

II Hvannafelliprofilet

III Skarvgjógvprofilet

IV Víkarprofilet

V Reipsáprofilet

VI Skorag $\varnothing$ taprofilet

VII Høvdagjógvprofilet

VIII Krossafelliprofilet

IX Tjørndalseggprofilet

$\mathrm{X}$ Sneisprofilet

XI Villingadalsfjallprofilet

Medens alle profiler i den mellemste og den $\varnothing$ verste basaltserie er konnekteret ved hjælp af A-, B- og C-horisonterne samt de på kortet indtegnede hjælpehorisonter, er profilerne i den nederste basaltserie søgt korreleret ved beregning og konstruktion. 


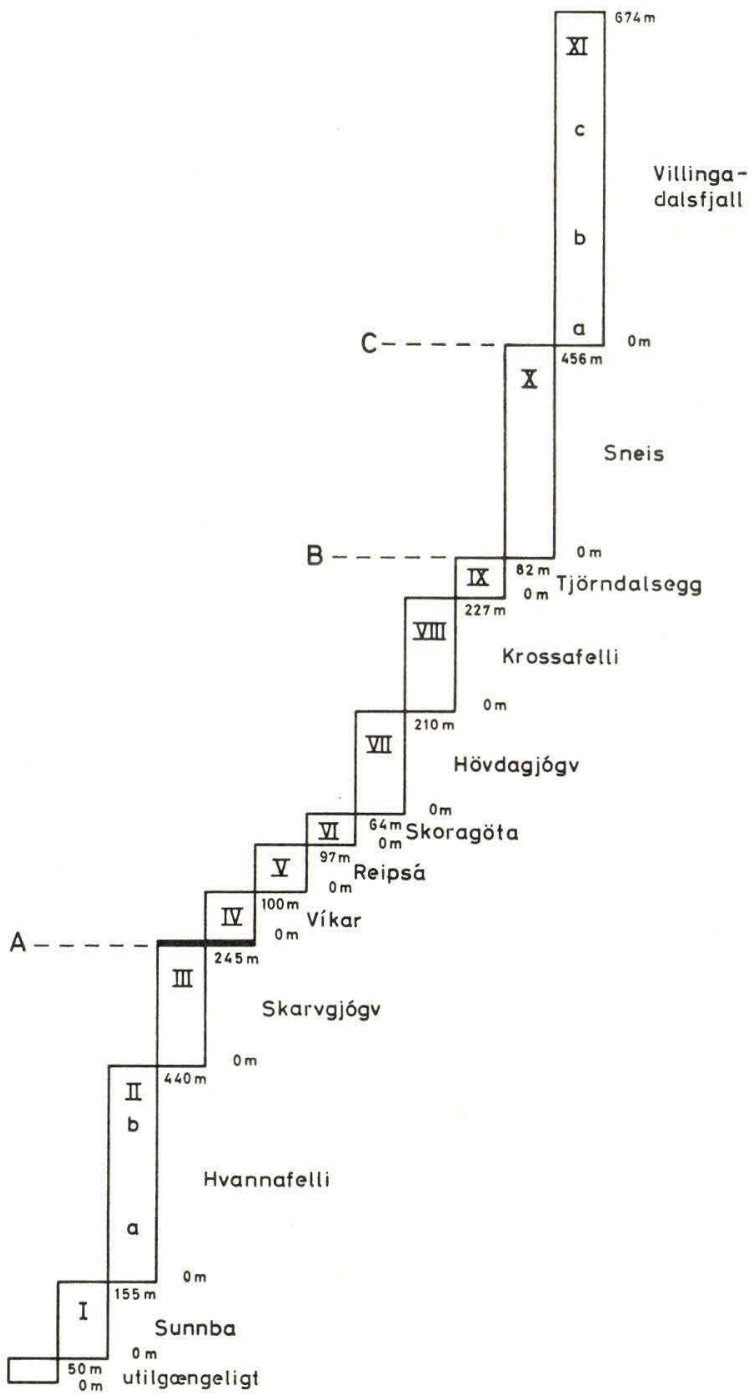

Fig. 5. Hovedprofilet (Idealprofilet). Meginskurðurin (fyrimyndarskurむurin). The main profile. 
Ved addition af alle de målte profiler får vi en samlet lavalagmægtighed på $2.800 \mathrm{~m}$. Ved nødvendig korrektion for fald af Vágaprofilerne, ca. $125 \mathrm{~m}$, opnås en samlet lavamagtighed på $2.925 \mathrm{~m}$.

Nederste basaltserie:

Utilgængelig fjeldvæg nord for Sunnba ....... ca. $50 \mathrm{~m}$

Sunnbaprofilet ................... $155 \mathrm{~m}$

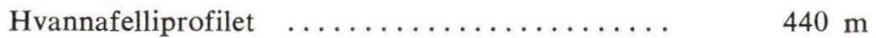

Skarvgjógvprofilet ............... $245 \mathrm{~m} \quad 890 \mathrm{~m}$

Mellemste basaltserie:

Víkarprofilet

$100 \mathrm{~m}$

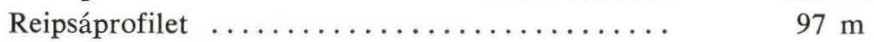

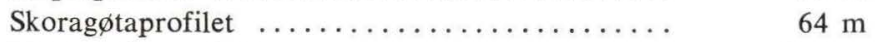

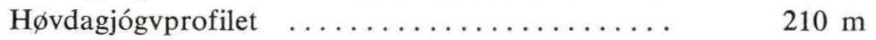

Krossafelliprofilet ................ $227 \mathrm{~m}$

Tjørndalseggprofilet $\ldots \ldots \ldots \ldots \ldots \ldots \ldots \ldots . \ldots \ldots$

Sneisprofilet .................... $456 \mathrm{~m}$

$1.236 \mathrm{~m}$

$\emptyset$ verste basaltserie:

Villingadalsfjallprofilet

\begin{tabular}{rrr} 
& $674 \mathrm{~m}$ & $674 \mathrm{~m}$ \\
\hline Ialt & $2.800 \mathrm{~m}$ \\
(korrektion... & $125 \mathrm{~m}$ & $125 \mathrm{~m}$ ) \\
\hline & Ialt & $2.925 \mathrm{~m}$
\end{tabular}

Da det ved kommende arbejde i marken kan have betydning at kunne finde frem til de på kortet angivne kotelokaliteter, skal der i det følgende gives en tabellarisk oversigt over disse med angivelse af kotetal (højde over havet), målebordsblad, lokalitet og eventuelle bemærkninger om forholdene på stedet.

Hvor der henvises til målebordsblad, henvises der med to tal - f. eks. 47,7, hvilket vil sige målebordsblad 47 inddelt i niendedele, i dette tilfælde således (fig. 6).

\begin{tabular}{|l|l|l|}
\hline 1 & 2 & 3 \\
\hline 4 & 5 & 6 \\
\hline \hline & 8 & 9 \\
\hline
\end{tabular}

Fig. 6. Inddeling af målebordsblade i 9-endedele.

Sundurbýting av $1: 20.000$ kortinum i 9 partar.

Division of map sheets. 


\begin{tabular}{|c|c|c|c|}
\hline $\begin{array}{l}\text { Højde } \\
\text { i m }\end{array}$ & $\begin{array}{l}\text { Målebords- } \\
\text { blad }\end{array}$ & Lokalitet & Bemarkninger \\
\hline 310 & 50,1 & $\begin{array}{l}\emptyset \text { stsiden af Hovstúgva ved } \\
\text { kildeudspring. }\end{array}$ & Grænsen vegetationsdækket. \\
\hline 400 & 49,3 & Vestsiden af Kolheyggjur. & $\begin{array}{l}\text { Grænsen blottet ved eftersøg- } \\
\text { ning efter kul. }\end{array}$ \\
\hline 412 & 47,7 & $\begin{array}{l}\text { Vestligste mineindgang } \\
\text { nord for Fámjin. }\end{array}$ & \\
\hline 342 & 47,7 & $\begin{array}{l}\text { Ved sydligste elv i Rossa- } \\
\text { rók. }\end{array}$ & $\begin{array}{l}\text { Grænsen blottet ved } \\
\text { prøvegravning. }\end{array}$ \\
\hline 316 & 47,4 & $\begin{array}{l}\text { Ved nordligste elv i Rossa- } \\
\text { rók. }\end{array}$ & $\begin{array}{l}\text { Grænsen blottet ved } \\
\text { prøvegravning. }\end{array}$ \\
\hline 295 & 47,4 & $\begin{array}{l}\text { Mineindgangen vest for } \\
\text { forkastningslinien ved } \\
\text { Botnsskarð. }\end{array}$ & \\
\hline 305 & 47,4 & $\begin{array}{l}\text { Mineindgangen umiddel- } \\
\text { bart vest for vestligste elv } \\
\text { i Rangibotnur. }\end{array}$ & \\
\hline 302 & 47,4 & Nordøstsiden af Mót. & $\begin{array}{l}\text { Grænsen blottet ved } \\
\text { prøvegravning. }\end{array}$ \\
\hline 267 & 47,8 & $\begin{array}{l}\text { Gl. mineindslag i nordøst- } \\
\text { siden af Oyrnafjall. }\end{array}$ & \\
\hline 390 & 47,8 & $\begin{array}{l}\text { Ved elv med kote } 390 \text { vest } \\
\text { for Valdaskarð. }\end{array}$ & G1. sammenstyrtet mineindslag. \\
\hline 275 & 47,4 & $\begin{array}{l}\text { Ved sydligste elv på vest- } \\
\text { siden af Tindur. }\end{array}$ & Gl. sammenstyrtet mineindslag. \\
\hline 240 & 46,6 & Nord for Skarvgjógv. & $\begin{array}{l}\text { Grænse og kulprofil ofte helt } \\
\text { eller delvis blottet i den stejle } \\
\text { fjeldvæg mod vest. }\end{array}$ \\
\hline 180 & 46,3 & $\begin{array}{l}\text { Suðuri undir Hæli } \\
\text { (øst for Bergstangi). }\end{array}$ & G1. sammenstyrtet mineindslag. \\
\hline 135 & 46,3 & $\begin{array}{l}\text { Undir Bergsleiti (syd for } \\
\text { Heygsmúli). }\end{array}$ & $\begin{array}{l}\text { Gl. endnu åben mine i fjeld- } \\
\text { væggen. }\end{array}$ \\
\hline 65 & 46,3 & Ved haugeskel $\emptyset$ kslin. & $\begin{array}{l}\text { Grænsen blottet ved prøve- } \\
\text { gravning. }\end{array}$ \\
\hline 110 & 46,3 & $\begin{array}{l}\text { Ved nordligste elv (syd for } \\
\text { kote } 280 \text { ) } \text { østsiden af } \\
\text { Prestfjall. }\end{array}$ & Kulmine. \\
\hline 176 & 46,3 & $\begin{array}{l}\text { Ved elv med kote } 150 \text {, syd- } \\
\varnothing \text { stsiden af Prestfjall. }\end{array}$ & Kulmine. \\
\hline 156 & 47,1 & $\begin{array}{l}\text { Ved elv nord for gangen i } \\
\text { Rókhagi. }\end{array}$ & Kulmine. \\
\hline 124 & 47,1 & $\begin{array}{l}\text { Elv med kote } 270 \text { (nordlige } \\
\text { elvforgrening) i Rókhagi. }\end{array}$ & $\begin{array}{l}\text { Grænsen blottet ved prøve- } \\
\text { gravning. }\end{array}$ \\
\hline
\end{tabular}




\begin{tabular}{|c|c|c|c|}
\hline $\begin{array}{l}\text { Højde } \\
\text { i m }\end{array}$ & $\begin{array}{l}\text { Målebords- } \\
\text { blad }\end{array}$ & Lokalitet & Bemærkninger \\
\hline 45 & 47,1 & Flekksá. & Grænsen ikke blottet. \\
\hline 0 & 44,7 & Tjørnunes. & \\
\hline 0 & 47,2 & Syd for Stapin, Hvannhagi. & \\
\hline 0 & 47,2 & Hvannhagi syd. & \\
\hline 0 & 48,7 & $\begin{array}{l}\text { Hellið (syd for } \\
\text { Froðbiarnípa). }\end{array}$ & \\
\hline 120 & 47,5 & $\varnothing \mathrm{kslin}$. & Gl. sammenstyrtet mineindslag. \\
\hline 202 & 47,4 & Hvannagjógv. & $\begin{array}{l}\text { Grænsen blottet ved prøve- } \\
\text { gravning. }\end{array}$ \\
\hline 66 & 43,9 & Vestsiden af Grímsfjall. & $\begin{array}{l}\text { Grænsen blottet ved prove- } \\
\text { gravning. }\end{array}$ \\
\hline 0 & 43,9 & Kolaratangi. & \\
\hline 0 & 43,9 & $\begin{array}{l}\text { Landingsstedet (det gamle) } \\
\text { Hvalba. }\end{array}$ & \\
\hline
\end{tabular}

\begin{tabular}{|c|c|c|c|}
\hline $\begin{array}{l}\text { Højde } \\
\text { i m }\end{array}$ & $\begin{array}{l}\text { Målebords- } \\
\text { blad }\end{array}$ & Lokalitet & Bemærkninger \\
\hline
\end{tabular}

$0 \quad 24,5 \quad$ Syd for Álkuklettur.

120 24,1 Ved bøgærdet, Gásadalur.

278 17,7 Syd for Barđið (Gilið á Målingen foretaget syd for Dýpinum). kløften.

$0 \quad 24,2 \quad$ Vestsiden af Viðvík (Víkar). I uren. 


\begin{tabular}{|c|c|c|c|}
\hline $\begin{array}{c}\text { H } \phi \text { jde } \\
\text { i m }\end{array}$ & $\begin{array}{l}\text { Målebords- } \\
\text { blad }\end{array}$ & Lokalitet & Bemærkninger \\
\hline
\end{tabular}

$370 \quad 30,2 \quad$ Krákureyn ved sogneskel.

25.8

404

47425,5 Ved profil IX nord for

\section{5,8}

Elvlфbet med kote 400 op mod Reynsatindur. Tjörndalsegg.

$338 \quad 25,6 \quad$ I vandl $\varnothing$ b $\phi$ st for Reynini.

Målingen af underkant er ca.; vegetation. Horisontbasalten iagttaget mod vest til elvforgreningerne i Lambá, derefter vegetation.

Horisontbasalten iagttaget igen syd for elven med kote 375 . Mægtighed her 2-3 m. Herfra til Stóragil kan den iagttages stykkevis, hvor den stikker frem i grus og vegetation. Samme mægtighed. Noget nord for Stóragil tiltager den igen i mægtighed. Mægtighed ved Stóragil ca. $12 \mathrm{~m}$. Underkant ved Stóragil $441 \mathrm{~m}$.

Syd for denne lokalitet, i Tjørndalsá, er mægtigheden 10-12 m. Underkant $418 \mathrm{~m}$. Herfra og mod nord er der vegetation. Horisontbasalten ses igen, når vi nærmer os Sogneskellet. Mægtighed her er $6 \mathrm{~m}$.

Mellem forrige lokalitet og denne kunne horisontbasalten ikke erkendes på en mindre strækning ved fortsættelsen af Leypanargjógv, skønt iagttagelsesmulighederne var gode og bjergarten blottet.

Ved Líðarurđ̋sfelli danner horisontbasalten terrænoverfladen.

25,9 Ravnagjógv.

I Ravnagjógv (sydlige vandl $\varnothing$ b) er underkanten af horisontbasaltserien beliggende i 360 m. Liggende: storkornet feldspatbasalt. Hængende: småprikket feldspatbasalt. Horisontbasaltseriens mægtighed ca. $25 \mathrm{~m}(1 / 2$ snes bænke af tæt blå basalt adskilte af porøse zeolitzoner). Serien ses tydeligt ned gennem hele dalen. 


\begin{tabular}{|c|c|c|c|}
\hline $\begin{array}{l}\text { Højde } \\
\text { i m }\end{array}$ & $\begin{array}{l}\text { Målebords- } \\
\text { blad }\end{array}$ & Lokalitet & Bemærkninger \\
\hline
\end{tabular}

$220 \quad 30,3 \quad$ Elven syd for Fossá.

$243 \quad 25,9 \quad$ I elven i Smyrlagjógv.

215 26,4 I vandløbet i Kálvadalur.

26,4 Hellá.

26,7

$120 \quad 31,1$ Forlængelsen af Oknadalsgjógv.
Horisontbasaltserien består her i området (Fossá-Grøná) af 4 bænke tæt blå basalt adskilte af porøse zeolitfyldte zoner. Liggende: storkornet feldspatbasalt. Hængende: småprikket feldspatbasalt.

Serien består ved Smyrlagjógv (sydlige vandl $\phi \mathrm{b}$ ) af $1 / 2$ snes bænke adskilt af zeolitzoner. Mægtighed ved Smyrlagjógv ca. $30 \mathrm{~m}$. Liggende: storkornet feldspatbasalt. Hængende: sandsynligvis (løse blokke) småprikket feldspatbasalt.

Liggende: storkornet feldspatbasalt.

Mægtighed ca. $7 \mathrm{~m}$. Seriens underkant $138 \mathrm{~m}$. Syd for Hellá er terrænet stærkt vegetationsklædt, så serien blev ikke iagttaget.

Dårlige iagttagelsesmuligheder. Serien blev iagttaget omkring Marragjógv; derefter ingen iagttagelsesmuligheder $\mathrm{f} \phi \mathrm{r} \quad \mathrm{i}$ Kellingardalur. I elven i Kellingardalur består horisontbasaltserien af 4-5 bænke adskilte af zeolitzoner. Mægtighed 10-12 m. Underkant beliggende $75 \mathrm{~m} \mathrm{o.h}$. Liggende: storkornet feldspatbasalt. Hængende: småprikket feldspatbasalt. Serien består her af 4 bænke skiftende med porøse zeolitfyldte zoner. Seriens samlede mægtighed 17-18 m. Liggende: storkornet feldspatbasalt. 


\begin{tabular}{|c|c|c|}
\hline $\begin{array}{l}\text { H } \phi \text { jde } \\
\text { i m }\end{array}$ & $\begin{array}{l}\text { Målebords- } \\
\text { blad }\end{array}$ & Lokalitet \\
\hline 0 & 26,5 & $\begin{array}{l}\text { Syd for den lille gjógv syd } \\
\text { for Vaðsteinagjógv. }\end{array}$ \\
\hline 38 & 26,2 & $\begin{array}{l}\text { Ovenover broen over } \\
\text { Leynará ca. } 50 \mathrm{~m} \text { syd for } \\
\text { „ból « på elvens nordbred. }\end{array}$ \\
\hline 118 & 26,1 & Víkará, Kvívík. \\
\hline 221 & 25,3 & Elvløb til Sunnaragjógv. \\
\hline 292 & 18,9 & $\begin{array}{l}\text { Sydsydvest for trig. st. } 317 \\
\text { i Økslin. }\end{array}$ \\
\hline 164 & 19,7 & $\begin{array}{l}\text { I Heljareyga umiddelbart } \\
\text { фst for Rangagjógv. }\end{array}$ \\
\hline 270 & 18,6 & $\begin{array}{l}\text { Ved det } 1 \text {. vandl } \varnothing \mathrm{b} \phi \text { st for } \\
\text { rørledningen ned til kraft- } \\
\text { stationen ved Fossá. }\end{array}$ \\
\hline 250 & 18,6 & $\begin{array}{l}\text { I nordsiden af kløften i } \\
\text { Bjarnadalsá. }\end{array}$ \\
\hline 298 & 18,3 & I hovedvandløbet til Vatnið. \\
\hline 325 & 18,6 & $\begin{array}{l}\text { Ved vardestien op mod Dal- } \\
\text { kinn. }\end{array}$ \\
\hline 334 & 18,6 & $\begin{array}{l}\text { Ved sydsydvest-nordnord- } \\
\varnothing \text { st forl } \varnothing \text { bende gærde i den } \\
\text { lille fjeldknold syd for Dal- } \\
\text { kinn. }\end{array}$ \\
\hline 400 & $\begin{array}{l}18,2 \\
18,2\end{array}$ & $\begin{array}{l}\text { I elven (med kote } 410 \text { ) op } \\
\text { mod Snædalur. }\end{array}$ \\
\hline
\end{tabular}

Horisontserien tynder ud efter Norðaraskarð. I Norðaraskarð danner den selve overfladen; kan derefter kun iagttages langs en kortere strækning mod syd. Liggende: storkornet feldspatbasalt og hængende: småprikket feldspatbasalt ses for det meste her umiddelbart over hinanden. I Øksnadalur kunne den ikke erkendes med nogenlunde sikkerhed, men den synes dog at optræde langs en kortere strækning i fjeldvæggen nordøst for Nálagjógv. 


\begin{tabular}{|c|c|c|c|}
\hline $\begin{array}{c}\text { H } \phi \text { jde } \\
\text { i m }\end{array}$ & $\begin{array}{l}\text { Målebords- } \\
\text { blad }\end{array}$ & Lokalitet & Bemærkninger \\
\hline
\end{tabular}

$390 \quad 11,8$ I $\varnothing$ st-vest løbende gjógv syd for Giljar.

$338 \quad 11,9$ I elv med kote 400 ved hauge og sogneskel.

\footnotetext{
28411,9 Umiddelbart vest for kote 280.

$245 \quad 11,9 \quad$ Klovsá.
}

Med sikkerhed kan den iagttages igen fra gangen nord for Postulakirkja og øst og nord på.

Vest for gangen er forholdene mere uoverskuelige og horisontserien synes at tynde helt ud vest på. På sydsiden af Norðaraskarð (ved haugeskellet) optræder horisontserien med de karakteristiske tynde bænke af tæt blå basalt adskilt af porøse zeolitzoner. Liggende: feldspatbasalt med lister. I $440 \mathrm{~m}$ optræder et r $\varnothing \mathrm{dbrunt}$ tuflag (ca. $25 \mathrm{~cm}$ ). Derover igen tæt blå basalt med temmelig udpræget fluidalstruktur og horisontal lamellering. I de horisontalt udtrukne porer ses ofte zeolitudfyldninger. I $445 \mathrm{~m}$ går denne bænk over $\mathrm{i}$ en slagget zone, der overlejres af småprikket feldspatbasalt. Nord for Norðaraskarð finder vi lignende forhold som på sydsiden af Norðaraskarơ.

Horisontseriens mægtighed måltes her til $26 \mathrm{~m}$.

Horisontseriebasalten er her blottet hele vejen op. Mægtigheden måltes til $29 \mathrm{~m}$. Serien er karakteristisk med tynde bænke af tæt blå basalt adskilt af porøse zeolitfyldte zoner. Liggende: tuf og under denne feldspatbasalt. Ca. $300 \mathrm{~m}$ sydvest for hauge- og sogneskellet måltes mægtigheden til $38 \mathrm{~m}$, feldspatbasalt både over og under. 


\begin{tabular}{|c|c|c|}
\hline $\begin{array}{l}\mathrm{H} \phi \text { jde } \\
\text { i m }\end{array}$ & $\begin{array}{l}\text { Målebords- } \\
\text { blad }\end{array}$ & Lokalitet \\
\hline 100 & 19,1 & $\begin{array}{l}\text { Elven } \phi \text { st for Bjendalsfoss- } \\
\text { ar, der løber ud i Stórá ved } \\
\text { kote } 18 \text {. }\end{array}$ \\
\hline 0 & 19,2 & $\begin{array}{l}\text { Umiddelbart } \emptyset \text { st for både- } \\
\text { skurene på sydsiden af } \\
\text { Hvalvík. }\end{array}$ \\
\hline 510 & 11,8 & $\begin{array}{l}\text { Syd for kote } 555 \text { ved gjógv } \\
\text { syd for Urðardrangur. }\end{array}$ \\
\hline 466 & 11,5 & $\begin{array}{l}\text { Vestligste elvgren i Skora- } \\
\text { dalur. }\end{array}$ \\
\hline 361 & 11,5 & Elven i Vatnsdalur. \\
\hline 282 & 11,6 & Nord for Svínagjógv. \\
\hline 365 & 11,8 & Reyná. \\
\hline
\end{tabular}

$445 \quad 11,8$ Sydsydvest hjørnet af Pætursfjall, umiddelbart under kote 464 .

$0 \quad 19,2$ Ca. $450 \mathrm{~m}$ syd for Grønhólmur.

$143 \quad 12,7$ Streymnesfossar.

250 11,6 Tvørá.

$308 \quad 11,2 \quad \emptyset$ stlige ende af gærde ved varderuten til Tjørnuvík.

$362 \quad 11,2$ Ved de vestligste elvforgreninger ned mod Ostagjógv.

11,2 Ud mod havet over kote 346 i sydsiden af dalen ved Svínaskorá.

$383 \quad 5,8$ Sydvest for kote 280 i sydsiden af Norðaridalur.
Bemærkninger
Horisontseriens mægtighed her målt til $39 \mathrm{~m}$. Tæt blå basalt $\mathrm{i}$ tynde bænke adskilt af porøse zoner. Tiltagende olivin nedad.

Både $\emptyset$ st for denne lokalitet, ved denne lokalitet og vest for den er lejringsforholdene typiske.

Lejringsforholdene stadig typiske.

Liggende: Feldspatbasalt, derefter ca. $1 \mathrm{~m}$ typisk tuf og derefter igen horisontseriens basaltbænke.

Typisk. Horisontserien går derefter ud i fjeldvæggen og fortsætter nordpå.

Typiske lejringsforhold gennem hele dalen ved Svínaskorá, men serien er delvis vegetationsdækket.

Typisk. Horisontserien fortsætter herefter videre nordpå gennem den stejle fjeldvæg lige til Sjendir. 


\begin{tabular}{|c|c|c|c|}
\hline $\begin{array}{l}\text { H } \varnothing \text { jde } \\
\text { i m }\end{array}$ & $\begin{array}{l}\text { Målebords- } \\
\text { blad }\end{array}$ & Lokalitet & Bemærkninger \\
\hline
\end{tabular}

227 5,5 Stejlvæggen mellem Sjendir og Mýlingur.

$293 \quad 5,5 \quad$ Elv med kote 360 i Svarthamar.

$310 \quad 5,8 \quad$ Sydenden af Svarthamar. Typisk.

$285 \quad 5,8 \quad$ Sydvestligste till $\varnothing \mathrm{b}$ til Brekká.

$268 \quad 5,8 \quad$ Syd $\varnothing$ stligste till $\varnothing \mathrm{b}$ til Brekká.

$298 \quad 5,8 \quad$ For enden af hammer nordvest for kote 320 .

$265 \quad 5,8 \quad$ Vardestien til Sjendir.

$225 \quad 5,5 \quad$ Ved gjógv'en på $\varnothing$ stsiden af Sjendir (sydlige gjógvvæg).

$185 \quad 5,5 \quad$ Ved gjógv'en på østsiden af Sjendir (nordlige gjógvvæg).

$1605,6 \quad$ Nord for elv med kote 180 nord for Rangagjógv.

$1685,9 \quad$ Ved elv der l $\varnothing$ ber syd for elv med kote 220 ned mod bådeskure på vestsiden af Tjørnuvík.

2035,9 I elven der løber ned fra Mýrin i den store gjógv.

$1365,6 \quad$ Nordvest for kote 180 nord for Lundagjógv.

$122 \quad 6,7 \quad$ Ved stien op fra Haldórsvík øst for kote 150.

118 12,1 Ca. 100 m syd for Fossá.

$87 \quad 12,8 \quad$ Norðaragjógv (sydlige gjógvvæg).

$0 \quad 19,2 \quad$ I det dyrkede areal overfor Oyrarbakki.
Højdemålingen synes alt for lav, men dette skyldes forkastningen gennem Mýlingur.

Typisk.

Typisk.

Typisk.

Typisk.

Typisk.

Typisk.

Typiske lejringsforhold, ca. 1 $\mathrm{m}$ tuf.

$61 \quad 6,4$ På sydvestlige side af forkastningen mellem Múlaklettur og Skíndalsklettur. 


\begin{tabular}{|c|c|c|c|}
\hline $\begin{array}{l}\text { Højde } \\
\text { i m }\end{array}$ & $\begin{array}{l}\text { Målebords- } \\
\text { blad }\end{array}$ & Lokalitet & Bemærkninger \\
\hline 0 & 12,8 & $\begin{array}{l}\text { Syd for indmarken i Norð- } \\
\text { skáli (ved kote } 12 \text { på kor- } \\
\text { tet). }\end{array}$ & \\
\hline 65 & 12,5 & $\begin{array}{l}\text { Elven (med kote } 10 \text { og 130) } \\
\text { nord for indmarken i } \\
\text { Svínáir. }\end{array}$ & \\
\hline 63 & 12,2 & I elven Ljósá. & \\
\hline 60 & 6,7 & I Hellisá. & \\
\hline 0 & 6,4 & $\begin{array}{l}\text { Elven (med kote 49) mel- } \\
\text { lem Mø̣lin og Tröllshövdið. }\end{array}$ & \\
\hline
\end{tabular}




\begin{tabular}{|c|c|c|c|}
\hline $\begin{array}{l}\text { Højde } \\
\text { i m }\end{array}$ & $\begin{array}{l}\text { Målebords- } \\
\text { blad }\end{array}$ & Lokalitet & Bemærkninger \\
\hline 0 & 40,6 & $\begin{array}{l}\text { Umiddelbart nord for lan- } \\
\text { dingsstedet, Skúvoy. }\end{array}$ & \\
\hline 117 & 40,2 & $\begin{array}{l}\text { Umiddelbart sydøst for } \\
\text { kote } 132, \text { Høvdin. }\end{array}$ & $\begin{array}{l}\text { Liggende: rødt tuflag ca. } 1 \mathrm{~m} \text {. } \\
\text { Horisontbænken:tæt blå grund- } \\
\text { masse med enkelte spredte } \\
\text { feldspatlister. Nedre del af } \\
\text { bænken kraftig horisontalt la- } \\
\text { melleret. }\end{array}$ \\
\hline 0 & 40,3 & Nord for Skarvagjógv. & \\
\hline \multicolumn{3}{|c|}{ C-horisonten } & Sandoy \\
\hline $\begin{array}{l}\mathrm{H} \phi \mathrm{jde} \\
\mathrm{i} \mathrm{m}\end{array}$ & $\begin{array}{l}\text { Målebords- } \\
\text { blad }\end{array}$ & Lokalitet & Bemærkninger \\
\hline
\end{tabular}

$0 \quad 38,5$ Nord for elven med kote 20, Svínadalur.

6438,4 Syd for Álarnir (Nord for kote 73).

$30 \quad 38,1 \quad$ Elv (med kote 10) i Søltuvík.

$47 \quad 38,1 \quad$ Nordvestlige hjørne af bøgærde i Søltuvík.

Horisonten går her ud i stejlvæggen.

Horisontbænken består af storkornet feldspatbasalt.

Liggende: porøs basalt (delvis vegetationsdækket). Horisontbasalten storkornet feldspatbasalt. Bænkens mægtighed her ca. $10 \mathrm{~m}$. Horisonten går herefter ud i den vestlige stejlvæg (fuglefjelde) på Sandoy.

14037,1 I elv med kote 60 (фistlige Liggende: slaggezoner og poelvforgrening) ved Rættin, nordspidsen af Sandoy.

$90 \quad 37,4 \quad \emptyset$ st for Erskoraklettur (vest for lille elv).

2537,4 Ved den nordlige ende af indsøen ved Stórihøvdi.

$0 \quad 37,4 \quad$ Umiddelbart syd $\phi$ st for Harðaberg. røs basalt. Horisontbasalten: storkornet feldspatbasalt (mægtighed mindst $20 \mathrm{~m}$ ).

Horisonten går ud i stejlvæg.

Grovkornet feldspatbasalt med lister. Mægtighed i Stórih $\varnothing$ vdi mindst $20 \mathrm{~m}$.

Horisontbænken består af grovkornet feldspatbasalt med store feldspatlister. 


\begin{tabular}{rlll}
\hline $\begin{array}{c}\text { Højde } \\
\text { i m }\end{array}$ & $\begin{array}{c}\text { Målebords- } \\
\text { blad }\end{array}$ & \multicolumn{1}{c}{ Lokalitet } & \multicolumn{1}{c}{ Bemærkninger } \\
\hline 0 & 35,7 & $\begin{array}{l}\text { Nordsiden af Loftið. } \\
\text { Ved gærde syd for Ormur. }\end{array}$ & $\begin{array}{l}\text { Horisontniveauet går i havet. } \\
\text { Horisontbasalten: tæt blå ba- } \\
\text { salt. Nord for Byrgisstakkur } \\
\text { tynder horisontbasalten ud syd- } \\
\text { på. }\end{array}$ \\
0 & 35,4 & $\begin{array}{l}\text { Ca. 200 m nord for } \\
\text { landingsstedet. }\end{array}$ &
\end{tabular}

C-horisonten

Koltur

\begin{tabular}{|c|c|c|c|}
\hline $\begin{array}{c}\text { Hojde } \\
\text { i m }\end{array}$ & $\begin{array}{l}\text { Målebords- } \\
\text { blad }\end{array}$ & Lokalitet & Bemærkninger \\
\hline
\end{tabular}

$124 \quad 34,3 \quad$ Sydvestlige ende af gærde (ved kote 124).

188 34,2 I næstvestligste vandløb Horisontbasalten: tæa blå ba(ved kote 190).

$112 \quad 34,3 \quad$ Nord $\phi$ stligste ende af gærde (ved kote 119). salt.

Liggende: feldspatbasalt ( $r \varnothing \mathrm{dl}$. porøs ovent.). Horisontbænken: tæt blå basalt.

\begin{tabular}{|c|c|c|c|}
\hline $\begin{array}{c}\mathrm{H} \phi \text { jde } \\
\text { i m }\end{array}$ & $\begin{array}{l}\text { Målebords- } \\
\text { blad }\end{array}$ & Lokalitet & Bemærkninger \\
\hline
\end{tabular}

$0 \quad 35,1 \quad$ Ved Hiplingsh $\phi$ vdi, nord for

Velbastaður.

13032,4 Ca. $100 \mathrm{~m}$ nord for elven Fra denne lokalitet og sydpå fra Fólkaskarð, Norðra- er der ingen eller kun meget dalur.

$144 \quad 32,1 \quad$ Vestligste elvforgrening (med kote 220) ned fra dårlige iagttagelsesmuligheder. Liggende: storkornet feldspatbasalt. Ingen tuf, men brænNeytaskarð, Norðradalur. dingshorisont. Tæt blå basalt. Profilet på Kaldbaksiden og profilet på Norơradalsiden viser påfaldende forskelle $\mathrm{i}$ betragtning af den korte afstand. 


\begin{tabular}{|c|c|c|c|}
\hline $\begin{array}{l}\text { Højde } \\
\text { i m }\end{array}$ & $\begin{array}{l}\text { Målebords- } \\
\text { blad }\end{array}$ & Lokalitet & Bemærkninger \\
\hline
\end{tabular}

26,9 I vandl $\phi$ b umiddelbart $\phi$ st for den lille $s \varnothing$ (med kote 355) på nordsiden af Gjáarbotnur. Trantur. 2. varde nord for kote 347 (varde).
Ved gentagen sammenligning må dog foranstående antages at være rigtigt. Ved en måling af horisontseriens mægtighed på Kaldbaksiden og på Norðradalsiden fandtes henholdsvis $43 \mathrm{~m}$ og $13 \mathrm{~m}$. Godt $1 / 2 \mathrm{~km}$ vest for denne lokalitet tynder horisontserien helt ud, den kan heller ikke iagttages længere vestpå, men her er dog nærmest helt vegetationsdækket.

Godt et par hundrede m længere mod $\varnothing$ st danner horisontserien kontakt med silloverfladen. Horisontserien blev ikke iagttaget igen mod syd $f \varnothing r$ ved ovennævnte lokalitet (Neytaskarð, Norðradalur), sandsynligvis er den afbrudt ved sillintrusionen.

I vestsiden af Skælingur og Trantur ses horisontserien som en hammer af ret stor mægtighed. Den kan følges mod nord$\varnothing$ st til den igen bliver afbrudt af sillen.

De typiske lejringsforhold er her: storkornet feldspatbasalt m. lister ( $\phi$ verst er denne bænk rødlig), derefter tuf og derefter igen horisontbasalten. Horisontbasaltserien er her langs $\varnothing$ stsiden af Streymoy ligesom i det meste af Kollfjarðardalur fremtrædende og grænsen mellem mellemste basaltserie og $\phi$ verste basaltserie udtalt.

Som ovenfor. 


\begin{tabular}{|c|c|c|}
\hline $\begin{array}{l}\text { Højde } \\
\text { i m }\end{array}$ & $\begin{array}{l}\text { Målebords- } \\
\text { blad }\end{array}$ & Lokalitet \\
\hline 167 & 27,4 & $\begin{array}{l}\text { Vandfald i elven umiddel- } \\
\text { bart } \varnothing \text { st for stien op fra } \\
\text { Signab } \emptyset \text { ur. }\end{array}$ \\
\hline 150 & 27,5 & Jøkilsgjógv. \\
\hline 0 & 27,9 & $\begin{array}{l}\text { Syd for »ból syd for } \\
\text { Krákugjógv. }\end{array}$ \\
\hline 0 & 32,2 & $\begin{array}{l}\text { Et par hundrede } m \text { vest for } \\
\text { bøgærdet, Sund. }\end{array}$ \\
\hline 103 & 32,1 & $\begin{array}{l}\text { Ca. } 100 \mathrm{~m} \text { sydøst for elv } \\
\text { med kote } 150 \text {, } \\
\text { Kaldbaksbotnur syd. }\end{array}$ \\
\hline 160 & 27,7 & $\begin{array}{l}\text { Fjarđará (hovedløb fra } \\
\text { Mannafellsdalur), }\end{array}$ \\
\hline 68 & 32,1 & Gorrtalagjógv. \\
\hline 0 & 32,2 & $\begin{array}{l}\text { Ca. } 600 \mathrm{~m} \text { vestsydvest for } \\
\text { landingspladsen, Kaldbak. }\end{array}$ \\
\hline 420 & 26,5 & Klettsgjógv ( $\varnothing$ stsiden). \\
\hline
\end{tabular}

45026,5 Umiddelbart vest for gangen syd i Sátan.

49526,2 Ca. $40 \mathrm{~m}$ syd for vandløbet syd for Navirnar.

$480 \quad 26,2 \quad \emptyset$ stsiden af Navagjógv.
Som ovenfor.

Som ovenfor.

Liggende: grovkornet feldspatbasalt og rød tuf. 103-146 m. Horisontbasaltserien (typisk). Typiske lejringsforhold.

Typisk.

Bygden Kaldbak ligger på horisontbasaltserien.

I vestlige side af Klettsgjógv er lagfølgen således: storkornet feldspatbasalt, tuf, horisontbasaltserien med agglutinat (ca. 8-9 m), sill (underkant $433 \mathrm{~m}$ ).

Ved gangen syd i Sátan skærer sillen gennem horisontserien. Tuflaget under horisontserien ses over sillen på vestsiden af gangen og under sillen på фstsiden af gangen.

Horisontbasaltserien bliverigen her afbrudt af sillintrusionen. Stik nord i Sátan danner horisontbasaltserien nedre del og sillen $\emptyset$ vre del af stejlvæggen. Mod фst danner sillen $\phi v r e$ hammer og horisontbasaltserien nedre hammer.

362 26,3 Djúpagil.

$465 \quad 19,8$ Slugt (vest for kote 557) i fortsættelse af gang.

$568 \quad 19,5 \quad$ Vestligste pynt af Bollin. 


\begin{tabular}{|c|c|c|c|}
\hline $\begin{array}{l}\text { Højde } \\
\text { i m }\end{array}$ & $\begin{array}{l}\text { Målebords- } \\
\text { blad }\end{array}$ & Lokalitet & Bemærkninger \\
\hline 425 & 19,9 & I Smørdalsá (Hósvík). & $\begin{array}{l}\text { Tæt blå basalt-agglutinat - tæt } \\
\text { blå basalt. }\end{array}$ \\
\hline 261 & 27,1 & $\begin{array}{l}\text { Umiddelbart } \phi s t \text { for trig. st. } \\
266 \varnothing \text { st for Miðgerðaá. }\end{array}$ & \\
\hline 278 & 27,1 & I Kirkjuá. & \\
\hline 265 & 27,1 & $\begin{array}{l}\text { I elv } \varnothing \text { st for kote } 280 \mathrm{i} \\
\text { nord } \phi s t s i d e n \text { af Dyllan. }\end{array}$ & \\
\hline 566 & 19,8 & Sydøstpynten i Stígarnir. & \\
\hline 633 & 19,4 & Nordvestpynten af Sneis. & \\
\hline \multicolumn{3}{|c|}{ C-horisonten } & Eysturoy \\
\hline $\begin{array}{l}\text { Højde } \\
\text { i m }\end{array}$ & $\begin{array}{l}\text { Målebords- } \\
\text { blad }\end{array}$ & Lokalitet & Bemærkninger \\
\hline
\end{tabular}

$\begin{array}{rrl}0 & 27,6 & \begin{array}{l}\text { Ca. 1,1 km syd for } \\ \text { Kolbjarnargjógv. }\end{array} \\ 166 & 27,2 & \text { I Tungáir (vestlige elv). }\end{array}$

$282 \quad 20,8 \quad$ I Gjógvará (sydlige side).

332 20,4 Østnordøst for kote 260, Rókin.

20,4

20,1

476
Lagfølge: grovkornet feldspatbasalt - rød tuf - tæt blå basalt (horisontserien). Lige nord for denne lokalitet bliver horisontserien afbrudt af sillintrusion.

Typisk. Umiddelbart nordvest for denne lokalitet afbrydes horisontserien af den store Eysturoysill.

I området nordøst for Borgarfelli er horisontseriens overflade påfaldende slagget og agglutiniseret. Horisontbasaltserien har her $i$ området meget stor mægtighed og omfatter alt det på det topografiske kort som faststånde klippe skraverede område.

Horisontbasaltserien ses igen på den lille "basaltø « i sillen ved Ryssugil og derefter igen ved Fransahús.

Typisk.

Oyrargjógv ved kote 383 . 


\begin{tabular}{|c|c|c|c|}
\hline $\begin{array}{l}\text { Hojde } \\
\text { i m }\end{array}$ & $\begin{array}{l}\text { Målebords- } \\
\text { blad }\end{array}$ & Lokalitet & Bemærkninger \\
\hline
\end{tabular}

490

19,3 I elv med kote 440 vest for Oyrarskarð.

$498 \quad 12,9 \quad$ Umiddelbart $\phi$ st for elv med kote 480 sydøst for Nøvin.

$505 \quad 12,9 \quad$ Ca. $100 \mathrm{~m}$ vest for kote 520 i nordvestsiden af $\mathrm{N} \phi$ vin.

$513 \quad 12,9 \quad$ Ved sogne- haugeskel syd for Skarðið undir Nøvini. Lokkafellsgjógv.

$458 \quad 13,7 \quad$ Umiddelbart syd for Lokkafellsgjógv.

$410 \quad 13,7 \quad$ Umiddelbart syd for varde. (med kote 405) sydvest for Skálafjall.

$428 \quad 13,7 \quad$ Vestligst i Skálafjall (ca. 50 $m$ vest for elven, der løber ned mod Fjarđará).

$428 \quad 13,7 \quad$ Stik nord for den vestligste inds $\varnothing$ på Skálafjall.

$415 \quad 13,7 \quad$ I nord $\varnothing$ sthjørnet af Skálafjall.

$415 \quad 13,7 \quad$ I kløft mellem de to elve på sydsiden af Skálafjall.

$38420,1 \quad$ Nordligste elvforgrening til Svínagjógv.

$332 \quad 20,2 \quad$ Ved vardestien til Skálabotnur.

$260 \quad 20,6 \quad$ Hagagjógv.

18420,9 Skálagerơisá.

$80 \quad 27,3 \quad$ I lille elv nord for Ljósá.

$0 \quad 27,6 \quad$ Næsset syd for Heygsst $\varnothing \varnothing$.

52512,9 Ved enden af hammer ca. $100 \mathrm{~m}$ vest for elv med kote 530, Lítlafelli.
Horisontbasaltserien kan følges til området ved Oyrarskarð, hvor lejringsforholdene er typiske. Vest for elv med kote 440 vest for Oyrarskarð afbrydes horisontserien igen af sill.

Typisk. Sillens vestlige kontakt med horisontserien ca. $40 \mathrm{~m}$ $\varnothing$ st for elv m. kote 480 .

Typisk.

Grænsen vegetationsdækket.

Grænsen vegetationsdækket.

Liggende: grovkornet feldspatbasalt. Selve grænsen grusdækket.

Typisk.

Typisk.

Typisk. Tuf og liggende formentlig grovkornet feldspatbasalt.

Typisk.

Grænsen grusdækket.

Typisk. 
Højde Målebords-

i $\mathrm{m}$ blad Lokalitet Bemærkninger

525 12,6 Ved sogne- haugeskel i Typisk.

nordvesthjørnet af Lítlafelli.

521 12,9 Lige over gjógv i sydøst- Grænsen grusdækket.

hjфrnet af Lítlafelli.

$564 \quad 12,6 \quad$ Ved enden af hammer (syd for kote 570) i sydvesthjørnet af Miðalfelli.

$570 \quad 12,6$ Ca. $100 \mathrm{~m}$ syd for sognehaugeskel (med kote 570) i nordvesthjørnet af Miðalfelli.

$545 \quad 12,6 \quad$ Ved sogne- haugeskel i syd$\emptyset$ sthjørnet af Miðalfelli.

12,6 I sydsiden af Skerðingur ved sogne- haugeskel.

600
12,3 Ved sogne- haugeskel sydøst for Oknadalsskarð.
Grænsen vegetationsdækket. Nord for denne lokalitet oph $\phi$ rer horisontseriebasalten ganske efter at være aftaget i mægtighed nordpå.

Typisk. Horisontseriebasaltens nordligste punkt i østsiden af Miðalfelli, (hvor hammer holder op på det topografiske kort) målt til $555 \mathrm{~m}$ o.h. Grænsen nedad mod grovkornet feldspatbasalt vegetationsdækket. Fra en anslået mægtighed på 20-25 m tynder horisontserien her pludselig ud over en anslået strækning på ca. 100 $\mathrm{m}$. Nordligere ses intet til denne. Horisontniveauet nordpå markeres af grovkornet feldspatbasalt overlejret af finkornet feldspatbasalt. På den sidste strækning (såvel på ф́stsiden som på vestsiden) er grænsens forl $\varnothing b$ noget svingende.

Horisontniveauet markeres af overgangen grovkornet feldspatbasalt - finkornet feldspatbasalt med mellemlejret $\mathrm{r} \phi \mathrm{d}$ brun tuf. Horisontseriebasalten mangler.

Lagfølge: grovkornet feldspatbasalt - brun tuf - tæt blå basalt (ganske tynd). 


\begin{tabular}{|c|c|c|c|}
\hline $\begin{array}{l}\text { Højde } \\
\quad \text { i m }\end{array}$ & $\begin{array}{l}\text { Målebords- } \\
\text { blad }\end{array}$ & Lokalitet & Bemærkninger \\
\hline
\end{tabular}

574 12,6 I Harðbaksenni (i østsiden af Skerðingur).

$60512,3 \quad$ Ved sogne- haugeskel nord for Oknadalsskarð.

$620 \quad 12,2 \quad$ I sydvesthjørnet af

Svartbakstindur (ved sydlige ende af hammer $\varnothing$ st for kote 520).

$61512,2 \quad$ Ved haugeskel stik vest for toppen $(792 \mathrm{~m})$ af

Blámannsfjall.

$605 \quad 6,8 \quad$ Ved sogne- haugeskel syd $\varnothing$ st for Vatndalsskarð.

$583 \quad 6,9 \quad$ Ved haugeskel sydsydøst for Nón ( $\varnothing$ st for kote 600).

$602 \quad 12,3 \quad$ Ved haugeskel ( $\varnothing$ st for kote 720) på $\varnothing$ stsiden af Blámannsfjall.

$610 \quad 6,8$ Ved sogne- haugeskel i sydфsthjørnet af Vaðhorn.

$634 \quad 6,8$ I vestsiden af Vaðhorn ved kote 640 .

$608 \quad 6,8$ Ved sogne- haugeskel i nordsiden af Vaðhorn.
Lejringsforholdene typiske (rødt tuflag ca. $1 / 2 \mathrm{~m}$ ). Horisontbasalten noget mere grovkornet end sædvanligt. Ved denne lokalitet ansloges mægtigheden af horisontbasalten til ca. $5 \mathrm{~m}$; den tynder ud mod gangen i sydøstsiden af Skerðingur. Ca. $200 \mathrm{~m}$ vest for Harðbaksenni går horisontbasalten under vegetation.

Typiske lejringsforhold (tuffen stærkt rødfarvet). Horisontbasalten ligner forannæunte.

Typiske lejringsforhold. 2-300 $\mathrm{m}$ i retning mod Oknadalsskarð ses horisontbasalten stikke frem af vegetation. Resten af strækningen mod Oknadalsskarð vegetationsdækket.

Typiske lejringsforhold. Varierende mægtighed fra forrige lokalitet.

Typisk. Horisontbasalten ret stor mægtighed.

Typiske lejringsforhold. Horisontbasaltens mægtighed ret stor. Rundt dalen går den under vegetation. Nord og øst for Svartbakstindur ses den fortsætte i stejlvæggen ud mod Sáttarenni.

Typiske lejringsforhold. Horisontbasaltens mægtighed meget stor.

Typiske lejringsforhold.

Typiske lejringsforhold. 


\begin{tabular}{|c|c|c|c|}
\hline $\begin{array}{l}\text { Højde } \\
\text { i m }\end{array}$ & $\begin{array}{l}\text { Målebords- } \\
\text { blad }\end{array}$ & Lokalitet & Bemærkninger \\
\hline
\end{tabular}

$595 \quad 6,5$ Sydvest for Hálsur

(Slættaratindur)

lige over kote 590 .

$553 \quad 6,5$ Umiddelbart syd for elv med kote 560 i $\varnothing$ ksnadalur.

$576 \quad 6,5 \quad$ Nordnordvest for trig. st. 612 i Mannssetur.

$507 \quad 6,6$ Elven i dalen nord for Gráfelli.

$460 \quad 6,2$ Sydvest for Hornfjall lige nord for gærde med kote 460 .

$457 \quad 6,2 \quad$ Nordhjørnet af Hornfjall.

$465 \quad 6,3 \quad$ Ved $\varnothing$ stlige ende af hammer vest for Rivá i Ambadalur.

$460 \quad 6,3 \quad$ Lige $\varnothing$ st for gærde i nordspidsen af Nøvin.

$485 \quad 6,6 \quad$ Ca. $100 \mathrm{~m}$ nord $\varnothing$ st for kote 480 sydligst i Garð̄ahamar.

$510 \quad 6,6 \quad$ I sydøstpynten af Gráfelli.

544 6,5 Fremra Dalsá (vestligste elvforgrening nord for Bláberg).

$550 \quad 6,6 \quad$ I det $\varnothing$ stlige hammerhjørne på sydflanken af Gívrarbotnur.

$445 \quad 6,3 \quad$ Ved nordlige ende af gærde (syd i Múlin).

432 6,3 I Múlin (nord).
Typiske lejringsforhold. Horisontbasalten stor mægtighed på den følgende strækning.

Typiske lejringsforhold.

Typisk. Horisontbasaltens mægtighed ca. $20 \mathrm{~m}$.

Typisk. Mægtigheden noget mindre.

Lagfølge: grovkornet feldspatbasalt - tuf - tæt blå basalt (skifter med porøse zoner). Mægtighed af horisontbasalten ca. $50 \mathrm{~m}$. Kraftig forkl $\varnothing$ ftning ved lokaliteten, (kompas ca. $\mathrm{N} 80^{\circ}$ ). Det store fald i forhold til foregående lokalitet skyldes sandsynligvis forkastning sydøst for lokaliteten.

Typiske lejringsforhold.

Typisk. Horisontbasaltens mægtighed i hele området overordentlig stor.

Grænsen rasdækket.

Typisk.

Grænsen rasdækket.

Typiske lejringsforhold.

Typiske lejringsforhold. Ca. $1 / 2$ $\mathrm{m}$ rød tuf.

Typiske lejringsforhold.

Typiske lejringsforhold. Højderyggen fra Múlin mod syd udgøres til sin top $(471 \mathrm{~m})$ af horisontseriens basalt. 


\begin{tabular}{|c|c|c|c|}
\hline $\begin{array}{l}\text { Højde } \\
\text { i m }\end{array}$ & $\begin{array}{l}\text { Målebords- } \\
\text { blad }\end{array}$ & Lokalitet & Bemærkninger \\
\hline
\end{tabular}

$574 \quad 6,9 \quad$ Ved haugeskel i vesthjørnet af Húsafjall.

$545 \quad 6,9 \quad$ Nord i Húsafjall.

$562 \quad 6,9 \quad$ Syd i Húsafjall.

$490 \quad 6,6 \quad$ Sydvesthjørnet af Middagsfjall (sydvest for kote 520).

$451 \quad 6,6$ Nordvesthjørnet af Middagsfjall.

$452 \quad 6,6 \quad \emptyset$ sthjørnet af Middagsfjall over Skúvadalsskarð.

$434 \quad 7,4 \quad$ Sydvesthjørnet af Tyril.

7,1 Nordhjørnet af Tyril (under kote 460 ).

$0 \quad 28,4 \quad$ Ca. $300 \mathrm{~m}$ nord for Saltnes (ca. $50 \mathrm{~m}$ syd for gærde).

0 28,4 Umiddelbart $\phi$ st for »ból « på sydsiden af bugten ved Heiðarnar.

$0 \quad 28,1 \quad$ Ved $0 \mathrm{~km}$ stenen (nord for Simonsens pakhuse, Heiðarnar). den store gjógv i Glyvrar. (syd $\varnothing$ st for varde med kote 61).

Typiske lejringsforhold. Horisontbasaltens mægtighed 10$15 \mathrm{~m}$.

Typisk. Horisontbasaltens mægtighed ca. $20 \mathrm{~m}$.

Typiske lejringsforhold. Mægtigheden stadig ret stor.

Typiske lejringsforhold.

Typiske lejringsforhold.

Grænsen rasdækket.

Liggende: grovkornet feldspatbasalt. Denne overlejres af en basalt med slagget udseende. Derefter r $\varnothing d$ tuf. Den typiske tætte blå basalt synes at mangle.

Grænsen grusdækket. Liggende: grovkornet feldspatbasalt, der overlejres af basalt med slagget udseende som $(8-10 \mathrm{~m}$ højere) går over i den karakteristiske horisontbasalt med udtalt fluidal-struktur.

Underkanten af horisontbasalten går i havet. Typisk.

Horisontbasalten går i havet. På denne strækning når horisontbasaltserien ingen steder op over stejlvæggen ud mod stranden.

Horisontbasaltserien i havniveau. Basalten noget por $\varnothing$, ca. $50 \mathrm{~cm}$ r $\phi d$ tuf under. Gennem indmarken mod nord er der dårlig blotning. Vegetation.

Typisk; ret stor mægtighed.

Selve grænsen er vegetationsdækket. Liggende: grovkornet feldspatbasalt. Horisontbasal- 


\begin{tabular}{|c|c|c|c|}
\hline $\begin{array}{l}\text { Højde } \\
\text { i m }\end{array}$ & $\begin{array}{l}\text { Målebords- } \\
\text { blad }\end{array}$ & Lokalitet & Bemærkninger \\
\hline & & & $\begin{array}{l}\text { ten tilsyneladende udtyndet og } \\
\text { blæret. Hele vejen fra Glyvrar } \\
\text { og videre mod } \varnothing \text { st langs syd- } \\
\text { siden af dalen kan den iagtta- } \\
\text { ges hist og her, hvor den stik- } \\
\text { ker frem af vegetationen. }\end{array}$ \\
\hline
\end{tabular}

$48 \quad 21,7$ Syd for sydlige bøgærde, Lambi (over »ból « med gærde ved kote 10).

$0 \quad 28,2$ Ca. $600 \mathrm{~m}$ vestnordvest for Lambanes (ved »ból " фst for elv med kote 150).

$0 \quad 21,8 \quad$ Umiddelbart vest for elv med kote 80 og 280 i Seyöhamar på nordsiden af Lambavík.

14021,7 I sydligste elv (med kote 10) i Sølmundarfjørður.

22020,6 Ved sogne-haugeskel på sydsiden af Gøtueiði.

133 21,4 I elven (nordlige elvforgrening i Djúpidalur).

$85 \quad 21,5 \quad$ Ved Tungan.

$0 \quad 21,8 \quad \varnothing$ st for Skáktangi.

278 20,3 Sydspidsen af Knyklarnir.

$351 \quad 13,8 \quad$ Ved elv vest for trig. st. 364 sydsiden af Trælavatnaskaro.

$380 \quad 13,8$ Elven med kote 380 vest for vardestien op fra Skálabotnur.

$412 \quad 13,5 \quad$ Ved vardestien på vestsiden af J $\emptyset$ klaskarð.
Liggende: Basalt med små feldspatstrøkorn, derefter ca. $40 \mathrm{~cm}$ rødbrun tuf.

Horisontbasalten synes (set fra nordsiden af Lambavík) at fortsætte sydøstpå som en ret tydelig bænk.

Horisontserien manglende.*)

Liggende basalt grusdækket. Tyndt rødt tuflag.*) Basalten ret porøs.

*)

Liggende: storkornet feldspatbasalt. R $\varnothing$ d tuf. Tæt blå basalt (iagttagelse vest for sogneog haugeskellet).*)

Horisontbasalten fulgt ud mod Brattaskoragjógv, men ikke iagttaget i gjógv'en, hvor lagene er blottede.*)

Horisontserien manglende.*)

Horisontbasalten er her tydelig forkl $\varnothing$ ftet (kompas $\mathrm{N} 90^{\circ}$ ).

*) Forholdene for det meste ret uoverskuelige. Fastlæggelsen noget usikker. 


\begin{tabular}{|c|c|c|c|}
\hline $\begin{array}{l}\text { Højde } \\
\text { i m }\end{array}$ & $\begin{array}{l}\text { Målebords- } \\
\text { blad }\end{array}$ & Lokalitet & Bemærkninger \\
\hline
\end{tabular}

417 13,5 Vestflanken (selve pynten) Grænsen vegetationsklædt. Fra i Hjarðardalur.

denne lokalitet ses horisontserien forl $\varnothing$ be rundt $\mathrm{Hjar}$ đardalur.

40513,2 Nordvesthjørnet af Slætta-

Horisontbasalten tyndet en del fjall (umiddelbart nord for kote 410).

ud det sidste stykke vej gennem dalen. Horisontserien kan ikke følges herfra mod $\emptyset$ st på grund af vanskelige terrænforhold. Den er desuden stærkt tyndet ud og ukarakteristisk.

398 13,2 Sydsiden af Fuglfjarðarskarð.

Grovkornet feldspatbasalt; rød tuf; noget blæret basalt (sandsynligvis horisontbasalten).

396 13,5 Bielv til Gjógvará på nordGrovkornet feldspatbasalt; r $\varnothing \mathrm{d}$ siden af J $\varnothing$ kladalur (1. elv øst for kote 480). tuf; tæt blå basalt (slagget og ukarakteristisk). Herfra mod $\emptyset$ st tynder horisontbasalten meget stærkt ud, er ukarakteristisk og blæret. $100 \mathrm{~m} \emptyset$ st for denne lokalitet og $\phi$ stligere blev horisontbasalten ikke iagttaget.

$400 \quad 13,5$ I Gjógvará (ved vardesti)

Storkornet feldspatbasalt (ligpå østsiden af Jøklaskarð.

gende), rød tuf; horisontbasalten. Mellem disse to sidste lokaliteter er horisonten typisk, men grænsen ofte vegetationsdækket. Horisontbasaltens mægtighed sydvest for forrige lokalitet (syd for kote 480) før den tynder ud фstpå, anslået til 20$30 \mathrm{~m}$.

$348 \quad 13,8$ Elven (sogne-haugeskel) der løber fra Trælav $\varnothing$ tn ned i Kambsdalur.

$460 \quad 13,4 \quad$ Ved haugeskel sydvest i Múlatindur.

Liggende: ingen grovkornet feldspatbasalt, porøs zone. Typisk tuf og horisontbasalt. Ca. $600 \mathrm{~m}$ nordligere (vest for kote 530) tynder horisontbasalten helt ud og grænsen forsvinder under ras og vegetation. 
Højde Målebords-

i m blad Lokalitet Bemærkninger

$470 \quad 13,4 \quad$ I elv med kote 480.

$46513,1 \quad$ Umiddelbart syd for $\emptyset \mathrm{ksna-}$ gjógv.

$450 \quad 7,7$ Ca. $100 \mathrm{~m}$ syd for telefonlinien mellem Maður og Lyngstúgva.

$428 \quad 7,7$ I nord $\varnothing$ sthjørnet af Lyngstúgva (lige over kote 420).

$451 \quad 13,1 \quad$ I nordligste till $\varnothing \mathrm{b}$ (elvforgrening med kote 370) til Kvíggjará i Vatnsdalur.

400 13,2 Nordøst i Veðurhorn.

442 13,4 I Laksá (sydlige gjógvvæg).

$438 \quad 13,4 \quad$ Sydøst for Múlatindur ca. $50 \mathrm{~m}$ syd for elv med kote 470 .

$516 \quad 13,1 \quad$ Nordspidsen af Hægstafjall (ved Dalkinn).
Ca. $150 \mathrm{~m}$ syd for haugeskel (m. kote 540) ses horisontbasalten igen. Den tiltager jævnt i mægtighed mod nord.

Mægtigheden stor. Dobbeltbænket.

Grovkornet feldspatbasalt; r $\varnothing \mathrm{d}$ tuf; tæt blå basalt (horisontbasalten).

Typiske lejringsforhold. Horisontbasaltens mægtighed 5-6 $\mathrm{m}$. Fra Lyngstúgva og til vandløbet syd for Maður er terrænet vegetationsdækket og gruset, så ingen iagttagelse er mulig. Inde i Vatnsdalur er horisonten tydelig.

Typiske lejringsforhold.

Typiske lejringsforhold. Horisontbasalten ret stor mægtighed. I fjeldvæggen vest for Heltnin fremtræder horisontbasalten tydeligt, ofte som to sorte bånd.

Liggende: slagget top af tæt blå basaltbænk (tilsyneladende er den sædvanligt forekommende grovkornede feldspatbasaltbænk nederoderet eller udtyndet). Tuf og horisontbasalt typiske. Langs den sidste strækning er horisontserien noget bugtet.

Storkornet feldspatbasalt, rødlig (liggende) tuf; horisontbasalten (tæet blå basalt) stor mægtighed.

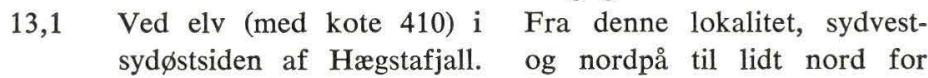


Højde Målebords-

i m blad Lokalitet Bemærkninger

25721,1 Ved vardestien på vestsiden af Lorvíksfjall.

$295 \quad 13,9 \quad$ Skoragjógv.

$277 \quad 14,7 \quad$ Fossagil.

14021,2 Over Hagaleiti (lige ved kote 140).

\section{$95 \quad 21,3 \quad$ I Gøtunesgjógv (nordsiden).}

Ólavsøkugjógv bliver horisontbasalten borte. Den kan ikke ses i Skipagjógv, hvor lagene er blottede.

Storkornet feldspatbasalt, rødlig (liggende); rød tuf ca. 30 $\mathrm{cm}$; horisontbasalten (tæt blå basaltbænk af stor mægtighed, slagget forneden).

Grænsen vegetationsdækket.

Nordøst for forrige lokalitet, i vestflanken af Ritudalur, går horisontbasalten bort og kan ikke iagttages igen for inde i dalen, Undir Skaröi. Den blev ikke iagttaget i Hálsur og Navirnar, hvor lagene er blottede. Lagfølgen, Undir Skarði: storkornet feldspatbasalt; tuf ikke synlig på grund af vegetation; horisontbasalten (typisk), mægtighed i midterpartiet ca. $15 \mathrm{~m}$. Ved Fossagil går horisontbasalten igen bort, ses igen langs en mindre strækning under Knúkur. Derefter ikke iagttaget igen før ud mod Gøtunes. Lejringsforholdene typiske: grovkornet feldspatbasalt; rød tuf; tæt blå basalt (horisontbasalten). Synes at tynde ud mod vest.

Horisontniveau (grænse mellem grovkornet og mindre storkornet feldspatbasalt). Horisontbasalten er igen tyndet helt ud. 


\begin{tabular}{|c|c|c|c|}
\hline $\begin{array}{l}\text { Højde } \\
\text { i m }\end{array}$ & $\begin{array}{l}\text { Målebords- } \\
\text { blad }\end{array}$ & Lokalitet & Bemærkninger \\
\hline
\end{tabular}

$21,3.2 .1$

$391 \quad 13,2 \quad$ Nord for Fuglfjarðarskarð.

$391 \quad 13,2 \quad$ Nord $\varnothing$ st i Rustartindur (lige over kote 380 ).

$356 \quad 13,6 \quad$ Heimaragjógv ( $\varnothing$ stlige elvforgrening).

$418 \quad 7,8 \quad$ Sydvest for trig. st. 504 Tindur. Tindur.
I Gøtunesgjógv hvor lagene er blottede, samt syd- og vestpå til vardestien ved Lorvíksfjall blev horisontbasalten ikke iagttaget.

Grovkornet feldspatbasalt; rød tuf; tæt blå basalt (horisontbasalten).

Typiske lejringsforhold: grovkornet feldspatbasalt; rød tuf; horisontbasalten. Inde i bunden af Góđidalur bliver horisontbasalten utilgængelig i stejlvæggen. Den ses fortsætte noget ind $\mathrm{i}$ dalen, hvorefter den tynder ud over en ganske kort strækning. Den blev ikke iagttaget længere mod $\varnothing$ st og syd.

Horisontniveauet (grovkornet feldspatbasalt; brunt til grønt tuflag ca. $1 / 2 \mathrm{~m}$; porøs basalt). Horisontbasalten blev ikke iagttaget igen $\mathrm{f} \phi \mathrm{r}$ syd for Fuglfjarðarskarð (nord for kote 380).

Lejringsforhold: grovkornet feldspatbasalt (liggende); rød og grønlig tuf ca. $50 \mathrm{~cm}$; tæt blå basalt $418-425 \mathrm{~m}$, (sandsynligvis horisontbasalten).

Af horisontbasalten er kun et par m ukarakteristiske rester tilbage. Tuflaget har derimod en mægtighed på op til $2 \mathrm{~m}$ (mørkebrunt til grønligt forneden, gulligt i midten og rødbrunt foroven).

Samme tuflag som ved forrige lokalitet. Det underlejres af grovkornet feldspatbasalt og overlejres af småkornet feldspatbasalt. Der ses intet spor af horisontbasalten. 


\begin{tabular}{|c|c|c|}
\hline $\begin{array}{l}\text { Højde } \\
\text { i m }\end{array}$ & $\begin{array}{l}\text { Målebords- } \\
\text { blad }\end{array}$ & Lokalitet \\
\hline
\end{tabular}

$204 \quad 14,5 \quad \emptyset$ stsyd $\varnothing$ st for Klubbin.

$254 \quad 14,4$ I første elvl $\varnothing$ b nordvest for indmarken i Blankskáli.

$26214,1 \quad$ Nordnordvest for kote 290 i Lágfjall.

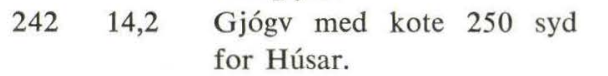

241 14,2 Første elv nord for Myllá i Knúksdalur.

221 Umiddelbart vest for kote 180 nordvest for Syðradalur.

205 14,5 Sydvest for Syðradalur, $\emptyset$ st for Knúkur.

272 14,1 I sydlige vandløb til Rættargjógv nordvest for Húsareiði.

3057,6 Vestsiden af Keldurnar umiddelbart over kote 280 .

$308 \quad 7,3 \quad$ Syd $\varnothing$ st for Heyggjurin Hvassi ved udspring af elv med kote 180 .

$302 \quad 7,3$ Umiddelbart nord for kote 341, Slættafjall.

$300 \quad 7,3 \quad$ I sydflanken af Mikladalur (over elvforgrening i elv med kote 157).

$290 \quad 7,3 \quad$ Hjørne af basaltbænk stik vest for Ritudalsgjógv.

$300 \quad 7,6 \quad$ I sydsiden af Ritudalur i gjógv nord for Byttufelli.

\section{Typisk.}

Typiske lejringsforhold.

Typiske lejringsforhold.

Typiske lejringsforhold.

Typiske lejringsforhold. Inde i Knúksdalur er horisonten rasdækket.

Typisk.

Typisk.

Horisontbænken er en ukarakteristisk, por $\varnothing s$ og slagget basalt. Lagfølgen ellers typisk. Liggende: ret storkornet feldspatbasalt, фverst tuflag ca. 3 $\mathrm{m}$ (forneden gråt, foroven rødt). Hængende: småprikket feldspatbasalt, noget porøs.

Lejringsforholdene som syd for Heyggjurin Hvassi, men horisontbænken tæt blå basalt.

Typisk.

Typiske lejringsforhold.

Typisk.

I Villingadalur tynder horisonten stærkt ud mod syd, men den tiltager igen mod $\phi$ st i dalens sydside. 
Højde Målebords.

$\begin{array}{lll}\mathrm{i} \mathrm{m} & \text { blad } & \text { Lokalitet }\end{array}$

3058,4 Inde $\mathrm{i}$ bunden af Hattar-

Lejringsforholdene ukaraktedalur.

ristiske i Hattardalur.

$295 \quad 8,7$ Sydlige side af Miðardalur

Typisk.

ca. $250 \mathrm{~m}$ фstsyd $\varnothing \mathrm{st}$ for kote 300 .

$284 \quad 8,7$ I sydlige side af Leitisdalur elv med kote 190.

$268 \quad 8,7$ Lige over nordlige bøgrænse Húsar.

Horisontbasaltens mægtighed her ca. $40 \mathrm{~m}$.

$1,6.9$

Da horisontbænken er vanskelig at identificere eller manglende, er horisontniveauet indf $\varnothing$ rt prikket på kortet. Set fra søsiden synes grænsen mellem mellemste basaltserie og $\varnothing v e r-$ ste basaltserie at være ret tydelig såvel i den vestlige, nordlige som $\varnothing$ stlige stejlvæg.

C-horisonten

Kunoy

\section{Højde Målebords- \\ i m blad}

$158 \quad 14,3 \quad$ Kunoyarnes (Brattanes)

Typisk.

umiddelbart over kote 100 .

$200 \quad 14,2$ I hovedelven i Hellisdalur.

Typiske lejringsforhold: storkornet feldspatbasalt; ca. $3 / 4 \mathrm{~m}$ rød tuf; tæt biå basalt. Horisontbasalten er her i området 3-delt med tuf imellem. Mægtigheden er stor.

Typisk.

Hjarðardalur over kote 140.

2338,8 Vest for Landsuð̛urknúkur Typisk lejring. umiddelbart under kote 240 sydøst for Kunoyar bygd. 


\begin{tabular}{|c|c|c|c|}
\hline $\begin{array}{l}\text { H } \varnothing \text { jde } \\
\text { i m }\end{array}$ & $\begin{array}{l}\text { Målebords- } \\
\text { blad }\end{array}$ & Lokalitet & Bemærkninger \\
\hline
\end{tabular}

$240 \quad 8,5 \quad$ Nordvesthjørnet af Skarðdalur lige over trig. st. 207.

$238 \quad 8,5 \quad$ Sydlige side af Skriðudalur (under kote 450).

236 8,2 Sydsiden af Móisdalur lige over kote 180.

$237 \quad 2,7 \quad$ Umiddelbart under kote 240 på sydsiden af dalen.

$238 \quad 2,8$ Sydøsthjørnet af Ytstidalur ved kote 240 .

$228 \quad 2,8 \quad$ I syd $\varnothing$ sthjørnet af Gjóardalur ved enden af basaltbænk.

$230 \quad 8,2 \quad$ I sydøsthjørnet af Miklidalur ca. $150 \mathrm{~m}$ sydvest for kote 210 .

$225 \quad 8,5$ Sydsiden af Skarðdalur ved enden af basaltbænk.

2218,6 I gjógv med kote 220 øst for Líraskor.

$216 \quad 8,6$ I elv med kote 110 syd for Vøtnini.
Garđáir (hovedløbet), Haraldsund.
Mellem disse lokaliteter (240238) er mægtigheden meget stor. Typisk.

Grænsen rasdækket. Horisontbasalten kan herfra iagttages nordpå med ret stor mægtighed.

Grænsen er vegetationsdækket, men nogle $\mathrm{m}$ lavere ses grovkornet feldspatbasalt. Horisontbasalten er her i dalen 2delt med et tykt tuflag imellem.

I nordsiden af Ytstidalur ses horisontserien at gå ud i stejlvæggen i ca. $230 \mathrm{~m}$. Den er i Ytstidalur af ret stor mægtighed.

Typiske lejringsforhold. Ret stor mægtighed.

Typiske lejringsforhold.

Typisk. Meget stor mægtighed. Typiske lejringsforhold; stor mægtighed.

Typisk. Ret stor mægtighed. I Búơadalur (mellem 221 og 216) er horisonten vegetationsdækket. Langs Vøtnini (nord for 216) er horisontbasalten tilsyneladende manglende.

Typiske lejringsforhold. Horisontbasalten tilsyneladende manglende langs det meste af strækningen mellem de to sidste lokaliteter (216-187). 
168 14,3 I elv langs gærde med kote 140.
I området Haraldsund og syd for Haraldsund (187-168) er horisontbasalten vegetationsdækket og synes at være af ringe mægtighed. Ligeledes er den næsten helt vegetationsdækket sydpå til Kunoyarnes. Hvor den er blottet er den tynd. Ved målepunktet (168) er den tynd og porøs. Tuflaget er ca. $3 / 4 \mathrm{~m}$.

\begin{tabular}{|c|c|c|c|}
\hline $\begin{array}{l}\text { Højde } \\
\text { i m }\end{array}$ & $\begin{array}{l}\text { Målebords- } \\
\text { blad }\end{array}$ & Lokalitet & Bemærkninger \\
\hline
\end{tabular}

$0 \quad 21,3 \quad$ Ca. $800 \mathrm{~m}$ syd for Ritugjógv.

130 14,6 I elven op mod Hálsur, mellem Klakkur og Hálgafelli.

12014,6 Ved det togrenede vandl $\phi b$ indenfor den nordligste kaj.

$57 \quad 15,7 \quad$ Ved det sydlige bøgærde (vestsiden af Boröoyarvík).

$0 \quad 15,7 \quad$ Ved det lille gærde nord for Taravíkstangi.

0
15,7 $\quad$ Syd for Skálaberg (Norðoyri).
Horisonten går under havniveau.

Liggende: noget porøs basalt og længere nede storkornet feldspatbasalt. Syd for Hálsur ses storkornet feldspatbasalt umiddelbart under horisontserien. Mod syd er den ikke så stærkt markeret i terrænet som mod nord. Nord for Klakkur findes der, i lighed med Kunoyarnes, en tydelig fremtrædende bænk i terrænet under horisonten (stenbruddet).

Herfra og mod syd bliver horisontserien igen kun lidt fremtrædende i terrænet.

Liggende: tynd, rød tuf og storkornet feldspatbasalt.

Horisonten går under havniveau.

Horisonten går under havniveau. 


\begin{tabular}{|c|c|c|c|}
\hline $\begin{array}{l}\text { Højde } \\
\text { i m }\end{array}$ & $\begin{array}{l}\text { Målebords- } \\
\text { blad }\end{array}$ & Lokalitet & Bemærkninger \\
\hline
\end{tabular}

$65 \quad 15,4 \quad$ Gravará.

$120 \quad 15,1$ Ánagjógv.

$150 \quad 14,3 \quad$ Stórá.

1658,9 Svartidalur (hovedvandløbet).

$1608,6 \quad$ Krossdalsáir.

$173 \quad 8,3 \quad$ Vandløbet (med kote 136) i Húsadalur syd for Skálatoftir.

1652,9 Múlagjógv.

$1462,9 \quad \emptyset$ stnord $\varnothing$ st for trig. st. på Múlin.
Liggende: r $\varnothing$ d tuf ca. 1/2 $\mathrm{m}$ og storkornet feldspatbasalt. Horisontserien ses svagt $\mathrm{i}$ terrænet mod syd til b $\emptyset$ gærde ved Oyri, $i$ indmarken ses den ikke, men den ses igen i stranden.

Liggende: storkornet feldspatbasalt, tuf ikke synlig, da selve grænsen i elven er grusdækket. Over Myrkjanoyri (ca. $95 \mathrm{~m}$ o.h. ved Ravnagil) er horisontbasalten meget markant og ses som tre adskilte bænke. Mod syd træder den tydeligt frem i terrænet til nordsiden af Gravardalur. Mod nord, til Ánirnar, er den mindre tydelig.

Lejringen er her noget ukarakteristisk med en 1-3 m slaggeagtig bænk mellem liggende storkornet feldspatbasalt og horisontbasalten.

Liggende: en snes $\mathrm{cm}$ r $\phi \mathrm{d}$ tuf og nedad storkornet feldspatbasalt.

Liggende: tuf, rød, $20-30 \mathrm{~cm}$; nedad ukarakteristisk.

Liggende: tynd, rød tuf og nedad storkornet feldspatbasalt.

Liggende: tynd, r $\varnothing$ d tuf ca. 20 $\mathrm{cm}$ og nedad storkornet feldspatbasalt.

Lejringsforholdene karakteristiske med tuf ca. $3 / 4 \quad \mathrm{~m}$ og nedad grovkornet feldspatbasalt. Horisontbasalten har her stor mægtighed. I dalen ved Múli er grænsen vegetationsog grusdækket; det samme er tilfældet mod syd. 


\begin{tabular}{|c|c|c|c|}
\hline $\begin{array}{l}\mathrm{H} \phi j \mathrm{de} \\
\mathrm{i} \mathrm{m}\end{array}$ & $\begin{array}{l}\text { Målebords- } \\
\text { blad }\end{array}$ & Lokalitet & Bemærkninger \\
\hline 158 & 9,1 & $\begin{array}{l}\text { Elv med kote } 170 \text { i sydsiden } \\
\text { af Argisdalur. }\end{array}$ & $\begin{array}{l}\text { Ukarakteristisk lejring. Lagf } \varnothing 1 \text { - } \\
\text { ge opad: por } \varnothing \mathrm{s} \text { basalt; tuf ca. } \\
\text { 3/4 m (gråbrun); tæt blå basalt } \\
\text { (horisontbænken). }\end{array}$ \\
\hline 150 & 9,1 & Krossdalsá. & $\begin{array}{l}\text { Lagfølge opad: tyndbænket } \\
\text { ukarakteristisk basalt; tuf; tæt } \\
\text { blå basalt (horisontbænken). }\end{array}$ \\
\hline 140 & 9,4 & Fossá. & $\begin{array}{l}\text { Ukarakteristiske lejringsfor- } \\
\text { hold. Liggende: r } \varnothing \text { dt tuflag, ca. } \\
30-40 \mathrm{~cm} \text { og nedad tæt blå } \\
\text { basalt. }\end{array}$ \\
\hline 105 & 9,7 & Toftá. & $\begin{array}{l}\text { Lejringsforhold som ved } \\
\text { Fossá. }\end{array}$ \\
\hline 0 & 15,2 & $\emptyset$ stnordøst for Toftamúli. & $\begin{array}{l}\text { Horisontserien går under hav- } \\
\text { niveau. Serien består her af } 4 \\
\text { adskilte bænke med tuf imel- } \\
\text { lem. }\end{array}$ \\
\hline 0 & 15,4 & Nordsiden af Kvíingadalur. & $\begin{array}{l}\text { Horisonten går under } \\
\text { havniveau. }\end{array}$ \\
\hline 92 & 15,1 & Elven ned til Árnafjøröur. & $\begin{array}{l}\text { Liggende: tuf, rød ca. } 30-50 \\
\mathrm{~cm} \text {, nedad storkornet feldspat- } \\
\text { basalt. Horisontbasalten noget } \\
\text { afvigende i udseende. }\end{array}$ \\
\hline 0 & 15,5 & Lítlagjógv ved Múlin. & $\begin{array}{l}\text { Horisonten går under } \\
\text { havniveau. }\end{array}$ \\
\hline
\end{tabular}

\begin{tabular}{|c|c|c|c|}
\hline $\begin{array}{l}\text { Højde } \\
\text { i m }\end{array}$ & $\begin{array}{l}\text { Målebords- } \\
\text { blad }\end{array}$ & Lokalitet & Bemærkninger \\
\hline
\end{tabular}

$0 \quad 9,6$ Sydøstsiden af Viðoy. Ved elv med kote 30 på syd$\emptyset$ stsiden af $\varnothing$ en når horisonten havniveau for atter at stige umiddelbart syd for elv med kote 40 . Mellem disse to lokaliteter er der ur i stranden, så muligvis når grænsen ikke under havniveau.

$72 \quad 9,8$ Ved gærde langs elv på syd- Ukarakteristisk. Liggende: var. siden af $\phi$ en. por $\varnothing$ se basalter. 


\begin{tabular}{|c|c|c|c|}
\hline $\begin{array}{l}\text { Højde } \\
\quad \text { i m }\end{array}$ & $\begin{array}{l}\text { Målebords- } \\
\text { blad }\end{array}$ & Lokalitet & Bemærkninger \\
\hline
\end{tabular}

9,2.3.5.

6.8 .9

$1259,5 \quad$ Ved elv ned mod syd $\varnothing$ sthjørnet af indhegning syd for Sandoyri.

$150 \quad 9,1 \quad$ Gjógv i fortsættelse af Leitisgjógv.

150
3,7 Nordvesthjørnet af Malinsfjall under kote 200 .
På den sydligste del af фen optræder pludselig flere tætte blå basaltbænke under horisontbænken hvilket ofte $\mathrm{g} \emptyset \mathrm{r}$ det vanskeligt at afgøre hvad der er selve horisontbænken. Fra Botnagjógv (sydøst for Botnagjógv) på vestsiden af фen og op mod Dalá på фstsiden af фen har vi derfor valgt at trække grænseniveauet mellem den tyndbænkede mellemste basaltserie og de tykkere tætte blå basaltbænke ovenover. Fra фstsiden af Dalá til Víkará og fra Viðvík фstpå er den tyndbænkede mellemste basaltserie overlejret af en feldspatbasaltbænk. Denne grænse er på den sydligste del af øen meget tydelig; man må dog have de nævnte noget usikre forhold in mente ved en eventuel faldberegning. Grænsen er blottet fra Torvstíggjur til Gásh øvdi.

Ukarakteristisk. Liggende: porøse basalter.

Lige nord for denne lokalitet er liggende typisk: tynd, rød tuf og derunder storkornet feldspatbasalt. Dette ses også længere nordpå. Sydpå, derimod, iagttoges ingen steder den karakteristiske storkornede feldspatbasalt.

Selve grænsen er ikke blottet, men storkornet feldspatbasalt kan dog iagttages under denne. $\emptyset$ stpå er terrænet vegetationsdækket. Grænsen er her afmærket efter de sparsomme blotninger der fandtes. 
Højde Målebords-

i m blad Lokalitet Bemærkninger

1109,2 Sydlige elvforgrening i Dalá.

$969,5 \quad$ Víkará.

$2,3.6$

$3,1.4$

135

3,4 Djúpagil.

Liggende: tynd, rød tuf og derunder storkornet feldspatbasalt. Målingen foretaget ved underkant af tæt blå basaltbænk, der sandsynligvis repræsenterer horisontbænken.

Liggende: storkornet feldspatbasalt. Målingen foretaget ved underkant af tæt blå basaltbænk, sandsynligvis horisontbænken. Denne bænk kan følges østpå til elven (med »ból«) midt i Viơvík.

På den nordlige del af Viðoy, nord for Viðareiði, er fastlæggelsen af grænsen mellem mellemste basaltserie og $\emptyset$ verste basaltserie (C-horisont-niveauet) behæftet med nogen usikkerhed, idet lagfølgen ikke er karakteristisk og grænsen ikke altid lige udtalt.

Profil:

$-135 \mathrm{~m}$ feldspatbasalt

(temmelig forvitret i overfladen), tyk brændingshorisont og фverst $1 \mathrm{~m} \mathrm{r} \phi \mathrm{d}$ tuf.

135-143 m basalt med tæt blå grundmasse og spredte store feldspatstrøkorn.

143-150 $\mathrm{m}$ vegetation.

$150-170 \mathrm{~m}$ storkornet feldspatbasalt, $\emptyset$ verst tuf.

170_ $\quad$ tæt blå basalt.

Vi har valgt at sætte grænseniveauet ved $135 \mathrm{~m}$, da grænsen mellem de to serier er mest udtalt her. 
Højde Målebords-

i m blad

Lokalitet

Bemærkninger

3,1 Østsiden af Villingadals- I $\varnothing$ stsiden af Villingadalsgjógv gjógv.

må korrelationshorisontniveauet være beliggende (bestemt fra $\varsigma \varnothing$ siden efter kote 120 på kortet) i omtrent $130 \mathrm{~m}$ højde.

1153,4 Ved gærde op fra Hamars- Nedre grænse for tæt, blå bagjógv. salt med spredte feldspatstr $\varnothing$ korn (selve grænsen vegetationsdækket). Dette er utvivlsomt samme bænk som ved Djúpagil $135 \mathrm{~m}$. 


\section{Profiler}

Foruden arbejdet med at forfølge korrelationsniveauerne, der ligger omtrent i kortets plan, har vi gennemført en udstrakt opmåling af profiler, omtrent vinkelret på højdekurverne, hvor på øerne, der var mulighed for det. Dette profilarbejde har været udført gennem hele arbejdsperioden og af mange forskellige hjælpere.

Vi gjorde s. 35 opmærksom på, at vort hovedprofil var sammensat af delprofiler, at det nok var kronologisk korrekt, men at den laterale forskydning af delprofilerne, som naturen selv påtvang os, kom til at betyde, at hovedprofilet ikke er et eentydigt, lodret profil gennem lagserien. Tværtimod, kan man næsten sige, fordi vi allerede temmelig tidligt under vort arbejde blev klar over, at der var betydelige laterale forskelle i lagseriens opbygning på samme stratigrafiske niveau. Strengt taget har således det på kortet markerede hovedprofil kun gyldighed langs opmålingslinjen og dens nære omgivelser, fordi lavaer kiler ud til siden og erstattes af andre.

Med det formål at belyse de laterale forskelle har vi blandt vore mange profiler udvalgt 36 , der er temmelig jæunt fordelt over hele $\emptyset$ gruppen. Udvælgelsen med dette for $\varnothing$ je bevirker imidlertid, at profiler, der er opmålt til forskellig tid under feltarbejdet og i noget forskellig oprindelig hensigt, ikke alle lader sig bringe på helt samme form.

Hovedprofilets lavaer er alle mikroskoperet, og så vidt muligt er den kvantitative mineralsammensætning, baseret på punkttælling af de enkelte tyndslib, angivet. Da det ofte drejer sig om meget finkornede bjergarter, må den dog tages med et vist forbehold, især synes pyroxenprocenten, sammenlignet med de kemiske analyser, at være lovlig høj (Noe-NygaArd og J. Rasmussen 1968 s. 290). For nogle andre profilers vedkommende er mineralsammensætningen ligeledes angivet, men det gælder langt fra alle. Der er medtaget profiler, hvorfra prøverne er mikroskoperet, og profiler, hvor kun en håndstykkebedømmelse foreligger, samt endvidere enkelte hvor feltbestemmelsen alene er lagt til grund; den deraf følgende uensartethed vil spores i de gengivne profiler, hvoraf nogle 


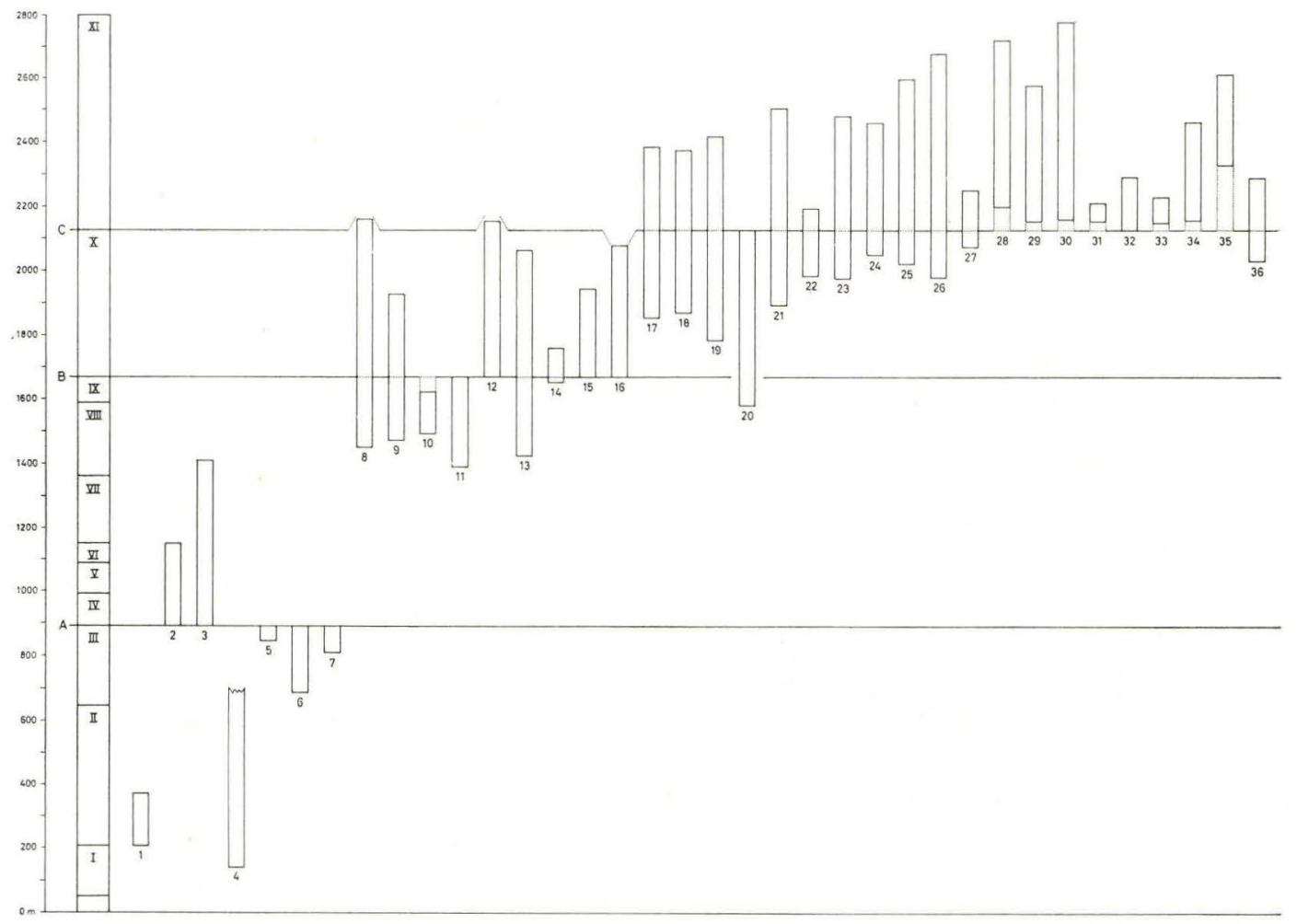

Fig. 7. Profiloversigt. Idealprofilet til venstre.

Skurðyvirlit. Meginskurðurin vinstru megin.

The 36 auxiliary profiles with the main profile to the left. 
kort og godt giver en petrografisk karakteristik af den enkelte lava og dennes plads i profilet, medens andre giver en beskrivelse af en lavas udseende i naturen samt dens omgivelser i profilet.

I de tilfælde, hvor der er foretaget bestemmelse af vægtfylden (d), er denne opgivet yderst til højre.

I fig. 7 er de 36 profiler indtegnet i nummerfølge og anbragt med reference til A, B eller C-niveauerne. Det sammensatte hovedprofil (idealprofilet) er vist yderst til venstre.

Korrelationsniveauerne tillader os nu at foretage en sammenligning mellem samtidige lavaer fra sted til sted.

Med A-niveauet som ledeplan kan vi belyse forholdene i den nederste basaltseries lavaer. Lagf $\varnothing$ lgen belyses i første række af delprofilerne I, IIa, IIb og IV, der indgår i hovedprofilet; men hertil kommer på Sưuroy profil 1, der nogenlunde dækker samme tidsrum som den nedre halvdel af profil IIa, samt profilerne 4, 5, 6 og 7, der belyser lagfølgen: Mykines-Tindhólmur - det vestlige Vágar fra vest mod $\varnothing$ st. Særlig kan vi bed $\varnothing$ mme de $\varnothing$ verste dele af den nederste basaltserie (III, 5, 6 og 7) lige under A-niveauet.

Den porfyritiske $\varnothing$ verste lavabænk i profil III findes ikke i 5, 6 og 7; det var på grund af den store indbyrdes afstand - på ca. 60 km - mellem Suðuroy og den nordlige фgruppe måske næppe heller at vente. Den $\varnothing$ verste lavabænk i 5 og 6 synes derimod at være den samme, men udviklet med forskellig tykkelse i de to profiler. Profil 7 viser atter en anden type.

Dette kunne enten betyde, at erosionen var nået til noget forskellig dybde i plateauet, eller måske snarere at overfladen primært har bestået af forskellige lavastr $\varnothing m m e$ på det tidspunkt, vulkanismen for en tid ophører for at gøre plads for den kulførende series dannelse.

Vi kan også anvende A-niveauet som udgangsplan for sammenligninger opad i lagserien forsåvidt angår den mellemste basaltseries nedre halvdel, d. v. s. hovedprofilerne IV til VIII på Vágar og profilerne 2 og 3 på Suðuroy.

Det har ved denne sammenligning ikke vist sig muligt at korrelere een eneste lavabænk fra profilerne i nord med en mulig tilsvarende fra profilerne i syd, derimod ses det, at mere markante omslag i bjergartsbeskaffenheden i store træk følges ad i tid. Der eksisterer imidlertid een iøjnefaldende forskel i beskaffenheden af de porfyritiske basalter i det nordlige og det sydlige område: i nord er de smuldrende og særdeles vanskelige at tage friske prøver i, mod syd 
er de hårde og kompakte, af hvilken grund prøvetagning her ikke har voldt vanskeligheder.

Den samme fremgangsmåde for sammenligninger mellem samtidige lavaer fra sted til sted har vi også forsøgt med B- og C-niveauerne som udgangsplaner.

Der er i denne forbindelse grund til at gøre opmærksom på nogle tilsyneladende uregelmæssigheder med hensyn til profilerne 8,12 , 16 og 20 i skemaet, fig. 7.

I profil 8, Malinstindur på Vágar mangler C-niveauets lava. Det samme gælder for profil 12, Ørviksfelli på det nordlige Streymoy, der med udgang i B-niveauet er målt opad uden at nå C-niveauet. Dette må enten betyde, at mægtigheden af lagserien mellem de to korrelationsniveauer her er større end de $450 \mathrm{~m}$, som hovedprofilet viser, eller at C-niveauets lava(er) ved fremtrængningen ikke er nået så langt vestpå.

Profil 16, Gjógvin ligger 5-6 km længere фstpå på det midterste Streymoy. Profilopmålingen begynder på B-niveauet og ender ved C-niveauet. På dette sted er afstanden mellem de to korrelationsniveauer omtrent $50 \mathrm{~m}$ mindre end i hovedprofilet.

I profil 20, Miðalfelli (Títlá) på det nordlige Eysturoy, der opad afsluttes med C-niveauet, har den karterende geolog ikke ment at have truffet B-niveauet endnu ved profilets nedre afslutning. Deri har han muligvis helt ret, men i så fald er afstanden imellem de to korrelationshorisonter på dette sted over 100 m større end i hovedprofilet. Ved en fornyet gennemgang af profilerne har vi dog noteret os tre lavabænke nederst i profilet, af hvilke måske een kunne være B-horisontens lava; vi har derfor ladet begge muligheder stå åbne, da vi tegnede profilet.

De fremdragne eksempler på uregelmæssigheder understreger vanskelighederne ved at arbejde stratigrafisk i et område, der er bygget op af linseformede elementer - endnu for st $\varnothing$ rstedelen med ukendt afgrænsning - samt den forsigtighed, hvormed man må gå frem ved anvendelsen af rent petrografiske kriterier.

Generelt set har vi imidlertid konstateret, at tætte, blålige olivinførende basalter opad i lagserien tiltager i mængde i nordlig og især i $\varnothing$ stlig retning indenfor $\emptyset$ gruppen. 


\section{Hovedprofilet}

\begin{tabular}{cccccccccc}
\hline $\begin{array}{c}\text { Prøve } \\
\text { nr. }\end{array}$ & Højde & i m & Bjergartstype & $\begin{array}{c}\% \\
\text { p1. }\end{array}$ & $\begin{array}{c}\% \\
\text { cpx. }\end{array}$ & $\begin{array}{c}\% \\
\text { ore }\end{array}$ & $\begin{array}{c}\% \\
\text { ol }\end{array}$ & $\begin{array}{c}\begin{array}{c}\% \\
\text { g1. }\end{array} \\
\text { gap. }\end{array}$ & d. \\
\hline
\end{tabular}

\section{Profil 1}

$10-15$ Afyrisk basalt

2 15- 30 Kryptofyrisk

basalt

2a 70 - 95 Kryptofyrisk

basalt

$\begin{array}{lll}40 & 38 \quad 15\end{array}$

7

3 95-105 Afyrisk basalt

4 105-140 Porfyritisk basalt

5 140-160 Kryptofyrisk

basalt

$\begin{array}{rrr}38 & 36 & 8 \\ 34 & 43 & 14 \\ 36 & 49 & 4 \\ 36 & 45 & 8 \\ & & \\ 39 & 40 & 9\end{array}$

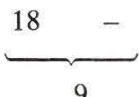

9

$11-$

$11-$

93

Profil II a

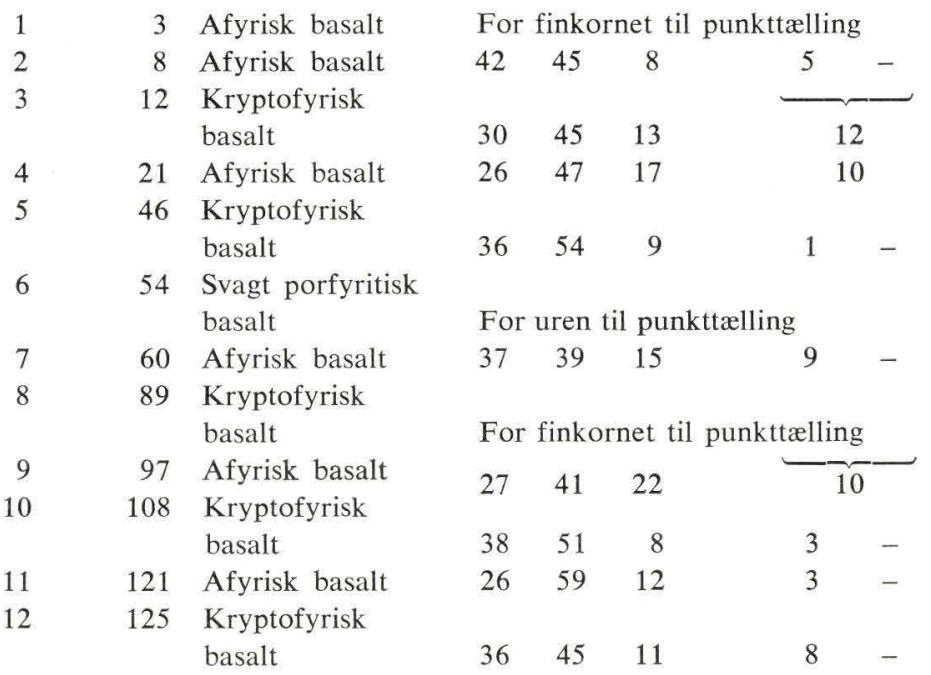

* Forkortelserne i kolonnerne over den kvantitative mineralsammensætning er følgende:

pl. = plagioklas

cpx. $=$ clinopyroxen (d.v.s. augit og/eller pigeonit)

ore $\quad=$ malm (magnetit og/eller ilmenit)

ol $=$ olivin

gl. $=$ glas

gap $=$ green alteration products - d.v.s. gr $\varnothing$ nne alterations $(=$ omdannelses) produkter

d. = densitet, d.v.s. vægtfylde (massefylde).

De internationale betegnelser er valgt for at lette adgangen til materialet. 


\begin{tabular}{|c|c|c|c|c|c|c|c|c|c|}
\hline $\begin{array}{c}\text { Pr } \phi \text { ve } \\
\text { nr. }\end{array}$ & $\begin{array}{c}\text { Højde } \\
\text { i m }\end{array}$ & Bjergartstype & $\begin{array}{l}\% \\
\text { pl. }\end{array}$ & $\begin{array}{c}\% \\
\text { cpx. }\end{array}$ & $\begin{array}{l}\% \\
\text { ore }\end{array}$ & $\begin{array}{l}\% \\
\text { ol }\end{array}$ & $\begin{array}{l}\% \\
\text { gl. }\end{array}$ & $\begin{array}{c}\% \\
\text { gap. }\end{array}$ & d. \\
\hline
\end{tabular}

\section{Profil $11 b$}

14157 Svagt porfyritisk

basalt

16197 Svagt porfyritisk basalt

$18 \quad 221$ Svagt porfyritisk basalt

19236 Svagt porfyritisk basalt

For tæt pigmenteret til punkttælling

$41 \quad 43 \quad 6$

10

$\begin{array}{lll}33 & 48 & 9\end{array}$

$\begin{array}{lll}37 & 49 & 8\end{array}$

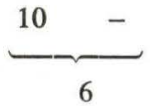

$20 \quad 275$ Kryptofyrisk basalt

$254321^{*}$

11

21285 Kryptofyrisk basalt

$22 \quad 295$ Kryptofyrisk basalt

23

330 Kryptofyrisk basalt

24

355 Afyrisk basalt

$\begin{array}{lll}31 & 53 & 15\end{array}$

$\begin{array}{lll}44 & 45 & 8\end{array}$

For omdannet til punkttælling

$$
37 \quad 49 \quad 12 * *
$$

2

\section{Profil III}

1 0- 20 Kryptofyrisk basalt

2 20- 36 Kryptofyrisk basalt

3 36- 45 Kryptofyrisk basalt

4 45- 60 Kryptofyrisk basalt $\begin{array}{lll}46 & 32 & 11\end{array}$

$-\quad 11$

$\begin{array}{lll}32 & 42 \quad 6\end{array}$

$4 \quad 13$

$\begin{array}{lll}32 & 48 & 25\end{array}$

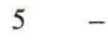

$\begin{array}{lll}36 & 36 & 14\end{array}$

$-\quad 14$

5 60- 95 Porfyritisk basalt

$\begin{array}{lll}37 & 30 & 16\end{array}$

$-\quad 17$

$6 \quad 95-148$ Kryptofyrisk basalt

3

7 148-166 Porfyritisk basalt

8 166-192 Afyrisk basalt $39 \quad 38 \quad 11 * *$

$-12$

$\begin{array}{lll}43 & 39 \quad 6\end{array}$

$-12$

$\begin{array}{lll}36 & 49 \quad 6\end{array}$

$-9$

9 198-226 Kryptofyrisk basalt 3

10 230-245 Porfyritisk basalt

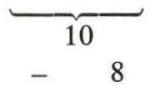

* heri indregnet en udbredt forekommende pigmenteringssubstans.

** omfatter tillige rustringe omkring malmkornene. 


\begin{tabular}{|c|c|c|c|c|c|c|c|c|c|}
\hline $\begin{array}{c}\text { Pr } \phi \text { ve } \\
\text { nr. }\end{array}$ & $\begin{array}{l}\text { Højde } \\
\text { i m }\end{array}$ & Bjergartstype & $\begin{array}{l}\% \\
\text { pl. }\end{array}$ & $\begin{array}{c}\% \\
\text { cpx. }\end{array}$ & $\begin{array}{l}\% \\
\text { ore }\end{array}$ & $\begin{array}{l}\% \\
\text { ol }\end{array}$ & $\begin{array}{l}\% \\
\text { gl. }\end{array}$ & $\begin{array}{c}\% \\
\text { gap. }\end{array}$ & d. \\
\hline
\end{tabular}

\section{Profil IV}

\begin{tabular}{|c|c|c|c|c|c|c|c|c|c|}
\hline 1 & 32 & Kryptofyrisk basalt & 33 & 46 & 8 & - & 13 & - & 2,87 \\
\hline 2 & 45 & Olivinporfyritisk & & & & & & & \\
\hline & & basalt & 25 & 54 & 4 & 14 & - & - & 2,90 \\
\hline 3 & 56 & $\begin{array}{l}\text { Ganske fint } \\
\text { plagioklas - }\end{array}$ & & & & & & & \\
\hline & & porfyritisk basalt & 29 & 54 & 10 & - & 7 & - & 2,82 \\
\hline 4 & 66 & Afyrisk basalt & 20 & 47 & 8 & - & 18 & 7 & 2,71 \\
\hline 5 & 70 & Afyrisk basalt & 19 & 46 & $\begin{array}{r}10^{*} \\
+7)\end{array}$ & - & 18 & - & 2,84 \\
\hline 6 & 73 & Afyrisk basalt & 29 & 56 & 6 & - & 9 & - & 2,84 \\
\hline 7 & 76 & $\begin{array}{l}\text { Kryptofyrisk } \\
\text { basalt }\end{array}$ & 28 & 54 & 5 & - & 13 & - & 2,68 \\
\hline 8 & 82 & $\begin{array}{l}\text { Ganske fint } \\
\text { plagioklas - } \\
\text { porfyritisk basalt }\end{array}$ & 35 & 53 & 5 & 3 & 4 & - & 2,94 \\
\hline 9 & 91 & $\begin{array}{l}\text { Kryptofyrisk } \\
\text { basalt** }\end{array}$ & & & & & & & 2,70 \\
\hline 10 & 97 & $\begin{array}{l}\text { Olivinporfyritisk } \\
\text { basalt }\end{array}$ & 27 & 48 & 5 & 18 & - & 2 & 2,92 \\
\hline & 100 & $\begin{array}{l}\text { Olivinporfyritisk } \\
\text { basalt }\end{array}$ & 22 & 46 & 4 & 28 & - & - & 2,96 \\
\hline
\end{tabular}

\section{Profil V}

1

80 Olivinporfyritisk

$$
\text { basalt }
$$

$19 \quad 56 \quad 11$

$14-\quad-\quad 2,88$

2

105 Plagioklasporfyritisk basalt

$42 \quad 44$

$7 \quad-$

$7 \quad-2,83$

3

136 Olivinporfyritisk basalt

$\begin{array}{lllll}32 & 46 & 5 & 12 & 5\end{array}$

\section{Profil VI}

1

2

3

128 Fint porfyritisk

basalt (pl.cpx.ol.)

153 Olivinporfyritisk

basalt

188 Olivinporfyritisk

basalt

$$
\begin{array}{lllllll}
36 & 54 & 5 & 4 & 1 & - & 2,97 \\
35 & 53 & 4 & 8 & - & - & 2,77 \\
40 & 37 & 4 & 14 & 5 & - & 2,91
\end{array}
$$

* pigmenterede felter, som er opake (7\%), er talt med under malm.

** Bjergarten er for finkornet til at tillade punkttælling. 


\begin{tabular}{|c|c|c|c|c|c|c|c|c|c|}
\hline $\begin{array}{c}\text { Prøve } \\
\text { nr. }\end{array}$ & $\begin{array}{c}\text { Højde } \\
\text { i m }\end{array}$ & Bjergartstype & $\begin{array}{l}\% \\
\text { pl. }\end{array}$ & $\begin{array}{c}\% \\
\text { cpx. }\end{array}$ & $\begin{array}{l}\% \\
\text { ore }\end{array}$ & $\begin{array}{l}\% \\
\text { ol }\end{array}$ & $\begin{array}{l}\% \\
\text { gl. }\end{array}$ & $\begin{array}{c}\% \\
\text { gap. }\end{array}$ & d. \\
\hline
\end{tabular}

Profil VII

1264 Plagioklas-

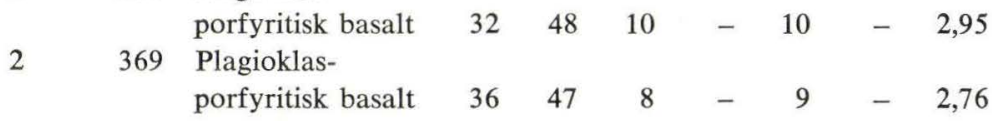

\section{Profil VIII}

\begin{tabular}{|c|c|c|c|c|c|c|c|c|c|}
\hline 1 & 244 & $\begin{array}{l}\text { Fint porfyritisk } \\
\text { basalt }\end{array}$ & 53 & 35 & 10 & - & 2 & - & 2,91 \\
\hline 2 & 255 & Afyrisk basalt & 61 & 29 & 8 & - & 2 & - & 2,86 \\
\hline 3 & 340 & $\begin{array}{l}\text { Plagioklas- } \\
\text { porfyritisk basalt }\end{array}$ & 46 & 45 & 5 & - & 4 & - & 2,90 \\
\hline 4 & 488 & $\begin{array}{l}\text { Plagioklas- } \\
\text { porfyritisk basalt }\end{array}$ & 61 & 23 & 5 & - & 9 & - & 2,70 \\
\hline 5 & 505 & Afyrisk basalt & 29 & 53 & 9 & - & 9 & - & 2,79 \\
\hline
\end{tabular}

\section{Profil IX}

$1 \quad 370 \quad$ Plagioklas-

2388 Fint porfyritisk

basalt (pl. ol. ore) $\quad \begin{array}{lllllll}36 & 48 & 10 & 6 & - & - & 2,73\end{array}$

Profil $X$

2181 Plagioklas-

4194 porfyritisk basal

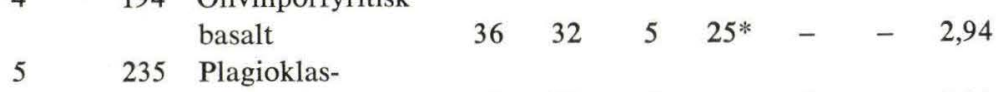

$\begin{array}{lllllll}\text { porfyritisk basalt } & 51 & 38 & 5 & - & 6\end{array}$

6318 Plagioklas-

$8 \quad 332$ Plagioklas-

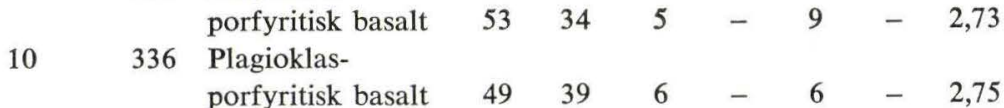

11411 Fint porfyritisk

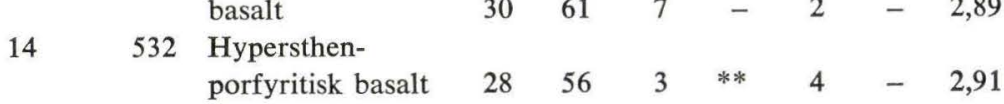

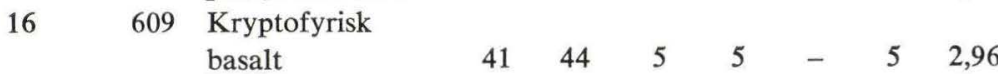

* Inkl. $2 \%$ serp.

** hy. $9 \%$. 


\begin{tabular}{|c|c|c|c|c|c|c|c|c|c|}
\hline $\begin{array}{c}\text { Prøve } \\
\text { nr. }\end{array}$ & $\begin{array}{c}\text { Højde } \\
\text { i m }\end{array}$ & Bjergartstype & $\begin{array}{l}\% \\
\text { pl. }\end{array}$ & $\begin{array}{c}\% \\
\text { cpx. }\end{array}$ & $\begin{array}{l}\% \\
\text { ore }\end{array}$ & $\begin{array}{l}\% \\
\text { ol }\end{array}$ & $\begin{array}{c}\% \\
\text { gl. }\end{array}$ & $\begin{array}{l}\% \\
\text { gap. }\end{array}$ & d. \\
\hline
\end{tabular}

Profil XI a

$1 \quad 171-178$ Olivinporfyritisk

\begin{tabular}{|c|c|c|c|c|c|c|c|}
\hline & 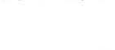 & basalt & 40 & 41 & 4 & 13 & - \\
\hline 2 & $179-185$ & $\begin{array}{l}\text { Olivinporfyritisk } \\
\text { basalt }\end{array}$ & 38 & 37 & 3 & 22 & - \\
\hline 3 & $187-195$ & $\begin{array}{l}\text { Kryptofyrisk } \\
\text { basalt }\end{array}$ & 48 & 41 & 6 & 5 & - \\
\hline 4 & 197 & $\begin{array}{l}\text { Olivinporfyritisk } \\
\text { basalt }\end{array}$ & 41 & 43 & 9 & 7 & - \\
\hline & 231 & Afyrisk basalt* & & & & & \\
\hline
\end{tabular}

Profil $X I b$

6245 Plagioklasporfyritisk basalt $\begin{array}{lllllll}48 & 43 & 5 & - & 4\end{array}$

7 277-293 Plagioklasporfyritisk basalt $\begin{array}{lllllll}37 & 50 & 10 & - & 3 & -\end{array}$

8 293-303 Plagioklasporfyritisk basalt $49 \quad 31 \begin{array}{r}7^{* *} \\ (+6)\end{array}$

9304 Plagioklasporfyritisk basalt $\begin{array}{lllllll}48 & 42 & 5 & - & 5 & -\end{array}$

$10 \quad 328$ Kryptofyrisk basalt

11 355-359 Plagioklas$\begin{array}{lllll}36 & 44 \quad 10 & - & 10\end{array}$ $\begin{array}{lllllll}\text { porfyritisk basalt } & 50 & 31 & 13 & 1 & 5 & -\end{array}$

12 390-409 Plagioklasporfyritisk basalt $\begin{array}{llllll}36 & 49 & 11 & -\end{array}$

\section{Profil XI c}

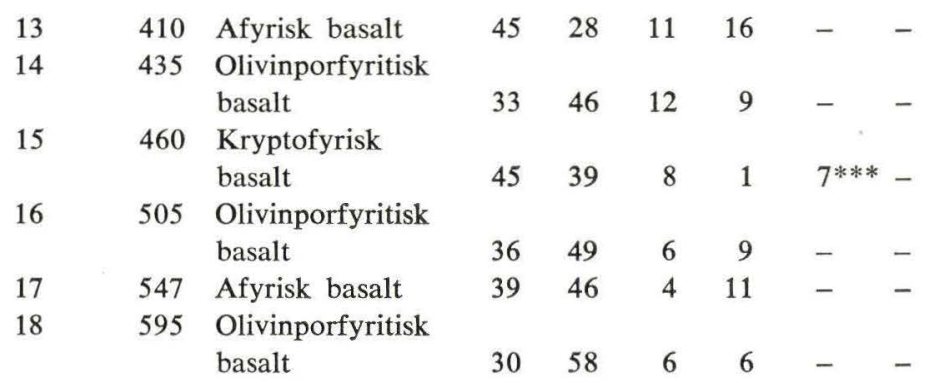

* For finkornet til punkttælling.

$* *+6 \%$ opakt pigment.

*** Pigmenterede interstitier med små, brunlige glaspletter i. 


\begin{tabular}{|c|c|c|c|c|c|c|c|c|c|}
\hline $\begin{array}{l}\text { Prøve } \\
\text { nr. }\end{array}$ & $\begin{array}{l}\text { Højde } \\
\text { i m }\end{array}$ & Bjergartstype & $\begin{array}{l}\% \\
\text { pl. }\end{array}$ & $\begin{array}{c}\% \\
\text { cpx. }\end{array}$ & $\begin{array}{l}\% \\
\text { ore }\end{array}$ & $\begin{array}{l}\% \\
\text { ol }\end{array}$ & $\begin{array}{l}\% \\
\text { gl. }\end{array}$ & $\begin{array}{l}\% \\
\text { gap. }\end{array}$ & d. \\
\hline 19 & 655 & $\begin{array}{l}\text { Olivinporfyritisk } \\
\text { basalt }\end{array}$ & 33 & 58 & 5 & 4 & - & - & \\
\hline 20 & 704 & $\begin{array}{l}\text { Fint porfyritisk } \\
\text { basalt }\end{array}$ & 30 & 56 & 10 & 1 & 3 & - & \\
\hline 21 & 735 & $\begin{array}{l}\text { Olivinporfyritisk } \\
\text { basalt }\end{array}$ & 30 & 55 & 10 & 4 & 1 & - & \\
\hline 22 & 775 & $\begin{array}{l}\text { Fint porfyritisk } \\
\text { basalt }\end{array}$ & 36 & 53 & 9 & 2 & 1 & - & \\
\hline 23 & 864 & $\begin{array}{l}\text { Plagioklas- } \\
\text { porfyritisk basalt }\end{array}$ & 40 & 46 & 6 & - & 8 & - & \\
\hline
\end{tabular}




\section{Kemiske analyser af hovedprofilets bjergarter}

(Chemical analyses of the samples from the main profile)

I hovedtekstens forskellige afsnit er indføjet en række kemiske bjergartsanalyser, der allerede forefandtes i den foreliggende litteratur; men her til kommer en række nye analyser, der er blevet udført specielt til dette arbejde af civilingeniør Me Mouritzen, således at de tre hovedafdelingers bjergartsserier, gange, uregelmæssige intrusiver og sills har kunnet belyses på relevant măde.

I efterf $\varnothing$ lgende tabel offentligg $\varnothing$ res et sæt kemiske analyser, der dækker hele hovedprofilet gennem den færøske lagrække. De første fem analyser er udført af lic. techn. Ib Sørensen som »rapidanalyser «, de $\varnothing$ vrige er r $\varnothing$ ntgenfluorescensanalyser, udf $\varnothing r t$ under hans tilsyn, men med supplerende »våd vej«s analyser af alkalier samt af divalent og trivalent jern; disse bestemmelser er udført af $\mathrm{Me}$ Mouritzen. Desuden har cand, real. Haldis Bollingberg udført spektralanalyser af mangan i forbindelse med bestemmelsen af en række sporelementer. De dobbeltbestemmelser af kalium og mangan, som ved de anvendte fremgangsmåder er blevet mulig viser god overensstemmelse indbyrdes.

Når der ikke overalt er angivet samme antal decimaler i analyserne, beror det på, at flere af værdierne i analysekolonnerne er bestemt ved anden metodik end røntgenfluorescens.

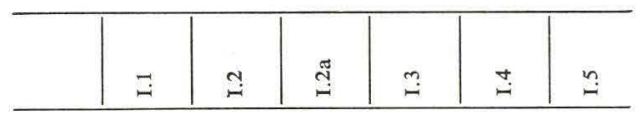

$\begin{array}{lllllll}\mathrm{SiO}_{2} & 48.56 & 46.73 & 47.08 & 49.44 & 47.89 & 48.44\end{array}$

$\begin{array}{lllllll}\mathrm{TiO} & 3.54 & 2.98 & 2.98 & 3.32 & 2.20 & 3.02\end{array}$

$\begin{array}{lllllll}\mathrm{Al}_{2} \mathrm{O}_{3} & 11.88 & 12.70 & 12.76 & 12.11 & 13.21 & 12.29\end{array}$

$\begin{array}{lllllll}\mathrm{Fe}_{2} \mathrm{O}_{3} & 10.13 & 5.53 & 5.46 & 5.09 & 5.46 & 5.75\end{array}$

$\mathrm{FeO}$

6.10

8.72

8.82

9.67

$8.54 \quad 8.97$

$\mathrm{MnO}$

0.18

0.25

0.22

0.20

$\begin{array}{ll}0.21 & 0.22\end{array}$

$\mathrm{MgO}$

$\begin{array}{lll}4.45 & 5.85 & 5.65\end{array}$

$\begin{array}{lll}9.30 & 10.45 & 10.50\end{array}$

4.75

$5.45 \quad 5.40$

Cao

2.6

2.73

2.73

$\begin{array}{llll}9.55 & 11.35 & 10.30\end{array}$

$\mathrm{Na}_{2} \mathrm{O}$

0.7

0.52

0.38

0.31

0.58

2.62

$2.43 \quad 2.56$

$\begin{array}{lll}0.52 & 0.33 & 0.40\end{array}$

$\mathrm{P}_{2} \mathrm{O}_{5}$

1.58

$99.42 \quad 99.18 \quad 99.57 \quad 99.6199 .93 \quad 99.86$

\begin{tabular}{|c|c|c|c|c|c|c|}
\hline & $\Xi$ & $\stackrel{1}{\sim}$ & 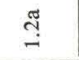 & $\stackrel{m}{-}$ & $\stackrel{ \pm}{-}$ & $\dddot{n}$ \\
\hline$q$ & 10.8 & 1.8 & 2.0 & 7.5 & 3.8 & 5.7 \\
\hline or & 4.3 & 3.2 & 3.5 & 3.2 & 2.0 & 2.4 \\
\hline$a b$ & 22.6 & 23.9 & 23.8 & 22.7 & 21.1 & 22.2 \\
\hline an & 19.0 & 21.6 & 21.5 & 20.2 & 24.8 & 21.4 \\
\hline ne & 0.0 & 0.0 & 0.0 & 0.0 & 0.0 & 0.0 \\
\hline ap & 0.9 & 0.8 & 0.8 & 0.9 & 0.6 & 0.7 \\
\hline en & 2.1 & 7.2 & 6.7 & 6.1 & 6.1 & 6.3 \\
\hline fs & 0.0 & 3.4 & 3.4 & 4.3 & 3.6 & 3.4 \\
\hline di & 19.9 & 24.2 & 24.4 & 21.2 & 25.5 & 23.5 \\
\hline fo & 0.0 & 0.0 & 0.0 & 0.0 & 0.0 & 0.0 \\
\hline $\mathrm{fa}$ & 0.0 & 0.0 & 0.0 & 0.0 & 0.0 & 0.0 \\
\hline $\mathrm{mt}$ & 10.2 & 8.3 & 8.2 & 7.6 & 8.1 & 8.5 \\
\hline $\mathrm{hm}$ & 3.3 & 0.0 & 0.0 & 0.0 & 0.0 & 0.0 \\
\hline il & 6.9 & 5.9 & 5.8 & 6.5 & 4.3 & 5.9 \\
\hline
\end{tabular}




\begin{tabular}{|c|c|c|c|c|c|c|c|c|c|c|c|}
\hline $\overrightarrow{\mathrm{g}}$ & $\stackrel{\text { ָี }}{=}$ & 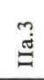 & $\begin{array}{l}+ \\
\stackrel{\Xi}{\Xi}\end{array}$ & $\stackrel{n}{\stackrel{n}{\Xi}}$ & $\begin{array}{l}0 \\
\stackrel{\Xi}{=}\end{array}$ & 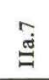 & $\begin{array}{l}\infty \\
\Xi \\
\Xi\end{array}$ & 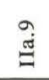 & $\begin{array}{l}\stackrel{0}{0} \\
\stackrel{0}{=}\end{array}$ & $=$ & $\stackrel{\Xi}{\Xi}$ \\
\hline
\end{tabular}

$\begin{array}{lllllllllllll}\mathrm{SiO}_{2} & 53.5 & 47.2 & 47.5 & 50.0 & 46.8 & 46.6 & 51.18 & 49.5 & 46.2 & 51.8 & 47.0 & 47.0\end{array}$ $\begin{array}{lllllllllllll}\mathrm{TiO}_{2} & 3.7 & 2.9 & 3.6 & 2.8 & 3.3 & 3.3 & 3.2 & 3.0 & 2.1 & 2.8 & 2.7 & 2.4\end{array}$ $\begin{array}{lllllllllllll}\mathrm{Al}_{2} \mathrm{O}_{3} & 10.9 & 12.2 & 11.3 & 13.5 & 11.9 & 11.9 & 12.2 & 12.9 & 12.2 & 13.9 & 12.4 & 13.3\end{array}$ $\begin{array}{llllllllllll}\mathrm{Fe}_{2} \mathrm{O}_{3} \\ 16.8 * & 8.2 & 5.2 & 7.7 & 7.8 & 8.1 & 8.5 & 17.5 & 9.9 & 4.3 & 7.6 & 9.3\end{array}$

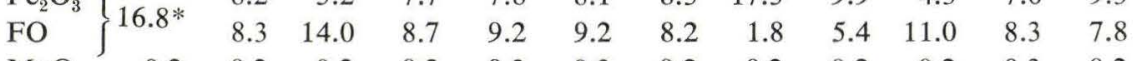
$\begin{array}{lllllllllllll}\mathrm{MnO} & 0.2 & 0.2 & 0.2 & 0.2 & 0.3 & 0.3 & 0.2 & 0.2 & 0.2 & 0.2 & 0.3 & 0.2\end{array}$ $\begin{array}{lllllllllllll}\mathrm{MgO} & 4.3 & 6.8 & 6.1 & 5.3 & 6.8 & 7.1 & 5.0 & 6.8 & 8.1 & 5.0 & 7.4 & 5.8\end{array}$ $\begin{array}{lllllllllllll}\mathrm{CaO} & 7.0 & 10.9 & 9.6 & 10.1 & 10.8 & 10.5 & 9.4 & 10.0 & 11.3 & 10.6 & 11.2 & 10.9\end{array}$ $\begin{array}{lllllllllllll}\mathrm{Na}_{2} \mathrm{O} & 3.4 & 2.1 & 2.6 & 2.4 & 2.2 & 2.2 & 2.4 & 2.7 & 2.1 & 2.4 & 2.3 & 2.4\end{array}$ $\begin{array}{lllllllllllll}\mathrm{K}_{2} \mathrm{O} & 0.8 & 0.2 & 0.3 & 0.5 & 0.4 & 0.4 & 0.4 & 0.5 & 0.2 & 0.5 & 0.3 & 0.3\end{array}$

* all iron stated as $\mathrm{Fe}_{2} \mathrm{O}_{3}$

\begin{tabular}{lrrrrrrrrrr} 
q & 5.6 & 0.7 & 7.6 & 3.6 & 3.4 & 12.6 & 4.1 & 5.8 & 2.3 & 4.9 \\
or & 1.2 & 1.8 & 2.9 & 2.4 & 2.4 & 2.3 & 1.2 & 2.9 & 1.8 & 1.8 \\
ab & 18.0 & 21.9 & 20.1 & 11.7 & 18.7 & 20.1 & 18.2 & 19.8 & 19.6 & 20.4 \\
an & 23.5 & 18.2 & 24.3 & 21.5 & 21.5 & 21.1 & 23.8 & 25.1 & 22.7 & 24.8 \\
ne & 0.0 & 0.0 & 0.0 & 0.0 & 0.0 & 0.0 & 0.0 & 0.0 & 0.0 & 0.0 \\
ap & 0.0 & 0.0 & 0.0 & 0.0 & 0.0 & 0.0 & 0.0 & 0.0 & 0.0 & 0.0 \\
en & 7.6 & 9.3 & 6.1 & 7.7 & 8.7 & 4.7 & 8.5 & 6.8 & 8.6 & 5.3 \\
fs & 1.8 & 9.6 & 2.5 & 2.5 & 2.6 & 1.2 & 0.0 & 6.7 & 2.4 & 1.1 \\
di & 24.8 & 24.2 & 20.3 & 25.9 & 24.6 & 19.9 & 26.1 & 21.7 & 26.4 & 23.5 \\
fo & 0.0 & 0.0 & 0.0 & 0.0 & 0.0 & 0.0 & 0.0 & 0.0 & 0.0 & 0.0 \\
fa & 0.0 & 0.0 & 0.0 & 0.0 & 0.0 & 0.0 & 0.0 & 0.0 & 0.0 & 0.0 \\
mt & 12.0 & 7.5 & 11.0 & 11.4 & 11.8 & 12.2 & 12.3 & 0.0 & 0.0 & 0.0 \\
hm & 0.0 & 0.0 & 0.0 & 0.0 & 0.0 & 0.0 & 1.7 & 0.0 & 0.0 & 0.0 \\
il & 5.6 & 6.8 & 5.3 & 6.3 & 6.3 & 6.0 & 4.1 & 5.2 & 5.2 & 4.6 \\
\hline
\end{tabular}




\begin{tabular}{|c|c|c|c|c|c|c|c|c|c|}
\hline & $\begin{array}{l} \pm \\
\geqq\end{array}$ & $\begin{array}{l}\frac{0}{0} \\
\cong\end{array}$ & $\frac{\infty}{0}$ & $\begin{array}{l}\stackrel{0}{0} \\
ٍ\end{array}$ & $\begin{array}{l}\text { กิ } \\
\stackrel{\Xi}{ }\end{array}$ & $\begin{array}{l}\bar{N} \\
\stackrel{\Xi}{ }\end{array}$ & $\begin{array}{l}\text { ָे } \\
\stackrel{\Xi}{0}\end{array}$ & $\begin{array}{l}\tilde{n} \\
\stackrel{\Xi}{\Xi}\end{array}$ & $\begin{array}{l}\underset{J}{D} \\
\stackrel{\Xi}{ }\end{array}$ \\
\hline $\mathrm{SiO}_{2}$ & 46.8 & 47.0 & 47.0 & 50.6 & 48.0 & 47.8 & 48.4 & 51.2 & 52.5 \\
\hline $\mathrm{TiO}_{2}$ & 2.2 & 2.2 & 2.4 & 2.5 & 2.8 & 2.9 & 2.6 & 3.4 & 2.7 \\
\hline $\mathrm{Al}_{2} \mathrm{O}_{3}$ & 13.4 & 13.9 & 13.0 & 13.6 & 13.0 & 13.7 & 14.1 & 13.9 & 14.1 \\
\hline $\mathrm{Fe}_{2} \mathrm{O}_{3}$ & 8.7 & 7.5 & 6.9 & 6.2 & 9.6 & 9.3 & 8.9 & 4.2 & 5.1 \\
\hline $\mathrm{FeO}$ & 6.8 & 8.0 & 8.5 & 9.0 & 6.3 & 7.2 & 5.6 & 11.8 & 10.0 \\
\hline $\mathrm{MnO}$ & 0.2 & 0.2 & 0.2 & 0.2 & 0.2 & 0.4 & 0.2 & 0.2 & 0.2 \\
\hline $\mathrm{MgO}$ & 6.8 & 6.6 & 6.4 & 5.6 & 7.1 & 6.0 & 5.8 & 4.8 & 4.5 \\
\hline $\mathrm{CaO}$ & 10.9 & 11.6 & 11.2 & 10.6 & 10.4 & 10.5 & 10.7 & 10.3 & 9.9 \\
\hline $\mathrm{Na}_{2} \mathrm{O}$ & 2.3 & 2.0 & 2.2 & 2.4 & 2.5 & 2.4 & 2.4 & 2.3 & 2.5 \\
\hline $\mathrm{K}_{2} \mathrm{O}$ & 0.2 & 0.2 & 0.3 & 0.6 & 0.6 & 0.6 & 0.4 & 0.7 & 0.7 \\
\hline q & 4.5 & 3.9 & 3.4 & 5.8 & 4.6 & 5.3 & 7.1 & 5.4 & 7.8 \\
\hline or & 1.2 & 1.2 & 1.8 & 3.5 & 3.5 & 3.5 & 2.4 & 4.0 & 4.1 \\
\hline$a b$ & 19.8 & 17.1 & 19.0 & 20.0 & 21.1 & 20.1 & 20.5 & 18.9 & 20.7 \\
\hline an & 26.1 & 28.6 & 25.2 & 24.3 & 22.4 & 24.6 & 26.8 & 24.8 & 24.6 \\
\hline ne & 0.0 & 0.0 & 0.0 & 0.0 & 0.0 & 0.0 & 0.0 & 0.0 & 0.0 \\
\hline ap & 0.0 & 0.0 & 0.0 & 0.0 & 0.0 & 0.0 & 0.0 & 0.0 & 0.0 \\
\hline en & 7.7 & 8.0 & 7.5 & 6.7 & 7.1 & 5.8 & 4.9 & 6.7 & 6.0 \\
\hline fs & 0.9 & 2.6 & 3.0 & 3.7 & 0.0 & 0.6 & 0.0 & 7.3 & 5.3 \\
\hline di & 22.8 & 23.6 & 25.3 & 22.5 & 22.6 & 21.3 & 20.9 & 20.6 & 19.3 \\
\hline fo & 0.0 & 0.0 & 0.0 & 0.0 & 0.0 & 0.0 & 0.0 & 0.0 & 0.0 \\
\hline fa & 0.0 & 0.0 & 0.0 & 0.0 & 0.0 & 0.0 & 0.0 & 0.0 & 0.0 \\
\hline $\mathrm{mt}$ & 12.8 & 11.0 & 10.2 & 8.9 & 12.8 & 13.4 & 11.3 & 5.9 & 7.3 \\
\hline $\mathrm{hm}$ & 0.0 & 0.0 & 0.0 & 0.0 & 0.7 & 0.0 & 1.2 & 0.0 & 0.0 \\
\hline il & 4.3 & 4.2 & 4.7 & 4.7 & 5.3 & 5.5 & 5.0 & 6.3 & 5.0 \\
\hline
\end{tabular}




\begin{tabular}{|c|c|c|c|c|c|c|c|c|c|c|}
\hline & $\bar{\Xi}$ & $\stackrel{\stackrel{\Xi}{\Xi}}{ }$ & 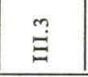 & $\stackrel{\stackrel{\Xi}{\Xi}}{\Xi}$ & $\stackrel{n}{\Xi}$ & $\stackrel{\bullet}{\stackrel{\Xi}{\Xi}}$ & & $\stackrel{\infty}{\Xi}$ & $\stackrel{g}{\Theta}$ & $\stackrel{\circ}{\stackrel{\Xi}{\Xi}}$ \\
\hline $\mathrm{SiO}_{2}$ & 45.6 & 44.2 & 47.7 & 44.2 & 45.0 & 47.7 & 43.4 & 48.6 & 48.9 & 48.1 \\
\hline $\mathrm{TiO}_{2}$ & 2.0 & 1.5 & 2.8 & 2.7 & 2.7 & 2.0 & 1.0 & 1.6 & 2.9 & 1.5 \\
\hline $\mathrm{Al}_{2} \mathrm{O}_{3}$ & 14.1 & 12.1 & 13.4 & 14.7 & 11.5 & 14.2 & 15.0 & 14.9 & 12.7 & 15.3 \\
\hline $\mathrm{Fe}_{2} \mathrm{O}_{3}$ & 7.5 & 8.2 & 10.9 & 8.2 & 9.6 & 5.0 & 7.2 & 3.8 & 5.6 & 5.5 \\
\hline $\mathrm{FeO}$ & 7.3 & 6.6 & 5.3 & 8.0 & 7.3 & 9.0 & 6.5 & 9.5 & 8.4 & 8.9 \\
\hline $\mathrm{MnO}$ & - & - & - & - & - & - & - & - & - & - \\
\hline $\mathrm{MgO}$ & 6.2 & 6.6 & 5.8 & 6.2 & 4.4 & 7.7 & 5.1 & 5.5 & 5.1 & 4.8 \\
\hline $\mathrm{CaO}$ & 11.2 & 10.9 & 11.0 & 9.9 & 9.4 & 11.7 & 12.2 & 12.3 & 10.2 & 11.9 \\
\hline $\mathrm{Na}_{2} \mathrm{O}$ & 2.46 & 1.97 & 2.40 & 2.18 & 2.32 & 2.10 & 1.89 & 1.90 & 2.32 & 2.14 \\
\hline $\mathrm{K}_{2} \mathrm{O}$ & 0.22 & 0.36 & 0.56 & 0.31 & 0.51 & 0.39 & 0.25 & 0.23 & 0.53 & 0.23 \\
\hline$q$ & 1.7 & 3.8 & 6.0 & 2.7 & 8.9 & 0.0 & 2.1 & 3.3 & 7.5 & 3.9 \\
\hline or & 1.4 & 2.3 & 3.3 & 1.9 & 3.2 & 2.3 & 1.6 & 1.4 & 3.2 & 1.4 \\
\hline$a b$ & 21.6 & 18.0 & 20.3 & 19.1 & 21.2 & 17.8 & 17.3 & 16.4 & 20.3 & 18.4 \\
\hline an & 27.7 & 25.0 & 24.2 & 30.5 & 21.0 & 28.2 & 34.3 & 32.0 & 23.5 & 32.0 \\
\hline ne & 0.0 & 0.0 & 0.0 & 0.0 & 0.0 & 0.0 & 0.0 & 0.0 & 0.0 & 0.0 \\
\hline ap & 0.0 & 0.0 & 0.0 & 0.0 & 0.0 & 0.0 & 0.0 & 0.0 & 0.0 & 0.0 \\
\hline en & 7.0 & 7.1 & 3.5 & 9.7 & 1.9 & 10.7 & 4.8 & 7.4 & 5.5 & 5.8 \\
\hline fs & 1.8 & 1.2 & 0.0 & 2.2 & 0.2 & 5.1 & 1.6 & 6.3 & 2.6 & 4.5 \\
\hline di & 23.7 & 26.5 & 23.7 & 16.3 & 23.0 & 24.2 & 25.0 & 24.8 & 23.4 & 23.0 \\
\hline fo & 0.0 & 0.0 & 0.0 & 0.0 & 0.0 & 0.4 & 0.0 & 0.0 & 0.0 & 0.0 \\
\hline $\mathrm{fa}$ & 0.0 & 0.0 & 0.0 & 0.0 & 0.0 & 0.2 & 0.0 & 0.0 & 0.0 & 0.0 \\
\hline $\mathrm{mt}$ & 11.3 & 12.9 & 9.0 & 12.3 & 15.0 & 7.3 & 11.3 & 5.6 & 8.4 & 8.1 \\
\hline $\mathrm{hm}$ & 0.0 & 0.0 & 4.7 & 0.0 & 0.0 & 0.0 & 0.0 & 0.0 & 0.0 & 0.0 \\
\hline il & 3.9 & 3.1 & 5.3 & 5.3 & 5.5 & 3.8 & 2.1 & 3.1 & 5.7 & 2.9 \\
\hline
\end{tabular}




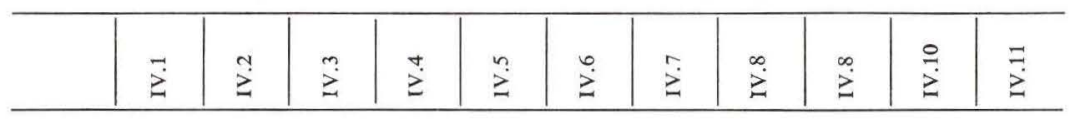

$\begin{array}{llllllllllll}\mathrm{SiO}_{2} & 47.0 & 47.9 & 47.9 & 47.5 & 45.0 & 46.9 & 44.6 & 47.2 & 46.9 & 46.7 & 44.6\end{array}$ $\begin{array}{llllllllllll}\mathrm{TiO}_{2} & 2.04 & 2.33 & 2.00 & 2.15 & 2.07 & 2.11 & 2.05 & 2.05 & 2.25 & 1.73 & 1.96\end{array}$ $\begin{array}{llllllllllll}\mathrm{Al}_{2} \mathrm{O}_{3} & 13.3 & 14.0 & 13.4 & 13.3 & 13.6 & 14.1 & 13.5 & 14.2 & 12.8 & 13.7 & 11.4\end{array}$ $\begin{array}{llllllllllll}\mathrm{Fe}_{2} \mathrm{O}_{3} & 5.7 & 2.8 & 5.4 & 6.2 & 5.4 & 4.7 & 4.4 & 3.7 & 7.2 & 3.4 & 4.2\end{array}$ $\begin{array}{llllllllllll}\mathrm{FeO} & 7.32 & 9.77 & 7.03 & 6.33 & 7.32 & 8.18 & 8.18 & 9.03 & 5.94 & 8.67 & 10.31\end{array}$ $\begin{array}{llllllllllll}\mathrm{MnO} & 0.36 & 0.18 & 0.18 & 0.17 & 0.17 & 0.17 & 0.17 & 0.18 & 0.18 & 0.18 & 0.22\end{array}$ $\begin{array}{llllllllllll}\mathrm{MgO} & 10.3 & 9.7 & 9.2 & 9.7 & 7.7 & 7.7 & 7.4 & 7.4 & 7.1 & 9.5 & 13.0\end{array}$ $\begin{array}{llllllllllll}\mathrm{CaO} & 10.95 & 12.10 & 11.55 & 11.05 & 10.75 & 11.30 & 11.00 & 12.30 & 10.80 & 11.20 & 8.85\end{array}$ $\begin{array}{llllllllllll}\mathrm{Na}_{2} \mathrm{O} & 1.89 & 1.80 & 1.82 & 1.72 & 1.46 & 2.02 & 1.80 & 1.78 & 3.77 & 1.80 & 2.11\end{array}$ $\begin{array}{llllllllllll}\mathrm{K}_{2} \mathrm{O} & 0.28 & 0.32 & 0.26 & 0.35 & 0.62 & 0.45 & 0.71 & 0.25 & 0.24 & 0.55 & 0.37\end{array}$

$\begin{array}{llllllllllll}\mathrm{q} & 0.0 & 0.0 & 1.8 & 2.5 & 2.4 & 0.2 & 0.0 & 0.4 & 0.0 & 0.0 & 0.0\end{array}$

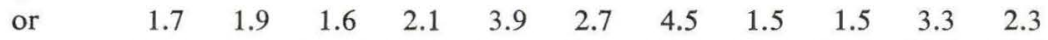
$\begin{array}{llllllllllll}\mathrm{ab} & 16.1 & 15.1 & 15.6 & 14.8 & 13.1 & 17.5 & 16.2 & 15.4 & 31.0 & 15.6 & 18.4\end{array}$ $\begin{array}{llllllllllll}\text { an } & 27.2 & 28.9 & 28.0 & 28.0 & 30.5 & 28.8 & 28.4 & 30.6 & 17.8 & 28.4 & 21.2\end{array}$

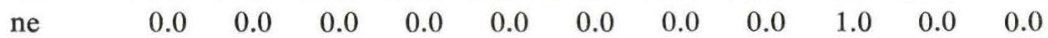
$\begin{array}{llllllllllll}\text { ap } & 0.0 & 0.0 & 0.0 & 0.0 & 0.0 & 0.0 & 0.0 & 0.0 & 0.0 & 0.0 & 0.0\end{array}$

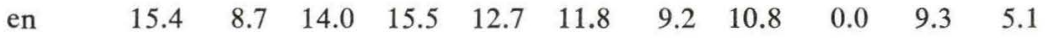

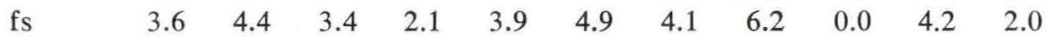
$\begin{array}{llllllllllll}\text { di } & 21.9 & 24.8 & 23.9 & 21.9 & 20.9 & 23.1 & 24.0 & 25.7 & 29.3 & 23.1 & 19.4\end{array}$ $\begin{array}{llllllllllll}\text { fo } & 1.4 & 5.1 & 0.0 & 0.0 & 0.0 & 0.0 & 1.8 & 0.0 & 3.9 & 5.1 & 15.1\end{array}$ $\begin{array}{llllllllllll}\text { fa } & 0.4 & 2.8 & 0.0 & 0.0 & 0.0 & 0.0 & 0.9 & 0.0 & 0.4 & 2.5 & 6.5\end{array}$ $\begin{array}{llllllllllll}\mathrm{mt} & 8.3 & 4.0 & 7.9 & 9.1 & 8.3 & 7.0 & 6.8 & 5.5 & 10.7 & 5.1 & 6.3\end{array}$ $\begin{array}{llllllllllll}\text { hm } & 0.0 & 0.0 & 0.0 & 0.0 & 0.0 & 0.0 & 0.0 & 0.0 & 0.0 & 0.0 & 0.0\end{array}$

$\begin{array}{llllllllllll}\text { il } & 3.9 & 4.4 & 3.9 & 4.2 & 4.2 & 4.1 & 4.2 & 4.0 & 4.4 & 3.4 & 3.8\end{array}$




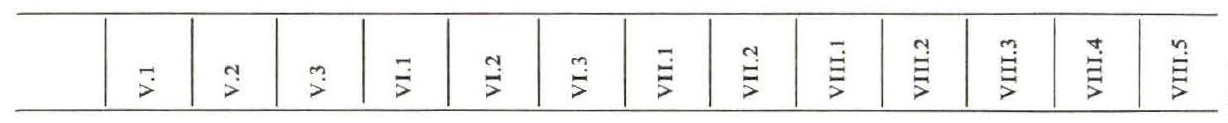

$\begin{array}{llllllllllllll}\mathrm{SiO}_{2} & 46.6 & 47.7 & 46.5 & 48.1 & 46.9 & 49.0 & 49.2 & 49.4 & 47.2 & 50.6 & 45.8 & 46.5 & 47.9\end{array}$ $\begin{array}{llllllllllllll}\mathrm{TiO}_{2} & 2.27 & 2.20 & 1.98 & 1.80 & 1.83 & 1.74 & 2.38 & 2.77 & 2.29 & 1.87 & 2.02 & 2.59 & 2.33\end{array}$

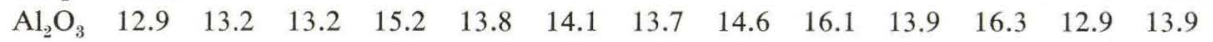

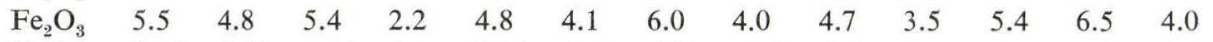
$\begin{array}{llllllllllllll}\mathrm{FeO} & 7.49 & 8.41 & 8.44 & 9.08 & 7.22 & 8.62 & 6.18 & 8.69 & 6.70 & 8.19 & 5.88 & 5.67 & 9.19\end{array}$ $\begin{array}{llllllllllllll}\mathrm{MnO} & 0.20 & 0.18 & 0.20 & 0.17 & 0.18 & 0.18 & 0.18 & 0.17 & 0.16 & 0.17 & 0.16 & 0.18 & 0.20\end{array}$ $\begin{array}{llllllllllllll}\mathrm{MgO} & 9.7 & 7.7 & 14.5 & 6.9 & 8.3 & 10.9 & 7.5 & 6.9 & 5.2 & 8.3 & 7.8 & 9.2 & 6.6\end{array}$

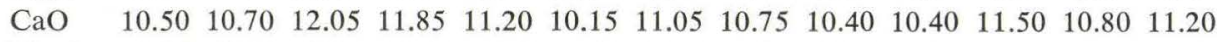
$\begin{array}{llllllllllllll}\mathrm{Na}_{2} \mathrm{O} & 1.96 & 2.05 & 1.75 & 2.02 & 1.65 & 1.91 & 2.11 & 2.51 & 2.51 & 2.20 & 2.28 & 2.30 & 2.20\end{array}$ \begin{tabular}{llllllllllllll}
$\mathrm{K}_{2} \mathrm{O}$ & 0.53 & 0.17 & 0.19 & 0.44 & 0.75 & 0.31 & 0.46 & 0.46 & 0.28 & 0.45 & 0.41 & 0.31 & 0.20 \\
\hline
\end{tabular}

$\begin{array}{llllllllllllll}\mathrm{q} & 0.0 & 2.6 & 0.0 & 0.0 & 1.0 & 0.0 & 5.2 & 1.5 & 3.7 & 2.5 & 0.0 & 1.0 & 2.0\end{array}$ $\begin{array}{llllllllllllll}\text { or } & 3.2 & 1.0 & 1.1 & 2.7 & 4.6 & 1.8 & 2.8 & 2.7 & 1.7 & 2.7 & 2.5 & 1.9 & 1.2\end{array}$ $\begin{array}{llllllllllllll}\text { ab } & 17.0 & 11.9 & 14.2 & 19.0 & 14.5 & 16.0 & 18.1 & 21.2 & 22.2 & 18.7 & 19.8 & 20.1 & 19.1\end{array}$ an $\quad \begin{array}{llllllllllllll}25.4 & 27.2 & 26.5 & 30.9 & 29.0 & 28.7 & 26.9 & 27.1 & 33.3 & 26.8 & 33.9 & 24.2 & 28.1\end{array}$ ne $\quad \begin{array}{lllllllllllll}0.0 & 0.0 & 0.0 & 0.0 & 0.0 & 0.0 & 0.0 & 0.0 & 0.0 & 0.0 & 0.0 & 0.0 & 0.0\end{array}$

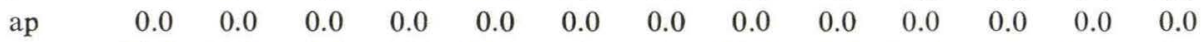

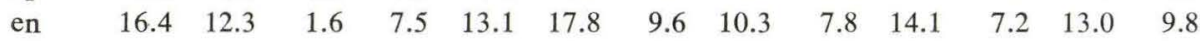

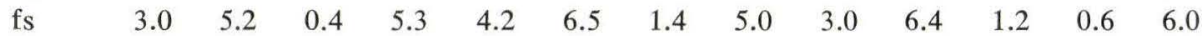
di $\quad \begin{array}{lllllllllllll}22.6 & 22.3 & 24.6 & 23.8 & 22.8 & 17.0 & 22.6 & 21.1 & 16.6 & 20.2 & 19.5 & 23.9 & 23.4\end{array}$

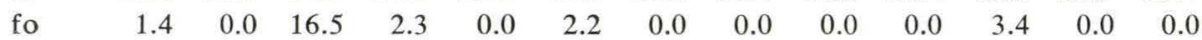
$\begin{array}{llllllllllllll}\mathrm{fa} & 0.3 & 0.0 & 4.1 & 1.8 & 0.0 & 0.9 & 0.0 & 0.0 & 0.0 & 0.0 & 0.6 & 0.0 & 0.0\end{array}$ $\begin{array}{llllllllllllll}\mathrm{mt} & 6.0 & 7.2 & 7.5 & 3.3 & 7.2 & 5.9 & 8.8 & 5.8 & 7.1 & 5.1 & 8.0 & 9.7 & 5.9\end{array}$

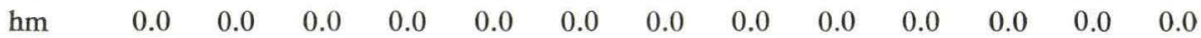
$\begin{array}{llllllllllllll}\text { il } & 3.3 & 4.3 & 3.6 & 3.5 & 3.6 & 3.3 & 4.6 & 5.3 & 4.6 & 3.6 & 3.9 & 5.1 & 4.5\end{array}$ 


\begin{tabular}{|c|c|c|c|c|c|c|c|c|c|c|c|}
\hline & $\overrightarrow{\dot{x}}$ & $\ddot{\ddot{x}}$ & $\ddot{x}$ & $\stackrel{\ddot{x}}{\dot{x}}$ & $\ddot{x}$ & $\stackrel{0}{\dot{x}}$ & $\stackrel{\infty}{x}$ & $\frac{0}{\dot{x}}$ & $\overline{\bar{x}}$ & $\frac{ \pm}{\dot{x}}$ & $\begin{array}{l}0 \\
\ddot{x}\end{array}$ \\
\hline $\mathrm{SiO}_{2}$ & 47.9 & 57.5 & 46.8 & 45.2 & 49.2 & 47.8 & 49.1 & 49.2 & 55.9 & 55.6 & 45.9 \\
\hline $\mathrm{TiO}_{2}$ & 2.69 & 2.32 & 3.17 & 1.08 & 2.61 & 2.98 & 2.18 & 2.58 & 2.60 & 1.40 & 1.02 \\
\hline $\mathrm{Al}_{2} \mathrm{O}_{3}$ & 15.1 & 15.5 & 14.0 & 14.7 & 13.0 & 15.1 & 14.6 & 14.3 & 14.2 & 11.2 & 15.3 \\
\hline $\mathrm{Fe}_{2} \mathrm{O}_{3}$ & 6.1 & 2.0 & 4.01 & 3.3 & 5.2 & 4.1 & 3.9 & 4.1 & 5.8 & 4.7 & 4.7 \\
\hline $\mathrm{FeO}$ & 6.38 & 9.76 & 5.14 & 9.26 & 8.55 & 8.84 & 8.48 & 8.27 & 7.23 & 7.70 & 8.12 \\
\hline $\mathrm{MnO}$ & 0.17 & 0.18 & 0.14 & 0.21 & 0.20 & 0.17 & 0.18 & 0.17 & 0.17 & 0.19 & 0.20 \\
\hline $\mathrm{MgO}$ & 6.3 & 6.0 & 6.0 & 9.7 & 6.9 & 6.6 & 6.3 & 6.3 & 6.0 & 10.6 & 9.5 \\
\hline $\mathrm{CaO}$ & 10.30 & 11.75 & 9.00 & 11.55 & 11.10 & 10.30 & 10.50 & 10.40 & 10.30 & 8.45 & 12.55 \\
\hline $\mathrm{Na}_{2} \mathrm{O}$ & 2.42 & 2.14 & 3.02 & 1.74 & 2.39 & 2.50 & 2.14 & 2.43 & 2.13 & 1.82 & 1.72 \\
\hline $\mathrm{K}_{2} \mathrm{O}$ & 0.32 & 0.37 & 0.62 & 0.17 & 0.19 & 0.24 & 0.24 & 0.21 & 0.52 & 0.73 & 0.30 \\
\hline 4 & 4.8 & & 3 & & & 1 & 7 & 4.3 & 12.9 & 9.0 & 0.0 \\
\hline or & 1.9 & 2.0 & 4.0 & 1.0 & 1.1 & 1.4 & 1.5 & 1.3 & 2.9 & 4.2 & 1.8 \\
\hline$a b$ & 21.0 & 16.8 & 27.8 & 15.2 & 20.4 & 21.5 & 18.6 & 21.0 & 17.2 & .15 .0 & 14.7 \\
\hline an & 30.1 & 29.4 & 24.8 & 32.8 & 24.3 & 29.7 & 30.2 & 28.1 & 26.4 & 19.8 & 33.4 \\
\hline ne & 0.0 & 0.0 & 0.0 & 0.0 & 0.0 & 0.0 & 0.0 & 0.0 & 0.0 & 0.0 & 0.0 \\
\hline ap & 0.0 & 0.0 & 0.0 & 0.0 & 0.0 & 0.0 & 0.0 & 0.0 & 0.0 & 0.0 & 0.0 \\
\hline en & 8.9 & 8.5 & 8.2 & 5.6 & 8.9 & 10.9 & 10.3 & 9.6 & 7.7 & 19.6 & 4.4 \\
\hline fs & 1.5 & 7.2 & 0.6 & 3.0 & 3.9 & 5.5 & 6.0 & 4.8 & 2.3 & 6.2 & 1.8 \\
\hline di & 17.6 & 20.4 & 18.6 & 21.3 & 25.1 & 17.9 & 18.8 & 19.9 & 17.9 & 17.0 & 23.6 \\
\hline fo & 0.0 & 0.0 & 0.0 & 8.8 & 0.0 & 0.0 & 0.0 & 0.0 & 0.0 & 0.0 & 8.0 \\
\hline fa & 0.0 & 0.0 & 0.0 & 5.2 & 0.0 & 0.0 & 0.0 & 0.0 & 0.0 & 0.0 & 3.6 \\
\hline $\mathrm{mt}$ & 9.1 & 2.7 & 6.3 & 4.9 & 7.6 & 6.0 & 5.8 & 6.1 & 8.0 & 6.7 & 6.9 \\
\hline $\mathrm{hm}$ & 0.0 & 0.0 & 0.0 & 0.0 & 0.0 & 0.0 & 0.0 & 0.0 & 0.0 & 0.0 & 0.0 \\
\hline il & 5.2 & 4.1 & 6.6 & 2.1 & 5.0 & 5.7 & 4.2 & 5.0 & 4.7 & 2.6 & 2.0 \\
\hline
\end{tabular}




\begin{tabular}{|c|c|c|c|c|c|c|c|c|c|c|c|c|}
\hline & $\overrightarrow{\dot{x}}$ & $\underset{x}{\stackrel{x}{x}}$ & $\frac{m}{\vec{x}}$ & $\stackrel{+}{\dot{x}}$ & $\stackrel{n}{x}$ & $\stackrel{\dot{x}}{\dot{x}}$ & $\tilde{\vec{x}}$ & $\stackrel{\infty}{\vec{x}}$ & $\dot{\vec{x}}$ & $\stackrel{\circ}{\stackrel{x}{x}}$ & $=$ & $\stackrel{\dddot{x}}{\vec{x}}$ \\
\hline $\mathrm{SiO}_{2}$ & 44.1 & 44.5 & 45.8 & 44.7 & 47.3 & 53.9 & 46.9 & 47.3 & 48.8 & 49.0 & 47.6 & 48.9 \\
\hline $\mathrm{TiO}_{2}$ & 0.90 & 0.90 & 1.04 & 1.00 & 0.99 & 1.15 & 2.68 & 2.92 & 1.36 & 1.29 & 2.98 & 2.48 \\
\hline $\mathrm{Al}_{2} \mathrm{O}_{3}$ & 14.0 & 14.5 & 15.0 & 15.3 & 14.3 & 14.9 & 13.8 & 13.5 & 15.5 & 14.9 & 14.0 & 13.7 \\
\hline $\mathrm{Fe}_{2} \mathrm{O}_{3}$ & 4.60 & 1.7 & 3.8 & 3.4 & 8.4 & 2.15 & 3.7 & 4.7 & 2.9 & 2.6 & 5.9 & 3.9 \\
\hline $\mathrm{FeO}$ & 8.05 & 9.9 & 8.8 & 8.3 & 3.9 & 8.25 & 10.6 & 10.6 & 8.3 & 10.4 & 7.1 & 10.4 \\
\hline $\mathrm{MnO}$ & 0.19 & 0.15 & 0.19 & 0.18 & 0.19 & 0.16 & 0.19 & 0.20 & 0.17 & 0.19 & 0.17 & 0.19 \\
\hline $\mathrm{MgO}$ & 10.9 & 10.6 & 8.4 & 7.9 & 10.7 & 6.4 & 6.6 & 5.1 & 6.3 & 5.7 & 5.9 & 6.4 \\
\hline $\mathrm{CaO}$ & 12.1 & 12.1 & 11.6 & 12.7 & 12.0 & 10.1 & 10.9 & 10.3 & 11.0 & 11.2 & 9.8 & 10.6 \\
\hline $\mathrm{Na}_{2} \mathrm{O}$ & 1.56 & 1.62 & 1.88 & 1.83 & 1.80 & 2.32 & 2.10 & 2.00 & 2.11 & 2.22 & 2.56 & 2.32 \\
\hline $\mathrm{K}_{2} \mathrm{O}$ & 0.34 & 0.22 & 0.33 & 0.22 & 0.30 & 0.55 & 0.22 & 0.55 & 0.32 & 0.26 & 0.69 & 0.48 \\
\hline$q$ & 0.0 & 0.0 & 0.0 & 0.0 & 0.4 & 6.4 & 0.8 & 4.3 & 2.4 & 0.9 & 4.0 & 1.6 \\
\hline or & 2.1 & 1.4 & 2.0 & 1.4 & 1.8 & 3.3 & 1.3 & 3.3 & 2.0 & 2.2 & 4.2 & 2.9 \\
\hline$a b$ & 13.6 & 14.1 & 16.4 & 16.2 & 15.3 & 19.7 & 18.2 & 17.4 & 18.5 & 19.2 & 22.4 & 19.8 \\
\hline an & 31.2 & 32.9 & 32.5 & 34.4 & 30.1 & 28.7 & 28.2 & 27.0 & 32.9 & 30.3 & 25.5 & 25.7 \\
\hline ne & 0.0 & 0.1 & 0.0 & 0.0 & 0.0 & 0.0 & 0.0 & 0.0 & 0.0 & 0.0 & 0.0 & 0.0 \\
\hline ap & 0.0 & 0.0 & 0.0 & 0.0 & 0.0 & 0.0 & 0.0 & 0.0 & 0.0 & 0.0 & 0.0 & 0.0 \\
\hline en & 1.8 & 0.0 & 6.4 & 2.1 & 16.0 & 11.0 & 10.6 & 7.5 & 10.7 & 9.2 & 7.7 & 9.8 \\
\hline fs & 0.6 & 0.0 & 3.6 & 1.2 & 0.0 & 8.1 & 8.0 & 6.6 & 7.4 & 9.9 & 1.9 & 7.5 \\
\hline di & 24.8 & 24.0 & 21.8 & 25.6 & 23.0 & 17.6 & 22.2 & 21.1 & 19.2 & 22.0 & 19.7 & 22.3 \\
\hline fo & 12.3 & 14.1 & 5.9 & 7.4 & 0.0 & 0.0 & 0.0 & 0.0 & 0.0 & 0.0 & 0.0 & 0.0 \\
\hline $\mathrm{fa}$ & 4.9 & 9.2 & 3.6 & 4.6 & 0.0 & 0.0 & 0.0 & 0.0 & 0.0 & 0.0 & 0.0 & 0.0 \\
\hline $\mathrm{mt}$ & 6.9 & 2.6 & 5.7 & 5.2 & 10.3 & 3.1 & 5.5 & 7.0 & 4.4 & 3.9 & 8.9 & 5.7 \\
\hline $\mathrm{hm}$ & 0.0 & 0.0 & 0.0 & 0.0 & 1.3 & 0.0 & 0.0 & 0.0 & 0.0 & 0.0 & 0.0 & 0.0 \\
\hline il & 1.8 & 1.8 & 2.0 & 2.0 & 1.9 & 2.2 & 5.2 & 5.7 & 2.7 & 2.5 & 5.9 & 4.7 \\
\hline
\end{tabular}




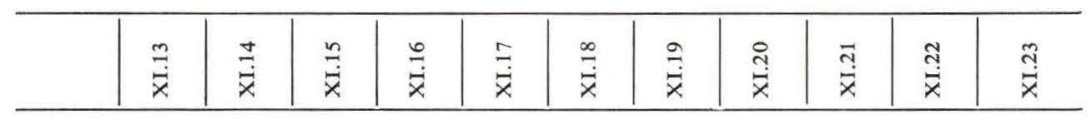

$\begin{array}{llllllllllll}\mathrm{SiO}_{2} & 46.2 & 44.5 & 47.4 & 44.9 & 45.0 & 46.1 & 45.6 & 46.2 & 46.6 & 47.1 & 47.8\end{array}$

$\begin{array}{llllllllllll}\mathrm{TiO}_{2} & 0.91 & 0.96 & 1.13 & 0.97 & 0.88 & 1.55 & 1.04 & 0.99 & 1.03 & 1.09 & 1.11\end{array}$ $\begin{array}{llllllllllll}\mathrm{Al}_{2} \mathrm{O}_{3} & 16.2 & 14.4 & 14.3 & 14.8 & 15.9 & 15.2 & 14.7 & 15.1 & 15.3 & 15.0 & 15.2\end{array}$ $\begin{array}{llllllllllll}\mathrm{Fe}_{2} \mathrm{O}_{3} & 3.1 & 4.2 & 5.2 & 1.8 & 3.0 & 4.8 & 3.3 & 5.5 & 3.0 & 2.5 & 5.6\end{array}$ $\begin{array}{llllllllllll}\mathrm{FeO} & 7.1 & 8.2 & 9.1 & 10.4 & 7.5 & 7.8 & 9.1 & 7.5 & 9.2 & 9.7 & 6.8\end{array}$ $\begin{array}{llllllllllll}\mathrm{MnO} & 0.17 & 0.19 & 0.2 & 0.19 & 0.16 & 0.19 & 0.18 & 0.20 & 0.19 & 0.19 & 0.19\end{array}$ $\begin{array}{llllllllllll}\mathrm{MgO} & 7.1 & 10.1 & 7.6 & 9.6 & 7.9 & 6.4 & 8.6 & 8.4 & 7.6 & 6.8 & 7.4\end{array}$ $\begin{array}{llllllllllll}\mathrm{CaO} & 12.3 & 12.4 & 13.0 & 12.3 & 12.8 & 12.8 & 13.1 & 12.4 & 12.9 & 12.7 & 12.4\end{array}$ $\begin{array}{llllllllllll}\mathrm{Na}_{2} \mathrm{O} & 2.00 & 1.66 & 2.08 & 1.75 & 1.94 & 1.92 & 1.78 & 1.86 & 2.07 & 2.00 & 2.00\end{array}$ \begin{tabular}{llllllllllll}
$\mathrm{K}_{2} \mathrm{O}$ & 0.42 & 0.24 & 0.28 & 0.18 & 0.25 & 0.37 & 0.29 & 0.22 & 0.29 & 0.29 & 0.29 \\
\hline
\end{tabular}

$\begin{array}{llllllllllll}\mathrm{q} & 0.0 & 0.0 & 0.0 & 0.0 & 0.0 & 0.0 & 0.0 & 0.0 & 0.0 & 0.0 & 1.0\end{array}$ $\begin{array}{llllllllllll}\text { or } & 2.6 & 1.5 & 1.7 & 1.1 & 1.6 & 2.3 & 1.8 & 1.3 & 1.8 & 1.8 & 1.7\end{array}$ $\begin{array}{llllllllllll}\text { ab } & 17.7 & 14.5 & 17.6 & 15.1 & 17.2 & 16.7 & 15.4 & 16.0 & 17.8 & 17.4 & 17.1\end{array}$ $\begin{array}{llllllllllll}\text { an } & 35.6 & 32.1 & 28.8 & 33.0 & 35.6 & 32.7 & 32.0 & 32.7 & 32.2 & 31.9 & 32.0\end{array}$ $\begin{array}{llllllllllll}\text { ne } & 0.0 & 0.0 & 0.0 & 0.1 & 0.0 & 0.0 & 0.0 & 0.0 & 0.0 & 0.0 & 0.0\end{array}$ $\begin{array}{llllllllllll}\text { ap } & 0.0 & 0.0 & 0.0 & 0.0 & 0.0 & 0.0 & 0.0 & 0.0 & 0.0 & 0.0 & 0.0\end{array}$ $\begin{array}{llllllllllll}\text { en } & 5.3 & 2.0 & 4.8 & 0.0 & 0.8 & 7.2 & 1.0 & 8.1 & 1.5 & 4.7 & 10.0\end{array}$

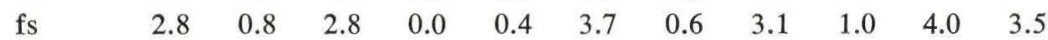
$\begin{array}{llllllllllll}\text { di } & 23.0 & 25.3 & 28.9 & 24.5 & 25.1 & 26.5 & 28.1 & 24.0 & 27.0 & 27.0 & 24.3\end{array}$ $\begin{array}{llllllllllll}\text { fo } & 4.2 & 10.8 & 3.6 & 12.3 & 8.3 & 0.5 & 8.6 & 3.4 & 7.0 & 3.8 & 0.0\end{array}$ $\begin{array}{llllllllllll}\text { fa } & 2.4 & 4.9 & 2.3 & 9.3 & 4.7 & 0.3 & 5.6 & 1.4 & 5.3 & 3.6 & 0.0\end{array}$ $\begin{array}{llllllllllll}\mathrm{mt} & 4.7 & 6.3 & 7.5 & 2.7 & 4.6 & 7.2 & 4.9 & 8.1 & 4.4 & 3.7 & 8.2\end{array}$ $\begin{array}{llllllllllll}\mathrm{hm} & 0.0 & 0.0 & 0.0 & 0.0 & 0.0 & 0.0 & 0.0 & 0.0 & 0.0 & 0.0 & 0.0\end{array}$ $\begin{array}{llllllllllll}\text { il } & 1.8 & 1.9 & 2.1 & 1.9 & 1.8 & 3.0 & 2.0 & 1.9 & 2.0 & 2.1 & 2.1\end{array}$ 


\section{Hicelpeprofiler}

$\begin{array}{cl}\text { Profil } & \text { 1. Sunnba } \\ - & \text { 2. Hattur } \\ - & \text { 3. Sandvík } \\ - & \text { 4. Mykines } \\ - & \text { 5. Tindhólmur } \\ - & \text { 6. Streymnes } \\ - & \text { 7. Víkar } \\ - & \text { 8. Malinstindur } \\ - & \text { 9. Hægstafjall } \\ - & \text { 10. Hagagarosá } \\ - & \text { 11. Heljardalsá } \\ - & \text { 12. Ørviksfelli } \\ - & \text { 13. Fossá } \\ - & \text { 14. Víkará } \\ - & \text { 15. Stykkið̋ } \\ - & \text { 16. Gjógvin } \\ - & \text { 17. Breiðadalsá } \\ - & \text { 18. Dyllan }\end{array}$
Profil 19. Deildará
- 20. Miðalfelli
- 21. Breiðá-Kambur
- 22. Urðará
- 23. Løgdalsá
- 24. Hattardalstindur
- 25. Kunoyarbygd
- 26. Svartidalur
- 27. Hálsur
- 28. Torvadalsá
- 29. Stórá
- 30. Klubbin
- 31. Hvíthamar
- 32. Norð̋araenni
- 33. Skálsáklettar
- 34. Reynsendi
- 35. Tindur
- 36. Skúvoy 


\begin{tabular}{|c|c|c|c|c|c|c|c|}
\hline $\begin{array}{c}\text { Prøve } \\
\text { nr. }\end{array}$ & $\begin{array}{l}\text { Højde } \\
\text { i m }\end{array}$ & Bjergartstype & $\begin{array}{l}\% \\
\text { pl. }\end{array}$ & $\begin{array}{c}\% \\
\text { cpx. }\end{array}$ & $\begin{array}{l}\% \\
\text { ore }\end{array}$ & $\begin{array}{l}\% \\
\text { gl. }\end{array}$ & $\begin{array}{c}\% \\
\text { gap. }\end{array}$ \\
\hline
\end{tabular}

Profil 1.

\begin{tabular}{|c|c|c|c|c|c|}
\hline $160-180$ & Kryptofyrisk basalt & 40 & 41 & 7 & 10 \\
\hline $180-195$ & Kryptofyrisk basalt & 37 & 48 & 8 & 4 \\
\hline $195-245$ & Afyrisk basalt & 38 & 40 & 14 & 1 \\
\hline 257 & $\begin{array}{l}\text { Svagt porfyritisk } \\
\text { basalt }\end{array}$ & 34 & 47 & 9 & 8 \\
\hline & $\begin{array}{l}\text { Svagt porfyritisk } \\
\text { basalt }\end{array}$ & 42 & 44 & 8 & 5 \\
\hline 320 & $\begin{array}{l}\text { Svagt porfyritisk } \\
\text { basalt }\end{array}$ & 41 & 46 & 7 & 5 \\
\hline
\end{tabular}

\begin{tabular}{lcc}
\hline $\begin{array}{c}\text { Prøve } \\
\text { nr. }\end{array}$ & Højde & \\
\hline
\end{tabular}

Profil 2.

1

2

Kulførende serie. Vegetationsklædt skråning.

225 Tæt, blålig olivinholdig basalt med tiltagende zeolitindhold opad.

230 Tæt, blålig, olivinholdig basalt med meget små strøkorn og spredte zeoliter

240 Tæt, blålig basalt m. små strøkorn (som pr. 2). 1-2 m tykke bænke veksler med zeolitholdige, porøse bænke. Tydelige bænke i $255 \mathrm{~m}$, $260 \mathrm{~m}$ og $265 \mathrm{~m}$.

275 Småprikket feldspatbasalt, opadtil porøs og zeolitholdig.

310 Tæt, blålig basalt med friske str $\varnothing$ korn af olivin. Grundmassen tæt. Mange zeoliter.

315 Samme bjergart, men olivinrigere.

330 Finprikket feldspatbasalt, opad med tiltagende indhold af zeoliter. Delvis vegetationsklædt.

335 Vekslende kompakte og porøse bænke af tæt, blålig basalt.

385 Småprikket feldspatbasalt med tæt grundmasse, opad porøs og zeolitholdig.

410 Tæt, blålig basalt med olivinstrøkorn og små strøkorn af plagioklas. Tiltagende zeolitindhold opad.

426 Tæt, blålig olivinholdig basalt med små str $\varnothing$ korn af plagioklas.

$\rightarrow 488$ Vegetationsdække afløst af grus af småprikket feldspatbasalt.

* tilhører samme lavastrøm som Prфve no. 10, men er taget i Uttarafjall. 
Profil 3.

0- 33 Tynde bænke af småprikket feldspatbasalt, vekslende med porøse zoner.

33- 49 Overvejende por $\varnothing$ s basalt med zeoliter.

49- 54 Elvgrus.

255 Småprikket feldspatbasalt i tynde bænke, vekslende med porøse og zeolitfyldte zoner - opad grusdækket. 2,89

$360-80$ Porøs zone, der overgår i tynd bænk af basalt med tæt, blå grundmasse og indeholdende enkelte zeoliter. $\quad 2,82$

$4 \quad 80-88$ Småprikket feldspatbasalt. Bænken består af $6 \mathrm{~m}$ kompakt bjergart og $2 \mathrm{~m}$ porøs $\varnothing \mathrm{vre}$ zone.

5 88- 96 Småprikket feldspatbasalt. Kompakt bænk.

6 96-133 Vekslende, tynde bænke af småprikket feldspatbasalt og porøse, zeolitfyldte zoner.

$7 \quad 133-138$ Bænk af feldspatbasalt med ret store plagioklaslister; går opadtil over i en porøs zone.

8 147-149 Feldspatbasalt med ret store strøkorn.

9 149-176 Samme bjergartstype.

176-185 Vegetationsklædt.

$10 \quad 185-190$ Grovkornet feldspatbasalt.

190-208 Vegetationsklædt.

11 (1) 208-301 Basalt med tæt grundmasse og enkeltliggende, store feldspatstrøkorn.

301-315 Vegetationsklædt.

12 (2) 315-319 Tæt, blålig basalt uden strøkorn.

\begin{tabular}{|c|c|c|c|c|c|c|c|c|}
\hline $\begin{array}{c}\text { Prøve } \\
\text { nr, }\end{array}$ & $\begin{array}{l}\text { Højde } \\
\text { i m }\end{array}$ & Bjergartstype & $\begin{array}{l}\% \\
\text { pl. }\end{array}$ & $\begin{array}{c}\% \\
\text { cpx. }\end{array}$ & $\begin{array}{l}\% \\
\text { ore }\end{array}$ & $\begin{array}{l}\% \\
\text { g1. }\end{array}$ & $\begin{array}{c}\% \\
\text { gap. }\end{array}$ & d. \\
\hline
\end{tabular}

\section{Profil 4.}

50 Svagt porfyritisk basalt

$$
\text { 81- } 83 \text { Kryptofyrisk basalt * }
$$

202 Porfyritisk basal

$\begin{array}{lll}44 & 34 & 9\end{array}$

Svagt porfyritisk basalt

270 Svagt porfyritisk

$\begin{array}{lll}40 & 43 & 9\end{array}$

76

basalt

355 Svagt porfyritisk basalt

510 Porfyritisk basalt

* For finkornet til punkttælling. 


\begin{tabular}{ccc}
\hline $\begin{array}{c}\text { Prøve } \\
\text { nr. }\end{array}$ & $\begin{array}{c}\text { Højde } \\
\text { i m }\end{array}$ & Bjergartstype \\
\hline
\end{tabular}

\section{Profil 5.}

$10-10$ Kryptofyrisk, olivinholdig basalt.

10- 12 Brændingshorisont.

$2 \quad 12-20$ Kryptofyrisk olivinholdig basalt.

20- 23 Slaggezone og brunt ler.

$4 \quad 23-31$ Svagt porfyritisk basalt.

$5 \quad 31-35$ Slaggezone - derefter $2 \mathrm{~m}$ brunt ler, $\varnothing$ verst $20 \mathrm{~cm}$ r $\varnothing \mathrm{d}$ tuf.

$7 \quad 35-45$ Kryptofyrisk olivinholdig basalt. Kulserien.

\begin{tabular}{cccc}
\hline $\begin{array}{c}\text { Prøve } \\
\text { nr. }\end{array}$ & $\begin{array}{c}\text { Højde } \\
\text { i m }\end{array}$ & Bjergartstype & d. \\
\hline
\end{tabular}

\section{Profil 6.}

$\begin{array}{lllll}8 & 0- & 8 & \text { Svagt porfyritisk basalt } 2,85\end{array}$

$\begin{array}{llll}9 & 8-17 & \text { Svagt porfyritisk basalt. } & 2,92\end{array}$

$\begin{array}{llll}10 & 17-32 & \text { Kryptofyrisk basalt. } & 2,93\end{array}$

12 95-102 Kryptofyrisk olivinholdig basalt. 2,90

$\begin{array}{llll}13 & 112-117 & \text { Svagt porfyritisk basalt. } & 2,95\end{array}$

14 143-161 Porfyritisk basalt. 2,94

$15 \quad 168-177$ Svagt porfyritisk basalt. -

$16 \quad 177-186$ Svagt porfyritisk basalt $\quad 2,90$

17 186-203 Svagt porfyritisk, olivinholdig basalt. 2,95 pl $37 \%$ cpx $43 \%$ ore $7 \%$ gl $8 \%$ ol $5 \%$.

\begin{tabular}{cccc}
\hline $\begin{array}{c}\text { Prøve } \\
\text { nr. }\end{array}$ & $\begin{array}{c}\text { Højde } \\
\text { i m }\end{array}$ & Bjergartstype & d. \\
\hline
\end{tabular}

\section{Profil 7 (målt oppefra nedefter)}

$120-20 *$ Kryptofyrisk basalt. 2,88

u. kul

$1320-40 *$ Svagt porfyritisk basalt. 2,78

u. kul

$14 \quad 40-60 *$ Svagt porfyritisk basalt 2,89

u. kul

$15 \quad 60-80 *$ Porfyritisk basalt. $\quad 2,90$

u. kul

* Bænktykkelserne anslået. 


\begin{tabular}{ccc}
\hline $\begin{array}{c}\text { Prøve } \\
\text { nr. }\end{array}$ & $\begin{array}{c}\text { Højde } \\
\text { i m }\end{array}$ & Biergartstype \\
\hline
\end{tabular}

Profil 8

0- 10 Grusfyldt elvleje (vest for Sandavágs sandur går en småprikket feldspatbasalt helt ned til stranden).

$1.210-40$ Finkornet, lys, porfyritisk basalt.

3 40-115 Storkornet, porfyritisk basalt i mange, tynde strømme med zeolitzoner imellem.

4 115-127 Tæt, blålig basalt med noget »kornet « og let forvitrende grundmasse; mange zeolitzoner.

127 Tuf.

127-136 Storkornet, porfyritisk basalt.

136 Tuf.

137-144 Storkornet, porfyritisk basalt.

144-173 Finkornet, porfyritisk basalt med porøse zoner og zeoliter.

173-222 Storkornet, porfyritisk basalt, opad med zeolitzoner.

9 222-229 Gråsort, olivinholdig basalt med runde zeoliter, men uden strøkorn (B-horisonten).

10.11 229-234 Tre bænke af tæt, blålig, olivinholdig basalt med zeolitzoner i og med brændingszoner imellem.

234-237 Grusdække, delvis med vegetation.

237-245 Småprikket feldspatbasalt.

245-250 Småprikket feldspatbasalt.

250-258 Storkornet feldspatbasalt.

258-268 Småprikket feldspatbasalt.

268-305 Storkornet feldspatbasalt med meget varierende strøkornsstørrelse fra bænk til bænk; øverst meget tildækket.

305-325 Småprikket feldspatbasalt.

325-342 Vegetationsklædt, men hele vejen med spredte blotninger af storkornet feldspatbasalt.

342-475 Lagf $\varnothing$ lge af vekslende feldspatbasalter, nederst med småprikket feldspatbasalt, opad med afvekslende strøkornsstørrelse. Serien indeholder porøse zoner med zeoliter.

475-586 Storkornet porfyritisk basalt. Opad i lagserien veksellejrer basaltbænkene med porøse, zeolitfyldte zoner og strøkornsstørrelsen varierer. En del grusdækket.

586-606 Tæt, blålig, olivinholdig basalt. Olivinen optræder som små, friske strøkorn.

606-655 Storkornet porfyritisk basalt veksellejrer med finkornet.

655-683 Småprikket feldspatbasalt med porøse og zeolitholdige horisonter.

710 Top, grus- og vegetationsdækket. 


\begin{tabular}{cc}
\hline $\begin{array}{c}\text { Prøve } \\
\text { nr. }\end{array}$ & Højde \\
\hline
\end{tabular}

Profil 9.

$0-10$ Vegetationsdækket grus.

$1,210-84$ Porfyritiske basalter, indeholdende brændingszoner og zeolitfyldte, porøse lag.Tiltagende plagioklas-strøkornsindhold opad.

$3 \quad 84-88$ Tæt, grå, olivinholdig basalt.

88- 92 Grusdække.

92- 98 Porøs, zeolitholdig basalt, фverst med brændingshorisont.

98-102 Tæt, blålig basalt med eller uden olivin.

102-124 Vegetation.

4 124-142 Tæt, blålig, olivinholdig basalt med søjledannelse i hammeren. Udtrukne porer og fluidalstruktur. Øverst brændingszone.

$6 \quad 142-165$ Pikritisk (oceanitisk) olivinbasalt.

165-178 Vegetation.

178-193 Tæt, blålig, olivinholdig basalt med ret få, men store olivinstrøkorn.

193-195 Porfyritisk basalt.

195-202 Næsten helt grusdækket.

202-235 Tæt, blålig basalt, som opad indeholder flere brændingszoner.

235-302 Vegetation.

302-324 Tæt, blålig basalt, kompakte og porøse zoner (rødbrændte) skifter hyppigt.

324-380 Vegetation.

380-405 Storkornet, porfyritisk basalt, $\emptyset$ verst noget por $\varnothing$ s og zeolitholdig.

456 Mellem- til storkornet porfyritisk basalt.

Profil 10.

49 Porfyritisk basalt, фverst med brændingshorisont.

49- 65 Porfyritisk basalt.

$6520 \mathrm{~cm}$ tuf.

65- 69 Hård, blålig, olivinførende basalt med rødfarvet topslagge.

69- 85 Småprikket feldspatbasalt, øverst med brændingszone.

85- 88 Småprikket feldspatbasalt, øverst med brændingszone.

88-110 Porfyritisk basalt, $\emptyset$ verst med brændingszone.

110-117 Porfyritisk basalt, фverst med brændingszone.

117-129 Porfyritisk basalt, $\emptyset$ verst med brændingszone.

129-140 Porfyritisk basalt, $\varnothing$ verst næsten storfeldspatbasalt.

$140 \mathrm{Ca} .1 / 2 \mathrm{~m} \mathrm{r} \phi \mathrm{d} /$ brun tuf.

140-145 Mellemkornet, blålig basalt med forvitringsskorpe.

$14510 \mathrm{~cm}$ tuf.

145-157 Porfyritisk basalt, næsten storfeldspatbasalt, $\emptyset$ verst med brændingszone. 


\begin{tabular}{ccc}
\hline $\begin{array}{c}\text { Prøve } \\
\text { nr. }\end{array}$ & $\begin{array}{c}\text { Højde } \\
\text { i m }\end{array}$ & Bjergartstype \\
\hline
\end{tabular}

Profil 10 (fortsat)

157 Finkornet, hård, blålig basalt med megen olivin (Ejdeseriens bund).

Profil 11.

- Storkornet porfyritisk basalt.

- Småprikket feldspatbasalt dækket af ca. $40 \mathrm{~cm}$ brun tuf i

$9999 \mathrm{~m}$ højde.

99-104 Hammer af porfyritisk basalt, фverst med brændingszone.

104-131 Porfyritisk basalt $\mathrm{m}$. afrundede forvitringsformer.

131-135 Storfeldspatbasalt med grå grundmasse. Stellar vækst hos strøkornene.

135-147 Småprikket feldspatbasalt med enkelte, tynde, mere storkornede lag.

147-150 Porfyritisk basalt med ret store strøkorn i stjernevækst.

150-191 Grovkornet, porfyritisk basalt på overgangen til storfeldspatbasalt. $30 \mathrm{~cm}$ tuf.

191-195 Storfeldspatbasalt.

195-197 Mellemkornet, blålig basalt med ganske små strøkorn af plagioklas.

197-200 Storfeldspatbasalt.

200-280 Tætte, blålige, olivinporfyritiske basalter med netåret forvitringsoverflade (Ejdeserien).

280 Tæt, blålig basalt (= B-horisonten).

\section{Profil 12.}

2 299-315 Over et tuflag følger tæt, blålig basalt med porøse zoner i, (B-horisonten).

315-320 Grusdække.

320-322 Tæt, blålig basalt med porezoner.

$3 \quad 322-345$ Finkornet, porfyritisk basalt.

345-364 Vegetationsklædt med småblotninger af porfyritisk basalt.

364-390 Småprikket feldspatbasalt.

4.390 Porfyritisk basalt med stellar vækst af str $\varnothing$ kornene.

398 Porfyritisk basalt med lange feldspatlister.

398-430 Samme bjergart.

430-466 Småprikket feldspatbasalt.

466-506 Tynde bænke af porfyritisk basalt med lange feldspatlister.

506-565 Grusdække.

$6 \quad 565-570 \quad$ Småprikket feldspatbasalt.

570-598 Småprikket feldspatbasalt med porøse zoner. 


\begin{tabular}{ccc}
\hline $\begin{array}{c}\text { Prøve } \\
\text { nr. }\end{array}$ & Højde & \\
& i m & Bjergartstype \\
\hline
\end{tabular}

\section{Profil 12 (fortsat)}

7

598-657 Porfyritisk basalt med større feldspatstrøkorn og en del grønjord (=gap).

8

657-675 Porfyritisk basalt med tiltagende indhold af str $\varnothing$ korn opad.

675-744 Småprikket feldspatbasalt i 1-2 m tykke bænke med mange porehorisonter.

744 Tynd tufzone.

744-754 Tæt, blålig basalt med fluidalstruktur.

754 Brun tuf.

10

Profil 13.

0-212 Småprikket feldspatbasalt med blålig grundmasse og klare feldspatstrøkorn, indholdet af disse tiltager i rigelighed opad fra $142 \mathrm{~m}$.

212-230 Temmelig forvitret, str $\varnothing$ kornsfri, tæt basalt (særlig type) dækket af tyndt tuflag.

230-232 Porfyritisk basalt, dækket af tyndt tuflag.

232-235 Tæt, strøkornsfri basalt (særlig type).

235-237 Storkornet, porfyritisk basalt.

237-239 Tuf. Nederst grønlig, opad gående over i ca. $15 \mathrm{~cm}$ sideromelantuf, $\varnothing$ verst $35 \mathrm{~cm}$ r $\varnothing \mathrm{d}$ tuf.

239-250 Tæt, blålig basalt.

250-256 Storkornet, porfyritisk basalt.

256-285 Tæt, blålig basalt. Flere kompakte lag skifter med porøse, zeolitfyldte zoner (B-horisonten).

285-316 Småprikket feldspatbasalt.

316-330 Småprikket feldspatbasalt.

330-340 Tæt, blålig basalt, фverst med tynd brændingshorisont.

340-365 Småprikket feldspatbasalt.

365-375 Småprikket feldspatbasalt, der gradvis overgår i storkornet feldspatbasalt.

375-418 Storkornet feldspatbasalt.

418-545 Nederst småprikket feldspatbasalt, fra $510 \mathrm{~m}$ gradvis overgang i storkornet feldspatbasalt.

545-568 Småprikket feldspatbasalt, øverst en tynd brændingshorisont. 568-590 Storkornet feldspatbasalt, $\emptyset$ verst en tynd brændingshorisont. 


\begin{tabular}{ccc}
\hline $\begin{array}{c}\text { Prøve } \\
\text { nr. }\end{array}$ & $\begin{array}{c}\text { Højde } \\
\text { i m }\end{array}$ & Bjergartstype \\
\hline
\end{tabular}

Profil 13 (fortsat)

590-622 Småprikket feldspatbasalt, фverst med en brændingshorisont.

622-638 Tæt, blålig basalt med fluidalstruktur.

Profil 14.

$1 \rightarrow 108$ Finkornet, mørk, strøkornsfri basalt, dækket af $1 / 2 \mathrm{~m}$ tuf.

2 108-118 Grovkornet, porfyritisk basalt med enkelte oliviner. Kompakte og porøse zoner veksler.

3 118-128 Tæt, blålig basalt med synlig olivin, noget zeolitførende nær toppen (B-horisonten).

4 128-138 Samme bjergart.

(5) 134-140 Sill, grusdækket.

155-158 Porøs zeolitzone.

$6 \quad 158-172$ Lys, finkornet, porfyritisk basalt.

$8 \quad 172-178$ Grovkornet, porfyritisk basalt med tendens til stellar vækst af strøkornene. Noget porøs opad.

182-190 Grovkornet, porfyritisk basalt. Noget porøs opad.

9 200-208 Over $1 / 2 \mathrm{~m}$ rød tuf følger olivinrig, blålig basalt, hvori små plagioklasstrøkorn kan ses på forvitret overflade.

208 Over en $1 / 2 \mathrm{~m}$ tyk tuf følger atter tæt, blålig basalt.

\section{Profil 15.}

$1-50$ Tæt, blå, olivinf $\varnothing$ rende basalt (= B-niveauet).

$250-70$ Tæt, blå, olivinførende basalt. Tynde bænke på 1-2 m veksler med porøse zoner.

370 Ca. $30 \mathrm{~cm}$ tyk, brun tuf.

$4 \quad 70-85$ Tykkere bænke af plagioklasporfyritisk basalt, vekslende porøse zoner.

$5 \quad 85 \quad 10-20 \mathrm{~cm}$ tuf.

6 85-106 Grovkornet, plagioklasporfyritisk basalt. Tykke kompakte bænke veksellejrer med porøse zoner.

$7 \quad 106 \quad 40-50 \mathrm{~cm}$ rød tuf.

8 106-120 Tæt, blå, olivinfфrende basalt, Bænke på fra 1 til $5 \mathrm{~m}$ veksler med porøse zoner.

$9120 \quad 1 / 2 \mathrm{~m}$ brun tuf.

10 120-158 Finkornet, plagioklasporfyritisk basalt. Bænke på 4-6 m veksellejrer med porøse zoner.

11, 12 158-215 Grovkornet (især $\varnothing$ verst) plagioklasporfyritisk basalt med ganske enkelte olivinkorn. Bænke på 6-8 m veksellejrer med porøse zoner. 


\begin{tabular}{ccc}
\hline $\begin{array}{c}\text { Prøve } \\
\text { nr. }\end{array}$ & $\begin{array}{c}\text { Højde } \\
\text { i m }\end{array}$ & Bjergartstype \\
\hline
\end{tabular}

\section{Profil 15 (fortsat)}

$13 \quad 215-224$ Porfyritisk basalt med aftagende kornstørrelse.

14 224-260 Bænke af porfyritisk basalt med varierende størrelser af strøkornene.

15 260-285 Finkornet porfyritisk basalt.

bænke vekslende med porøse zoner.

285-295 Vegetation.

16,17 295-325 Lys, porfyritisk basalt med ganske små, spredte plagioklasstrøkorn. Bænkene er 3-4 m tykke og veksler med porøse zoner.

325 Vegetation.

Profil 16.

$\rightarrow 70 \quad$ (B-horisonten).

$170-84$ Vegetationsklædt med spredte blotninger af tæt, hård, blålig basalt med synlig olivin. $\emptyset$ verst $1 / 2 \mathrm{~m}$ r $\varnothing \mathrm{d}$ tuf.

2 85-140 Porfyritiske basalter. Nederste bænk er 12-15 m, resten tyndere. De veksellejrer med por $\varnothing$ se zoner. Str $\varnothing$ kornsst $\varnothing r r e l s e n$ tiltager opad.

3 140-215 Storfeldspatbasalt. 1-4 m tykke bænke veksellejrer med porøse zoner.

215-234 Vegetation.

4 234-250 Porøs basalt, der overgår opad i porfyritisk.

250-310 Vegetation.

$5 \quad 310-318$ Mellemkornet, porfyritisk basalt.

318-328 Vegetation.

6 328-336 Porfyritisk basalt med få, mellemstore str $\varnothing$ korn og m $\varnothing$ rk grundmasse.

336-365 Vegetation.

7 365-390 Lys, porfyritisk basalt, hvori kompakte og porøse zoner veksler.

390-400 Vegetation.

9 400-406 Hvilende på $25 \mathrm{~cm}$ brun tuf, strøkornsfattig, porfyritisk basalt med blålig, finkornet grundmasse.

406-412 Fjeldmark.

10 412-415 M $\varnothing$ rk basalt med strøkorn af pyroxen. Noget forvitret (overgangstype).

415-420 Vegetation.

11 420-440 Mørk basalt med strøkorn af pyroxen (overgangstype).

440-464 Vegetation.

464-476 Grovkornet, porfyritisk basalt, dækket af $1 / 2 \mathrm{~m}$ rød tuf.

476 Tæt, blålig, olivinførende basalt (C-horisonten). 


\begin{tabular}{ccc}
\hline $\begin{array}{c}\text { Prøve } \\
\text { nr. }\end{array}$ & $\begin{array}{c}\text { Høide } \\
\text { i m }\end{array}$ & Bjergartstype \\
\hline
\end{tabular}

Profil 17.

1,2 80-114 Storfeldspatbasalt med mørk grundmasse og tiltagende størrelse af strøkorn opad. En række kompakte bænke veksler med porøse zoner. Overlejret af $2 \mathrm{~m}$ tuf, nederst grøn, $\varnothing$ verst rød.

En ganske tynd porfyritisk lavabænk kiler ud mellem de to tuffer med forskellig farve i ca. $116 \mathrm{~m}$ højde.

5,6 116-146 Bænke på 2-3 m veksler med porøse zoner, bænkene består af porfyritiske lavaer med m $\varnothing \mathrm{rk}$ grundmasse. I $146 \mathrm{~m}$ et rødt tuflag på $1 / 2 \mathrm{~m}$.

8,9 146-157 Tynde bænke af porfyritiske lavaer med m $\varnothing \mathbf{r k}$ grundmasse veksellejrer med porøse zoner. Dækkes af $1 / 2 \mathrm{~m}$ brun tuf.

11 157-175 Tynde bænke af porfyritiske lavaer, stadig med m $\varnothing$ rk grundmasse veksellejrer med por $\varnothing$ se zoner. Tynd tuf $\varnothing$ verst (ca. $10 \mathrm{~cm})$.

13 175-208 Porfyritisk basalt. Strøkornene viser tendens til stjernevækst, kornst $\varnothing$ rrelsen tiltager opad. Basalterne udgør tynde bænke, som veksellejrer med por $\varnothing$ se zoner.

14 208-224 Porfyritisk basalt med sort grundmasse. Listerne er 1-2 cm lange.

16 224-254 Porfyritisk basalt med mørk grundmasse, enkelte zeoliter.

17 254-264 Porfyritisk basalt med lys, "sandet « grundmasse. Temmelig store lister.

264-295 Skiftende udvikling af porfyritiske lavaer, de fleste er småprikkede.

18 295-350 Skiftende bænke af porfyritiske lavaer, de fleste med stellar vækst af plagioklasstr $\varnothing$ kornene.

19.20 350-405 Tæt, blålig, olivinholdig basalt i bænke, der veksellejrer med stærkt rødfarvede, porøse og zeolitførende zoner (C-horisonten).

405-424 Porfyritisk basalt med veludviklede, 1-2 cm lange str $\varnothing$ kornslister.

21 424-444 Tæt, blålig, olivinf $\varnothing$ rende basalt, som er noget slagget udviklet, opad vegetation.

22490 Grovkornet porfyritisk basalt med sort grundmasse. Vegetation.

$23 \quad 520-530$ Porfyritisk basalt med mørk grundmasse. Strøkornslister på $1 / 2$ til $1 \mathrm{~cm}$.

Vegetation.

24 555-583 Storfeldspatbasalt.

583-588 Tæt, blålig basalt. Nederst en kompakt bænk på ca. $3 \mathrm{~m}$, opad går denne over i en tyk, porøs zone. Der forekommer enkelte plagioklasstr $\phi$ korn.

588-610 Grovkornet, porfyritisk basalt. 


\begin{tabular}{ccc}
\hline $\begin{array}{c}\text { Pr } \varnothing \mathrm{ve} \\
\text { nr. }\end{array}$ & Højde & \\
\hline
\end{tabular}

Profil 18.

$0-4$ Porfyritisk basalt.

4- 60 Vegetation.

60- 66 Porfyritisk basalt.

66- 70 Porøs, porfyritisk basalt.

70-100 Porfyritisk basalt.

100-126 Porfyritisk basalt.

126 Tæt, blålig, olivinførende basalt, delvis vegetationsklædt op til næste hammer.

140-160 Porfyritisk basalt.

160-172 Porfyritisk basalt, dækket af tuf.

172 Ny bænk af porfyritisk basalt, som fortsætter opad.

192 Ny bænk af porfyritisk basalt, som fortsætter opad.

224-260 Grovkornet, porfyritisk basalt. Tuf.

260-270 Tæt, blålig, olivinf $\varnothing$ rende basalt (C-horisonten).

270-295 Vegetation.

295-302 Porfyritisk basalt.

302-314 Vegetation.

7 315-323 Porfyritisk basalt.

323-332 Vegetation.

$8 \quad 332-348$ Porfyritisk basalt.

348-368 Vegetation.

9 368-373 Porfyritisk basalt.

373-384 Vegetation.

384-400 Porfyritisk basalt.

400-430 Vegetation.

430-454 Porfyritisk basalt.

12,13 454-501 Grovkornet, porfyritisk basalt (top af fjeldet).

Profil 19.

340 Porfyritisk basalt.

$15 \quad 340-360$ Tæt, blålig, olivinførende basalt (C-horisonten).

360-366 Vegetation.

366-382 Porfyritisk basalt.

382-400 Vegetation.

400-410 Tæt, blålig basalt.

410-414 Vegetation.

414-420 Porfyritisk basalt.

420-435 Vegetation.

435-460 Porfyritisk basalt.

460-490 Vegetation.

490-494 Porøs, porfyritisk basalt. 


\begin{tabular}{ccc}
\hline $\begin{array}{c}\text { Prøve } \\
\text { nr. }\end{array}$ & $\begin{array}{c}\text { Højde } \\
\text { i m }\end{array}$ & Bjergartstype \\
\hline
\end{tabular}

\section{Profil 19 (fortsat)}

22 494-506 Grovkornet, porfyritisk basalt.

506-572 Vegetation.

572-575 Tæt, blålig basalt.

575-578 Vegetation.

578-595 Porfyritisk basalt.

595-616 Fjeldmark.

616-620 Porfyritisk basalt.

620-632 Tæt, blålig basalt.

Profil 20.

0- 26 Mørk, ofitisk, olivinf $\varnothing$ rende basalt. Tuf.

26- 40 Mørk, ofitisk, olivinf $\emptyset$ rende basalt.Tuf.

40- 77 Porfyritisk basalt med kun få strøkorn.

77-110 Mørk, ofitisk, olivinførende basalt.

$8 \quad 110-158$ Porfyritisk basalt med m $\varnothing \mathrm{rk}$, finkornet grundmasse.

158-171 Tæt, blålig basalt.

171-187 Finkornet, porfyritisk basalt. Tuf.

188-206 Porfyritisk basalt. Tuf.

206-278 Porfyritisk basalt.

278-288 Grusdækket.

288-325 Porfyritisk basalt.

325-330 Vegetationsdækket med småblotninger af porfyritisk basalt.

330-353 Porfyritisk basalt.

353-415 Vegetationsdækket med småblotninger af porfyritisk basalt.

415-430 Vegetationsdækket med blotninger af rødligt, porøst, opalførende materiale.

430-493 Samme materiale fortsætter som løst grus med vegetationspletter.

493-540 Vegetation.

540-545 Porfyritisk basalt.

545 Mørk, blålig, olivinf $\varnothing$ rende basalt (C-horisonten).

\section{Profil 21.}

$10-22$ Mellemkornet, porfyritisk basalt. $1 \mathrm{~m}$ r $\varnothing \mathrm{d}$ tuf.

2 24- 32 Tynde bænke af mellemkornet porfyritisk basalt.

32- 38 Sill.

39- 70 Flere tynde bænke af porfyritiske basalter. Øverst brændingshorisont.

70- 90 Flere bænke af grå, mellemkornet, porfyritisk basalt. 


\begin{tabular}{ccc}
\hline $\begin{array}{c}\text { Pr } \phi v e \\
\text { nr. }\end{array}$ & $\begin{array}{c}\text { Højde } \\
\text { i m }\end{array}$ & Bjergartstype \\
\hline
\end{tabular}

\section{Profil 21 (fortsat)}

5 90-140 Tæt, blålig basalt, nederst kompakt, dernæst flere, tynde, porøse bænke.

7 140-144 Stjernefeldspatbasalt, $\emptyset$ verst en brændingshorisont.

145-162 Tæt, blålig, meget olivinrig basalt.

10 162-167 Grovkornet porfyritisk basalt. Tuf.

11 169-228 Grovkornede, porfyritiske basalter. Tuf.

228-250 Lamelleret, tæt, blålig basalt med synlig olivin (C-horisonten).

250-252 Vegetation.

253-264 Tæt, blålig basalt i slagget udformning.

265-282 Finprikket, porfyritisk basalt.

282-286 Ras. Helt tilskredet.

14 286-298 Tæt, blålig basalt.

298-300 Ras.

300-308 Grusdækket, men med små blotninger af tæt, blålig basalt. Tuf.

$15 \quad 308-342$ Flere bænke af grovkornet, porfyritisk basalt.

342-360 Ras.

360-457 Bænke af porfyritiske basalter, grovkornede. Tuf.

$16 \quad 458-490$ Markant hammer af porfyritisk basalt.

490-554 Ras.

17 554-562 Markant hammer af tæt, blålig basalt.

562-576 Ras.

18 577-610 Mellemkornet porfyritisk basalt.

Profil 22.

$20-10$ Lys, grovkornet, porfyritisk basalt. Strøkornene aftager i størrelse opad.

10 - 48 Porøse lavaer, zeolitrige, med indslag af porfyritiske basalter. $1 / 2 \mathrm{~m}$ rød tuf.

48- 75 Porfyritiske basalter med porøse zoner. $10-20 \mathrm{~cm}$ rød tuf $\emptyset$ verst.

5 75- 88 Tæt, blålig basalt med olivinstrøkorn. Danner hammer, men bliver opad slagget og porøs.

88-140 Porfyritisk basalt med mørk grundmasse (forvitrer til »kandisgrót «). Øverst 30-40 cm rød tuf.

$8 \quad 140-180$ Tæt, blålig basalt med et violet eller rødligt skær på frisk brudflade. Opad noget por $\varnothing$ s og grusdækket (C-horisonten).

180-183 Tuf, som nederst er grøn, $\varnothing$ verst r $\varnothing \mathrm{d}$.

183-200 Finkornet, porfyritisk basalt med tynde tufsmører. Øverst brændingshorisont. 


\begin{tabular}{ccc}
\hline $\begin{array}{c}\text { Pr } \varnothing v e \\
\text { nr. }\end{array}$ & H $\varnothing$ jde & \\
i m & Bjergartstype \\
\hline
\end{tabular}

\section{Profil 22 (fortsat)}

11 200-206 Markant hammer af olivinholdig basalt, temmelig porøs og med zeoliter.

206-210 Grusdække.

210 Porfyritisk basalt.

Profil 23.

0 - 48 Mellemkornet porfyritisk basalt.

48- 50 Tæt, blålig basalt.

50- 67 Meget ukarakteristisk lavabænk.

67-115 Porøs, porfyritisk basalt.

115-125 Tæt, blålig, strøkornsfri basalt (lidt tvivlsom type).

125-130 Mellemkornet, porfyritisk basalt.

150-160 Grusdække over serie af tynde bænke af blålig, olivinholdig basalt (C-horisonten).

160-165 Porøs, ukarakteristisk lavabænk, dækket af tuf.

166-193 Finprikket, porfyritisk basalt.

7 193-202 Tæt, blålig, noget blæret basalt med fluidallinjer.

202-242 En bænk af finprikket, porfyritisk basalt.

242-256 Finprikket, porfyritisk basalt.

256-265 Vegetation.

265-280 Brokket, mellem- til grovkornet, porfyritisk basalt.

280-303 Vegetation.

303-327 Mellem- til grovkornet, brokket, porfyritisk basalt.

327-345 Vegetation.

345-380 Brokket, mellem- til grovkornet, porfyritisk basalt.

380-400 Fin- til mellemkornet porfyritisk basalt.

400-415 Småbænket, tæt, blålig basalt (fremtræder lamelleret i terrænet).

415-450 Grusdækket og vegetationsklædt.

450-490 Mellem- til grovkornet, porfyritisk basalt.

490-503 Tæt, blålig basalt.

Profil 24.

220 Lys, tæt, olivinholdig basalt med sandstensagtig forvitring (= samme bænk, som går frem i stenbrud ved Klakksvík) Tuf.

Porfyritisk basalt. Tuf.

230 Brokket, porfyritisk basalt. 


\begin{tabular}{ccc}
\hline $\begin{array}{c}\text { Prøve } \\
\text { nr. }\end{array}$ & $\begin{array}{c}\text { Højde } \\
\text { i m }\end{array}$ & Bjergartstype \\
\hline
\end{tabular}

Profil 24 (fortsat)

250 »Sandstensagtig « basalt med str $\varnothing$ korn af augit og plagioklas.

280 Grovkornet, porfyritisk basalt. Tuf.

295-320 Mørk, hård, klingende basalt (C-horisonten).

355 Hammer af porfyritisk basalt.

375 Hammer af lidt mørkere, porfyritisk basalt.

380 Hammer af lignende bjergart.

430 Porfyritisk basalt.

$9440 \quad$ Porfyritisk basalt.

ca. 470 Porfyritisk basalt, går opad over i en anden type og bliver str $\varnothing$ kornsfri. Indeholder her mange zeoliter.

475 Hård, klingende basalt.

505 Efter tuflag porfyritisk basalt.

525 Mørk, porfyritisk basalt.

11a 530 Porfyritisk basalt. Tuf. Over denne hård, sort, tæt basalt.

12a 555 Porfyritisk basalt.

12b Herover tæt, blålig basalt.

630 Grovkornet, mørk basalt med synlig olivin og plagioklasstrøkorn.

Profil 25.

150-170 Lys, tæt, olivinholdig basalt (= samme bænk, som går frem i stenbrud ved Klakksvík).

234 Porfyritisk basalt med mørk grundmasse (forvitrer som »kandisgrót «).

255 Kompakt, mørk, olivinf $\varnothing$ rende basalt (C-horisonten). Tuf.

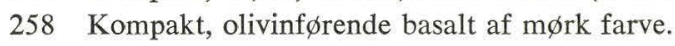

280 Samme bjergart, men med flere zeoliter.

290 Porfyritisk basalt med enkelte olivinstrøkorn. Tuf.

305 Porfyritisk basalt med enkelte olivinkorn.

330 Porfyritisk basalt med enkelte olivinkorn.

363 Porfyritisk basalt med brokket forvitring.

389 Samme bjergart.

410 Over tuf brokket til gruset, porfyritisk basalt.

440 Flere små hamre af tætte, næsten sorte basalter.

455 Samme bjergart fortsætter.

465 Olivinf $\varnothing$ rende, sort basalt.

475 Grovkornet, porfyritisk basalt.

510 Porfyritisk basalt. Tuf i $520 \mathrm{~m}$.

520 Porfyritisk basalt.

535 Lys, grå, lamelleret, porfyritisk basalt. 


\begin{tabular}{ccc}
\hline $\begin{array}{c}\text { Pr } \phi \text { ve } \\
\text { nr. }\end{array}$ & $\begin{array}{c}\text { Højde } \\
\text { i m }\end{array}$ & Bjergartstype \\
\hline
\end{tabular}

Profil 25 (fortsat)

555 Porfyritisk basalt.

563 Over tuf tæt, hård, sort basalt.

570 Over tuf porfyritisk basalt.

575 Over tuf porfyritisk basalt.

605 Strøkornsfri, olivinf $\varnothing$ rende basalt.

610 Sort, tæt basalt.

630 Sort, tæt, olivinf $\varnothing$ rende basalt.

640 Over tuf blåsort, hård basalt, dernæst olivinførende, blåsort, hård basalt.

660 Olivinførende, blåsort, grovkornet basalt.

670 M $\varnothing$ rk plagioklas- og olivinf $\varnothing$ rende basalt.

675 Grovkornet, porfyritisk basalt.

22685 Rødlig, olivinførende basalt.

690 Zeolitzone.

705 M $\varnothing$ rk, tæt basalt.

24715 Grovkornet, m $\varnothing$ rk til r $\varnothing$ dlig basalt.

725 Over tuf sort, tæt basalt.

\begin{tabular}{|c|c|c|c|c|c|c|c|c|c|}
\hline $\begin{array}{l}\text { Prøve } \\
\text { nr. }\end{array}$ & $\begin{array}{l}\text { Højde } \\
\text { i m }\end{array}$ & Bjergartstype & $\begin{array}{l}\% \\
\text { pl. }\end{array}$ & $\begin{array}{c}\% \\
\text { cpx. }\end{array}$ & $\begin{array}{l}\% \\
\text { ore }\end{array}$ & $\begin{array}{l}\% \\
\text { ol. }\end{array}$ & $\begin{array}{l}\% \\
\text { gl. }\end{array}$ & $\begin{array}{c}\% \\
\text { gap. }\end{array}$ & d. \\
\hline
\end{tabular}

Profil 26.

0 Sandstensagtigt forvitrende feldspatbasalt. Plagioklasens mængde tiltager opad. Bjergarten har mange farvenuancer.

52 Grålig, tæt, hård, olivinf $\varnothing$ rende basalt

60 Finkornet, olivinf $\varnothing$ rende basalt afbrydes her af et ca. 2 $\mathrm{m}$ tykt agglomerat. Herover hammer på 5-6 $\mathrm{m}$ af feldspatbasalt med brokket forvitring.

75 Hård, blålig basalthammer med svagt udviklet kugleformet afsondring. 


\begin{tabular}{cccccccccc}
\hline $\begin{array}{c}\text { Prøve } \\
\text { nr. }\end{array}$ & $\begin{array}{c}\text { Højde } \\
\mathrm{i} \mathrm{m}\end{array}$ & Bjergartstype & $\begin{array}{c}\% \\
\mathrm{pl}\end{array}$ & $\begin{array}{c}\% \\
\mathrm{cpx} .\end{array}$ & $\begin{array}{c}\% \\
\text { ore }\end{array}$ & $\begin{array}{c}\% \\
\text { ol }\end{array}$ & $\begin{array}{c}\% \\
\text { gl. }\end{array}$ & $\begin{array}{c}\% \\
\text { gap. }\end{array}$ & d. \\
\hline
\end{tabular}

Profil 26 (fortsat)

90 Overkant af denne hammer.

103 Basalt med store strøkorn af olivin.

4 125-150 Lysegrå, noget brokket feldspatbasalt. Opad bliver grundmassen mørkere. Øverst tuf.

5 150-165 Hammer af tæt, blålig basalt (C-horisonten).

165 Tæt, rødligsort basalt med nogen kugleafsondring.

175 Sort, olivinf $\varnothing$ rende basalt. Tuf i $187 \mathrm{~m}$.

$\begin{array}{llllll}26 & 56 & 7 & 5 & 6 & -\end{array}$ $\begin{array}{llllll}36 & 49 & 14 & - & 1 & -\end{array}$

Sort, olivinf $\varnothing$ rende basalt med nogen kugleafsondring. Rødlig opad.

215 Olivinførende basalt med zeolit $\varnothing$ jne, farven, der er grå, bliver lysere opad.

260 Porfyritisk basalt

280 Lignende bjergart, $\begin{array}{llllll}45 & 46 & 3 & - & 6 & -\end{array}$ lidt mørkere.

305 Sort, zeolitprikket basalt.

335 Sort til svagt rødig basalt med svingende indhold af olivin.

352 Hammer af porfyritisk basalt af mørk farve.

371 Tuf, herover rødlig, hård basaltbænk.

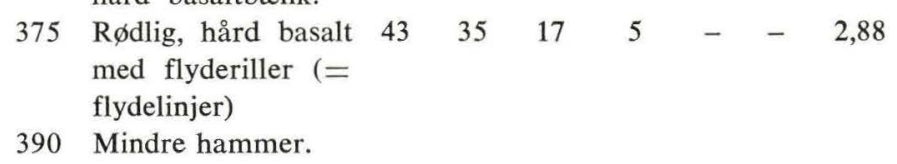




\begin{tabular}{cccccccccc}
\hline $\begin{array}{c}\text { Pr } \phi \text { ve } \\
\text { nr. }\end{array}$ & $\begin{array}{c}\text { H } \phi \text { jde } \\
\text { i m }\end{array}$ & Bjergartstype & $\begin{array}{c}\% \\
\text { pl. }\end{array}$ & $\begin{array}{c}\% \\
\text { cpx. }\end{array}$ & $\begin{array}{c}\% \\
\text { ore }\end{array}$ & $\begin{array}{c}\% \\
\text { ol }\end{array}$ & $\begin{array}{c}\% \\
\text { gl. }\end{array}$ & $\begin{array}{c}\% \\
\text { gap. }\end{array}$ & d. \\
\hline
\end{tabular}

Profil 26 (fortsat)

10

11

12

13

14
410 Sandgrå porfyritisk 4 basalt.

445 Sorteblå, tæt, klin- 35 gende, zeolitprikket basalt.

464 Sorteblå, tæt basalt uden zeoliter.

480 Sorteblå, tæt basalt med olivinstrøkorn. Bliver opad mere grovkornet.

510 Samme bjergart fortsætter.

540 Tuf, derover mindre hammer af samme bjergartstype.

565 Samme bjergartstype fortsætter med vekslende røde og gråsorte zoner.

588 Tuf, hvorover zeolitprikket basalt, som bliver sort og tæt opad.

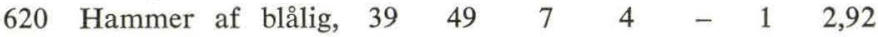
tæt, porfyritisk ba-

salt. (Overgangsform).

700 Tuf, hvorover rødlig, zeolitprikket basalt.

(Fjeldet er $50 \mathrm{~m} \mathrm{~h} \varnothing$ jere, men toppen er én grusbunke uden blotninger). 


\begin{tabular}{ccc}
\hline $\begin{array}{c}\text { Prøve } \\
\text { nr. }\end{array}$ & $\begin{array}{c}\text { Højde } \\
\text { i m }\end{array}$ & Bjergartstype \\
\hline
\end{tabular}

\section{Profil 27.}

1 61- 74 Grå, tæt, olivinf $\varnothing$ rende basalt (= samme bænk, som går frem i stenbrud ved Klakksvík).

74-100 Spredte blotninger af agglomerater, rødfarvede basalter og tuf.

100-113 Grovkornet, porfyritisk basalt.

113-121 2 bænke af grovkornet, porfyritisk basalt.

121-137 Tæt, blålig, olivinholdig basalt udg $\varnothing \mathrm{r}$ nederste, markante hammer i fjeldet (C-horisonten).

137 Samme bjergart fortsætter. I $144 \mathrm{~m}$ zeolitzone.

15 155-158 Over tuf, hård, blålig, olivinf $\varnothing$ rende basalt.

16158 Porfyritisk basalt.

185 Hammer af porfyritisk basalt (med calcedon). I $188 \mathrm{~m} \mathrm{r} \varnothing \mathrm{d}$ brændingszone.

17 189-202 Porfyritisk basalt med m $\varnothing$ rk grundmasse. Tuf.

203-223 Serie af tyndere bænke af porfyritiske basalter.

18

223 Tæt, blålig, olivinf $\varnothing$ rende basalt.

237 Hård, grålig (forvitret?) bænk, som er den фverste i profilet.

Profil 28.

(Undergrænsen for C-niveauet ligger ca. $75 \mathrm{~m}$ under havniveau).

40- 50 Feldspatbasalt med brændingszone $\varnothing$ verst.

50- 57 Storkornet feldspatbasalt, $\varnothing$ verst med $3 \mathrm{~m}$ slagger.

57- 74 Storkornet feldspatbasalt, $\varnothing$ verst med ca. $4 \mathrm{~m}$ tyk slaggezone.

74-140 Tynde lavastrømme, adskilt af porøse zoner. Grundmassen er blålig, der er enkelte små plagioklasstrøkorn. Tuf.

140-148 Småprikket feldspatbasalt, фverst med $3 \mathrm{~m}$ slaggezone.

148-155 Lava med blålig grundmasse og små, utydelige str $\varnothing$ korn af plagioklas. Serien består af tynde strømme med porøse zoner imellem.

155-195 Vegetation.

195-200 Tæt, blålig basalt.

200-205 Feldspatbasalt med spredtliggende, store plagioklasstr $\varnothing$ korn, $\emptyset$ verst en brændingshorisont. Tufsmøre.

205-220 Basalt med tæt, blålig grundmasse og enkelte mørke str $\varnothing$ korn. Nogle zeoliter. Tuflag.

220-225 Samme bjergart fortsætter.

Vegetation. (Profilet forskudt).

3 280-305 Finkornet, porfyritisk basalt.

4 305-340 Tæt, blålig basalt.

$5 \quad 340-350$ Tæt, blålig basalt. 


\begin{tabular}{ccc}
\hline $\begin{array}{c}\text { Prøve } \\
\text { nr. }\end{array}$ & Højde & \\
& i m & Bjergartstype \\
\hline
\end{tabular}

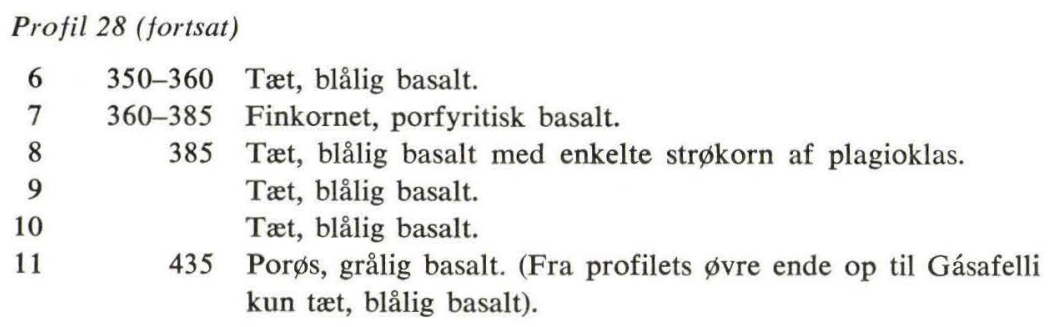

Profil 29.

0- 11 Grovkornet porfyritisk basalt på overgangen til storfeldspatbasalt. Zeolitfyldte porer.

11- 58 Tæt, blålig basalt med for det meste synlig olivin.

v. $17 \mathrm{~m}$ små zeoliter.

v. $36 \mathrm{~m}$ uden zeoliter.

v. $46 \mathrm{~m}$ med ganske små strøkorn også af plagioklas.

v. $52 \mathrm{~m}$ med brokket forvitring.

v. $55 \mathrm{~m}$ brændingshorisont.

58-142 Tæt, blålig basalt med synlig olivin og spredte zeoliter. v. $80 \mathrm{~m}$ ganske små strøkorn af plagioklas.

v. $110 \mathrm{~m}$ do.

142-422 Bænke af ensartet, tæt, blålig basalt med tydelig horisontal stribning.

300-307 m brændingshorisont.

Profil 30.

85 Hammer af tæt, blålig basalt, noget zeolitprikket. Herover grusdække.

115 Hammer af tæt, blålig basalt.

165 Hammer af tæt, blålig basalt. Herover vekslende, blærede, zeolitfyldte zoner og tynde bænke af tæt, blålig basalt.

240 Over tuflag hammer af tæt blålig basalt.

250 Hammer af tæt, blålig basalt, som hviler på en blæret, zeolitfyldt zone.

265 Stor hammer af tæt, blålig basalt, som hviler på en brændingshorisont.

280 Hammer af tæt, blålig basalt. Den består af en serie af bænke, der er indbyrdes adskilt af zeolitzoner.

315 Hammer af tæt, blålig basalt, som hviler på en zeolitfyldt brændingszone. 
Profil 30 (fortsat)

1332 Hammer af blågrå, meget olivinrig (pikritbasaltisk) basalt.

445 Flere blålige basalter, undertiden adskilt af underordnede tuflag.

2

620 Blålig, mellemkornet basalt med synlig olivin (top).

Profil 31.

$125-48$ Grovkornet, porfyritisk basalt.

48- 56 Vegetation.

56- 79 Grovkornet, porfyritisk basalt.

79- 82 Brændingshorisont.

2 82-104 Fin-mellemkornet, porfyritisk basalt.

Profil 32.

0- 10 Porøs, ukarakteristisk bjergart.

$10-12$ Tuf.

$8 \quad 12-18$ Grovkornet, porfyritisk basalt.

18- 25 Vegetation.

9 25-100 Mellem- til grovkornet, porfyritisk basalt.

100-103 Vegetation.

10 103-124 Grovkornet, porfyritisk basalt, som danner en tydelig hammer.

124-160 Vegetationsklædt med småblotninger af porfyritisk basalt. I $160 \mathrm{~m}$ tuf.

12 160-190 Fin- til mellemkornet porfyritisk basalt.

Profil 33.

25- 35 Grusdækket.

$135-51$ Finkornet, porfyritisk basalt.

51- 53 Brændingshorisont.

$253-63$ Fin- til mellemkornet porfyritisk basalt.

63- 65 Grusdækket.

$3 \quad 65-85$ Fin- til mellemkornet porfyritisk basalt.

85-105 Vegetation.

4 105-123 Tæt, blålig basalt med ganske enkelte plagioklasstrøkorn. 
Prøve Højde

nr. i m Bjergartstype

Profil 34.

$30-35$ Tuf.

35- 60 Tæt, blålig basalt (= samme bænk som i profil 33: 105$123 \mathrm{~m})$. Tyndt tuflag.

$9 \quad 60-69$ Porfyritisk basalt.

10 69-103 Finkornet, porfyritisk basalt. Tyndt tuflag.

$11 \quad 103-118$ Tæt, blålig basalt.

118-155 Finkornet, porfyritisk basalt.

155-165 Tæt, blålig basalt.

165-183 Vegetation.

183-200 Porøs, porfyritisk basalt.

200-212 Vegetation.

212-225 Hvilende på et tuflag, basalt med blålig grundmasse og få plagioklasstrøkorn.

225-255 Vegetation.

255-256 Tuf.

$15 \quad 256-273$ Tæt, blålig basalt med lys vejrskal.

273-286 Vegetation.

286-300 Porfyritisk basalt.

300-336 Vegetationsklædt ur.

336 Lyst forvitrende, tæt, blålig basalt (top).

Profil 35.

198-203 Grusdækket.

203-233 Tæt, blålig basalt.

233-253 Grusdækket.

(253-344) Udgøres af en serie gråt forvitrende, kompakte bænke.

2

5

344-368 v. $261 \mathrm{~m}$ finkornet, porfyritisk basalt. v. $343 \mathrm{~m}$ tæt, blålig basalt.

Grovkornet, blålig basalt.

376-398 Tilskredet (Profil flyttet).

$7 \quad 398-422$ Grovkornet, blålig basalt.

8 422-453 Tynde bænke af tætte, blålige basalter.

9 453-465 Blålige basalter med enkelte, klare strøkorn af plagioklas (overgangstype).

10 465-475 Hvilende på tuf, en tæt, blålig basalt, helt uden strøkorn.

11 475-479 Hvilende på tuf, olivinrig, blålig basalt. 


\section{Profil 36.}

$10-20$ Grovkornet, porfyritisk basalt.

20- 40 Grusdække.

$240-57$ Meget grovkornet, porfyritisk basalt.

$357-72$ Fin- til mellemkornet porfyritisk basalt.

$72-87$ Elvgrus.

4 87-100 Mellemkornet, porfyritisk basalt.

100-104 Elvgrus.

104-105 Rød tuf.

6 105-120 Tyk, lamelleret bænk med meget spredt optrædende strøkorn af plagioklas i en blålig grundmasse (= C-horisonten).

120-140 Vegetation og grus.

(140-257) Hele strækningen er stærkt vegetationsdækket, men ved de angivne højder er faststående bjergarter konstateret.

$7 \quad 140$ Fin- til mellemkornet porfyritisk basalt.

8155 Mellem- til grovkornet, porfyritisk basalt.

9195 Basalt med ganske enkelte plagioklasstrøkorn i en blålig grundmasse.

10210 Småprikket, porfyritisk basalt.

11232 Tæt, blålig basalt med mørke strøkorn.

248 Tæt blålig basalt med såvel lyse som mørke strøkorn (overgangstype).

257 Top. 


\section{Nederste basaltserie}

Den nederste basaltserie forekommer på Suðuroy, Mykines, Gáshólmur, Tindhólmur og Vágar. Laghældningen på Suðuroy er NNØ, $N \varnothing$ og $\varnothing \mathrm{N} \varnothing$, og den nederste basaltseries $\varnothing$ verste lag skærer allerede havniveau på den nordlige del af фen langs linjen Froðbiarnípa, Hvannhagi, Tjørnunes og Kolaratangi. Hele den sydlige del af Suðuroy er således opbygget af den nederste basaltseries lavaer. På Mykines varierer laghældningen fra $S \varnothing$ til $\varnothing S \emptyset$; på den vestlige del af Vágar er den $\varnothing \mathbf{S} \emptyset$. Mykines og Gáshólmur består udelukkende af bænke, der tilhører den nederste basaltserie, medens kun den vestligste del af Vágar og den nederste del af Tindhólmur tilhører denne serie, hvis $\varnothing$ verste bænk når havniveau ved $\varnothing$ stspidsen af Tindhólmur og langs linjen Álkuklettur - Víkar på Vágar. Den nederste basaltserie er opbygget af 10-30 m tykke lavabænke med underordnede, interbasaltiske sedimenter, hvis mægtighed sjældent når op til en halv snes meter, sædvanligvis er den betydelig mindre. Tyndere lavabænke forekommer dog, og der ses også enkelte bænke helt op til 50-70 m mægtighed. Bjergarten er meget ensartet; det er en tæt, hård, blålig basalt, som kun undtagelsesvis fører strøkorn. Den udviser oftest mere eller mindre veludviklet, sjældent ganske regelmæssig søjlestruktur. Bænkenes overflade er slagget, por $\varnothing$ s og rødligtfarvet. Seriens samlede mægtighed bel $\varnothing$ ber sig til knapt $900 \mathrm{~m}$.

\section{Suðuroy}

Ved betragtning af Suðuroys stejle vestkyst kan man i naturligt forekommende, lodrette snit, bl. a. ved Beinisvørður, Rávan og Vágseiði på den sydlige del af фen (nedre del af lagserien), mellem Vágseiði og Fámjin (den midterste del af lagserien) og omkring Geitaskor - Prestskorar på den nordlige del af $\varnothing$ en ( $\varnothing$ vre del af lagserien), få et udmærket overblik over den nederste basaltseries enkle og regelmæssige geologiske opbygning: Det stadige skifte mellem basaltlag med slaggeoverflader og tuf eller andre interbasaltiske sedimenter. (Fig. 8, 9). 


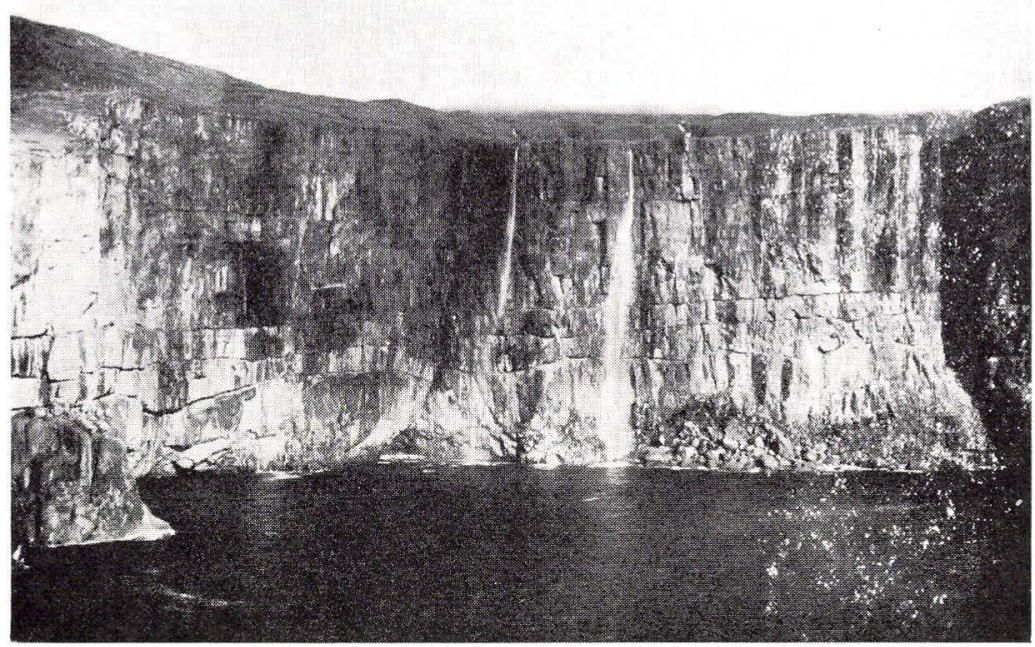

Fig. 8. Fjeldvæggen syd for Vágseiði.

s. $f$. Vágseiði.

The rock wall south of Vágseiði, Suðuroy.

Basaltbænkene fra Sunnba til Vágseiði har gennemgående den for nederste basaltserie sædvanlige mægtighed med mere eller mindre tydelig udviklet søjlestruktur og slaggezoner. Slaggezonerne forløber på strækningen Akrabyrgi - Vágseiði ofte uregelmæssigt. Noget tyndere lavabænke ses bl. a. ved Lónirnar nord for Sunnba og syd for Vágseið̃i. Nederosion af lagoverflader og udkiling af lagene kan ses flere steder bl. a. nord for Bølluhálsur, nord for Lomvigastakkur og syd for Vágseiði. I den stejle kystfjeldvæg omkring Beinisvørður findes mange røde tuflag, de er dog ikke ret tykke; slaggezonerne synes at have langt større mægtighed. I Beinisvørður (469 m) blev der fra søsiden talt ca. 20 basaltbænke.

Mellem Vágseiði og Fámjin synes basaltbænkenes mægtighed almindeligvis at være af samme størrelsesorden som nordligere. Tufslaggezoneforløbet er oftest bugtet, overfladen er uregelmæssig. Søjlestrukturen er ikke altid lige fremtrædende, men f.eks. ved Forstólur ses dog tydeligt en noget uregelmæssig søjlestruktur gennem hele fjeldvæggen. I den stejle, knapt $300 \mathrm{~m}$ høje fjeldvæg nord 


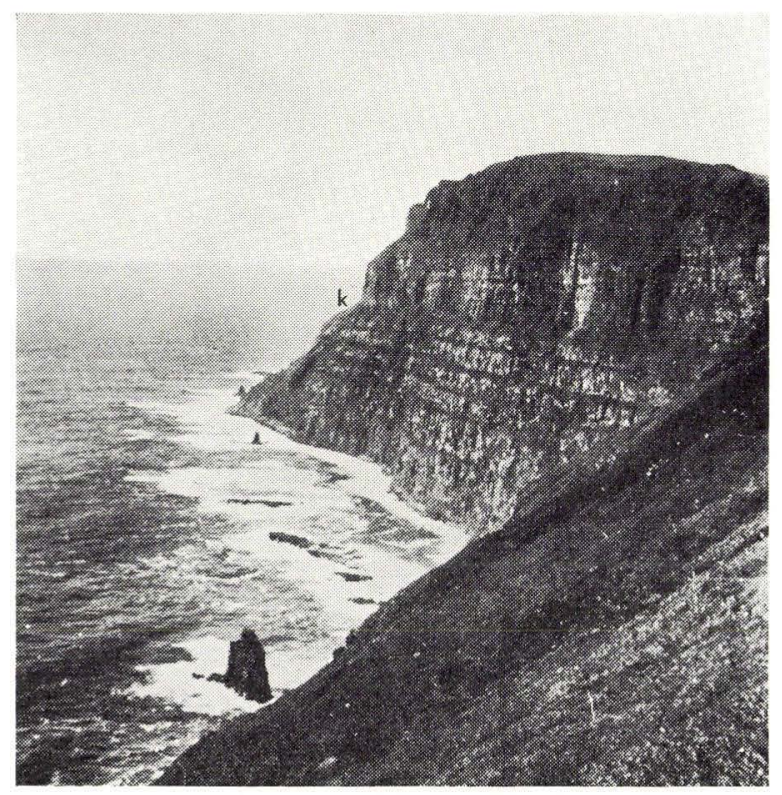

Fig. 9. Vestsiden af Suðuroy, Geitaskor og Prestskorar, nederste basaltserie - kulførende serie $(\mathrm{k})$ - mellemste basaltserie.

Vestantil á Suðuroy (Geitaskor og Prestskorar). Niðaru basaltfláirnar kolalindin $(k)$ - miðfláirnar.

West side of Suðuroy, Geitaskor and Prestskorar: Lower basalt series coal-bearing horizon - middle basalt series.

for Vágseiði blev der talt 15 bænke. Syd for Botnur synes lagene at have et regelmæssigt forløb med temmelig jævn mægtighed. Nord for Botnur kan man se en bænk kile ud, dens mægtighed er noget mindre end almindeligt her, og dens forløb nordpå er bugtet; mægtigheden varierer. Mellem Laðanbergstangi og Nakkurin Langi varierer lagtykkelsen ligeledes noget, og der ses enkelte udkilinger af lagene.

Omkring Geitaskor og Prestskorar på den nordlige del af фen findes i fjeldvæggen samme regelmæssige skifte mellem basaltbænke og interbasaltiske lag som på den sydligere del, men medens vi mod syd udelukkende ser den nederste basaltserie for os, optager denne mod nord kun nedre del af fjeldvæggen, $\emptyset$ vre del består af den mellemste basaltseries lavaer; mellem de to serier løber den kulførende serie under en græsklædt afsats, Geitaskor og Prestskorar (fig. 9).

Den liggende basalt for den kulførende serie er en udpræget 


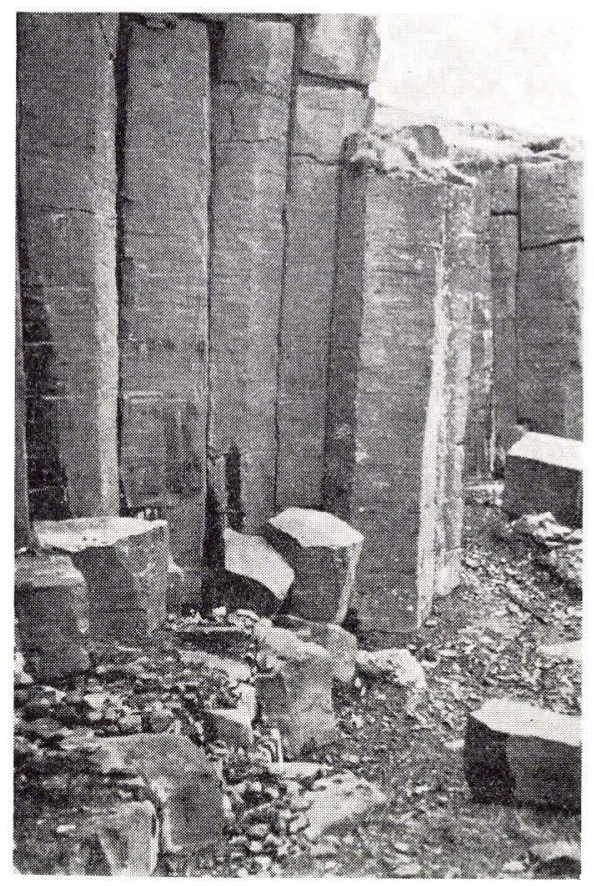

Fig. 10. Basaltsøjler i gl. stenbrud i Trongisvágur. Stabbagrót inni í Trongisvági.

Basalt columns in an old quarry at Trongisvágur.

søjlebasalt. Dens overflade er ujævn og bugtet og bærer tydeligt præg af langvarig subaerisk forvitring. Det synes som om søjlestrukturen er mere udviklet i den $\emptyset$ verste del af lagserien end længere nede - sydligere. På søjlernes prismeflader ses ofte en udtalt tværstribning med udtrukne porer, der på forvitrede flader fremtræder som riller; søjlerne viser en ret udtalt klфvningstilbøjelighed i denne retning. (Fig. 10, 11, 12, 13).

Af let tilgængelige lokaliteter for søjlebasalter skal nævnes kysten $\varnothing$ st for Froðba, Uttarihválur og Innarihválur på nordsiden af Trongisvágur samt et gammelt stenbrud inde i Trongisvágur, hvor søjlerne er særlig regelmæssige. Desuden kan de iagttages langs den vestlige vejside mellem bygderne Øravík og Hov, hvor de ofte har uregelmæssige, buede og forvredne former. Ved Kúlugjógv $\varnothing$ st for Froðba findes i kysten et agglomerat-parti, der er overdækket af en søjlebasaltbænk. Øst og vest for agglomeratet står søjlerne lodret, men ind imod agglomeratet bliver de efterhånden mere 


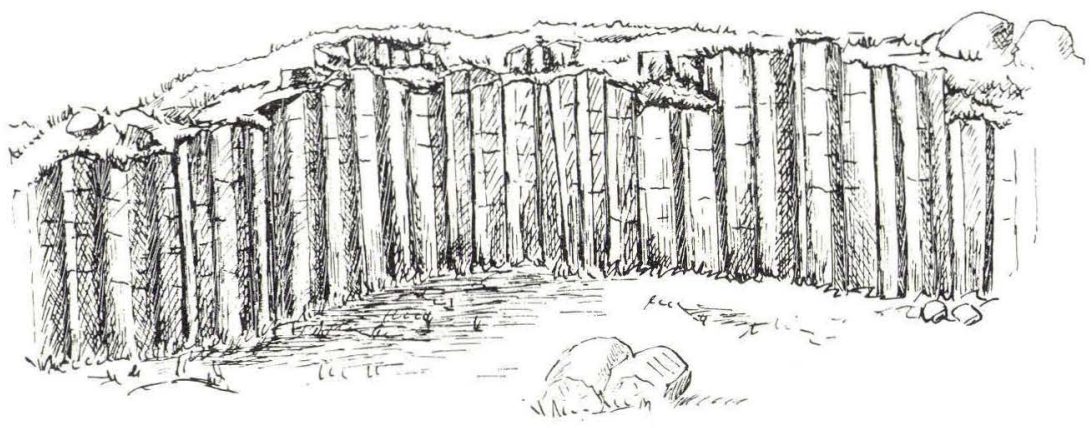

Fig. 11. Basaltsøjler i gl. stenbrud i Trongisvágur.

Stabbagrót inni i Trongisvági.

Basalt columns in an old quarry at Trongisvágur.
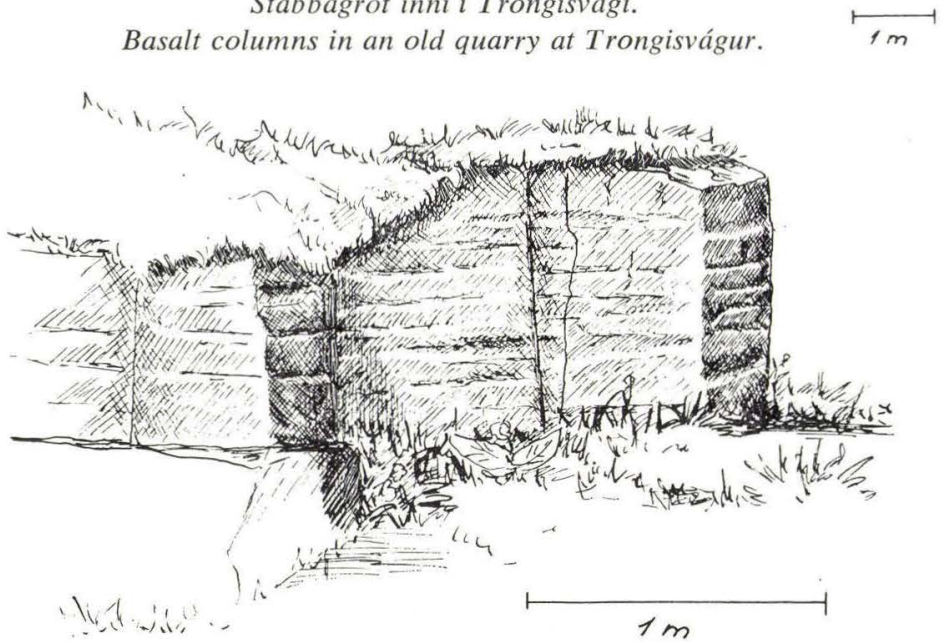

Fig. 12. Basaltsøjler i gl. stenbrud i Trongisvágur.

Stabbagrót inni i Trongisvági.

Basalt columns in an old quarry at Trongisvágur.

skråtstillede og står til sidst omtrent vinkelret på dettes $\emptyset$ stlige og vestlige begrænsning. Over agglomeratblotningens nederoderede midterparti er søjlerne vifteformede. Denne, fra gammel tid velkendte og i litteraturen ofte omtalte lokalitet, er nærmere beskrevet hos Walker og Davidsson (1936) og Rasmussen (1952). (Fig. 14, $15,16)$.

For at få et indtryk af de enkelte basaltbænkes mægtighed skal der nedenfor gengives to profiler, et fra Trongisvágsbotnur på nordvestsiden af Suðuroy og et fra Skarvgjógv ca. $2 \mathrm{~km}$ nordligere. Begge profiler går fra havniveau op til den kulførende serie. 
Profil Trongisvágsbotnur:

0- $2 \mathrm{~m}$ basalt

2- $4 \mathrm{~m}$ brun tuf

4- $25 \mathrm{~m}$ basalt

$25-29 \mathrm{~m}$ rødbrun tuf

29- $80 \mathrm{~m}$ grus og vegetation

$80-100 \mathrm{~m}$ basalt

$100-103 \mathrm{~m}$ r $\phi \mathrm{d}$ tuf

103-118 m basalt

118-120 $\mathrm{m}$ ras og vegetation

$120-130 \mathrm{~m}$ basalt

$130-131 \mathrm{~m}$ rød tuf

131-150 m basalt

150-162 $\mathrm{m}$ ras og vegetation

$162-177 \mathrm{~m}$ basalt

$177-180$ m vegetation

$180-190 \mathrm{~m}$ basalt

190-192 $\mathrm{m}$ tuf

192-206 m basalt

206-211 m porøs bjergart

211-228 m basalt

228-233 m ras, фverst $2 \mathrm{~m}$ tuf

233-255 $\mathrm{m}$ basalt

$255-258 \mathrm{~m}$ ras og vegetation

258-285 $\mathrm{m}$ basalt

285-289 $\mathrm{m}$ ras og vegetation

289-309 m basalt

309-315 $\mathrm{m}$ ras og vegetation

315-345 m basalt

345- m kulførende serie.
Profil Skarvgjógv:

$0-20 \mathrm{~m}$ basalt, $\emptyset$ verst slaggezone og tuf

$20-36 \mathrm{~m}$ basalt, $\emptyset$ verst slaggezone og rød tuf

$36-45 \mathrm{~m}$ basalt, $\varnothing$ verst et par meter slaggezone og tynd r $\varnothing \mathrm{d}$ tuf

45- $60 \mathrm{~m}$ basalt, $\varnothing$ verst slaggezone 8-10 m

$60-95 \mathrm{~m}$ basalt, $\varnothing$ verst slaggezone og tuf 3-4 m

95-148 m basalt, фverst slaggezone og tuf 8-9 m

148-166 m basalt, фverst slaggezone og rød tuf, $4 \mathrm{~m}$

$166-192 \mathrm{~m}$ basalt

192-198 m lersediment

$198-226 \mathrm{~m}$ basalt

226-230 m lersediment

$230-245 \mathrm{~m}$ basalt

245- m kulførende serie.

Heraf fremgår det, at bænktykkelsen i profilet fra Trongisvágsbotnur (13 bænke) varierer fra $10-30 \mathrm{~m}$ med en gennemsnitsmægtighed på 18,5 m (bænken 0-2 m ikke medregnet, da kun den $\emptyset$ verste del er over havniveau). I Skarvgjógvprofilet er gennemsnitsmægtigheden af 10 bænke knapt $20 \mathrm{~m}$, medens slaggezonerne varierer fra et par meter til ca. $10 \mathrm{~m}$. Den største mægtighed af en enkelt basaltbænk - ca. $50 \mathrm{~m}$ - fandtes i fjeldvæggen umiddelbart nord for Fámjin.

Som foran nævnt er laghældningen på Suðuroy gennemgående $\mathrm{NN} \emptyset, \mathrm{N} \emptyset$ og $\varnothing \mathrm{N} \emptyset$; på nordvestsiden af $\varnothing$ en er den dog stedvis nærmest nordlig og langs sydøstkysten er den nærmest $\emptyset$ stlig. Det største fald forekommer ud mod sydøstkysten, ca. $61^{1 / 2}{ }^{\circ}$ (Porkerisnes og Víkarbyrgi) og de mindste fald, $3^{\circ}$ på nordvestsiden af фen. På den sydlige del af $\varnothing$ en er laghældningen angivet på kortet med 


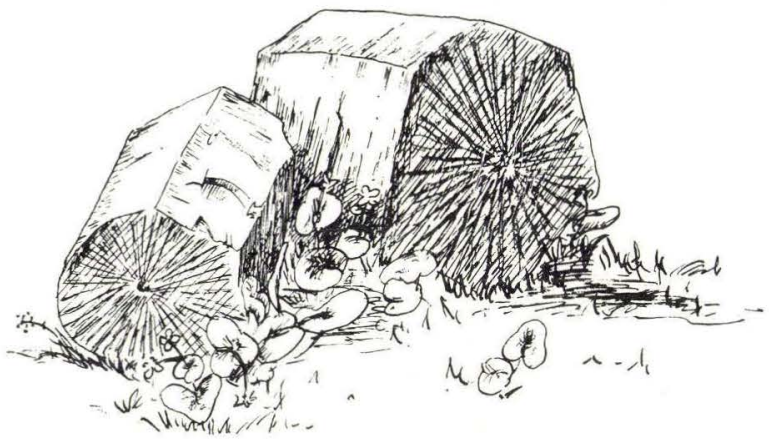

$1 \mathrm{~m}$

Fig. 13. Basaltsøjler i gl. stenbrud i Trongisvágur. Stabbagrót inni í Trongisvági.

Basalt columns in an old quarry at Trongisvágur.

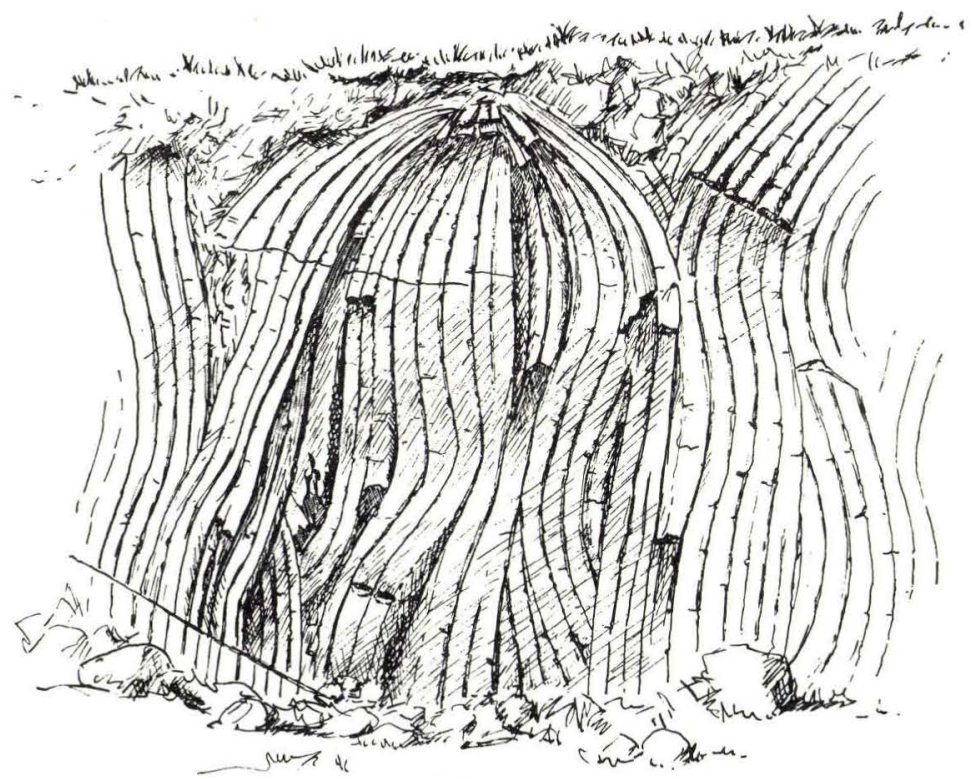

Fig. 14. Forvredne basalts $\varnothing$ jler ovenover bygden Hov. Stabbagrót við Hovsvegin, Hov.

Irregular columns above the village of Hov, Suðuroy. 

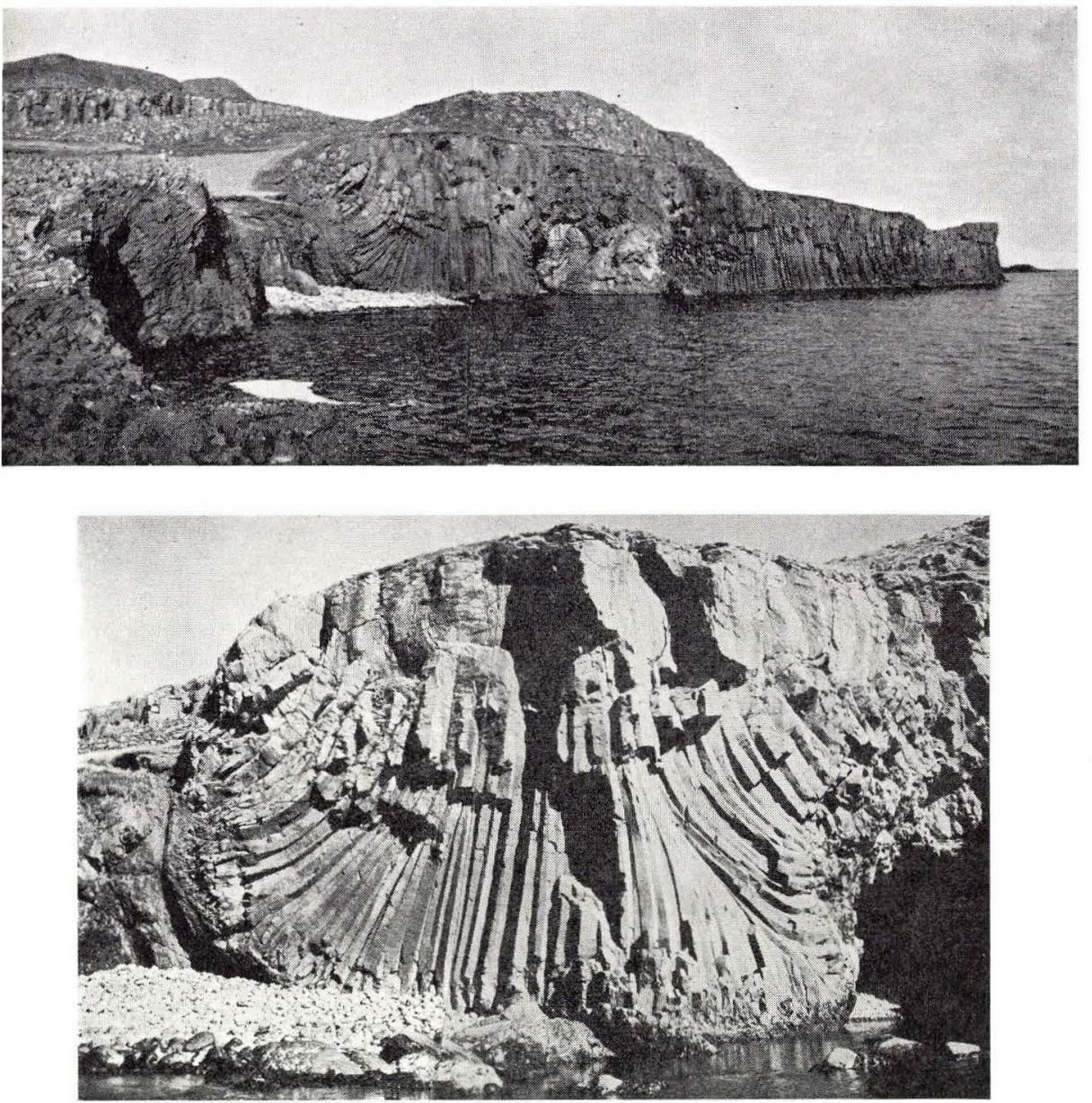

Fig. 15 og 16. Vifteformede basaltsøjler ved Kúlugjógv øst for Froðba. Stabbagrót við Kúlugjógv, Froðba.

Fan of basalt columns at Kúlugjógv, east of Froðba, Suðuroy.

hældningstegn, på den nordlige del fremgår den let af de på kortet viste koter for underkanten af den kulførende serie.

De interbasaltiske sedimenter i den nederste basaltserie begrænser sig i det væsentlige til tuf- og lersedimenter, skiferler, basaltiske sandstenssedimenter- og konglomerater.

Tuflagene varierer stærkt $\mathrm{i}$ farve. De er almindeligst brunlige eller rødlige, undertiden stærkt røde. De kan også være gullige, grønne eller gråsorte i farven. Mægtigheden varierer almindeligvis 


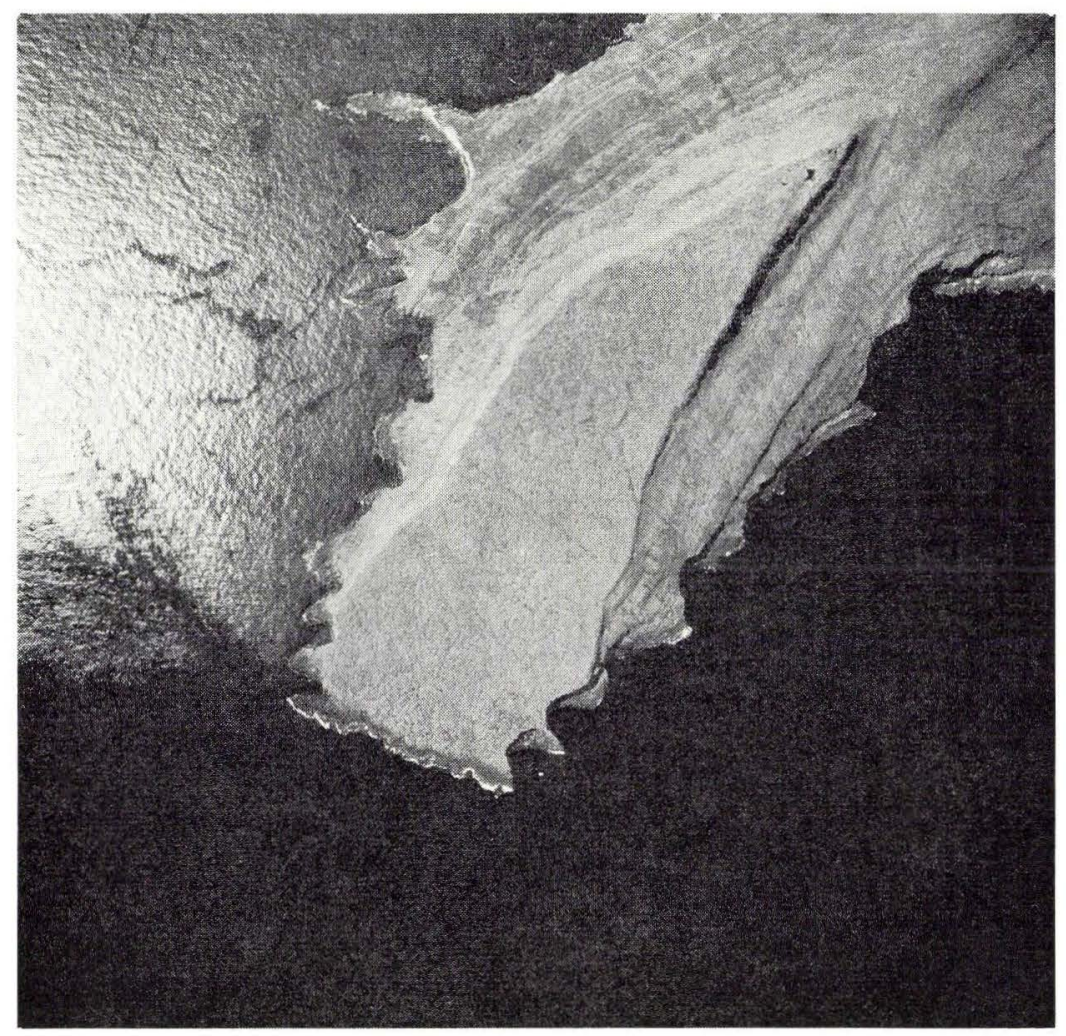

Fig. 17. Blottet lavaoverflade ved Porkerisnes, Suðuroy. Kambur á Porkerisnesi er sami hamarin (sama grótflógvin) allur sum hann er.

Lava surface at Porkerisnes, Suðuroy, stripped by erosion.

fra mindre end $1 \mathrm{~m}$ til $2-3 \mathrm{~m}$, noget større mægtigheder er dog ikke sjældne. I profilet fra Trongisvágsbotnur måltes det tyndeste tuflag til $1 \mathrm{~m}$ og det tykkeste til $4 \mathrm{~m}$. Gennemsnitstykkelsen var ca. 2,3 m. Da tuflagene overlejrer den liggende basaltbænks meget uregelmæssige slaggezone, kan mægtigheden af samme tuflag være noget svingende. Undertiden optræder tynde gange af tuf som udfyldninger i lodret forløbende sprækker i den liggende basaltbænks overflade. Medens et tuflags nedre grænse er en almindelig pålejringsgrænse, vil man ved dets $\varnothing$ vre grænse tit spore svagere eller stærkere tegn på varmepåvirkning, der hidrører fra den senere dannede hængende basaltbænk. Varmepåvirkningen kan være ganske 
svag, men ofte ses tuflagets $\varnothing$ verste del og basaltbænkens nederste del at være fuldstændig sammensvejset i grænsezonen, således at der ikke kan påvises nogen skarp grænse, men derimod en omtrent jævn overgang fra tuf til basalt. Tuffen antager i sådanne tilfælde et blåligt skær i grænsezonen. Hvis tuflaget mellem to basaltbænke er så godt som manglende eller ubetydeligt, fremtræder den $\varnothing$ verste del af slaggezonen mellem de to bænke som en por $\varnothing$, r $\varnothing$ dligfarvet brændingshorisont.

Medens den rene tuf almindeligvis er uden tydelig lagdeling og mere eller mindre fast eller hård alt efter brændingsgraden, finder vi sædvanligvis en tydeligere lagdeling i lersedimenterne, der til gengæld er mere smuldrende. Skiferleret fremtræder ofte med sortblå farve. Sandstenssedimenter og konglomerater forekommer, men er ikke så almindelige i nederste basaltserie som i den kulførende serie.

I flere tilfælde er der blevet iagttaget kul i disse interbasaltiske sedimenter. Det drejer sig dog i alle tilfælde kun om ubetydelige eller rent sporadiske forekomster, som ikke destomindre sammen med de sedimenter, hvori de forefindes, tyder på flere ophold i den vulkanske virksomhed, der førte til dannelsen af nederste basaltserie.

På Suðuroy er der blevet iagttaget interbasaltiske kulførende sedimenter ved følgende lokaliteter (her og i det følgende angivet nedefra og op):

På vestsiden af Grímsfjall ca. $50 \mathrm{~m} \mathrm{o.} \mathrm{h.} \mathrm{(underkant} \mathrm{af} \mathrm{tuf):}$

Liggende basalt med slaggezone op til ca. $7 \mathrm{~m}$

$200 \mathrm{~cm}$ tuf, meget $r \varnothing \mathrm{d}$

$400 \mathrm{~cm}$ brunligt og broget ler

$100 \mathrm{~cm}$ gråligt ler med ganske tynde, kun få mm tykke striber af kul og sort ler

hængende basalt (liggende for den kulførende serie).

Undir Bergsleiti sydvest for Hvalbiareið ca. $115 \mathrm{~m} \mathrm{o}$. h. (underkant af gråbrunt ler):

Liggende basalt

$195 \mathrm{~cm}$ gråbrunt ler, opad mere gråligt

$35 \mathrm{~cm}$ mørkt kulholdigt ler, ofte i striber

$75 \mathrm{~cm}$ gråbrunligt ler med kulstriber

$5 \mathrm{~cm}$ sort ler

hængende basalt (liggende for den kulførende serie). 
Vest for Tjørnunes på sydsiden af Hvalbiarfjørður ses på et par lokaliteter i en broget lerserie ved kysten tynde kulstriber på et par $\mathrm{cm}$ samt kullinser, hvoraf den største er $10-15 \mathrm{~cm}$ tyk og ca. $2 \mathrm{~m}$ lang. Hængende basalt (liggende for den kulførende serie).

I Hvannhagi på nordøstsiden af Suðuroy ses inde i bugten vest for Stapin et interbasaltisk lersedimentlag på 1-2 m med tynde striber af kul. Hængende basalt (liggende for den kulførende serie).

Ved Innarihválur på nordsiden af Trongisvágur findes et lille stenbrud. Den nedre grænse af den basaltbænk, der brydes, ligger her $76 \mathrm{~m} \mathrm{o}$. h. Herunder ses et ca. $2 \mathrm{~m}$ tykt lerlag, der er noget varierende $\mathrm{i}$ farve, mest brunt og r $\varnothing \mathrm{dbrunt}$. Midt i brudet ligger en kullinse 3-4 cm tyk og ca. $60 \mathrm{~cm}$ lang på grænsen mellem basalt og ler.

Under den $\varnothing$ verste basaltbænk i Fjallið Mikla $\varnothing$ st for bygden Fámjin forekommer i ca. $428 \mathrm{~m}$ h $\varnothing$ jde et $1,5 \mathrm{~m}$ tykt, nederst gulligt og opad gråligt lerlag, hvoraf de $\emptyset$ verste $15 \mathrm{~cm}$ er kulholdige med et rent kulbånd på ca. $3 \mathrm{~cm}$.

I den stejle fjeldvæg nord for Fámjin ca. $170 \mathrm{~m} \mathrm{o.} \mathrm{h.} \mathrm{ved} \mathrm{Keppur}$ er en ca. $7 \mathrm{~m}$ tyk broget lerserie blottet med flere - i profillinjen 4 kulstriber og linser på 2-5 cm.

Umiddelbart syd for Svínagjógv, mellem Borgin og Borgarknappur, findes i ca. $480 \mathrm{~m}$ højde et tyndt mørkt lerlag med sporadisk kul.

På vestsiden af Hvannafelli ligger der et tyndt kulførende lerlag ca. $520 \mathrm{~m} \mathrm{o.} \mathrm{h.} \mathrm{(underkant} \mathrm{af} \mathrm{mørkt} \mathrm{ler):}$

Liggende basalt

$10 \mathrm{~cm}$ mørkt ler

$18 \mathrm{~cm} \mathrm{kul}$

$15 \mathrm{~cm} \mathrm{ler}$

hængende basalt.

Syd for Hovshólmur findes nær kysten et gammelt mineindslag $1,5 \mathrm{~m}$ i firkant og en halv snes meter dybt. Efter beboernes udsagn har man tidligere brudt lidt kul her. Syd for minen måltes følgende profil:

$$
\begin{aligned}
& 0-4 \text { m basalt } \\
& 4-8,5 \text { m slaggezone }
\end{aligned}
$$


8,5-10 m ler, nederst brunt, opad lyst, øverst gråt. I det grå ler iagttages sporadisk kul

10- m basalt.

Umiddelbart vest for vejen nord for Porkeri blev der i ca. 160 $\mathrm{m}$ højde i et brunt lerlag (grav) iagttaget tynde kulstriber.

Under en fos i Áin Mikla, Porkeri, ses i ca. $185 \mathrm{~m}$ højde et lersediment. Ca. $30 \mathrm{~m}$ nord for fossen er det ca. 4,5 m tykt. Her iagttoges ca. $1 \mathrm{~m}$ over lerbunden to tynde kulstriber på 2-3 cm hver.

På nordsiden af Mýrifjørður (sydøstsiden af Suðuroy) optræder i en ca. $2 \mathrm{~m}$ tyk brunlig og blålig lerserie spredte kullinser, 1-5 $\mathrm{cm}$ tykke og op til $1 \mathrm{~m}$ lange.

\section{Mykines}

Mykines består som nævnt udelukkende af bænke, der tilhører den nederste basaltserie. Ligesom på Suðuroy giver de stejle kyster såvel på nordsiden som på sydsiden af øen et udmærket overblik over lagserien, der med hensyn til opbygning, lagmægtighed og struktur knytter sig nær til forholdene på Suđuroy. Den tykkeste basaltbænk på Mykines, ca. $70 \mathrm{~m}$, fandtes ved Hólmgjógv (sundet mellem Mykines og Mykineshólmur). På sydsiden af holmen går en basaltoverflade i stranden, den er poret og indeholder udskillelser af calcedon og kalkspat. Basalten er stærkt forkløftet, og sprækker med strygning i $\varnothing$ ens faldretning er særlig hyppige.

Der ses overalt tendens til søjledannelse, tydeligst på skærene ved den vestlige ende af holmen; også i fjeldvæggen på øens sydside, ved Barmur, viser bænkene ret fremtrædende søjlestruktur. Mest udpræget er søjlestrukturen dog i Korkadalur på фens nordside; her ses to markante søjlebænke over hinanden. Søjlerne når en højde af op til ca. $30 \mathrm{~m}$ (fig. 18).

I fjeldvæggen på sydsiden af фen ses udkilinger af lagene bl. a. syd for Steinshellisgjógv, vest for Tindskriðubarmur, på фstsiden af Smørbúshellisgjógv og i Barmur.

På Mykines er laghældningen beregnet til ca. $13^{\circ}$ S $\varnothing$ omkring Hólmgjógv og til ca. $8^{\circ} \varnothing \mathrm{S} \emptyset$ på den $\emptyset$ stlige del af фen. Vestligst på Mykineshólmur er der iagttaget en laghældning på ca. $20^{\circ}$ (fig. 19). 


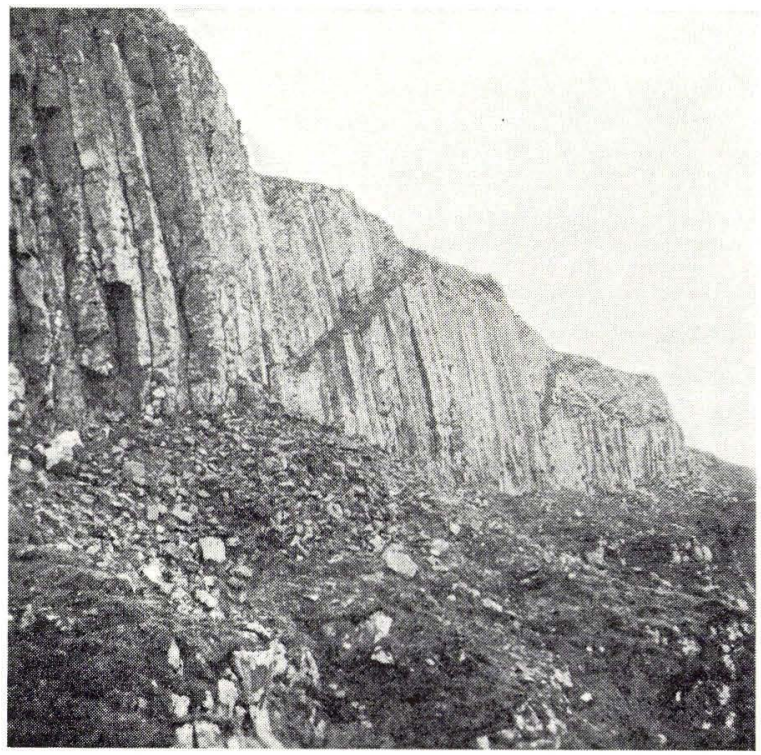

Fig. 18. Basaltsøjler i Korkadalur, Mykines.

Stabbagrót í Korkadali, î Mykinesi.

Basalt columns in Korkadalur, Mykines.

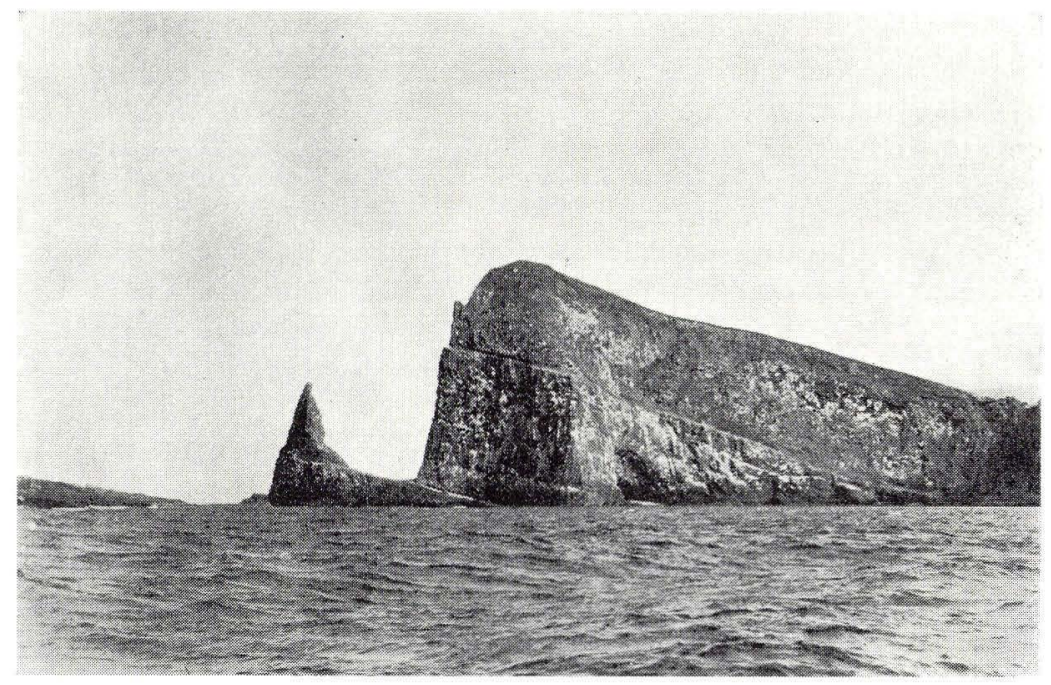

Fig. 19. Vestsiden af Mykineshólmur. Mykineshólmur vestantil.

West face of Mykineshólmur. 


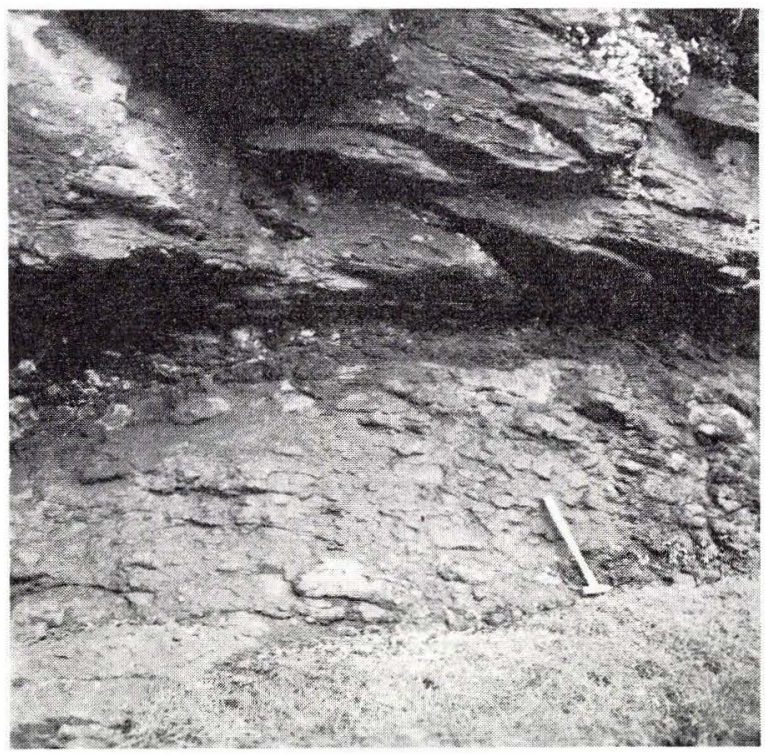

Fig. 20. Sedimentserien ved Hólmgjógv, Mykines. Grænsen mellem nedre og øvre del.

Legugrýti við kolasprekum millum basaltfláirnar við Hólmgjógv, Mykineshólmur. Miðparturin.

The boundary between the upper and lower parts of the sedimentary beds at Hólmgjógv, Mykines.

Ligesom på Suðuroy indeholder de interbasaltiske sedimenter ofte spor af kul.

På Mykineshólmur forekommer en sedimentserie med følgende profil ca. $150 \mathrm{~m}$ vest for broen over Hólmgjógv (fig. 20, 21, 22):

$0-24 \mathrm{~m}$ basalt

24-27 m svagt lagdelt ler med stort indhold af stenmateriale. Stenene er af meget forskellig størrelse og er ofte orienteret efter fladsiden

27-31 m noget tydeligere lagdelt, hovedsagelig brunt ler. Leret indeholder små brudstykker af tuf og afrundet grus (tæet blå basalt) op til $2-4 \mathrm{~cm}$ i diameter. Lerlaget indeholder tillige få mm tykke linser af kul. Der er en skarp grænse mellem laget $24-27 \mathrm{~m}$ og laget $27-31 \mathrm{~m}$.

En sedimentserie фverst på Fjørudalsnev nær landingspladsen på Mykines (RASMUSSEN 1947, 1951) er allerede fra gammel tid vel- 


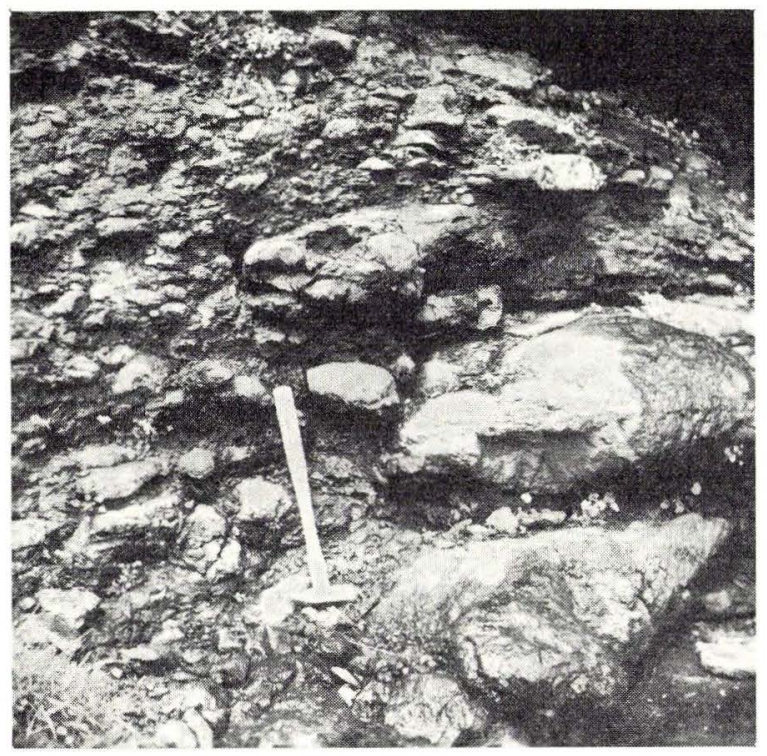

Fig. 21. Sedimentserien ved Hólmgjógv, Mykines. Nedre Del. Legugrýti við kolasprekum millum basaltfláirnar við Hólmgjógv, Mykineshólmur. Niðari parturin.

Lower part of the sedimentary beds at Hólmgjógv, Mykines.

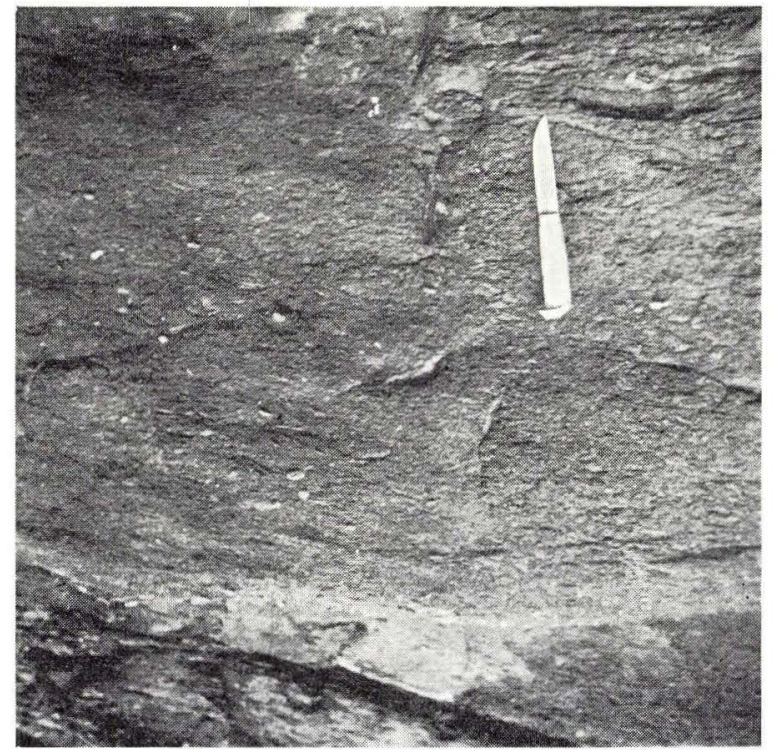

Fig. 22. Sedimentserien ved Hólmgjógv, Mykines. Øvre Del. Legugrýti við kolasprekum millum basaltfláirnar við Hólmgjógv, Mykineshólmur. Ovari parturin.

Upper part of the sedimentary beds at Hólmgiógv, Mykines. 
kendt, den er omtalt for sit fossilindhold af bl. a. ubestemmelige løvblade (HARTZ 1903, R. RASMUSSEN 1925) og af Metaseqoia occidentalis (RASMUSSEN og KocH 1963). Et profil фverst på nordsiden af Fjørudalsnev viser:

$20-20,35 \mathrm{~m}$ brunt ler med årer af lerjernsten fra få mm op til ca. $3 \mathrm{~cm}$ tykke

20,35-20,40 m noget federe ler med sporadisk forekommende kul. I dette lag og grænseområdet til det overliggende lag findes Metaseqoia occidentalis

20,40-21 m sort skiferler

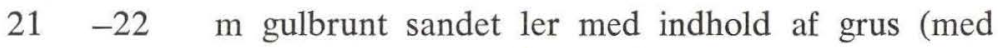
stendiameter op til $1 / 2 \mathrm{~cm}$ )

$22-25 \quad m$ r $\varnothing$ dbrunt tuffoid ler.

På en afsats i fuglefjeldet på sydsiden af фen forekommer en kulf $\varnothing$ rende sedimentserie. Det er muligvis samme serie, der forekommer under Ketilsheyggjur midt på øen og i Kálvadalur på nordøstsiden. (Fig. 23):

Liggende basalt

74-78 m brunligt ler

78-80 m kulførende mørkt skiferler. Kullene forekommer ikke som et enkelt kulbånd, men som en række på ca. 20 tynde bånd og linser. De enkelte bånds tykkelse varierer fra få $\mathrm{mm}$ til $4-6-8 \mathrm{~cm}$. Det $\varnothing$ verste, tykkeste bånd målte ca. $15 \mathrm{~cm}$

hængende basalt.

I et andet, tilsvarende profil (ca. $100 \mathrm{~m}$ vestligere og ca. $82 \mathrm{~m}$ o. h.) iagttages spor af kul i det brunlige lerlag. I den kulførende skiferler målte det tykkeste kulbånd ca. $35 \mathrm{~cm}$; de $\emptyset$ vrige kulbånd svarede omtrent til forrige profil.

Ved Ketilsheyggjur midt på øen i ca. $370 \mathrm{~m}$ højde har der tidligere været en lille mine, hvor man hentede kul til husholdningsbrug. Den er nu sammenstyrtet og tilgroet, men ved gravning kan man endnu finde kulgrus og løse kulstumper.

I Kálvadalur syd for Biðigjógv på nordøstsiden af фen måltes følgende profil:

Liggende basalt

130-135 m brunligt ler 


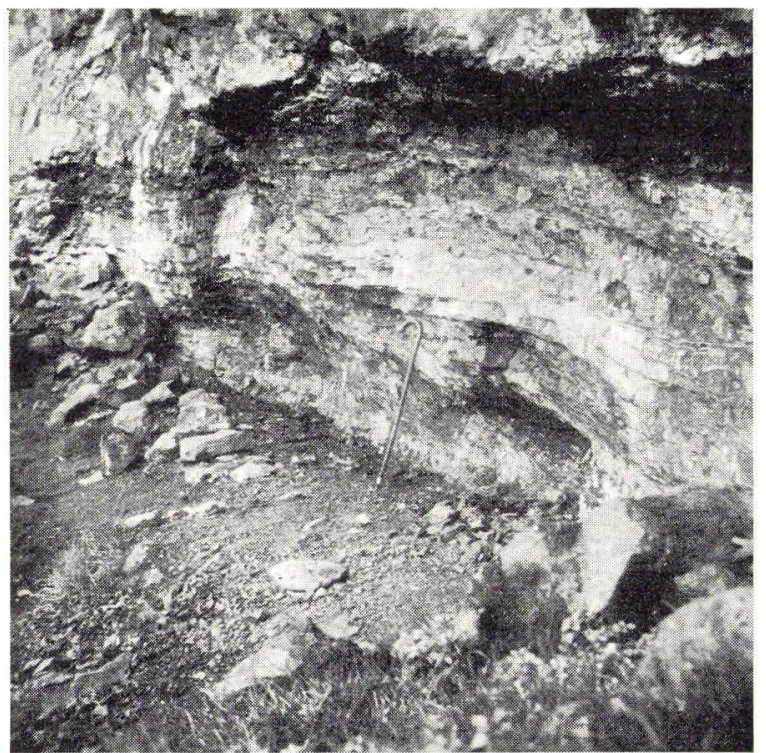

Fig. 23. Sedimentserien i fjeldvæggen på sydsiden af Mykines. Kolið í berginum fyri sunnan í Mykinesi.

Sedimentary beds on the mountainside on the south side of Mykines.

135-140 m blåligsort skiferler med ca. en halv snes tynde kulbånd varierende fra få $\mathrm{mm}$ op til $3-5 \mathrm{~cm}$

hængende basalt.

I endnu et tilsvarende profil omkring $400 \mathrm{~m}$ sydligere ca. 116 $\mathrm{m}$ o. h. fandtes kun svage spor af kul; der var ikke noget egentligt kulbånd.

\section{Gáshólmur}

består af 4 basaltbænke, der tilhører den nederste basaltserie. De er adskilt af 3 slagge-brændingshorisonter. Den næst $\varnothing$ verste bænk, der hviler på et tuflag, når den største mægtighed på 30-40 $\mathrm{m}$, medens de andre kun har en tykkelse på ca. $10 \mathrm{~m}$ eller knap det.

\section{Tindhólmur}

På Tindhólmur findes ligeledes 4 bænke tilhørende nederste basaltserie. Det er sandsynligvis den store (næst $\varnothing v e r s t e)$ bænk på 


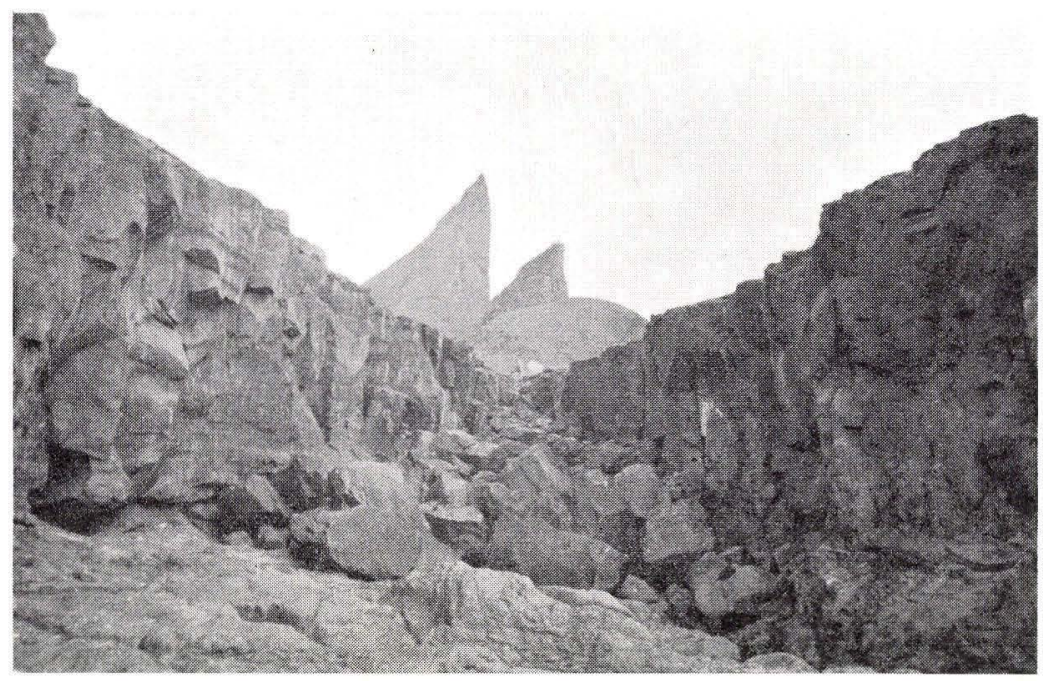

Fig. 24. Basaltbænk på vestsiden af Tindhólmur.

Basalthamari vestantil í Tindhólmi.

Lava flow on the west side of Tindhólmur.

Gáshólmur, som svarer til den nederste bænk på Tindhólmur. Lavaer fra den nederste basaltserie er enerådende på den vestlige og nordlige del af holmen, mod syd og фst er de overlejret af den kulførende serie, tuf-agglomeratzonen og lag af den mellemste basaltserie (fig. 24).

Et profil gennem den nederste basaltserie på vestsiden af holmen viser fra vest til $\emptyset$ st:

$0-10 \mathrm{~m}$ basalt

$10-12 \mathrm{~m}$ rødlig slagge-brændingshorisont varierende fra $0,5-2,5$ $\mathrm{m}$ i tykkelse

12-20 m basalt

20-23 m ca. 1,5 m slaggezone og ca. 1,5 m brunt ler

23-31 m basalt

31-35 m ca. $1 \mathrm{~m}$ slaggezone, 2-3 m ler og $\varnothing$ verst ca. $20 \mathrm{~cm}$ rød tuf

$35-45 \mathrm{~m}$ basalt.

I basaltbænkenes overflade ses der mod vest (nederste og næstnederste bænk) et sprækkesystem, der stryger $\mathrm{N}$ ca. $120^{\circ}$, d. v. s. omtrent i faldretningen. Den samme retning ses også i lerlaget over 


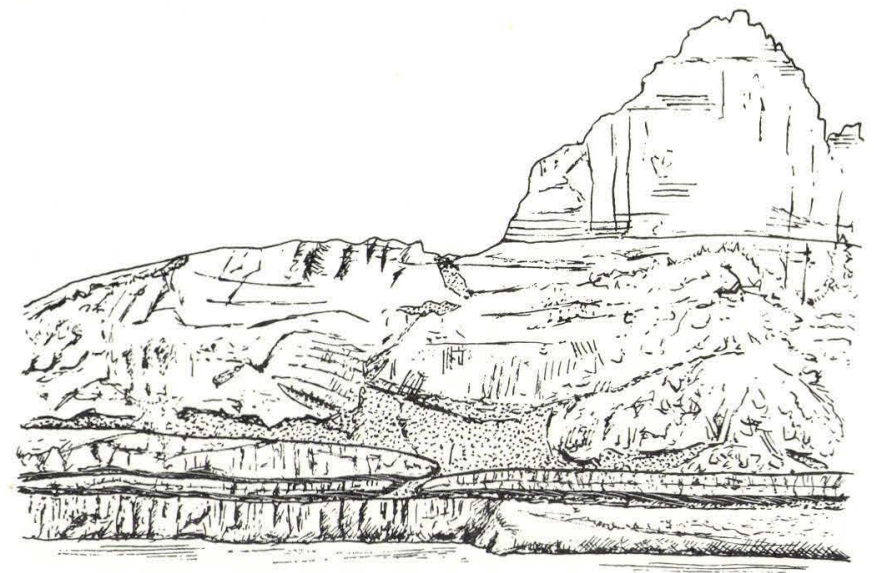

Fig. 25. Udkiling af basaltbænke på sydsiden af Tindhólmur.

Hamrar sum ganga burtur sunnantil í Tindhólmi.

Basalt flows wedging out on the south side of Tindhólmur.

næstnederste bænk. S $\varnothing$ jlestruktur findes, men er meget uregelmæssig, ofte er den kun antydet.

Laghældningen er på vestsiden af holmen $\varnothing S \emptyset$, medens den på $\emptyset$ stsiden nærmest er SS $\varnothing$. Dette skyldes en forkastning gennem Neytagjógv ( $\mathrm{N} 125^{\circ}$ ) med en sænkning på ca. $4 \mathrm{~m}$ af vestsiden, og muligvis også senere intrusion (s. 299).

Medens de tre nederste bænke skærer havniveau på holmen, kiler den $\varnothing$ verste bænk ud, henholdsvis inderst i bugten ved Hólmsm $\varnothing 1$ på den nordøstlige side af holmen og inde i bugten vest for Júgur

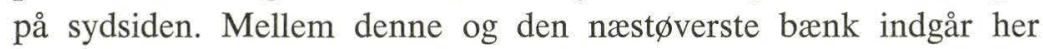
en ny, tyndere bænk, der kiler ud mod vest midt over strandfladen vest for Júgur og mod øst ved skærene фst for Júgur. På de små skær $\varnothing$ st for holmen og langs strandkanten ved holmens $\varnothing$ stpynt ses basalt stedvis over havniveau. (Fig. 25).

\section{Vágar}

På Vágar forekommer lavaer, der tilhører den nederste basaltserie, kun på den allervestligste del af фen, idet de фverste lag når havniveau langs en linje, der forløber fra syd for Álkuklettur til $\emptyset$ st for Víkar. Den højeste beliggenhed finder vi ved Barðið $278 \mathrm{~m}$

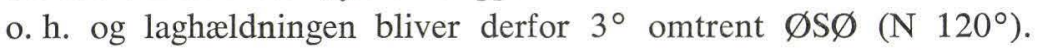
Lavabænke, der tilhører den nederste basaltseries $\emptyset$ vre del, kan 


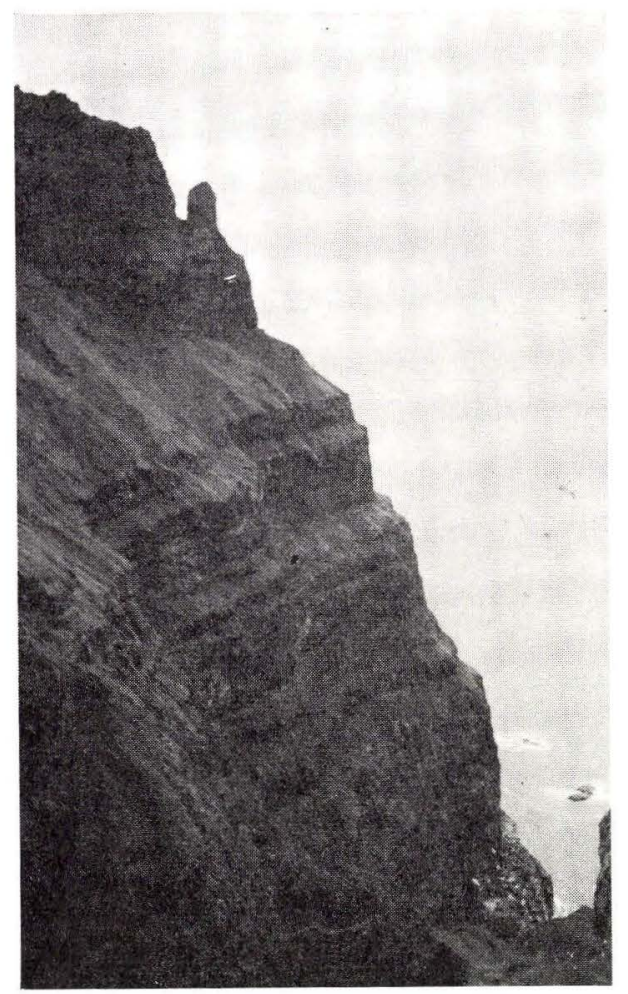

Fig. 26. Nederste basaltserie - kulførende serie - mellemste basaltserie mellem Gásadalur og Barđið.

Niðaru basaltfláirnar - kolalindin - miðfláirnar, millum

Gásadals og Barðið.

Lower basalt series - coal-bearing horizon - middle basalt series, between Gásadalur and Barðið.

iagttages i fjeldvæggen mellem Gásadalur og Víkar, de er ligesom på Tindhólmur overlejret af den kulførende serie, tuf-agglomeratzonens lag og den mellemste basaltseries lavaer (fig. 26).

Langs hele strækningen Gásadalur - Víkar ses interbasaltiske tuf-lersedimenter, hvoraf de to фverste serier har den største mægtighed, ca. en halv snes meter. Også på Vágar indeholder disse sedimenter stedvis lidt kul.

I fjeldvæggen umiddelbart vest for bygden Gásadalur ses ca. $60 \mathrm{~m}$ o. h. en lille smule kul i en ca. $10 \mathrm{~m}$ tyk tuf-lerserie under den liggende basaltbænk for den egentlige kulførende serie (fig. 27).

I den brede bugt vest for Víkar forekommer en kun delvis blottet 


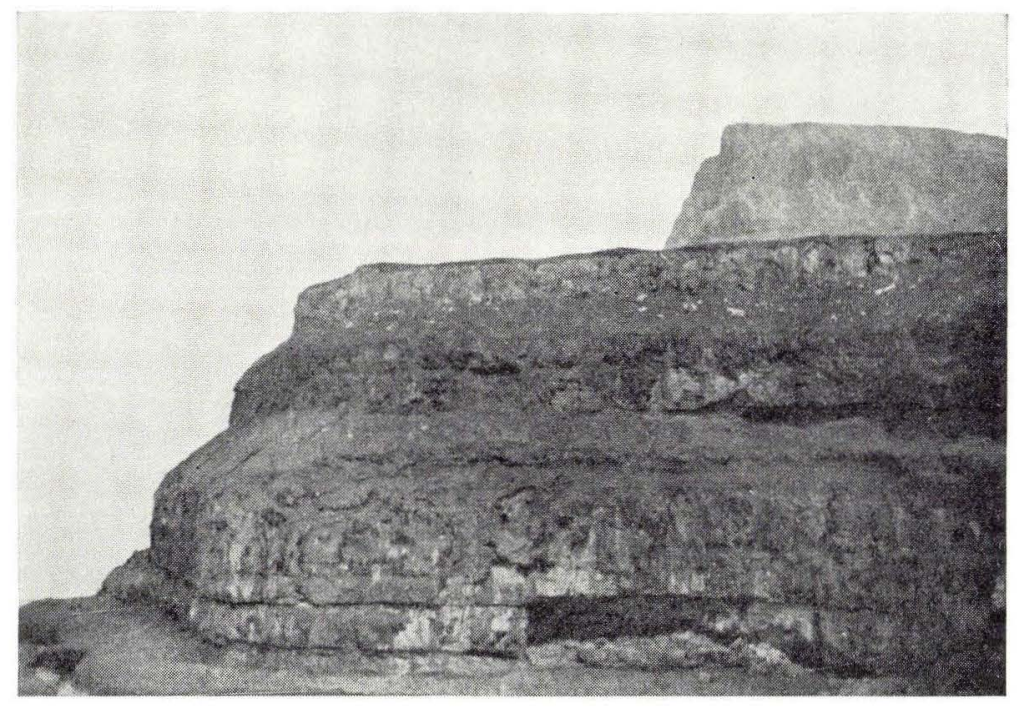

Fig. 27. De interbasaltiske tuf-lersedimenter umiddelbart vest for bygden Gásadalur.

Royðugrýtislindir i bakkanum vestan fyri Gásadal.

The interbasaltic tuff-clay sediments just west of Gásadalur, Vágar.

sedimentserie nær kysten. Den består hovedsagelig af brunt, lagdelt ler med tynde årer af lerjernsten, de er ca. $1 \mathrm{~cm}$ tykke. Der ses også enkelte striber af kul fra ganske tynde op til ca. $1,5 \mathrm{~cm}$.

I bugten $\varnothing$ st for Víkar når en anden sedimentserie havniveau. Dens mægtighed er 3-4 m. Den består af lagdelt ler, hovedsagelig af brun farve med tyndere striber af mørkere, samt gult og gråt ler. Desuden forekommer tynde bugtede, ca. $2 \mathrm{~cm}$ tykke, årer af lerjernsten og tynde striber kul fra mindre end $1 \mathrm{~cm}$ til op til $3 \mathrm{~cm}$.

Den vulkanske aktivitet har været rytmisk, således at forstå, at en aktivitet, som er resulteret i dannelsen af en lavastrøm, i regelen har været efterfulgt af en kortere eller længere hvileperiode. De vulkanske materialer er først og fremmest lava, underordnet agglomerater og tuf. Hvileperioden markerer en midlertidig standsning af vulkanismen og kan give sig til kende ved subaerisk forvitring, erosion af basaltoverfladen, aflejring af interbasaltiske sedimenter og indvandring eller tilførsel af vegetation, som røber sig gennem tilstedeværelsen af tynde kullag eller linser. (Kulforekomster er mærket med c på kortet). 
Vi kender ikke direkte spor af tilførselskanaler til vulkanismen i den nedre serie, men vi anser det på grund af den store bænktykkelse og bænkenes store udbredelse for sandsynligt, at den er sket gennem spalter. Spalterne har sandsynligvis haft samme retning som Wyville-Thompson ryggen og forløbet af det fær $\varnothing$ ske fjordsystem, idet tuf-agglomeratzonen (s. 174), der må antages at dække over eruptionsspalter og deres nærmeste omgivelser både på Suð̋uroy og Vágar, de to eneste mulige iagttagelsessteder, indtager langstrakte områder af flere km's længde med nordvest-sydøstlig retning. En kraftig lineamentgruppe såvel på den sydlige som på den centrale del af Suðuroy peger i samme retning. Lineamenterne er brede og gør sig topografisk stærkt gældende, deres hovedretning har et nordvest-syd østligt forløb. Mod nordvest viser et kraftigt lineament med samme retning en forkastning på 10-11 m med en nedsænkning af den vestlige side; denne forkastning er ældre end den mellemste basaltserie. Hovedretningen af gangene på Suðuroy, der følger lineamentsystemet (se kortet), er ligeledes nordvest-syd $\varnothing$ st.

Det b $\varnothing \mathrm{r}$ endvidere bemærkes, at de st $\varnothing$ rste tykkelser hos enkeltbænke er målt mod vest ved Fámjin $50 \mathrm{~m}$ og Mykines $70 \mathrm{~m}$, hvilket måske kan betyde, at et aktivt udbrudsspalte-system har ligget ikke langt vest for Suðuroys nuværende vestkyst.

Hældningen indenfor den nederste basaltserie kan aflæses af det geologiske kort; den ses at være фstlig på den sydøstlige del af Suðuroy, længere mod nord bliver den nordøstlig og mod nordvest omtrent nordlig. Man får nærmest indtrykket af en domedannelse eller eksistensen af en antiklinallejring med svagt nordligt dyk. Den overlejrende mellemseries lag hælder mod nordøst nord$\emptyset$ stligt og mod nordvest nordvestligt til nordligt.

Overgangen fra nordøstlig til nordlig hældning er næsten umærkelig og løser ikke éntydigt spørgsmålet, om der findes en diskordans mellem den nederste og den mellemste basaltserie. Den på det nordlige Suðuroy exceptionelt tykke tuf-agglomeratzone (s. 175) og det store indhold af yngre, intrusive basalter (s. 294), såvel i den kulførende serie som i den overliggende zone, har yderligere vanskeliggjort denne afgørelse.

Går vi derimod fra Sưuroy til Mykines-Vágar, finder vi klar markering af en diskordans. Strygningen i den nederste basaltserie på det $\varnothing$ stlige Mykines og på det vestlige Vágar er så godt som den samme, selvom laghældningen på Mykines er en del større end på 
Vágar. Bevæger vi os her fra vest mod $\varnothing$ st, ser vi, at lavaerne i den mellemste basaltserie har en anden strygningsretning og dermed et mere $\varnothing$ stligt fald (fig. 133); hældningsvinkelens størrelse er imidlertid omtrent den samme. Dette viser, at der mellem de to lagserier er en, omend ikke særlig markeret, diskordans. Den ene af forfatterne (J. R.) har haft lejlighed til at flyve over Sørvágsfjørður og har fra luften tydeligt set den diskordante pålejring af den mellemste basaltserie i det område, hvor de to basaltserier direkte overlejrer hinanden. Diskordansen er vanskelig at konstatere på stedet i det kritiske område, fordi der er kraftige forstyrrelser forårsaget af intrusive basalter. På grundlag af vor nuværende viden kan vi imidlertid fastslå, at diskordansen i hvert fald er ældre end den mellemste basaltserie. Der må med andre ord forud for dannelsen af denne være sket en svag vipning af den først dannede del af plateauet.

Opbygningen af det færøske plateau i sin helhed er således ikke sket som resultat af en kontinuerlig vulkansk aktivitet; men det af den kulførende series dannelse tydeligt registrerede ophold i aktiviteten har varet længe nok til, at en justering af balanceforholdene har kunnet finde sted.

De allerfleste lavaer er afyriske eller kryptofyriske, men nu og da findes en svag porfyritisk tendens udviklet, således bl. a. i den nedre del af profil II a. De små strøkorn her ses især på de forvitrede overflader.

Under mikroskop fremtræder bjergarterne som fin- eller mellemkornede, deres textur er intergranular.

Spredt, og som det synes ret tilfældigt, forekommer ganske enkelte oliviner eller pseudomorfoser efter olivin, fyldt ud med et bowlingitisk materiale. Bjergarter, der indeholder frisk olivin, er tidligere beskrevet fra Suðuroy (WALKer og Davidson, 1936).

Vi har ikke fundet rombisk krystalliserende pyroxen i nogen af vore lavaer.

Monoklint krystalliserende pyroxen viser gradvis overgang i størrelse fra grundmasseindivider gennem quasi-strøkorn til halv-str $\varnothing$ korn. De pyroxener, der har overstørrelse, har ofte en uregelmæssig timeglas-struktur samt tvillingdannelse efter (100). Zonardannelse ses hyppigt og er i regelen normal, men kan undtagelsesvis være oscillerende. Som almindelig regel gælder, at $2 \mathrm{~V} \gamma$ er større i midten end i yderzonerne. Variationen i $2 \mathrm{~V} \gamma$ går fra $54^{\circ}$ til $42^{\circ}$; 


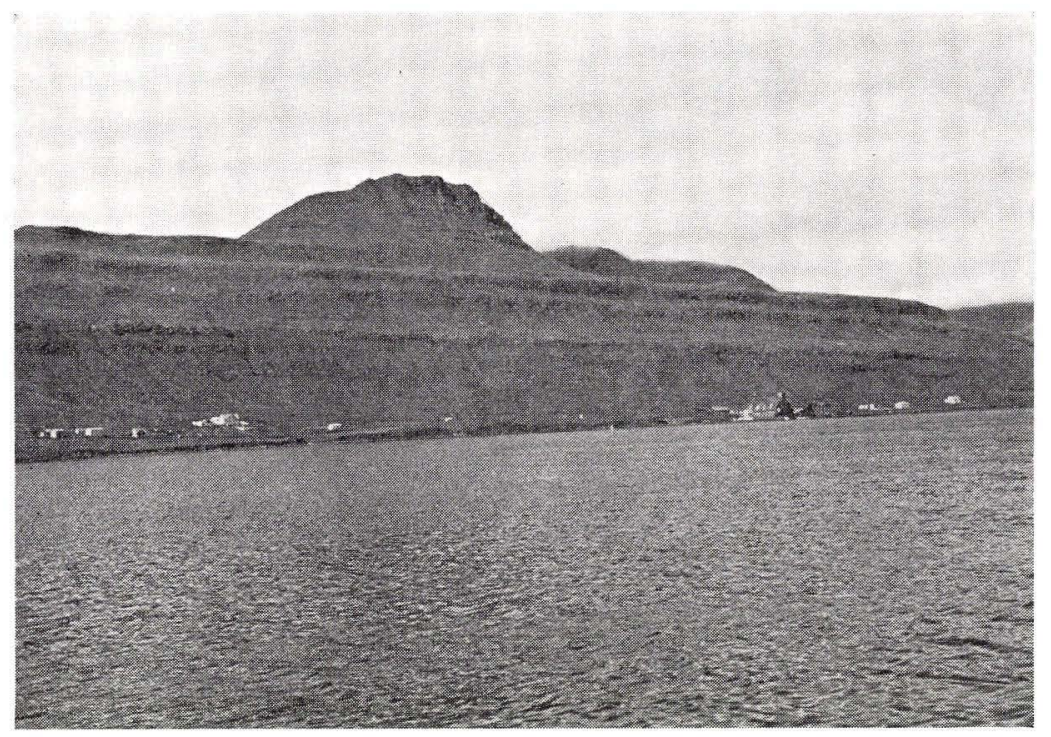

Fig. 28. Typisk stortrappet landskabsform i den nederste basaltserie.

Sydsiden af Trongisvágur.

Eyðkent landslag fyri niðaru basaltfláirnar. Sunnan fyri Trongisvág.

Typical landscape with big steps in the lower basalt series.

South side of Trongisvágur.

i et enkelt tilfælde blev $39^{\circ}$ målt. $\mathrm{C} \wedge \gamma$ varierer fra $39^{\circ}$ til $42^{\circ}$. Ved måling af brydningsindex $\mathrm{n} \beta$ fandtes en variation fra 1.691 til 1.705, hvilket svarer til ca. $12 \%$ fs; ved indsættelse i et af de almindeligt anvendte diagrammer findes det at svare til en forandring fra $w_{41} \mathrm{fs}_{18} \mathrm{en}_{41}$ til $\mathrm{wo}_{37} \mathrm{fs}_{30} \mathrm{en}_{33}$. Alle halvstrøkorn må klassificeres som augiter, de, der er rigest på fs, ligger på grænselinjen til ferro-augiter.

Grundmasserne viser sig at indeholde to clinopyroxener, én der er augitisk med $2 \mathrm{~V} \gamma$ varierende fra $52^{\circ}$ til $40^{\circ}$, og en anden, som er pigeonitisk med $2 \mathrm{~V}$ varierende fra 0 til $25^{\circ}$. Pigeoniten viser ingen tvillingdannelse og har dårligt udviklede spalteflader. De augiter, der tillige med pigeoniterne sammensætter grundmassen, er for ca. $10 \%$ vedkommende tvillingdannede efter (100). Grundmassernes clinopyroxener har en størrelse, der går op til 90-100 $\mu$. Maximalmængden af pigeonit i en given bjergart er 10-12 Vol- $\%$.

De quasi- til semi-fenokrystiske plagioklaser er i regelen labradoritiske i sammensætning, kernernes anorthitindhold viser en variation fra $72 \%$ til $62 \%$, gennemsnittet er ca. $65 \%$, yderzonerne 


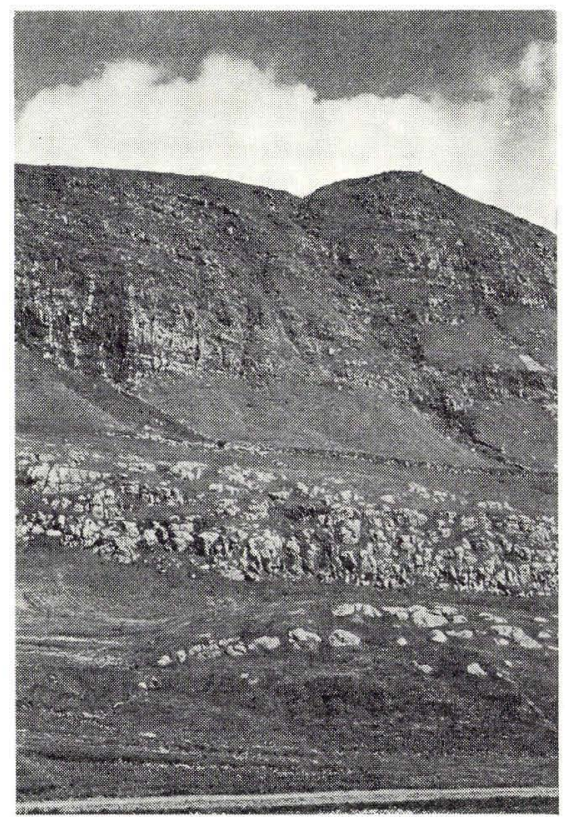

Fig. 29. Overgangen mellem den nederste basaltserie, den kulførende serie (under grønsværen) og den mellemste basaltserie ved Froðbiarnípa.

Niðaru basaltfláirnar, kolalindin (vallađ) og miðfláirnar. Frođbiarnípan.

Topographic transition from the lower basalt series via the coal-bearing horizon (below the grass-covered slope) to the middle basalt series at Froðbiarnípa, Suðuroy.

kan gå helt ned til $54 \%$, men har et gennemsnit på ca. $60 \%$. Grundmasseplagioklasen er for det meste af samme sammensætning som yderzonen i de plagioklaser, der har overstørrelse. De fremherskende tvillinglove er albit, Carlsbad og Roc-tourné, men også Manebach og periklin er bemærket.

De plagioklaser, der udgør en væsentlig del af grundmasserne, er listeformede med dårligt udviklede ender.

I de lavaer, som ligger lige under den kulførende serie, er plagioklaserne gerne dybtgående omdannet, og der kan ofte ses en begyndende zeolitdannelse i dem (lavaerne i profil III). Dette skyldes uden tvivl, at nedsivende overfladevand, der i den hvileperiode i den vulkanske aktivitet, som sedimentserien er vidnesbyrd om, er trængt et godt stykke ned i den del af plateauet, der den gang var dannet.

Sort malm (i skemaerne betegnet med den engelske term ore) 
forekommer i to generationer, een, der består af større individer, som mere eller mindre udtalt er i besiddelse af egne krystalbegrænsninger og een, som tilhører grundmassen og som består af små afrundede individer. I nogle af de lavaer, der opbygger profilstykkerne II a og II b, findes der en iøjnefaldende type af tidligt dannede halv-strøkorn af malm. De viser tydelige till $\varnothing \mathrm{b}$ til udvikling af egne krystalgrænser, men er stærkt indskårne og gennemsat af kanaler og huller (fig. 4 b). Der er altid normativ magnetit og ilmenit til stede; et malmmikroskopisk arbejde er ikke afsluttet.

Glas kan udgøre op til $10 \%$ af en given lavabjergart, men indholdet svinger fra bænk til bænk. Glassen er for det meste brunlig i forskellige nuancer, men også grønlige og gullige farver optræder, dobbeltbrydende omdannelsesborter kan være til stede.

Grønne omdannelsesprodukter (i skemaerne forkortet til gap $=$ grønne alterations-produkter) forekommer udbredt, ganske særligt i profilstykke III, hvor de optræder sammen med de ovenfor nævnte omdannede plagioklaser. Der er ikke udført specielle bestemmelser fra slib til slib af deres natur, men forskellige typer er bemærket.

Den gennemsnitlige mineralsammensætning af de afyriske og de kryptofyriske lavaer er følgende: $\mathrm{pl}=36 \%, \mathrm{cpx}=44 \%$, malm $(=$ ore $)=11 \%$, glas og gap $=9 \%$. Olivin og pseudomorfoser efter olivin udgør mindre end $0,2 \%$.

Kemiske analyser af lavaer fra nederste basaltserie

\begin{tabular}{lrrrrr} 
& \multicolumn{1}{c}{1.} & \multicolumn{1}{c}{2.} & \multicolumn{1}{c}{3.} & \multicolumn{1}{c}{4.} & \multicolumn{1}{c}{5.} \\
$\mathrm{SiO}_{2}$ & 49,70 & 48,02 & 45,40 & 47,43 & 47,34 \\
$\mathrm{TiO}_{2}$ & 4,83 & 2,20 & 3,20 & 1,36 & 1,97 \\
$\mathrm{Al}_{2} \mathrm{O}_{3}$ & 10,98 & 14,17 & 14,54 & 15,81 & 13,22 \\
$\mathrm{Fe}_{2} \mathrm{O}_{3}$ & 3,02 & 3,62 & 1,96 & 5,35 & 6,27 \\
$\mathrm{FeO}$ & 11,19 & 8,37 & 10,45 & 7,07 & 8,00 \\
$\mathrm{MnO}$ & 0,22 & 0,16 & 0,25 & 0,06 & 0,18 \\
$\mathrm{MgO}$ & 5,34 & 7,08 & 6,25 & 5,92 & 5,98 \\
$\mathrm{CaO}$ & 9,71 & 11,02 & 11,72 & 11,27 & 11,25 \\
$\mathrm{Na}_{2} \mathrm{O}$ & 2,22 & 1,73 & 2,08 & 1,99 & 2,41 \\
$\mathrm{~K}_{2} \mathrm{O}$ & 0,63 & 0,27 & 0,49 & 0,16 & 0,16 \\
$\mathrm{P}_{2} \mathrm{O}_{5}$ & 0,35 & 0,08 & 0,24 & 0,19 & 0,24 \\
$\mathrm{H}_{2} \mathrm{O}^{+}$ & 0,96 & 1,00 & 1,50 & 1,81 & 1,52 \\
$\mathrm{H}_{2} \mathrm{O}^{-}$ & 0,92 & 2,40 & 2,00 & 1,43 & 1,56 \\
$\mathrm{CO}_{2}$ & - & $n i l$. & nil. & - & - \\
$\mathrm{S}$ & 0,05 & - & tr. & - & - \\
\hline & 100,12 & 100,12 & 100,08 & 99,85 & 100,10
\end{tabular}


Katanorm

$\begin{array}{lrrrrr}\text { q } & 7,68 & 3,97 & 0 & 4,31 & 3,60 \\ \text { or } & 3,94 & 1,68 & 3,06 & 1,00 & 1,00 \\ \text { ab } & 21,13 & 16,38 & 19,75 & 18,88 & 22,90 \\ \text { an } & 19,22 & 31,75 & 30,55 & 35,64 & 26,23 \\ \text { ap } & 0,78 & 0,18 & 0,53 & 0,42 & 0,53 \\ \text { en } & 8,27 & 13,32 & 5,84 & 10,62 & 8,14 \\ \text { fs } & 4,96 & 5,20 & 3,64 & 3,52 & 2,74 \\ \text { di } & 23,53 & 20,29 & 23,42 & 17,70 & 24,95 \\ \text { fo } & 0 & 0 & 3,89 & 0 & 0 \\ \text { fa } & 0 & 0 & 2,43 & 0 & 0 \\ \text { mt } & 3,35 & 3,99 & 2,17 & 5,91 & 6,94 \\ \text { il } & 7,13 & 3,23 & 4,71 & 2,00 & 2,90\end{array}$

1. Ikke-porfyritisk basalt, Vágur, Suðuroy. A. Holmes. Anal. H. F. Harwood. (Analysen omfatter tillige bestemmelsen af $\mathrm{V}_{2} \mathrm{O}_{3}=0,03, \mathrm{BaO}=0,01 \mathrm{og}$ $\mathrm{Cl}=0,02)$.

2. Olivinførende basalt, Tvфroyri, Suðuroy. Walker og Davidson. Anal. W. H. Herdsmann.

3. Olivinførende basalt, Trongisvágur, Suðuroy. J. Simpson. Anal. W. H. Herdsmann.

4. Olivinførende basalt fra tyk lavastrøm med søjledannelse, lige under den kulførende serie i Rangibotnur. Arne Noe-Nygaard. Anal. Me Mouritzen.

5. Olivinførende basalt, Mykineshólmur, sydsiden. Arne Noe-Nygaard og J. Rasmussen. Anal. Me Mouritzen. 


\section{Den kulførende serie}

Efter dannelsen af den ca. $900 \mathrm{~m}$ mægtige nederste basaltserie indtrådte der en langvarig hvileperiode, i hvilken der først skete en vis erosion af lagene og derefter aflejring af den kulførende series sedimenter (fig. 30).

Den kulf $\varnothing$ rende serie er aflejret på den nederste basaltseries nederoderede og subaerisk forvitrede overflade; undertiden hvilende på den $\varnothing$ verste bænk og undertiden, hvor denne er eroderet bort, først

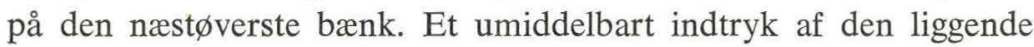
basalts stærkt bulede og ujævne overflade kan man få, hvor denne ved skæring med havniveau er blevet renvasket af bølgeslaget; særlig tydeligt ses dette ved Kolaratangi på nordvestsiden af Grímsfjall. Man kan ligeledes iagttage store »buler « i den liggende basalt i kulminerne, hvor de er til stor gene for kulbrydningen( fig. 31, 32).

Den kulførende serie forekommer på Suðuroy, Tindhólmur og Vágar. Kun på Suðuroy forekommer kullene imidlertid i sådanne mængder, at de har været gjort til genstand for egentlig kulbrydning.

\section{Suðuroy}

Den kulførende serie dækker her et areal på ca. $23 \mathrm{~km}^{2}$. I naturlige snit kan den iagttages i fjeldvæggen på фens vestside fra strandkanten ved Kolaratangi på nordvestsiden af Grímsfjall stigende mod syd til fjeldene syd for Trongisvágur, hvor den har sin højeste beliggenhed, ca. $425 \mathrm{~m}$ o. h., ved Knúkur umiddelbart syd for Fámjins minerne. På $\varnothing$ stsiden af фen ses kullene i stranden ved Froðbiarnípa, i Hvannhagi - Lónin og omkring Tjørnunes på sydsiden af Hvalbiarfjørður. På nordsiden af Hvalbiarfjørður når sedimentserien havniveau inderst i bugten, men kullene synes her at være tyndet helt ud. Den kulførende series aflejringer gennemskærer således fjeldene fra Grímsfjall i nordvest til Hovstúgva i sydøst afbrudt af Hvalbiareið, Trongisvágurdalen og området mellem Oyrnafjall og Kolheyggjur (fig. 33). 


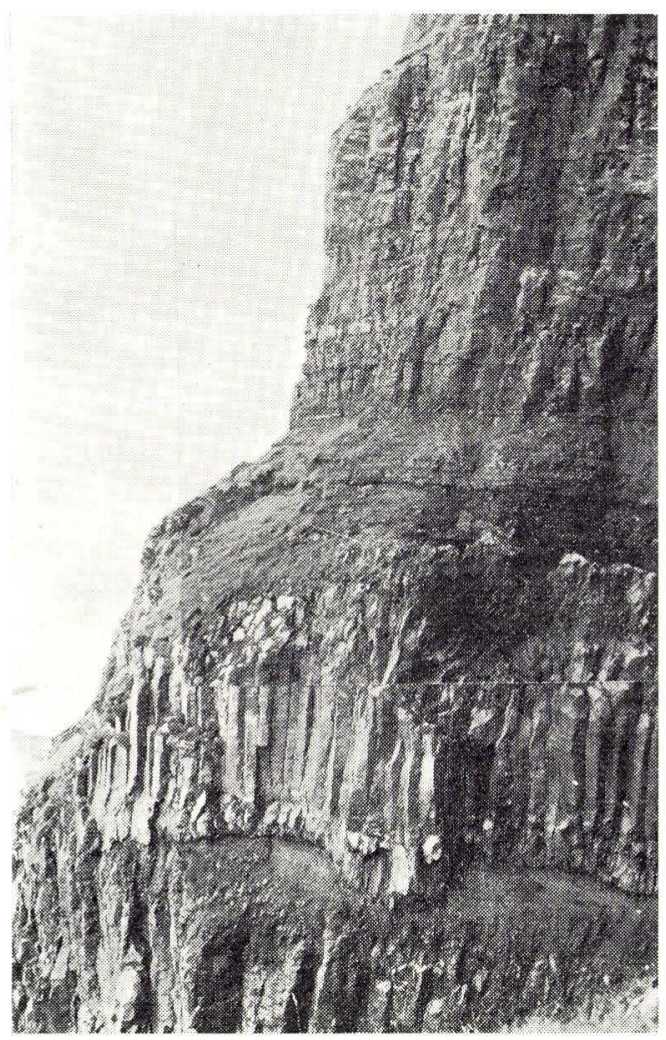

Fig. 30. Nederste basaltserie - kulførende serie - mellemste basaltserie i fjeldvæggen nord for Geitaskoragjógv.

Niðaru basaltfláirnar - kolalindin - miðfláirnar í berginum nordan fyri Geitaskoragjógv.

Lower basalt series - coal-bearing horizon - middle basalt series in the mountain wall north of Geitaskoragjógv, Suðuroy.

Det samlede kulareal falder i 4 adskilte kulfelter:

\section{Grimsfjall}

2. Nordlige kulfelt (m. Hvalbaminerne)

3. Sydlige kulfelt (m. Rangibotnurminerne) og

4. Kolheyggjur-Hovstúgva.

Den kulførende series mægtighed beløber sig almindeligvis til omkring 10 meter, med lokale afvigelser. Kullene forekommer i regelen som to adskilte bånd, den typiske lagfølge er denne: Nederst forekommer et lag lyst (hvidt-gråt) bundler, der på stedet benæv- 


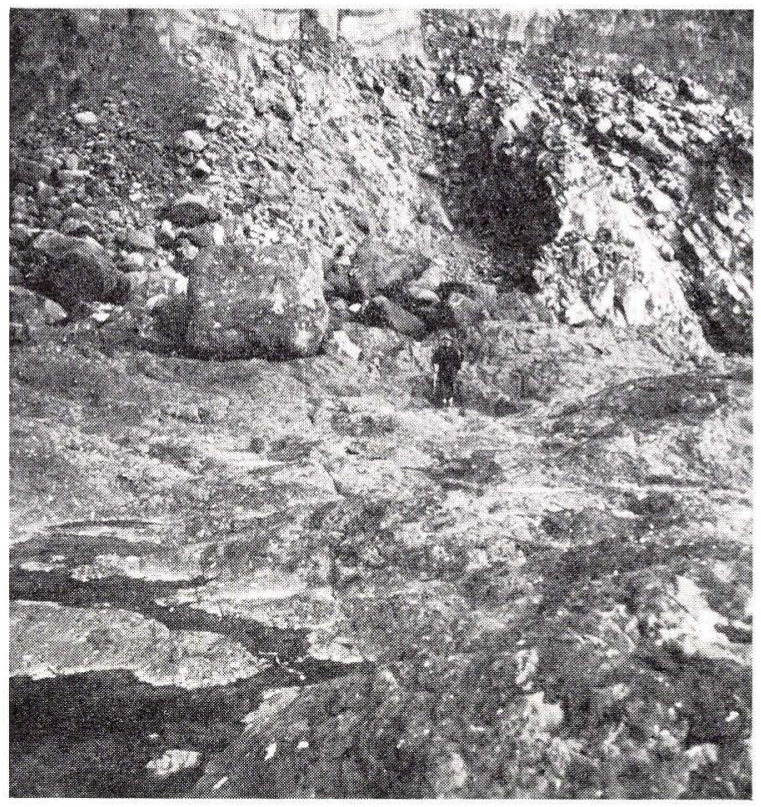

Fig. 31. Bule i den liggende basalts overflade (Kolaratangi). ój申vn og kullut hella undir kolalindini (Kolaratangi).

Bulge in the surface of the underlying basalt (Kolaratangi).

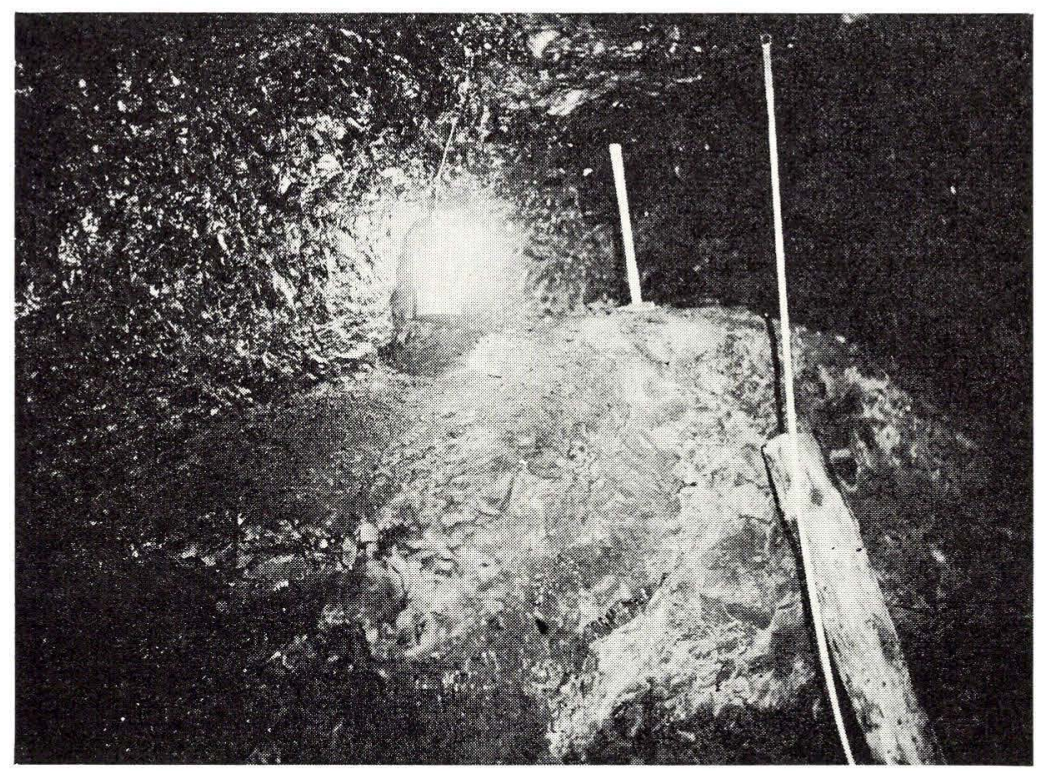

Fig. 32. Bule i den liggende basalt i minegang i Rangibotnur. Banki i kolaholi i Rangabotni.

Bulge in the surface of the underlying basalt in the mine in Rangibotnur. 


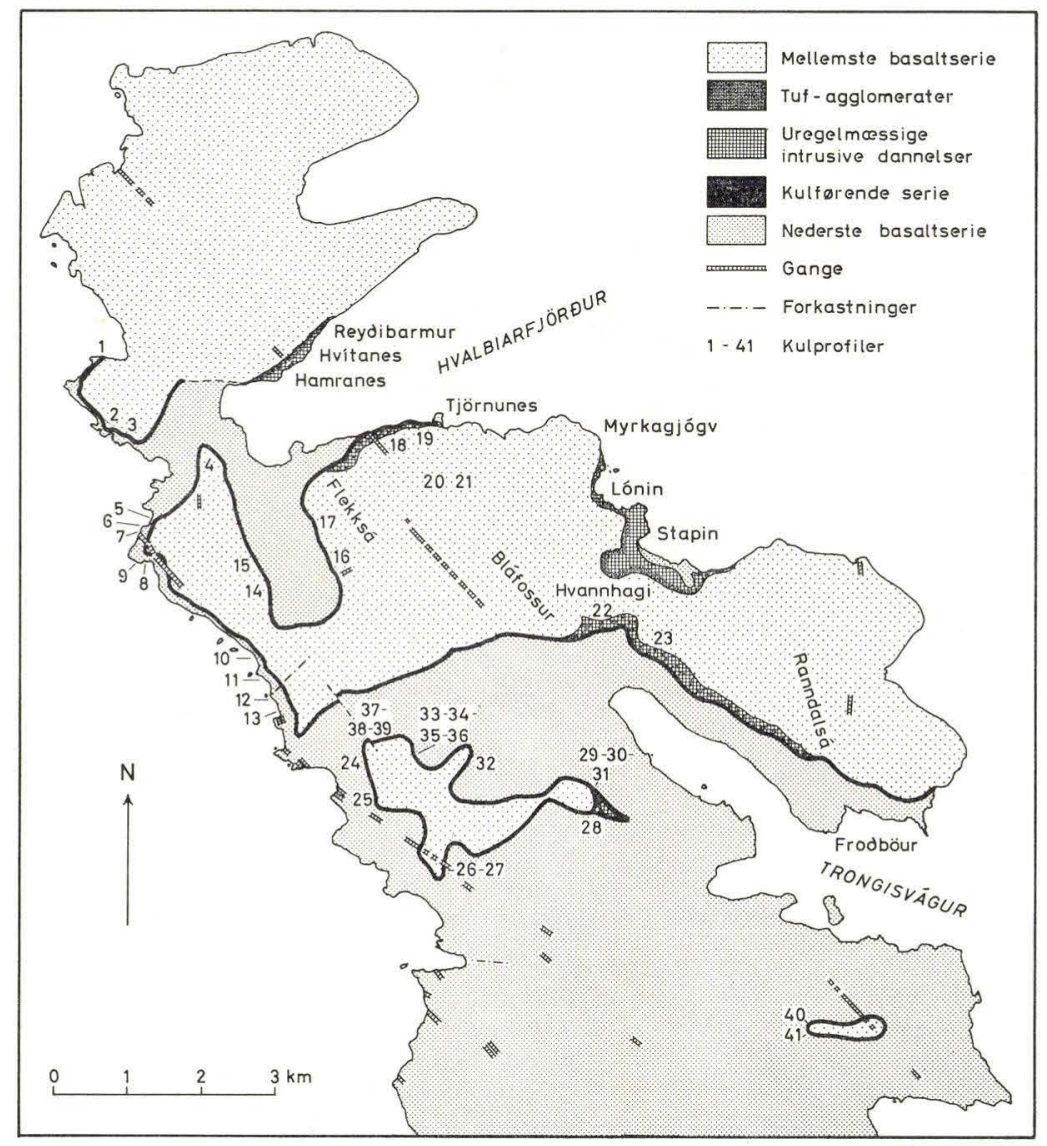

Fig. 33. Kort over den kulførende series udbredelsesområde på Suðuroy: tallene angiver profillokaliteter.

Kort av kolaøkinum í Suð̋uroy. Tølini vísa á, har skurđirnir eru mátað̋ir. Map of the area of outcrop of the coal-bearing horizon on Suðuroy.

Localities of profiles are indicated by arabic numerals.

nes »bankin«. Herover ses det nedre kulbånd »stabbin«, der er adskilt fra det фvre kulbånd ved et lag mørkt skiferler »rannin«, som ofte indeholder striber eller linser af kul. Det фvre kulbånd kaldes $\gg$ kolbandið «, det overlejres af et flere meter tykt lag tagler »úrstin« (nedre del) og »takleir« ( $\varnothing$ vre del). Undertiden forekommer fluviatile konglomerater eller »basaltisk « sandsten i stedet for, eller over tagleret (RASMUSSEN 1952). I den nedre del af tagleret »úrstin« findes ofte små mængder kul i form af linser eller 
Profil nr.: Lokalitet:

Profil nr. 1:

Profil 22:

Kolaratangi

Profil nr. 2:

Myllá

Vestsiden af Grímsfjall

Profil nr. 23:

$\emptyset \mathrm{kslin}$ (v. Trongisvágur)

Profil nr. 3:

Vestsiden af Grímsfjall

Profil nr. 24:

Profil nr. 4:

$\emptyset \mathrm{kslin}$ (Prestfjall)

Profil nr. 5:

Undir Bergsleiti

Profil nr. 6:

Undir Bergsleiti

Profil nr. 7:

Undir Bergsleiti

Profil nr. 8:

Suðuri undir Hæli

Profil nr. 9:

Suơuri undir Hæli

Profil nr. 10:

Nord for Skarvgjógv

Profil nr. 11:

Syd for Skarvgjógv

Profil nr. 12:

Nord for Geitaskoragjógv

Profil nr. 13:

Syd for Geitaskoragjógv

Profil nr. 14:

$\emptyset$ stsiden af Prestfjall

Profil nr. 15:

$\emptyset$ stsiden af Prestfjall

Profil nr. 16:

Rókhagi S

Profil nr. 17:

Rókhagi N

Profil nr. 18:

Øst for Seiðagjógv

Profil nr. 19:

Vest for Tjørnunes

Profil nr. 20:

Vatnsdalur, vest for elven

Rossarók N

Profil nr. 25:

Rossarók S

Profil nr. 26:

Fámjinsminerne

Profil nr. 27:

Fámjinsminerne

Profil nr. 28:

$\emptyset$ st for Oyrnafjall (sydsiden)

Profil nr. 29:

Nordøstsiden af Oyrnafjall

Profil nr. 30:

Nordøstsiden af Oyrnafjall

Profil nr. 31:

Nordøstsiden af Oyrnafjall

Profil nr. 32:

Nordøstsiden af Mót

Profil nr. 33:

Rangibotnur

Profil nr. 34:

Rangibotnur

Profil nr. 35:

Rangibotnur

Profil nr. 36:

Rangibotnur

Profil nr. 37:

Gudmunds mine

Profil nr. 38:

Gudmunds mine

Profil nr. 39:

Gudmunds mine

Profil nr. 40:

Kolheyggjur N

Profil nr. 41:

Kolheyggjur S

Profil nr. 21:

Vatnsdalur, øst for elven 


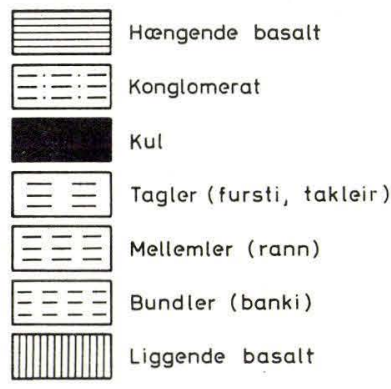

Signaturforklaring til kulprofilerne 1-41.

Teknlýsing til kolaskurðirnar 1-41.

Legend for profiles 1-41 of the coal-bearing horizon.

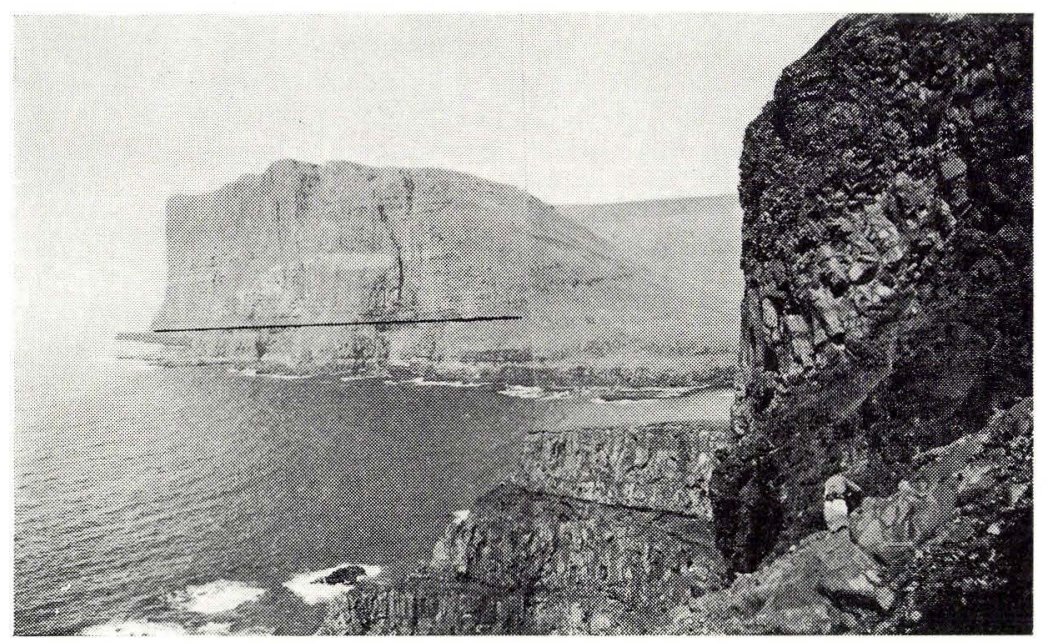

Fig. 34. Kulførende serie i Grímsfjall. I forgrunden nederste basaltserie kulførende serie - mellemste basaltserie. Undir Bergsleiti ved profilerne 5,6 og 7 .

Aftantil á myndini: Kolalindin í Grímsfjalli. Frammantil: Niðaru basaltfláirnar - kolalindin - miðfláirnar. Undir Bergsleiti við skurđirnar 5,6 og 7 .

The coal-bearing horizon on Grimsfiall. - In the foreground the lower basalt series, overlain by the coal-bearing horizon and the middle basalt series. Undir Bergsleiti at the locality for profiles 5. 6 and 7.

striber, samt lerjernsten og andre imprægnationer. Lagdelingen varierer en del og er noget forskellig for det nordlige og det sydlige kulfelt. I det nordlige kulfelt er »stabbin « sædvanligvis tykkere end »kolbandið«, medens det modsatte er tilfældet i det sydlige kul- 
felt. På overgangen mellem de to felter er det ikke ualmindeligt, at der forekommer flere kulbånd, samt at seriens lagdeling i det hele taget er noget atypisk.

1. Grímsfjall. I Grímsfjall optager den kulførende serie et areal på $1,36 \mathrm{~km}^{2}$. Den når havniveau ved Kolaratangi på nordvestsiden af Grímsfjall og formodentlig ligeledes ved det gamle landingssted inde i bugten ved Hvalba, hvor den dog synes at være stærkt udtyndet. (Fig. 34).

Ved profil 1 på Kolaratangi er den liggende basalt blottet, dens overflade er renvasket af bølgeslaget, ujævn og stærkt bulet. I nedre del af tagleret, 4-4,5 m, ses hyppigt tynde kullinser og kulstriber på få $\mathrm{cm}$ eller endnu tyndere. I den $\varnothing v r e$ del af tagleret, som har et blåligt skær, er der ingen kul.
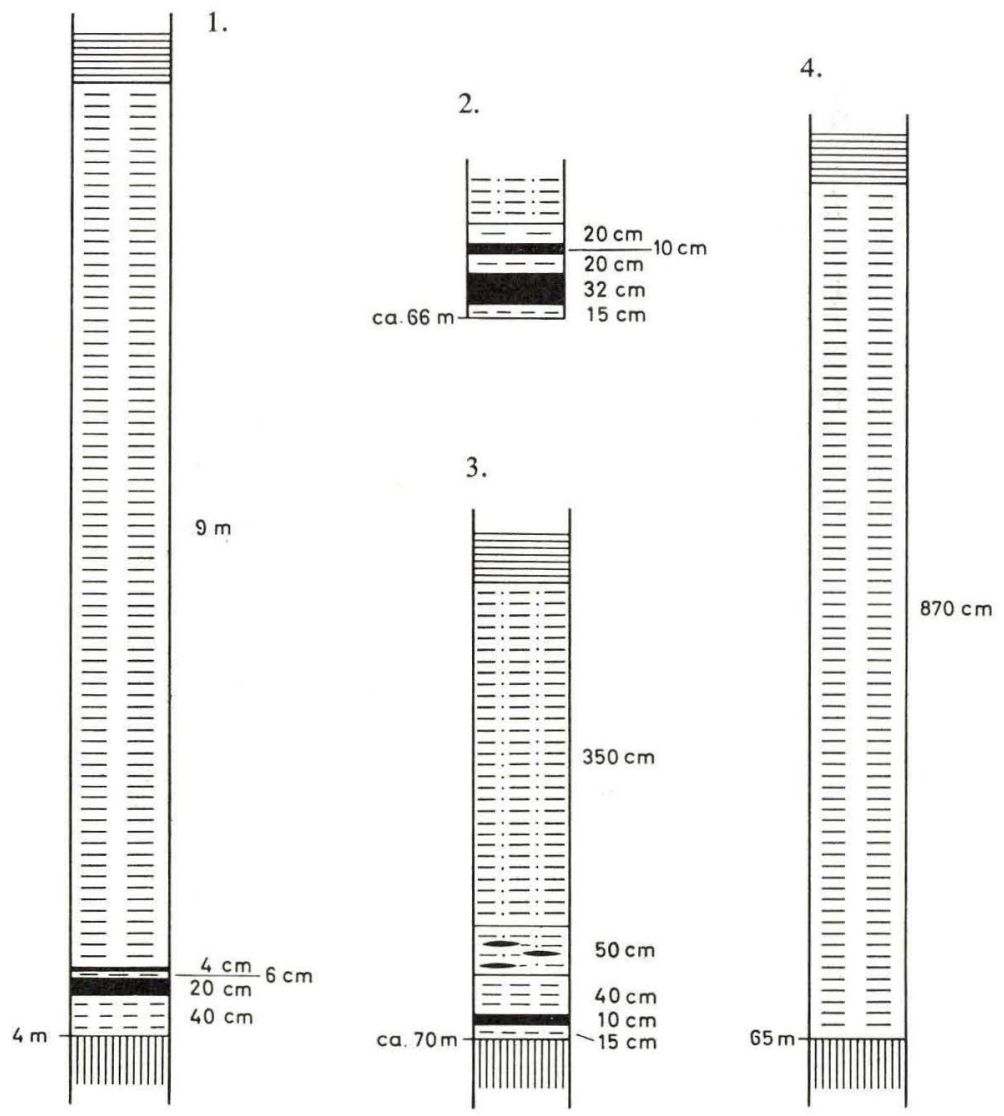
Ved profil 2 på vestsiden af Grímsfjall er tagleret kun $20 \mathrm{~cm}$ tykt; det erstattes højere oppe i profilet af et konglomerat, der består af groft grus $(20 \mathrm{~cm})$ med velafrundede sten og derefter af finere fluviatilt materiale, som skifter med tynde grusårer.

Ved profil 3, ca. $100 \mathrm{~m}$ syd for profil 2, er der kun et tyndt kulbånd (trækul).* I stedet for tagleret optræder her ca. $4 \mathrm{~m}$ fluviatilt sand og grus, i de nederste $50 \mathrm{~cm}$ med tynde, almindeligvis 1-3 cm tykke kullinser. Langs $\varnothing$ stsiden af Grímsfjall er den kulførende serie ikke blottet. De her og i det følgende omtalte profiler er dels naturligt blottede og dels profiler, som er blotlagt ved prøvegravninger, samt endelig opmålinger i ældre og nyere kulminer.

2. Nordlige kulfelt. I det nordlige kulfelt omfatter serien et areal på $18,74 \mathrm{~km}^{2}$. Af praktiske grunde, som der senere vil blive gjort rede for, vil det være formålstjenligt at betragte det nordlige kulfelt som sammensat af et vestligt område på $11,00 \mathrm{~km}^{2}$ og et $\phi$ stligt på $7,74 \mathrm{~km}^{2}$. Serien har sin højeste beliggenhed i sydvest og når havniveau ved Froðbiarnípa og ved Tjørnunes.

Ved profil 4 i Økslin, nordspidsen af Prestfjall, fandtes kun 870 $\mathrm{cm}$ brunt ler, som stedvis er mere gråligt eller mørkt. Der iagttages ingen kul i profilet. Langs nordvestsiden af Prestfjall går kullene ikke i dagen, men ved en enkelt lokalitet blev den nedre grænse for den kulførende serie blottet ved prøvegravning. Efter udsagn fra mænd, der har arbejdet i de gamle, nu sammenstyrtede miner på nordvestsiden af Prestfjall, fandtes der på dette sted en grovkornet konglomerataflejring i stedet for - eller over - tagleret.

Af profilerne 5, 6 og 7 Undir Bergsleiti er profil 5 opmålt inde i bunden af en gammel, endnu åben mine (26 m inde). Minen ligger umiddelbart ud til en ca. $135 \mathrm{~m}$ lodret stejlvæg mod havet kun $3 \mathrm{~m}$ fra fjeldkanten. Profil 6 er opmålt umiddelbart nord for mineindgangen og profil $7,37 \mathrm{~m}$ syd for mineindgangen. Såvel i profil 5 som i profil 6 er der konglomerat foroven i profilet i stedet for tagler, i profil 6 er det $280 \mathrm{~cm}$ tykt, фverst med kullinser. Konglomeraterne er skiftende med hensyn til kornstørrelse. Omtrent midt i serien findes et bånd af langt finere materiale, således som målt fra neden: $120 \mathrm{~cm}$ konglomerat, $30 \mathrm{~cm}$ finere materiale, $130 \mathrm{~cm}$ konglomerat. I profil 7 fandtes ikke konglomerat, men almindelig

* Her forstås ved trækul, kul med velbevaret vedstruktur. 


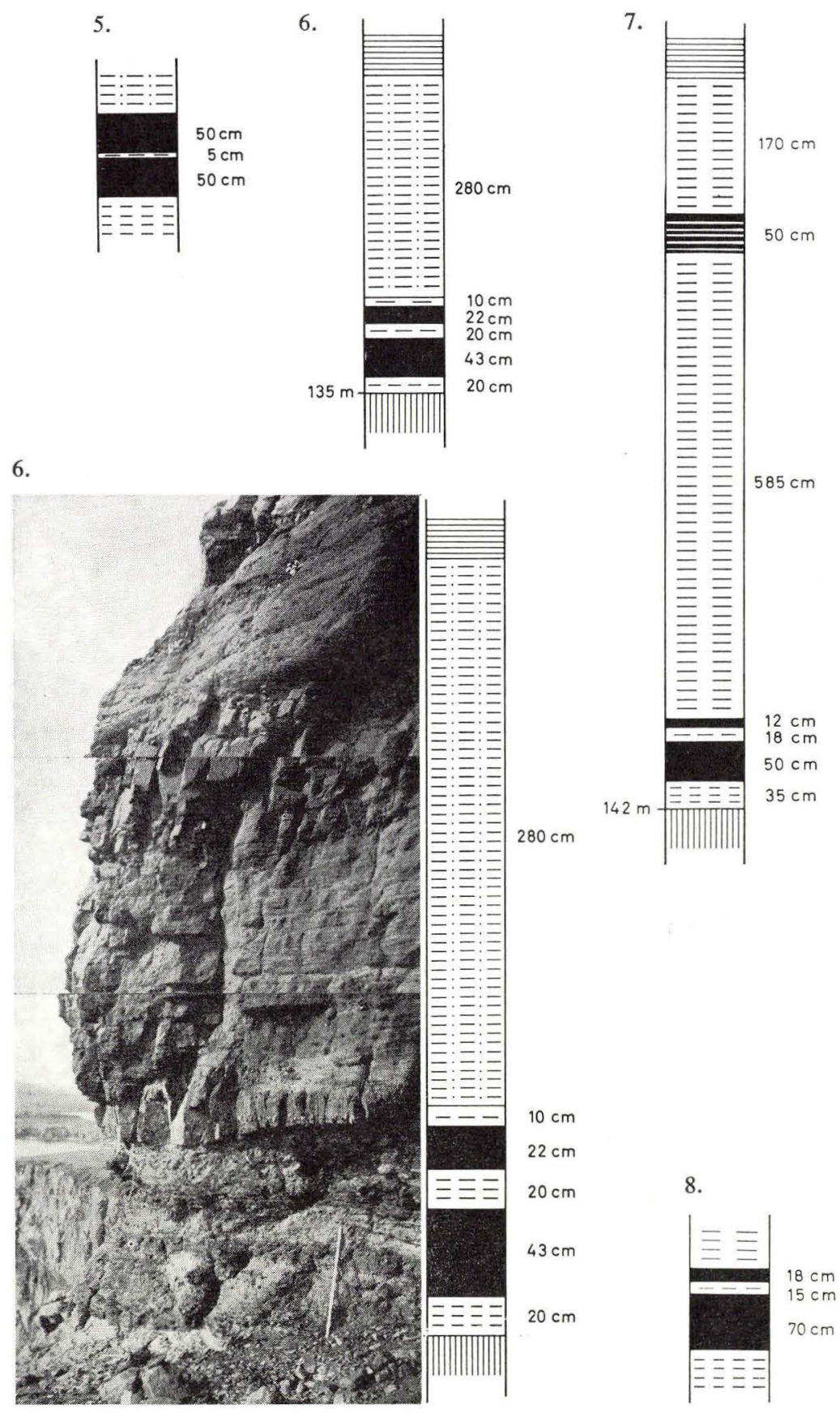

Fig. $35=$ profil 6 . 
10.

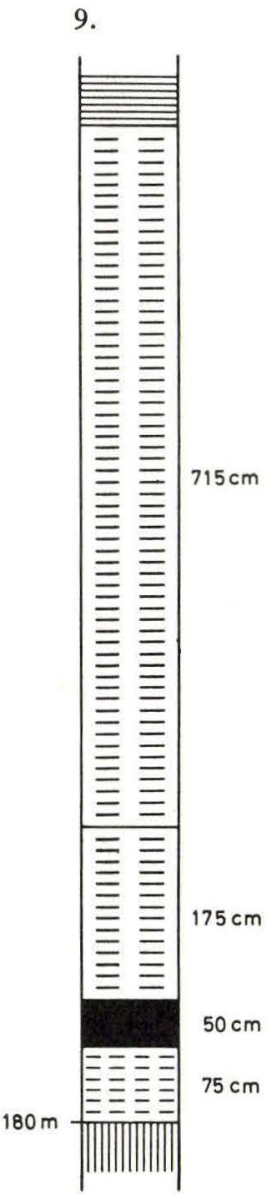

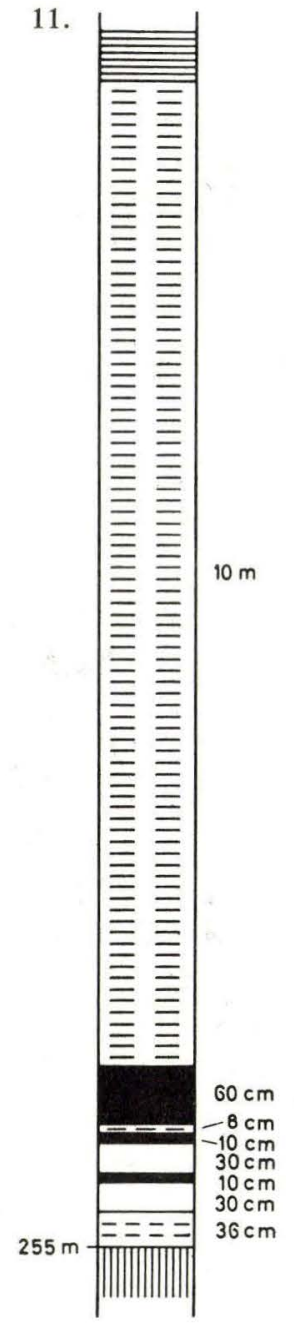

m $\varnothing$ rkt brunligt, undertiden lysere tagler. Foruden de hyppigt forekommende tynde kulstriber i den nederste del af tagleret fandtes der her ca. $50 \mathrm{~cm}$ med skiftende tynde kulbånd og ler i den фverste del af tagleret. Medens hele den kulførende serie ved profil 6 kun havde en samlet mægtighed på $395 \mathrm{~cm}$, målte den ved profil 7 kun $37 \mathrm{~m}$ sydligere $920 \mathrm{~cm}$.

Profilerne 8 og 9 er opmålt $1 / 2 \mathrm{~km}$ sydligere, Suðuri undir Hæli, profil 8 inde i en gammel, nu sammenstyrtet mine og profil 9 ca. $45 \mathrm{~m}$ vest for denne. I profil 8 er aflejringsforholdene normale; 
ved dette profil blev der, på grænsen mellem tagler og hængende basalt, fundet en forkullet trærod. I profil 9 mangler det $\emptyset$ vre kulbånd (kolbandið). De nederste $175 \mathrm{~cm}$, bestående af gråbrunt, mørkt tagler i dette profil, indeholder som sædvanlig tynde kullinser, de $\varnothing$ verste $715 \mathrm{~cm}$ udgøres af brunt ler.

Langs det meste af den vestlige stejlvæg danner den kulf $\varnothing$ rende serie en afsats, Prestskorar og Geitaskor. Den ses undertiden blottet, undertiden er den skjult under den frodige vegetation. Profil 10 nord for Skarvgjógv og profil 11 syd for Skarvgjógv viser begge noget atypiske lejringsforhold.

I profil 10 forekommer der, over det $12 \mathrm{~cm}$ tykke lyse bundler, $70 \mathrm{~cm}$ brunt ler og derefter $16 \mathrm{~cm}$ brunt ler, som er isprængt kul. I profil 11 forekommer der over $36 \mathrm{~cm}$ bundler $30 \mathrm{~cm}$ sort fedt ler, фverst med tynde kulstriber og derefter $10 \mathrm{~cm}$ trækul (stammestykker) og derefter igen $30 \mathrm{~cm}$ mørkt ler. Kullinserne i den nedre del af tagleret når undtagelsesvis $10 \mathrm{~cm}$ i tykkelse. Så langt serien er blottet mod nord, forekommer der stadig forkullede stammestykker og trærester, men laget går ind under grønsvær, før vi når Skarvgjógv.

I profil 12 nord for Geitaskoragjógv finder vi ligesom i det sydlige område, at det $\varnothing$ vre kulbånd har større mægtighed end det nedre. Foruden de sædvanlige tynde kulstriber i den nedre del af tagleret ses, ca. $2,5 \mathrm{~m}$ over det $\emptyset$ vre kulbånd, et kullag på 10-20 $\mathrm{cm}$. Øverst i tagleret, mellem 8 og $9 \mathrm{~m}$ oppe i profilet, findes et blåsort lerlag, som kan følges langt nordpå. Dette lag er ofte tidligere blevet forvekslet med kul.

Profil 13 er opmålt i en gammel kun $7 \mathrm{~m}$ lang, nu sammenstyrtet mine ca. $1 / 2 \mathrm{~km}$ syd for Geitaskoragjógv. Det nedre kulbånd går helt ned til minegulvet, så bundleret ikke er synligt. Der ses trækul nederst i det nedre kulbånd og i tagleret en kullinse eller et kulbånd på $30 \mathrm{~cm}$.

Langs фstsiden af Prestfjall ligger der en lang række, for en del endnu åbne miner. De ældste af disse blev anlagt allerede i 1780'erne.

Profilerne 14 og 15 er begge repræsentative og typiske for dette område; det skal dog bemærkes, at kulmægtigheden i mineområdet er noget varierende og ikke sjældent noget mindre end $\mathrm{i}$ de to nævnte profiler. Fig. 36 viser kullagenes forl $\varnothing \mathrm{b}$ ved en $2 \mathrm{~m}$ h $\varnothing \mathrm{j}$ bule i den liggende basalts overflade nær profil 14 .

Kullene synes at være tyndet ud i den nordligste del af Prest- 


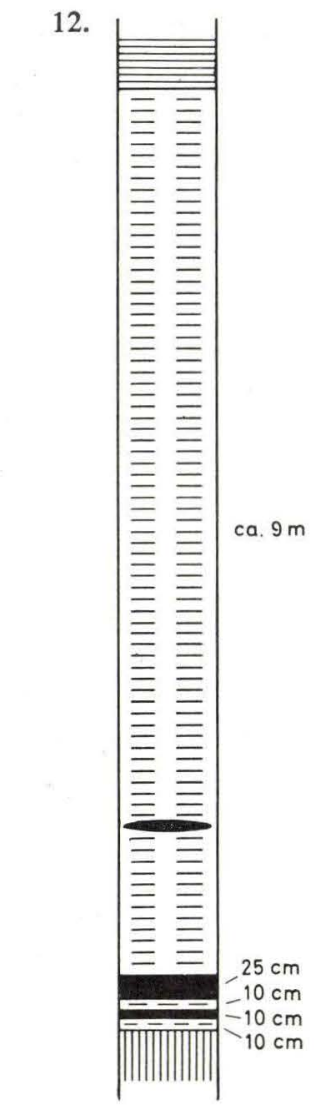

15.
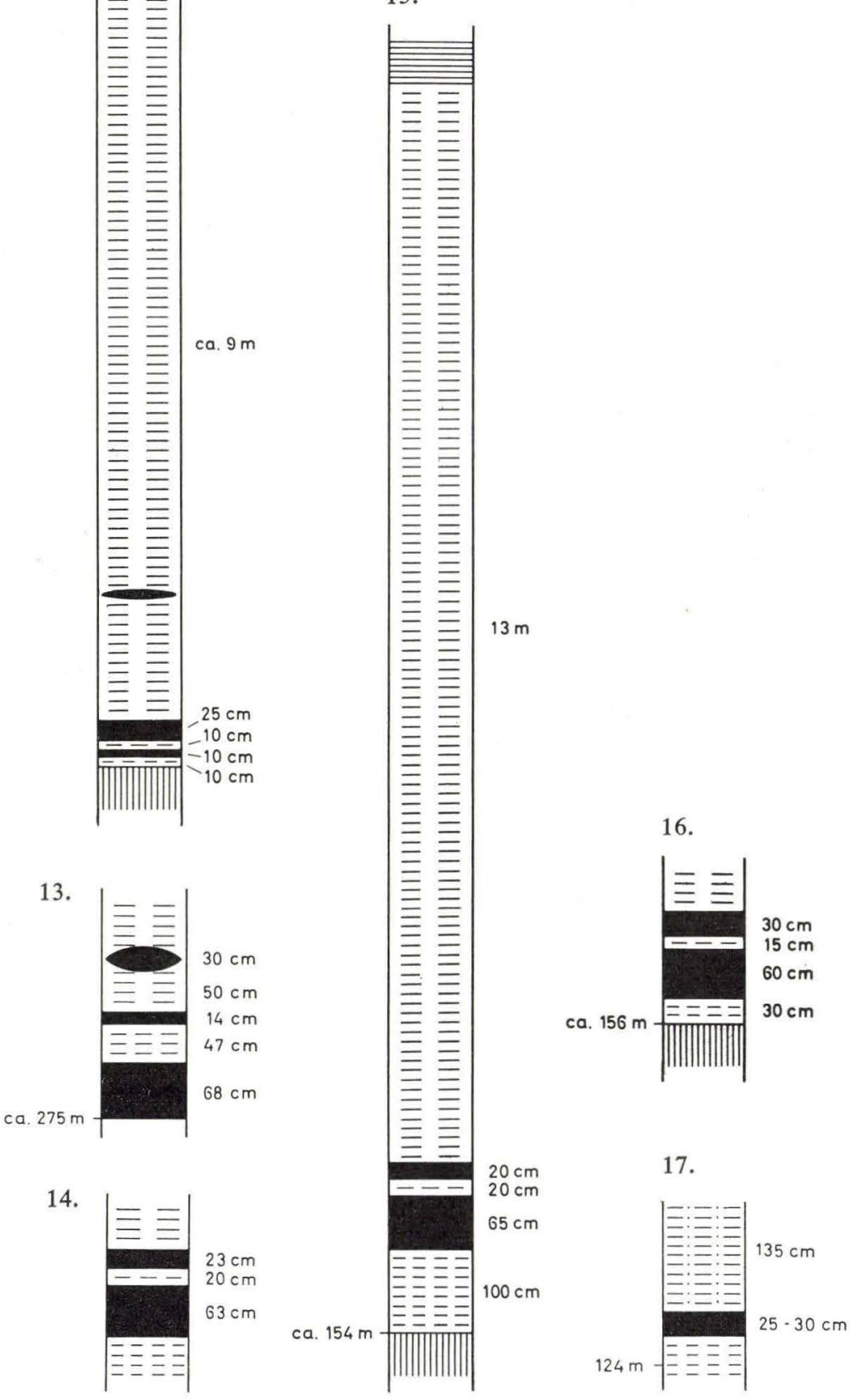


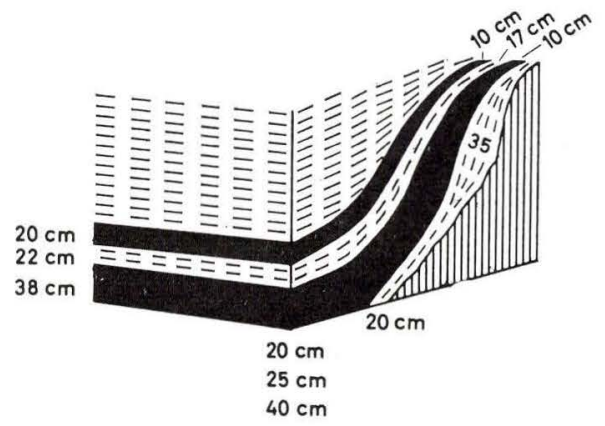

Fig. 36. En bule i den liggende basalts overflade nær profil 14.

Banki narindis skurði 14.

Bulge in the surface of the underlying basalt near profile 14.

fjall. I en mine, ca. $1 / 2 \mathrm{~km}$ syd for profil 4 , blev der således kun iagttaget tynde linser af kul.

På østsiden af dalen syd for Hvalba er profilerne 16 og 17 blevet afdækket ved prøvegravning. Medens profil 16 viser typiske lejringsforhold og stor kulmægtighed $(90 \mathrm{~cm})$, viser profil 17, der ligesom forrige profil ikke blev rengravet i hele sin længde, atypiske lejringsforhold, idet der kun forefindes et kulbånd på $25-30 \mathrm{~cm} \mathrm{og}$ derover $135 \mathrm{~cm}$ konglomerat (svarende til højden af prøvegravningen).

Til det $\emptyset$ stlige område regner vi området $\emptyset$ st for Trongisvágurdalens forlængelse, d. v. s. фst for tuf-agglomeraternes vestlige begrænsning (se s. 175). Kullene er i dette område tyndet betydeligt ud, således at der ofte slet ikke mere er tale om sammenhængende kullag. Aflejringsforholdene er i det hele taget meget uensartede og profilerne varierer derfor stærkt fra sted til sted. Da serien tilmed er gennembrudt af efterfølgende eksplosiv udbrudsvirksomhed og endvidere ikke sjældent disloceret ved senere intrusion, vil området næppe nogensinde få praktisk betydning med henblik på kulbrydning (RASMUSSEN 1952).

Langs sydsiden af Hvalbiarfjørður er aflejringsforholdene skiftende, for det meste afvigende og ret uoverskuelige. Profilerne 18 og 19, der begge er opmålt nær stranden, gælder derfor kun for selve profillinjen. I profil 18 фst for Seiðagjógv er de opgivne tal kun omtrentlige, da forløbet af de enkelte lag er meget uregelmæssigt. Profil 19 vest for Tjørnunes blev blottet ved prøvegravning. I 


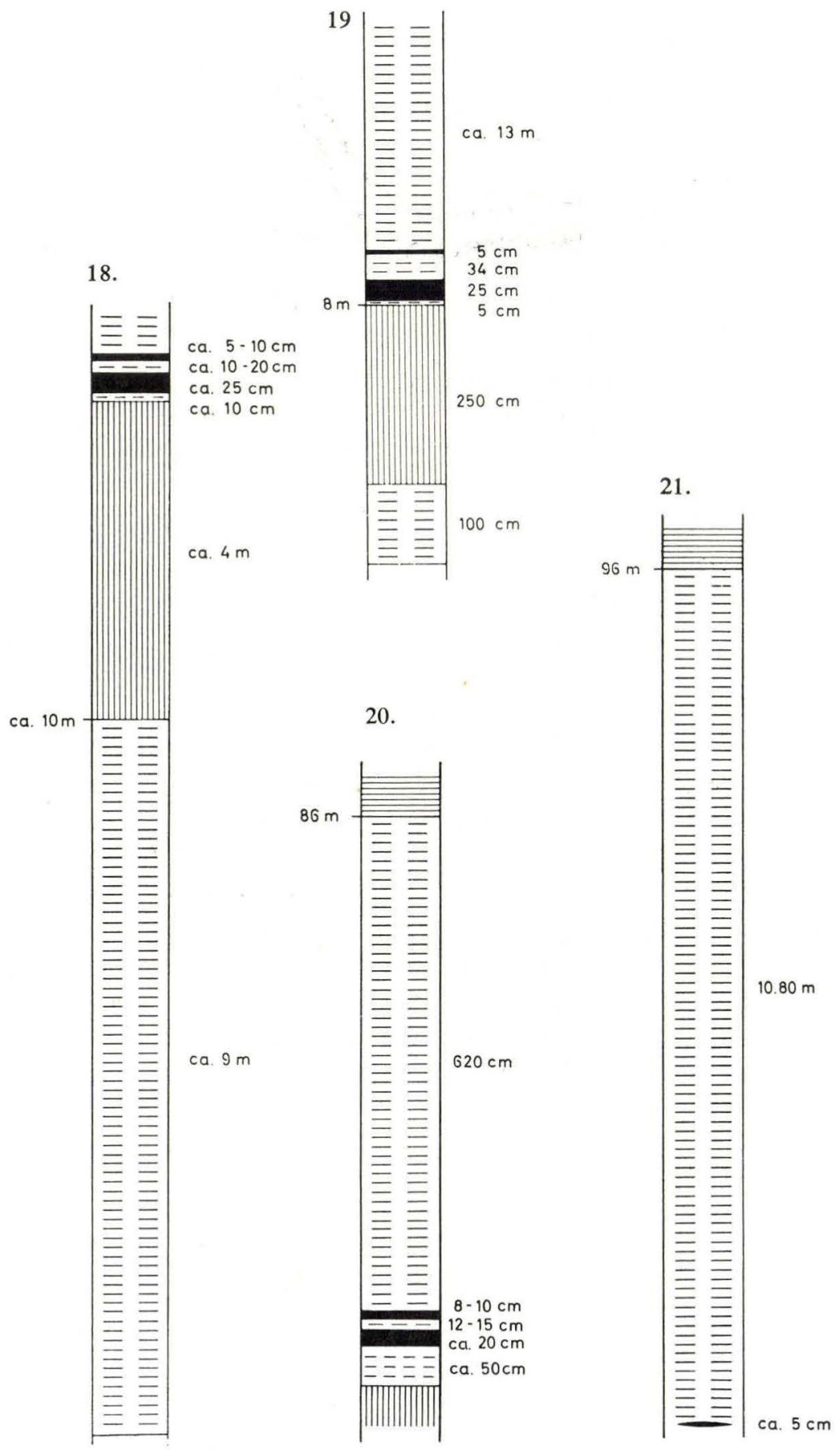




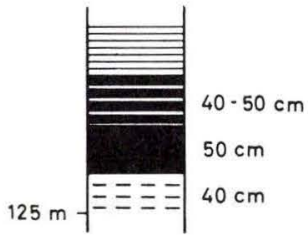

22.

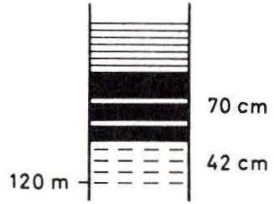

23 A.

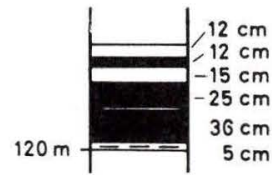

$23 \mathrm{~B}$.

selve profillinjen er tagleret ophvælvet og måler $13 \mathrm{~m}$, medens det umiddelbart $\emptyset$ st for profilet kun måler $6 \mathrm{~m}$. Den kulførende serie er omkring Tjørnunes gennembrudt af basalt, der mod vest danner kontakt (nedre) mod tagleret.

Inde i Vatnsdalur syd for Tjørnunes er den kulførende serie delvis synlig, idet den $\emptyset$ verste del af tagleret går i dagen under fossen i elven Vatnsdalsá.

Profilerne 20 og 21 er fremkommet ved rengravning og boring videre nedad.

I profil 20, vest for elven, blev tagleret gravet rent $5 \mathrm{~m}$ ned, og ved boring videre nedad fremkom det angivne profil. I profil 21, $\emptyset$ st for elven, blev tagleret rengravet til $8 \mathrm{~m}$ dybde, og der blev derefter boret $2,80 \mathrm{~m}$ ned. Dette profil når næppe bunden, og det tynde kullag på $5 \mathrm{~cm}$ er sandsynligvis kun en kullinse i den $\varnothing$ verste del af tagleret.

Det er utvivlsomt den kulførende serie, der ses igen langs stranden i den lille bugt, Lónin på nordøstsiden af Suðuroy. Den liggende bænk er her meget ujævn og bulet, og serien er stærkt disloceret og intruderet. Stedvis, nord for Svínadalsá, ses den at være overlejret af tuf-agglomerater, og stedvis, syd for Svínadalsá, ses »basaltisk « sandsten med kullinser i taget. Kullene er tynde, kun få centimeter, og forekommer oftest kun som linser.

På nordsiden af bugten ved Hvannhagi ligger rester af den kulførende serie som indeslutninger i intruderet basalt. I sydøstsiden af bugten ses den kulførende serie nær kysten (10-15 m o. h.); den er stærkt disloceret, og der ligger intruderet basalt over den.

Langs nordsiden af Trongisvágur forekommer ingen naturlig blotning af den kulførende serie, men den har dog været tilgængelig for måling ved nogle for længst nedlagte fors $\emptyset$ gsminer ved Botnsskarð, ved Myllá, ved Økslin og ved vandløbene over bygden Froðba.

Profil 22, Myllá og profil 23, Økslin, er begge opmålt i gamle, forladte fors $\varnothing$ gsminer. Ingen af profilerne er typiske. I profil 22 er 
kun de nederste $50 \mathrm{~cm}$ ren kul, medens de overliggende $40-50 \mathrm{~cm}$ er lerblandet kul og vekslende ler- og kulbånd. Basalten ovenover er intrusiv. I profil 23 er A opmålt udenfor minen. Det viser 70 $\mathrm{cm}$ lerblandet kul, efterfulgt opad af intruderet basalt. B er opmålt $7 \mathrm{~m}$ inde i minen og viser $36 \mathrm{~cm}$ ren kul og derover $100 \mathrm{~cm}$ skiftende ler- og kulbånd.

Den kulførende serie når havniveau ved Froðbiarnípa. Den фvre del af serien er blottet i den stejle fjeldvæg, den nedre del er dækket af ur. Der synes ikke at være noget sammenhængende kulbånd.

3. Sydlige kulfelt. Det sydlige kulfelt ligger sydvest for Trongisvágur og indtager et areal på $2,60 \mathrm{~km}^{2}$. I hovedtrækkene svarer det typiske profil i det nordlige og i det sydlige kulfelt til hinanden. Som foran nævnt er dog det фvre kulbånd (kolbandið) tyndere i det nordlige kulfelt, medens vi i det sydlige kulfelt almindeligvis ser det omvendte forhold. Bundleret har i det sydlige kulfelt almindeligvis grå farve, medens det i det nordlige kulfelt ofte er lysere. Skiferlerlaget, der adskiller de to kulbånd (rannin), indeholder i det sydlige kulfelt ofte en del gode kul i form af kullinser, glanskul (nýrakol); ligesom i det nordlige kulfelt er den nedre del af tagleret almindeligvis isprængt tynde kulstriber.

Profil 24, nordlige Rossarók, og profil 25, sydlige Rossarók, blev afdækket ved rengravning af hele serien. De viser begge den typiske lagdeling for området. I profil 24 forekommer der et lag $(20 \mathrm{~cm})$ af sortgråt ler mellem bundleret og det nedre kulbånd. Dette er ret almindeligt i området. I begge profiler indeholder skiferleret, der adskiller de to kulbånd (rannin), kul, således i profil 24: $10 \mathrm{~cm}$ ler, $21 \mathrm{~cm}$ kul, $5 \mathrm{~cm}$ ler og profil 25: $10 \mathrm{~cm}$ ler, 16 $\mathrm{cm}$ kul og $4 \mathrm{~cm}$ ler. I begge profiler er den nedre del af tagleret isprængt tynde kulstriber.

Profil 26 er opmålt ca. $50 \mathrm{~m}$ inde i den vestligste af Fámjinsminerne, profil 27 kun ca. $25 \mathrm{~m}$ inde i samme mine. I profil 27 blev det nedre kulbånd ikke helt afdækket.

I terrænet umiddelbart $\varnothing$ st for Oyrnafjall er den kulførende serie, der her har ringe mægtighed, overdækket af intruderet basalt. I lavningen mellem Oyrnafjall og den intruderede basalt $\phi$ st for Oyrnafjall er den kulførende serie blottet gennem erosion, således at den $\varnothing$ vre del af tagleret danner terrænoverfladen. Mod syd ses en enkelt lille isoleret rest af den mellemste basaltseries lavaer ovenpå tagleret. 


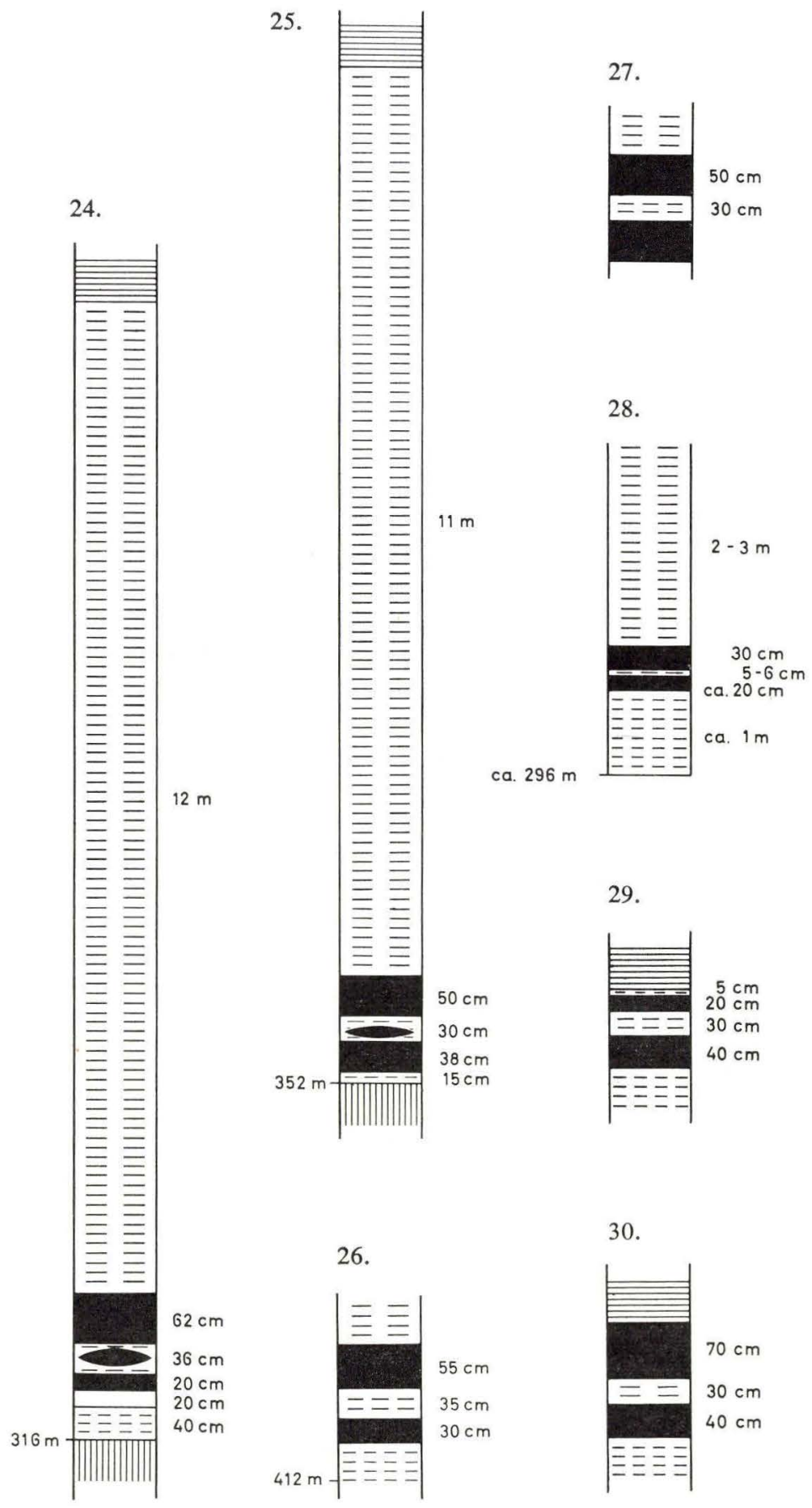




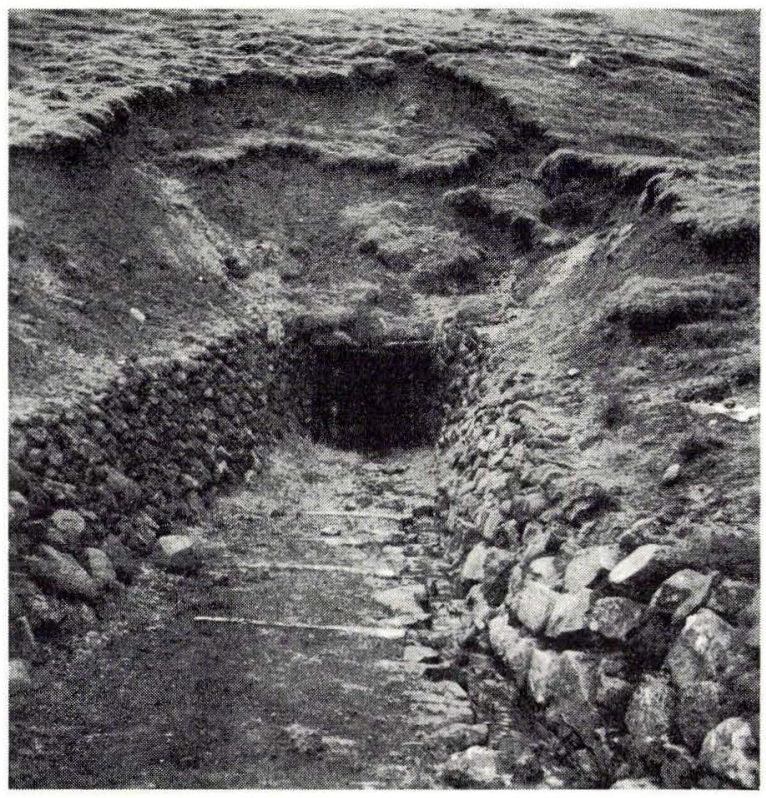

Fig. 37. G1. mineindgang, Rangibotnur.

Kolahol i Rangabotni.

Old mine entrance, Rangibotnur.

På nordsiden af den intruderede basalt ses kun lidt til den kulførende serie, men på sydsiden fremkom ved rengravning profil 28.

Profilerne 29, 30, 31 stammer fra en gammel, kun $15 \mathrm{~m}$ lang minegang med et par ganske korte sidegange på nordøstsiden af Oyrnafjall. Lagene er stærkt varierede med hensyn til mægtighed, de er dislocerede, bugtede og undertiden trykket stærkt sammen af intruderet basalt, som træder frem i taget inde i minen og ovenover mineindgangen.

I profil 32 på nordøstsiden af Mót er mægtigheden af den kulførende serie kun ca. $3 \mathrm{~m}$. Den liggende basalt er på dette sted bulet og gråligforvitret i overfladen, bundler mangler. Rannin indeholder $10 \mathrm{~cm}$ kul. Over tagleret ligger en $50 \mathrm{~cm}$ tyk konglomeratisk, fluviatil aflejring. Ved en prøvegravning på $\emptyset$ stsiden af Mót længere inde i Hvammabotnur fandtes ingen kul, kun ler. Serien havde også her kun ringe mægtighed.

Profilerne 33, 34, 35, 36 er opmålt inde i en produktiv mine i Rangibotnur. De viser ikke seriens samlede mægtighed, idet de kun når op til mineloftshøjde. (Fig. 37, 38). 


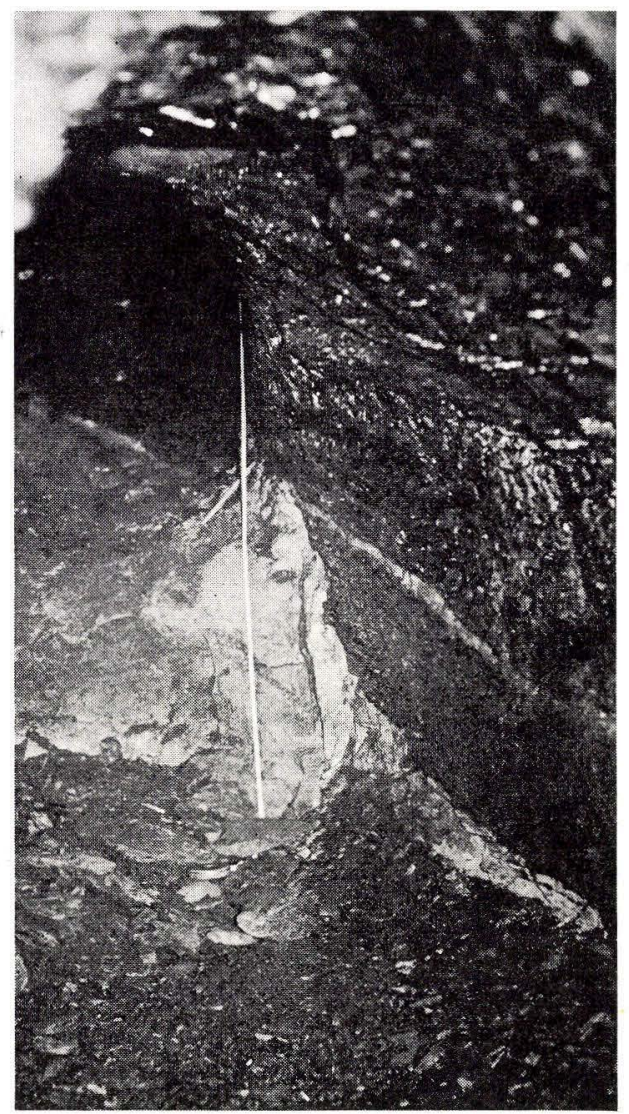

Fig. 38. En minegang i Rangibotnur. Kolahol í Rangabotni. A mine gallery in Rangibotnur.

I profil 33 ses omtrent midt $\mathrm{i}$ bundleret en trækullinse på $7 \times$ $80 \mathrm{~cm}$. Trækul forekommer i det hele taget ret almindeligt under det nedre kulbånd i dette område. I profil 34 er det nedre kulbånd adskilt i midten af et tyndt lerbånd. Dette forekommer undertiden også andre steder.

Som tidligere nævnt er den liggende basalts overflade ofte ujævn og bulet (fig. 31, 32, 36, 39). Profil 36 er opmålt på midten af en sådan 16,5 m lang bule (banke).

Profilerne 37, 38, 39 er opmålt inde i en nu nedlagt kulmine sydøst for Botnsskarð (Gudmunds mine). Ca. $60 \mathrm{~m} \emptyset$ st for denne 


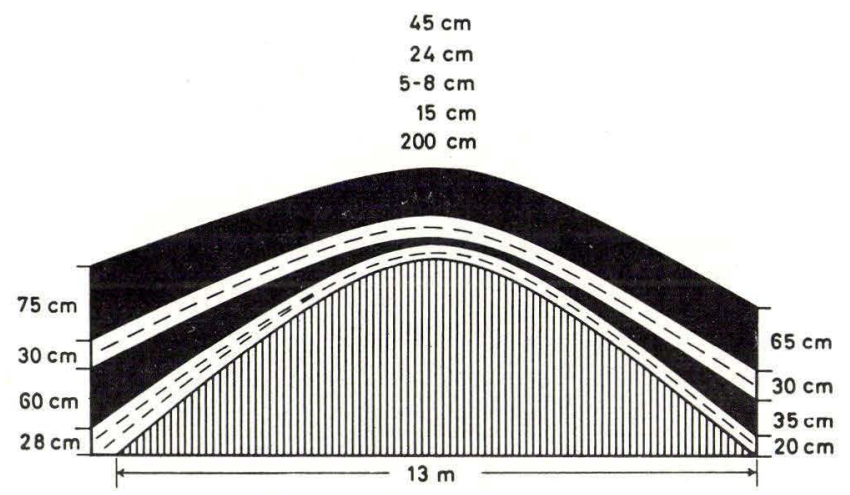

Fig. 39. En bule i den liggende basalts overflade i Rangibotnur i nærheden af profil 36.

Banki î Rangabotni narindis skurði 36.

Bulge in the surface of the underlying basalt in Rangibotnur near profile 36.

31.

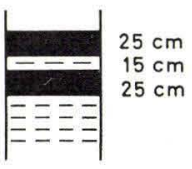

32.

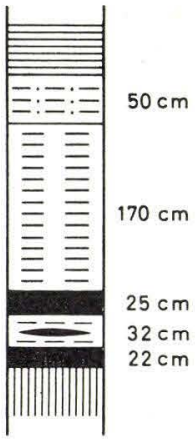

33.

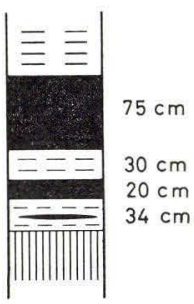

34.

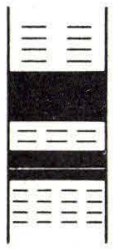

$30 \mathrm{~cm}$

$30 \mathrm{~cm}$ $30 \mathrm{~cm}$

35.

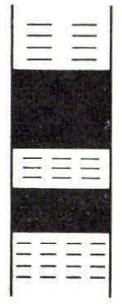

36.

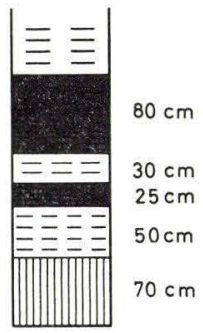

37.

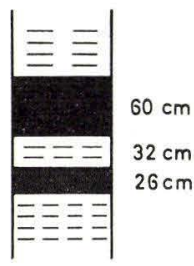

38.

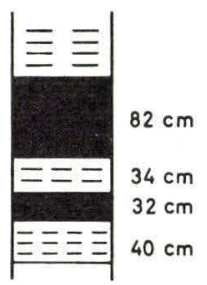

39.

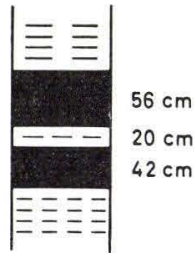


mine ses en omtrent NV-S $\varnothing$ forløbende forkastning med en sænkning af vestsiden på ca. $10 \mathrm{~m}$. Inde i kulminen danner forkastningen en flexur i de фstlige sidegange. Ovenover, i den mellemste basaltserie, ses kun et svagt lineament, men ingen forkastning. Forkastningen kan følges mod sydøst; фst for Fámjinsminerne er sænkningen mod vest $11 \mathrm{~m}$; i nordvestlig retning aftager den, ved Hvalbiareið er den således kun ca. $1 \mathrm{~m}$.

4. Kolheyggjur-Hovstúgva. Dette kulfelt, der ligger mellem bygderne Øravík og Hov, indtager kun et areal på $0,24 \mathrm{~km}^{2}$. Mod vest, i Kolheyggjur, er den kulførende series nedre grænse beliggende ca. $400 \mathrm{~m}$ o. h. og mod $\varnothing$ st, i Hovstúgva, ca. $310 \mathrm{~m} \mathrm{o.} \mathrm{h.}$ Ved den vestlige ende af Kolheyggjur, hvor der fors $\varnothing$ gsvis er blevet gravet efter kul, er den kulførende serie delvis blottet langs en strækning på ca. $70 \mathrm{~m}$. Profilerne 40 og 41 er opmålt her med 6 $\mathrm{m}$ mellemrum. Medens profil 41, det sydlige profil, viser den almindelige lagdeling, er profil 40, det nordlige profil, atypisk, idet der kun findes ét kulbånd (det nederste) og umiddelbart derover tagler isprængt kul. Seriens samlede mægtighed varierer fra 3 til $4 \mathrm{~m}$.

Ved den $\varnothing$ stlige side af Hovstúgva blottedes ved prøvegravning et 4-5 m tykt, brunligt, undertiden lysere gråligt lerlag. I den nederste del af dette lerlag fandtes tynde, 1-5 cm tykke, kulstriber.

Kullene er i hvert fald delvis allochtone kul, idet den trævegetation, som har været udgangsmateriale for kuldannelsen, ikke stammer fra en bevoksning på selve stedet, men fra trærester, som er blevet tilført fra omliggende egne. Dette materiale er blevet aflejret i et bassin på en gammel stærkt forvitret og nederoderet overflade, hvilket bl. a. fremgår af, at det underlag, hvorpå kullene hviler, er stærkt kuperet, og at kullagene varierer en del i tykkelse. De grovkornede konglomerater med indlejrede stamme- og grenstykker på begge sider af Hvalbiareið tyder muligvis på tilstedeværelsen af et indl $\varnothing \mathrm{b}$ her.

Alment kan siges, at kultykkelsen er størst mod sydvest, og at den aftager såvel i nordlig som i $\varnothing$ stlig retning.

I hele det vestlige kulområde er den kulførende serie gennemgående uforstyrret, der findes kun få gange og forkastninger her, bortset fra den tidligere nævnte NV-S $\varnothing$ forløbende forkastning i Gudmunds mine; almindeligvis er forkastningerne så små, at de sjældent volder større ulemper ved kulbrydningen. I det $\emptyset$ stlige om- 

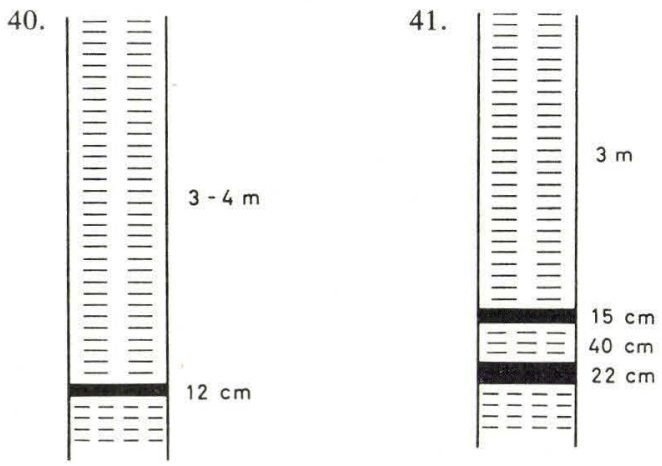

råde er lagene derimod som omtalt, stærkt forstyrrede, dislocerede og delvis destruerede af eksplosiv udbrudsvirksomhed og senere intrusion.

Såvel i den vestlige fjeldvæg som i kulminerne på østsiden forekommer der forkullede stamme- og grenstykker, mest udbredt mellem bundleret og det nedre kulbånd, men også til stede højere oppe i profilet. De ses således undertiden i tagleret og ofte som foran nævnt i de fluviatile konglomerater, der stedvis, f. eks. ved Hvalbiareið, overlejres af eller træder i stedet for dette. Ligeledes blev der under profil 8, Suðuri undir Hæli, omtalt en forkullet trærod på grænsen mellem tagleret og den hængende basalt. Lignende rodfragmenter er også blevet fremdraget fra kulminerne. Desværre har en nærmere bestemmelse af disse stamme-, gren- og rodfragmenter hidtil ikke været mulig. Bladaftryk synes at være yderst sjældent forekommende. (Fig. 40).

Medens makrofossilmaterialet således ikke har kunnet danne noget grundlag for en aldersbestemmelse af kullagene, synes mikrofossilerne (spore- og pollenmateriale) at give en mulighed for at anse alderen for Eocæn (LAUFELD 1965).

De færøske kul ligger i grænseområdet mellem brunkul og bituminøse kul. Med hensyn til udseende og kvalitet skelner vi mellem to typer: glanskul (vitrit) og matkul (durit). Glanskullene er glinsende, hårde med muslet brud, meget rene og ret modstandsdygtige mod vejrets indflydelse. De findes sædvanligvis som linser eller »nyrer (deraf det færøske navn »nýrakol«). Matkullene er ofte stribede (vekslende lag af vitrit og durit), de er ikke så rene som glanskullene, de er skøre, og de smuldrer let, når de henligger i luften. Det er vanskeligt at udtrykke mængdeforholdet mel- 

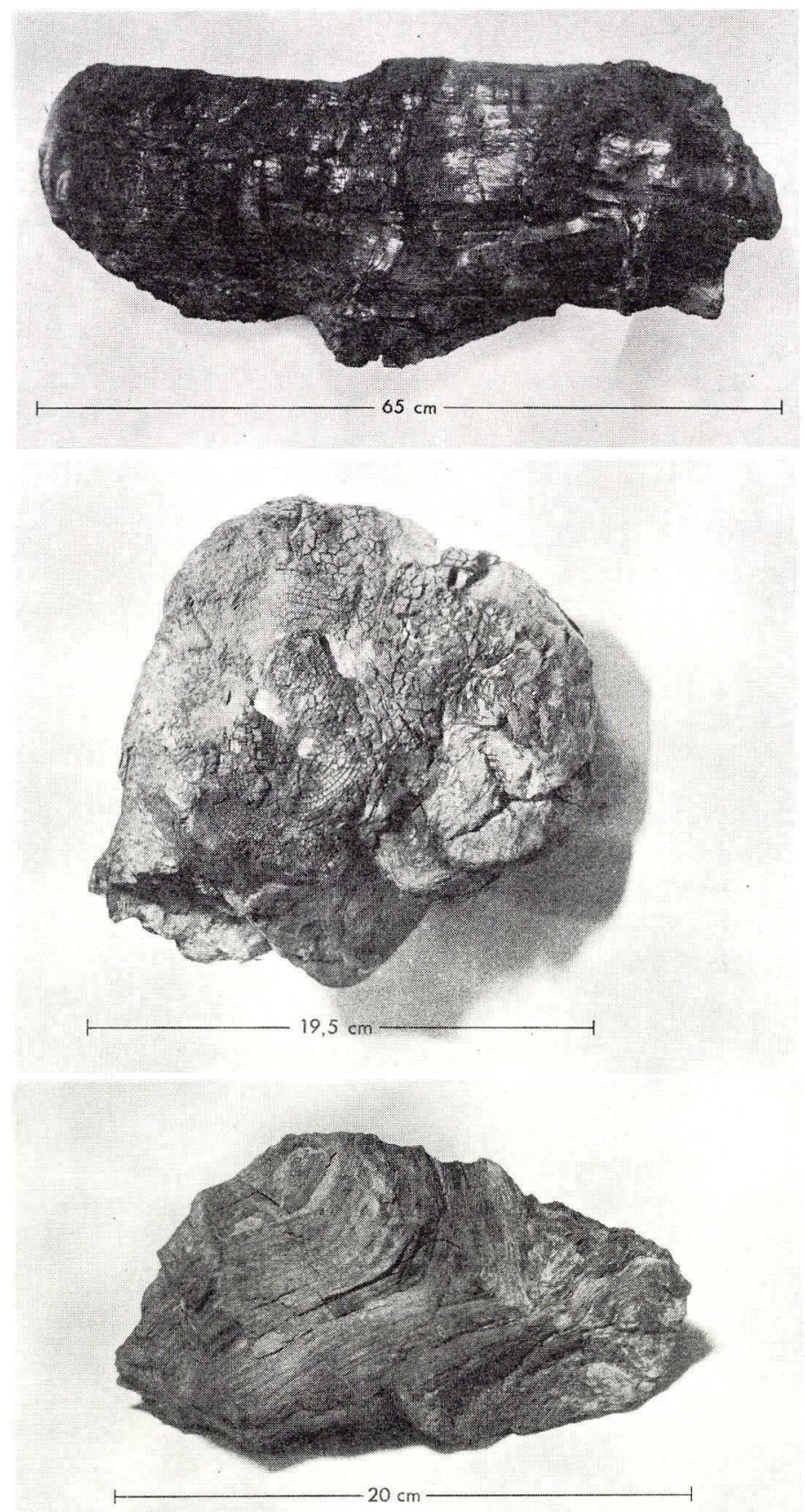

Fig. 40. Stammestykke og rodfragmenter. Kolađur viðabulur og klótupetti. 
lem de to kultyper blot med nogenlunde sandsynlighed, men man kan i hvert fald sige, at glanskullene forekommer i langt mindre mængde end matkullene. Glanskullene forekommer oftest i det фvre kulbånd; kullene i det nedre kulbånd er for det meste matte, stribede kul. De kul, der undertiden, særlig i det sydlige kulfelt, forekommer i rannin (det lerlag, der adskiller nederste og $\varnothing$ verste kulbånd) er oftest glanskul. Den effektive brændværdi ligger for glanskullene omkring $6.000 \mathrm{Kcal}$. og for matkullene almindeligvis 4-5.000 Kcal. For glanskullenes vedkommende ligger askeprocenten lavt, under $5 \%$, medens den for matkullenes vedkommende ligger betydeligt højere, ofte henimod $20 \%$ og undertiden endnu højere.

\begin{tabular}{|c|c|c|c|c|c|c|c|c|c|}
\hline \multirow[b]{2}{*}{ Kulfelt } & \multirow[b]{2}{*}{ Lokalitet } & \multicolumn{2}{|c|}{$\begin{array}{l}\text { Effektiv bræendværdi } \\
\text { Kcal/kg }\end{array}$} & \multicolumn{2}{|c|}{ Aske \% } & \multicolumn{2}{|c|}{ Svovl \% } & \multicolumn{2}{|c|}{ Fugtighed \% } \\
\hline & & $\begin{array}{c}\text { Glans- } \\
\text { kul }\end{array}$ & $\begin{array}{l}\text { Mat- } \\
\text { kul }\end{array}$ & $\begin{array}{c}\text { Glans- } \\
\text { kul }\end{array}$ & $\begin{array}{l}\text { Mat- } \\
\text { kul }\end{array}$ & $\begin{array}{c}\text { Glans- } \\
\text { kul }\end{array}$ & $\begin{array}{l}\text { Mat- } \\
\text { kul }\end{array}$ & $\begin{array}{c}\text { Glans- } \\
\text { kul }\end{array}$ & $\begin{array}{c}\text { Mat- } \\
\text { kul }\end{array}$ \\
\hline 1. Sydlige & Rangibotnur & 5.886 & & 2,77 & & 0,74 & & 12,50 & \\
\hline 2. & - & & 4.025 & & 29,50 & & 1,10 & & 12,00 \\
\hline 3. & - & 5.763 & & 3,36 & & 0,78 & & 11,60 & \\
\hline 4. & - & & 3.152 & & 42,70 & & 0,80 & & 10,00 \\
\hline 5. Nordlige & Prestfjall & 6.125 & & 1,12 & & 0,54 & & 11,30 & \\
\hline- & - & & 5.086 & & 16,20 & & 1,24 & & 10,00 \\
\hline
\end{tabular}

Kulreserverne har til forskellige tider og i takt med den voksende og faldende interesse for en $\varnothing$ konomisk udnyttelse af kulforekomsterne været underkastet skiftende vurderinger. Således hos LANDT (1800), Henchel (1778), Kabell (1851),* Johnstrup (1873), Stokes (1874), Helland (1880), Ussing (1902), Bergh (1905), Les Gisements de Houille de Suderö (1908), NielSen (1933), Humlum (1943) og Marstrander (1950). Disse vurderinger svinger imidlertid fra ganske realitetsbetonede tal til ren og skær $\varnothing$ nsketænkning. En vurdering på grundlag af en kartering af den kulførende serie på Suðuroy i årene 1952-54 samt en kritisk gennemgang af tidligere opgivelser findes hos RASMUSSEN $(1958,1959)$.

På grundlag af de i årene 1952-54 afgrænsede kularealer skulle den tilstedeværende brydeværdige kulmængde for det samlede vestlige område være nedenstående:**

\footnotetext{
* Beretning til Indenrigsministeriet af 3. januar 1851 med henvisning til professor Forchhammer 26. maj 1840 .

** Gennemsnitstykkelsen er for de fire kulfelter sat til: Grímsfjall $19 \mathrm{~cm}$, nordlige kulfelt $72 \mathrm{~cm}$, sydlige kulfelt $79 \mathrm{~cm}$ og Kolheyggjur-Hovstúgva $25 \mathrm{~cm}$. Tallene bygger på henholdsvis 4, 20, 15 og 3 opmålte og til formålet udvalgte profiler. Vægtfylden 1,35 er regnet som gennemsnit af 10 bestemmelser.
} 
1. Grímsfjall

$\left.\begin{array}{lc}\text { areal } & 1,36 \mathrm{~km}^{2} \\ \text { vf. } & 1,35 \\ \text { tykkelse } & 19 \mathrm{~cm}\end{array}\right\}$

$348.840 \mathrm{t}$

2. Nordlige kulfelt

$\left.\begin{array}{lc}\text { areal } & 11,00 \mathrm{~km}^{2} \\ \text { vf. } & 1,35 \\ \text { tykkelse } & 72 \mathrm{~cm}\end{array}\right\}$

$10.692 .000 \mathrm{t}$

3. Sydlige kulfelt

areal

vf.

tykkelse

$2,60 \mathrm{~km}^{2}$

1,35

$79 \mathrm{~cm}$

$2.772 .900 \mathrm{t}$

4. Kolheyggjur-Hovstúgva

$\begin{array}{ll}\text { areal } & 0,24 \mathrm{~km}^{2} \\ \text { vf. } & 1,35 \\ \text { tykkelse } & 25 \mathrm{~cm}\end{array}$

$81.000 t$

$13.894 .740 \mathrm{t}$

Af disse ca. 14 mill. $\mathrm{t}$ må ca. 2 mill. $\mathrm{t}$ anses for allerede at være brudt eller indelukket af forladte og sammenstyrtede miner, så fremtidig brydning ikke er mulig. Tilbage bliver ca. 12 mill. $t$, der må anses for at udgøre den totale brydeværdige kulmængde.

De to små områder Grímsfjall og Kolheyggjur vil næppe nogensinde få praktisk betydning, herved reduceres reserven med ca. $1 / 2$ mill. t. Desuden må det påpeges, at såvel tidligere som nyere erfaringer viser, at brydningsforholdene i Oyrnafjallsområdet på grund af lejringsforholdene må betegnes som ugunstige, og at der under selve brydningen må regnes med et vist tab af den samlede mængde.

For det фstlige område kan af tidligere nævnte grunde ingen egentlig beregning af kulmængden foretages, og det er derfor ikke forsvarligt at inddrage dette område $\mathrm{i}$ en vurdering af brydeværdige kul. Arealet er på 7,74 km², kullenes vægtfylde 1,35 og hvis gennemsnitstykkelsen anslås til $40 \mathrm{~cm}$ eller noget mindre, skulle reserven tilnærmelsesvis være henimod 5 mill. $t$, men en brydning her vil som nævnt møde helt uregelmæssige lagstillinger, der vil påf $\varnothing$ re arbejdet meget store omkostninger.

Ved en eventuel kommende kulbrydning på Suðuroy bør herefter ikke regnes med en større kulreserve end 10-12 mill. t.

Når man ofte finder så stor forskel mellem tidligere vurderinger af kulreserverne på Sưuroy og de resultater, der nu er fremskaffet, så skyldes dette: 1. at kularealerne ved mange tidligere vurderinger er regnet for store, idet man ved den perifere afgrænsning af disse har medtaget nogle af de pletvis forekommende kulf $\varnothing$ rende dannelser, der tilhører et lavere niveau, 2. at gennemsnitstykkelsen 
ofte er blevet anslået for højt, 3. at man ikke har været på det rene med og derfor ikke har taget tilstrækkeligt hensyn til, at lagene tynder stærkt ud mod nord og mod $\varnothing$ st og derfor har en betydelig lavere gennemsnitstykkelse i det nordøstlige område, 4. at man ved vurderingen af kulreserverne ofte har regnet med flere brydeværdige kullag, end der findes.

\section{Tindhólmur}

Kullene på Tindhólmur danner ikke noget sammenhængende lag. De forekommer ganske spredt som tynde striber, linser eller nyrer. Serien er stærkt disloceret og i det hele taget vanskelig at få rede på.

\section{Vágar}

På Vágar indtager den kulførende serie den vestligste del af фen vest for linjen Álkuklettur - $\emptyset$ st for Víkar, hvor den når havniveau. Dens højeste beliggenhed finder vi ved Barđið (syd for Gilið á Dýpinum) $278 \mathrm{~m} \mathrm{o}$. h. Det eneste sted, hvor kullene har nogen nævneværdig mægtighed, er i Hellisgjógv, hvor den samlede kultykkelse er ca. $90 \mathrm{~cm}$, dog indbefattet flere gennemgående lerbånd, således at der ikke findes noget rent kullag på mere end ca. $10 \mathrm{~cm}$. Lyst bundler kan stedvis skimtes. Kullene tynder betydeligt ud mod $\emptyset$ st og forekommer længere $\emptyset$ stpå oftest kun helt sporadisk. Set ind mod Hellisgjógv er fjeldvægsprofilet opbygget således nedefra og opad: 1. basaltbænke af ret stor mægtighed med slaggezoner og tuf (nederste basaltserie), 2. lersedimentserie (kulførende serie) og 3 . tynde lavastr $\varnothing$ mme med por $\varnothing$ se mellemzoner (mellemste basaltserie), et profil, der er fuldstændig identisk med fjeldvægsprofilet på nordvestsiden af Suðuroy. (Fig. 41, 42).

Mellem Hellisgjógv og Barðið synes den kulførende serie at være uforstyrret og at have et nogenlunde regelmæssigt forløb. Langs strækningen Barðið (syd for Gilið á Dýpinum) til lidt syd for Streymnes ses stedvis ganske ubetydelige kulforekomster. Hele serien er på denne strækning, hvor den overlejres af tuf-agglomerater, ligesom sydligere, i Bíggjarurð syd for bygden Gásadalur, disloceret med unormale lagstillinger (se s. 182).

På strækningen Hellisgjógv-Víkar, på nordsiden af фen, er den kulførende serie kun sparsomt blottet. Vest for Hjallabølsflesjar ligger dens nedre grænse ca. $220 \mathrm{~m} \mathrm{o}$. h. Ved denne lokalitet indgår der et fluviatilt konglomerat på 2-3 m mægtighed i serien. 


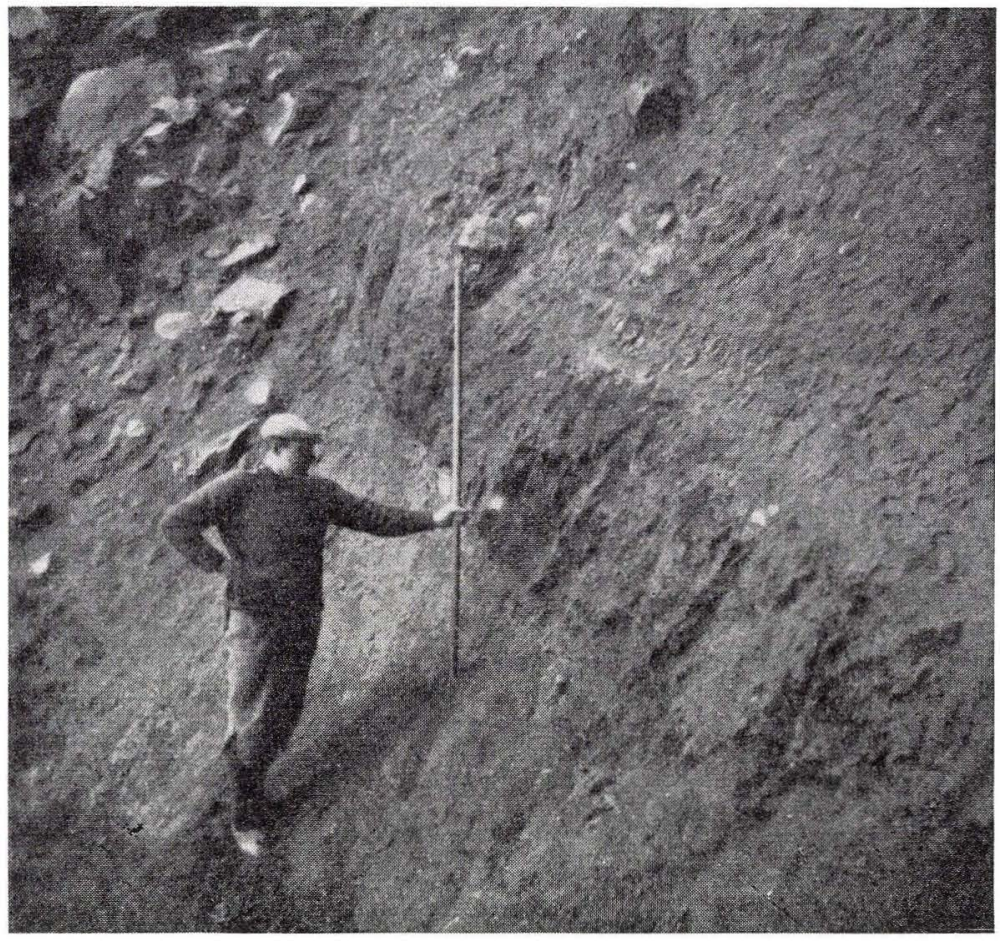

Fig. 41. Den kulførende serie ved Hellisgjógv, Vágar.

Kolalindin í Hellisgjógv í Vágum.

The coal-bearing horizon at Hellisgjógv, Vágar.

\begin{tabular}{|c|c|c|c|c|c|c|c|c|c|}
\hline \multirow[b]{2}{*}{ Kulfelt } & \multirow[b]{2}{*}{ Lokalitet } & \multicolumn{2}{|c|}{ Effektiv brændværd } & \multicolumn{2}{|c|}{ Aske \% } & \multicolumn{2}{|c|}{ Svovl \% } & \multicolumn{2}{|c|}{ Fugtighed \% } \\
\hline & & $\begin{array}{c}\text { Glans- } \\
\text { kul }\end{array}$ & $\begin{array}{c}\text { Mat- } \\
\mathrm{kul}\end{array}$ & $\begin{array}{c}\text { Glans- } \\
\text { kul }\end{array}$ & $\begin{array}{c}\text { Mat- } \\
\text { kul }\end{array}$ & $\begin{array}{c}\text { Glans- } \\
\text { kul }\end{array}$ & $\begin{array}{l}\text { Mat- } \\
\text { kul }\end{array}$ & $\begin{array}{c}\text { Glans- } \\
\text { kul }\end{array}$ & $\begin{array}{c}\text { Mat- } \\
\text { kul }\end{array}$ \\
\hline Vágar & Hellisgjógv & 6.268 & & 3,00 & & & & 8,10 & \\
\hline - & v. Rættargarð & & 4.377 & & 8,70 & & & & 13,50 \\
\hline
\end{tabular}

Hvor langt tilbage i tiden, man har haft kendskab til de færøske kulforekomster, er det lidt vanskeligt at danne sig nogen begrundet mening om; men det må dog anses for sandsynligt, at kullene, allerede århundreder tilbage i tiden, er blevet bemærket af de mænd, der havde deres daglige gang i de vestvendte stejle og nøgne fjelde, hvor kullene går i dagen.

Den ældste omtale af de færøske kulforekomster finder vi i en skrivelse dateret 26. april 1626* til fogden på Færøerne med ordre

* N. T. s. 540 (Rigsarkivet). 


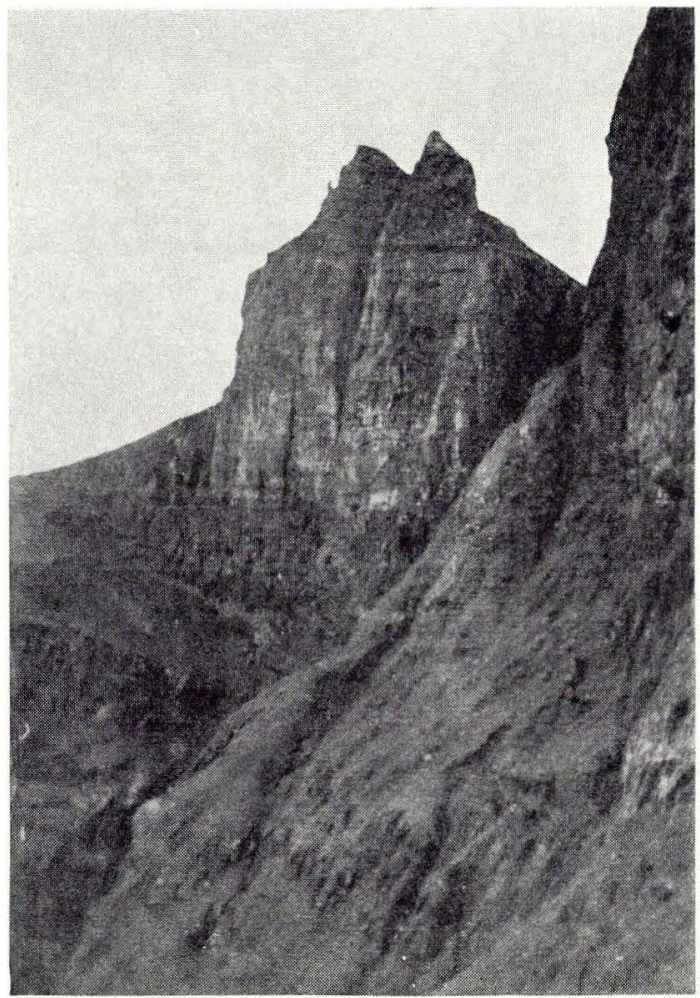

Fig. 42. Nederste basaltserie - kulførende serie - mellemste basaltserie ved Hellisgjógv, Vágar.

Niðaru basaltfláirnar - kolalindin - miðfláirnar. Við Hellisgjógv i Vágum. The lower basalt series - the coal-bearing horizon - the middle basalt series at Hellisgjógv, Vágar.

til at undersøge, hvor på Færøerne der findes kul, samt i en indberetning fra samme år, hvori der udtales, at man har fundet kul på to steder i et fjeld, der benævnes Suudfjeld på Suðuroy.

I litteraturen omtales kullene første gang hos LuCAS Debes (Færoæ et Færoa Reserata 1673); senere nævnes i en kommissionsbetænkning af 1709 og 1710 angående Færøernes tilstand ved overtagelse af enehandelen på Færøerne, at man har fundet kul på tre forskellige steder; disse er alle afmærkede på det af KOMMAND $\emptyset \mathrm{R}$ JUUL i samme anledning udfærdigede kort over Færøerne.

Det fremgår tydeligt heraf, at kendskabet til kullene i hvert fald går tilbage til begyndelsen af det 17 . århundrede; men der fore- 
ligger ikke noget om, at man har gjort noget forsøg på at udnytte dem.

Det første forslag hertil blev, såvidt vides, stillet i 1723 af ADMIRAL RABEN, stiftsbefalingsmand over Island og Færøerne; men der kom dog intet ud af hans forslag, idet de to kularbejdere fra Lüttich, som man havde indforskrevet til formålet, nægtede at rejse videre efter at være kommet til København i 1725 .

I 1733 blev der anlagt en mine i Oyrnafjall syd for Trongisvágur af en englænder, som var sendt derop af et interessentskab, der var dannet med det formål at foretage kulbrydning på Suðuroy. Men det blev ved det ene fors $\varnothing \mathrm{g}$; man opgav allerede året efter.

I 1756 blev der givet befaling til landfogden om at gøre indberetning om kullenes kvalitet og om muligheden for at nedsende dem som ballast med den kongelige handels skibe; men heller ikke denne gang førte det til noget resultat.

I 1760-erne blev der if $\varnothing$ lge Svabo* fors $\varnothing$ gsvis gravet efter kul (i Prestfjall i Hvalba) af en proberer Wølner og schagtstiger Torgersen.

Det er først i 1777, at der bliver iværksat mere indgående unders $\varnothing$ gelser af Fær $\varnothing$-kullene. Dette år blev bjergværksassessor HENCHEL sendt til Færøerne, og i årene 1777-1779 foretog han en ret omfattende søgen efter kul. If $\emptyset$ lge hans første rapport af 17. januar 1778 fandtes der kul på Suðuroy, Vágar og Mykines. Han nævner en halv snes lokaliteter, hvor han har iagttaget kul på Suðuroy, men siger, at de ikke er brydeværdige med undtagelse af kullene i Oyrnafjall syd for Trongisvágur, hvor han angiver mægtigheden til $13 / 4$ alen kul og ler. Da Henchel i 1778 atter tog til Fær$\emptyset$ erne medbragte han to kongsbergske bjergværksarbejdere, og han forblev nu deroppe til 1779. If $\varnothing l g e$ hans anden rapport af 11. april 1780 blev der arbejdet med to hoveddrifter, én på nordvestsiden af Oyrnafjall og én nord for Fámjin. Samtidig med kulbrydningen foretog Henchel søgen efter flere kul, og der blev fors $\emptyset$ gsvis anlagt en drift på nordsiden af Trongisvágurdalen. Brydningen voldte Henchel mange kvaler; af fagfolk havde han kun de to kongsbergske minearbejdere, resten af mandskabet var folk fra stedet uden indsigt $\mathrm{i}$ den slags arbejde. Fra minerne blev kullene transporteret på hesteryg til stranden, derfra med båd til Tórshavn og videre med skib til København. Henchels beskrivelse af forholdene i minerne

\footnotetext{
* Jens Chr. Svabo: Indberetninger 1781-1782 s. 859.
} 
og de vanskeligheder, han her støder på, svarer fuldkommen til senere erfaringer fra dette område. Da Henchel rejste til København i 1779, efterlod han de to kongsbergske arbejdere. Disse fortsatte brydningen på nordvestsiden af Oyrnafjall, men da de ifølge deres beretning stødte på adskillige vanskeligheder både her og andre steder syd for Trongisvágurdalen, forlod de området og påbegyndte en brydning i Hvalbadalen. Trods Henchels protest imod denne forandring i planen besluttede bjergværksdirektoratet, at brydningen i Prestfjall skulle fortsætte. Kulbrydningen fortsatte derefter i dalen syd for bygden Hvalba. Da hele driften imidlertid syntes at være temmelig planløs, både hvad brydning og transport angik, sendte man i 1789 bjergkandidat KRUUSE derop for at gøre forslag til en mere rationel driftsmåde. Der skete dog ikke større forandringer, og i 1798 overdrog man derfor brydningen til velfærdsselskabet, men efter nogle fors $\varnothing \mathrm{g}$ blev hele foretagendet opgivet i 1804 .

I de følgende år, fra 1804-1827, blev der kun brudt kul privat til husholdningsbrug i Hvalba.

Fra statens side blev der gjort endnu et fors $\varnothing \mathrm{g}$ i årene 1827-1839. Kullene blev dels ført til Tórshavn og solgt på stedet og dels ført til København som ballast; men store mængder af kul blev liggende tilbage på Suðuroy og smuldrede hen; man opgav atter fors $\varnothing$ get, og minerne blev bortforpagtet til private.

Efter at kuldriften således definitivt var opgivet fra statens side, søgte The Peninsular Steam-Navigation Company i 1840 om retten til kulbrydning. Der blev i den anledning indhentet en mængde erklæringer fra bl. a. prof. J. G. ForchHAmmer (26. maj 1840) og senere fra Jap. Steenstrup (11. nov. 1844). Men da de betingelser, som selskabet $b \varnothing d$, udelukkende var til fordel for det selv, og de indhentede svar var stærkt modstridende, blev ansøgningen aldrig bevilget.

Der foreligger en indberetning af 3. januar 1851 fra overinspektør KABELL, der af indenrigsministeriet var anmodet om at afgive en udtalelse om, hvorledes kullene på Suðuroy eventuelt ville kunne lade sig udnytte, når den kgl. enehandel på Færøerne blev ophævet (det skete i 1856). I denne indberetning finder vi en oversigt over hele den ældre kulbrydning på Færøerne samt en vurdering af kullene og forslag til deres anvendelse. Kabell har imidlertid ikke unders $\emptyset \mathrm{gt}$ forholdene på stedet, og hans indberetning bygger på arkivalier. 
I 1872 blev opmærksomheden atter henledt på de færøske kulforekomster i anledning af de stigende kulpriser, og da der indkom andragender til regeringen om koncession til kulbrydning, blev professor JoHnStrup anmodet om at tage til Færøerne, idet man $\emptyset$ nskede nye oplysninger om kullenes mægtighed, udstrækning og lejringsforhold, inden man tog nogen endelig bestemmelse. Resultaterne af Johnstrups unders $\emptyset$ gelser med en indledende historisk oversigt findes dels i afhandlingen $» \mathrm{Om}$ Kullagene paa Færøerne 1873 og dels i en indberetning til regeringen af 30. november 1872.

Af kulundersøgelser på et geologisk grundlag forelå der på det tidspunkt, da de første koncessioner blev givet - i 1873 - kun Forchhammers og Johnstrups arbejder. I den følgende tid bliver der foretaget en lang række - dog for det meste fragmentariske unders $\emptyset$ gelser, dels af geologisk og dels og langt overvejende af kulteknisk art.

I 1879 bes $\varnothing$ gte den norske geolog Amund Helland og den skotske geolog James GeiKIE Færøerne sammen. Medens Geikies omtale af kullene er ret kortfattet, er disse mere indgående behandlet hos Helland, der forsøger en beregning af kulareal og kulmængde på grundlag af egne og tidligere undersøgelser.

I årene 1873-1880 blev der foretaget kulunders $\varnothing$ gelser på Fær$\varnothing$ erne bl. a. af $\mathrm{kgl}$. engelsk mineinspekt $\varnothing \mathrm{r}$ i Derbyshire, ARTH. H. Stokes (1873 og 1879), den svenske mineingeniør TH. NordSTR $\varnothing \mathrm{M}$ (1877) og af den svenske mineingeniør TH. Ihrmann. Medens Stokes har publiceret i hvert fald en del af sine resultater, og Th. Nordstrøm ligeledes, synes det som om Ihrmann ikke har offentliggjort sit materiale i nogen særskilt afhandling.

Der udkom i Paris i 1908 en samling rapporter, analyser, kort og skitser vedrørende kulforekomsterne på Suðuroy. Der refereres her bl. a. til Stokes, Nordstrøms og Ihrmanns profiler samt til udtalelser af forskellige personer om muligheden for en rentabel kul-lerdrift. Publikationen er meget stærkt sensationspræget og synes at være et fors $\emptyset \mathrm{g}$ på at vække interesse for financiering af et større kul-ler foretagende.

I oktober 1933 bes $\varnothing$ gte den dansk-engelske mineingeniør HARALD Nielsen Færøerne for ved selvsyn at danne sig et sk $\varnothing$ n over de færøske kulforekomster. Der foreligger fra hans hånd en artikel »Danmark og Kullene på Færøerne« (Tilskueren 1933) og en utrykt rapport »Rapport over Unders $\varnothing$ gelsen af Forekomsten af de færøske Kul« (1933). Denne rapport indeholder egne undersøgel- 
sesresultater samt en sammenstilling af foreliggende analyser og profiler, hovedsagelig fra ovennævnte franske beretning, og går ud på at undersøge muligheden for en rentabel kuldrift bl. a. ved omdannelse af kullene til benzin.

Samme år, 1933 og i 1934 foretog professor P. E. RaAschou kulundersøgelser på Suðuroy. Hans resultater blev publiceret i afhandlingen »Om Kulforekomsterne paa Færøerne (1937). Afhandlingen indeholder bl. a. en oversigt over tidligere undersøgelser samt koncessioner og rettigheder og en sammenligning mellem Ihrmanns, Nordstr $\emptyset \mathrm{ms}$, Stokes og Johnstrups profiler med egne opmålinger. Han påviser, at Nordstrøms og Stokes profiler i den franske rapport ikke er samstemmende med dem, de oprindeligt publicerede.

I 1944 bes $\varnothing$ gte den engelske minesagkyndige professor RiTson kulminerne i Rangibotnur (syd for Trongisvágur) efter anmodning fra lagtingets budgetudvalg. Man $\varnothing$ nskede i særdeleshed, at han skulle undersøge hele minespørgsmålet i Rangibotnur med henblik på den tilsyneladende fare for en sammenstyrtning af hovedminen på grund af en revne i fjeldet. Hans udtalelse herom og om kulproduktionen $\mathrm{i}$ almindelighed foreligger i en rapport » Report on the coal position in the Faeroe Islands «.

I 1950 stillede Færøernes lagting forslag om endnu en gang at få unders $\emptyset \mathrm{gt}$ mulighederne for en mere rationel kuldrift tilligemed en sagkyndig inspektion af minerne samt forslag til tekniske forbedringer. Ved henvendelse gennem den danske regering til The Economic Cooperation Administration i Washington fik man udpeget ingeniør H. MARSTRANDER, der i forvejen havde et indgående kendskab til sagen, til at udføre dette arbejde. I løbet af marts, april og maj måned 1950 inspicerede Marstrander minerne og foretog de n $\varnothing$ dvendige unders $\varnothing$ gelser på stedet. Hans rapport »Report on the coal position on the Faeroe Islands « indeholder resultaterne af hans unders $\varnothing$ gelser samt 2 detaillerede forslag til eventuel fremtidig drift.

Da spørgsmålet, om der fandtes eet eller flere brydeværdige kullag, syntes noget svævende, anbefalede Marstrander, at der blev foretaget mere indgående geologiske unders $\varnothing$ gelser af kulforekomsterne, og på det færøske landstyres initiativ blev disse spørgsmål derfor taget op af FøROYA JARDFR $\emptyset$ ĐISAVN samtidig med DANMARKS Geologiske Undersøgelses geologiske kartering af Suðuroy i årene 1952-1954.

Senere har bergingenjör J. Cleyndert, Höganäs, på det danske statsministeriums foranledning udarbejdet en rapport: Rapport be- 
träffande möjligheterna för en rationaliserad brytning av kol och lera på Suderö, Färöarna 1959-1960.

Tilstedeværelsen af kulførende dannelser på Vágar findes omtalt hos Henchel (1777), Rasmussen (1921) og hos Lindwall (1923), der tillige nævner kullene på Tindhólmur. ForchHAMMER (1824) omtaler ikke kullene på Vágar, men derimod kullene på Tindhólmur. Det er hos ældre forfattere almindeligt antaget, at kullene på Sư̋roy, Mykines, Tindhólmur og Vágar hører til samme geologiske niveau, dog mente Forchhammer, at kulforekomsterne på Tindhólmur var en lille lokal dannelse. RASMUSSEN (1951, 1951) har påvist, at de kulførende dannelser på Suouroy, Tindhólmur og Vágar tilhører én og samme horisont, medens kullene på Mykines ligger på et lavere geologisk niveau. 


\section{Tuf-agglomeratzonen}

Efter at den nederste basaltserie var færdigdannet og efter den påfølgende længere hvileperiode med aflejring af den kulførende series sedimenter, begyndte den vulkanske aktivitet påny med en højeksplosiv indledningsfase, hvori der så godt som udelukkende produceredes løse udbrudsprodukter: vulkanske bomber, lapilli og aske. Disse aflejringer af løse udbrudsprodukter, der ligger mellem den kulf $\varnothing$ rende serie og den mellemste basaltseries nederste lavaer, betegner vi som tuf-agglomeratzonen.

I eksplosionsfasen er den kulførende serie blevet sprængt igennem og udbrudsprodukterne aflejret ovenpå den kulførende serie langs med udbrudsstederne. Aflejringen af et så uensartet materiale som det, der fremkommer ved et eksplosivt udbrud, vil naturligt få karakter af en sammenhobning, og mægtigheden vil følgelig variere meget fra-sted til sted. Da tuf-agglomeraterne desuden hyppigt er underlejret og gennemtrængt af intrusive basalter (se s. 294) vil det - hvis de ikke forefindes fuldstændig blotlagte - være meget vanskeligt at bedømme deres sande mægtighed, selvom både den nedre og den $\varnothing$ vre grænse kan erkendes.

Som følge af den nordøstlige laghældning på Suðuroy og den sydøstlige laghældning på Vágar skærer grænsen mellem den kulførende serie og den mellemste basaltserie havniveau allerede på den nordøstlige del af Suðuroy og den vestlige del af Vágar, tufagglomeratzonen vil derfor kun forekomme over havniveau vest for disse skæringslinjer. Tuf-agglomeratzonens aflejringer, der som nævnt må antages at dække over store udbrudsspalter og deres nærmeste omgivelser, indtager langstrakte, omtrent NV-S $\varnothing$ orienterede områder på nordsiden af Suđuroy langs Suðuroyarfjørour, på vestsiden af Vágar og på Tindhólmur langs Mykinesfjørður og Sørvágsfjørơur, en retning, der svarer til den dominerende NVS $\varnothing$ fjordretning (RASMUSSEN 1952, 1957, 1962).

Forekomsten af betydelige agglomerataflejringer på Suðuroy er tidligere iagttaget og forbigående omtalt hos FORCHHAMMER (1824), Geikie (1880), Helland (1880), BøgGild (1922) og WALKer og DAvidsson (1936), dog uden at være blevet sat i forbindelse med udbrudsspalter. 


\section{Suðuroy}

På den nordøstlige side af Suðuroy måler det område, indenfor hvilket tuf-agglomerater forekommer, ca. $10 \mathrm{~km}$ i længderetningen og ca. $2 \mathrm{~km}$ i bredden. Da tuf-agglomeraterne går under havniveau mod nord og $\varnothing$ st, er disse tal minimumstal. Tuf-agglomeraterne ses i og nær kysten på nordsiden af Hvalbiarfjørður fra det gamle landingssted ud til østsiden af Reyðibarmur, en strækning på ca. 1700 m, på sydsiden af Hvalbiarfjørður fra Flekksá østpå til Myrkagjógv og derefter mod syd ind i Lónin og Hvannhagi. Desuden kommer de frem i elvløb og kløfter på nordsiden af Trongisvágur fra Myllá (Bláfossur) til området vest for Ranndalsá ved Frođba.

Ved Reyðibarmur, der er en ca. $550 \mathrm{~m}$ lang, stærkt iøjnefaldende rødlig kystklint på nordsiden af Hvalbiarfjørður, dannes omtrent hele kystprofilet af tuf-agglomeratzonens løse udbrudsprodukter.

Mod vest begrænses klintprofilet af den her i stranden forekommende intruderede basalt. Denne danner termal kontakt med agglomeratet i kystklinten og sender store udløbere op i det. I agglomeratet, der almindeligvis er brunligt eller gråligt, ses bomber, lapilli samt bjergartsfragmenter. Blotningen af tuf-agglomerat når her op til ca. $30 \mathrm{~m}$ højde. (Fig. 43).

Omtrent midt i klintprofilet intruderer en basaltmasse, der i kysten er ca. $70 \mathrm{~m}$ bred, tuf-agglomeratzonen op til ca. $10 \mathrm{~m} \mathrm{~h} \varnothing \mathrm{jde}$, idet den forgrener sig i lange apofyser. Øst og vest for denne er tuf-agglomeraterne r $\varnothing \mathrm{de}$, ofte stærkt r $\varnothing \mathrm{de}$. Vest for den intruderede basaltmasse når tuf-agglomeratzonen op til ca. $50 \mathrm{~m}$ højde, hvorefter den endnu en halv snes $m$ højere opad ses at veksellejre med tynde basaltbænke, der tilhører mellemserien. (Fig. 44).

Den $\varnothing$ stlige del af klintprofilet i Reyðibarmur består af en aflejring af grovere og finere pyroklastisk materiale af grå til brunlig farve. Den overlejres af et tyndt, rødt tuflag og derefter af den mellemste basaltseries lavaer efter en nogenlunde jævnt forl $\emptyset$ bende linje, som med nordøstlig hældning skærer havniveau ved fossen $\emptyset$ st for Reyðibarmur.

Fra Reyðibarmur fortsætter tuf-agglomeratzonen indad mod vest, hvor den ligger over de intruderede basalter, der ses langs kysten. Der forekommer imidlertid kun sparsomme blotninger, og zonen synes at forsvinde omtrent over den gamle landingsplads.

Ved vandløbet vest for Reyðibarmur måles følgende profil: 


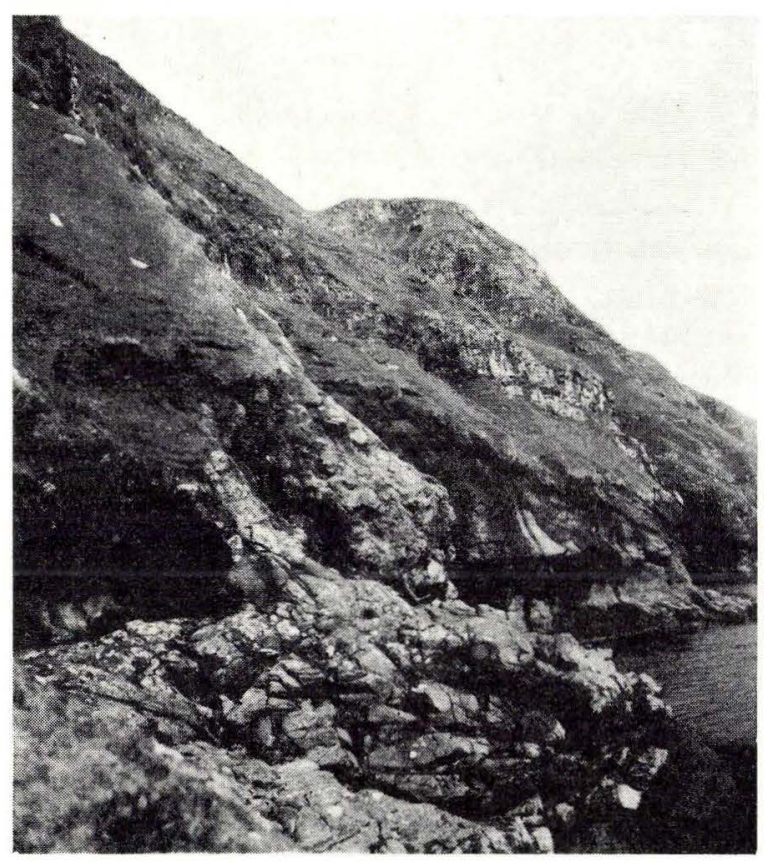

Fig. 43. Reyðibarmur (vestl. Del).

Reyðibarmur vestantil.

Western part of Reyðibarmur.

0-12 m intrusiv basalt, $12 \mathrm{~m}-30 \mathrm{~m}$ ras og grus, $30 \mathrm{~m}-70 \mathrm{~m}$ tuf-agglomerat, rødligt (de фverste ca. $10 \mathrm{~m}$ overgangszone med mellemlejret basalt), $70 \mathrm{~m}$ - lavaer fra den mellemste basaltserie.

Ved vandløbet vest for Hamranes optoges dette profil: 0 - ca. $35 \mathrm{~m}$ intrusiv basalt, ca. $35 \mathrm{~m}-55 \mathrm{~m}$ tuf-agglomerat, $55 \mathrm{~m}-$ den mellemste basaltseries lavaer.

På sydsiden af Hvalbiarfjørður ses tuf-agglomerater ved Flekksá fra ca. $100 \mathrm{~m}-140 \mathrm{~m} \mathrm{o}$. h. De er underlejret af intrusive basalter, hvorfra der går apofyser op i tuf-agglomeratzonen, som igen overlejres af den mellemste basaltserie (fig. 45).

Mellem Flekksá og Tjørnunes ses kun spredte blotninger af tufagglomeratzonen. Tjørnunes, der udelukkende består af intruderet basalt, er $\emptyset$ verst, ind mod fjeldvæggen, dækket af tuf-agglomerater. Ligeledes findes de både $\varnothing$ st og vest for Tjørnunes, medens de ikke ses over havniveau på en mindre strækning - ca. $300 \mathrm{~m}$ mellem Tjørnunes og Snæbjarnarhol. Her ser hele fjeldvæggen ud 


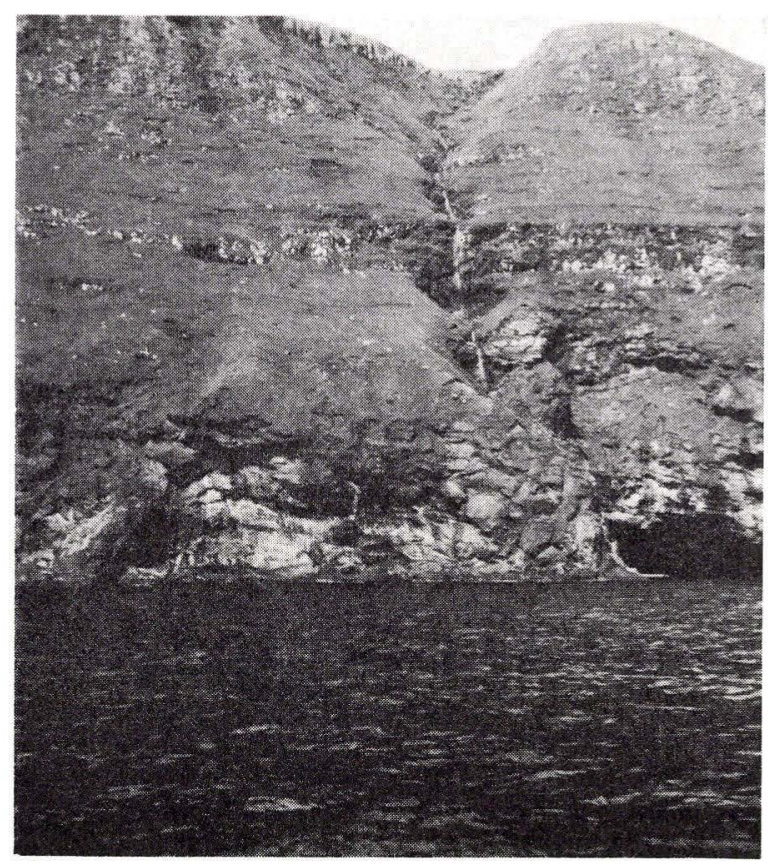

Fig. 44. Reyðibarmur (midtområdet). Reyðibarmur.

Central area of Reyðibarmur.

til at bestå af lavabænke tilh $\not$ rende den mellemste basaltserie. Videre фstpå, til Myrkagjógv, og sydpå til Lónin, er tuf-agglomeraterne nær kysten underlejret af intrusiv basalt. De overlejres af den mellemste basaltserie.

I Akraskor, nord for Lónin forekommer følgende profil i fjeldvæggen indenfor Hvannhólmur, beskrevet nedefra og opad: intruderet basalt med uregelmæssig søjlestruktur; tuf-agglomerat gennembrudt nedefra af intrusiv basalt; intruderet basalt med regelmæssige vertikale søjler og derefter igen tuf-agglomerat. På sydsiden af Akraskor afgrænses tuf-agglomeraterne, som ind mod uren er stærkt røde, mod nord af en bred intrusivmasse. Grænsen mellem tuf-agglomerat og mellemste basaltserie ligger umiddelbart syd for uren i ca. $60 \mathrm{~m}$ højde. I lighed med forholdene ved Reyðibarmur ses også ved Lónin en overgangszone med veksellejrende basalt (mellemste basaltserie) og tuf-agglomerat.

I Hvannhagi er tuf-agglomeraterne blottet i strandkanten ved 


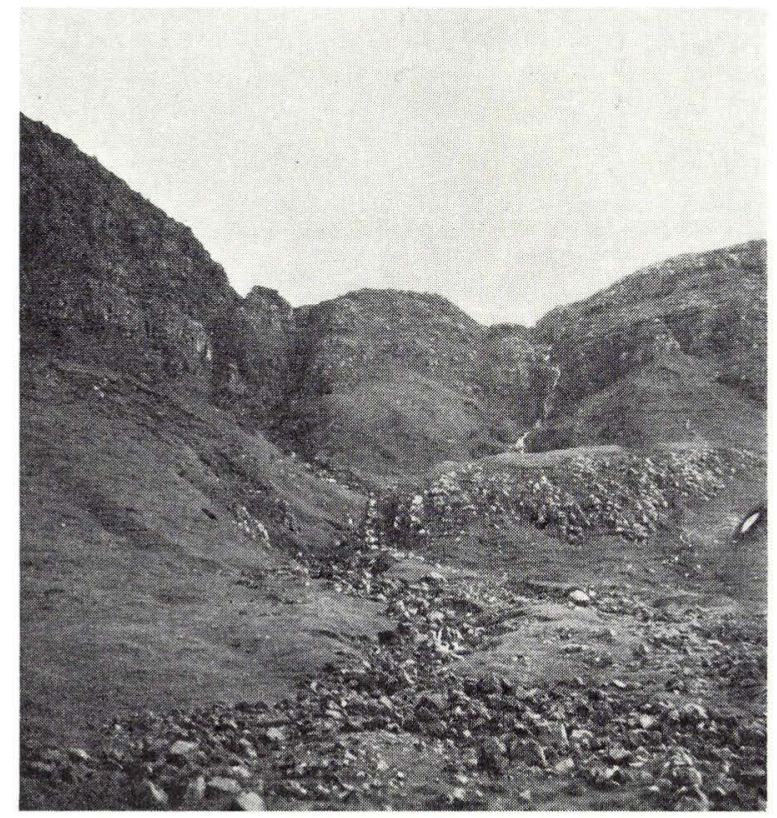

Fig. 45. Flekksá.

Stapin og ved Ribbingamúli. Det fladstrandede kystområde umiddelbart vest for Stapin består udelukkende af agglomerat og slagger langs en strækning på ca. $150 \mathrm{~m}$. Kystklinten inderst i den lille bugt sydvest for Stapin udg $\emptyset$ res af den nederste basaltseries $\emptyset$ verste bænk, der viser tiltagende opblanding med løse udbrudsprodukter henimod tuf-agglomeraterne i kystområdet vest for Stapin. Dette kunne også tyde på, at vi befinder os nær ved et udbrudssted.

Stedvise blotninger af grænsen mellem tuf-agglomeratzonen og den mellemste basaltserie forekommer langs hele fjeldvæggen fra Todnes, syd- og vestpå ind i hængedalen med den lille $s \varnothing$ og videre mod $\varnothing$ st til et par hundrede meter $\varnothing$ st for Frostgjógv. Endvidere findes hyppige grænseblotninger fra $\varnothing$ stsiden af Dysjarnar ud til Ribbingamúli. Ved Todnes (ved stejlvæggen ud mod nord) ligger denne grænse $110 \mathrm{~m}$ o. h., vest for Stapin $125 \mathrm{~m}$, øst for Gásagjógv $150 \mathrm{~m}$, ca. $200 \mathrm{~m}$ фst for Frostgjógv $150 \mathrm{~m}$, ved фstsiden af Dysjarnar (v. kote 110) 110 m, i Myrkagjógv 90 m og фstligst i Hvannhagi (ved overgangen til kysten ud mod Ribbingamúli) $85 \mathrm{~m} \mathrm{o.} \mathrm{h.}$ 


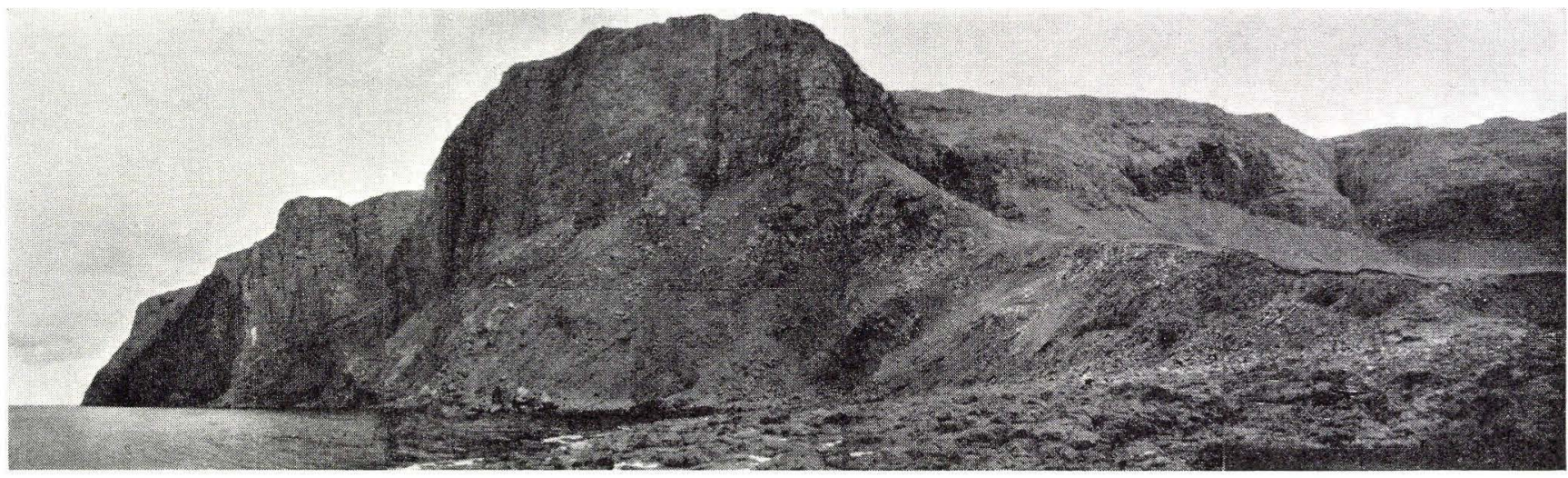

Fig. 46. Ribbingamúli og sydkysten af Hvannhagi. I forgrunden ses den nederste basaltserie, i midten af billedet intruderet basalt og tuf-agglomerat. Øverst mellemste basaltserie.

Ribbingamúli og suðurstrondin i Hvannhaga. Framman síggjast niðaru basaltfláirnar, miðskeiđis á myndini innskot og gosmyrja. Ovast miðfláirnar.

Ribbingamuli and the south coast of Hvannhagi. In the foreground the lower basalt series is visible, and in the centre, intrusive basalt and tuffagglomerate. At the top, the middle basalt series. 


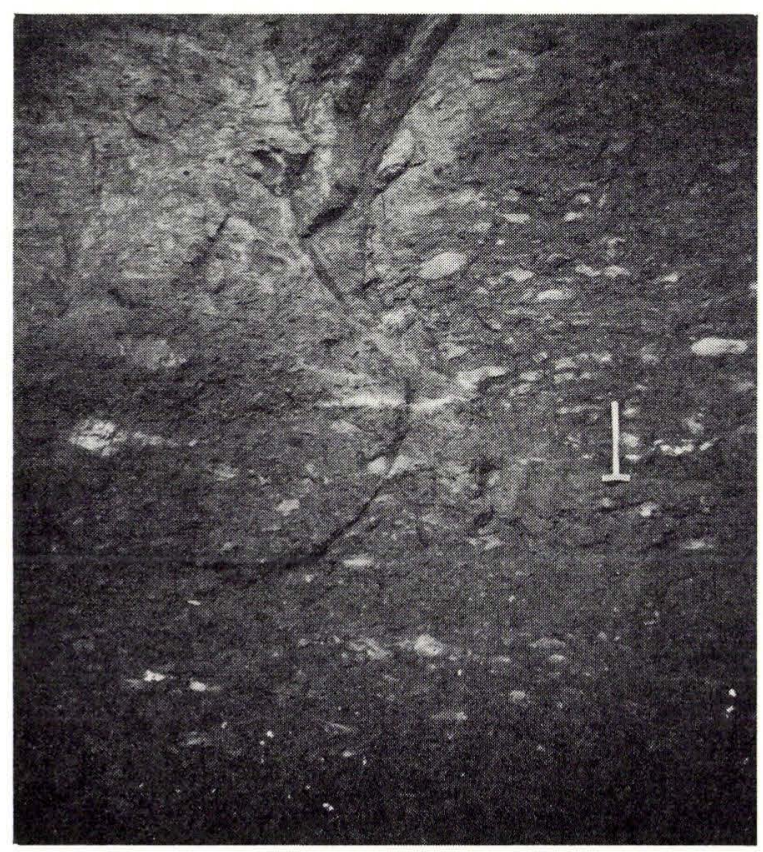

Fig. 47. Agglomeratparti ved Ribbingamúli. Gosmyrja, Ribbingamúli. Agglomerate body at Ribbingamúli.

Grænsen nedad mellem tuf-agglomerat og intrusiv basalt ses i Myrkagjógv, hvor den ligger i $70 \mathrm{~m}$ højde og i den $\varnothing$ stligste elv i Hvannhagi, hvor den ligger i $60 \mathrm{~m}$ højde. Ligeledes kan den erkendes østligst i Hvannhagi (ved overgangen til kysten ud mod Ribbingamúli). Selve tuf-agglomeratzonens mægtighed er således i Myrkagjógv $20 \mathrm{~m}$, i den $\varnothing$ stlige elv i Hvannhagi $25 \mathrm{~m}$, medens den ved overgangen til kysten ud mod Ribbingamúli kun når op på ca. $5 \mathrm{~m}$.

Kystvæggen ud mod Ribbingamúli består fra stranden og op til mellemste basaltserie overvejende af intrusiv basalt. Tuf-agglomeraterne ses i fjeldvæggen mellem de intruderede basalter og den mellemste basaltserie, men de andrager i almindelighed kun få meter. Undertiden forekommer de dog indesluttet i de intruderende basalter. Der ses ikke sjældent mere eller mindre udtalt lagdeling i tuf-agglomeraterne. (Fig. 46, 47).

I hængedalen i den nordvestlige del af Hvannhagi er grænsen 
mellem tuf-agglomeratzonen og den mellemste basaltserie mere svingende. Øst for Gásagjógv er tuf-agglomeraterne afbrudt af intruderet basalt, som går helt op i den mellemste basaltserie. Grænsen er her ca. $150 \mathrm{~m}$ o. h. Herfra er den jævnt stigende ind mod Grønagjógv, således at den vest for Gásagjógv er 170 m, på østsiden af Grønagjógv 190, men på vestsiden af Grønagjógv 170 m o. h. Dette svarer nogenlunde til forholdene på hængedalens sydside, hvor grænsen ca. $200 \mathrm{~m}$ фst for Frostgjógv ligger i $150 \mathrm{~m}$ højde, på $\varnothing$ stsiden af Frostgjógv i $180 \mathrm{~m}$, men på vestsiden af Frostgjógv i $165 \mathrm{~m}$ højde. Ved den nordlige vandløbsgren til søen er grænsen mellem tuf-agglomeratzonen og den mellemste basaltserie $150 \mathrm{~m}$ o. h. Tuf-agglomeratzonen overskæres her af en stor intruderet basaltmasse, som går helt op til den mellemste basaltserie. Ved den sydligste vandløbsgren til søen (vandløbet fra gjógv'en) ses mellemste basaltseries lavaer nord for gjógv'en helt ned til $140 \mathrm{~m}$ (derefter er de vegetationsklædte), syd for gjógv'en går tuf-agglomeraterne op til $180 \mathrm{~m}$. De underlejres syd for gjógv'en af intruderet basalt. En bred gangagtig apofyse går op gennem hele gjógv'en.

Langs nordsiden af Trongisvágur kan tuf-agglomeratzonen ses i vandløb og kløfter fra Myllá (Bláfossur) i vest til Húsagarđsá i $\emptyset$ st. Dens $\emptyset$ vre grænse er som regel blottet og svarer til den mellemste basaltseries nedre grænse. Tufagglomeratzonens nedre grænse er derimod kun tilnærmelsesvis angivet, idet den almindeligvis er vegetationsdækket. Undertiden, bl. a. ved elven vest for Tvørá, ved Tippisá og ved Sílá forekommer agglomerater imidlertid på lavere niveau end den angivne grænse. Disse må antages at befinde sig på sekundært leje. Ved Myllá (Bláfossur) kan tuf-agglomeratet observeres ned til ca. $140 \mathrm{~m}$ o. h., medens grænsen mellem tuf-agglomeratzonen og den mellemste basaltserie ligger i $185 \mathrm{~m}$ h $\varnothing$ jde. Svalbarðaá giver 3 profilmuligheder gennem tuf-agglomeratzonen. I midtprofilet kan agglomeratet følges fra ca. $125 \mathrm{~m}$ til $160 \mathrm{~m}$ o. h., men profilet er ikke blottet i hele sin længde. I elven ca. $400 \mathrm{~m}$ vest for Tvørá er zonens $\emptyset$ vre grænse beliggende i $195 \mathrm{~m}$ højde, agglomeraterne ses stedvis blottet ned til ca. $160 \mathrm{~m}$. I Tvørá kan tuf-agglomerater iagttages fra ca. $155 \mathrm{~m}$ til $185 \mathrm{~m} \mathrm{o.} \mathrm{h.} \mathrm{Ma-}$ terialet er grovere nedad, finere opad, og der ses en lagvis anordning af agglomeratets bestanddele. Ved gjógv'en фst for Tvørá er agglomeratet blottet fra ca. $160 \mathrm{~m}$ til $180 \mathrm{~m} \mathrm{o}$. h. Ligesom ved Tvørá er nedre del grovere, den $\varnothing$ vre del finere og bedre lagdelt. 
Ved Tippisá (Hválsgjógv) blev der gjort stedvise iagttagelser fra ca. $170 \mathrm{~m}$ til $200 \mathrm{~m}$ o. h. Ved Súlá foreligger ligeledes stedvis iagttagelse fra ca. $140 \mathrm{~m}$ til ca. $170 \mathrm{~m}$ og ved vandløbet vest for Leirgjáarkneysi fra ca. $160 \mathrm{~m}$ til $170 \mathrm{~m} \mathrm{o.} \mathrm{h.} \mathrm{Ved} \mathrm{Húsagarđsá} \mathrm{ses}$ tuf-agglomerat fra ca. $145 \mathrm{~m}$ til $165 \mathrm{~m} \mathrm{o.h.} \mathrm{på} \mathrm{den} \emptyset$ stlige side af vandløbet. Ved den vestlige side af vandløbet (ca. $25 \mathrm{~m}$ vestligere) ligger den $\varnothing$ vre grænse ca. $8 \mathrm{~m}$ højere.

\section{Tindhólmur og Vágar}

På nordvestsiden af Vágar kan tuf-agglomeratzonen iagttages i kystprofil fra området vest for bygden B $\emptyset$ ur til bygden Gásadalur og videre nordpå i kløfter samt i vandløb fra Gásadalur ud mod Barðið.

Fra den lille bugt $\varnothing$ st for Hvalsker til bugten $\varnothing$ st for Akranes ses veksellejring mellem tuf-agglomerat og de nederste bænke af den mellemste basaltserie i kystsnit. Agglomeratet kiler ud $\emptyset$ stligst i bugten $\varnothing$ st for Hvalsker og fortsættes mod $\varnothing$ st af et tuflag. Agglomeratmægtigheden beløber sig umiddelbart фst for Húnagjógv til ca. 6 m, midt mellem Húnagjógv og Hvalsker til ca. $3 \mathrm{~m}$ og vestligst i den lille bugt $\varnothing$ st for Akranes afskæres tuf-agglomeraterne og de omgivende bænke af mellemste basaltserie efter en uregelmæssigt vertikalt forløbende linje af intruderede basalter fra vest.

Herefter ses agglomerater ikke igen før i området ved Akranesfossur, idet Akranes og Akranessker udelukkende består af intruderet basalt. I fjeldvæggen under Akranesfossur, der for langt den overvejende del består af intrusiv basalt, forekommer store inklusioner af agglomerat og lersedimenter, der hidrører fra den kulførende serie. Desuden ses agglomerat i elven til Akranesfossur fra fjeldkanten til $72 \mathrm{~m}$ o. h., på et enkelt sted veksellejrende med basalt fra den mellemste basaltserie. I den store ur mellem Akranes og Gásadalur - Bíggjarurð - består hele området mellem den nederste basaltserie, der ses ned mod kysten, og den mellemste basaltserie, der ses som en lodret stejlvæg over uren, af intruderet basalt samt af dislocerede og indesluttede partier af agglomerat og fragmenter af den kulførende serie. (Fig. 48, 49, 50).

Nord for Gásadalur er agglomerater blevet iagttaget sammen med intruderede basalter over den kulførende serie i alle åbne kløfter eller vandløb fra Streymnes ud til Barðið. Kun få steder er dog 


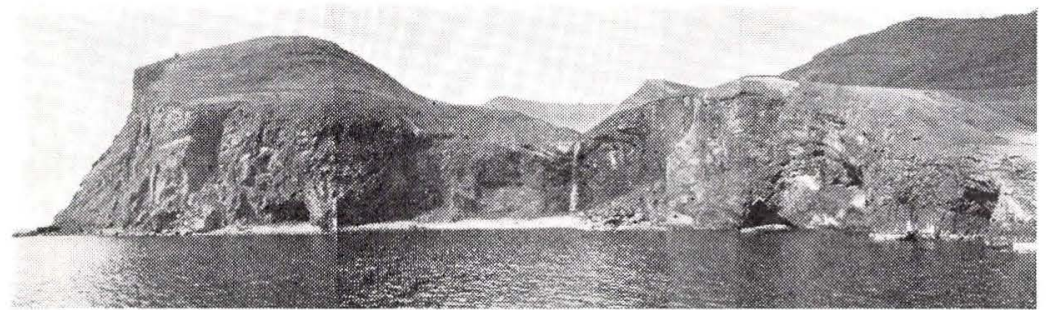

Fig. 48. Kysten mellem Akranes og Bíggjarurð (længst til venstre).

Millum Akranes og Bíggjarurð.

Coast between Akranes and Biggjarurð (extreme left).

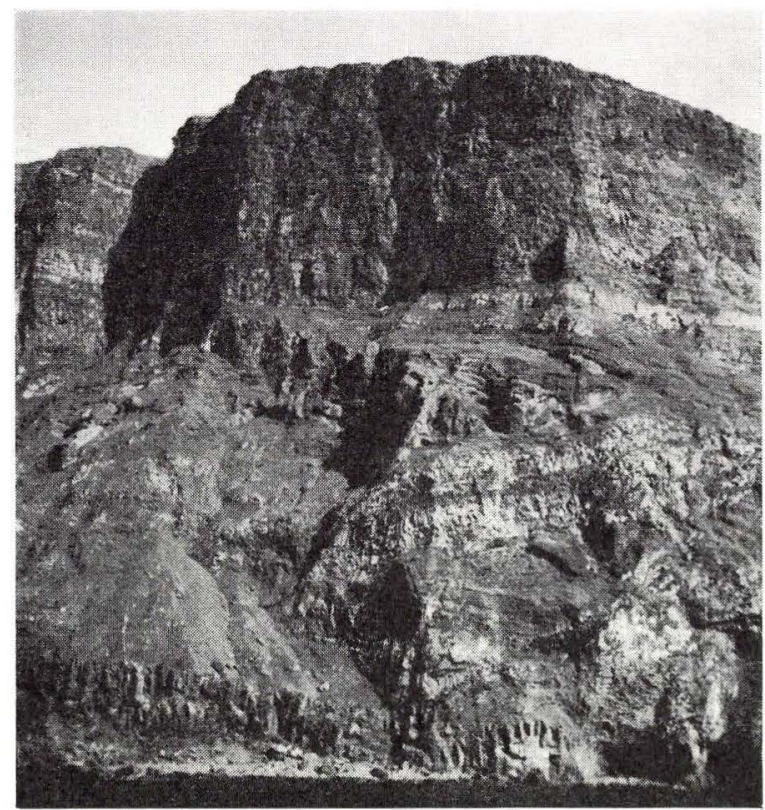

Fig. 49. Bíggjarurơ. Den nederste basaltserie ses i kysten, derefter tufagglomerater og intruderet basalt. $\emptyset$ verst ses den mellemste basaltserie. Bíggjarurð. Niðaru basaltfláirnar síggjast dygst niđri við sjóvarmálan, ovari gosmyrja og innskotið blágrýti og ovast miðfláirnar.

Biggjarurd. The lower basalt series is visible at sea level, with intrusive basalt and tuff-agglomerate above it. At the top, the middle basalt series.

både den nedre og den $\emptyset$ vre grænse synlige, som f. eks. i vandløbet nord for Sæurðardrangur: Her ligger den nedre grænse i $232 \mathrm{~m}$ og den $\varnothing v$ re i $258 \mathrm{~m}$ højde. Ved Skrápsgilið ligger den nedre grænse i ca. $245 \mathrm{~m}$ og den $\varnothing$ vre i ca. $270 \mathrm{~m}$ h $\varnothing$ jde. Veksellejring 


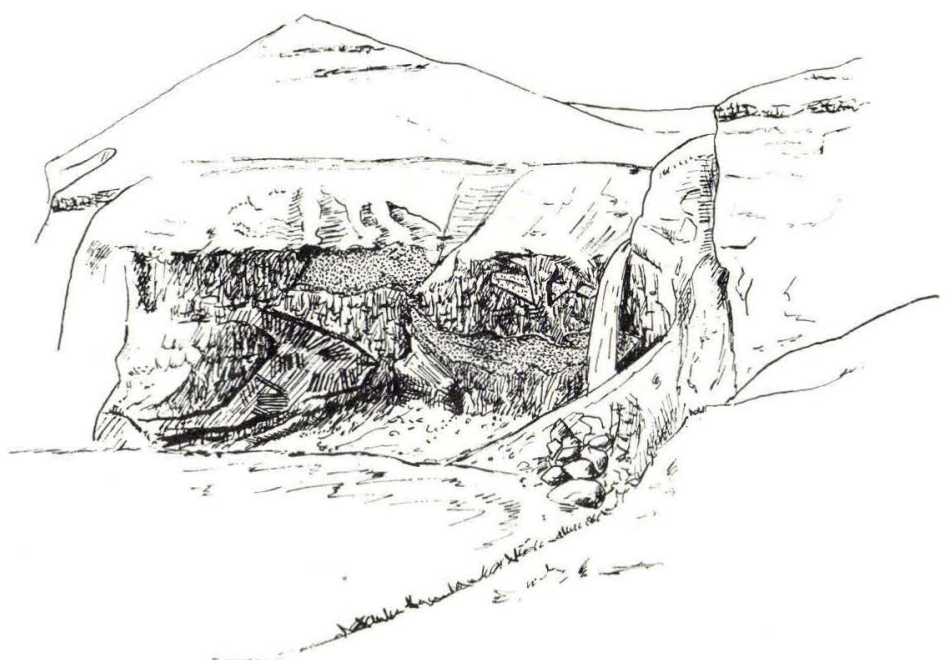

Fig. 50. Intruderet basalt med inklusioner af tuf-agglomerat og lersedimenter ved Akranesfossur.

Innskotið blágrýti, gosmyrja og leirlegugrýti (kolalindin) undir Akranesfossi. Vágar.

Intrusive basalt with inclusions of tuff-agglomerate and clayey sediments at Akranesfossur.

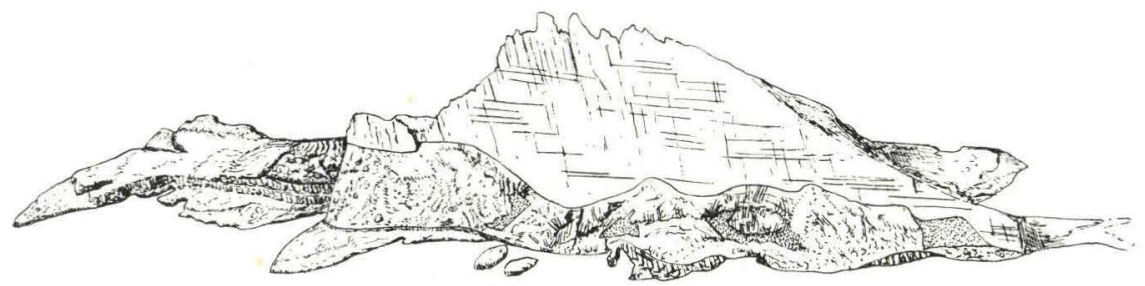

Fig. 51*. Sydsiden af Tindhólmur. I kysten mod vest ses den nederste basaltserie. Derover tuf-agglomerater og intruderede basalter. Øverst den mellemste basaltserie.

Tindhólmur sunnantil. Niðri við strondina vestantil síggjast niðaru basaltfláirnar, ovari gosmyrja og innskotið blágrýti, ovast miðfláirnar.

South side of Tindhólmur. On the coast towards the west there are flows of the lower basalt series, overlain by tuff-agglomerate and intrusive basalts.

The uppermost lavas belong to the middle basalt series.

*Konturerne tegnet efter luftbillede. 
mellem tuf-agglomerat og lavaer fra den mellemste basaltserie ses stedvis, f. eks. ved Streymnes og ved Sæurðardrangur. Dette er også tilfældet ved Víkar over bugten vest for Víkar og ved Reipsáfossur.

På Tindhólmur fremtræder tuf-agglomeratzonen i den lodrette fjeldvæg på фens sydside mellem den nederste basaltserie langs kysten og den mellemste basaltserie højere oppe i stejlvæggen. Ligesom i Bíggjarurð er agglomeraterne disloceret og indesluttet i intruderet basalt sammen med fragmenter af den kulførende serie. Tuf-agglomeratzonens $\varnothing$ vre grænse er på dette sted stærkt bugtet (fig. 51). 


\section{Mellemste basaltserie}

Den mellemste basaltseries nedre grænse er, som nævnt, undertiden udformet som en overgangszone med veksellejring mellem tuf-agglomeratdannelser og tynde basaltstrømme. Dette kan ses såvel på Suðuroy som på Vágar og gør det sandsynligt, at den lavaproduktion, der førte til dannelse af den mellemste basaltserie, blev indledt allerede i eksplosionsfasens slutstadium.

Den mellemste basaltserie er enerådende på den nordligste del af Sưuroy, på langt den overvejende del af Vágar, på den nordlige del af Streymoy og på den nordvestligste del af Eysturoy. På den mellemste del af Suðuroy (mellem Hvalba og Fámjin), på Tindhólmur og på den allervestligste del af Vágar (vest for AkranesVíkar) overlejrer den de foran beskrevne ældre serier. På den sydlige del af Streymoy, på Eysturoy og de $\varnothing$ vrige фer er den for størstedelen overlejret af den $\emptyset$ verste basaltserie.

Vulkanismen har efter den eksplosive indledningsfase i $\varnothing$ vrigt været kontinuerlig og kun haft ringe eksplosivitet; lavastrømmene har uden væsentlige ophold successivt overflydt hinanden. Bænktykkelsen er langt mindre $\mathrm{i}$ den mellemste basaltserie end $\mathrm{i}$ de to andre serier og den afviger ligeledes såvel i strukturel som i morfologisk henseende fra disse. I storlandskabet adskiller den sig således fra de to andre udpræget »trappeformede « serier ved at have en blød, konveks landskabsform, hvis udformning sandsynligvis skyldes den store forvitringstilbøjelighed i højderne, der særligt gør sig gældende overfor den mellemste basaltserie, og en efterfølgende nedskylning af forvitringsmaterialet til lavere liggende egne. De enkelte lavaer er almindeligvis tynde, fra br $\varnothing$ kdele af en meter til 1-2 meter, de danner ofte mindre serier op til en snes meter eller noget mere, f. eks. B-horisontbænkene (se s. 34 og fig. 53). Det er i mange tilfælde vanskeligt at afgøre, om man har med en egentlig lavastrøm eller blot med en underafdeling - en flydeenhed - at gøre; f. eks. mindre, successive aftapninger fra en delvis konsolideret lavastrøm. Øverst i den mellemste basaltserie er bænkmægtigheden noget tiltagende og kan undtagelsesvis blive henimod en halv snes meter. I den enkelte lavastrøm findes nederst en zone med mere 
eller mindre opadrettede piber, herover kommer et mere kompakt og tæt midtparti og фverst en stærkt porøs og blæret zone, der skyldes luftarter, der er blevet frigjort som følge af det formindskede tryk i lavaen på jordoverfladen. Piber og porer er udfyldt med sekundært udskilte mineraler som zeoliter, opal, kvarts og kalkspat. Tovværkslavaoverflader (ropy lava) ses overalt, og negativaftryk af sådanne overflader forekommer hyppigt på lavastrømmenes underside. Flydestrukturer, flydelinjer og udtrukne porer, er for det meste udpræget i disse lavastrømme, undertiden er de så udtalte, at de ligefrem har forårsaget en lamellar opspaltning af bjergarten. (Fig. $54,55,56,57,58)$.

De langstrakte, i tværsnit cirkulære eller ovale legemer af intrusiv karakter, der må betragtes som udfyldte lavatunneler, ses jævnligt såvel i den mellemste som i den $\emptyset$ verste basaltserie. En sådan dannelse nær stranden umiddelbart vest for bygden Rituvík er allerede beskrevet af Forchhammer i hans dagbog fra 1821. Den har elliptisk tværsnit: storakse $3,25 \mathrm{~m}$ og lilleakse $1 \mathrm{~m}$. Dens blottede længde er ca. $18 \mathrm{~m}$, hvorefter den, en del udtyndet, går ind under en moræne. Termal kontaktvirkning ses på hele overfladen, ligesom der går apofyser ind i sidestenen. En lignende dannelse ses på nordvestspidsen af Sandoy. Dens bredde er inde ved land 10,5 m; den er bredere længere ude; den kommer igen i tværsnit i holmen (Tr $\varnothing$ llh $\varnothing v d i)$ nord for Sandoy over havniveau. Andre eksempler kan nævnes fra kysten mellem Velbastaður og Kirkjubøur og ved Bláfossur på sydsiden af Kollafjørður. Ikke udfyldte lavatunneler af lignende dimensioner ses også jævnligt; de er bl. a. ofte iagttaget på de nordlige øer. (Fig. 59, 60, 61).

Tuf er yderst sjældent forekommende i den nedre del af den mellemste basaltserie og i alle tilfælde kun som ganske tynde lag. Opad i serien bliver tuflag hyppigere, således forekommer tuf ret udbredt lige under B-horisontbænkene. Ved Argisfossar på Midtstreymoy forekommer der et tuflag på 1-3 m af grøn og rød farve, det har tidligere været gjort til genstand for brydning, og ved bygden Eiði på Eysturoy forekommer der et tuflag, ligeledes af grøn og rødbrun farve på 1-1,5 m.

En rent lokal interbasaltisk dannelse indeholdende glasbasalt fra sydvestsiden af Grímsfjall skal omtales. Her ser man i fjeldvæggen ca. $95 \mathrm{~m}$ o. h. en basaltbænk, der kiler ud mod nord. Dens horisontale udstrækning anslås på vestsiden til ca. $50 \mathrm{~m}$, på sydsiden til 15-20 m, hvorefter den går ind under grønsværet. Dens 


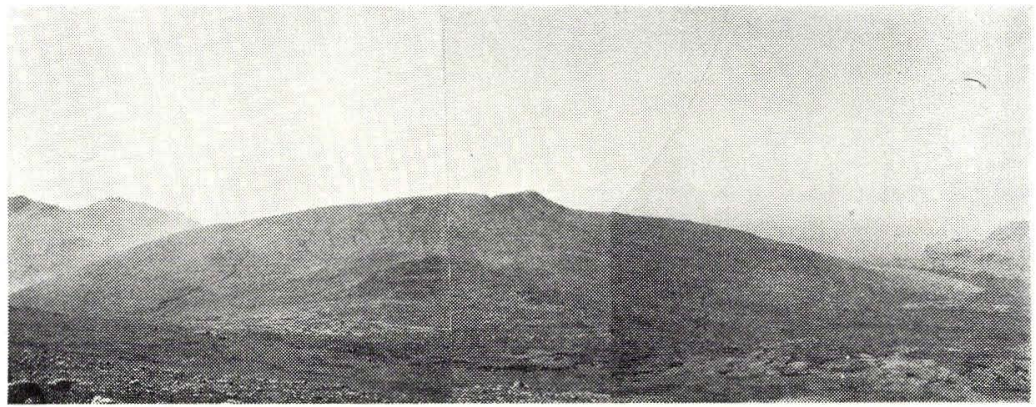

Fig. 52. Typisk storlandskabsform for den mellemste basaltserie (Tungufelli, Vágar).

Eyðkent landslag fyri miðfláirnar. Tungufelli i Vágum.

Typical landscape form of the middle basalt series. (Tungufelli, Vágar).

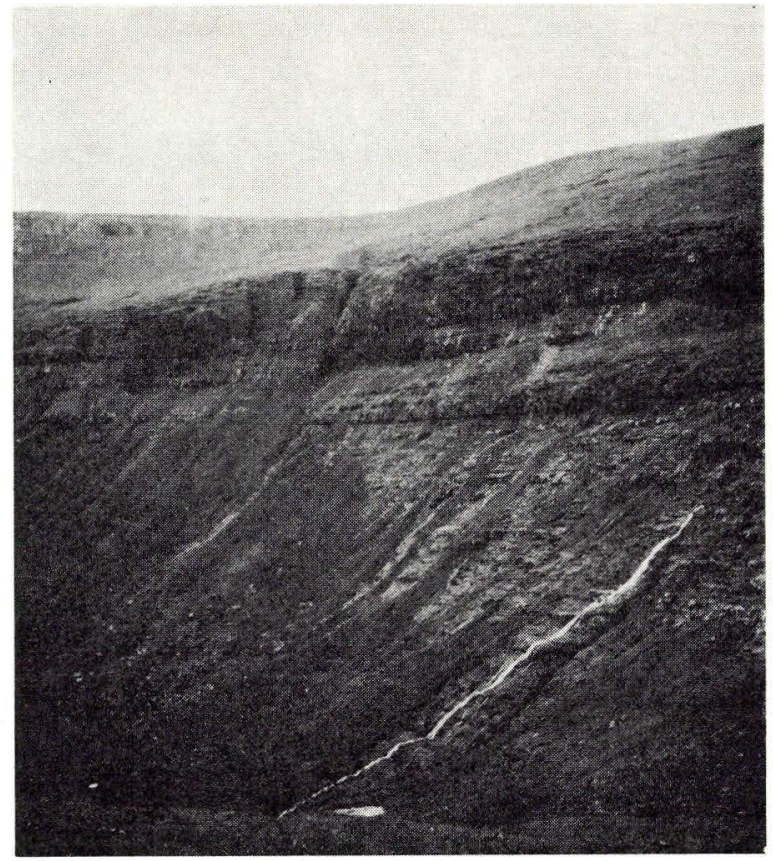

Fig. 53. B-horisontbænkene. Østsiden af Sjendir, nordligste Streymoy. $B$-lindin, Sjendir.

B-level flows. East side of Sjendir, north-coast of Streymoy. 


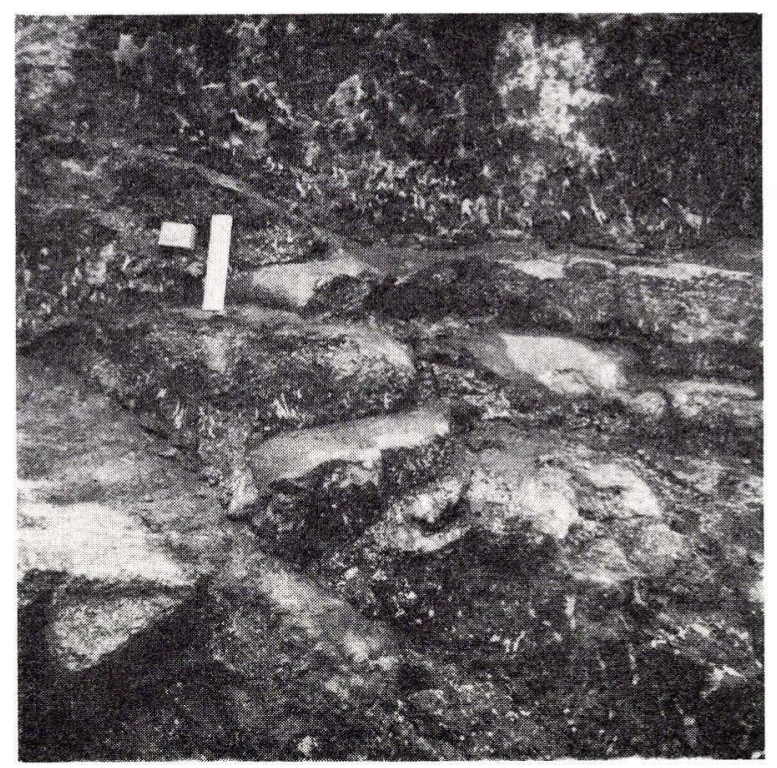

Fig. 54. Flydeenheder i den mellemste basaltserie.

Tunnar lavafláir í miðfláunum. Vestmanna. Flow units in the middle basalt series.

maximale mægtighed er ca. $6 \mathrm{~m}$. Bænken er underlejret af et 10$15 \mathrm{~cm}$ tykt, og overlejret af et $15-35 \mathrm{~cm}$ tykt lersediment. Den har svag pillow lava karakter, særlig forneden; dens $\phi$ vre del er mere por $\varnothing$ s, zeolitfyldt og mindre glasholdig (fig. 62).

Hist og her, såvel i den mellemste som i den $\emptyset$ verste basaltserie forekommer sideromelantuf (NoE-NYGAARD 1939), som er en dannelse, der tyder på en meget hastig og effektiv afkøling af tuffens glaskorn. Sideromelan er almindelig i de kvartære, vulkanske dannelser på Island, hvor de er dannet under subglaciale forhold; men sideromelan kan ligeledes dannes under vanddækning, subaquatisk.

Under kortlægningsarbejdet har vi observeret sideromelantuf i den mellemste basaltserie ved Vestmanna og Eiði samt i vejtunnelen mellem Árnafjørđur og Depil, og i den фverste basaltserie på Nólsoy og Fugloy. De færøske forekomster af sideromelan vidner sandsynligvis om, at udbrudsstederne for disse tuflag har ligget under vand på det tidspunkt, asken blev dannet; men vi kan ikke afgøre, om udbrudene har fundet sted i søer på landjorden eller i et lavvandet havområde. 

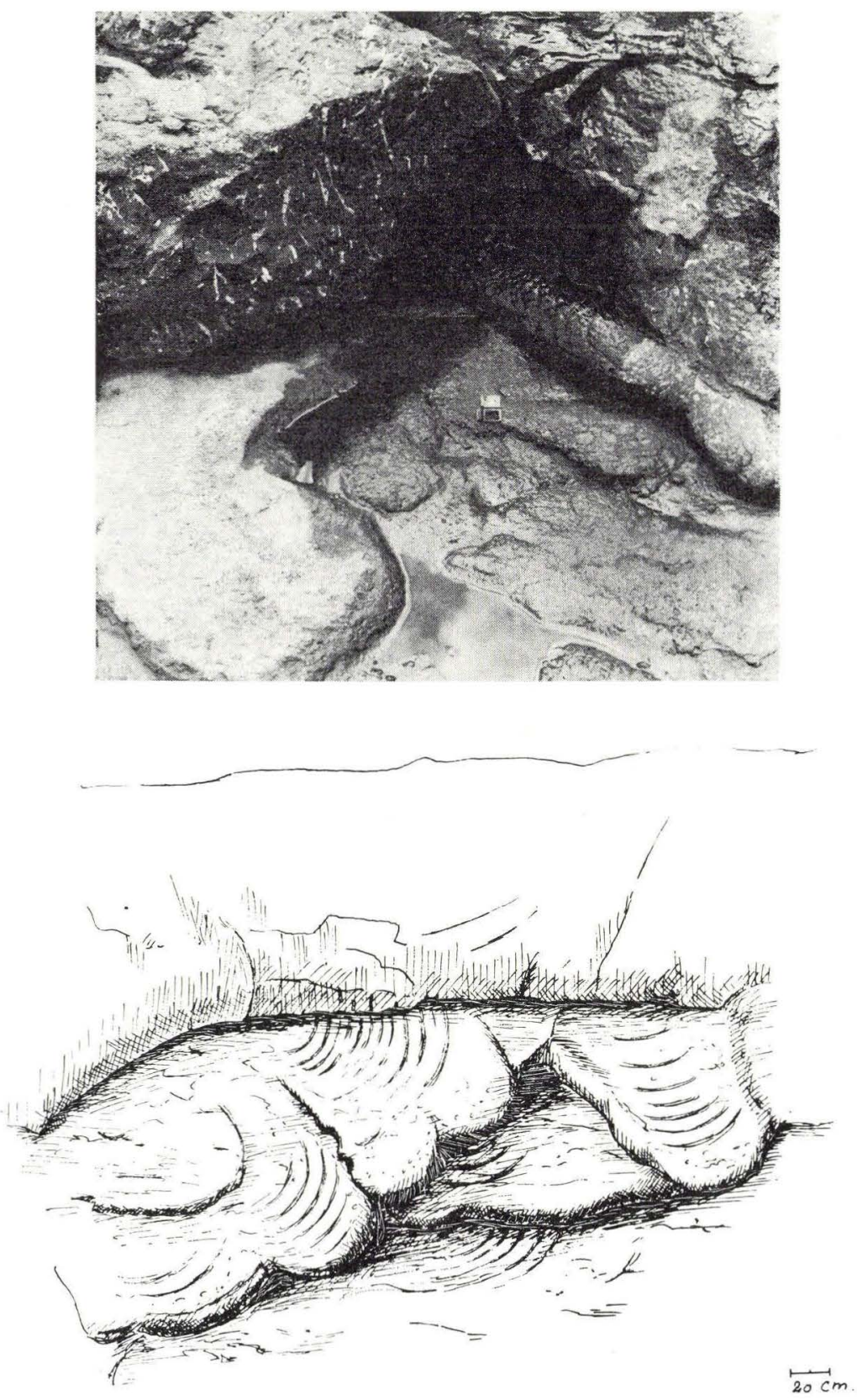

Fig. 55. Flydeenheder i den mellemste basaltserie (lavatunger). Lavatungur í miðfláunum. Vestmanna.

Flow units in the middle basalt series (lava tongues). 
Bænkene i den mellemste basaltserie er almindeligvis adskilt af pore- og brændingshorisonter, og serien, særlig den nedre del, giver i modsætning til de to andre serier, et langt større indtryk af at udgøre en sammensvejset helhed end disse. Denne helhedsfornemmelse får man særlig tydeligt i de lodrette forbjerge ud mod havet, hvor der ofte kan iagttages en karakteristisk stribning som følge af flydestruktur og erosion (vinderosion) af de mindre modstandsdygtige porezoner (fig. 63, 64).

Ligesom der næppe kan herske tvivl om, at udbrudsvirksomheden under dannelsen af den nederste basaltserie har været knyttet til langstrakte spalter af store dimensioner, er der al mulig grund til at antage, at den vulkanvirksomhed, der er ansvarlig for dannelsen af den mellemste basaltseries lavaer, har været lokaliseret til udbrudssteder af en langt ringere st $\varnothing$ rrelse. Rester af sådanne udbrudssteder ses $\mathrm{i}$ den mellemste basaltserie $\mathrm{i}$ form af de langs sunde og fjorde forekommende naturlige snit gennem vulkanske tilførselskanaler eller »vents«. De ses i kystsnit, varierende fra mindre end $50 \mathrm{~m}$ til op til ca. $1,5 \mathrm{~km}$, hvor iagttagelser synes at godtgøre, at de må have haft aflang eller elliptisk form.

Under nærværende arbejdes udførelse er der blevet iagttaget 10 sådanne vents i kystsnit: 1 på Vágar, 2 på Koltur, 1 på Streymoy, 1 på Kallsoy, 1 på Borðoy, 3 på Viðoy og 1 på Fugloy. Der er i alle disse tilfælde tale om velafgrænsede vents; mere tilfældigt optrædende agglomeratpartier er ikke medregnet (RASMUSSEN 1962).

Syd for Marragjógv på Vágar findes en vent i kysten ud mod Vestmannasund. Langs strandkanten måler den ca. $50 \mathrm{~m}$, den overskærer her de regelmæssige basaltbænke, aftager i bredde opad og overdækkes i ca. $20 \mathrm{~m}$ højde af et tuflag og lavastrømme (plagioklasporfyritisk basalt). Mellem sidestenen og det pyroklastiske udfyldningsmateriale ses intruderet basalt (ligeledes plagioklasporfyritisk), der åbenbart har dannet en ca. 1,5 m tyk kappe udenom agglomeratet med tydelig termal kontakt såvel ud mod sidestenen som ind mod agglomeratet. Askeindholdet synes at dominere ud til siderne og op mod toppen, medens det por $\varnothing$ se lavamateriale dominerer i midtpartiet og nedad. Askens farve veksler fra grå til rødlig, grå inderst og rødlig ude ved siderne og op mod toppen. Stenmaterialet varierer i størrelse fra ærtestørrelse til henimod $1 \mathrm{~m}$; 15-20 cm er dog mest almindeligt. Blokmaterialet består for langt den overvejende del af plagioklasporfyritiske basalter og stærkt po- 

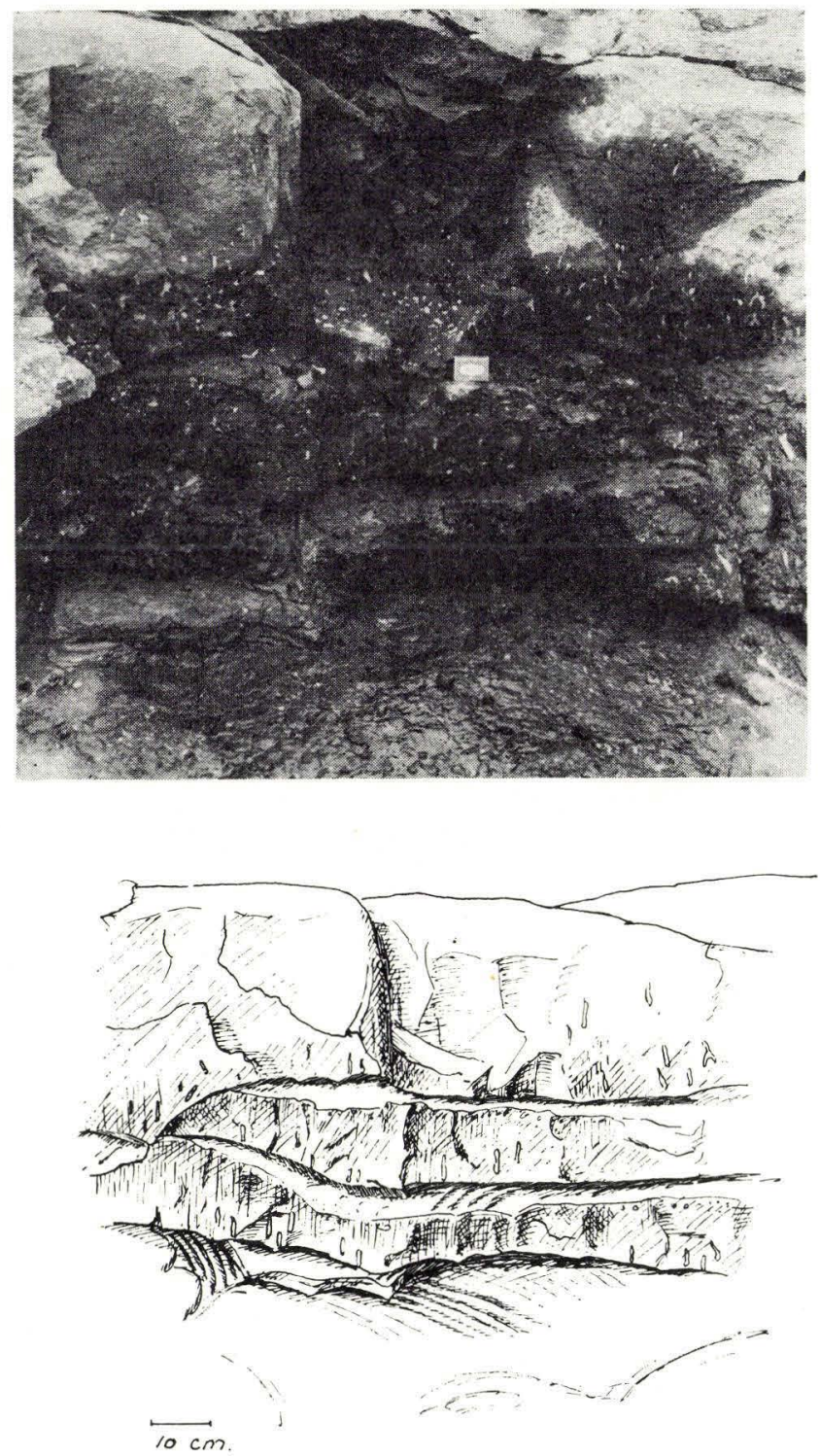

Fig. 56. Flydeenheder i den mellemste basaltserie.

Tunnar lavafláir í miðfláunum, pípur í neđra og poknur i erva. Vestmanna. Flow units in the middle basalt series. 


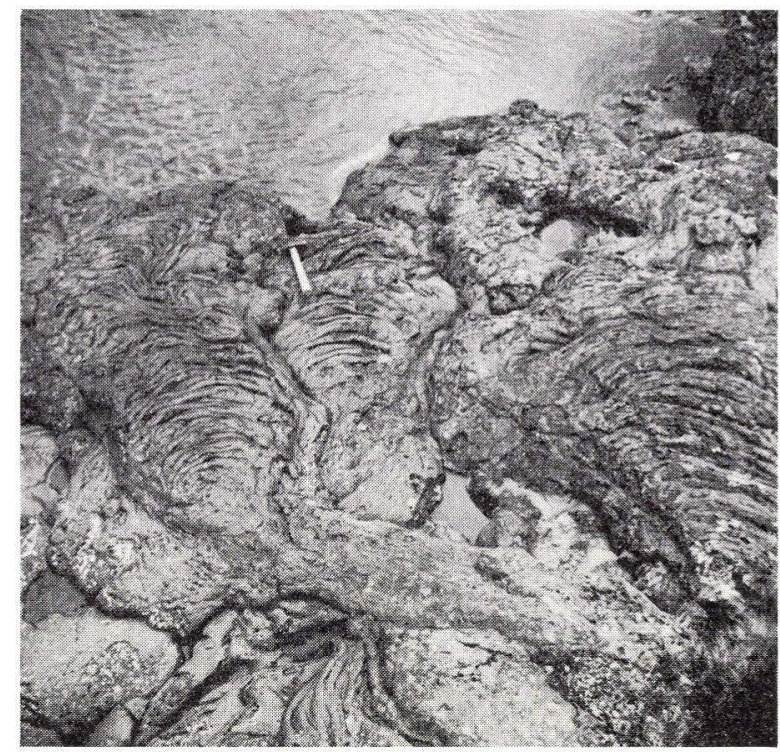

Fig. 57. »Ropylava« i den mellemste basaltserie.

Lavabørkur (ropy lava) i miðfláunum.

Ropy lava in the middle basalt series.

røse basalter. Der udgår apofyser fra intrusionskappen såvel ind i agglomeratet som op i tuflaget foroven. (Fig. 65).

Umiddelbart nord for bygden Koltur nord for Gróthústangi ses en agglomeratblotning, der sandsynligg $ø r$ tilstedeværelsen af en lille vent. Desuden forekommer der pletvis agglomerat i fjeldvæggen længere nordpå og ligeledes på vestsiden af $\emptyset$ en.

Nordøstsiden af Koltursnakkur. Mellem de to nordligste kløfter på nordøstsiden af Koltursnakkur overskæres basaltbænkene af en agglomeratmasse efter en omtrent lodret linje. Agglomeratoverfladen er nederoderet i midten og lavningen er senere udfyldt af basalt (fig. 66).

Dalsnípa, Streymoy. GeIKIE (1896) beskriver et agglomeratområde, der ligger nord for Dalsnípa som tværsnit gennem 5 små vents. Efter vor opfattelse (RASMUSSEN 1962) drejer det sig imidlertid om forskellige snit gennem et smalt, langstrakt udbrudssted med NNV-SS $\varnothing$ retning. Langs strækningen Seyðaskor i nord til Dalsnípa i syd ses en agglomeratmasse i den nedre del af fjeldvæggen. Agglomeratet begrænses mod vest af gangen Str. 226, 227, 228, 229 og mod $\varnothing$ st af den stejle fjeldvæg, der bagved agglome- 


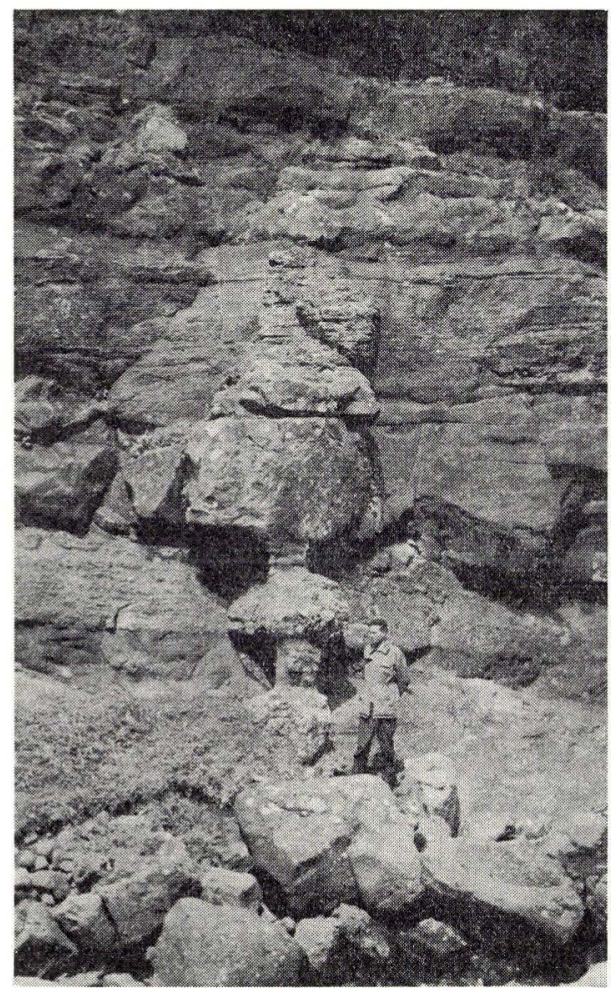

Fig. 58. Forskellige forvitringsformer i forskellige lavastrømme i den mellemste basaltserie.

Ymislig taring í ymiskum fláum.

Different weathering forms in different lava flows in the middle basalt series.

ratmassen fremtræder med tynde regelmæssige basaltstrømme. Det er derfor sandsynligt, at der her er tale om et længdesnit gennem et udbrudssted på ca. $1500 \mathrm{~m}$ længde og en anslået bredde på 10$50 \mathrm{~m}$ (fig. 67).

Nord for Lambagjógv på sydvestsiden af Kallsoy ses en mindre vent i kystsnit. Mod nord begrænses den af en tynd gang. Grænseforløbet ud mod sidebasalten er svagt indadrettet (fig. 68).

Ved Svartiklettur på nordvestsiden af Borðoy ligger en vent* (fig. 69). Afstanden mellem agglomeratets nordlige og sydlige be-

* Der er muligvis her tale om den samme vent som Walker og Davidson (1936) omtaler som en vent fra nordvestsiden af Kunoy, hvor vi ikke har kunnet iagttage nogen; i så fald er den placeret forkert på deres kort. 

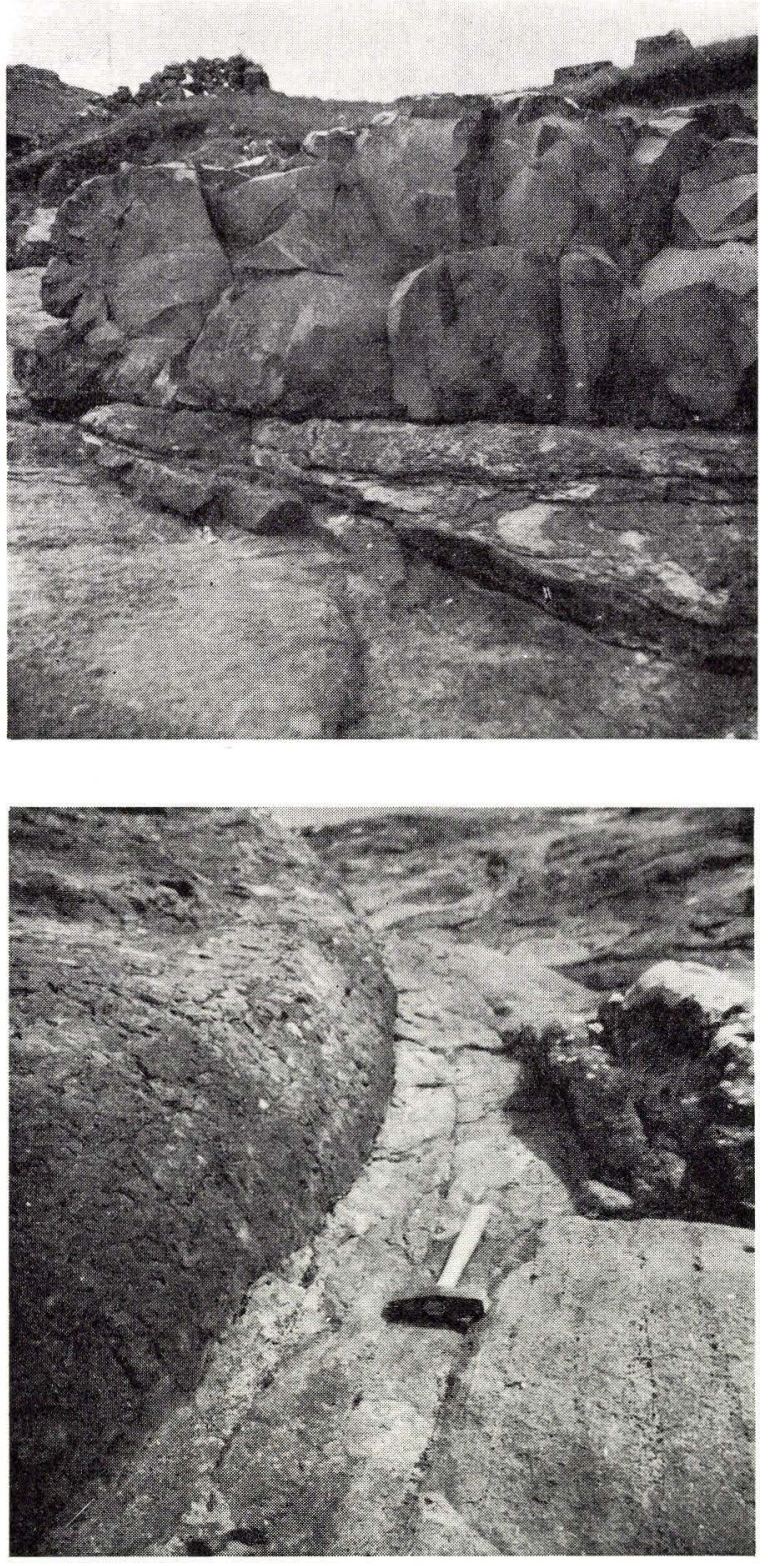

Fig. 59 og 60. Udfyldt lavatunnel, Rituvík. Innskot í lavatunli. Rituvík.

Filled lava tunnel, Rituvík, Eysturoy. 


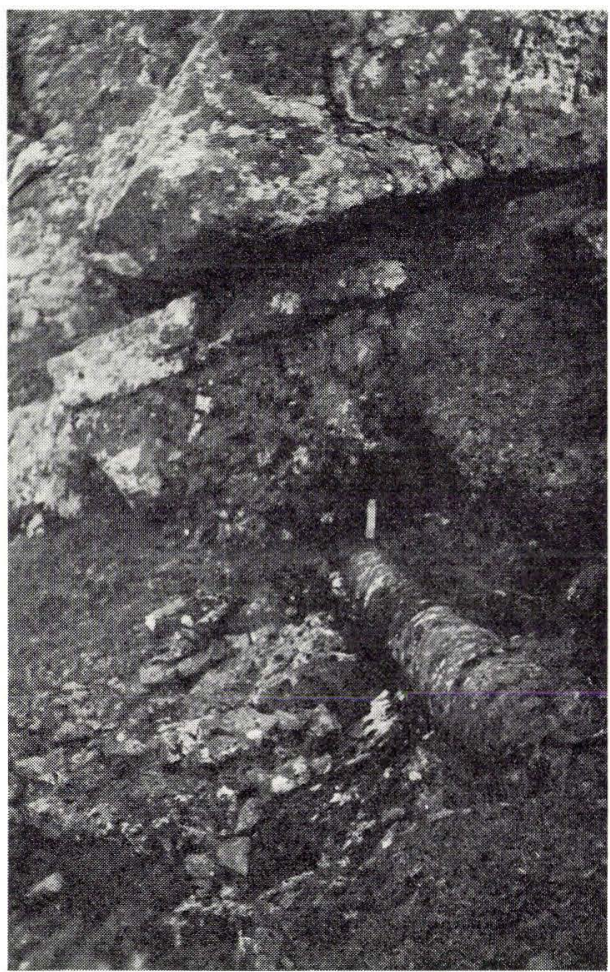

Fig. 61. Udfyldt lavatunnel. Sydsiden af Kollafjørður (ved Bláfossur).

Innskot í lavatunli. Sunnan fyri Kollafjørð, við Bláfoss.

Filled lava tunnel, south side of Kollafjørđur, near Bláfossur.

grænsning er henimod $50 \mathrm{~m}$, og grænserne (såvel den nordlige som sydlige) mellem agglomerat og sidebasalt er rettet udad. Midtområdet er stærkt nederoderet og lavningen udfyldt med basalt, nederst mørk - opad lysere med vifteformede søjler rettet mod agglomeratoverfladen. I kystprofilet overdækkes den af endnu to basaltbænke.

På nordvestsiden af Viðoy forekommer en vent syd for bygden Viðareiði. Den fremtræder i vertikalt kystsnit med lodrette grænser mellem agglomeratet og basaltbænkene til siderne (fig. 70).

På sydvestsiden af Viðoy omtales hos WALKER og DAvidson (1936) en vent med formodet tilførsel til en overliggende lavabænk. Ligesom ved Svartiklettur er der her en lavning i agglomeratet, der er udfyldt med basalt med søjler rettet vinkelret på 


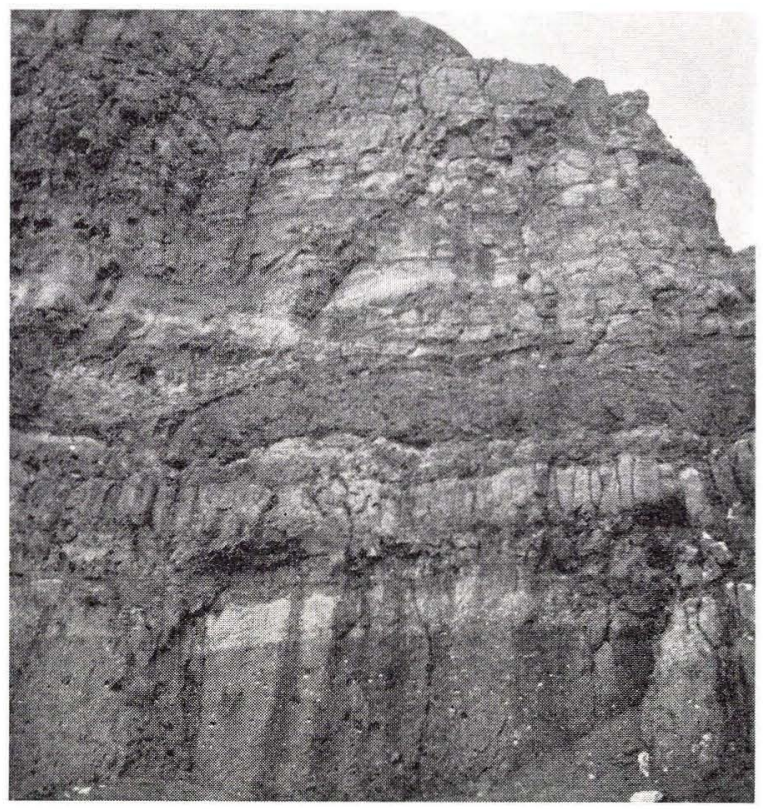

Fig. 62. Interbasaltisk sedimentserie med glasbasalt på vestsiden af Grímsfjall. Leirlegugrýti við glarbasalti, vestantil í Grímsfjalli.

Interbasaltic sediments with a thin flow of glassy basalt in them, west side of Grimsfiall.

agglomeratoverfladen. Der findes tydelig forbindelse mellem basalten i lavningen og en overliggende basaltbænk, uden at der her skal tages endelig stilling til, om den har været tilførende til denne, eller om der er tale om en lavastrøm, der har udfyldt lavningen, det sidste forekommer sandsynligst. (Fig. 71).

På sydøstsiden af Viðoy forekommer en vent på vestsiden af Viðvík mellem de to kløfter Gjógvin Stóra og Gjógvin Lítla. Den kan ses langs en kyststrækning på ca. $145 \mathrm{~m}$ og op til ca. $20 \mathrm{~m}$ o. h. Den overskærer de regelmæssige basaltbænke med en tilnærmelsesvis lodret grænse både mod syd og mod nord. Fra den sydlige grænse strækker agglomeraterne sig ca. $75 \mathrm{~m}$ mod nord og fra den nordlige grænse ca. $40 \mathrm{~m}$ mod syd. De to agglomeratområder er langs en strækning på ca. $30 \mathrm{~m}$ afbrudt af en fordybning i overfladen, der er udfyldt med basalt. Nederst i fordybningen er der jævn overgang mellem agglomerat og basalt, medens der længere oppe er tydelig termal kontakt mellem dem. I agglomeratet 


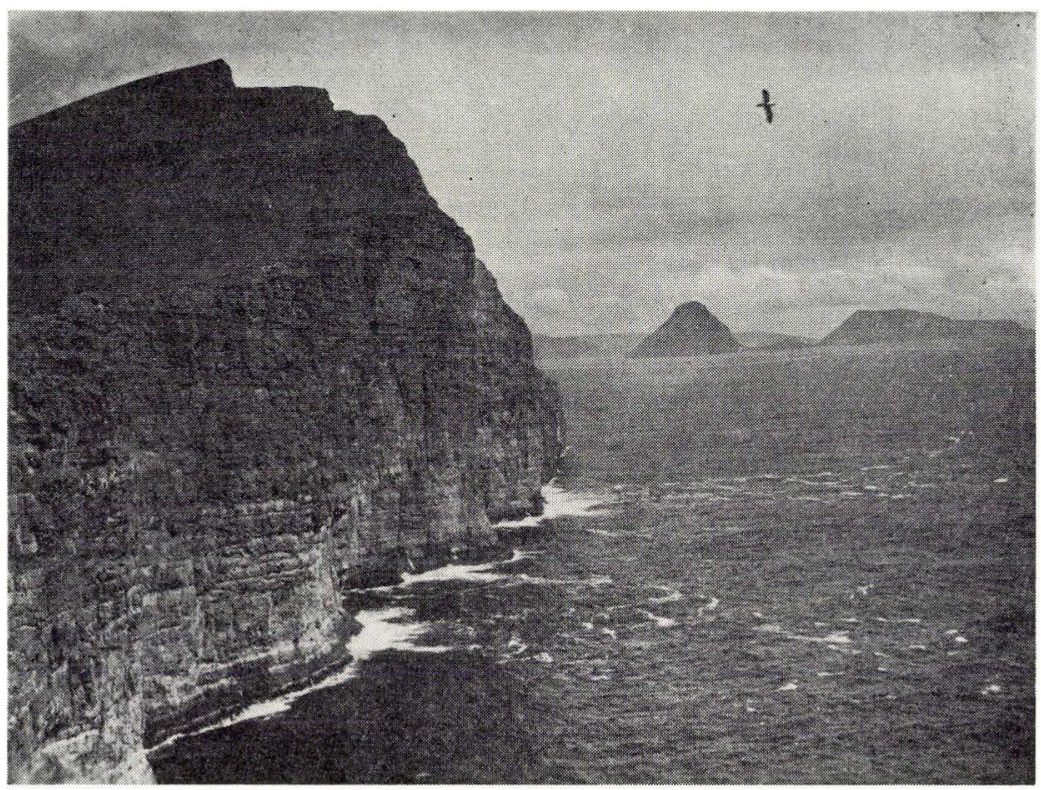

Fig. 63. Den mellemste basaltserie ved Trælanípa, Vágar. Miðfláirnar í Tralanípuni, Vágar.

The middle basalt series at Traelanípa, Vágar.

ses, særlig ud til siderne, basaltapofyser med flydestrukturer, undertiden helt op til de overliggende basaltbænke. Blokmaterialet i agglomeratet er overvejende tæt, blå basalt og underordnet feldspatbasalt.

Umiddelbart $\varnothing$ st for bygden Kirkja på Fugloy vest for Nevið Óða forekommer en lille vent, den ses i lodret kystsnit. Den er kuppelformet, højde og bredde anslås til 10-15 m. Agglomeratet er omgivet af en tynd kappe af intrusiv basalt. (Fig. 72).

Ved en betragtning af fig. 73, der gengiver et forenklet snit gennem den færøske lagserie, hvor de foran nævnte, som udgør alle de af os iagttagne vents, er afmærkede, fremgår, at de alle er beliggende i den mellemste basaltserie, fra noget over dennes midte og op i grænseområdet mellem den mellemste basaltserie og den $\emptyset$ verste basaltserie (C-horisonten), således: syd for Marragjógv på Vágar ca. 550 m, nord for Lambagjógv på Kallsoy ca. 260 m, ved Dalsnípa på Streymoy ca. $250 \mathrm{~m}$, på nordøstsiden af Koltursnakkur på Koltur ca. 190 m, ved Svartiklettur på nordvestsiden af Borðoy 


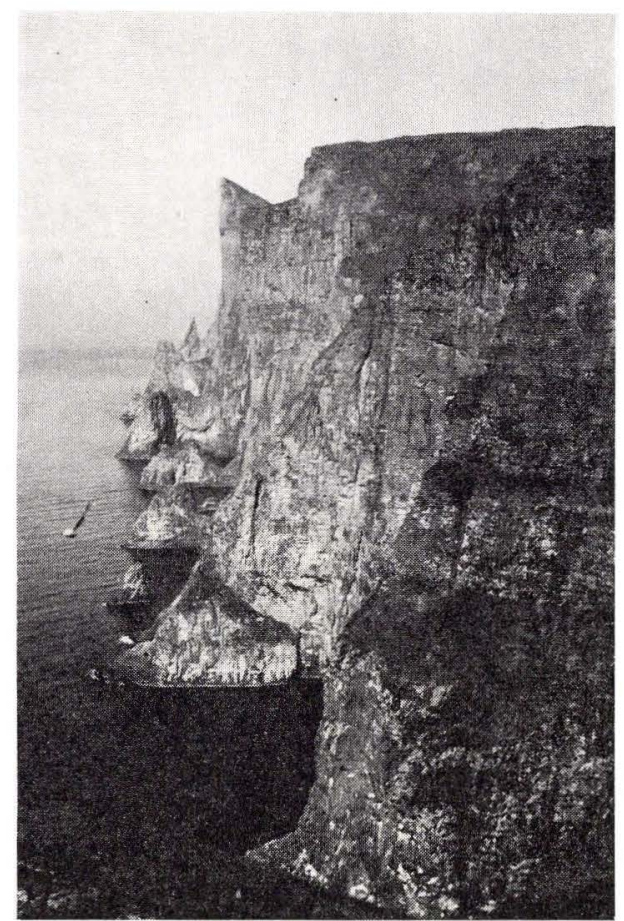

Fig. 64. Den mellemste basaltserie. Nordvestkysten, Streymoy. Miðfláirnar norđurvestantil á Streymoynni.

The middle basalt series. North-west coast of Streymoy.

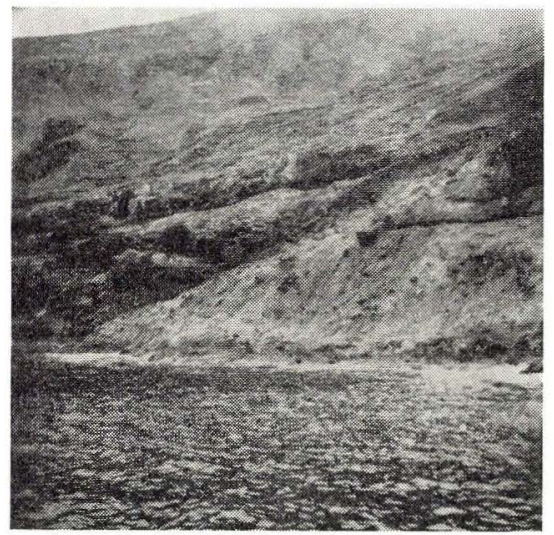

Fig. 65. Den sydlige del af en vent ved Marragjógv, Vágar.

Sunnari partur av goshálsi við Marragjógv, Vágar.

The southern part of a vent at Marragjógv, Vágar. 

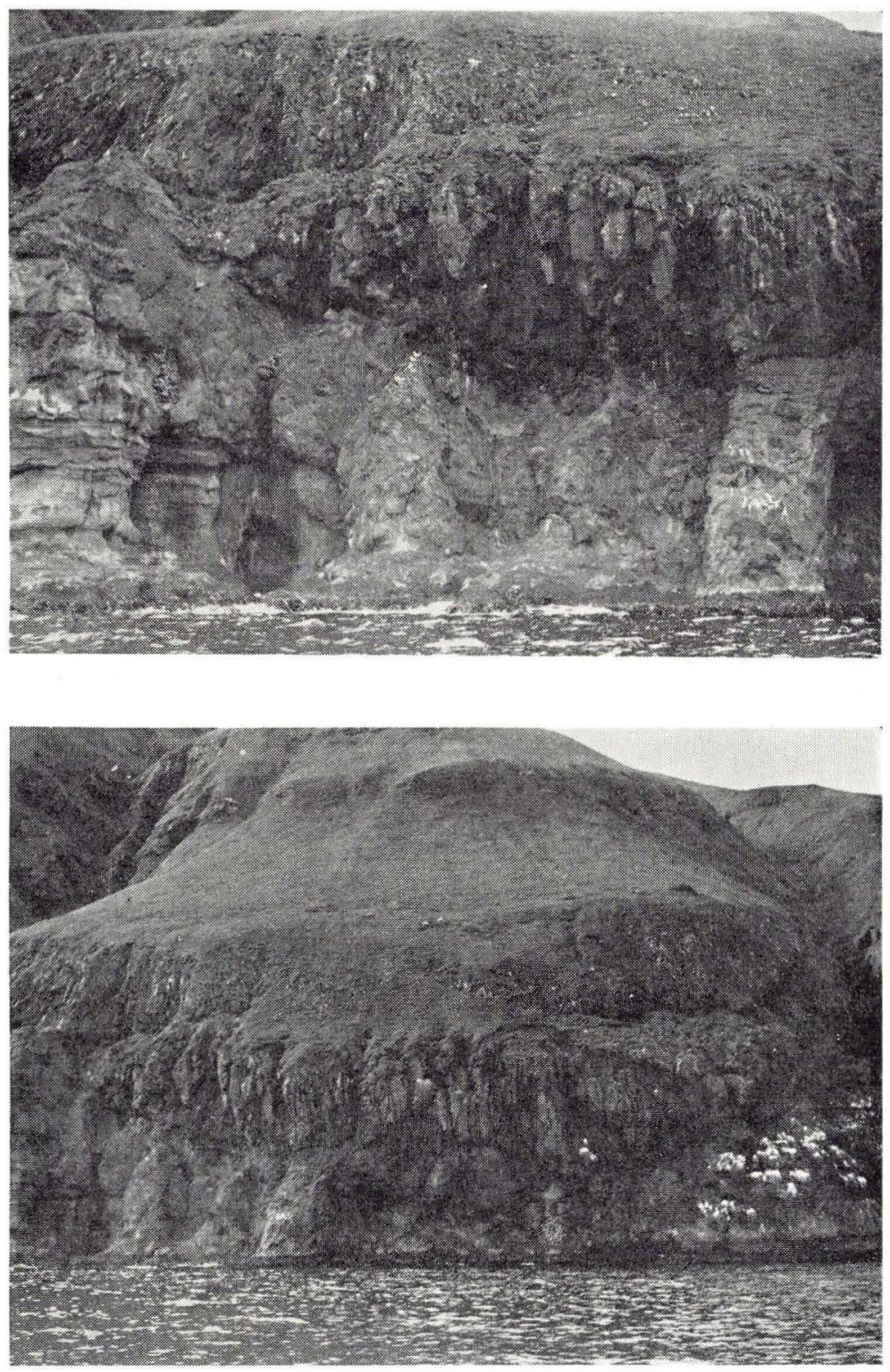

Fig. 66. Vent. Nordøstsiden af Koltursnakkur, Koltur. Goshálsur í landnyrðingshorninum á Koltursnakki.

Vent. North-east side of Koltursnakkur, Koltur. 
ca. $170 \mathrm{~m}$, syd for bygden Viðareiði på Viðoy ca. $150 \mathrm{~m}$, nord for bygden Koltur ca. 95 m, på sydøstsiden af Viðoy ca. $60 \mathrm{~m} \mathrm{og}$ på sydvestsiden af Viðoy ca. $20 \mathrm{~m}$ under C-horisonten. Den omtalte lille vent $\varnothing$ st for bygden Kirkja på Fugloy ligger faktisk lige over den karterede grænse mellemste basaltserie- $\varnothing$ verste basaltserie (C-horisonten), men dog antagelig i selve grænseområdet, idet den til siderne begrænses af lavastr $\varnothing$ mme med typisk mellemseriekarakter, hvorimod den overlejres af bænke med фvreseriekarakter.

Der er under karteringsarbejdet hverken blevet iagttaget vents i $\phi$ verste basaltserie eller i nederste basaltserie. Den af WALKER og DAvidson (1936) beskrevne vent ved Froðba står sandsynligvis $\mathrm{i}$ forbindelse med den under den nederste basaltserie omtalte NV-S $\varnothing$ forløbende udbrudsspalte på Suðuroy (RASMUSSEN 1952).

Det må således anses for godtgjort, at de omtalte vents har været tilførselskanaler til den mellemste basaltseries lavaer.

Af kortet, fig. 74 fremgår det, at tuf-agglomeratområderne og dermed de udbrudssteder, som antages at have været tilførende til den nederste basaltserie, og hvis oprindelse og retning var bestemt af et forudgående tektonisk brudlinjesystem, har et NV-S $\varnothing$ forl $\varnothing \mathrm{b}$ ligesom fjordene. Af samme figur fremgår endvidere, at alle iagttagne vents ligger langs de samme NV-S $\varnothing$ forløbende fjorde; der er aldrig blevet observeret vents inde i landet trods gode iagttagelsesmuligheder. Det må derfor antages, at udbrudsvirksomheden under hele vulkanismens forløb har været lokaliseret til disse zoner, og at fjorddannelsen siden har været betinget af det samme brudlinjesystem (RASMUSSEN 1962).

De nederste, henved $200 \mathrm{~m}$ af den mellemste basaltserie er meget varierende af sammensætning, et vigtigt bjergartselement er afyriske lavaer af ganske samme type som i den nederste serie, hertil kommer nu endvidere plagioklasporfyritiske basalter, der i hyppighed tiltager opad, for til sidst at blive den mellemste series hovedbjergart; endelig indgår der lavabænke af olivinrige bjergarter af en type, der først i den $\emptyset$ verste serie bliver dominerende.

Over denne sammensatte, nedre del af den mellemste serie følger henved $500 \mathrm{~m}$ plagioklasporfyritiske lavaer; ca. $700 \mathrm{~m}$ over basis kommer et indslag af mørke, olivinf $\emptyset$ rende basalter omkring B-horisonten, de veksellejrer med plagioklasporfyritiske lavaer. De $\emptyset$ verste ca. $300 \mathrm{~m}$ af mellemserien domineres igen af plagioklasporfyritiske lavaer, men rummer tillige de fleste afvigende bjerg- 


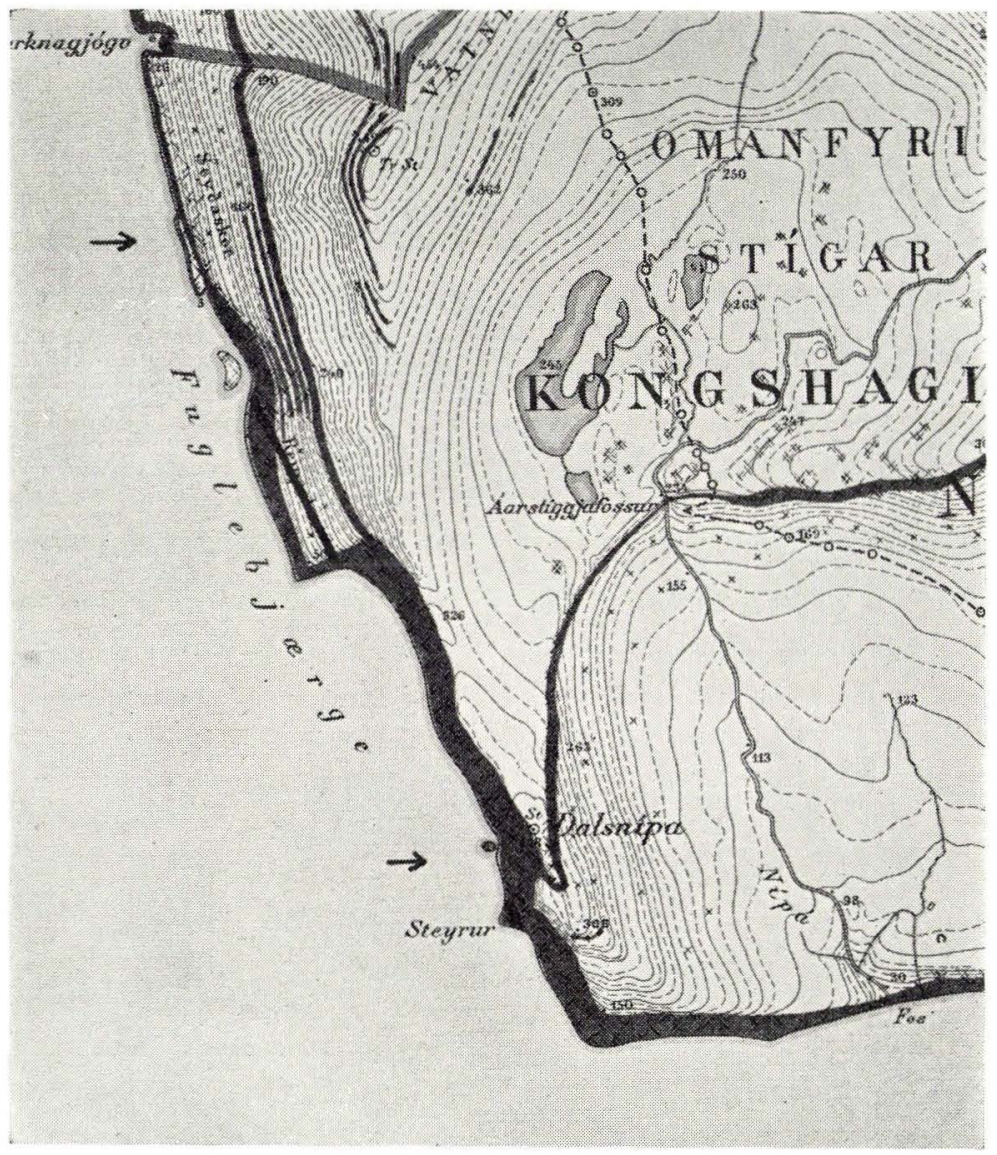

Fig. 67. Dalsnípa, Streymoy. Pilene viser den nordligste og den sydligste iagttagelse af agglomerat.

Goshálsur á Dalsnípuni, Streymoy. Ørvarnir vísa norður- og suðurmarkið. Dalsnipa, Streymoy. The arrows show the northernmost and the southernmost occurences of agglomerate observed.
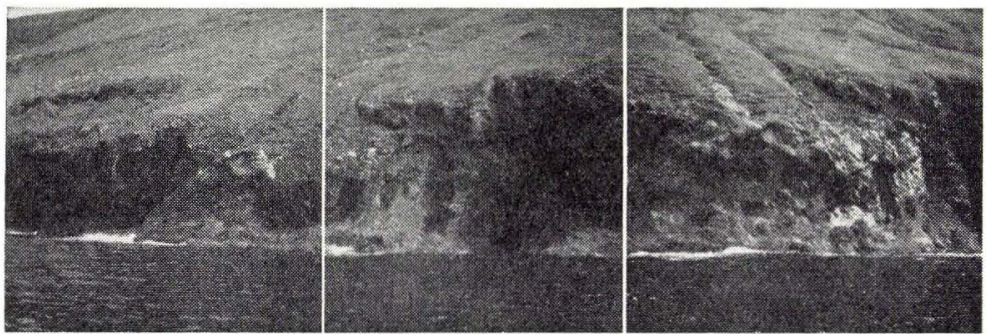

Fig. 68. Vent. Sydvestkysten, Kallsoy.

Goshálsur norðan fyri Lambagjógv, vestantil á Kallsoynni.

Vent. South-west coast of Kallsoy. 
artstyper i plateauet som helhed; i hovedprofilet bemærkes således et par andesitiske lavastr $\varnothing \mathrm{mme}$, Tjørndalsegg 2 og Sneis 11 samt den helt specielle Sneis 14, men også i andre profiler træffes afvigende bjergartstyper på dette sted i lagserien.

De afyriske lavaers petrografier er omtalt under behandlingen af den nederste serie, de olivinf $\phi$ rende vil blive udskudt til behandlingen af $\phi$ verste serie, og vi vil her således i første række holde os til hovedbjergarterne: de plagioklasporfyritiske basalter.

Ved plagioklasporfyritiske basalter forstår vi normalt basalter med et betydeligt antal strøkorn af plagioklas; mængden af disse varierer fra omkring $10 \%$ af hele bjergartsmassen til ca. $30 \%$. Foruden strøkorn af plagioklas indeholder bjergarten nogle få strøkorn af augit, disse er betydeligt mindre end plagioklaserne, og deres antal er ringe. Augitstrøkornene ligger gerne enkeltvis eller parvis sammen med plagioklasstrøkornene, når disse danner klynger.

De porfyritiske basalter, der dominerer mellemserien, har for det meste lys, grå farve og en ru overflade; der er ikke nogen særlig forskel mellem den friske og den forvitrede bjergartsoverflades farve. De porfyritiske lavaer smuldrer for det meste let under forvitringens indflydelse, det giver afrundede fjeldformer og ofte »sandede « talusskråninger.

Der findes nogle få, næsten sorte, porfyritiske lavastrømme i mellemserien, de har glat overflade og danner skarpkantet forvitringsgrus.

Betragtet i mikroskop viser grundmassen helt overvejende intergranular textur.

Magnesiumrig olivin, med en aksevinkel (2 V) på nær ved $90^{\circ}$, kan forekomme, men er altid langt sparsommere til stede end pyroxen. Serpentin og iddingsit kan være udviklet langs randen og langs brede revner i olivinen. Pigeonitrande er ikke udviklet.

Der er ikke påvist rombisk pyroxen i nogen af de porfyritiske basalter, mineralet er kun med sikkerhed fundet i en afvigende bjergartstype af andesitisk sammensætning (Sneis 14).

Clinopyroxen findes som strøkorn, der sjældent er mere end 1-2 mm i tværmål; sammensætningen er den samme som i de afyriske lavaer i den nederste serie. Den positive aksevinkel $(2 \mathrm{~V} \gamma)$ varierer fra $56^{\circ}$ til $38^{\circ}$, tvillingdannelse efter første endeflade (100) er almindelig, og en noget diffus timeglas-struktur er udbredt. Variationen i lysbrydning ( $\mathrm{n} \beta$ ) dækker samme interval som i de afyriske lavaer i nedre serie. Mineralet er augit. Den samlede strøkorns- 


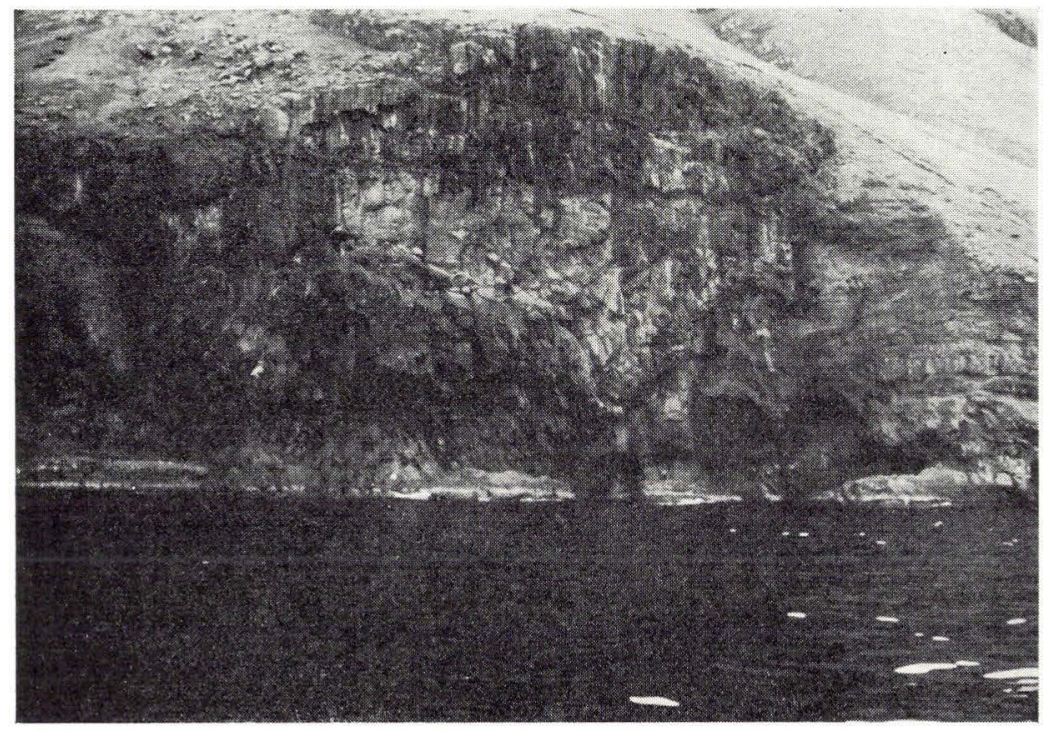

Fig. 69. Vent. Svartiklettur på nordvestsiden af Borðoy. Goshálsur við Svartaklett á Borðoynni.

Vent. Svartiklettur, on the north-west side of Borðoy.

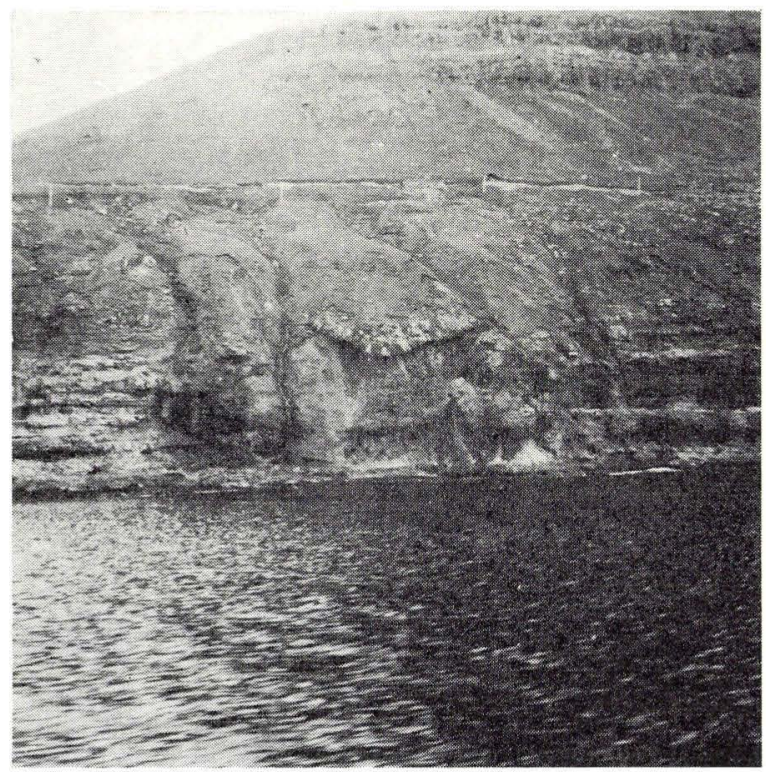

Fig. 70. Vent. Syd for Bygden Viðareiði.

Goshálsur sunnan fyri Viðareiðis bygd. Vent. South of the village of Viðareiði, Viðoy. 
mængde af augit er normalt kun 1-2 \% og overskrider næppe nogensinde $5 \%$.

Grundmassen indeholder både augit og pigeonit.

Plagioklas er det helt dominerende strøkornsmineral, det udgør fra under $10 \%$ til over $30 \%$. De enkelte plagioklasstrøkorn kan nå en længde af omkring $1 \mathrm{~cm}$, meget ofte udgøres et strøkorn af 2-3 individer, der ligger tæt sammen i en klynge. I adskillige lavastr $\varnothing$ mme udg $\varnothing \mathrm{r}$ plagioklasstr $\varnothing$ kornene stjerneformede hobe, der gerne indbefatter et par augitkorn af væsentlig mindre størrelse - halvstrøkorn - disse sidder gerne nær ved sammenvoksningscentret. Endvidere findes der typer af plagioklasporfyritiske lavaer med egentlig sammensatte strøkorn, disse har samme størrelse som almindelige gennemsnitsstr $\varnothing$ korn, men består af et stort antal - undertiden op til 30-40 små individer; også i disse strøkorn kan der findes nogle få små augitkorn og undtagelsesvis et enkelt olivinkorn.

Mange store plagioklasstrøkorn viser en ejendommelig krakelering i tyndslib, og en begyndende omdannelse kan hist og her iagttages.

I de fleste tilfælde er der en klar størrelsesforskel mellem plagioklaserne i strøkorns- og grundmassegenerationerne, men ikke så sjældent kan man finde hel gradvis overgang i størrelse. Plagioklaserne i grundmassen optræder med listeform og ofte med slet afgrænsede ender.

Plagioklasens sammensætning er labrador, anorthitindholdet ligger omkring $66 \%$ i strøkornenes centrale dele (kernerne) og lidt lavere i de ydre zoner, ca. $60 \%$, denne sammensætning svarer til grundmasseplagioklasens. I de meget store plagioklasstrøkorn har kernerne bytownitisk sammensætning.

De sorte malmkorn findes ofte udviklet i to generationer; blandt de større korn af første generation er skeletvækst almindelig.

Glas udgør gennemsnitlig omkring $5 \%$ af bjergarten, men kan nå op på $10 \%$. Brune og gule farver dominerer; i de mest grovkornede bjergarter er glassen undertiden omdannet langs sin ydre grænse eller langs indre porer, hvor dobbeltbrydende borter da forekommer.

Grønne omdannelsesprodukter er for det meste kun underordnet til stede. 

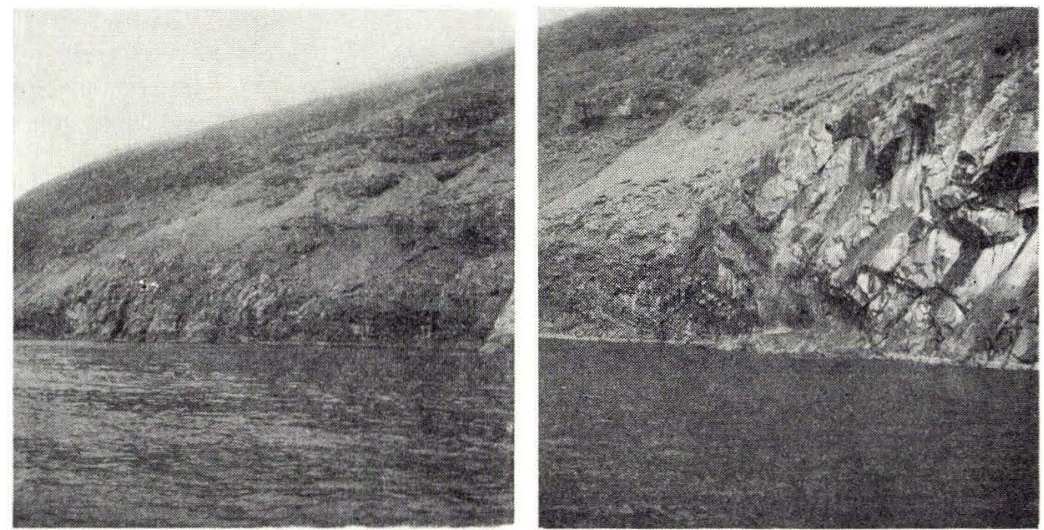

Fig. 71. Vent. Sydvestkysten af Viðoy.

Goshálsur sunnantil á Viðoynni.

Vent. South-west coast of Viðoy.

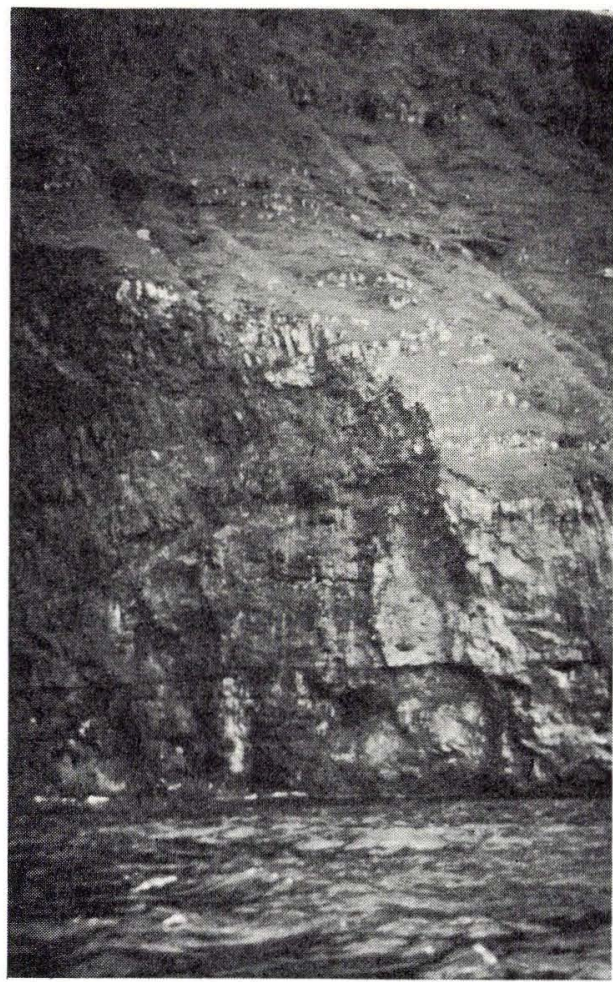

Fig. 72. Lille vent $ø$ st for bygden Kirkja, Fugloy. Litil goshálsur beint eystan fyri bygdina Kirkja, Fugloy. Small vent east of the settlement of Kirkja, Fugloy. 


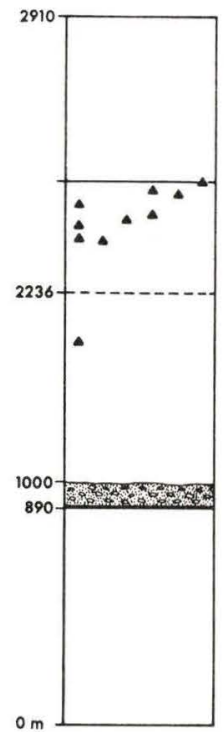

Fig. 73. Forenklet snit gennem den færøske lagserie med indtegnede vents. Goshálsar avmerktir á ein yvirlitsskurð gjфgnum foroysku fláaaskipanina. Simplified section of the Faeroese sequence showing the stratigraphic positions of known vents. 


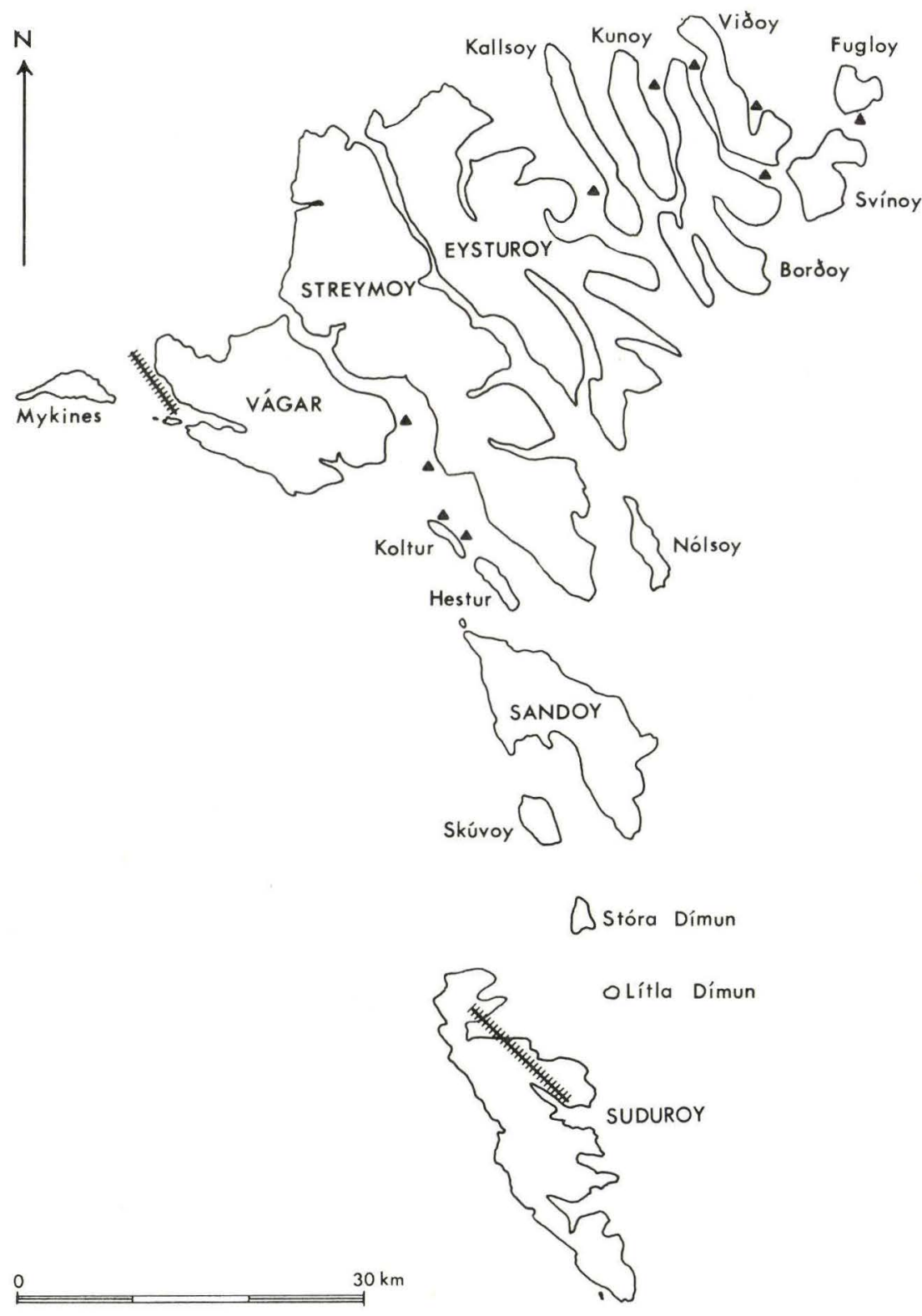

Fig. 74. Tuf-agglomeratzoner og vents. Gosmyrja (goskluftir) og goshálsar.

Tuff-agglomerate zones and vents. 
Kemiske analyser af basalter fra den mellemste basaltserie

\begin{tabular}{lrrr} 
Vægt \% & \multicolumn{1}{c}{1.} & \multicolumn{1}{c}{2.} & \multicolumn{1}{c}{3.} \\
$\mathrm{SiO}_{2}$ & 44,40 & 46,13 & 53,30 \\
$\mathrm{TiO}_{2}$ & 0,75 & 1,05 & 1,70 \\
$\mathrm{Al}_{2} \mathrm{O}_{3}$ & 12,25 & 13,73 & 9,37 \\
$\mathrm{Fe}_{2} \mathrm{O}_{3}$ & 1,50 & 3,03 & 5,09 \\
$\mathrm{FeO}$ & 8,92 & 9,65 & 8,11 \\
$\mathrm{MnO}$ & 0,18 & 0,63 & 0,20 \\
$\mathrm{MgO}$ & 17,66 & 10,32 & 8,60 \\
$\mathrm{CaO}$ & 10,00 & 12,49 & 8,99 \\
$\mathrm{Na} 2$ & 0,95 & 2,40 & 4,12 \\
$\mathrm{~K}_{2} \mathrm{O}$ & 0,25 & 0,05 & 0,37 \\
$\mathrm{P}_{2} \mathrm{O}_{5}$ & 0,04 & 0,16 & 0,14 \\
$\mathrm{H}_{2} \mathrm{O}^{+}$ & 1,60 & 0,56 & 0,04 \\
$\mathrm{H}_{2} \mathrm{O}^{-}$ & 1,60 & 0 & 0,35 \\
$\mathrm{CO}_{2}$ & 0 & n.d. & n.d. \\
\hline & 100,10 & 100,20 & 100,38
\end{tabular}

Katanorm

$\begin{array}{lccc}\text { q } & 0 & 0 & 0,58 \\ \text { or } & 1,49 & 0,30 & 2,20 \\ \text { ab } & 8,58 & 17,80 & 37,18 \\ \text { an } & 28,58 & 26,64 & 6,01 \\ \text { ne } & 0 & 2,29 & 0 \\ \text { ap } & 0,08 & 0,34 & 0,29 \\ \text { en } & 7,36 & 0 & 12,14 \\ \text { fs } & 1,81 & 0 & 3,56 \\ \text { di } & 16,83 & 27,60 & 30,32 \\ \text { fo } & 26,19 & 14,23 & 0 \\ \text { fa } & 6,45 & 6,17 & 0 \\ \text { mt } & 1,58 & 3,18 & 5,35 \\ \text { hm } & 0 & 0 & 0 \\ \text { il } & 1,05 & 1,47 & 3,38\end{array}$

1. Pikritisk basalt (af forf. benævnt ultrafemic olivine basalt), sydøst for Eiði kirke, Eysturoy. Walker og Davidson 1936. Anal. W. H. Herdsmann.

2. Olivinførende basalt (alkali-olivin basalt), Kollur, Eysturoy. Noe-Nygaard og Rasmussen 1957. Anal. Me Mouritzen.

3. Lysegrå, olivinførende basalt, stenbruddet nordvest for Klakksvík. Ibidem. Anal. Me Mouritzen. 


\section{Øverste basaltserie}

Efter endnu en stilstandsperiode af ukendt varighed, indtræder den tredie og sidste, effusive udbrudsperiode, der fører til dannelsen af den $\varnothing$ verste basaltserie. Vulkanismen, som under opbygningen af hele den mellemste basaltserie gør indtryk af at have været kontinuerlig, har igen fået rytmisk karakter, ligesom tilfældet var under dannelsen af den nederste basaltserie.

Den $\emptyset$ verste basaltserie forekommer ikke på Suðuroy, Mykines, Gáshólmur, Tindhólmur og Vágar. Den forekommer heller ikke på den nordlige del af Streymoy eller på den nordvestligste del af Eysturoy. På den фvrige del af фerne overlejrer den, når man ser bort fra nederoderede dal- og fjordområder, overalt den mellemste basaltserie. Langs $\varnothing$ ernes $\varnothing$ stsider, fra Sandoy til Fugloy, er den $\phi$ verste basaltserie praktisk talt enerådende.

Da den $\varnothing$ verste basaltserie, ligesom den nederste basaltserie, er opbygget af regelmæssigt skiftende basalt- og tuflag, finder vi atter her det trappeformede landskab med nøgne afsatser og vegetationsklædte skråflader, men da hverken basaltbænkene eller de mellemlejrede tuflag sædvanligvis når den mægtighed, som er almindelig i nederste basaltserie, er landskabsformen gennemgående mere småtrappet (fig. 75, 76).

Grænsen: mellemste basaltserie - $\emptyset$ verste basaltserie (C-horisonten) svarer, som nævnt i den stratigrafiske oversigt, til underfladen af en række 2-3 eller endnu flere bænke (undtagelsesvis kun én bænk) af tæt, blå basalt, som er adskilte af zeolitfyldte blærezoner, sjældnere tynde tuflag. De fremviser ofte udtalt flydestruktur med flyderiller og udtrukne porer. Horisontbænkenes overside er næsten overalt udformet mere eller mindre som et agglutinat, d. v. s. at overfladen, undertiden også den underliggende overflade, er dækket af en blåviolet skorpe af løse udbrudsprodukter, især sprængstykker, der er sammensvejset af lava (fig. 77).

Hvor lagfølgen omkring C-horisonten er mest typisk, hviler horisontbasaltbænkene på et rødt tuflag, der igen underlejres af en storkornet, i overfladen ofte rødligfarvet, feldspatbasalt med str $\varnothing$ korn, hyppigt af store plagioklaslister. I tuflaget ses tit gulligtfar- 


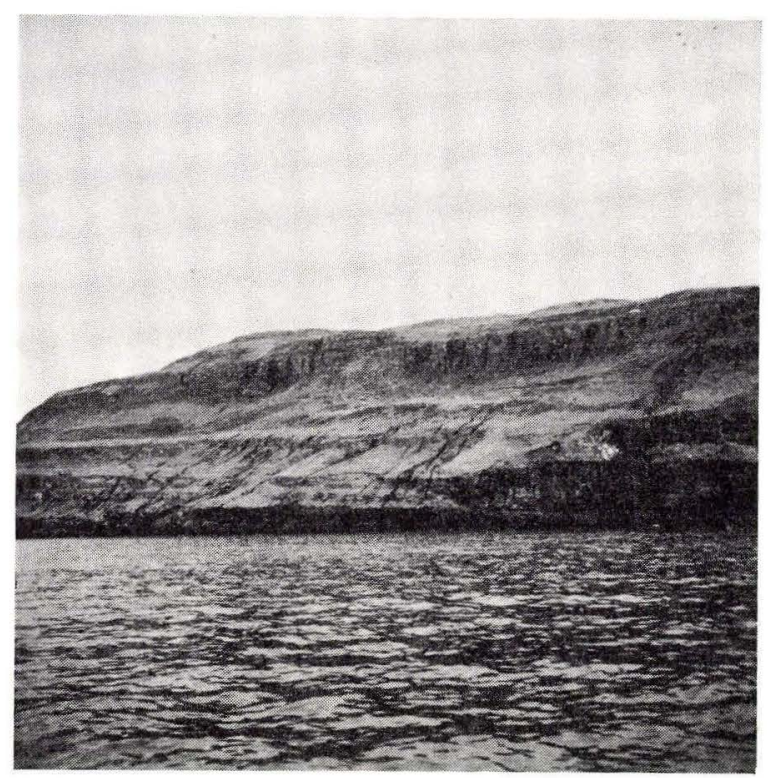

Fig. 75. Typisk småtrappet landskabsform i den øverste basaltserie (Nólsoy). Eyðkent landslag fyri ovaru basaltfláirnar, Nólsoy.

Typical landscape form with low steps in the upper basalt series, Nólsoy.

vede, ubestemmelige aftryk af fragmenterede plantedele. Horisontbasaltbænkene overlejres af en småprikket feldspatbasalt. Der forekommer dog naturligvis ikke sjældent afvigelser fra denne lagfølge.

Grænsen er på kortet optrukket som en sort linje, men visse steder, hvor iagttagelse har været særlig vanskelig eller direkte umulig, er den optrukket som en stiplet linje. Der hvor horisontbasalten, trods gode iagttagelsesmuligheder, er konstateret som manglende eller i hvert fald ganske usikker, er grænseniveauet betegnet med en prikket linje.

C-horisontbænkene er ikke alle vegne flydt ud over en jævn landoverflade; lokalt har erosionen bevaret ujævne hårde partier, der blev omflydt af C-lavaerne, og altså en tidlang har raget op som øer gennem disse.

Når vi ved indtegningen af grænsefladen mellem den mellemste og den $\emptyset$ verste basaltserie på kortet har valgt at se bort fra disse lokale afvigelser, som f. eks. på vestsiden af Koltur og Hestur, på sydvestsiden af Sandoy og på sydsiden af Viðoy, skyldes det, at vi har villet fastholde det generelle grænseniveau over hele området 


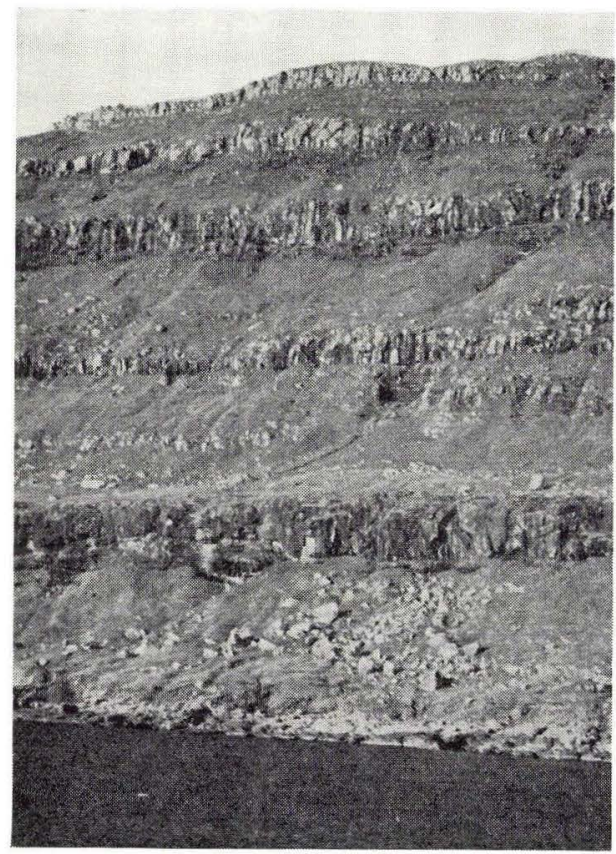

Fig. 76. Basaltbænke i den øverste basaltserie mellem Kaldbak og Kollafjørơur.

Hamrar í ovaru basaltfláunum millum Kaldbaks og Kollafjørð. Lava flows in the upper basalt series between Kaldbak and Kollafiфrður.

for at kunne måle ud fra det, men tillige at afvigelserne i regelen har ringe udstrækning.

Den vulkanske aktivitet i den $\emptyset$ verste basaltserie må have bevæget sig fra $\varnothing$ st mod vest, idet den indledende eksplosivitet kan spores på lavere niveau i lagserien i de $\varnothing$ stlige egne end i de vestlige. På de nordlige фer, omkring Klakksvík, finder vi således eksplosivt materiale under C-horisonten, medens vi mod vest - i området vest for Árnadalstindur - finder eksplosivt materiale fra C-horisonten og opad. Dette vil med andre ord sige, at dersom karteringen af C-horisonten var foregået fra $\emptyset$ st mod vest, i stedet for som tilfældet har været fra vest mod $\varnothing$ st, ville den have fået en noget lavere beliggenhed.

Det underlag, som de første lavastrømme har overflydt, har sandsynligvis dannet en ujævn, svagt skrånende eller hældende lag- 


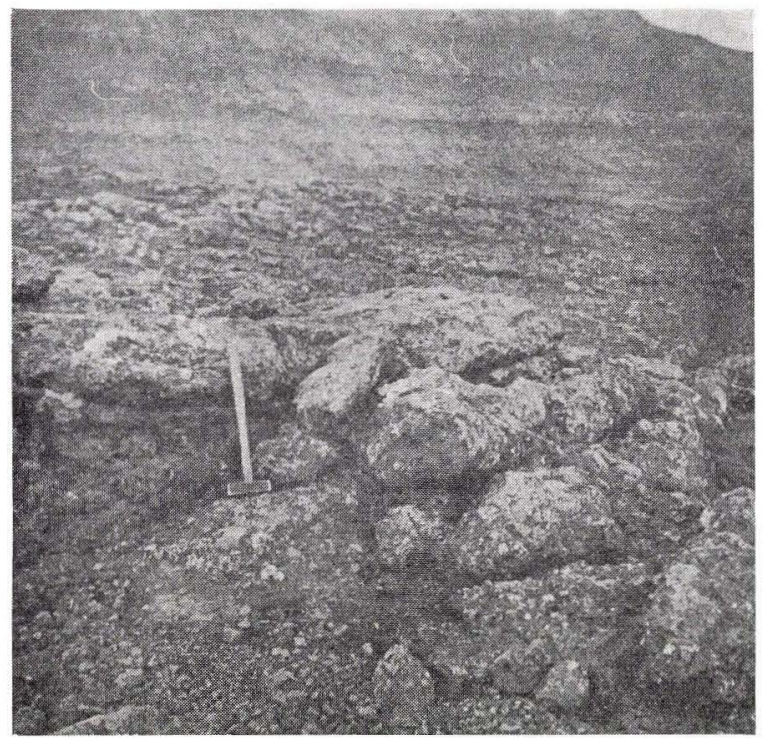

Fig. 77. Agglutinat. C-horisontserien i Bøllufjall, Streymoy. Agglutinat. C-lindin í Bøllufjalli, Streymoy. Agglutinate. C-level flows on Bollufjall, Streymoy.

overflade, idet man på enkelte lokaliteter f. eks. ved nordenden af Hestur og i fjeldvæggen mellem Kaldbaksfjørður og Kollafjørður, kan iagttage nonkonform eller diskordant pålejring af den $\emptyset$ verste series lavaer. Om dette kun skyldes, at en oprindelig ujæun, skrånende eller nederoderet landoverflade er blevet dækket af ny lava, eller der har fundet svage tektoniske bevægelser sted forinden, kan ikke på nuværende tidspunkt afgøres med sikkerhed (fig. 78).

I den tabellariske oversigt over indmålte koter for C-horisonten er der under særlige »bemærkninger « givet en del oplysninger fra dagbogsnotater om lejringsforholdene på det pågældende sted. Der skal derfor ved gennemgangen nu kun gives en generel oversigt over C-horisontens karterede udbredelsesområde og de forhold, der måtte have særlig interesse i denne forbindelse.

Langs фstsiden af Streymoy, fra Sneis og Bollin i nord til Dyllan og Árnadalstindur i syd samt i området mellem Kaldbaksfjørður og Kollafjørður fremtræder C-horisonten i terrænet som en iøjnefaldende, veldefineret linje, der adskiller den for den mellemste basaltserie så karakteristiske bløde, konvekse storlandskabsform, som 


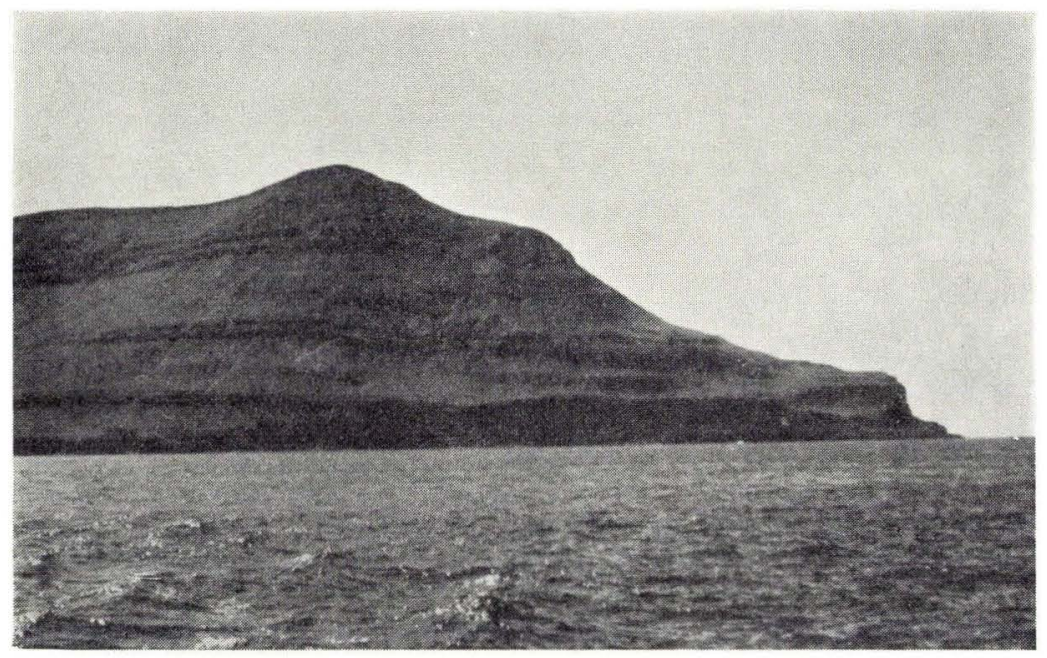

Fig. 78. Nordenden af Hestur.

Hestur norðantil.

North end of Hestur.

er fremherskende på Vágar og Norðstreymoy, og det for den фverste basaltserie typiske bænkede eller »trap«formede landskab. I fjeldvæggen mellem Kollafjørður og Kaldbaksfjørður ses den foran omtalte diskordans særlig tydeligt. Langs vestsiden af Streymoy er forholdene noget mere uklare, fordi den store Streymoysill her gennemskærer horisontbænkene. Disse er tydelige i Sátan og i Trantur-Skælingur, hvor de kan følges sydpå til nordsiden af Gjáarbotnur. Derimod er det slet ikke muligt at genfinde dem i området mellem Gjáarbotnur og Norơradalur, hvor de muligvis er tyndet ud eller blot er fortrængt ved sillintrusionen. Syd for Norðradalur er iagttagelsesmulighederne gennemgående meget dårlige, og niveauet er indtegnet fra båd.

Medens det ikke har voldt synderlige problemer at føre C-horisonten videre mod $\varnothing$ st med tilstrækkelig sikkerhed, har det været langt mere vanskeligt at føre den mod vest og syd, da afstanden mellem фerne i disse retninger er større og grænsen ikke nær så karakteristisk udviklet som på de nordlige фer. Man må derfor her regne med et vist usikkerhedsmoment.

På Koltur er der blevet målt 3 koter på den formodede horisont, der iøvrigt for størstedelen er indtegnet fra båd. På nordsiden 
af Hestur findes, som tidligere nævnt, ukonform eller diskordant overlejring, idet lagene mellem Ormur og Hestboði hælder omtrent SV, medens den sydligere del af $\varnothing$ en har $\varnothing \mathrm{S} \varnothing$ laghældning. Horisontbænken, der går i havet nord for landingsstedet ved bygden, kan følges vestpå til nord for Byrgisstakkur, hvor den tynder ud. C-horisontniveauet kan derefter følges i fjeldvæggen, til det når havniveau nord for Loftið. Grænsen mellem de to serier er på Koltur og Hestur meget ujævn og delvis udvisket, men C-horisontniveauet er på kortet her, ligesom andre steder, hvor der forekommer lokale afvigelser, blevet bibeholdt. På den nordlige del af Sandoy er grænsen mellemste basaltserie - $\emptyset$ verste basaltserie tydelig, men horisontbasalten er i dette område en storkornet feldspatbasalt. Mod syd bliver grænsen derimod mindre typisk, syd for Søltuvík består hele fjeldvæggen - bortset fra et par enkelte bænke - af mellemserietype. På Skúvoy underlejres den formodede horisontbænk, der også her er en storkornet feldspatbasalt, af et rødt, ca. 1 meter tykt tuflag. På store og lille Dímun har beliggenheden af C-horisontniveauet kun kunnet beregnes.

Fra Sundalagið (sundet mellem Streymoy og Eysturoy) og østpå bliver det ret almindeligt, at enkelte bænke under C-horisontniveauet står frem i terrænet. Mellem Nøvin, nord for Oyri, og Reyðafellstindur gennemskæres horisontbasaltbænkene af den store Eysturoysill. C-horisontforløbet på den nordlige del af Eysturoy illustreres bedst af fig. 80 Blámannsfjall, Nón, Vaðhorn, Slættaratindur, Gráfelli, Middagsfjall og Tyril set fra Húsafjall, fig. 81 Middagsfjall, Gráfelli, Sandfelli set fra Tyril og fig. 82 Mannssetur-Gráfelli. Ligeledes ses dens forløb i området nord og vest for Fuglafjørður af fig. 83, nordsiden af Jøkladalur set fra Gjógvará og fig. 84 Hjarðardalur. På den sydligste del af Eysturoy har det voldt ret store vanskeligheder at få C-horisonten karteret, idet horisontbænkene dels er atypiske, dels er stærkt dækket af løse jordlag og endelig undertiden direkte mangler.

På de nordlige øer fremtræder C-horisonten over betydelige strækninger ret tydeligt i terrænet (fig. 85, 86). På den nordligste del af Kallsoy og den nordligste del af Viðoy er horisontbasalten dog så tvivlsom, at grænsen er indtegnet prikket. I de stejle nordvendte fuglefjelde er grænsen: mellemste basaltserie - $\varnothing$ verste basaltserie undertiden tydelig, undertiden noget udvisket. På nordenden af Viðoy, hvor den ellers ikke er umiddelbart let at få $\varnothing j e$ på i fjeldvæggen, er den således ganske tydelig ved Enniberg og nord for 


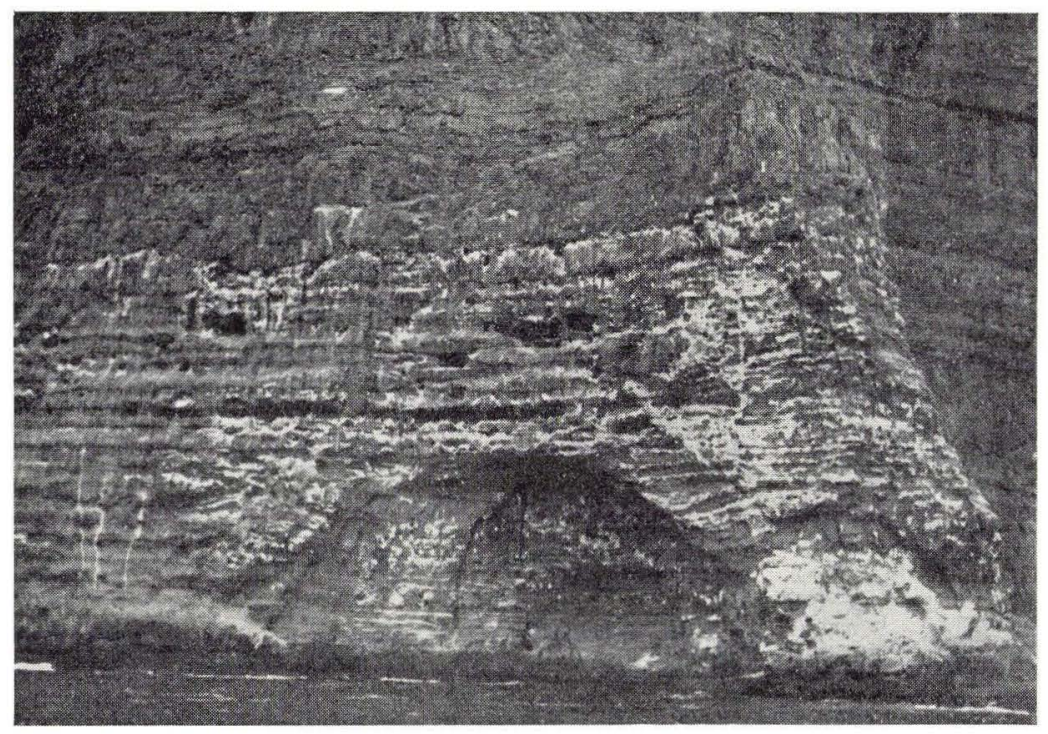

Fig. 79. C-horisonten på nordvestsiden af Sandoy markeres tydeligt af fugleekskrementer, idet fuglene her aldeles overvejende bebor den mellemste basaltserie.

C-lindin. Markið millum miðfláirnar og ovaru basaltfláirnar sast skilliga her, tí fuglurin býr mest i miðfláunum. Vestantil á Sandoynni.

The position of the C-level on the north-west side of Sandoy is clearly marked by the distribution of bird dung. The birds nest almost exclusively in the middle basalt series.

Eiðsvík. På sydsiden af Viðoy og overfor på den modsatte side af Hvannasund, på Borðoy, er grænsen: mellemste basaltserie - $\emptyset$ verste basaltserie meget fremtrædende, til trods for at selve horisontbasalten er noget problematisk, idet der lokalt, umiddelbart under C-horisontniveauet, optræder en række bænke, der er af samme type som horisontbasalten.

Bænktykkelserne er i den $\emptyset$ verste basaltserie gennemgående mindre end i den nederste basaltserie, men dog betydelig større end lavaernes mægtighed i den mellemste basaltserie. En opmåling af 15 bænke i Kirkjubøreyn på den sydlige del af Streymoy gav en gennemsnitstykkelse på ca. $9 \mathrm{~m}$, en opmåling af 13 bænke i Villingadalsfjall på den nordlige del af Viðoy en gennemsnitstykkelse på ca. $8 \mathrm{~m}$. En optælling af bænke i den lodrette fjeldvæg på østsiden af Svínoy (Eysturhøvdi, Høvdin, Áarberg) og division af bænkantallet op i fjeldhøjden på stedet giver gennemsnitstal, 


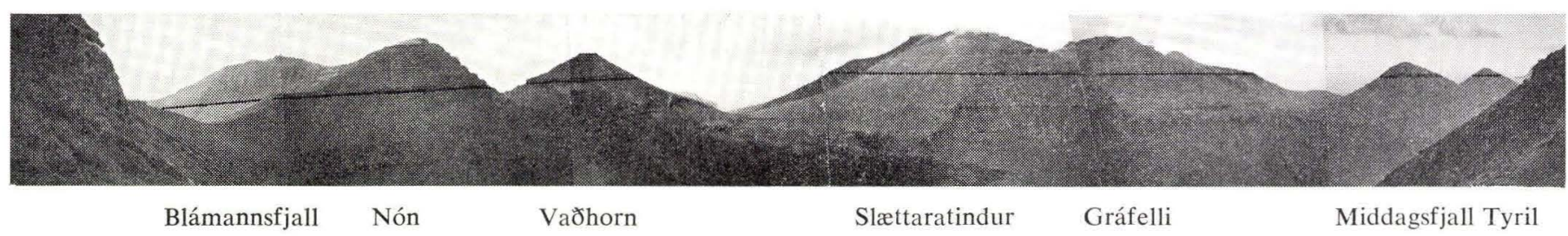

Fig. 80. C-horisonten i Blámannsfjall, Nón, Vaðhorn, Slættaratindur, Gráfelli, Middagsfjall og Tyril.

C-lindin í Blámannsfjalli, Nón, Vaðhorni, Slattaratindi, Gráfelli, Middagsfjalli og Tyrli.

The C-level on Blámannsfjall, Nón, Vađhorn, Slattaratindur, Gráfelli, Middagsfjall and Tyril. 


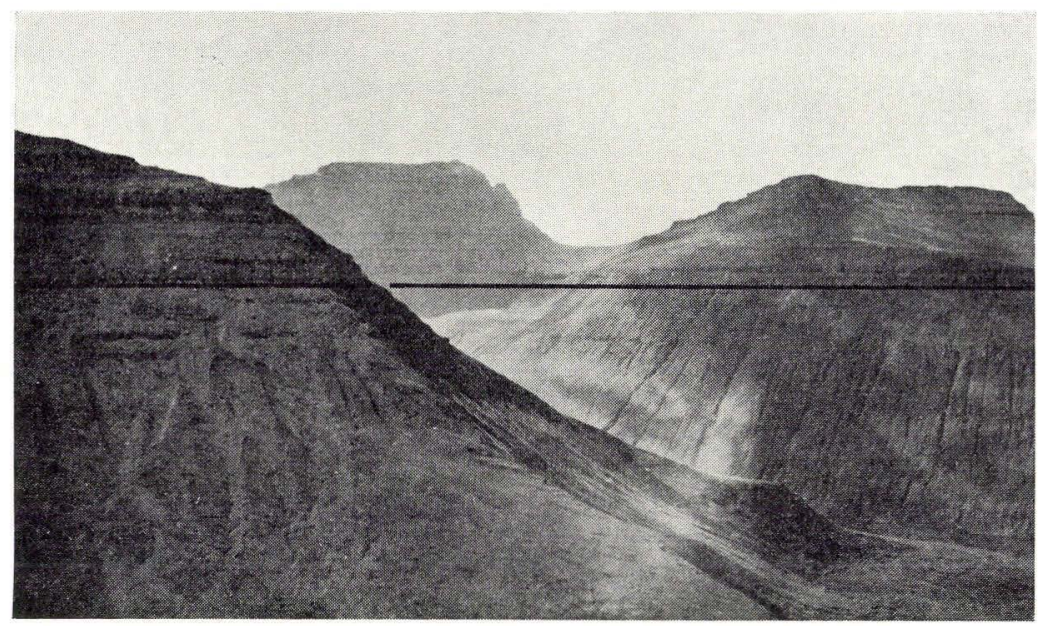

Fig. 81. C-horisonten i Middagsfjall, Gráfelli og Sandfelli.

C-lindin í Middagsfjalli, Gráfelli og Sandfelli.

The C-level on Middagsfjall, Gráfelli and Sandfelli.

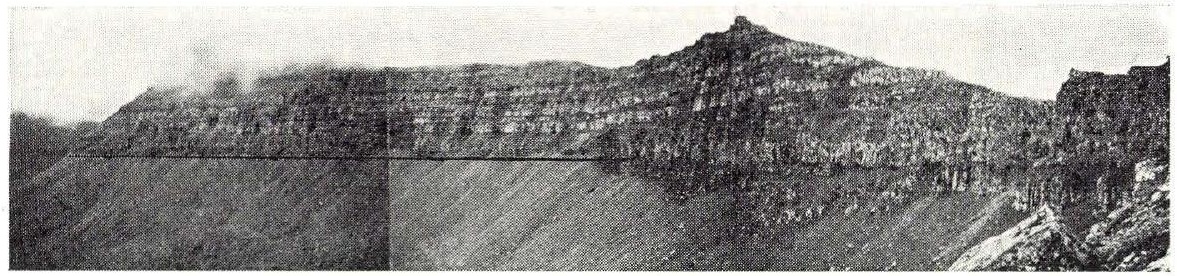

Fig. 82. C-horisonten i Mannssetur-Gráfelli.

C-lindin í Mannssetri og Gráfelli.

The C-level on Mannssetur - Gráfelli.

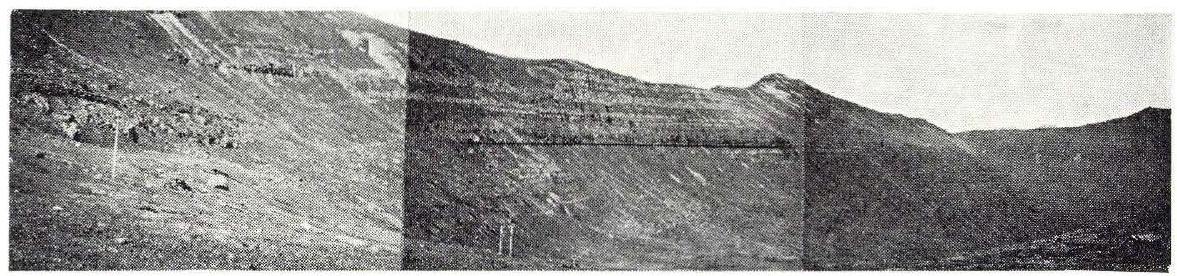

Fig. 83. C-horisonten i nordsiden af J $\varnothing$ kladalur.

C-lindin norðantil í Jøkladali.

The C-level on the north of Jokladalur. 
der varierer fra 10 til godt $11 \mathrm{~m}$. Det er indlysende, at disse sidste tal let kommer til at blive lidt for høje; dels vil det ikke altid lykkes at tælle de højest beliggende bænke med og dels er brændingshorisonter og tuflag medregnet, fordi de ikke kan udskilles på afstand. Et profil langs Stórá op mod Knúkur (Svínoy) 340-455 m gav et lignende resultat, nemlig $10,5 \mathrm{~m}$, også her er mellemlejrede tuflag og brændingshorisonter medregnet. Alment kan det siges, at bænktykkelsen for den $\varnothing$ vre del af serien ligger mellem 5 og $10 \mathrm{~m}$ med udsving til begge sider. I den nedre del af serien er bænktykkelsen ikke sjældent større end højere oppe. Området ved Tórshavn f. eks. består således kun af tykke bænke feldspatbasalt (Walker og Davidson: »Torshavn type«), hvoraf den ene, den der forløber langs havnen, måler ca. $30 \mathrm{~m}$. Undertiden ses, særlig tydeligt på de nordlige øer, indslag af mellemserielignende lavaer i $\emptyset$ verste basaltserie. Bænke af tæt, blå basalt tynder langsomt ud og bliver ganske flade til sidst, de mere viskose feldspatbasaltbænke holder derimod pludseligt op med en mere but udkiling. På vestsiden af Borðoy ser man flere sådanne »lamellerede serier «, der på $\emptyset$ stsiden af $\varnothing$ en forenes, idet de adskillende bænke tynder ud i $\emptyset$ stlig retning.

De enkelte bænke i den $\varnothing$ verste serie er sædvanligvis tydeligt adskiit fra hinanden af brændingshorisonter og tuf, bortset fra de næunte indslag af mellemserielignende lavaer »lamellerede serier «. Søjledannelse forekommer, men den er gennemgående svag og uregelmæssigt udviklet. Flydestruktur ses tydeligst i bænke af tæt, blå basalt.

De interbasaltiske dannelser omfatter i det væsentlige tuf og tuffoide lersedimenter. Tuflagene skifter stærkt med hensyn til mægtighed, konsistens og farve. Mægtigheden varierer almindeligvis fra brøkdele af $1 \mathrm{~m}$ op til 3-4 $\mathrm{m}$, konsistensen fra finkornet og fast til sandet og mere $1 \varnothing \mathrm{s}$, og farven fra gullig over brunlig til stærkt r $\varnothing \mathrm{d}$, undertiden grønlig. Tuffen indeholder ikke sjældent spredt forekommende, svage aftryk af ubestemmelige planterester, således f. eks. et tuflag under den NV-S $\varnothing$ strygende stejle basaltbænk i Húsahagi ca. 1,5 km udenfor byen Tórshavn, hvor der er fundet aftryk, sandsynligvis af en Sequoiagren (Noe-NygaARD, 1940). De tuffoide lersedimenter opnår ofte betydelig større mægtighed, ikke sjældent en halv snes meter eller der omkring; de varierer også i konsistens og farve. Flere af disse tuf-lerserier har tidligere været brudt med eksport for $\emptyset \mathbf{j e}$, særlig en sedimentserie ved Hósm $\varnothing 1$ på 


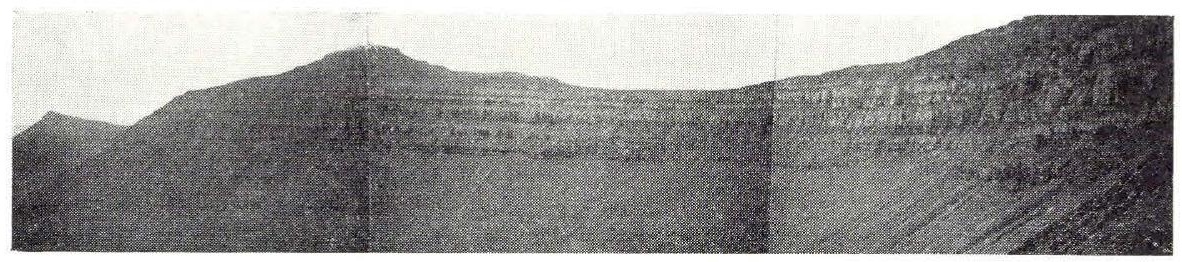

Fig. 84. C-horisonten i Hjarðardalur.

C-lindin í Hjarðardali.

The C-level on Hjarđardalur.

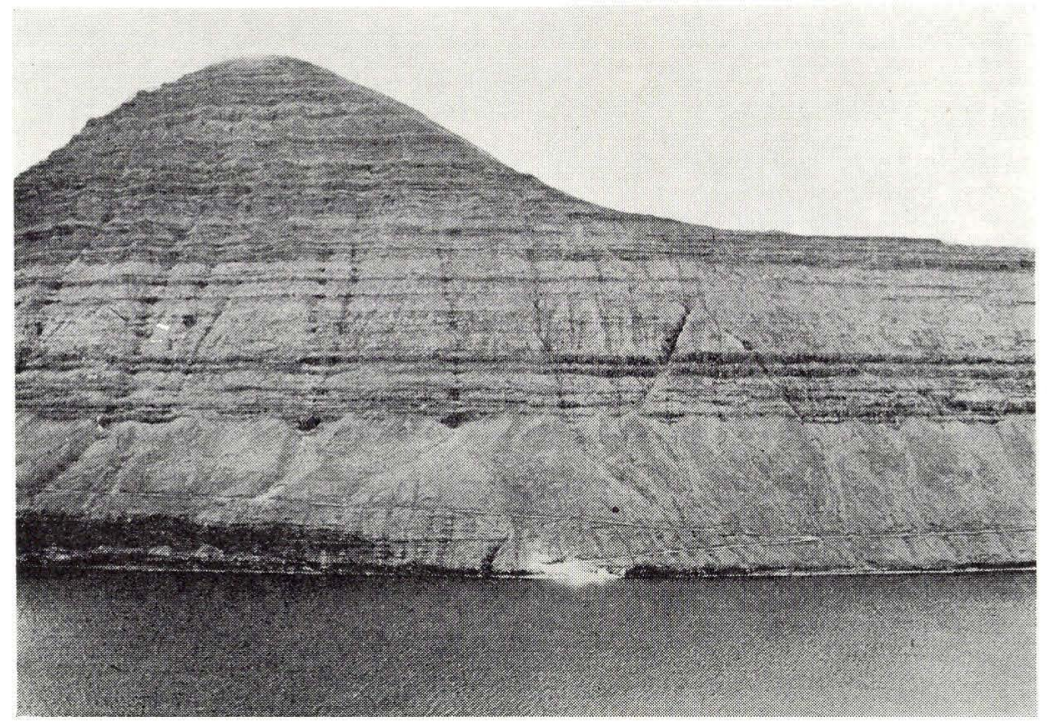

Fig. 85. Mellemste basaltserie - Øverste basaltserie (Malinsfjall, Viðoy). Markið millum miðfláirnar og ovaru basaltfláirnar i Malinsfjalli á Viðoynni. The middle basalt series and the upper basalt series, Malinsfjall, Viðoy.

Nólsoy, een på sydenden af Sandoy og, i mindre grad, en sedimentserie nord for Skálavík på Sandoy.

Der skal som eksempel gives et profil gennem tuf-lerserien på Hósmøl, Nólsoy. Profilet er blevet opmålt lige indenfor Flesin á Hósmøl (fig. 87, 88):

Hængende: Basaltbænk, 3 m tyk.

$350 \mathrm{~cm}$ : Overvejende okkerfarvet ler, gennemsat i alle retninger af småsprækker, der for det meste viser en belægning af brun farve. 


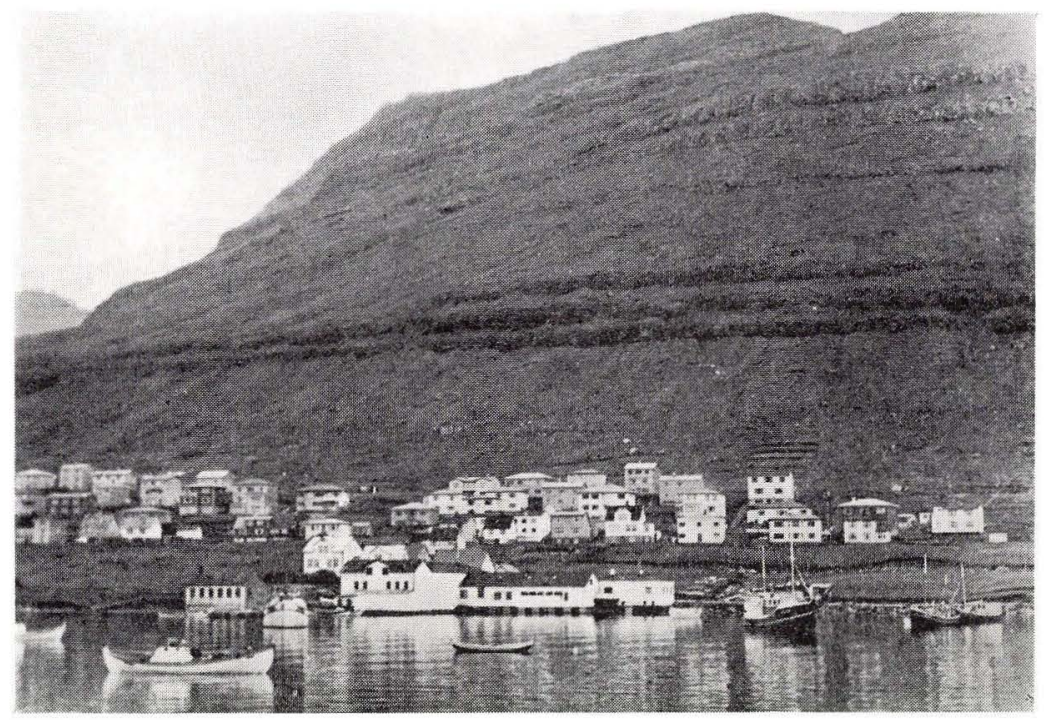

Fig. 86. C-horisontbænkene (Klakksvík). C-lindin, Klakksvík.

The C-level flows at Klakksvík.

$185 \mathrm{~cm}$ : Overvejende gulligt ler af samme beskaffenhed. I den $\emptyset$ vre del findes nogle mørkere bånd.

$85 \mathrm{~cm}$ : Stejlvægđannende, sortegråt sediment, der springer med splintet brud; bjergarten består af langt grovere materiale end foregående og har nærmest sandet eller gruset karakter.

$60 \mathrm{~cm}$ : Veksellejrende lysebrune-okkerfarvede og gule tuf-lerlag.

$10 \mathrm{~cm}$ : Hårdt, groft, rødlig-violet lag med inkrustationer af zeolitisk materiale.

$80 \mathrm{~cm}$ : Veksellejrende lysebrune-okkerfarvede og ganske lyse gullige lag.

$10 \mathrm{~cm}$ : Hårdt, groft, rødlig-violet lag med inkrustationer af zeolitisk materiale.

$36 \mathrm{~cm}$ : Veksellejrende brunlige og gullig-grønne tuf-lerlag.

$68 \mathrm{~cm}$ : Hårdt, lysebrunt skiferler indeholdende et par grønlige, mere grovkornede mellemlag.

Over denne serie, men adskilt fra den og fra hinanden indbyrdes af basaltbænke, findes endnu to serier af lignende karakter og mægtighed, således går bunden af den nederste serie i havet umiddel- 


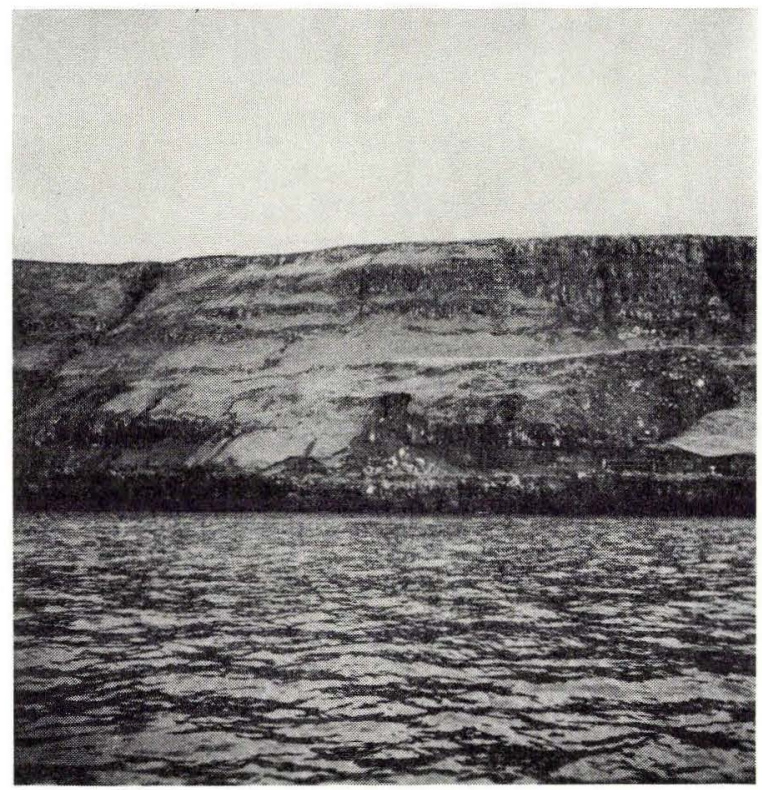

Fig. 87. Tuf-lerserien på Hósmøl (Nólsoy). Royðuleirgrýtislindin á Hósmøl, Nólsoy. Tuff-claystone series at Hósmфl, Nólsoy.

bart syd for Flesin á Hósmøl, af den midterste serie ca. $500 \mathrm{~m}$ sydligere og af den фverste serie endnu ca. $650 \mathrm{~m}$ sydligere. På $\varnothing$ stsiden af фen går bunden af den nederste serie i havet ca. 500 $\mathrm{m}$ syd for Bólstaðtangi, af den midterste serie ca. $700 \mathrm{~m}$ sydligere og af den $\varnothing$ verste serie igen ca. $600 \mathrm{~m}$ sydligere. Den nederste serie ligger i ca. $100 \mathrm{~m} \mathrm{~h} \varnothing \mathrm{jde}$ ved vardestien, der fra Nólsoyarbygd går sydpå op over фen.

Sedimentserien på den sydlige del af Sandoy har været genstand for brydning såvel ved bygden Dalur som ved Dalsnípa. Lagfølgen er fra neden: Brun tuf, gråbrun tuf, rød eller rødbrun tuf. Mægtigheden af de tre lag er, taget som et gennemsnit af seks målte profiler, henholdsvis $142 \mathrm{~cm}, 30 \mathrm{~cm}, 250 \mathrm{~cm}$. Det er kun den nederste brune tuf, der er blevet udnyttet.

Der skal nævnes endnu en tuf-lerserie af betydelig mægtighed. Den ligger i sydøstsiden af Hálgafelli på Borðoy i godt $420 \mathrm{~m}$ højde; den er ca. $8 \mathrm{~m}$ tyk, farven er nederst lysegul, opad mere brunlig, фverst lys rødlig. Bjergarten, der taget i sin helhed er 


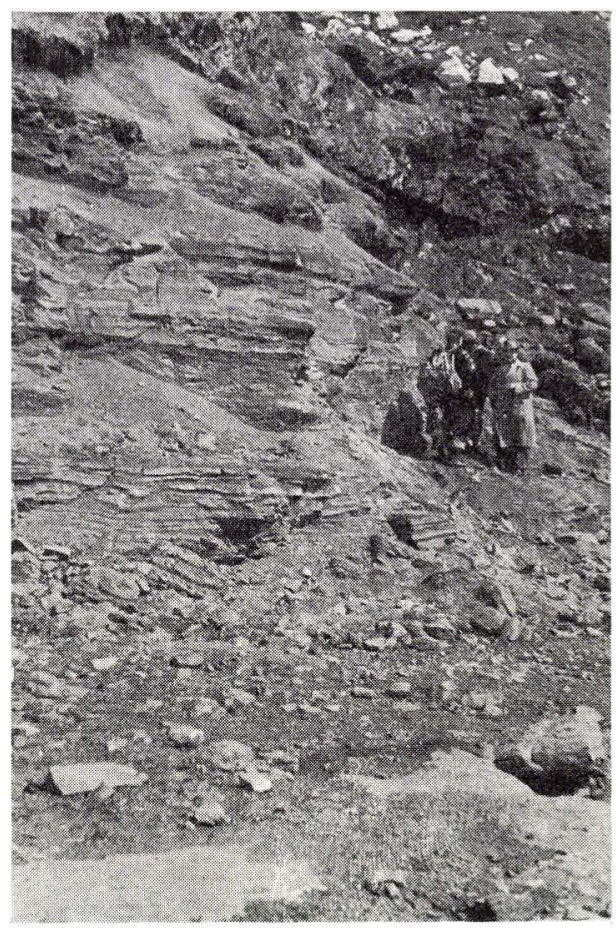

Fig. 88. Tuf-lerserien på Hósmøl (Nólsoy). Royðuleirgrýtislindin á Hósmøl, Nólsoy. Tuff-claystone series at Hósmфl, Nólsoy.

temmelig grovklastisk, indeholder tynde lag af småsten. Det er muligvis den samme serie, der ses i Kunoyarnes i ca. $510 \mathrm{~m}$ højde, også her med en mægtighed på ca. $8 \mathrm{~m}$, og i Gøtunestindur på Eysturoy i ca. $460 \mathrm{~m}$ højde, med en mægtighed på 6-8 m.

Som omtalt s. 212 hviler lavaerne i den $\varnothing$ verste basaltserie transgressivt på mellemste series lavaer; den større hyppighed på afvigende, men gennemgående lystfarvede lavastrømme i den aller$\varnothing$ verste del af mellemserien danner en klar kontrast til den $\emptyset$ verste series mørke, ofte blålige lavaer, i hvilke olivin tit er synlig allerede i marken. Grænsen imellem mellemste og фverste basaltserie er i første række lagt af geologiske grunde: En stilstand i den vulkanske aktivitet $i$ en periode og derefter fornyet vulkanvirksomheds begyndelse efter en svag vipning mod $\varnothing$ st af det indtil da dannede lava- 
plateau. Men tillige sker der et omslag i lavaernes sammensætning, således at også petrografiske grunde støtter den foretagne tredeling af den færøske lagserie. Den nye vulkanske aktivitet indledes i $\varnothing$ st og rykker efterhånden vestpå, s. 212. De nye lavaer fra den $\emptyset$ verste serie danner på en måde en afstøbning af topografien i den mellemste series overflade.

Den $\varnothing$ verste basaltserie falder petrografisk i tre hoveddele, henholdsvis XIa, XIb og XIc. Af disse er bjergarterne XIb ganske overensstemmende med mellemseriens plagioklasporfyritiske basalter, et par storfeldspatbasalter forekommer, og også en andesitisk lava, der stærkt minder om lignende bjergarter $\varnothing$ verst i mellemserien, er til stede, Vil. 6.

Hovedbjergarten i den $\emptyset$ verste basaltserie er imidlertid den, som udgør profilstykkerne XIa og XIc i hovedprofilet med undtagelse af den allerøverste bænk (Vil. 23). Det er følgelig den, vi her først og fremmest vil omtale.

De olivinførende basalter i den $\varnothing$ verste basaltserie er mørke, ofte blåsorte bjergarter, i første række dem, der hentydes til med det færøske lokalnavn blágrýti; de er hårde og seje og har ofte en slags vandret liggende skiveformet opbygning, der fremhæves af udtrukne zeolitfyldte mandler. Ved slag dannes glatte brudflader; bjergarten viser ved kløvning tilbøjelighed til at danne flade brudstykker - skiver -, som er parallelle med lavabænkens over- og underside.

De fleste af lavaerne indeholder en vis mængde strøkorn af plagioklas og olivin dog altid mindre og færre end i de plagioklasporfyritiske lavaer; ofte er plagioklasstrøkornene sammensat af mange små individer; olivinen er i regelen synlig med det blotte фje (fig. 89).

Under mikroskop ses grundmassens textur overvejende at være ofitisk (fig. 89 b) eller subofitisk, enkelte eksempler på intergranular textur (fig. 89 a) forekommer dog.

Magnesiumrig olivin med $2 \mathrm{~V}=$ ca. $90^{\circ}$ dominerer blandt str $\phi$ kornene, for det meste er den ganske frisk. I nogle tilfælde er olivinen i besiddelse af tykke opakrande, i andre forekommer disse ikke. Individer, der har søjleform og længder op til 3,3 mm (fig. 4 e) kan helt præge én bjergart, medens oliviner med en ganske anden, bred habitus (fig. $4 \mathrm{f}$ ) helt præger en anden, undertiden kan begge former dog findes side om side i ét og samme præparat. Mange olivinstrøkorn viser tydelig afrunding, og ikke ualmindeligt forekommer resorptionsindbugtninger og -kanaler (fig. 4 e). Kun i få tilfælde 


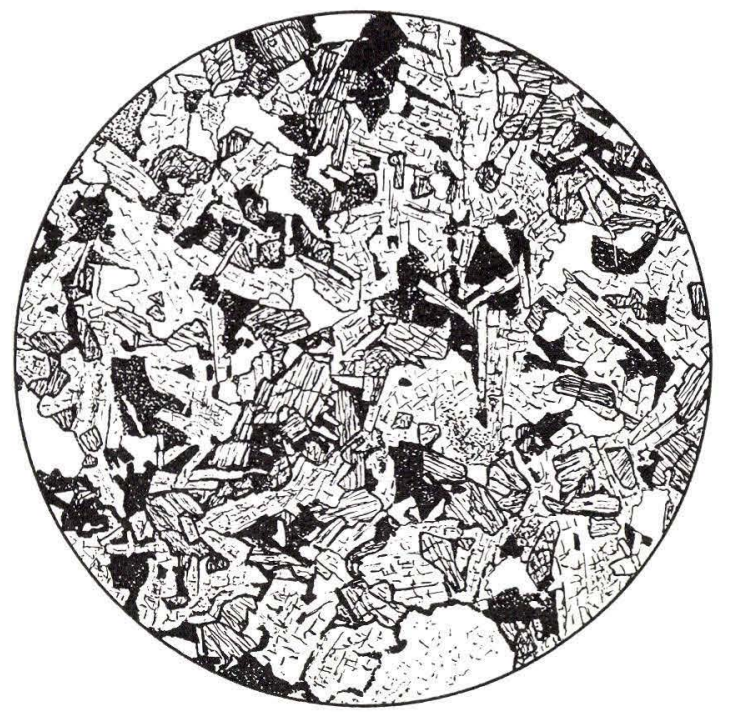

Fig. 89a. Intergranular textur. $14 \times$ Forst. Profil VIII. no. 5.

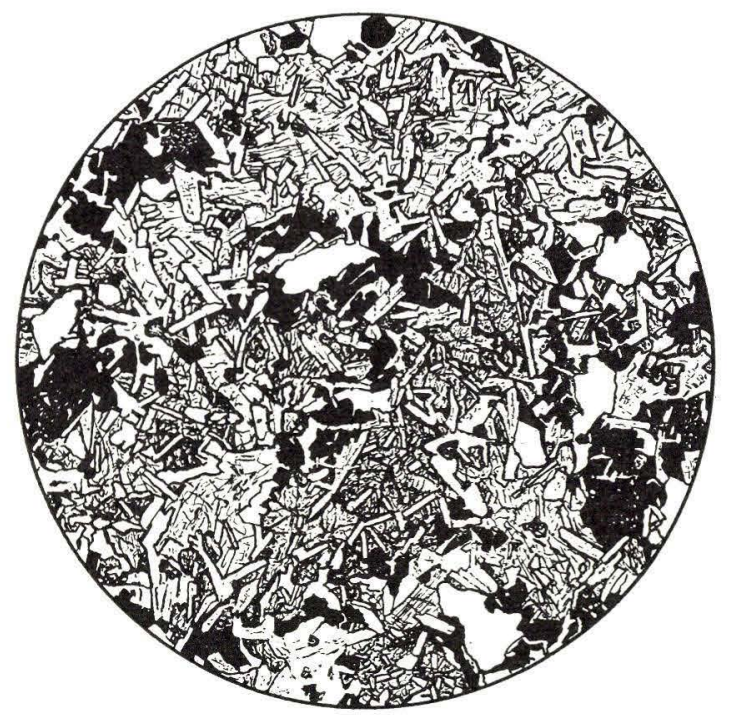

Fig. 89 b. Ophitisk textur. $14 \times$ Forst. Profil 26. no. 9 . 
optræder olivin alene som grundmassebestanddel, dens jernindhold er da en lille smule højere end normalt.

Rombisk pyroxen er ikke påvist.

Den monokline pyroxen er en augit, pigeonit har endnu ikke kunnet eftervises i nogen af grundmasserne.

Plagioklasstr $\varnothing$ kornene er bytownitiske af sammensætning og indeholder i gennemsnit $84 \%$ an i kernen, $64 \%$ i den yderste zone, hvilket temmelig nøje svarer til den sammensætning, grundmasseindividerne har.

Størstedelen af malmkornene er små og ækvidimensionale, de forekommer mindre talrigt end i de porfyritiske og de afyriske lavaer.

Glas er i mange tilfælde overhovedet ikke til stede; forekommer glas, er det kun i meget små mængder. Grønne omdannelsesprodukter findes ligeledes kun sjældent.

De olivinf $\varnothing$ rende basalter, der begynder at optræde allerede i den skiftende serie, der danner den indledende fase til den mellemste basaltserie, og som gennem enkeltstrømme nu og da forekommer i de plagioklasporfyritiske lavaserier i mellemserien, ganske særlig udtalt nær B-niveauet, adskiller sig ikke fra den $\varnothing$ verste basaltseries olivinførende basalter. Den givne beskrivelse af disse dækker derfor også de tidligere dannede, olivinførende basalter.

Enkelte lavaer af olivinførende basalt kan være så rige på olivinstrøkorn, at de må klassificeres som pikritbasalter og tydes i analogi med storfeldspatbasalterne i den porfyritiske lavagruppe, nemlig som opstået ved akkumulation af et tidligt dannet mineral - her olivin i smelten. Ganske særlig hyppige er disse pikritbasalter i et område ved Eiði på det nordlige Eysturoy, hvor deres plads i lagserien er omkring B-niveauet i den mellemste serie.

I den $\varnothing$ verste basaltserie optræder en pikritbasaltisk bænk i profil 26, en anden på Kunoy ud mod Haraldssund i ca. 500 m højde.

Kemiske analyser af basalter fra den $\emptyset$ verste basaltserie

\begin{tabular}{lrrrrrr} 
Vægt \% & \multicolumn{1}{c}{1.} & \multicolumn{1}{c}{2.} & \multicolumn{1}{c}{3.} & \multicolumn{1}{c}{4.} & \multicolumn{1}{c}{5.} & \multicolumn{1}{c}{6.} \\
$\mathrm{SiO}_{2}$ & 42,62 & 46,40 & 47,58 & 48,05 & 48,09 & 48,10 \\
$\mathrm{TiO}_{2}$ & 1,98 & 3,05 & 2,72 & 4,42 & 3,58 & 2,50 \\
$\mathrm{Al}_{2} \mathrm{O}_{3}$ & 12,11 & 16,30 & 17,12 & 13,64 & 13,23 & 16,01 \\
$\mathrm{Fe}_{2} \mathrm{O}_{3}$ & 6,56 & 3,60 & 3,03 & 8,43 & 10,77 & 3,47 \\
$\mathrm{FeO}$ & 3,40 & 7,17 & 8,73 & 3,70 & 2,90 & 7,16 \\
& & & & & & (Fortsættes)
\end{tabular}


(Fortsat)

\begin{tabular}{|c|c|c|c|c|c|c|}
\hline Vægt \% & 1. & 2. & 3. & 4. & 5. & 6. \\
\hline $\mathrm{MnO}$ & 0,24 & 0,23 & 0,14 & 0,24 & 0,26 & 0,15 \\
\hline $\mathrm{MgO}$ & 17,54 & 6,00 & 5,18 & 6,45 & 6,49 & 6,00 \\
\hline $\mathrm{CaO}$ & 9,75 & 11,04 & 10,12 & 10,91 & 10,32 & 10,55 \\
\hline $\mathrm{Na}_{2} \mathrm{O}$ & 1,12 & 2,14 & 3,89 & 2,21 & 2,27 & 2,50 \\
\hline $\mathrm{K}_{2} \mathrm{O}$ & 0,34 & 0,29 & 0,86 & 0,61 & 0,83 & 0,30 \\
\hline $\mathrm{P}_{2} \mathrm{O}_{5}$ & n.d. & 0,23 & 0,41 & 0,28 & 0,27 & 0,10 \\
\hline $\mathrm{H}_{2} \mathrm{O}^{+}$ & 3,33 & 1,10 & 0,13 & 0,84 & 0,78 & 2,30 \\
\hline $\mathrm{H}_{2} \mathrm{O}^{-}$ & 1,26 & 2,40 & 0,06 & 0,71 & 0,53 & 1,00 \\
\hline $\mathrm{CO}_{2}$ & n.d. & 0 & n.d. & n.d. & n.d. & 0 \\
\hline $\mathrm{S}$ & 0 & spor & 0 & 0 & 0 & 0 \\
\hline $\mathrm{CuO}$ & n.d. & n.d. & n.d. & n.d. & n.d. & 0 \\
\hline & 00,25 & 99,95 & 99,97 & 100,50 & 100,32 & 100,14 \\
\hline
\end{tabular}

Katanorm

$\begin{array}{lcccccc}\text { q } & 0 & 2,45 & 0 & 6,23 & 6,08 & 2,48 \\ \text { or } & 2,05 & 1,81 & 5,12 & 3,75 & 5,11 & 1,86 \\ \text { ab } & 10,29 & 20,28 & 29,17 & 20,66 & 21,25 & 23,50 \\ \text { an } & 27,63 & 35,91 & 26,94 & 26,55 & 24,46 & 33,06 \\ \text { ne } & 0 & 0 & 3,63 & 0 & 0 & 0 \\ \text { ap } & 0 & 0,51 & 0,86 & 0,61 & 0,59 & 0,22 \\ \text { en } & 5,84 & 11,16 & 0 & 7,38 & 7,85 & 11,00 \\ \text { fs } & 3,64 & 3,17 & 0 & 0 & 0 & 3,60 \\ \text { di } & 23,42 & 16,26 & 16,79 & 22,32 & 21,67 & 16,84 \\ \text { fo } & 21,65 & 0 & 6,75 & 0 & 0 & 0 \\ \text { fa } & 0 & 0 & 3,70 & 0 & 0 & 0 \\ \text { mt } & 4,43 & 3,97 & 3,19 & -0,08 & -0,14 & 3,80 \\ \text { hm } & 1,73 & 0 & 0 & 6,17 & 7,92 & 0 \\ \text { il } & 2,82 & 4,48 & 3,82 & 6,41 & 5,20 & 3,65\end{array}$

1. Pikritisk basalt (oceanit). Blankskálalíð, Kallsoy. A. Noe-Nygaard og J. Rasmussen 1957. Anal. S. Palmquist.

2. Porfyritisk basalt, Hoyvík, Streymoy. J. B. Simpson 1928. Anal. W. H. Herdsmann.

3. Porfyritisk basalt, Tórshavn, Streymoy. H. S. Washington 1922. Anal. H. S. Washington.

4. Lys, porfyritisk basalt, Nestindar, Kallsoy. A. Noe-Nygaard og J. Rasmussen 1957. Anal. S. Palmquist.

5. Storfeldspatbasalt med mørk grundmasse, Nestindar, Kallsoy. A. NoeNygaard og J. Rasmussen. Anal. S. Palmquist.

6. Storfeldspatbasalt, Velbastaður, Streymoy. Walker og Davidson 1936. Anal. W. H. Herdsmann. 


\section{Extrusiv vulkanisme}

Man ved i virkeligheden kun meget lidt om, hvorledes et plateaubasaltområdes vulkaner har set ud (MAC Donald 1968). Det er blevet en almindelig opfattelse blandt geologer, at de mange gange har haft med lavatilførslen at gøre; men det er næppe rigtigt, bl. a. fordi gangene så at sige alle vegne kan ses at være yngre end plateaulavaerne.

De fortræffelige blotninger ud mod det åbne hav og ind mod de store fjorde på Færøerne har trods 20 års feltarbejde ikke vist os eet eneste eksempel, hvor en gang går over i en lavastrøm. En tidligere omtalt iagttagelse fra Viðoy (WALKER og DAVIDSON 1936) har næppe længere gyldighed (se s. 196).

Vi må straks sige, at vi ikke har fundet centralvulkaner, altså vulkaner som skulle have været virksomme på et og samme sted gennem længere tid. Bjergarternes ensartethed, bl. a. den fuldstændige mangel på sure endeled gør det heller ikke troligt, at de har været der. Radiære og koncentriske strukturer savnes ligeledes.

Dersom vi derfor ville fors $\emptyset$ ge at besvare spørgsmålet om, hvorfra de færøske lavaer var kommet, måtte vi søge andre vulkanmodeller og gå andre veje for at finde og eventuelt lokalisere dem. Vi udvalgte os to individuelle lavastrømme eller rettere to sæt, som højst bestod af nogle få sammenhørende lavabænke, og prøvede dernæst at følge dem over hele deres udbredelsesområde. Derigennem fik vi fat i deres geometriske form og kunne siden indkredse deres centralområde. Dette arbejde udkrævede hundreder af kilometers vandringer langs laggrænserne; vi brugte derfor til formålet først horisont lavaerne, fordi fastlæggelsen af deres undergrænse alligevel var et led i vort stratigrafiske arbejde; desuden anvendte vi en lys, letkendelig, olivinførende lava, der ligger ca. 100 m lavere i den stratigrafiske søjle. Denne lava findes bl. a. godt blottet i et lille stenbrud nord for Klakksvík på Borðoy.

De to bænke viser hver sin extrusionsform; for kortheds skyld vil vi i det følgende omtale dem som C-laget og Klakksvíklaget. Vi vil begynde med Klakksvíklaget. 
Allerede tidligt i kortlægningsarbejdet lagde vi mærke til Klakksvíklaget, fordi dets karakteristiske udseende ville tillade os at bruge det som en fremtidig ledehorisont. Primært fulgte vi det på begge sider af Haraldssund og videre til Kallsoy; derimod fandt vi det ikke omkring Lorvík på Eysturoy. I sommeren 1966 påtog stud. scient.'erne Niels Hald og Regin Waagstein sig at forfølge Klakksvíklaget over det meste af dets udbredelsesområde; efterf $\varnothing$ lgende redegørelse bygger i hovedsagen på deres rapport om dette arbejde.

Som helhed er Klakksvíklaget godt blottet og kan over betydelige strækninger følges som en markant hammer. De bedste og længste blotninger forekommer på Kallsoys stejle vestside, men de er her vanskeligt tilgængelige.

Klakksvíklaget hviler over det meste af dets udbredelsesområde på en serie af tyndbænkede, blærede zeolitrige basalter, som let forvitrer.

Normalt er der udviklet en temmelig tynd, $1 / 4-1 / 2$ m tyk bundslagge på Klakksvíklaget og en kraftig topslagge; de er i regelen stærkt rødfarvede. Topslaggen kan lokalt være $25 \mathrm{~m}$ tyk, og en tykkelse på $10 \mathrm{~m}$ er blevet målt over lange strækninger; gennemsnitstykkelsen ligger mellem 1 og $5 \mathrm{~m}$. Lokalt kan topslaggen helt mangle. Næsten alle vegne kan man i slaggeområderne finde op til meterstore, men spredt forekommende klumper af medrevet lys, grå basalt. Ialt ca. $1 / 4$ af Klakksvíklaget består af slaggemateriale.

Klakksvíklagets fortsættelse mod nordvest er eroderet bort, mod sydøst dukker det - stadig med betydelig tykkelse - under havniveau; der er således intet, der tyder på, at man er nær lagets ydergrænser i længderetningen.

Klakksvíklaget er bevaret på en strækning af $21 \mathrm{~km}$ og har en bredde på mellem 5 og $8 \mathrm{~km}$; dette giver et skønnet mindsteareal på 125-150 $\mathrm{km}^{2}$. Med en gennemsnitlig lagmægtighed på $10-12 \mathrm{~m}$ vil dette sige, at lagets volumen er mindst $1,5 \mathrm{~km}^{3}$.

Lavatykkelsens variation inden for Klakksvíklagets udbredelsesområde og en konstatering af tilstedeværelsen af et fra sted til sted vekslende antal individuelle bænke viser, at der må have eksisteret flere udstr $\varnothing$ mningspunkter langs spalten. Nogle steder forekommer store mængder af slagger, og lavalagene bliver her tynde og kan eventuelt mangle.

Klakksvíklagets vidnesbyrd om extrusionsformen bliver herefter således: Det vulkanske materiale er trængt frem gennem en mere end $20 \mathrm{~km}$ lang spalte, og der har på denne været flere udbruds- 
steder, der producerede lava. Den nærmeste velkendte analogi til denne udbrudsform finder vi i Lakagígar på Island, selv om udbruddets st $\varnothing$ rrelse har været væsentlig mindre end dette: $1,5 \mathrm{~km}^{3}$ $\bmod 12 \mathrm{~km}^{3}$.

C-horisontens lavaer afviger som nævnt i bjergartsmæssig henseende tydeligt fra de plagioklasporfyritiske lavaer, som de hviler på med en svag diskordans; man kan derfor lettere følge C-lavaerne, end man ellers kunne have gjort. Man kan sige, at de danner en afst $\varnothing$ bning af det gamle, vulkanske landskab, som den mellemste series vulkanske aktivitet efterlod sig.

Under arbejdet med at følge dette kronostratigrafiske niveau var vi i begyndelsen af den opfattelse, at det bestod af et over alle de nordlige фer sammenhængende lag. Men som arbejdet skred frem, og en udtegning begyndte, bemærkede vi, at C-laget ikke var sammenhængende, men stammede fra $i$ hvert fald tre forskellige oprindelsessteder, imellem hvilke der fandtes uregelmæssige bælter, hvor det helt forsvandt.

To af oprindelsesstederne for C-lavaer ligger inden for de nuværende фer, det tredie kun delvis. Da de alle hviler på samme oprindelige landoverflade, må de være praktisk taget samtidige.

De tre vulkanlegemer har noget forskellig størrelse, men er principielt af samme form - omtrent som flade spejlæg. I almindeligt vulkanologisk sprog ville man betegne dem som uhyre flade skjoldvulkaner. Den største af dem har sit centralområde nær Kollafjørður på Streymoy, lavaens hovedudbredelse findes på Streymoy og Eysturoy, vulkanlegemets flanke har en hældningsvinkel på under en halv grad. Vi har ikke fundet noget spor af en tilførselskanal, men lavaen i centralområdet er over adskillige hundrede $m^{2}$ fyldt med store blokke, også sådanne som hidrører fra de underliggende porfyritiske lavaer og lokalt har karakter af et xenolit-agglutinat.

Lava fra det andet udbrudssted dækker over Kallsoy, Kunoy og Borðoy, det er af lignende type, men mindre og har samme ydre form, dets »gulv « afviger imidlertid, idet vi $\varnothing$ st for den centrale del finder et aflangt område, hvor lavalaget bliver meget tyndt og til sidst helt forsvinder i et lille område. Det vil antagelig sige, at der på den gamle landoverflade, som lavaen flød udover, lå en flad vulkansk bakke, som den ikke helt formåede at overdække, men måtte flyde udenom.

Det tredie udbrudssted ligger i Eysturoys nordende og er kun 
delvis bevaret, måske er der i grænseområdet overgribning mellem lavaerne fra først- og sidstnævnte udbrudssted.

Vulkanen nær Kollafjørður opnår en lavatykkelse på $55 \mathrm{~m}$ i det centrale område, har en hældningsvinkel af flanken på 29' og dækker et areal på ca. $11 \times 12 \mathrm{~km}$. Den producerede lavamængde bel $\varnothing$ ber sig til $7 \mathrm{~km}^{3}$. Vulkanen, der dækker Kallsoy-KunoyBorðoy, er kun 40 m tyk i det centrale område, har en hældningsvinkel af flanken på $25^{\prime}$ og dækker et areal på ca. $8 \times 10$ $\mathrm{km}$. Lavamængden er ca. $3,5 \mathrm{~km}^{3}$. Vi har ikke fors $\varnothing \mathrm{gt}$ at beregne lavamængden fra det tredie udbrudssted, fordi det er så stærkt medtaget af erosionen, at det kun er halvt bevaret.

De tre små skjoldvulkaners centralområde er lidt aflangt, hvilket utvivlsomt må betyde, at de er bygget op over ganske korte spalter som f. eks. Eldborg på Island i post-glacial tid. Det er foreslået af NoE-NygaARD (1968) at kalde denne slags vulkaner for skjoldvulkaner af scutulum type (scutulum er på latin diminutiv for skjold $=$ scutum).

Analogier til disse små scutulum vulkaner må søges blandt Islands mindre, dog noget stejlere skjoldvulkaner som Kjalhraun og Leggjabrotur, der begge har produceret $4 \mathrm{~km}^{3}$, Baldheiði, som har leveret $2 \mathrm{~km}^{3}$ og Selvogsheiði, der kun tegner sig for $1 \mathrm{~km}^{3}$.

Naturligvis afgiver viden om kun to grupper af lavastrømmes extrusionsmekanik i et plateaubasalt område et spinkelt grundlag for en generel vurdering; men i betragtning af, at man ved så lidt om emnet på forhånd, er der dog tilvejebragt holdepunkter for et fors $\varnothing \mathrm{g}$ på at sige noget om forholdene, i hvert fald hvad angår Færøerne.

Vi har tidligere (s. 24) henledt opmærksomheden på fjordretningen, og under omtalen af mellemserien nævnt, at man kun her finder vents og agglomeratrester med lineær udstrækning (s. 198), samt at den vulkanske virksomhed i fjordsystemet har strakt sig over en lang tidsperiode (s. 201).

Ser vi på Klakksvíklagets længdeudstrækning finder vi, at den er næsten parallel med fjordretningen, hvilket bekræfter, at NVS $\varnothing$ retningen i Færøernes tektonisk-vulkanske historie er et hovedelement.

WEGMANN (1938) har i Sydgrønland i dybe grundfjeldssnit vist, at hvor der - i et gangsværmsområde - er mange gange, har de tilbøjelighed til at gruppere sig i bælter eller zoner, således at forstå, at der $\mathrm{i}$ en vis zone træffes et meget stort antal gange, $\mathrm{i}$ et om- 
råde ved siden af næsten ingen, så følger atter en zone med mange gange og dernæst igen én med få eller ingen o. s. v.

Et skema af denne art vil kunne passe på Færøerne, dersom vi antager, at de nu til fjorde uderoderede bælter har dannet lokaliseringssteder for den vulkanske virksomhed op gennem tiden, samt at den var begrundet i spalteformede tilførselskanaler på dybere niveau.

Scutulum skjoldvulkanerne synes at have en uregelmæssig fordeling.

Det antydede mønster for Færøerne minder mest af alt om den neovulkanske zone på Island i nutiden: Et bælte med parallelle eller subparallelle vulkanspalter, inden for hvilket der forekommer et antal skjoldvulkaner med ujævn fordeling.

At både spalteudbrud og skjoldvulkaner forekommer i Ódađahraun på Nordisland har allerede tidligere givet RutTEN (1964) anledning til at teoretisere over deres mulige betydning for dannelsen af plateaubasalter. 


\section{Intrusive dannelser}

Da den extrusive vulkanisme var afsluttet og basaltplateauet færdigdannet, er der i dette som følge af sætninger eller indsynkninger i underlaget opstået spændinger i plateauet med påfølgende revnedannelse, hvorved magmaet endnu en gang, som slutfase i den vulkanske virksomhed er trængt op og har intruderet selve plateauet, dels op i lodrette revner (lamelzoner): gange, dels i den kulf $\varnothing$ rende serie og tuf-agglomeratzonen, d. v. s. mellem den nederste og den mellemste basaltserie: de uregelmæssige intrusive dannelser og endelig i grænseområdet mellem den mellemste basaltserie og den $\emptyset$ verste basaltserie: sills.

\section{Gange}

Gange er dannet ved indtrængning - intrusion - af et magma i lodrette eller stejltstående revner i jordskorpen. Ved størkningen kommer gangene til at danne langstrakte, plade- til linseformede legemer, som overskærer de omgivende, normalt lejrede bjergarters struktur (fig. 90).

Gange kan være enkle, multiple eller sammensatte. En enkel gang er resultatet af en enkelt magmaintrusion, en multipel gang er resultatet af to eller flere intrusioner med samme slags magma, og en sammensat gang (composite dyke) er resultatet af to eller flere magmaintrusioner med forskellig slags magma.

Gangene gennemsætter hele det færøske basaltplateau og er intruderet i et sprække- eller lamelzonesystem, hvis dannelse i tid ligger forud for gangintrusionen (s. 333).

Gangene er sædvanligvis retlinjede, noget buede eller let ondulerende, dette vil i nogen grad være afhængigt af, hvor stor eller hvor ringe den modstand har været, som vedkommende svaghedszone (lamelzone) har ydet. Ikke sjældent er et gangforløb noget slingrende, idet magmaet under intrusionen har mødt så megen modstand, at det er trængt ud til siderne, hvor modstanden har været mindre. Man kan også iagttage tilfælde, hvor en gang helt skifter retning, idet den fortsætter sit forløb i en krydsende lamelzone.

Iagttager man gange i nøgne, lodrette fjeldvægge, ser man, at gan- 


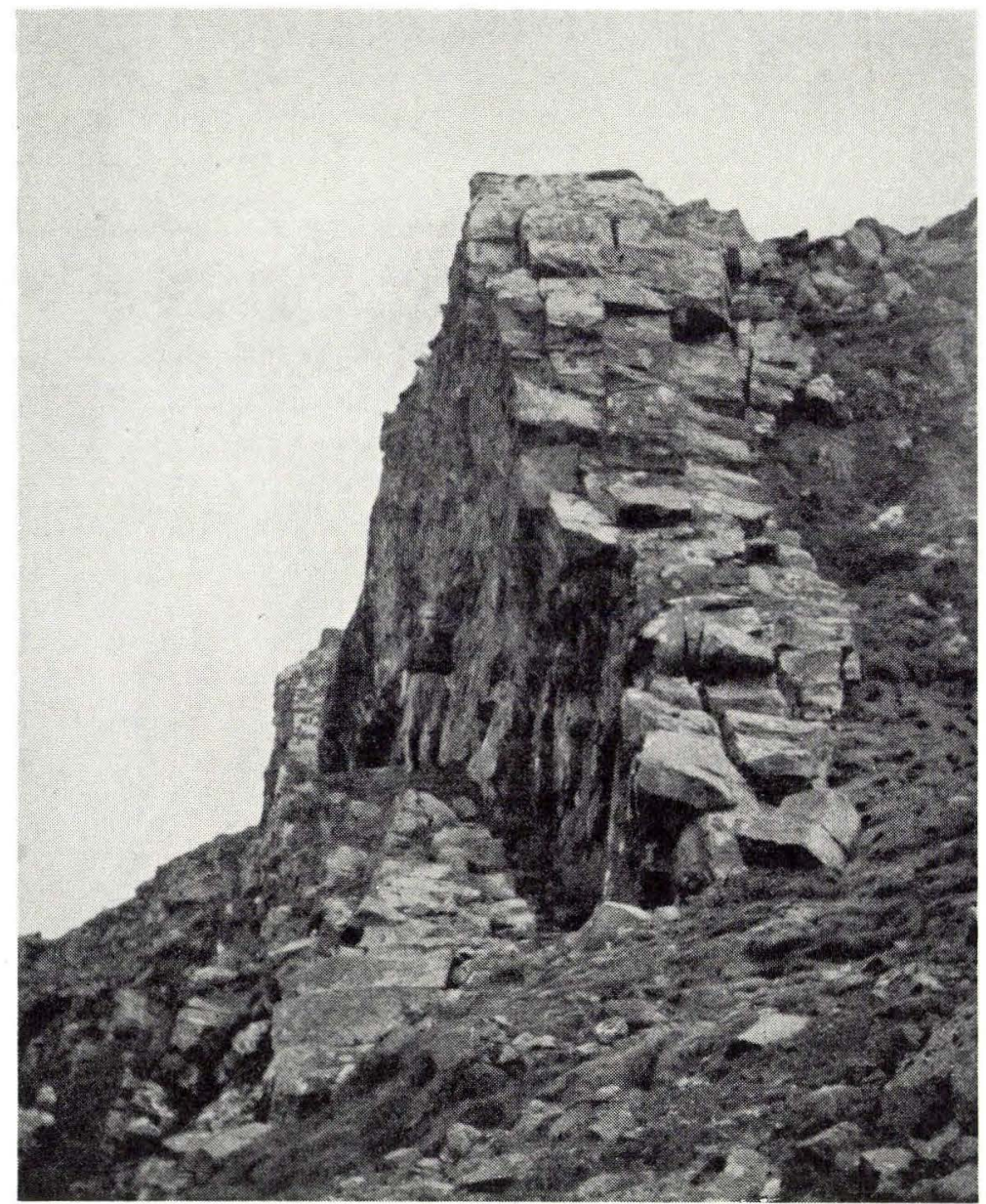

Fig. 90. Gang i Postulakirkja nord for Vestmanna.

Gong i Postulakirkju norðan fyri Vestmanna.

Dyke on Postulakirkja, north of Vestmanna.

gene for langt den største dels vedkommende er vertikale, men en svag hældning bort fra det lodrette ses dog ikke sjældent. Inde i landet er iagttagelsesmulighederne begrænsede, da terrænet for en stor del er dækket af løse glacialaflejringer, moser og forvitringsmaterialer. Iagttagelser her bliver derfor ofte fragmentariske, og en sikker korrelation af de enkelte gangiagttagelser ret vanskelig. Signaturen for gange på det geologiske kort angiver derfor oftest iagttagelse af enkelte gangblotninger; en forlængelse af gangsignaturen, ud over 
den iagttagne blotning, er kun foretaget, når det har været skønnet fuldt forsvarligt. De enkelte iagttagne gangblotninger, eller undertiden flere sikkert korrelerede gangblotninger, er på det geologiske kort forsynet med et kursiveret arabertal, der refererer til den skematiske oversigt over de gangdata, som det har været muligt at måle eller med rimelighed bedømme (s. 253).

Det samlede antal således iagttagne gangblotninger bel $\varnothing$ ber sig til 845, og de fordeler sig på de enkelte фer som følger: Fugloy 14, Svínoy 13, Viðoy 25, Borđoy 74, Kunoy 47, Kallsoy 51, Eysturoy 207, Streymoy 231, Nólsoy 3, Sandoy 8, St. Dímun 1, Suðuroy 53, Hestur 3, Koltur 4, Mykines 2 og Vágar 109.

Som næunt repræsenterer gangsignaturen på kortet iagttagne gangblotninger. Der er hidtil ikke blevet iagttaget nogen gang, der er blottet langs hele sin længde, men i adskillige tilfælde kan en korrelation af enkeltblotninger dog foretages med ret stor sikkerhed over en kortere eller længere strækning, idet gange, såvel som lamelzoner, ofte kan spores i terrænet som mere eller mindre tydelige lineamenter. Man skal dog være varsom med at drage for vidtgående slutninger heraf, idet det ikke sjældent er iagttaget, at en lamelzone fortsætter som et lineament i terrænet, efter at gangen er tyndet helt ud, eller at en gang pludselig skifter retning.

Ved sammenstykning af enkeltblotninger er det således lykkedes at forfølge gange på strækninger af helt op til $21 \mathrm{~km}$.

Af gange på mellem 10 og $21 \mathrm{~km}$ længde skal nævnes: Gangen syd for Egilsnes ved Vestmanna til Trantur nord for Skælingur, (Str. 182, 183, 197, 198, 199, 200, 221, 216 og 215) er ca. 10,5 $\mathrm{km}$. Bjergarten er plagioklasporfyritisk basalt med store, i gangens længderetning, orienterede plagioklaslister. Gangen følger et i terrænet ikke helt retlinjet lineament; den er mod syd afbrudt af den store Streymoysill, og silloverfladen er på strækningen mellem de to gangpartier tydelig lamelleret. Medens gangen syd for Egilsnes (Str. 182) er afbrudt mod nordvest af Vestmannasund, kan dens naturlige afslutning mod syd tydeligt iagttages i gjógv'en op mod Trantur (Str. 215). Den aftager her i mægtighed, i $420 \mathrm{~m}$ højde er dens bredde godt $4 \mathrm{~m}$ og i $560 \mathrm{~m}$ højde godt $1 \mathrm{~m}$. Herefter opløses den i tynde uregelmæssige apofyser. Samtidig hermed aftager feldspatstrøkornene både i størrelse og i antal.

Gangen syd for Ljósá til Oyndarfjørður, (Ey. 172, 178, 181, $19,20,22,26)$ er ca. $10,8 \mathrm{~km}$ og har buet forløb. Bjergarten er en tæt, blå basalt. 
Gangen Djúpidalur til Hvalvík, (Str. 112, 118, 150, 151, 152) er ca. $11,5 \mathrm{~km}$. Dens forløb er let buet. Bjergarten er tæt, blå basalt.

Gangen Dalagjógv til Sundalagið, (Str. 104, 110, 61, 60, 69, 49, 79, 78, Ey. 173) er ca. $12 \mathrm{~km}$ og har næsten retlinjet forløb. Den består af tæt, blå basalt.

Gangen Trogará (Eysturoy) til nord for Knúksdalur (Kallsoy), (Ey. 174, 192, 191, 186, 51, 49, 48, 34, 33, 32, 31, Ka. 31, 27) er ca. $19,5 \mathrm{~km}$ - forløbet er buet. Bjergarten er tæt, blå basalt.

Gangen i den sydlige Glyvursgjógv, (Str. 82, 99, 102, Ey. 196, 197, 59, 87, 88, 98) er ca. 19,7 km. Den har et omtrent retlinjet forl $\varnothing \mathrm{b}$ fra Gøtugjógv henimod den sydlige Glyvursgjógv, foretager derefter en sydlig bøjning ind over Saksunardalur og fortsætter som et lineament i terrænet (lamelzone) ca. $5,5 \mathrm{~km}$ til Grótdalsgjógv syd for Saksun. Gangen består af tæt, blå basalt.

Gangen Tvørgjógv (nordlige Suðuroy) til sydsiden af Hovsfjørður, (Su. 1, 2, 9, 10, 11, 27, 28, 29, 30, 40) er ca. $21 \mathrm{~km}$. Mellem Úlvsgjógv (Su. 9) og Knúkaborg (Su. 11) ses en horisontal forskydning af gangen i terrænet. Fra Tvørgjógv til nordsiden af Hovsfjørður har gangen en bredde på 8-12 m, medens den på sydsiden af Hovsfjørður, som er sidste iagttagelsessted mod syd, kun er $1 \mathrm{~m}$ bred; den består af tæt, blå basalt.

I alle de tilfælde, hvor man har iagttaget afslutningen af et gangforløb, ses det, at gangen ret pludselig aftager i mægtighed og opløser sig i uregelmæssigt forløbende, tynde apofyser (f. eks. B. 63, Ey. 149, Str. 215, Su. 37), men da man ikke i noget tilfælde har iagttaget afslutningen af et sådant gangforl $\varnothing \mathrm{b}$ i begge gangretninger, kan der ikke siges noget absolut om gangenes oprindelige, maximale længde.

Gangmægtigheden (gangtykkelsen) varierer fra brøkdele af en meter til en snes meter. Den største gangmægtighed, ca. $20 \mathrm{~m}$, er blevet iagttaget ved landingspladsen i Sunnba (Su. 50).

Af 535 gange fordelt over hele plateauet og i alle tre basaltserier er 1 gang $20 \mathrm{~m}$ bred, 19 gange $10-15 \mathrm{~m}, 110$ gange 5 til $10 \mathrm{~m}$ og resten (405 gange) under $5 \mathrm{~m}$. Gennemsnitsmægtigheden for alle disse gange er ca. $4 \mathrm{~m}$.

Hvis man betragter den nederste og den $\varnothing$ verste basaltserie for sig, viser nederste basaltserie (35 gange) en gangmægtighed på 4,9 m, og фverste (116 gange) 3,8 m.

Det er aldrig blevet iagttaget, at en gang breder sig ud til siderne 


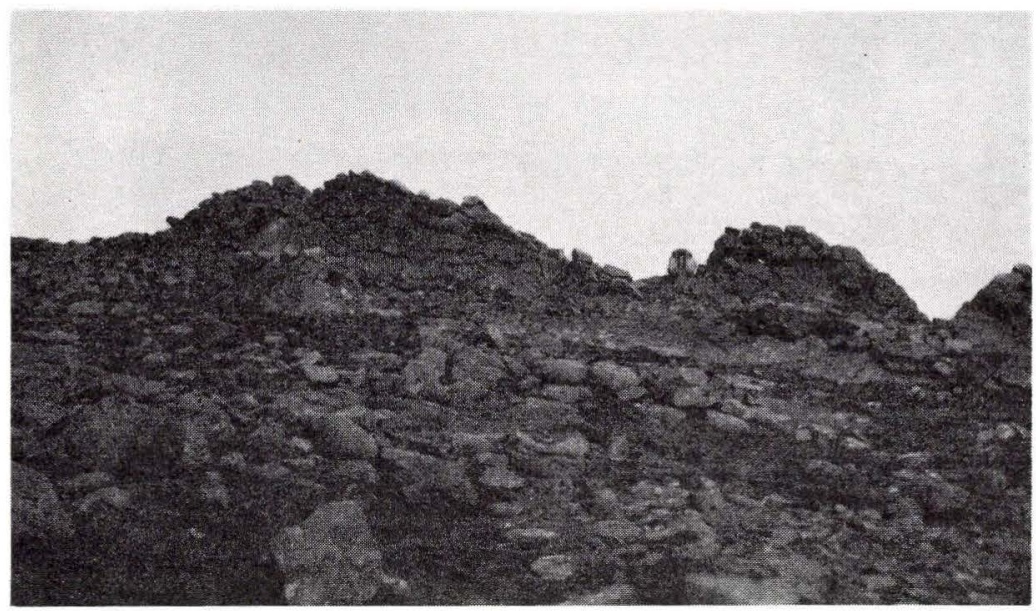

Fig. 91. Jatnagarðar, Vágar.

og fortsætter som en lavastrøm, men det er derimod i flere tilfælde (f. eks. Sv. 4, Við. 23, B. 21) blevet iagttaget, at en gang tynder ud opad og opløser sig i apofyser på samme måde, som det er blevet iagttaget ved den laterale afslutning af et gangforl $\varnothing \mathrm{b}$ i terrænet.

Hvis en gang yder større modstand mod erosion end den omgivende bjergart, vil den komme til at rage op over terrænet som en mur eller en vold. Det mest kendte, færøske eksempel herpå er Jatnagarðar på Vágar (Vá. 17, 18) (fig. 91).

Hvis gangen yder mindre modstand end den omgivende bjergart, vil der dannes en kløft (fær. gjógv). Sådanne stejlvæggede, dybe, langstrakte kløfter (fær. gjáir) er et markant morfologisk træk i det fær $\varnothing$ ske landskab. Disse udbredt forekommende kløfter gør en nærmere betragtning af gangenes intrusionsforhold mulig, idet vi finder blotninger såvel af gangenes sider som af den omgivende bjergarts lodrette sidevægge (fig. 92).

Som følge af kontraktionen under magmaets størkning har gangene altid mere eller mindre udpræget søjlestruktur. Søjlerne står vinkelret på sidevæggene, der har fungeret som afkølingsflader. Da de spændingsudligninger i plateauet, der har været årsag til dannelsen af lamelzonerne, i adskillige tilfælde har virket ogsă efter at være blevet udsat for en gangintrusion, ses der ofte en tydelig forkløftning af gangen i dens længderetning. Denne forkløftning kan være 


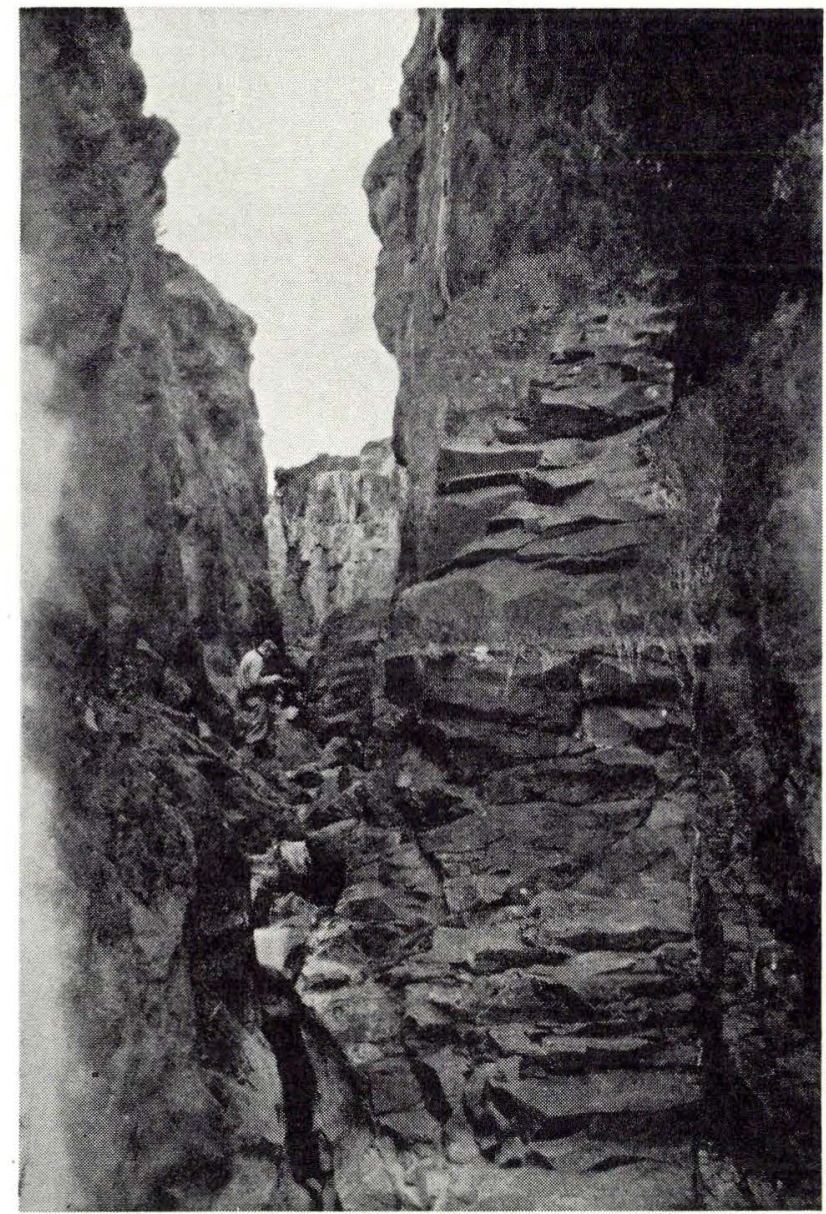

Fig. 92. Gang i Gjógvará, Vestmanna.

Gong i Gjógvará, Vestmanna.

Dyke in Gjógvará, Vestmanna.

så gennemgribende, at gangbasalten er blevet opspaltet i smalle parallelt forløbende lameller i gangens strygningsretning. Imellem lamellerne ses der ofte årer af kalkspat, zeoliter eller blegejord (montmorillonit) (fig. 93).

Selvom bjergarten i en og samme basaltgang er ret ensartet, er forskellen i kornst $\varnothing$ rrelse dog iøjnefaldende, hvis man ser på forholdene midt i gangen og ude langs kontakten, hvorfra tillige en tydelig varmepåvirkning undertiden kan spores ud i sidevæggen. 


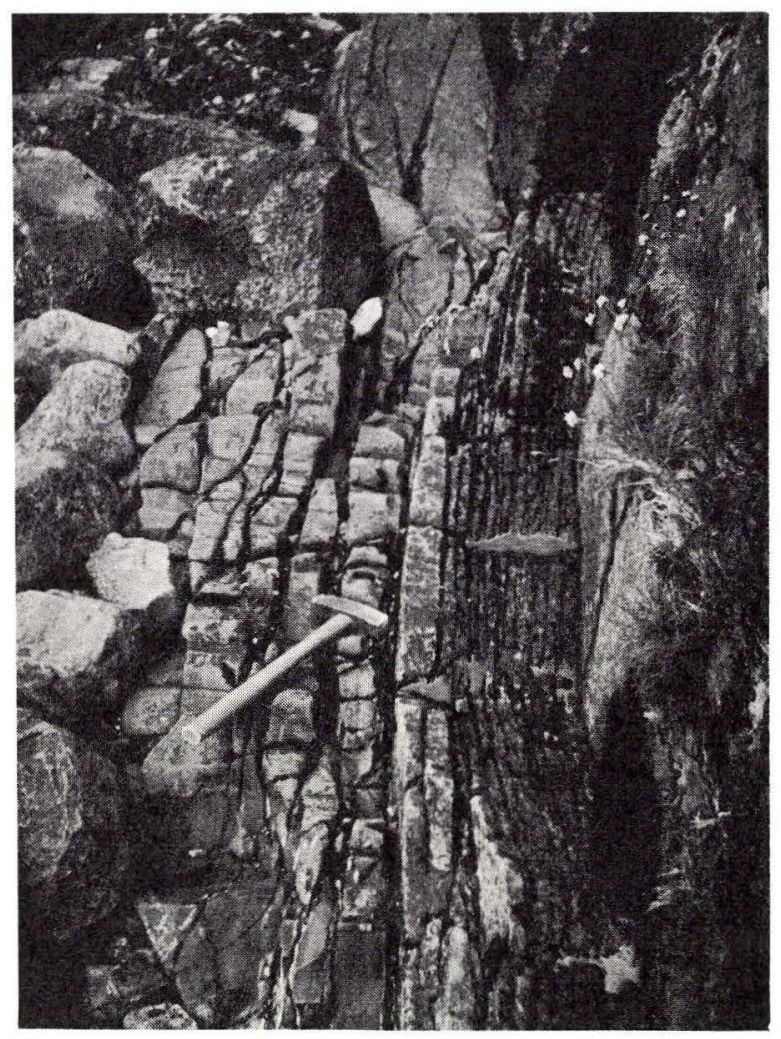

Fig. 93. Lamelleret gang med lamelleret sidesten. NØ for Tórshavn.

Rivuskipan í gong og í regluligu basaltfláunum til liðirnar. Boðanesgjógv, Tórshavn.

Lamellar dyke and wall rock, north-east of Tórshavn.

Der kan ligeledes iagttages en udtalt forskel i bjergartens karakter ud mod et gangforløbs afslutning, hvor denne tynder ud og opløser sig i apofyser, f. eks. Str. 216, der består af storkornet feldspatbasalt med plagioklaslister, idet feldspatstr $\varnothing$ kornene aftager stærkt i størrelse og antal i apofysebjergarten (Str. 215).

Medens de tynde apofyser, der afslutter et gangforl $\varnothing \mathrm{b}$ opad, er »gangapofyser «, idet de er intruderet i de lodrette lamelzoner, der ofte fortsætter gangforl $\varnothing$ bet, kan der på gangens sider eller i den omgivende bjergarts sidevægge ses apofyser, der er »sill-apofyser «, idet de er intruderet lateralt i svaghedszoner (tuflag, pore- eller zeolitzoner) mellem de enkelte basaltbænke i sidevæggen. I olivin- 
porfyriske basalter kan man i disse sillapofyser i mange tilfælde iagttage en nedsynkning af olivinkornene, således at de er sparsomt til stede $\varnothing$ verst i apofysen, medens de forneden har opnået en iøjnefaldende koncentration (NOE-NyGAARD 1945). (Fig. 94).

Der kendes ingen gange af anden sammensætning end basaltisk, og gangtyperne er ikke meget forskellige fra de typer, vi kender fra lavabænkene. Som hovedtyper kan de makroskopisk karakteriseres således: 1. Tæt, blålig, basalt, hård og uden strøkorn. 2. Porfyritisk basalt med små plagioklasstrøkorn. 3. Porfyritisk basalt med store strøkorn, og 4. »Olivinbasalt« med et betydeligt antal makroskopisk synlige olivinkorn.

I den efterfølgende skematiske oversigt over gangdata er de fire hovedtyper 1, 2, 3, 4 betegnet henholdsvis TB, FB, FFB og OB.

Fordelingen af disse typer beregnet på 513 prøver er således: Tæt, blå basalt 391 eller 76,2 \%, plagioklasporfyritisk basalt 62 eller $12,1 \%$, storfeldspatbasalt 33 eller $6,4 \%$ og »olivinbasalt « 27 eller 5,3 \%. Det fremgår heraf, at den tætte, blå basalt er den ganske dominerende gangbjergart.

Langt de fleste gange er enkelt-gange. Der forekommer dog både multiple gange og sammensatte gange.

Som eksempel på en multipel gang skal nævnes gangen, der krydser det vestlige tilløb til Halá syd for Hvalvík i ca. 300 m højde (Str. 162). Den består af to intrusioner. Den vestlige gang er ca. $10 \mathrm{~m}$ bred, den $\varnothing$ stlige ca. 1,5 m. Gangbjergarten er tæet, blå basalt. Efter kontaktforholdene at d $\varnothing$ mme er den $\emptyset$ stlige gang intruderet sidst. Gangen kan ses igen mod sydøst ved det $\varnothing$ stlige tilløb til Halá i ca. 360 m højde (Str. 163) og mod nordvest ved Hvalvíksgjógv i ca. $230 \mathrm{~m}$ højde (Str. 153). Ved Hvalvíksgjógv (Str. 153) ses en tynd midtlamel, der består af plateau-basalt. Gangen $\phi$ st for midtlamellen er kun ca. $1 \mathrm{~m}$ bred og gangen vest for midtlamellen ca. $12 \mathrm{~m}$. Ved det $\varnothing$ stlige till $\varnothing \mathrm{b}$ til Halá (Str. 163) ses to adskilte gange med ca. $5 \mathrm{~m}$ mellemrum. Den $\varnothing$ stlige gang er her ca. 1,5 m bred og den vestlige ca. $2 \mathrm{~m}$.

Som eksempel på sammensatte gange skal nævnes en gang ved kysten i Syðradalur på Kallsoy (Ka. 28) og en gang ved stranden vest for Lygnnes, Kollafjørður (Str. 11).

Gangen i Syðradalur (Ka. 28) forløber gennem en gjógv i omtrent $\varnothing \mathrm{N} \varnothing-\mathrm{VSV}$ retning. Den nordlige gang er ca. $4 \mathrm{~m}$ bred. Den består af tæt, blå basalt. Den sydlige gang er 5-5,5 m bred og består af plagioklasporfyritisk basalt. Gangene er adskilt af en side- 


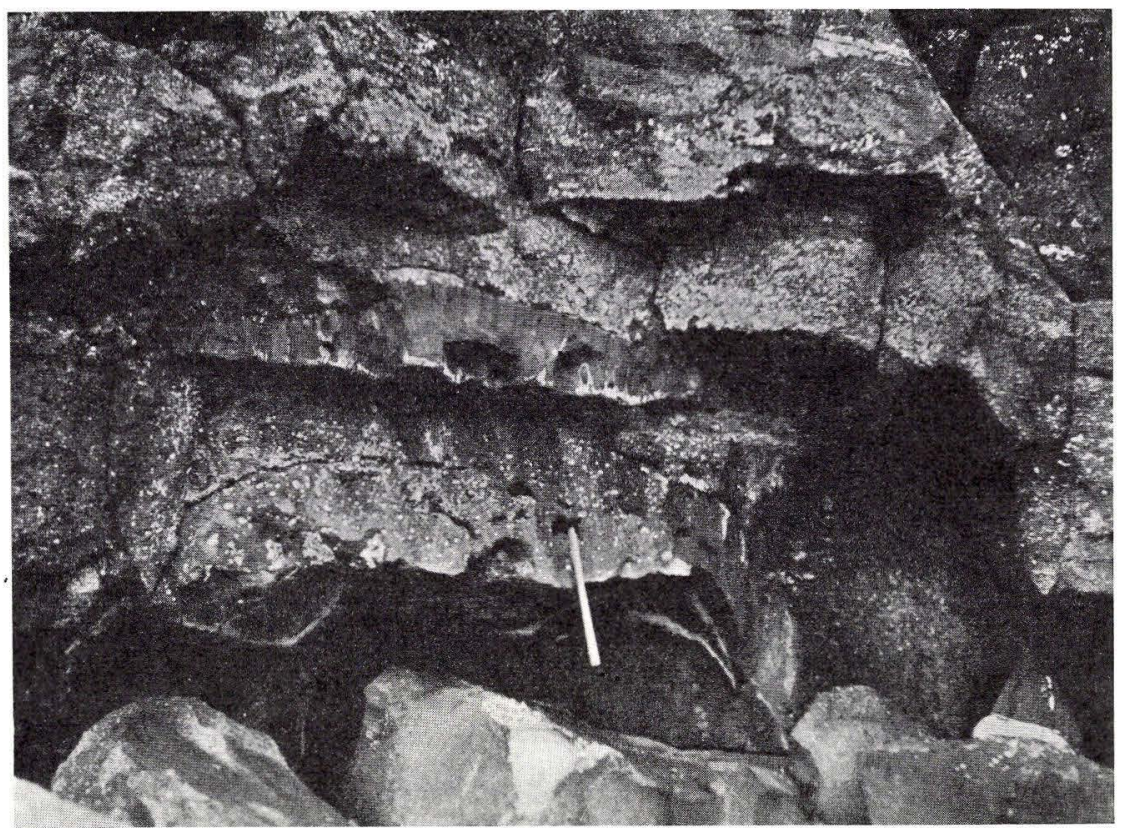

Fig. 94. Linseagtig apofyse fra gang (»sillapofyse«), Norðaragjógv, østsiden af Borgin, Eysturoy.

Utúrgerð frá einari gong, Norðaragjógv eystan fyri Borgina, Eysturoy. Lenticular apophysis from a dyke (sill-apophysis), Norðaragjógv, east side of Borgin, Eysturoy.

stenslamel på ca. $1 \mathrm{~m}$. Gangen er sandsynligvis den samme som den, der forløber i Hvalgjógv på sydvestsiden af Kunoy (Ku. 25) på den $\varnothing$ stlige side af Kallsoyarfjørður, men forholdet er blot her det omvendte, idet den nordlige gang består af plagioklasporfyritisk basalt og den sydlige af tæt, blå basalt. Også i Hvalgjógv forekommer en midtlamel på ca. $1 \mathrm{~m}$. Den samlede gangmægtighed er ca. $10 \mathrm{~m}$. De to gange må således antages at overskære hinanden og »bytte plads $\ll$ under vandet.

Gangen vest for Lygnnes, Kollafjørður (Str. 11) ses blottet på en flad strandstrækning. Den samlede bredde er ca. 4,40 m. Regnet fra vest finder vi: $1,20 \mathrm{~m}$ tæt, blå basalt, $1,50 \mathrm{~m}$ feldspatporfyritisk basalt med store plagioklaslister, orienteret i gangretningen og derefter igen $1,70 \mathrm{~m}$ tæt, blå basalt. Ud mod sidestenen (en porøs-zeolitholdig basalt) ses til begge sider, mod vest og mod $\varnothing$ st, en finkornet kontakt; den feldspatporfyritiske gang i 
midten viser glasagtig kontakt ud mod den tætte, blå basalt til begge sider. Den feldspatporfyritiske gang må derfor være den yngste og være intruderet i en ældre allerede afkølet gang af tæt, blå basalt.

Som følge af en spændingsudligning i plateauet med lamelzonedannelse efter gangintrusionen (s. 333) er gangene ofte tæt lamellerede i deres længderetning, undertiden ligefrem breccierede. Krydsende gange ses hyppigt at være horisontalt dislocerede langs denne yngre lamelzonedannelse. En sådan horisontal dislocation af en gang ses også i adskillige tilfælde, hvor en lamelzone uden intrusion krydser en gang. Størrelsen af disse gangdislocationer er meget forskellig, varierende fra mindre end en meter op til adskillige meter. Den største iagttagne horisontale dislocation af en gang - ca. 100 m - forekommer ved Rangagjógv (Str. 27) og Lundagjógv (Str. 36 ), der begge stryger i omtrent $\emptyset \mathrm{S} \emptyset-\mathrm{VNV}$ retning tværs over bugten ved Tjørnuvík på nordspidsen af Streymoy.

Særlig kraftige dislocationer fremtræder omkring Dalagjógv Djúpadalsgjógv, nord for Vestmanna, og langs det VSV-ØNØ forløbende bevægelsesstrøg fra Dalagjógv tværs over Saksunardalur (fig. 95, 96).

Området Dalagjógv - Djúpadalsgjógv. Gangen i Dalagjógv (Str. 105, storkornet feldspatbasalt) og gangen i Djúpadalsgjógv (Str. 112, tæt, blå basalt) krydses af to omtrent NV-S $\varnothing$ forløbende gange, Str. 113, 114, 106, 107 (olivinbasalt) og Str. 115, 116, 108, 109 (feldspatbasalt). Disse to gange er i området mellem Dalagjógv og Djúpadalsgjógv forskudt ca. $10 \mathrm{~m}$ langs Dalagjógv og ca. $40 \mathrm{~m}$ langs Djúpadalsgjógv, mod vest. Ved Giljar, øst for Dalagjógv, krydses gangen Str. 61 (tæt, blå basalt) af to gange, Str. 64, 65 (feldspatbasalt) og Str. 62, 63 (olivinbasalt). Også disse to gange er, syd for Dalagjógvstrøget, forskudt ca. $10 \mathrm{~m}$ mod vest.

F $\varnothing$ lger vi bevægelsesstr $\varnothing$ get fra Dalagjógv videre mod $\emptyset \mathrm{N} \varnothing$, finder vi de samme forhold ved Saksunardalur omkring den nordlige og sydlige Glyvursgjógv.

Området ved Glyvursgjógv, Saksunardalur. Gangen i den nordlige Glyvursgjógv (Str. 49, tæt, blå basalt) krydses af 3 gange: Str. 50, 51 (tæt, blå basalt), Str. 52, 53 (tæt, blå basalt) og Str. 80,81 (tæt, blå basalt). Disse gange er alle, syd for gjógv'en, forskudt ca. 18 m mod vest. Gangen i den sydlige Glyvursgjógv (Str. 82, tæt, blå basalt) krydses af 2 gange: Str. 83, 84 (tæt, blå basalt) og Str. 85, 86 (tæt, blå basalt). Disse er nord for gjógv'en forskudt ca. $55 \mathrm{~m}$ mod vest. I lighed med forholdene mellem Dala- 


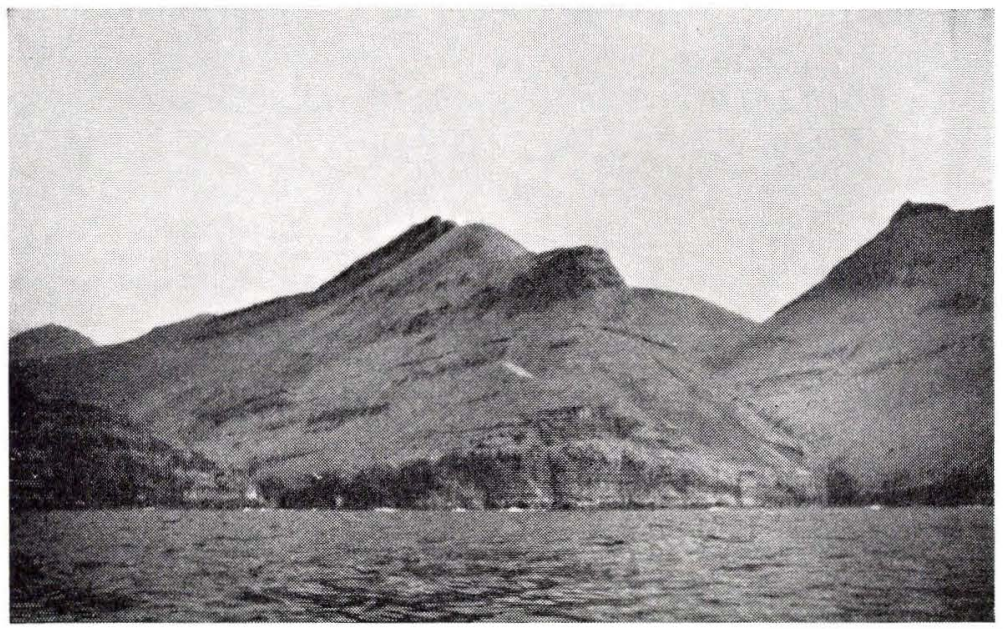

Fig. 95. Dalagjógv og Djúpadalsgjógv.

Dalagjógv og Djúpadalsgjógv.

Dalagjógv and Djúpadalsgjógv.

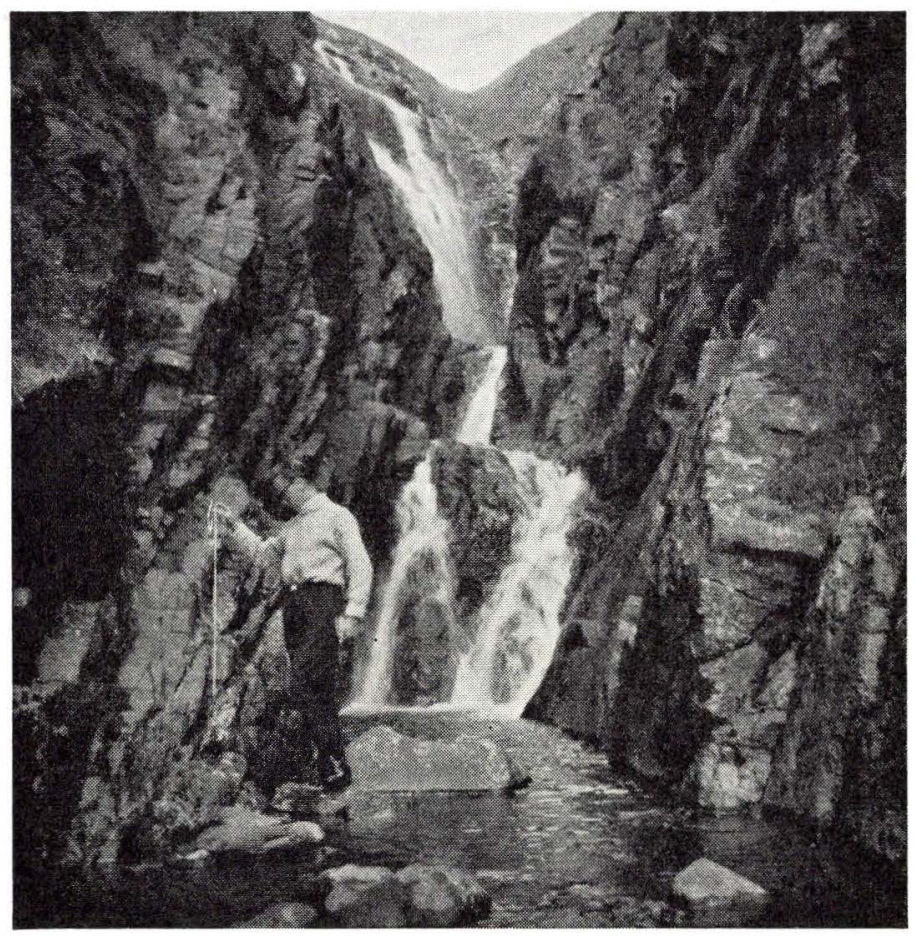

Fig. 96. Gangen i Dalagjógv. Gongin í Dalagjógv.

The dyke in Dalagjógv. 
gjógv og Djúpadalsgjógv er således hele området mellem den nordlige og sydlige Glyvursgjógv forskudt mod vest.

Såvel i Dalagjógv, i Giljar som i den nordlige Glyvursgjógv er selve gjógvbunden og gangmaterialet i den breccieret og tæt lamelleret i gjógv'ernes strygningsretning, men til trods for, at der her er tale om samme, næsten retlinjede lamelzone, er intrusionsmaterialet ikke det samme. Medens intrusionsmaterialet i den nordlige Glyvursgjógv (Str. 49) og i Giljar (Str. 61) er tæt, blå basalt, er intrusionsmaterialet i Dalagjógv (Str. 105) storkornet feldspatbasalt. Det er sandsynligt, at der i området mellem Dalagjógv og Giljar sker en knækning og krydsning af gangen således, at gangen fra Dalagjógv (Str. 105) skifter retning og fortsætter i фstlig retning op i Havursgjógv (Str. 67 storkornet feldspatbasalt), medens gangen fra nordlige Glyvursgjógv og Giljar fortsætter syd for Dalagjógv til Str. 110 og 104.

Området Ravnagilsá, Saksunardalur. Gangen i gjógv'en ved Ravnagilsá (Str. 87 storkornet feldspatbasalt) krydses af 3 gange, Str. 88, 89 (tæt, blå basalt), Str. 90, 91 (tæt, blå basalt) og Str. 92, 93 (tæt, blå basalt). Disse gange er, på nordvestsiden af gjógv'en ved Ravnagilsá, forskudt ca. $20 \mathrm{~m}$ mod nordøst. Gangen i gjógv'en ved Ravnagilsá (Str. 87) overskærer de krydsende gange og tilhører således, ligesom iagttaget ved andre feldspatporfyritiske gange, en yngre ganggeneration.

Området Ljóságjógv, Skipagjógv, Funningsfjørður. Følger vi Dalagjógvstrøget endnu længere mod $\varnothing \mathrm{N} \varnothing$ til Funningsfjørður, st $\varnothing$ der vi igen på et gangdislocationsområde mellem Ljóságjógv og Skipagjógv. Gangen i Olavsøkugjógv (Ey. 177, tæt, blå basalt) krydses af gangen i Ljóságjógv (Ey. 175, 176, tæt, blå basalt). Gangen i Skipagjógv (Ey. 191, tæt, blå basalt) krydses af gangen Ey. 189, 190 (tæt, blå basalt). De to krydsende gange er i området mellem Ólavsøkugjógv og Skipagjógv horisontalt forskudt henholdsvis ca. 20 og ca. $26 \mathrm{mmod}$ vest. På $\varnothing$ stsiden af fjorden overskærer en $\varnothing$ st-vest l $\emptyset$ bende horisontal forkastningszone gangen Ey. 182, 183 (storkornet feldspatbasalt). Nord for denne forkastningszone er gangen forskudt ca. $5 \mathrm{~m}$ i $\emptyset$ stlig retning.

Af andre lokaliteter, hvor horisontale gangdislocationer kan iagttages, skal nævnes: Vestsiden af Skarðsvík (Fu. 2), nord for Hvannasund (Við. 13), vestsiden af Árnafjørður (B. 18), Borðoyarnes (B. 33, 35), Sjóvará (Str. 4, 5), Tjørnuvík (Str. 28), Skúvadalsgjógv (Str. 132, 133), Norðaragjógv (Str. 188, 189 
og 190, 191), Heimaragjógv - Marknagil (Str. 218, 219), Bóndagjógv (Vá. 27), Ørgusgjógv (Vá. 48), Rangagjógv (Vá. 76). Hýsisá (Vá. 87).

For at få et overblik over de dominerende gangretninger er gangene blevet indtegnet på kompasroser således, at hver enkelt gangsignatur på kortet repræsenterer et givet linjestykke afsat på kompasrosen i gangens strygningsretning. På rosens indercirkel angives gradantallet og på dens ydercirkel antallet af gange med samme strygningsretning. For at kunne danne os et samlet billede af den areale retningsvariation, har vi tegnet kompasroser for de enkelte $\emptyset$ er eller фgrupper hver for sig. Med hensyn til de centralt beliggende mindre øer er gangantallet så lille, at en grafisk fremstilling er un $\varnothing$ dvendig.

Ved en sammenligning af gangroserne for Vágar, Streymoy, Eysturoy og Norðuroyar finder vi ret god overensstemmelse med en nogenlunde jævn spredning over hele rosen, dog således at NNØ NØ-SSV SV retningen på Norðuroyar bliver mere fremtrædende, hvilket må betragtes som en naturlig følge af denne øgruppes fjernere geografiske beliggenhed mod N $\varnothing$. På Suðuroy er NV-S $\varnothing$ retningen ganske dominerende. Sammenligner vi derefter gangroserne med lignende kompasroser for henholdsvis lamelzoner og gjógv'er, finder vi, at der kun er en svag overensstemmelse mellem gangroser og lamelzoneroser, medens der er en påfaldende stor overensstemmelse mellem lamelzoneretningen og gjógvretningen (fig. 97, 98, 99, 100, 101).

S. 240 nævntes den procentvise fordeling af de bjergartstyper i de færøske gange, som man kan genkende i håndstykke; denne inddeling er if $\varnothing l g e$ sagens natur grov. De tynde gange er ofte meget finkornede som følge af hurtig afkøling, man kan derfor ikke uden mikroskopi bedømme deres mineralsammensætning nøjere.

Til st $\varnothing t t e$ for det følgende har vi derfor gennemgået godt 50 tyndsnit fra gange, som er indsamlet af professor O. B. Bøggild under hans rejser til Færøerne i 1903 og 1904 og ca. 20 fra vore egne indsamlinger; de fordeler sig som følger: Fugloy 3, Svínoy 1, Viðoy 8, Borðoy 6, Kallsoy 1, Eysturoy 28, Streymoy 15, Tindhólmur 1 og Vágar 9, ialt 72. Det har kun i beskedent omfang været os muligt at henføre B $\varnothing$ ggilds pr $\varnothing v e r$ til de af os nummererede gangstykker på kortet, fordi de fleste lokalitetsangivelser er for vage, vi må derfor indskrænke os til at benytte dem til en en-bloc vur- 

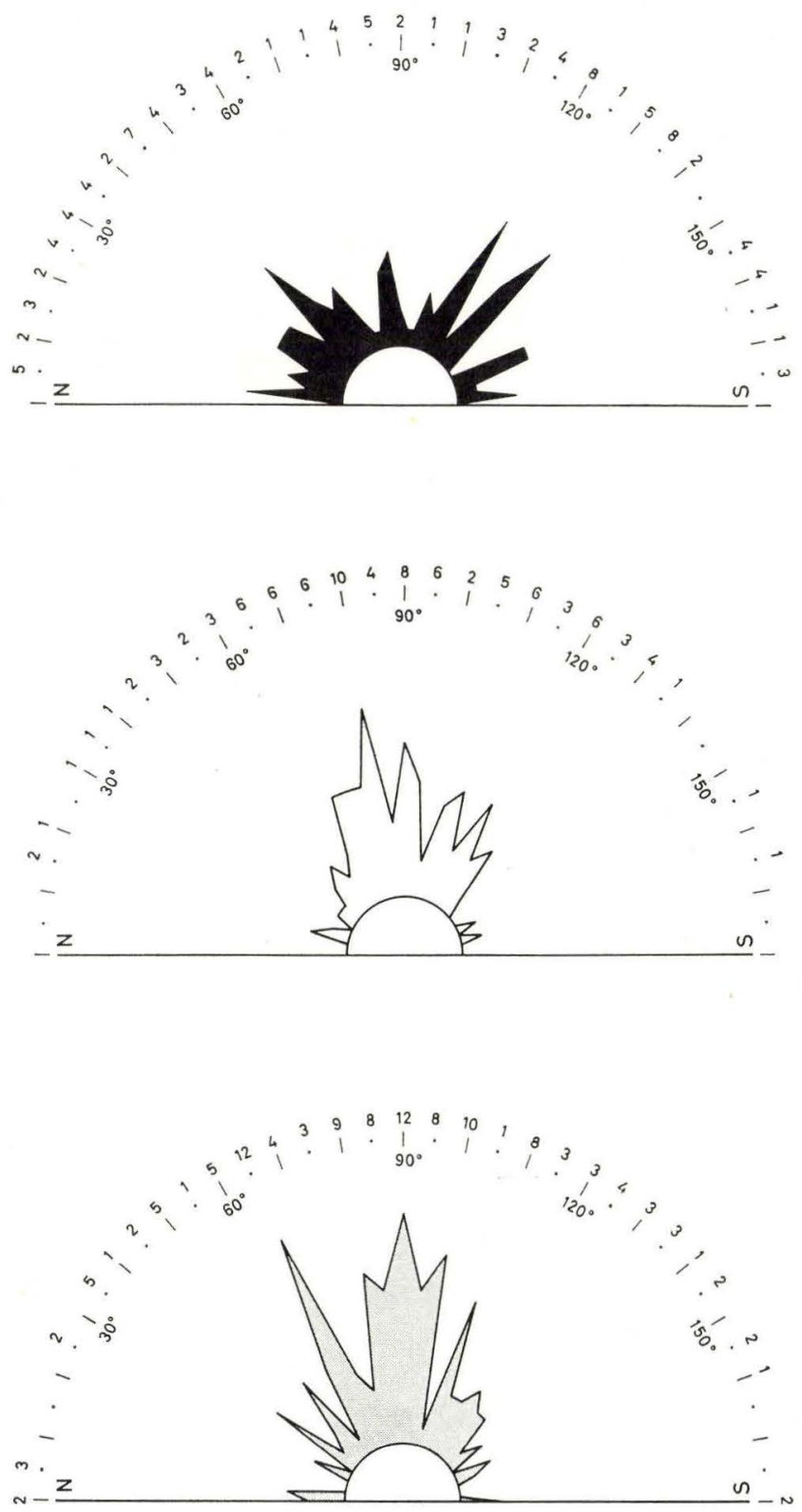

Fig. 97. Gangrose (sort), lamelzonerose (hvid) og gjógvrose (graa). Vágar. Gongir (svartar), rivuskipanir (hvítar) og gjáir (gráar) settar upp eftir attini tar ganga í. Vágar.

Rose diagrams of dykes (black), joints (white) and gjógvs (grey) on Vágar. 

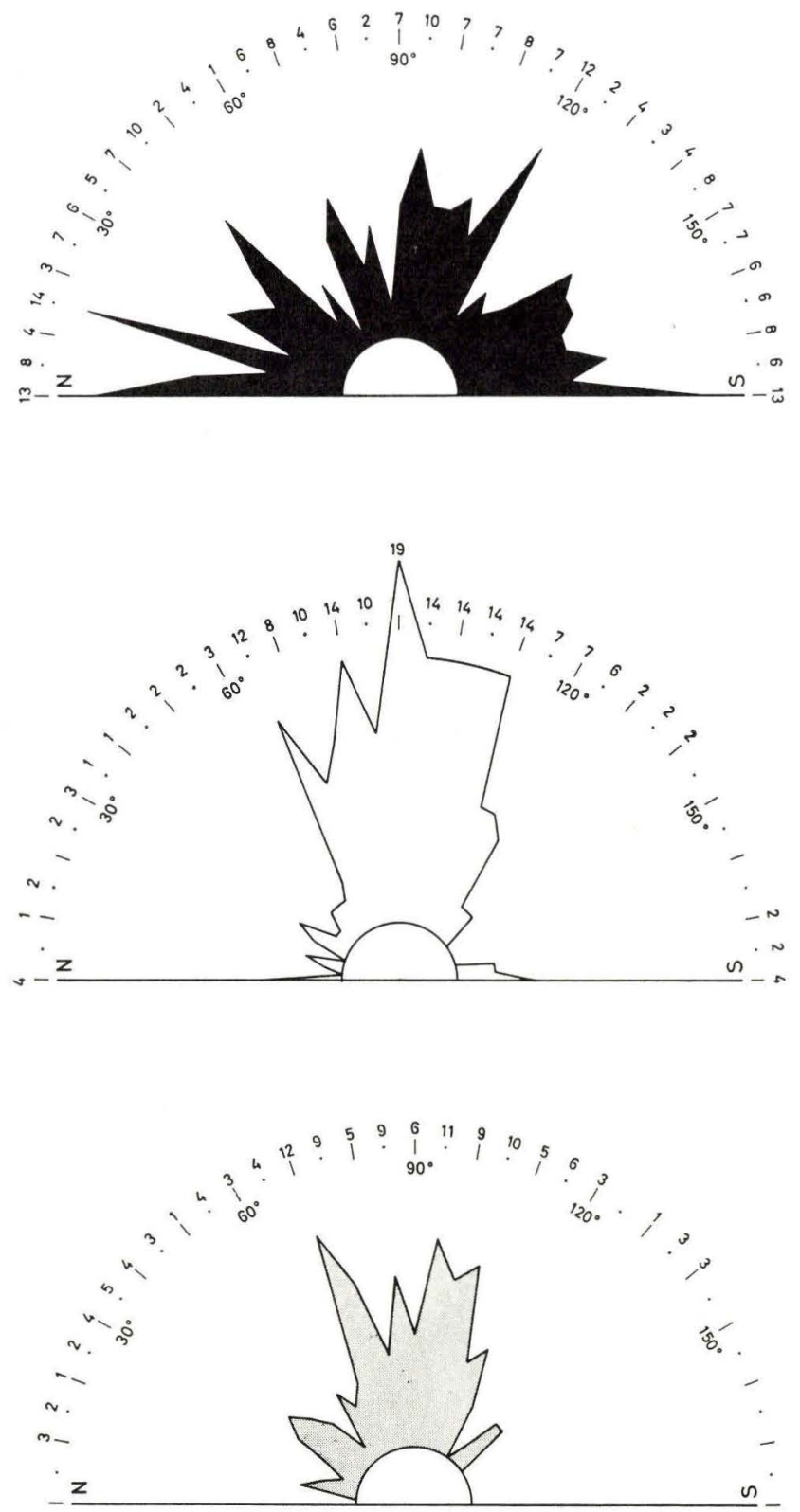

Fig. 98. Gangrose (sort), lamelzonerose (hvid) og gjógvrose (graa). Streymoy. Gongir (svartar), rivuskipanir (hvitar) og gjáir (gráar) settar upp eftir attini tar ganga í. Streymoy.

Rose diagrams of dykes, joints and gjógvs on Streymoy. 

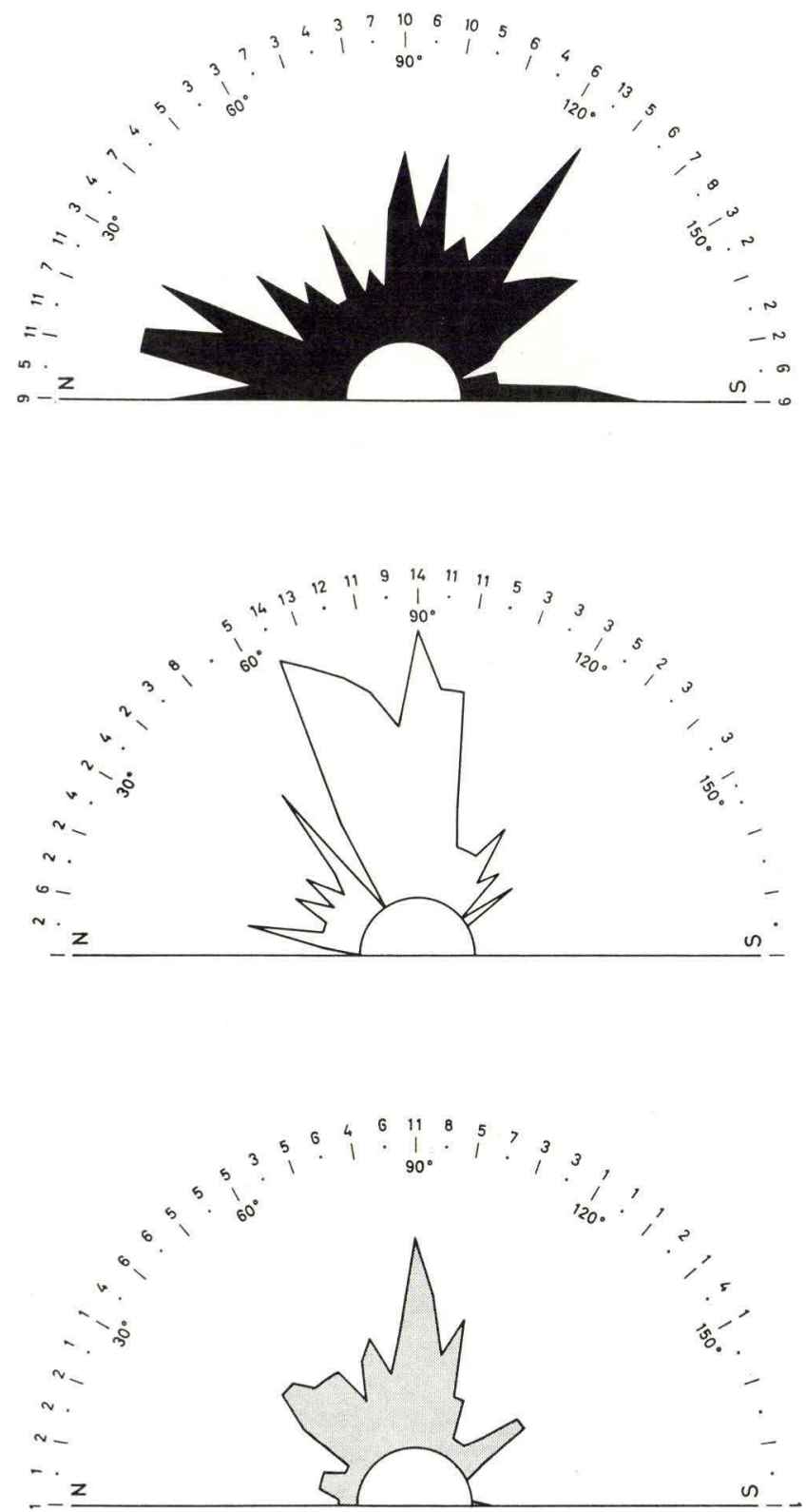

Fig. 99. Gangrose (sort), lamelzonerose (hvid) og gjógvrose (graa). Eysturoy. Gongir (svartar), rivuskipanir (hvitar) og gjáir (gráar) settar upp eftir attini tar ganga í. Eysturoy.

Rose diagrams of dykes, joints and gjógvs on Eysturoy. 

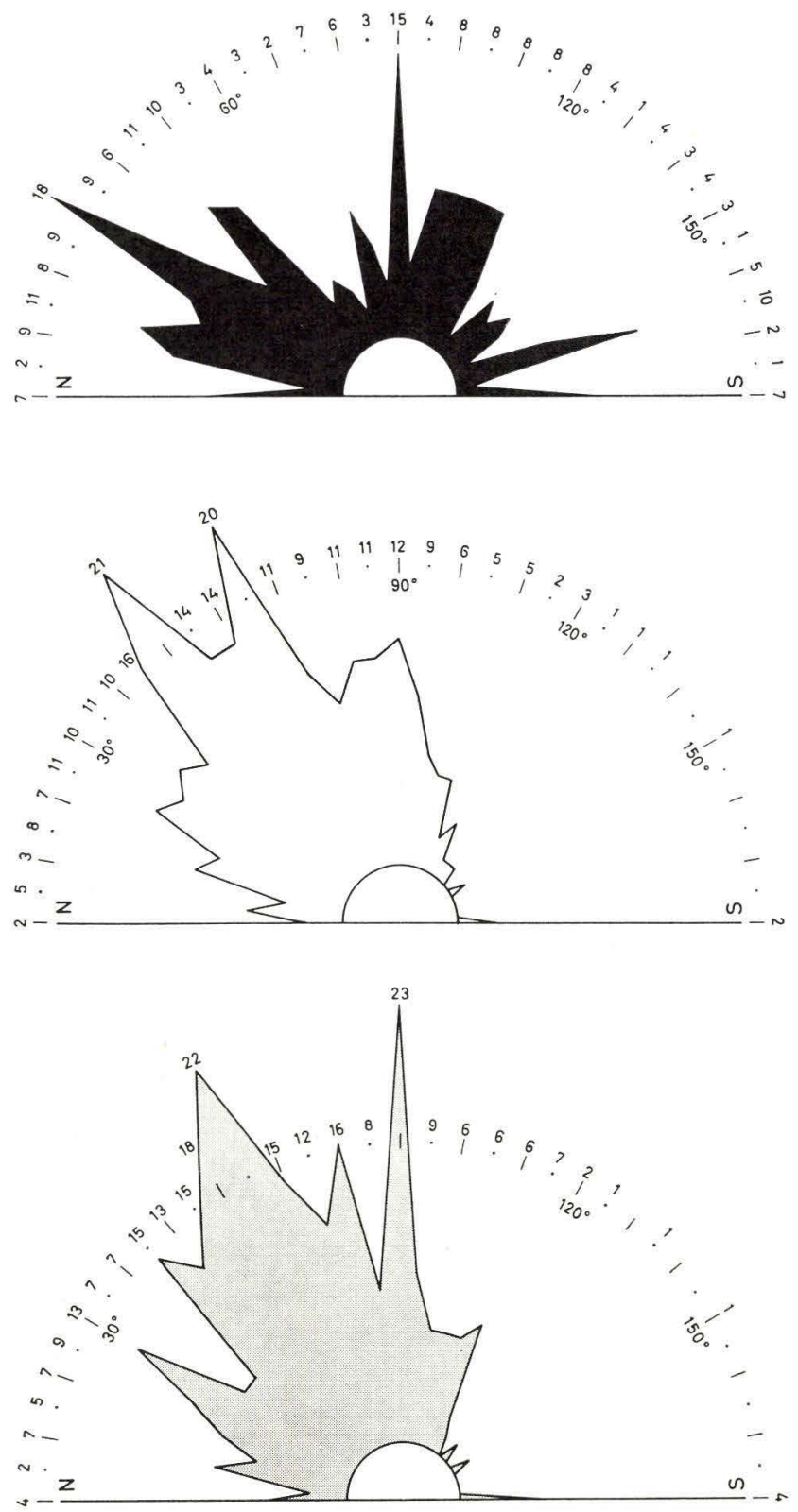

Fig. 100. Gangrose (sort), lamelzonerose (hvid) og gjógvrose (graa). Norðoyar. Gongir (svartar), rivuskipanir (hvítar) og gjáir (gráar) settar upp eftir attini tar ganga i. Norðoyar.

Rose diagrams of dykes, joints and gjógvs on Norðoyar. 

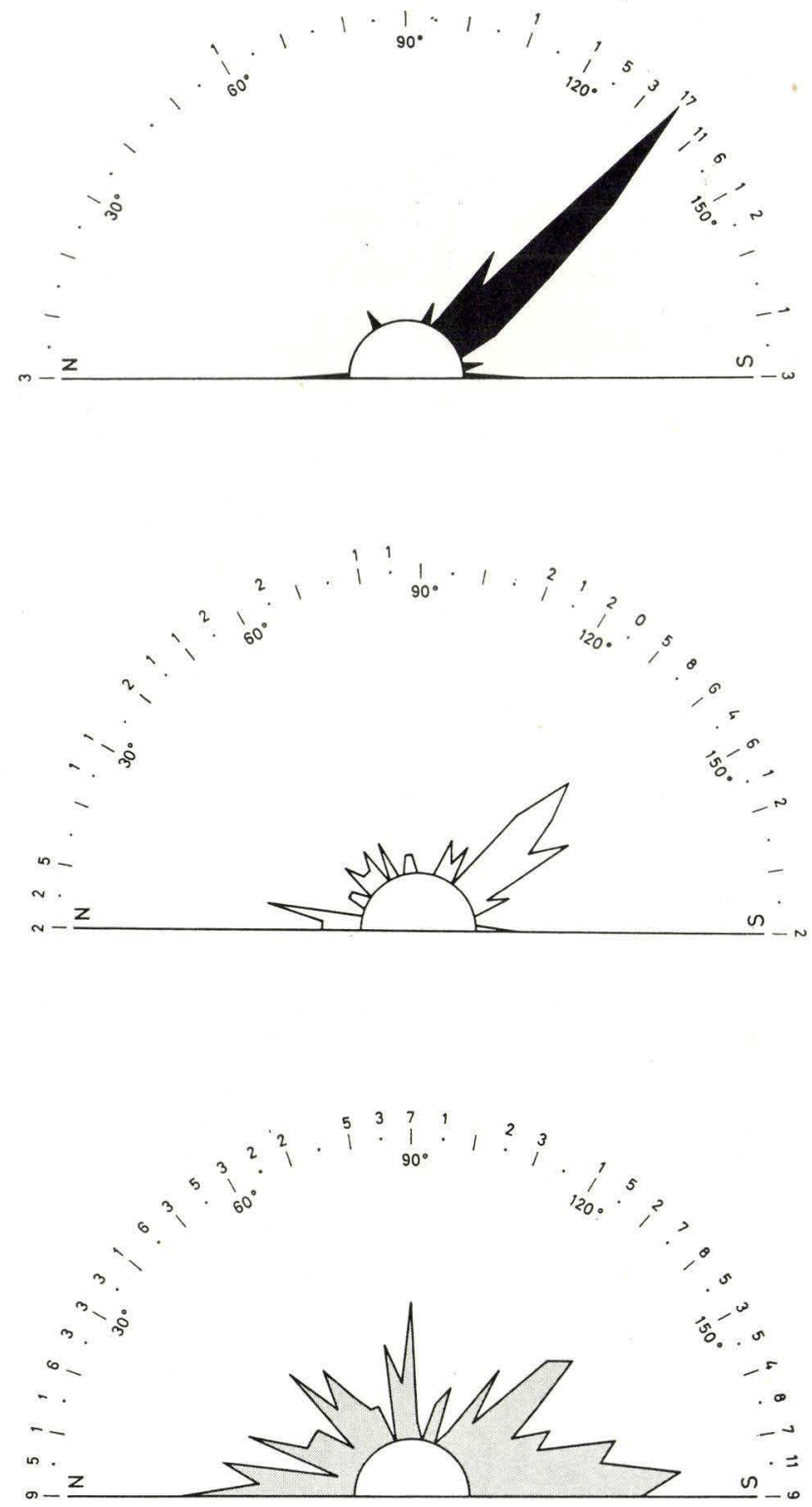

Fig. 101. Gangrose (sort), lamelzonerose (hvid), gjógvrose (graa). Suðuroy. Gongir (svartar), rivuskipanir (hvitar) og gjáir (gráar) settar upp eftir attini tar ganga í. Suðuroy.

Rose diagrams of dykes, joints and gjógvs on Suðuroy. 
dering af gangenes petrografiske sammensætning. Fordelingen på petrografiske typer er følgende: Tæt, blålig basalt $65,5 \%$, plagioklasporfyritisk basalt $26 \%$, storfeldspatbasalt $3 \%$ og basalt med en iøjnefaldende $\operatorname{str} \varnothing$ kornsgeneration af olivin 5,5\%. Der ses en forskydning på ca. $10 \%$ mellem de tætte, blålige basalter og de to plagioklasporfyritiske grupper, sammenlignet med håndstykkevurderingen (s. 240); da denne imidlertid bygger på iagttagelser på mere end 500 prøver fordelt over hele øgruppen, anser vi den for at være den pålideligste.

Af tidligere forfattere giver kun SiMPSON (1928) og WALKER og Davidson (1936) en kort omtale af de færøske ganges petrografi.

Simpson unders $\emptyset$ gte nogle omtrent $\emptyset-\mathrm{V}$ strygende gange på Streymoy og fandt, at disse lignede hinanden meget i petrografisk henseende. Han betegner dem som olivindoleriter med veludviklet ofitisk textur. Nær Kollafjørður undersøgte han en enkelt N-S strygende gang, som bestod af en finkornet, ikke-porfyritisk basalt med ganske lidt, serpentiniseret olivin. Walker og Davidson antyder, at de to forskellige bjergartstyper måske hører til to gangsystemer med forskellig retning; vore iagttagelser giver ikke holdepunkter for denne antagelse, derimod synes porfyritiske gange at være hyppigere på Vágar, Streymoy og Eysturoy end på Norðoyar.

Selvom bjergartstyperne i gangene ligner de tilsvarende hovedtyper fra lavaerne, er der en tydelig forskel, olivin har større udbredelse.

I porfyritiske gange og gange af storfeldspatbasalt findes i regelen enkelte olivinkorn, hvorimod disse forekommer ret sjældent i lavaer af samme typer. Kun ca. $10 \%$ af de tætte, blålige gange er helt uden olivin; størstedelen af dem har nogle få olivinkorn, som i regelen er en del serpentiniserede, denne type er åbenbart den, Simpson har fundet i Kollafjørour. Gangene er for det meste ganske finkornede, og texturen er intergranular; der synes fra disse at være en glidende overgang til gange med nogle få \% olivin. Med skiftet til ofitisk textur stiger olivinindholdet til omkring 10 $\%$. Mineralsammensætningen er af Walker og Davidson målt på en gangprøve af denne type fra Leynar på Streymoy: Pl $=50 \%$, $\mathrm{cpx}=35.5 \%, \mathrm{ol}=10.1 \%$, malm $=2.4 \%$ og zeolitisk fyldmasse $=2 \%$. De meget olivinrige gange nærmer sig en pikritbasaltisk sammensætning, de ligner de tilsvarende typer blandt la- 
vaerne f. eks. fra Víkarprofilet (IV) med op til ca. 25 vol \% olivin.

I tabellen gives fire kemiske analyser af gangbjergarter; de to første er på et tidligt trin i kortlægningen udvalgt efter en iøjnefaldende forskel i bjergartsfarve, henholdsvis mørk og lys, de to sidste stammer fra de to gange, der som en »sammensat gang « findes ved Syðradalur på Kallsoy (s. 240).

Som tabellen viser, er alle analyser kvartstholeiitiske med normativ kvarts og hypersthen.

Kemiske analyser af gange

\begin{tabular}{lrrrr} 
& \multicolumn{1}{c}{1} & \multicolumn{1}{c}{2} & \multicolumn{1}{c}{3} & \multicolumn{1}{c}{4} \\
$\mathrm{SiO}$ & 43,80 & 46,30 & 47,40 & 47,60 \\
$\mathrm{Al}_{2} \mathrm{O}_{3}$ & 12,35 & 17,63 & 15,98 & 14,88 \\
$\mathrm{Fe}_{2} \mathrm{O}_{3}$ & 12,66 & 5,88 & 6,16 & 8,38 \\
$\mathrm{FeO}$ & 2,10 & 3,64 & 3,50 & 4,13 \\
$\mathrm{MnO}$ & 0,22 & 0,26 & 0,24 & 0,20 \\
$\mathrm{MgO}$ & 7,14 & 7,15 & 8,22 & 6,18 \\
$\mathrm{CaO}$ & 11,85 & 10,76 & 13,41 & 11,05 \\
$\mathrm{Na}_{2} \mathrm{O}$ & 1,17 & 1,95 & 1,33 & 2,14 \\
$\mathrm{~K}_{2} \mathrm{O}$ & 0,61 & 0,49 & 0,41 & 0,46 \\
$\mathrm{TiO}_{2}$ & 0,84 & 3,29 & 1,70 & 3,63 \\
$\mathrm{P}_{2} \mathrm{O}_{5}$ & 0,05 & 0,49 & 0,15 & 0,25 \\
$\mathrm{H}_{2} \mathrm{O}^{+}$ & 3,32 & 1,43 & 1,02 & 0,79 \\
$\mathrm{H}_{2} \mathrm{O}^{-}$ & 3,88 & 1,06 & 0,76 & 0,74 \\
& 99,99 & 100,33 & 100,28 & 100,43
\end{tabular}

Katanorm

$\begin{array}{lrrrr}\text { q } & 5,82 & 3,27 & 3,64 & 6,07 \\ \text { or } & 4,02 & 3,00 & 2,49 & 2,83 \\ \text { ab } & 11,71 & 18,13 & 12,26 & 19,99 \\ \text { an } & 29,70 & 39,26 & 37,41 & 30,83 \\ \text { ap } & 0,12 & 1,06 & 0,32 & 0,54 \\ \text { en } & 7,79 & 15,36 & 11,34 & 7,95 \\ \text { di } & 28,37 & 10,17 & 23,93 & 19,60 \\ \text { mt } & 4,06 & 2,27 & 5,28 & 2,58 \\ \text { hm } & 7,13 & 2,73 & 0,89 & 4,35 \\ \text { il } & 1,30 & 4,75 & 2,43 & 5,26\end{array}$

1. Mørk, strøkornsfri basalt, Knúksdalur, Kallsoy: Kvartstholeiit. Anal. Sven Palmquist.

2. Grå, lamelleret basalt, фstsiden af Byttufelli, Kallsoy: Kvartstholeiit. Anal. Sven Palmquist.

3. Mørk, tæt basalt. Nordlige gang i gjógv'en ved Syðradalur, Kallsoy: Kvartstholeiit. Anal. Sven Palmquist.

4. Lysegrå, plagioklasporfyritisk basalt. Sydlige gang i gjógv'en ved Syöradalur, Kallsoy. Kvartstholeiit. Anal. Sven Palmquist. 


\begin{tabular}{|c|c|c|c|c|c|c|c|}
\hline Nr. & $\left.M^{1}\right)$ & Højde i m & Retning & Bredde i $\mathrm{m}$ & Type ${ }^{2}$ ) & Lokalitet & Bemærkninger \\
\hline 1 & 4,8 & & N. $145^{\circ}$ & & & Vest for Illitangi. & \\
\hline 2 & 4,8 & & N. $140^{\circ}$ & 2 & TB & Vestsiden af Skarosvík. & Horisontal forkastning ca. $4 \mathrm{~m}$. \\
\hline 3 & 4,8 & & N. $65^{\circ}$ & 2 & & Vestsiden af Skarơsvík. & \\
\hline 4 & 4,8 & & N. $15^{\circ}$ & & & Øst for Landfles, Skarðsvík. & \\
\hline 5 & 4,9 & & N. $165^{\circ}$ & & & $\begin{array}{l}\text { På vestsiden af Skorarnar } \\
\text { ( stsiden af Skarðsvík). }\end{array}$ & \\
\hline 6 & 4,9 & & N. $15^{\circ}$ & & & $\begin{array}{l}\text { På vestsiden af Skorarnar } \\
\text { (østsiden af Skarðsvík). }\end{array}$ & \\
\hline 7 & 4,9 & & N. $180^{\circ}$ & & & Skorarnar ( & \\
\hline 8 & 4,9 & & N. $160^{\circ}$ & & & Østsiden af Skorarnar. & \\
\hline 9 & 4,9 & & N. $160^{\circ}$ & & & Østsiden af Skorarnar. & \\
\hline 10 & 4,9 & & N. $25^{\circ}$ & & & Vest for Stapin. & \\
\hline 11 & 10,3 & & N. $90^{\circ}$ & & & Uren (sydlige del) syd for Stapin. & \\
\hline 12 & 10,2 & & N. $150^{\circ}$ & & $\mathrm{TB}$ & Kellingará. & \\
\hline 13 & 10,2 & & N. $15^{\circ}$ & & & Skoratangi. & \\
\hline 14 & 10,2 & & N. $60^{\circ}$ & $5-6$ & $\mathrm{~TB}$ & Nord for bøgærdet, Kirkja. & \\
\hline
\end{tabular}

1. M: målebordsblad.

2. TB: tæt blålig basalt. FB: porfyritisk basalt. FFB: storfeldspatbasalt. 
Svínoy (Sv.)

\begin{tabular}{|c|c|c|c|c|c|c|c|}
\hline Nr. & M 1) & Højde i m & Retning & Bredde i m & Type 2) & Lokalitet & Bemærkninger \\
\hline 1 & 10,4 & & N. $125^{\circ}$ & & & Nord for Heimastanes. & \\
\hline 2 & 10,4 & & N. $85^{\circ}$ & & & Nord for Heimastanes. & \\
\hline 3 & 10,5 & & N. $15^{\circ}$ & $2,5-3$ & TB & Vest for elven, Fyri Eystan. & Bugtet forl $\varnothing \mathrm{b}$. \\
\hline 4 & 10,5 & & N. $45^{\circ}$ & & & Syd for Svarturð. & Tynder ud opad, set fra søsiden. \\
\hline 5 & 10,8 & & N. $145^{\circ}$ & 4 & ТВ & Nordsiden af Svínoyarvík. & \\
\hline 6 & 10,7 & & N. $30^{\circ}$ & 2 & $\mathrm{~TB}$ & Nordsiden af Svínoyarvík. & Noget bugtet forl $\varnothing \mathrm{b}$. \\
\hline 7 & 10,7 & & N. $45^{\circ}$ & 2 & $\mathrm{~TB}$ & $\begin{array}{l}\text { Syd for udløbet af Stórá, } \\
\text { Svínoyarvík. }\end{array}$ & Noget bugtet forl $\varnothing b$. \\
\hline 8 & 16,1 & & N. $110^{\circ}$ & & & Gjógv syd for elven, Yvir í Dal. & \\
\hline 9 & 16,1 & & N. $15^{\circ}$ & & & Nord for elven, Yvir í Dal. & \\
\hline \multirow[t]{2}{*}{10} & $15,3-$ & & & & & & \\
\hline & 16,1 & & N. $50^{\circ}$ & & & Nord for elven, Yvir í Dal. & \\
\hline 11 & 10,7 & & N. $10^{\circ}$ & 2 & TB & Vestsiden af Svínoyareiði. & \\
\hline 12 & 10,7 & & N. $10^{\circ}$ & 5 & $\mathrm{OB}$ & Vestsiden af Svínoyareiði. & \\
\hline \multirow[t]{2}{*}{13} & 10,7 & & N. $170^{\circ}$ & 2 & $\mathrm{~TB}$ & Ved elven, Svínoyareioi. & Noget bugtet forl $\varnothing \mathrm{b}$. \\
\hline & & & & & & & Viðoy (Við.) \\
\hline Nr. & M i) & Højde i m & Retning & Bredde i m & Type 2) & Lokalitet & Bemærkninger \\
\hline 1 & 3,1 & & N. $175^{\circ}$ & & & Kassgjógv. & \\
\hline 2 & 3,1 & & N. $45^{\circ}$ & & & Sydøst for Kassgjógv. & \\
\hline 3 & 3,8 & & N. $45^{\circ}$ & & & Nord for Dalá. & \\
\hline 4 & 9,2 & & N. $145^{\circ}$ & 6 & TB & Syd for Stakkur. & \\
\hline
\end{tabular}




\begin{tabular}{|c|c|c|c|c|c|c|c|}
\hline Nr. & M 1) & Højde i nı & Retning & Bredde i m & Type 2) & Lokalitet & Bemærkninger \\
\hline 5 & 9,5 & & N. $5^{\circ}$ & & & Syd for Gjógvin Lítla. & \multirow{21}{*}{$\begin{array}{l}\text { Lamelleret. } \\
\text { Horisontal forkastning ca. } 5 \mathrm{~m} \text {. }\end{array}$} \\
\hline 6 & 9,6 & & N. $30^{\circ}$ & & & Marknagjógv. & \\
\hline 7 & 9,6 & & N. $75^{\circ}$ & & & Syd for Bildskoratangi. & \\
\hline 8 & 9,9 & & N. $65^{\circ}$ & & & $\begin{array}{l}\text { Gjógv } \emptyset \text { st for Áardalur, } \\
\text { sydøstsiden af Viðoy. }\end{array}$ & \\
\hline 9 & 9,9 & & N. $120^{\circ}$ & & & Sydøstspidsen af Viðoy. & \\
\hline 10 & 9,8 & & N. $90^{\circ}$ & & & $\begin{array}{l}\text { I kysten syd for Botnagjógv, } \\
\text { sydsiden af Viðoy. }\end{array}$ & \\
\hline 11 & 9,8 & & N. $10^{\circ}$ & & & $\begin{array}{l}\text { I kysten syd for Botnagjógv, } \\
\text { sydsiden af Viðoy. }\end{array}$ & \\
\hline 12 & 9,5 & & N. $45^{\circ}$ & & $\mathrm{TB}$ & Gjógv over Hvannasund. & \\
\hline 13 & 9,5 & 135 & N. $120^{\circ}$ & $2-3$ & $\mathrm{~TB}$ & $\begin{array}{l}\text { Øst for Sandoyri, nord for } \\
\text { Hvannasund. }\end{array}$ & \\
\hline 14 & 9,4 & & N. $120^{\circ}$ & & $\mathrm{TB}$ & I kysten vest for Tunnafjall. & \\
\hline 15 & 9,1 & & N. $30^{\circ}$ & 5 & $\mathrm{~TB}$ & Syd for Selgjógv. & \\
\hline 16 & 9,1 & & N. $30^{\circ}$ & & & Neytaskarð. & \\
\hline 17 & 9,1 & & N. $105^{\circ}$ & 5 & FB & Nordøst for Selgjógv. & \\
\hline 18 & 9,1 & & N. $110^{\circ}$ & & & Selgjógv. & \\
\hline 19 & 9,1 & & N. $5^{\circ}$ & & & I kysten sydvest for Hvilvtarskarð. & \\
\hline 20 & 9,1 & & N. $30^{\circ}$ & $4-5$ & TB & I kysten vest for Hvilvtarskarð. & \\
\hline 21 & 9,1 & & N. $30^{\circ}$ & & & Nordvest for Hvilvtarskaro. & \\
\hline 22 & 9,1 & & N. $90^{\circ}$ & $4-5$ & $\mathrm{~TB}$ & Leitisgjógv. & \\
\hline 23 & 3,7 & & N. $90^{\circ}$ & & & I kysten vest for Malinsfjall. & \\
\hline 24 & 2,6 & & N. $30^{\circ}$ & & & Nordvest for Fiskimúli (ved hule). & \\
\hline 25 & 2,6 & 180 & N. $30^{\circ}$ & 2,5 & TB & Sydsiden af Ormadalur. & \\
\hline
\end{tabular}




\begin{tabular}{|c|c|c|c|c|c|c|c|}
\hline $\mathrm{Nr}$. & $\left.M^{1}\right)$ & Højde i m & Retning & Bredde i m & Type 2) & Lokalitet & Bemærkninger \\
\hline \multirow[t]{2}{*}{1} & $8,3-$ & & & & & & \\
\hline & 9,1 & & N. $95^{\circ}$ & $3-4$ & $\mathrm{~TB}$ & Argdalsgjógv. & \\
\hline 2 & 9,1 & & N. $90^{\circ}$ & & & Kysten i fortsættelse af Lambagjógv. & Stærkt breccieret. \\
\hline 3 & 8,3 & & N. $115^{\circ}$ & & & Húsadalur (Skálatoftir). & \\
\hline 4 & 9,1 & & N. $115^{\circ}$ & $2-3$ & $\mathrm{~TB}$ & Syd for Krossdalsá. & \\
\hline 5 & 9,4 & & N. $20^{\circ}$ & 5 & $\mathrm{~TB}$ & Syd for Lítladalsá. & \\
\hline 6 & 9,4 & 228 & N. $10^{\circ}$ & 3,5 & TB & Fossdalur. & Stærkt lamelleret. \\
\hline 7 & 9,7 & & N. $95^{\circ}$ & 5 & $\mathrm{~TB}$ & Nord for Toftá, Norðtoftir. & \\
\hline 8 & 9,7 & & N. $15^{\circ}$ & 5 & $\mathrm{~TB}$ & Kløft i elven syd for Toftá. & Lamelleret. \\
\hline 9 & 9,8 & & N. $35^{\circ}$ & $3-4$ & & $\emptyset$ stsyd $\varnothing$ st for Norðtoftir. & Stærkt breccieret. \\
\hline 10 & 15,2 & 60 & N. $10^{\circ}$ & 1 & $\mathrm{~TB}$ & $\begin{array}{l}\text { I kysten syd for elven, Stóri } \\
\text { Hagadalur. }\end{array}$ & \\
\hline 11 & $15,2.3$ & & N. $85^{\circ}$ & $2-4$ & & $\begin{array}{l}\text { I kysten omtrent midt imellem Lítli } \\
\text { Hagadalur og Tjørnudalur. }\end{array}$ & \\
\hline 12 & 15,3 & & N. $20^{\circ}$ & $1-2$ & & Kløft $\varnothing$ st for elven i Tjørnudalur. & \\
\hline 13 & 15,5 & & N. $20^{\circ}$ & & & Hvannagjógv. & \\
\hline 14 & 15,1 & & N. $15^{\circ}$ & & & Toftaknúkur. & \\
\hline 15 & 15,1 & 480 & N. $135^{\circ}$ & $1-2$ & TB & Nordsiden af Breytarskarð. & \\
\hline 16 & 15,1 & 380 & N. $165^{\circ}$ & $1-2$ & $\mathrm{~TB}$ & $\begin{array}{l}\text { Nord for Vardestien } \phi \text { st for Katlar- } \\
\text { nir ved Vardekote } 412 \text {. }\end{array}$ & \\
\hline 17 & 15,1 & 22 & N. $90^{\circ}$ & & $\mathrm{TB}$ & Ved elv, østsiden af Ārnafjørour. & \\
\hline 18 & 15,4 & & N. $180^{\circ}$ & 1 & ТВ & Vestsiden af Ärnafjørður. & Horisontal forkastning ca. $10 \mathrm{~m}$. \\
\hline 19 & $15,7.8$ & & N. $90^{\circ}$ & $0,5-1$ & $\mathrm{~TB}$ & $\begin{array}{l}\text { I kysten ved Kvíingadalur, nord for } \\
\text { elven. }\end{array}$ & $\begin{array}{l}\text { Uregelmæssigt forl } \varnothing \mathrm{b} . \\
\text { Stærkt breccieret. }\end{array}$ \\
\hline 20 & 15,8 & & N. $30^{\circ}$ & & & Gjógv'en i Hellisdalur. & \\
\hline
\end{tabular}


$\exists$

\begin{tabular}{|c|c|c|c|c|c|c|}
\hline Nr. & M i) & Højde i m & Retning & Bredde i m & Type 2) & Lokalitet \\
\hline 21 & 15,8 & & N. $10^{\circ}$ & $1-2$ & & Mellem Hellisdalur og Lissah $\varnothing v d i$. \\
\hline 22 & 22,5 & & N. $25^{\circ}$ & 2 & & Øst for Djúpið. \\
\hline 23 & 22,5 & & N. $145^{\circ}$ & 2 & & Vest for Djúpið. \\
\hline 24 & 22,5 & & N. $35^{\circ}$ & 2 & & Gjógvarenni. \\
\hline 25 & 22,1 & & N. $50^{\circ}$ & & & Syd for Torvadalsá. \\
\hline 26 & 15,7 & & N. $25^{\circ}$ & 4 & TB & Ved nordlige bøgærde, Oyri. \\
\hline 27 & 15,7 & 150 & N. $25^{\circ}$ & & & Nord for Oyri. \\
\hline 28 & 15,4 & & N. $115^{\circ}$ & 1 & $\mathrm{~TB}$ & $\emptyset$ stsiden af Gravardalur. \\
\hline 29 & 15,4 & 223 & N. $115^{\circ}$ & 4 & $\mathrm{~TB}$ & Vestsiden af Gravardalur. \\
\hline 30 & 15,7 & & N. $25^{\circ}$ & 5 & $\mathrm{~TB}$ & $\begin{array}{l}\text { Vestsiden af Borðoyarvík, i kysten } \\
\text { under Neytadalur. }\end{array}$ \\
\hline 31 & 22,1 & & N. $90^{\circ}$ & 5 & & $\begin{array}{l}\text { Nord for Hálsgjógv, фstsiden af } \\
\text { Borðoyarnes. }\end{array}$ \\
\hline 32 & 22,1 & 280 & N. $125^{\circ}$ & 3 & TB & Sydøst for Háfjall. \\
\hline 33 & 22,1 & 60 & N. $125^{\circ}$ & 3 & TB & Nordvestsiden af Hálsgjógv. \\
\hline 34 & $22,1.4$ & & N. $35^{\circ}$ & $4-5$ & ТВ & Hálsgjógv, фstsiden af Borðoyarnes. \\
\hline 35 & 22,4 & & N. $120^{\circ}$ & & & $\begin{array}{l}\text { Kløft syd for Hálsgjógv, } \emptyset \text { stsiden af } \\
\text { Borðoyarnes. }\end{array}$ \\
\hline 36 & 22,4 & & N. $35^{\circ}$ & & & Hálsgjógv (vestsiden af Borðoyarnes). \\
\hline 37 & 22,1 & 280 & N. $90^{\circ}$ & 5 & TB & $\begin{array}{l}\text { Omtrent midt imellem Hálsgjógv og } \\
\text { Ritugjógv. }\end{array}$ \\
\hline 38 & 21,3 & & N. $35^{\circ}$ & & & Ritugjógv. \\
\hline 39 & 14,9 & & N. $80^{\circ}$ & $1-2$ & & I kysten sydøst for Háfjall. \\
\hline 40 & 14,9 & 120 & N. $145^{\circ}$ & 2 & $\mathrm{~TB}$ & Hammer over Leitio. \\
\hline 41 & 14,9 & & N. $70^{\circ}$ & 2 & & Nord for Leitio. \\
\hline
\end{tabular}

Stærkt lamelleret.

Lamelleret.
Horisontal forkastning (B. 35).
Horisontal forkastning (B. 33).

Stærkt lamelleret.

Meget uregelmæssig og bugtet. 


\begin{tabular}{|c|c|c|c|c|c|c|c|}
\hline Nr. & M 1) $\quad H$ & Hojde i m & Retning & Bredde i m & Type 2) & Lokalitet & Bemærkninger \\
\hline 42 & 14,9 & & N. $60^{\circ}$ & $3-4$ & TB & Gjógv nord for Leitið. & \\
\hline 43 & 14,9 & 30 & N. $165^{\circ}$ & & & I elv med bøjning mod Hálgafelli. & \\
\hline 44 & $14,9.6$ & 30 & N. $165^{\circ}$ & 2 & & Elven op mod Hálsur. & \\
\hline 45 & 14,6 & 30 & N. $160^{\circ}$ & & & 1. elv nord for Hálsur. & \\
\hline 46 & 14,6 & & N. $165^{\circ}$ & & & 2. elv nord for Hálsur. & \\
\hline 47 & 14,6 & 40 & N. $165^{\circ}$ & & TB & Elv ved "ból « syd for kote 20. & \\
\hline 48 & 14,6 & & N. $165^{\circ}$ & $1-2$ & ТВ & I kysten vest for Klakkur. & Bugtet og uregelmæssigt forl $\varnothing \mathrm{b}$. \\
\hline 49 & 14,9 & 40 & N. $165^{\circ}$ & & & Elv med bøjning mod Hálgafelli. & \\
\hline 50 & 14,6 & 40 & N. $155^{\circ}$ & & & 1. elv nord for Hálsur. & \\
\hline 51 & 14,6 & & N. $160^{\circ}$ & & & 2. elv nord for Hálsur. & \\
\hline 52 & 14,6 & 44 & N. $165^{\circ}$ & & TB & Elv ved »ból « syd for kote 20. & \\
\hline 53 & 14,6 & & N. $165^{\circ}$ & 0,5 & ТВ & I kysten vest for Klakkur. & Bugtet forl $\varnothing b$. Tynder ud mod syd. \\
\hline 54 & 14,6 & & N. $110^{\circ}$ & 1,5 & $\mathrm{~TB}$ & $\begin{array}{l}\text { Ved telefonkabel i kysten vest for } \\
\text { Klakkur. }\end{array}$ & \\
\hline 55 & 14,6 & & N. $100^{\circ}$ & 1,5 & $\mathrm{OB}$ & $\begin{array}{l}\text { Ved telefonkabel i kysten vest for } \\
\text { Klakkur. }\end{array}$ & \\
\hline 56 & 14,3 & . & N. $170^{\circ}$ & $2-3$ & TB & Syd for Ānirnar. & \\
\hline 57 & 15,1 & 450 & N. $90^{\circ}$ & 4,5 & TB & Sydsiden af Áarskarð. & \\
\hline 58 & 15,1 & 340 & N. $90^{\circ}$ & & $\mathrm{TB}$ & Over Ânagjógv. & \\
\hline 59 & 15,1 & & N. $100^{\circ}$ & & TB & Kløften nord for Ánagjógv. & \\
\hline 60 & 14,3 & & N. $105^{\circ}$ & $1,5-2$ & TB & Ánir. & \\
\hline 61 & 14,3 & & N. $35^{\circ}$ & 1,5 & $\mathrm{OB}$ & Ved kraftstationen syd for Strond. & \\
\hline 62 & 8,9 & & N. $50^{\circ}$ & & & Syd for Svartidalur. & \\
\hline 63 & 8,9 & & N. $95^{\circ}$ & & TB & Sydvest for Lokkagjógv. & Opløses i apofyser mod $\varnothing$ st. \\
\hline 64 & 8,9 & & N. $20^{\circ}$ & 4 & TB & Lokkagjógv. & \\
\hline
\end{tabular}




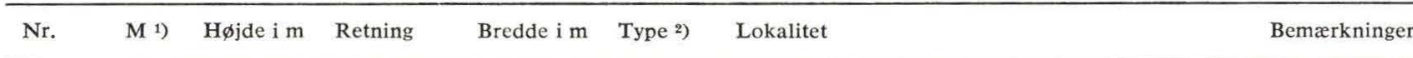

\begin{tabular}{lll}
\hline 65 & 8,9 & N. $115^{\circ}$ \\
66 & 8,6 & N. $140^{\circ}$ \\
67 & 8,6 & N. $100^{\circ}$ \\
68 & 8,6 & N. $15^{\circ}$ \\
69 & 8,3 & N. $105^{\circ}$ \\
70 & 8,3 & N. $110^{\circ}$ \\
71 & 8,3 & N. $110^{\circ}$ \\
72 & 2,9 & N. $105^{\circ}$ \\
73 & 2,9 & N. $80^{\circ}$ \\
74 & 2,9 & N. $160^{\circ}$
\end{tabular}

I kysten syd for Svartidalur.

Syd for Krossdalsáir.

Nord for Krossdalsáir.

Nord for Krossdalsáir.

Syd for Ásugjógv.

TB Ásugjógv.

Tinaldsgjógv.

I kysten v. Ørmannsdalur.

Múlagjógv.

Nord for Skarðsgjógv.

Kunoy (Ku.)

\begin{tabular}{|c|c|c|c|c|c|c|c|}
\hline Nr. & $M^{11}$ & Højde i m & Retning & Bredde i m & Type 2) & Lokalitet & Bemærkninger \\
\hline 1 & $2,5.8$ & & N. $135^{\circ}$ & & & Nordvestsiden af Kunoyarnakkur. & \\
\hline 2 & 2,8 & & N. $35^{\circ}$ & $1-2$ & & I kysten, sydsiden af Ytstidalur. & \\
\hline 3 & 2,8 & & N. $35^{\circ}$ & & & Nordsiden af Gjóardalur. & \\
\hline 4 & 2,8 & & N. $85^{\circ}$ & $1-2$ & & Nord for Gjóardalsgjógv. & \\
\hline 5 & 2,8 & & N. $115^{\circ}$ & & & Gjóardalsgjógv. & \\
\hline 6 & 2,8 & 230 & N. $40^{\circ}$ & 4 & $\mathrm{~TB}$ & Sydsiden af Gjóardalur. & \\
\hline 7 & 8,2 & & N. $40^{\circ}$ & & $\mathrm{TB}$ & Syd $\varnothing$ st for Havnartindur. & \\
\hline 8 & 8,2 & & N. $30^{\circ}$ & & FB & Syd $\phi$ st for Havnartindur. & \\
\hline 9 & 8,2 & & N. $30^{\circ}$ & & TB & Syd $\varnothing$ st for Havnartindur. & \\
\hline 10 & 8,2 & & N. $120^{\circ}$ & & & Miklidalur. & \\
\hline 11 & 8,2 & & N. $50^{\circ}$ & & & Miklidalur. & \\
\hline
\end{tabular}




\begin{tabular}{|c|c|c|c|c|c|c|c|}
\hline Nr. & $M^{1)} \quad I$ & Højde i m & Retning & Bredde i m & Type ${ }^{2)}$ & Lokalitet & Bemærkninger \\
\hline 12 & 8,2 & & N. $25^{\circ}$ & & & Nord for Skarð. & \\
\hline 13 & 8,2 & & N. $25^{\circ}$ & & & Nord for Skarð. & \\
\hline 15 & $8,5.6$ & 220 & N. $100^{\circ}$ & 5 & $\mathrm{~TB}$ & Øst for Líraskor. & \\
\hline 16 & 8,6 & & N. $95^{\circ}$ & & & I nordsiden af Búđadalur. & \\
\hline 17 & 8,9 & & N. $35^{\circ}$ & $6-8$ & ТВ & Syd for Búðadalur. & Lameller med blegejord. \\
\hline 20 & 14,3 & & N. $40^{\circ}$ & $3-4$ & & Sydlige B $\emptyset$ gærde, Haraldssund. & \\
\hline 21 & 14,3 & & N. $45^{\circ}$ & 6 & FB & Syd for Haraldssund. & \\
\hline 22 & 14,3 & 188 & N. $135^{\circ}$ & 4 & TB & Syd for Glyvursá. & \\
\hline 23 & 14,3 & & N. $135^{\circ}$ & $3-4$ & TB & Nord $\varnothing$ st for Kunoyarnes. & \\
\hline 24 & 14,3 & & N. $30^{\circ}$ & & & Vest for Kunoyarnes. & \\
\hline 25 & $14,2.3$ & & N. $50^{\circ}$ & 10 & $\begin{array}{l}\text { FB } \\
\text { TB }\end{array}$ & Hvalgjógv. & $\begin{array}{l}\text { Sammensat gang (TB sydl. gang } \\
\text { FB nordl. gang). Midtlamel. } \\
\text { Noget svingende forl } \varnothing \mathrm{b} \text {. }\end{array}$ \\
\hline 28 & 8,8 & 605 & N. $120^{\circ}$ & & & Syd for Landsuðurknúkur. & \\
\hline 29 & 8,8 & 510 & N. $120^{\circ}$ & 5 & & Syd for Landsuðurknúkur. & \\
\hline 30 & 8,8 & & N. $120^{\circ}$ & $2-3$ & OB & Teistagjógv. & \\
\hline 31 & 8,5 & 435 & N. $30^{\circ}$ & $3-4$ & & Nord for Kunoyarbygd. & \\
\hline 32 & 8,5 & 248 & N. $40^{\circ}$ & & OB & Nord for Kunoyarbygd. & \\
\hline 33 & 8,5 & & N. $50^{\circ}$ & & OB & Syd for Garðagjógv. & \\
\hline 34 & 8,5 & & N. $50^{\circ}$ & $3-4$ & TB & Garðagjógv. & \\
\hline
\end{tabular}




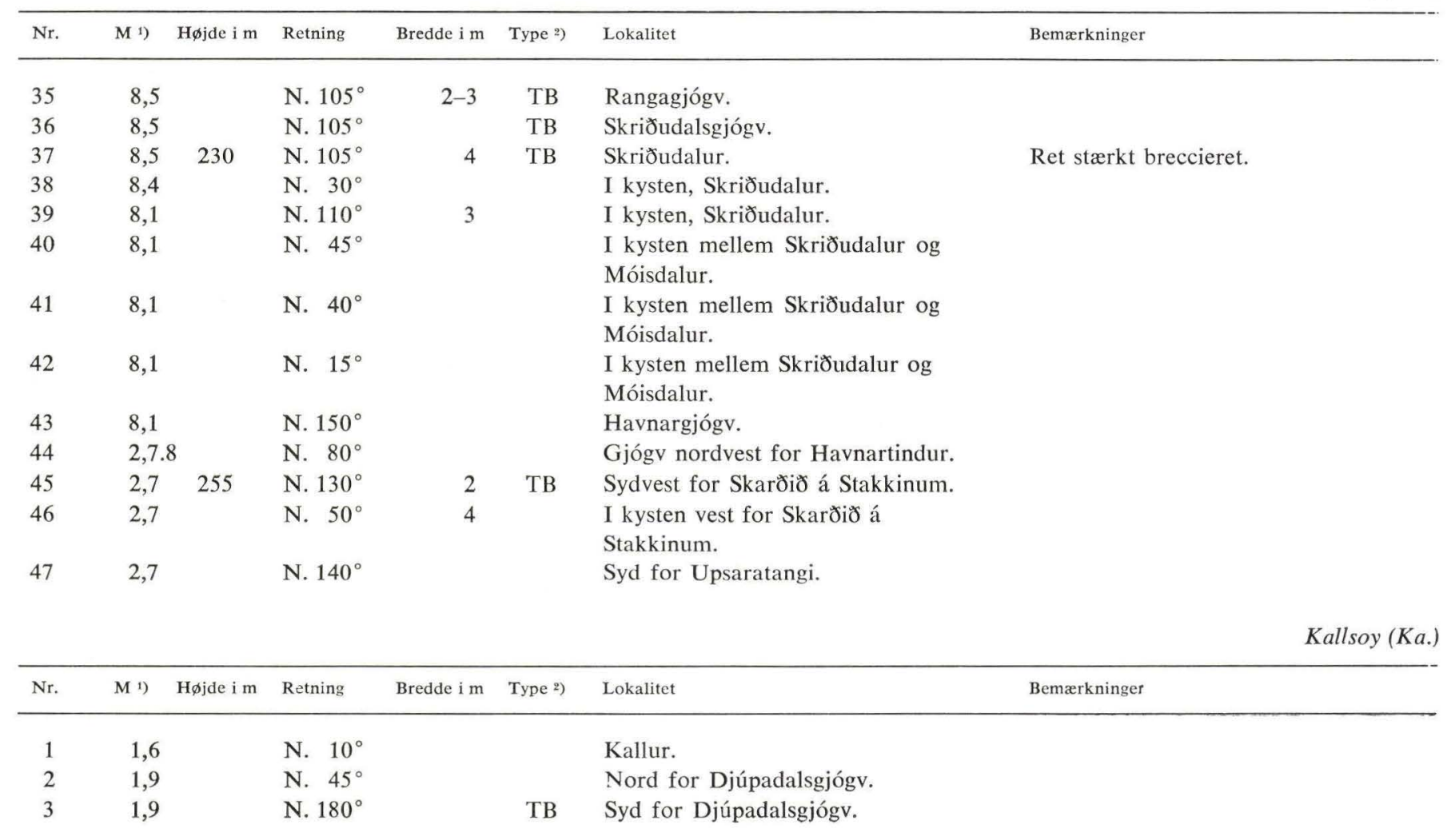




\begin{tabular}{|c|c|c|c|c|c|c|c|}
\hline Nr. & M 1) & Højde i m & Retning & Bredde i m & Type 2) & Lokalitet & Bemærkninger \\
\hline 4 & 1,9 & 280 & N. $180^{\circ}$ & $1-1,5$ & & Sydsiden af Djúpidalur. & Ret bugtet forl $\varnothing \mathrm{b}$. \\
\hline 5 & 1,9 & & N. $180^{\circ}$ & & $\mathrm{TB}$ & Syd for Djúpadalsgjógv. & \\
\hline 6 & 1,9 & 280 & N. $180^{\circ}$ & $1-1,5$ & & Sydsiden af Djúpidalur. & \\
\hline 7 & 1,9 & & N. $110^{\circ}$ & & & Nord $\varnothing$ st for Kambur. & \\
\hline 8 & 7,3 & & N. $75^{\circ}$ & 2 & & Lendingargjógv, Mikladalur. & Noget bugtet forl $\varnothing \mathrm{b}$. \\
\hline 9 & 8,1 & & N. $10^{\circ}$ & 5 & TB & Ritudalsgjógv. & \\
\hline 10 & 7,6 & 300 & N. $10^{\circ}$ & 4 & & Gjógv nord for Byttufelli. & \\
\hline 11 & 8,1 & & N. $100^{\circ}$ & & & I kysten nord $\emptyset$ st for Byttufelli. & \\
\hline 12 & 8,1 & & N. $75^{\circ}$ & & & I kysten nord $\varnothing$ st for Byttufelli. & \\
\hline 13 & 8,1 & & N. $75^{\circ}$ & & TB & Nord $\varnothing$ st for Byttufelli. & \\
\hline 14 & 8,4 & & N. $55^{\circ}$ & $6-7$ & TB & Lunnarsgjógv. & $\begin{array}{l}\text { Kontaktzonen lamelleret. } \\
\text { Blegejordsårer i midten. }\end{array}$ \\
\hline 15 & 8,4 & & N. $50^{\circ}$ & & & Nordsiden Hattardalur. & \\
\hline 16 & 8,4 & & N. $100^{\circ}$ & & & Hattardalur. & \\
\hline 17 & 8,4 & & N. $20^{\circ}$ & & & Sydsiden Hattardalur. & \\
\hline 18 & 8,7 & & N. $25^{\circ}$ & & & Nordsiden Miðardalur. & \\
\hline 19 & 8,7 & & N. $25^{\circ}$ & & & Miðardalur (nordl. elv). & \\
\hline 20 & 8,7 & & N. $40^{\circ}$ & & & Krákugjógv. & \\
\hline 21 & 8,7 & & N. $20^{\circ}$ & & & Nord for Húsar (Lítla Gjógv). & \\
\hline \multirow[t]{2}{*}{22} & $8,7-$ & & & & & & \\
\hline & 14,1 & 160 & N. $20^{\circ}$ & $3-4$ & TB & Syd $\varnothing$ st for Nøvin. & \\
\hline 23 & 14,1 & 200 & N. $150^{\circ}$ & & TB & Nordsiden af Húsaeið̋i. & \\
\hline 24 & $14,1.2$ & & N. $90^{\circ}$ & 5 & TB & Húsar (gjógv). & $\begin{array}{l}\text { Stærkt lamelleret til siderne. Zeolit- } \\
\text { og blegejordsårer. Mange apofyser. }\end{array}$ \\
\hline 25 & 14,2 & & N. $90^{\circ}$ & & TB & Nordsiden af Knúksdalur. & \\
\hline
\end{tabular}




\begin{tabular}{|c|c|c|c|c|c|c|c|}
\hline Nr. & $\left.M^{1}\right)$ & Højde i m & Retning & Bredde i m & Type 2) & Lokalitet & Bemærkninger \\
\hline 26 & 14,2 & & N. $95^{\circ}$ & & & I kysten Knúksdalur. & \\
\hline 27 & 14,2 & & N. $60^{\circ}$ & & & I kysten Knúksdalur. & \\
\hline \multirow[t]{2}{*}{28} & 14,5 & & N. $65^{\circ}$ & 4 & $\mathrm{~TB}$ & & Sammensat gang (TB nordl. gang. \\
\hline & & & & 5,5 & FB & Syðradalur. & FB sydl. gang). Midtlamel. \\
\hline 29 & 14,8 & & N. $180^{\circ}$ & & & Galvur. & \\
\hline 30 & 14,4 & & N. $75^{\circ}$ & $4,5-5$ & FB & Svínagjógv. & Stærkt lamelleret. \\
\hline 31 & 14,1 & 520 & N. $75^{\circ}$ & 5 & $\mathrm{~TB}$ & Hvannagjógv. & Stærkt lamelleret. \\
\hline 32 & 14,1 & & N. $110^{\circ}$ & 5 & TB & Lambagjógv. & \\
\hline 33 & 14,1 & & N. $90^{\circ}$ & & & Eiðisgjógv. & \\
\hline 34 & 8,7 & & N. $20^{\circ}$ & & & Gravargil. & \\
\hline 35 & 8,7 & & N. $30^{\circ}$ & & & Vest for Miðardalstindur. & \\
\hline 36 & 8,7 & & N. $115^{\circ}$ & & & Nord for Gravargil. & \\
\hline 37 & 8,4 & & N. $60^{\circ}$ & & & Deildargjógv (nedre). & \\
\hline 38 & 8,4 & & N. $45^{\circ}$ & & & Deildargjógv ( $\varnothing v r e)$. & \\
\hline \multirow[t]{2}{*}{39} & $7,6-$ & & & & & & \\
\hline & 8,4 & & N. $55^{\circ}$ & & & Âargjóta. & \\
\hline 40 & 7,6 & & N. $15^{\circ}$ & & & Stóragjógv. & \\
\hline 41 & 7,6 & & N. $100^{\circ}$ & & & Høvadalsleiti (syd for gjógv'en). & \\
\hline 42 & 7,6 & & N. $55^{\circ}$ & & & Høvadalsleiti (gjógv’en). & \\
\hline 43 & 7,6 & & N. $15^{\circ}$ & & & Vest for Ritudalsskarð. & \\
\hline 44 & 7,3 & & N. $100^{\circ}$ & 1 & & Nordvest for Ritudalsskarð. & \\
\hline 45 & 7,3 & & N. $75^{\circ}$ & & & Nordvest for Slættafjall. & \\
\hline 46 & 1,9 & & N. $90^{\circ}$ & & & Syd for Skjaldarboði. & \\
\hline 47 & 1,9 & & N. $30^{\circ}$ & & & Syd for Skjaldarboði. & \\
\hline 48 & 1,9 & & N. $30^{\circ}$ & 3 & $\mathrm{FB}$ & $\emptyset$ st for Dritstapi. & Lamelleret. Bugtet forløb. \\
\hline
\end{tabular}


Kallsoy (Ka.)

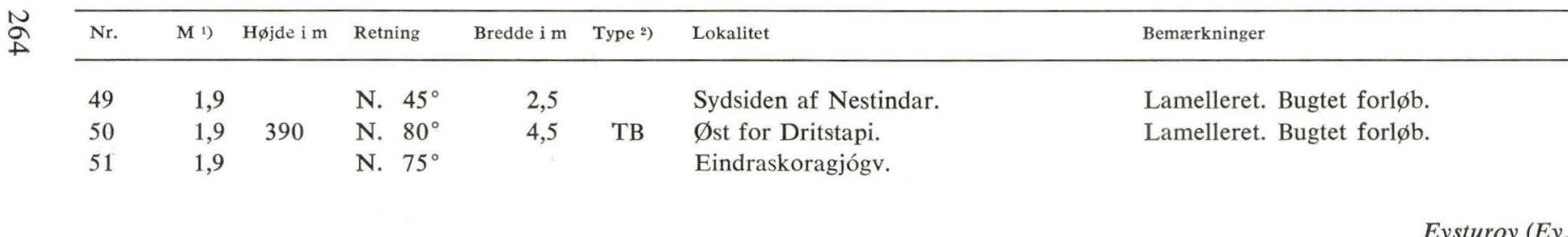

\begin{tabular}{llllll}
\hline Nr. & $M^{1)}$ Højde i m Retning Bredde im $\quad$ Type ${ }^{2}$ Lokalitet Bemærkninger \\
\hline
\end{tabular}

$\begin{array}{rll}1 & 7,1- & \\ & 6,3 & \text { N. } 155^{\circ} \\ 2 & 7,1.4 & \text { N. } 135^{\circ} \\ 3 & 7,1.4 & \text { N. } 10^{\circ} \\ 4 & 7,4 & \text { N. } 135^{\circ} \\ 5 & 7,4 & \text { N. } 10^{\circ} \\ 6 & 7,4 & \text { N. } 150^{\circ} \\ 7 & 7,7 & \text { N. } 25^{\circ} \\ 8 & 7,7 & \text { N. } 25^{\circ} \\ 9 & 7,7 & \text { N. } 130^{\circ} \\ 10 & 7,7 & \text { N. } 120^{\circ} \\ 11 & 7,7 & \text { N. } 175^{\circ} \\ 12 & 7,7 & \text { N. } 5^{\circ} \\ 13 & 7,8 & \text { N. } 170^{\circ} \\ 14 & 7,8 & \text { N. } 35^{\circ} \\ 15 & 7,8 & \text { N. } 95^{\circ}\end{array}$




\begin{tabular}{|c|c|c|c|c|c|c|c|}
\hline Nr. & M 1) & Højde i m & Retning & Bredde i m & Type 2) & Lokalitet & Bemærkninger \\
\hline 16 & 13,1 & 405 & N. $110^{\circ}$ & 5 & & Hagagjógv. & \\
\hline 17 & 13,1 & & N. $40^{\circ}$ & 5 & & Gjógv'en syd for Hagagjógv. & \\
\hline 18 & 13,1 & & N. $40^{\circ}$ & & & $\begin{array}{l}\text { Forts. af nr. } 17 \text { på vestsiden af } \\
\text { fjeldet. }\end{array}$ & \\
\hline 19 & 13,1 & & N. $90^{\circ}$ & & & Ólavsøkugjógv. & \\
\hline 20 & 13,1 & 310 & N. $75^{\circ}$ & $6-8$ & TB & Øksnagjógv (Dalkinn). & Stærk forkløftning i gangretningen. \\
\hline 21 & 13,1 & 200 & N. $125^{\circ}$ & 4 & TB & Nord for Øksnagjógv (Dalkinn). & \\
\hline 22 & 13,1 & & N. $75^{\circ}$ & & & Øksnagjógv (Undir Egg). & \\
\hline 23 & 13,2 & 180 & N. $180^{\circ}$ & 4 & $\mathrm{OB}$ & Laksá. & \\
\hline 24 & 13,5 & 228 & N. $180^{\circ}$ & & TB & Laksá. & \\
\hline 25 & 13,2 & & N. $90^{\circ}$ & 6 & & Rættargjógv (Oyndarfjøröur). & \\
\hline 26 & 13,2 & & N. $85^{\circ}$ & 3 & TB & Nord for Rættargjógv (Oyndarfjørður). & \\
\hline 27 & 13,2 & & N. $130^{\circ}$ & 3 & $\mathrm{~TB}$ & Hellur (Lille gjógv). & \\
\hline 28 & 13,3 & & N. $180^{\circ}$ & 1 & & $\emptyset_{\text {st }}$ for Nestangi. & 2 gange tæt sammen afmærket som 1. \\
\hline 29 & 13,3 & & N. $10^{\circ}$ & $4-6$ & $\mathrm{OB}$ & Nordnordvest for Rókin. & I kysten 2 gange. \\
\hline 30 & 13,3 & 12 & N. $60^{\circ}$ & $2-3$ & $\mathrm{~TB}$ & Nord for Halgadalsá. & Stærkt breccieret. \\
\hline 31 & 13,6 & 125 & N. $75^{\circ}$ & $4-6$ & $\mathrm{~TB}$ & Norðaragjógv. & Lamelleret. \\
\hline 32 & 13,6 & & N. $80^{\circ}$ & & $\mathrm{TB}$ & Borgin. & \\
\hline 33 & 13,6 & 280 & N. $90^{\circ}$ & $2-6$ & TB & Syd for Kirkjugjógv. & \\
\hline 34 & 13,6 & & N. $90^{\circ}$ & 3 & TB & Ved kajen, Fuglafjøröur. & Lamelleret. Uregelmæssigt forl $\varnothing \mathrm{b}$. \\
\hline 35 & 13,6 & 70 & N. $145^{\circ}$ & $2-3$ & $\mathrm{OB}$ & Nordøst for Heimaragjógv. & \\
\hline 36 & 13,6 & 26 & N. $145^{\circ}$ & $1-3$ & $\mathrm{~TB}$ & Heimaragjógv. & $\begin{array}{l}\text { Uregelmæssigt forl } \varnothing \text { b. Stærkt lamelleret } \\
\text { og breccieret. Talrige apofyser. }\end{array}$ \\
\hline 37 & 13,6 & & N. $90^{\circ}$ & 2 & $\mathrm{FB}$ & Vest for Heimaragjógv. & \\
\hline 38 & 13,6 & & N. $180^{\circ}$ & 1 & ТВ & Sydøstpynten, Fuglafjørður. & Noget bugtet forløb. \\
\hline
\end{tabular}




\begin{tabular}{|c|c|c|c|c|c|c|c|}
\hline Nr. & $M^{1)}$ & Højde i m & Retning & Bredde i m & Type 2) & Lokalitet & Bemærkninger \\
\hline 39 & 13,6 & & N. $90^{\circ}$ & 3 & TB & Sydøstsiden, Fuglafjørður. & Mange apofyser. \\
\hline 40 & 13,6 & & N. $90^{\circ}$ & 2 & $\mathrm{FB}$ & Syd $\varnothing$ stsiden, Fuglafjørður. & \\
\hline 41 & 13,6 & & N. $40^{\circ}$ & & & Sydøstsiden, Fuglafjørður. & \\
\hline 42 & 13,6 & 110 & N. $50^{\circ}$ & 5 & $\mathrm{~TB}$ & Kirkjugjógv. & $\begin{array}{l}\text { Stærkt lamelleret med tynde blegejords- } \\
\text { og zeolitårer. }\end{array}$ \\
\hline 43 & 13,6 & 378 & N. $180^{\circ}$ & 1 & $\mathrm{~TB}$ & Nord for Kirkjugjógv. & $\begin{array}{l}\text { Noget bugtet. } 1-2 \mathrm{~cm} \text { tykt } \\
\text { forvitringslag. }\end{array}$ \\
\hline 44 & 13,6 & & N. $170^{\circ}$ & 2 & & Nord for Kirkjugjógv. & \\
\hline 45 & 13,6 & 492 & N. $175^{\circ}$ & 5 & $\mathrm{FB}$ & Borgin. & Stærkt forvitret. \\
\hline 46 & 13,6 & & N. $40^{\circ}$ & $7-8$ & $\mathrm{~TB}$ & Syd for Breiðá. & Mange apofyser. \\
\hline 47 & 13,6 & & N. $30^{\circ}$ & 4 & TB & Syd for Breiðá. & $\begin{array}{l}\text { Stærkt lamelleret, stedvis breccieret. } \\
\text { Mange apofyser. }\end{array}$ \\
\hline 48 & 13,5 & 20 & N. $100^{\circ}$ & $4-5$ & TB & Gjógvará. & $\begin{array}{l}\text { Stærkt lamelleret. Noget uregelmæssigt } \\
\text { forl } \varnothing \text { b. I } 6 \mathrm{~m} \mathrm{~h} \varnothing \text { jde midtlamel. }\end{array}$ \\
\hline 49 & 13,5 & 95 & N. $100^{\circ}$ & & & Gjógvará. & \\
\hline 50 & 13,5 & 370 & N. $155^{\circ}$ & $3-4$ & TB & Nordvestsiden af Blábjørg. & \\
\hline 51 & 13,4 & 620 & N. $90^{\circ}$ & 5 & $\mathrm{~TB}$ & Forlængelse mod vest af Laksá. & \\
\hline 52 & 13,4 & 25 & N. $110^{\circ}$ & 3 & FB & Nord for Bláhamarskarđsá. & \\
\hline 53 & 13,4 & 60 & N. $25^{\circ}$ & 1 & TB & Vesturdalsá. & \\
\hline 54 & 13,4 & & N. $125^{\circ}$ & $3-4$ & & Sydvestsiden Múlatindur. & Ret stærkt lamelleret. \\
\hline 55 & 13,4 & & N. $120^{\circ}$ & $2-3$ & FFB & Sydøstsiden Múlatindur. & \\
\hline 56 & 13,7 & 170 & N. $120^{\circ}$ & $3-4$ & FFB & Heltnará. & Lamelleret. \\
\hline 57 & 13,7 & 242 & N. $25^{\circ}$ & 2 & $\mathrm{~TB}$ & Rákg $\varnothing$ tur. & \\
\hline 58 & 13,7 & 520 & N. $20^{\circ}$ & 5 & TB & $\emptyset$ stsiden af Lokkafelli. & \\
\hline 59 & 13,7 & & N. $110^{\circ}$ & & & Øksnagjógv. & Meget stærkt breccieret med zeolitårer. \\
\hline
\end{tabular}




\begin{tabular}{|c|c|c|c|c|c|c|c|}
\hline Nr. & $M^{1)}$ & Højde i m & Retning & Bredde i m & Type 2) & Lokalitet & Bemærkninger \\
\hline 60 & 13,8 & 24 & N. $30^{\circ}$ & 2,5 & $\mathrm{OB}$ & Fjarðará. & \\
\hline \multirow[t]{2}{*}{61} & 13,8 & 32 & N. $100^{\circ}$ & $3-4$ & ТВ & Fjarðará. \ & 2 gange med $7-8 \mathrm{~m}$ mellemrum afsat \\
\hline & 13,8 & & N. $100^{\circ}$ & $4-6$ & $\mathrm{~TB}$ & Fjarðará. & som 1 gang. \\
\hline 62 & 13,8 & 390 & N. $40^{\circ}$ & 3 & ТВ & Breiðáskarơ. & \\
\hline 63 & 13,8 & 380 & N. $50^{\circ}$ & 1 & FFB & Skarðbrúgv. & \\
\hline 64 & 13,9 & 190 & N. $110^{\circ}$ & 2 & FFB & Kambsdalur. & \\
\hline 65 & 13,9 & 384 & N. $15^{\circ}$ & $6-8$ & $\mathrm{~TB}$ & Vest for Tyrilsenni. & \\
\hline 66 & 13,9 & 115 & N. $15^{\circ}$ & & & Helláir (sydlige elv). & \\
\hline 67 & 13,9 & & N. $15^{\circ}$ & & & Syd for Toftanes. & \\
\hline 68 & 13,9 & & N. $180^{\circ}$ & 2 & $\mathrm{~TB}$ & Helláir (nordlige elv). & \\
\hline 69 & 13,9 & & N. $180^{\circ}$ & 2 & & Øst for Helláir (sydlige elv). & \\
\hline 70 & 13,9 & & N. $65^{\circ}$ & & & $\emptyset$ st for Varmakelda. & \\
\hline 71 & 14,7 & & N. $140^{\circ}$ & 2 & TB & Ritudalsá. & \\
\hline 72 & 14,7 & & N. $140^{\circ}$ & $3-4$ & TB & Hálsur. & \\
\hline 73 & 14,7 & & N. $140^{\circ}$ & $3-4$ & & Mannsgjógv. & - \\
\hline 74 & 14,7 & & N. $115^{\circ}$ & & & Tróndargjógv. & \\
\hline 75 & 14,7 & & N. $40^{\circ}$ & 1,5 & TB & Smalá. & \\
\hline 76 & 14,7 & & N. $15^{\circ}$ & & TB & Skúmagjógv. & \\
\hline 77 & 14,7 & & N. $60^{\circ}$ & & $\mathrm{TB}$ & Høvdagjógv. & \\
\hline 78 & 14,8 & & N. $5^{\circ}$ & 3 & & Vest for Stórá. & \\
\hline 79 & 14,8 & & N. $20^{\circ}$ & & & Ved Stórá. & \\
\hline 80 & 14,8 & & N. $50^{\circ}$ & & & Ved Stórá. & \\
\hline 81 & 20,1 & 480 & N. $120^{\circ}$ & 2 & $\mathrm{~TB}$ & Vest for Halgafellstindur. & \\
\hline 82 & 20,1 & & N. $125^{\circ}$ & $3-5$ & ТВ & Knubbagil. & \\
\hline 83 & 20,1 & & N. $125^{\circ}$ & & & Fransahús. & \\
\hline
\end{tabular}




\begin{tabular}{|c|c|c|c|c|c|c|c|}
\hline Nr. & $M^{1)}$ & Højde i m & Retning & Bredde i m & Type 2) & Lokalitet & Bemærkninger \\
\hline 84 & 20,2 & & N. $35^{\circ}$ & & & Nordøst for Lágarhálsur. & \\
\hline 85 & 20,2 & & N. $50^{\circ}$ & & TB & Svínagjógv. & \\
\hline 86 & 20,2 & & N. $40^{\circ}$ & 3 & $\mathrm{~TB}$ & Fjarđará. & \\
\hline 87 & 20,2 & 40 & N. $105^{\circ}$ & & $\mathrm{TB}$ & Elven fra Tundradalur. & \\
\hline 88 & 20,2 & 146 & N. $105^{\circ}$ & 8 & & Ānir. & Stærkt breccieret. \\
\hline 89 & 20,2 & & N. $15^{\circ}$ & 3 & TB & Ánir. & Noget breccieret. \\
\hline 90 & 20,2 & & N. $165^{\circ}$ & 3 & TB & Syd for Ennisá. & Ret stærkt lamelleret. \\
\hline 91 & 20,2 & & N. $180^{\circ}$ & $2-3$ & $\mathrm{~TB}$ & Syd for Ennisá. & \\
\hline 92 & 20,3 & 290 & N. $20^{\circ}$ & 5 & OB & Áanadalshamar. & \\
\hline 93 & 20,3 & & N. $25^{\circ}$ & 4 & OB & Drottningarsteinur. & Lamelleret. \\
\hline 94 & 20,3 & 240 & N. $\quad 5^{\circ}$ & 2 & TB & Nord for Lághálsur. & \\
\hline 95 & 20,3 & & N. $10^{\circ}$ & 3 & TB & Lághálsur. & \\
\hline 96 & 20,3 & & N. $10^{\circ}$ & 2 & TB & Nord for Tjørnunes. & \\
\hline 97 & 20,3 & & N. $5^{\circ}$ & 1 & & I elv, Syðrug $\varnothing$ ta. & \\
\hline 98 & 20,3 & & N. $95^{\circ}$ & & & Gøtugjógv. & \\
\hline 99 & 20,6 & & N. $45^{\circ}$ & $1,5-2$ & TB & Syd for Krákugil. & \\
\hline 100 & 20,6 & & N. $20^{\circ}$ & 4 & TB & Nord for Langasandur, Skáli. & Ret stærkt lamelleret. \\
\hline 101 & 20,6 & 25 & N. $120^{\circ}$ & 4 & TB & Over Langasandur, Skáli. & Lamelleret. \\
\hline 102 & 20,6 & & N. $15^{\circ}$ & $1-2$ & TB & Nord for Kumlá. & \\
\hline 103 & 20,5 & & N. $20^{\circ}$ & 4 & OB & Nord for Havaldará. & \\
\hline 104 & 20,5 & 262 & N. $10^{\circ}$ & 4 & OB & Havaldará. & Lamelleret. \\
\hline 105 & 20,4 & & N. $135^{\circ}$ & $2-3$ & TB & Ved Argisgjógv. & Lamelleret. \\
\hline 106 & 20,4 & & N. $55^{\circ}$ & $3-4$ & TB & Veðranes. & \\
\hline 107 & 20,9 & 236 & N. $125^{\circ}$ & $12-13$ & TB & Kumlá. & \\
\hline 108 & 20,9 & 220 & N. $100^{\circ}$ & & TB & Ved Gjógvará ( $\varnothing$ vre 1 $\varnothing$ b). & \\
\hline
\end{tabular}




\begin{tabular}{|c|c|c|c|c|c|c|c|}
\hline Nr. & M ') & Højde i m & Retning & Bredde i m & Type $\left.{ }^{2}\right)$ & Lokalitet & Bemæerkninger \\
\hline 109 & 20,9 & 200 & N. $125^{\circ}$ & & TB & Tilløb til Gjógvará. & \\
\hline 110 & 20,9 & 15 & N. $100^{\circ}$ & & FB & Gjógvará, Skáli. & Stærkt breccieret. \\
\hline 111 & 20,9 & 73 & N. $55^{\circ}$ & & $\mathrm{FB}$ & Ved Torvgil. & $\begin{array}{l}\text { Noget bugtet forløb. } \\
\text { Stærkt breccieret. }\end{array}$ \\
\hline 112 & 20,9 & 23 & N. $130^{\circ}$ & $3-4$ & $\mathrm{~TB}$ & Torvgil. & \\
\hline 113 & 20,9 & 10 & N. $130^{\circ}$ & & & Marknará. & \\
\hline 114 & 20,9 & & N. $130^{\circ}$ & $4-5$ & & Syd for Marknará. & \\
\hline 115 & 20,9 & & N. $50^{\circ}$ & & & Hálsur. & \\
\hline 116 & 21,1 & & N. $80^{\circ}$ & 5 & & Tvørgjógv, Gøtuvík. & Lamelleret. \\
\hline 117 & 21,1 & & N. $140^{\circ}$ & 0,5 & TB & Vest for Kýrgjógv, Gøtuvík. & Noget uregelmæssigt forløb. \\
\hline 118 & 21,1 & & N. $140^{\circ}$ & & & Kýrgjógv, Gøtuvík. & \\
\hline 119 & 21,2 & & N. $15^{\circ}$ & 4 & TB & Stóragjógv, Gøtuvík. & \\
\hline 120 & 21,2 & & N. $25^{\circ}$ & 2 & & Mellem Stóragjógv og Rangagjógv. & \\
\hline 121 & 21,2 & & N. $25^{\circ}$ & & & Mellem Stóragjógv og Rangagjógv. & \\
\hline 122 & 21,2 & & N. $125^{\circ}$ & 2 & ТВ & Rangagjógv. & \\
\hline 123 & 21,3 & & N. $100^{\circ}$ & & & Gøtunesgjógv. & \\
\hline 124 & 21,4 & & N. $35^{\circ}$ & $2-3$ & TB & Løgdalsá. & \\
\hline 125 & 21,4 & & N. $45^{\circ}$ & $4-6$ & & Sydøst for Selgjógv. & \\
\hline 126 & 21,5 & 40 & N. $75^{\circ}$ & $4-5$ & TB & Kjóadalsgjógv. & Buet forl $\varnothing \mathrm{b}$. \\
\hline 127 & 21,9 & & N. $180^{\circ}$ & $2-4$ & & Sydøst for Sekkjatangi. & \\
\hline 128 & 21,9 & & N. $80^{\circ}$ & $3-6$ & & Láturgjógv. & Stærkt lamelleret, buet forl $\varnothing$ b. \\
\hline 129 & 27,2 & & N. $25^{\circ}$ & 4,5 & $\mathrm{OB}$ & Morskranes. & \\
\hline 130 & 27,2 & & N. $65^{\circ}$ & 5 & ТВ & Syd for Morskranes. & Stærkt breccieret med zeolitårer. \\
\hline 131 & 27,2 & & N. $65^{\circ}$ & & $\mathrm{TB}$ & Tungáir. & \\
\hline 132 & 27,3 & & N. $65^{\circ}$ & & $\mathrm{TB}$ & Vest for Urơará. & \\
\hline
\end{tabular}




\begin{tabular}{|c|c|c|c|c|c|c|c|}
\hline Nr. & M 1) & Højde i m & Retning & Bredde i m & Type 2) & Lokalitet & Bemærkninger \\
\hline 133 & 27,3 & 110 & N. $165^{\circ}$ & 1 & TB & $\begin{array}{l}\text { Nord for Kolbjarnargjógv } \\
\text { (v. telefonkabel). }\end{array}$ & \\
\hline 134 & 27,6 & & N. $175^{\circ}$ & & TB & Syd for Kolbjarnargjógv. & \\
\hline 135 & 27,6 & & N. $85^{\circ}$ & & TB & Syd for Kolbjarnargjógv. & \\
\hline 136 & 27,6 & & N. $85^{\circ}$ & & TB & Syd for Kolbjarnargjógv. & \\
\hline 137 & 28.1 & & N. $140^{\circ}$ & & TB & Glyvrar. & \\
\hline 138 & 28,3 & & N. $70^{\circ}$ & $6-8$ & & Lágjógv. & \\
\hline 139 & 28,3 & & N. $20^{\circ}$ & $3-6$ & & Drangur. & \\
\hline 140 & 28,3 & & N. $90^{\circ}$ & & & Kýrgjógv. & Stærkt breccieret. \\
\hline 141 & 28,6 & & N. $145^{\circ}$ & & & Dirvisgjógv. & \\
\hline 142 & 28,5 & & N. $5^{\circ}$ & & & Øst for Rituvík. & \\
\hline 143 & 28,5 & 80 & N. $100^{\circ}$ & & FB & $\begin{array}{l}\text { Varderuten mellem Heiöarnar og } \\
\text { Rituvík (Innarihálsur). }\end{array}$ & \\
\hline 144 & 28,4 & & N. $65^{\circ}$ & $8-10$ & TB & Nord for Saltnes. & Tvedelt i kysten, 3-4 m mellemrun \\
\hline 145 & 28,4 & & N. $65^{\circ}$ & $10-12$ & $\mathrm{~TB}$ & Vest for Heiðarnar. & \\
\hline 146 & 28,7 & & N. $120^{\circ}$ & & & Nes. & \\
\hline 147 & 28,7 & & N. $70^{\circ}$ & & & Stóragjógv. & \\
\hline 148 & 28,8 & & N. $25^{\circ}$ & 5 & FB & Nord for Tinghella. & Lamelleret. \\
\hline 149 & 28,8 & & N. $140^{\circ}$ & 3 & TB & Nord for Skoragil. & Opløses i apofyser. \\
\hline 150 & 33,2 & 35 & N. $145^{\circ}$ & $3-4$ & TB & Ryssan (Eystnes). & \\
\hline 151 & 6,2 & & N. $175^{\circ}$ & & & N $\varnothing$ vin. & \\
\hline 152 & 6,2 & & N. $175^{\circ}$ & & & Vest for Hvalsryggur. & \\
\hline 153 & 6,3 & & N. $115^{\circ}$ & & & Syd for Sátan. & \\
\hline 154 & 6,6 & & N. $145^{\circ}$ & 2 & & Nordøst for Funningur. & \\
\hline 155 & 6,6 & & N. $145^{\circ}$ & 2 & & Nordøst for Funningur. & \\
\hline
\end{tabular}




\begin{tabular}{|c|c|c|c|c|c|c|}
\hline Nr. & M 1) & Højde i m & Retning & Bredde i m & Type 2) & Lokalitet \\
\hline 156 & 6,4 & & N. $175^{\circ}$ & 1 & TB & Trøllshøvðið. \\
\hline 157 & 6,4 & 20 & N. $125^{\circ}$ & 4,5 & FFB & $\emptyset$ stsiden af indsøen, Eiði. \\
\hline 158 & 6,4 & 45 & N. $125^{\circ}$ & & & Vestsiden af indsøen, Eiði. \\
\hline 159 & 6,4 & & N. $125^{\circ}$ & & & Krákuheyggjur. \\
\hline 160 & 6,4 & & N. $125^{\circ}$ & & & Vestsiden af Eiðiskollur. \\
\hline 161 & 6,4 & & N. $135^{\circ}$ & & & Vestsiden af Eiðiskollur. \\
\hline 162 & 6,4 & & N. $85^{\circ}$ & & & Vestsiden af Eiðiskollur. \\
\hline 163 & 6,4 & & N. $90^{\circ}$ & & & Nordøstsiden af Eiðiskollur. \\
\hline 164 & 6,7 & 65 & N. $25^{\circ}$ & 2 & $\mathrm{~TB}$ & Ved vejen mellem Breiðá og Hellisá. \\
\hline 165 & 6,7 & 30 & N. $105^{\circ}$ & 4 & TB & Hellisá. \\
\hline 166 & 6,9 & & N. $55^{\circ}$ & $4-5$ & $\mathrm{FB}$ & Sydl. bøgærde, Funningur. \\
\hline 167 & 6,9 & 440 & N. $115^{\circ}$ & $4-5$ & FFB & Nón. \\
\hline 168 & 6,9 & 440 & N. $105^{\circ}$ & $4-6$ & $\mathrm{~TB}$ & Nón. \\
\hline 169 & 6,9 & & N. $105^{\circ}$ & 6 & & Nordvestsiden af Húsafjall. \\
\hline 170 & 6,9 & & N. $115^{\circ}$ & $3-4$ & $\mathrm{~TB}$ & Hagagjógv. \\
\hline 171 & 6,9 & & N. $135^{\circ}$ & $4-5$ & & Sydvesthjørnet, Húsafjall. \\
\hline 172 & 12,2 & 72 & N. $95^{\circ}$ & $5-6$ & TB & Syd for Ljósá. \\
\hline 173 & 12,2 & 72 & N. $45^{\circ}$ & & $\mathrm{TB}$ & Nord for Trogará. \\
\hline 174 & 12,2 & & N. $110^{\circ}$ & 4 & & Trogará. \\
\hline 175 & 12,3 & & N. $145^{\circ}$ & $5-6$ & $\mathrm{~TB}$ & Ljóságjógv. \\
\hline 176 & 12,3 & & N. $145^{\circ}$ & & & Syd for Ólavsøkugjógv. \\
\hline 177 & 12,3 & & N. $65^{\circ}$ & & $\mathrm{TB}$ & Ólavs $\emptyset$ kugjógv. \\
\hline 178 & 12,3 & & N. $85^{\circ}$ & 7 & $\mathrm{~TB}$ & Syd for Ólavs $\varnothing$ kugjógv. \\
\hline
\end{tabular}

Ret stærkt lamelleret med zeolitårer. Bugtet, står frem i terrænet.

Stærkt breccieret.

Horisontal forkastning ca. $20 \mathrm{~m}$ (Ey. 176).

Horisontal forkastning ca. $20 \mathrm{~m}$ (Ey. 175).

Stærkt lamelleret med zeolitårer. 


\begin{tabular}{|c|c|c|c|c|c|c|c|}
\hline $\mathrm{Nr}$. & M 1) & Højde i m & Retning & Bredde i m & Type 2) & Lokalitet & Bemærkninger \\
\hline 179 & 12,3 & & N. $135^{\circ}$ & 2,5 & FFB & Nord for Ljóságjógv. & \\
\hline 180 & 12,3 & 75 & N. $110^{\circ}$ & 4 & $\mathrm{~TB}$ & Hagagjógv. & Stærkt breccieret. \\
\hline 181 & 12,3 & 2 & N. $70^{\circ}$ & 4 & $\mathrm{~TB}$ & Elv i Blæingsgjógv. & Stærkt lamelleret. \\
\hline 182 & 12,3 & 29 & N. $150^{\circ}$ & 1 & FFB & Syd for Blæingsgjógv. & $\begin{array}{l}\text { Horisontal forkastning } \\
\text { ca. } 5 \mathrm{~m} \text { (Ey. 183). }\end{array}$ \\
\hline 183 & 12,3 & & N. $150^{\circ}$ & & & Syd for Blæingsgjógv. & $\begin{array}{l}\text { Horisontal forkastning } \\
\text { ca. } 5 \mathrm{~m} \text { (Ey. 182). }\end{array}$ \\
\hline 184 & 12,3 & 15 & N. $35^{\circ}$ & 2 & $\mathrm{~TB}$ & Syd for Blæingsgjógv. & \\
\hline 185 & 12,6 & & N. $10^{\circ}$ & 2,5 & $\mathrm{~TB}$ & $\emptyset$ stsiden af Funningsfjall. & \\
\hline 186 & 12,6 & & N. $95^{\circ}$ & 4 & TB & $\begin{array}{l}\emptyset \text { stsiden af Funningsfjall ved } \\
\text { nordlige bøgærde. }\end{array}$ & Lamelleret med zeolitårer. \\
\hline 187 & 12,6 & & N. $10^{\circ}$ & 2,5 & $\mathrm{~TB}$ & Ved udløbet af Títlá. & \\
\hline 188 & 12,6 & 290 & N. $10^{\circ}$ & 3 & TB & Barkhellá. & \\
\hline 189 & 12,6 & & N. $20^{\circ}$ & 3 & $\mathrm{~TB}$ & Kvíandalsvatn. & $\begin{array}{l}\text { Horisontal forkastning ca. } 26 \mathrm{~m} \\
\text { (Ey. 190) bugtet forl } \varnothing \text { b. }\end{array}$ \\
\hline 190 & 12,6 & & N. $30^{\circ}$ & 2 & $\mathrm{~TB}$ & Nord for Skipanesoyri. & $\begin{array}{l}\text { Horisontal forkastning ca. } 26 \mathrm{~m} \\
\text { (Ey. 189) bugtet forl } \varnothing \mathrm{b} \text {. }\end{array}$ \\
\hline 191 & 12,6 & & N. $95^{\circ}$ & 6 & TB & Skipagjógv. & Stærkt breccieret. \\
\hline 192 & 12,6 & 589 & N. $95^{\circ}$ & $4-5$ & $\mathrm{~TB}$ & Syd i Skerðingur. & Noget breccieret. \\
\hline 193 & 12,5 & 286 & N. $10^{\circ}$ & 4 & $\mathrm{~TB}$ & Grábrúgv (Svíná). & \\
\hline 194 & 12,5 & & N. $10^{\circ}$ & 6 & $\mathrm{FB}$ & Elv ved nordl. bøgærde, Svínáir. & \\
\hline 195 & 12,5 & 74 & N. $85^{\circ}$ & 2 & $\mathrm{~TB}$ & $\emptyset$ st for Krossur. & \\
\hline 196 & 12,8 & 20 & N. $100^{\circ}$ & $4-5$ & $\mathrm{~TB}$ & Norðskáli. & Stærkt breccieret. \\
\hline 197 & 12,9 & 150 & N. $100^{\circ}$ & 2 & $\mathrm{~TB}$ & Skálá. & \\
\hline 198 & 12,9 & 435 & N. $15^{\circ}$ & $4-5$ & $\mathrm{~TB}$ & Vestsydvest for Lítlafelli. & \\
\hline
\end{tabular}




\begin{tabular}{lrrlrrl}
\hline Nr. & M $^{1)}$ & H $\phi$ jde i m & Retning & Bredde i m & Type 2) & Lokalitet \\
\hline 199 & 12,9 & 450 & N. $15^{\circ}$ & 2,5 & TB & Vest for N $\phi$ vin. \\
200 & 12,9 & 490 & N. $85^{\circ}$ & $3-5$ & FB & Vest for N $\varnothing v i n$ (Lille gjógv). \\
201 & 12,9 & 490 & N. $45^{\circ}$ & $5-6$ & FB & Vest for N $\phi v i n . ~$ \\
202 & 19,3 & & N. $15^{\circ}$ & & & Nord for Oyrargjógv. \\
203 & 19,3 & \multirow{2}{*}{120} & N. $125^{\circ}$ & & TB & Nord for Oyrargjógv. \\
204 & 19,3 & & N. $125^{\circ}$ & & & Syd for Oyrargjógv. \\
205 & 19,3 & & N. $15^{\circ}$ & 2 & TB & Syd for Oyri. \\
206 & 19,3 & & N. $25^{\circ}$ & 3,5 & & Syd for Oyri. \\
207 & 19,3 & & N. $60^{\circ}$ & 3 & TB & Syd for Oyri.
\end{tabular}

Streymoy (Str.)

\begin{tabular}{|c|c|c|c|c|c|c|c|}
\hline $\mathrm{Nr}$. & M 1) & Højde i m & Retning & Bredde i m & Type 2) & Lokalitet & Bemærkninger \\
\hline 1 & 27,1 & & N. $110^{\circ}$ & 6,5 & $\mathrm{FB}$ & Við Sjógv. & Lamelleret. \\
\hline 2 & 27,1 & 80 & N. $85^{\circ}$ & & $\mathrm{TB}$ & Sjóvará. & \\
\hline 3 & 27,1 & 95 & N. $90^{\circ}$ & & & Sjóvará. & \\
\hline 4 & 27,1 & 150 & N. $170^{\circ}$ & 4 & $\mathrm{~TB}$ & Sjóvará. & $\begin{array}{l}\text { Horisontal forkastning ca. } 20 \mathrm{~m} \\
\text { (Str. 5). }\end{array}$ \\
\hline 5 & 27,1 & 150 & N. $170^{\circ}$ & 4 & $\mathrm{~TB}$ & Sjóvará. & $\begin{array}{l}\text { Horisontal forkastning ca. } 20 \mathrm{~m} \\
\text { (Str. 4). }\end{array}$ \\
\hline 6 & 27,1 & 270 & N. $5^{\circ}$ & & TB & Østlige side af Dyllan. & \\
\hline 7 & 27,1 & 120 & N. $100^{\circ}$ & 5 & & Syd for Sjóvará. & \\
\hline 8 & 27,1 & & N. $100^{\circ}$ & & & Syd for Sjóvará. & \\
\hline 9 & 27,1 & 160 & N. $105^{\circ}$ & 6 & $\mathrm{~TB}$ & Sjóvará. & Mange apofyser. \\
\hline
\end{tabular}




\begin{tabular}{|c|c|c|c|c|c|c|c|}
\hline Nr. & $M^{1)}$ & Højde i m & Retning & Bredde i m & Type 2) & Lokalitet & Bemærkninger \\
\hline 10 & 27,4 & & N. $95^{\circ}$ & 4 & TB & Mellem Lygnnes og Viơ Sjógv. & Stærkt lamelleret. Mange apofyser. \\
\hline 11 & 27,4 & & N. $135^{\circ}$ & 4,5 & $\begin{array}{l}\text { TB } \\
\text { FFB }\end{array}$ & Vest for Lygnnes. & $\begin{array}{l}\text { Sammensat gang (FFB i midten. } \\
\text { TB til siderne). }\end{array}$ \\
\hline 12 & 27,4 & & N. $50^{\circ}$ & 3 & FFB & Vest for Tríggjaráir. & \\
\hline 13 & 27,4 & & N. $45^{\circ}$ & $2-3$ & ТВ & Vest for elven vest for Garðá. & Stærkt lamelleret. \\
\hline 14 & 27,4 & & N. $45^{\circ}$ & 1 & TB & Vest for elven vest for Garðá. & $\begin{array}{l}\text { Meget uregelmæssigt forl } \varnothing \mathrm{b} \text {. } \\
\text { Mange små apofyser. }\end{array}$ \\
\hline 15 & 32,1 & & N. $155^{\circ}$ & 4 & FFB & Kaldbaksbotnur. & \\
\hline 16 & 32,1 & & N. $40^{\circ}$ & 4 & $\mathrm{OB}$ & Gorrtalagjógv. & Lamelleret. \\
\hline 17 & 32,1 & 190 & N. $45^{\circ}$ & $6-7$ & TB & Fortsættelse af Dalagjógv. & \\
\hline 18 & 32,2 & & N. $70^{\circ}$ & 2 & FFB & Týggjará. & \\
\hline 19 & 32,7 & & N. $70^{\circ}$ & & & Syd for Lambatangi. & \\
\hline 20 & 32,9 & & N. $80^{\circ}$ & 6 & & Boðanes. & Stærkt lamelleret med zeolitårer. \\
\hline 21 & 35,5 & & N. $70^{\circ}$ & & & Öksnagjógv. & \\
\hline 22 & 5,5 & & N. $180^{\circ}$ & $1-2$ & & Vest for Sjendir. & Retning usikker. \\
\hline 23 & 5,5 & & N. $165^{\circ}$ & 1 & TB & Sjendir. & \\
\hline 24 & 5,5 & & N. $110^{\circ}$ & $5-6$ & TB & $\emptyset$ stsiden af Sjendir. & \\
\hline 25 & 5,6 & & N. $25^{\circ}$ & & & Øst for Stakkur. & \\
\hline 26 & 5,6 & & N. $20^{\circ}$ & & & Vestsiden af Tjørnuvík. & \\
\hline 27 & 5,6 & & N. $115^{\circ}$ & 6 & $\mathrm{~TB}$ & Rangagjógv. & Horisontal forkastning (Str. 36). \\
\hline 28 & 5,6 & & N. $115^{\circ}$ & & & Syd for Rangagjógv. & Horisontal forkastning. \\
\hline 29 & 5,9 & & N. $150^{\circ}$ & 3 & TB & Vestsiden af Tjørnuvík & \\
\hline & & & & & & v. bådeskurene. & Lamelleret. \\
\hline 30 & 5,9 & & N. $165^{\circ}$ & & & Sydvestsiden af Tjørnuvík. & \\
\hline 31 & 5,9 & & N. $45^{\circ}$ & & & Sydvestsiden af Tjørnuvík. & \\
\hline
\end{tabular}




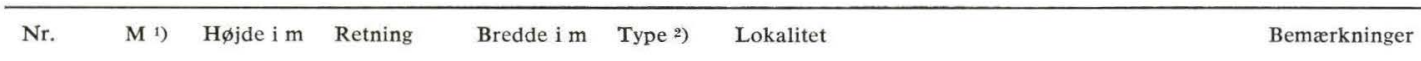

\begin{tabular}{llllll}
\hline 2 & 5,9 & 212 & N. $45^{\circ}$ & 1 & TB
\end{tabular} Ved elv nord for gjógv i Heiman-

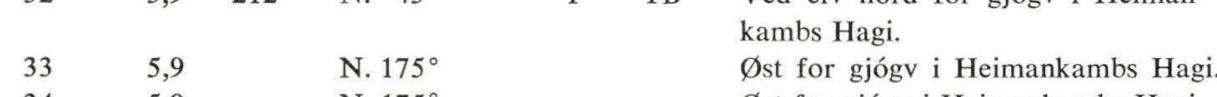

$34 \quad 5,9-175^{\circ}$

$35 \quad 5,9 \quad$ N. $145^{\circ}$

$365,9 \quad$ N. $120^{\circ}$

$37 \quad 5,9640 \quad$ N. $95^{\circ}$

$38 \quad 6,7 \quad$ N. $120^{\circ}$

$3911,2 \quad$ N. $15^{\circ}$

$40 \quad 11,2300 \quad$ N. $15^{\circ}$

$41 \quad 11,3 \quad$ N. $80^{\circ}$

$42 \quad 11,3400 \quad$ N. $170^{\circ}$

$43 \quad 11,3 \quad 640 \quad$ N. $5^{\circ}$

$44 \quad 11,6 \quad 515 \quad$ N. $175^{\circ}$

$45 \quad 11,6 \quad 515$ N. $5^{\circ}$

$\emptyset$ st for gjógv i Heimankambs Hagi.

Sydøstsiden af Tjørnuvík.

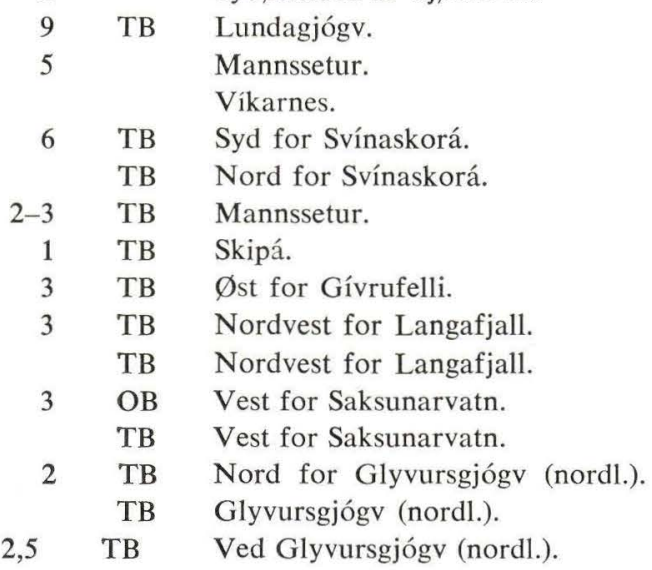

Horisontal forkastning (Str. 27).

\section{Lamelleret.}

Stærkt lamelleret.

TB Ved Glyvursgjógv (nordl.).

Ved Glyvursgjógv (nordl.).

Stærkt breccieret.

Horisontal forkastning ca. $18 \mathrm{~m}$ (Str. 51).

Horisontal forkastning ca. $18 \mathrm{~m}$ (Str. 50).

Horisontal forkastning ca. $18 \mathrm{~m}$ (Str. 53). 


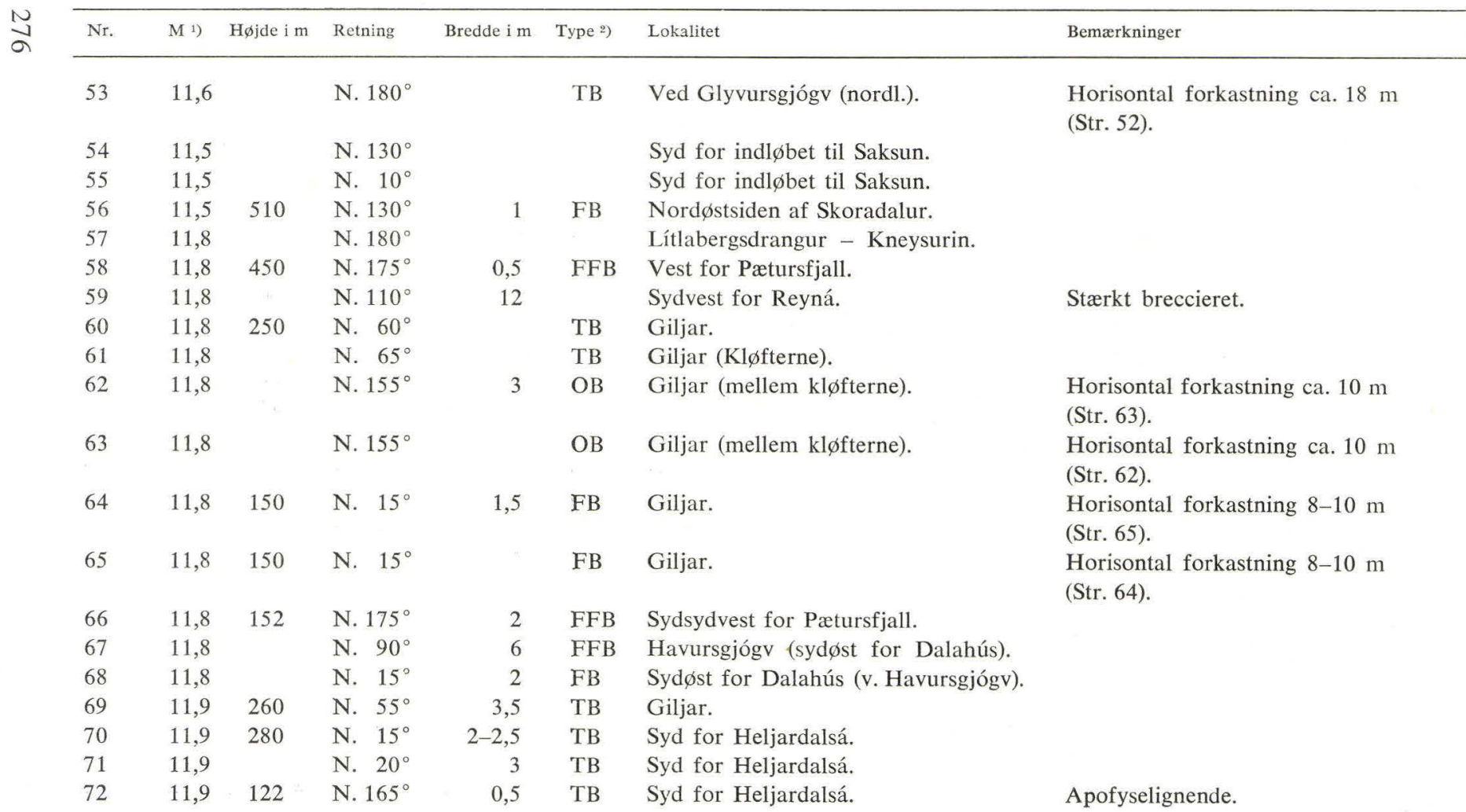




\begin{tabular}{|c|c|c|c|c|c|c|c|}
\hline Nr. & M i) & Høide i m & Retning & Bredde i m & Type 2) & Lokalitet & Bemærkninger \\
\hline 73 & 11,9 & & N. $35^{\circ}$ & 5 & ТВ & Nord for Stórá. & Lamelleret. \\
\hline 74 & 11,9 & & N. $25^{\circ}$ & $4-5$ & $\mathrm{~TB}$ & Stórá - Klovsá. & \\
\hline 75 & 11,9 & & N. $115^{\circ}$ & 12 & $\mathrm{~TB}$ & Stórá (gjógv). & Stærkt breccieret med zeolitårer. \\
\hline 76 & 11,9 & 520 & N. $100^{\circ}$ & & FFB & Syd for $\emptyset$ rviksfelli. & \\
\hline 77 & 11,9 & 160 & N. $115^{\circ}$ & 11 & $\mathrm{~TB}$ & Stórá. & $\begin{array}{l}\text { Stærkt lamelleret og breccieret med } \\
\text { zeolitårer. }\end{array}$ \\
\hline 78 & 12,4 & & N. $55^{\circ}$ & $5-6$ & $\mathrm{~TB}$ & Syd for Fossá. & \\
\hline 79 & 12,4 & 525 & N. $55^{\circ}$ & & $\mathrm{TB}$ & Sydøst for Langafjall. & \\
\hline 80 & 12,4 & 260 & N. $165^{\circ}$ & 2 & $\mathrm{~TB}$ & Glyvursgjógv (nordl.). & Horisontal forkastning (Str. 81). \\
\hline 81 & 12,4 & 260 & N. $165^{\circ}$ & 2 & $\mathrm{~TB}$ & Glyvursgjógv (nordl.). & Horisontal forkastning (Str. 80). \\
\hline 82 & 12,4 & 195 & N. $90^{\circ}$ & 5 & $\mathrm{~TB}$ & Glyvursgjógv (sydl.). & $\begin{array}{l}\text { Buet forl } \varnothing \text { b. Meget stærkt lamelleret } \\
\text { og breccieret. }\end{array}$ \\
\hline 83 & 12,4 & & N. $5^{\circ}$ & $1-2$ & $\mathrm{~TB}$ & Syd for Glyvursgjógv (sydl.). & $\begin{array}{l}\text { Horisontal forkastning ca. } 55 \mathrm{~m} \\
\text { (Str. 84). }\end{array}$ \\
\hline 84 & 12,4 & & N. $5^{\circ}$ & $1-2$ & $\mathrm{~TB}$ & Nord for Glyvursgjógv (sydl.). & $\begin{array}{l}\text { Horisontal forkastning ca. } 55 \mathrm{~m} \\
\text { (Str. 83). }\end{array}$ \\
\hline 85 & 12,4 & 280 & N. $25^{\circ}$ & $5-6$ & $\mathrm{~TB}$ & Syd for Glyvursgjógv (sydl.). & $\begin{array}{l}\text { Horisontal forkastning ca. } 55 \mathrm{~m} \\
\text { (Str. 86). }\end{array}$ \\
\hline 86 & 12,4 & 270 & N. $25^{\circ}$ & 5 & $\mathrm{~TB}$ & Nord for Glyvursgjógv (sydl.). & $\begin{array}{l}\text { Horisontal forkastning ca. } 55 \mathrm{~m} \\
\text { (Str. 85). }\end{array}$ \\
\hline 87 & 12,7 & 225 & N. $45^{\circ}$ & 4 & FFB & Gjógv’en v. Ravnagilsá. & Lamelleret. \\
\hline 88 & 12,7 & 170 & N. $180^{\circ}$ & 4 & $\mathrm{~TB}$ & V. Gjógv’en v. Ravnagilsá. & Horisontal forkastning (Str. 89). \\
\hline 89 & 12,7 & 170 & N. $180^{\circ}$ & 4 & $\mathrm{~TB}$ & V. Gjógv'en v. Ravnagilsá. & Horisontal forkastning (Str. 88). \\
\hline 90 & 12,7 & 140 & N. $170^{\circ}$ & $1-2$ & $\mathrm{~TB}$ & V. Gjógv’en v. Ravnagilsá. & $\begin{array}{l}\text { Horisontal forkastning ca. } 20 \mathrm{~m} \\
\text { (Str. 91). }\end{array}$ \\
\hline
\end{tabular}




\begin{tabular}{|c|c|c|c|c|c|c|c|}
\hline Nr. & M 1) & Højde i m & Retning & Bredde i m & Type 2) & Lokalitet & Bemærkninger \\
\hline 91 & 12,7 & 140 & N. $170^{\circ}$ & $1-2$ & TB & V. Gjógv’en v. Ravnagilsá. & $\begin{array}{l}\text { Horisontal forkastning ca. } 20 \mathrm{~m} \\
\text { (Str. 90). }\end{array}$ \\
\hline 92 & 12,7 & 105 & N. $125^{\circ}$ & 10 & TB & V. Gjógv’en v. Ravnagilsá. & $\begin{array}{l}\text { Horisontal forkastning ca. } 20 \mathrm{~m} \\
\text { (Str. 93). }\end{array}$ \\
\hline 93 & 12,7 & 105 & N. $125^{\circ}$ & 10 & $\mathrm{~TB}$ & V. Gjógv’en v. Ravnagilsá. & $\begin{array}{l}\text { Horisontal forkastning ca. } 20 \mathrm{~m} \\
\text { (Str. 92). }\end{array}$ \\
\hline 94 & 12,7 & 100 & N. $90^{\circ}$ & & FFB & V. Gjógv’en v. Ravnagilsá. & $\begin{array}{l}\text { Udløber fra FFB gangen i Gjógv'en i } \\
\text { Ravnagilsá (Str. 87) retning usikker. }\end{array}$ \\
\hline 95 & 12,7 & 130 & N. $120^{\circ}$ & & & Nordvest for Gjógv'en v. Ravnagilsá. & \\
\hline 96 & 12,7 & 100 & N. $170^{\circ}$ & 2 & ТВ & Stórá. & \\
\hline 97 & 12,7 & & N. $90^{\circ}$ & 3 & FFB & Streymnesfossar. & \\
\hline 98 & 12,8 & 220 & N. $80^{\circ}$ & 7 & FB & Tilløb til Sunnaragjógv. & Står frem i terrænet. \\
\hline 99 & 12,8 & 180 & N. $105^{\circ}$ & 6 & $\mathrm{~TB}$ & Tilløb til Sunnaragjógv. & Stærkt breccieret med zeolitårer. \\
\hline 100 & 12,8 & & N. $70^{\circ}$ & 1 & & $\begin{array}{l}\text { Elv mellem Norðaragjógv og } \\
\text { Sunnaragjógv. }\end{array}$ & \\
\hline 101 & 12,8 & & N. $75^{\circ}$ & $6-7$ & FB & Syd for Sunnaragjógv (Gjánoyri). & \\
\hline 102 & 12,8 & & N. $90^{\circ}$ & & & Syd for Gjánoyri. & \\
\hline 103 & 12,8 & 80 & N. $80^{\circ}$ & 2 & TB & Nord for Nesvík. & Stærkt lamelleret og breccieret. \\
\hline 104 & 18,1 & & N. $70^{\circ}$ & & & Mellem Dalagjógv og Djúpadalsgjógv. & \\
\hline 105 & 18,2 & & N. $70^{\circ}$ & $4-8$ & FFB & Dalagjógv. & $\begin{array}{l}\text { Stærkt lamelleret og breccieret } \mathrm{m} \text {. } \\
\text { zeolitårer. }\end{array}$ \\
\hline 106 & 18,2 & 6 & N. $160^{\circ}$ & $4-5$ & OB & V. Dalagjógv. & $\begin{array}{l}\text { Horisontal forkastning } 10-12 \text { m (Str. } \\
\text { 107). Lamelleret og breccieret med } \\
\text { zeolitårer. }\end{array}$ \\
\hline
\end{tabular}




\begin{tabular}{|c|c|c|c|c|c|c|c|}
\hline Nr. & $M^{1}$ i) $\quad H$ & Højde i m & Retning & Bredde i m & Type $\left.{ }^{2}\right)$ & Lokalitet & Bemærkninger \\
\hline 107 & 18,2 & 6 & N. $145^{\circ}$ & $4-5$ & $\mathrm{OB}$ & V. Dalagjógv. & $\begin{array}{l}\text { Horisontal forkastning } 10-12 \mathrm{~m} \text { (Str. } \\
\text { 106). Lamelleret og breccieret med } \\
\text { zeolitårer. }\end{array}$ \\
\hline 108 & 18,2 & 17 & N. $150^{\circ}$ & $2-3$ & FB & V. Dalagjógv. & $\begin{array}{l}\text { Horisontal forkastning } 9-10 \mathrm{~m} \\
\text { (Str. 109). }\end{array}$ \\
\hline 109 & 18,2 & & N. $145^{\circ}$ & $2-3$ & FB & V. Dalagjógv. & $\begin{array}{l}\text { Horisontal forkastning } 9-10 \mathrm{~m} \\
\text { (Str. 108). }\end{array}$ \\
\hline 110 & $\begin{array}{l}11,8- \\
18,2\end{array}$ & & N. $70^{\circ}$ & & TB & Syd for Dalahús (gjógv). & Apofyser. \\
\hline 111 & 18,2 & & N. $150^{\circ}$ & & & $\begin{array}{l}\text { Kjølurin (Dalagjógv - Djúpadals- } \\
\text { gjógv). }\end{array}$ & \\
\hline 112 & 18,2 & & N. $105^{\circ}$ & $8-9$ & TB & Djúpadalsgjógv. & \\
\hline 113 & 18,2 & 110 & N. $140^{\circ}$ & 4,5 & OB & V. Djúpadalsgjógv. & $\begin{array}{l}\text { Horisontal forkastning ca. } 40 \mathrm{~m} \\
\text { (Str. 114). }\end{array}$ \\
\hline 114 & 18,2 & & N. $160^{\circ}$ & & $\mathrm{OB}$ & V. Djúpadalsgjógv. & $\begin{array}{l}\text { Horisontal forkastning ca. } 40 \mathrm{~m} \\
\text { (Str. 113). }\end{array}$ \\
\hline 115 & 18,2 & 200 & N. $150^{\circ}$ & $3-4,5$ & FB & V. Djúpadalsgjógv. & $\begin{array}{l}\text { Horisontal forkastning ca. } 40 \mathrm{~m} \\
\text { (Str. 116). }\end{array}$ \\
\hline 116 & 18,2 & & N. $150^{\circ}$ & $3-4,5$ & FB & V. Djúpadalsgjógv. & $\begin{array}{l}\text { Horisontal forkastning ca. } 40 \mathrm{~m} \\
\text { (Str. 115). }\end{array}$ \\
\hline 117 & 18,2 & 590 & N. $15^{\circ}$ & 3 & FB & Sydvest for Mosar $\varnothing$ kur. & \\
\hline 118 & 18,2 & & N. $105^{\circ}$ & & & Sydøst for Mosarøkur. & \\
\hline 119 & 18,2 & 480 & N. $145^{\circ}$ & 6 & $\mathrm{FB}$ & $\emptyset$ st for Postulakirkja. & \\
\hline 120 & $18,1.2$ & 195 & N. $30^{\circ}$ & 1,5 & TB & $\varnothing$ ksnadalur. & $\begin{array}{l}\text { Stærkt lamelleret og breccieret. Opløser } \\
\text { sig i apofyser mod nordøst. }\end{array}$ \\
\hline
\end{tabular}




\begin{tabular}{|c|c|c|c|c|c|c|c|}
\hline Nr. & M 1) & Højde i m & Retning & Bredde i m & Type 2) & Lokalitet & Bemærkninger \\
\hline 121 & 18,3 & 270 & N. $65^{\circ}$ & 5 & $\mathrm{FB}$ & Nord for Vatnið. & Lamelleret. \\
\hline 122 & 18,6 & 400 & N. $150^{\circ}$ & 1 & $\mathrm{~TB}$ & Vestsydvest for Loysingafjall. & \\
\hline 123 & 18,6 & 280 & N. $40^{\circ}$ & 3 & $\mathrm{~TB}$ & Sydvest i Dalkinn. & Stærkt lamelleret og breccieret. \\
\hline 124 & 18,5 & 190 & N. $65^{\circ}$ & 2 & TB & Gjógvará. & Lamelleret m. zeolitårer. \\
\hline 125 & 18,5 & 185 & N. $\quad 5^{\circ}$ & 1,5 & & Gjógvará. & \\
\hline 126 & 18,5 & 225 & N. $145^{\circ}$ & 1 & $\mathrm{FB}$ & $\emptyset$ stnordøst for Melin. & \\
\hline 127 & 18,5 & 155 & N. $130^{\circ}$ & 4 & $\mathrm{OB}$ & Dalá. & \\
\hline 128 & 18,5 & 150 & N. $175^{\circ}$ & 2,5 & FB & Dalá. & \\
\hline 129 & 18,5 & 155 & N. $105^{\circ}$ & 1 & & Dalá. & Lamelleret og breccieret. \\
\hline 130 & 18,5 & & N. $100^{\circ}$ & & $\mathrm{TB}$ & Klovagjógv: & Let buet forl $\varnothing b$. \\
\hline 131 & 18,5 & & N. $65^{\circ}$ & 3 & $\mathrm{~TB}$ & Nálagjógv. & Let buet forløb. \\
\hline 132 & 18,5 & & N. $5^{\circ}$ & 2,5 & $\mathrm{~TB}$ & Skúvadalsgjógv. & Horisontal forkastning (Str. 133). \\
\hline 133 & 18,5 & 110 & N. $5^{\circ}$ & 2,5 & $\mathrm{~TB}$ & Skúvadalsgjógv. & Horisontal forkastning (Str. 132). \\
\hline 134 & 18,4 & & N. $35^{\circ}$ & 4 & $\mathrm{~TB}$ & Skoragjógv. & \\
\hline 135 & 18,4 & & N. $35^{\circ}$ & & & Grímsgjógv. & \\
\hline 136 & 18,8 & 105 & N. $15^{\circ}$ & 1 & $\mathrm{~TB}$ & Vest for Hagagjógv. & \\
\hline 137 & 18,8 & & N. $30^{\circ}$ & 2 & FB & Vest for Hagagjógv. & \\
\hline 138 & 18,8 & 115 & N. $25^{\circ}$ & & FB & Hórđará. & \\
\hline 139 & 18,8 & 112 & N. $40^{\circ}$ & 1,5 & $\mathrm{~TB}$ & Hagagjógv. & \\
\hline 140 & 18,8 & 100 & N. $35^{\circ}$ & & & V. bøgærdet, Rógva. & \\
\hline 141 & 18,9 & 55 & N. $30^{\circ}$ & $1,5-2$ & $\mathrm{~TB}$ & Hórðará. & \\
\hline 142 & 18,9 & & N. $120^{\circ}$ & 3,5 & $\mathrm{OB}$ & Gjógvará. & \\
\hline 143 & 18,9 & & N. $110^{\circ}$ & 2 & $\mathrm{FB}$ & Nord for Grananes. & \\
\hline 144 & 18,9 & & N. $110^{\circ}$ & & FB & Syd for Fiskinakulla (Kráargil). & \\
\hline 145 & 18,9 & & N. $95^{\circ}$ & & & Egilsnes. & \\
\hline
\end{tabular}




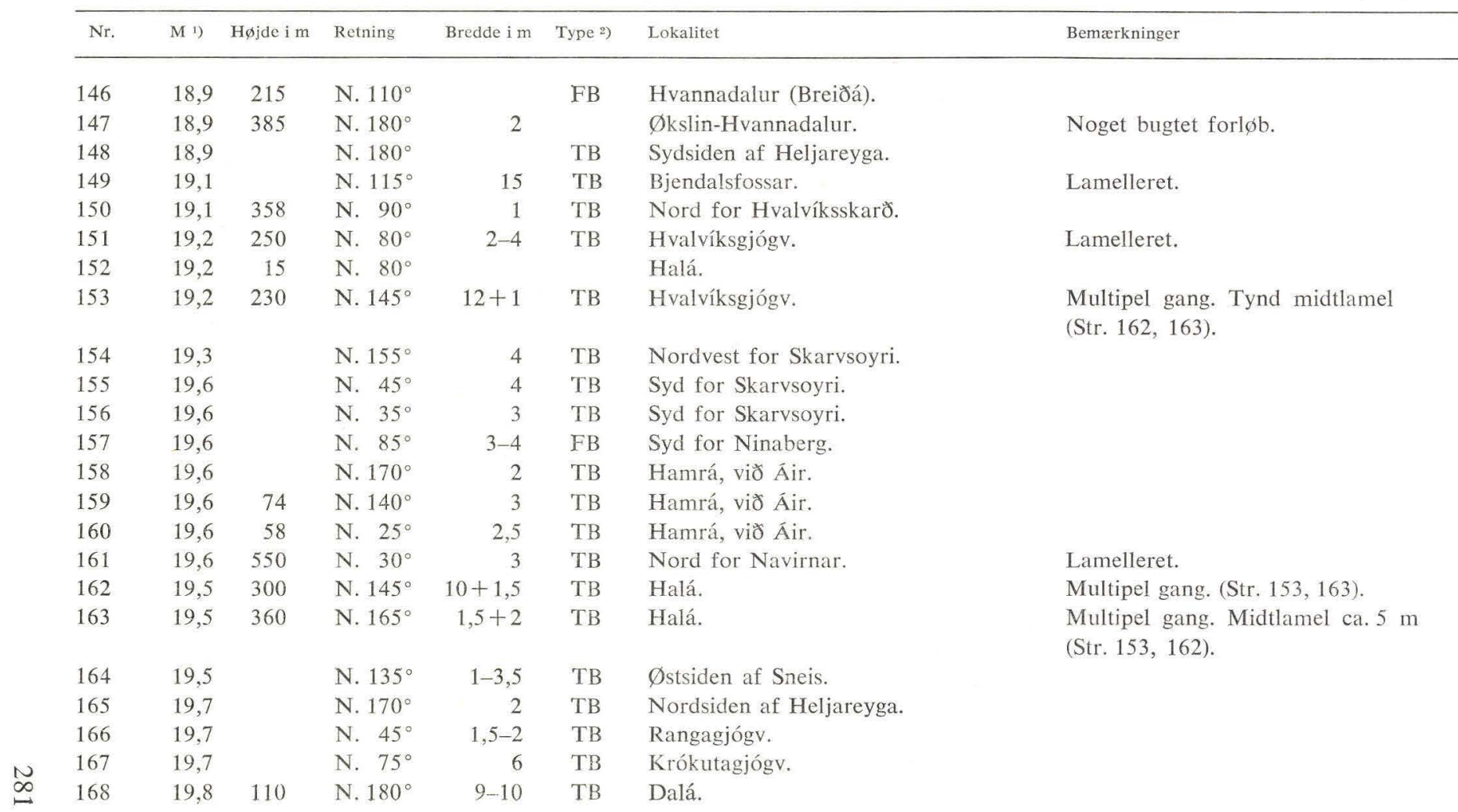




\begin{tabular}{|c|c|c|c|c|c|c|c|}
\hline Nr. & M 1) & Højde i m & Retning & Bredde i m & Type 2) & Lokalitet & Bemærkninger \\
\hline 169 & 19,8 & & N. $180^{\circ}$ & & & Øst for Dalá. & \\
\hline 170 & 19,8 & & N. $65^{\circ}$ & 1 & $\mathrm{~TB}$ & Nord for Rættá (gjógv). & \\
\hline 171 & 19,8 & & N. $40^{\circ}$ & 3 & $\mathrm{~TB}$ & Rættá (nordl. forgrening). & \\
\hline 172 & 19,8 & & N. $30^{\circ}$ & $2-3$ & $\mathrm{~TB}$ & Rangagjógv. & \\
\hline 173 & 19,8 & & N. $75^{\circ}$ & $2-3$ & & Stóragjógv. & Stærkt lamelleret med zeolitårer. \\
\hline 174 & 19,9 & 450 & N. $95^{\circ}$ & & TB & Nord for Gívrufjall. & \\
\hline 175 & 19,9 & 260 & N. $45^{\circ}$ & & TB & Tungubrekkuá. & Buet forl $\varnothing b$. \\
\hline 176 & 19,9 & 235 & N. $145^{\circ}$ & 1 & OB & Tungubrekkuá. & Eventuelt apofyse. \\
\hline 177 & 19,9 & 105 & N. $45^{\circ}$ & $4-5$ & OB & Torvadalsá. & \\
\hline 178 & 19,9 & & N. $105^{\circ}$ & 4 & $\mathrm{~TB}$ & Hósvík (v. nordl. bøgærde). & Stærkt lamelleret. \\
\hline 179 & 25,3 & 260 & N. $95^{\circ}$ & 7 & TB & Gassá. & \\
\hline 180 & 25,3 & & N. $105^{\circ}$ & 2 & & Syd for Egilsnes. & \\
\hline 181 & 25,3 & 310 & N. $140^{\circ}$ & 1 & $\mathrm{FB}$ & Høgareyn. & \\
\hline 182 & 25,3 & & N. $100^{\circ}$ & $3-4$ & & Syd for Egilsnes. & \\
\hline 183 & 25,3 & & N. $100^{\circ}$ & 5 & FFB & Høgareyn (Toppen). & \\
\hline 184 & 25,3 & & N. $70^{\circ}$ & 3 & & Gunnarsgjáir (nordl. elv). & \\
\hline 185 & 25,3 & 290 & N. $15^{\circ}$ & 3 & TB & Syd for Høgareyn. & \\
\hline 186 & 25,3 & & N. $150^{\circ}$ & 2 & & Nord for Lásvík. & \\
\hline 187 & 25,3 & 230 & N. $15^{\circ}$ & 2 & TB & Nord for Norðaragjógv. & \\
\hline 188 & 25,3 & & N. $160^{\circ}$ & 2,5 & $\mathrm{~TB}$ & V. Norðaragjógv. & $\begin{array}{l}\text { Horisontal forkastning ca. } 9 \mathrm{~m} \\
\text { (Str. 189). }\end{array}$ \\
\hline 189 & 25,3 & & N. $160^{\circ}$ & 2,5 & & V. Norðaragjógv. & $\begin{array}{l}\text { Horisontal forkastning ca. } 9 \mathrm{~m} \\
\text { (Str. 188). }\end{array}$ \\
\hline 190 & 25,3 & & N. $15^{\circ}$ & 1,5 & $\mathrm{~TB}$ & V. Norðaragjógv. & $\begin{array}{l}\text { Horisontal forkastning ca. } 9 \mathrm{~m} \\
\text { (Str. 191). }\end{array}$ \\
\hline
\end{tabular}




\begin{tabular}{|c|c|c|c|c|c|c|c|}
\hline Nr. & M I) & Højde i m & Retning & Bredde i m & Type 2) & Lokalitet & Bemærkninger \\
\hline 191 & 25,3 & & N. $15^{\circ}$ & 1,5 & & V. Norðaragjógv. & $\begin{array}{l}\text { Horisontal forkastning ca. } 9 \mathrm{~m} \\
\text { (Str. 190). }\end{array}$ \\
\hline 192 & 25,3 & & N. $15^{\circ}$ & & & Syd for Norðaragjógv. & \\
\hline 193 & 25,3 & & N. $160^{\circ}$ & $2-3$ & & Syd for Norðaragjógv. & \\
\hline 194 & 25,3 & & N. $10^{\circ}$ & 5 & & Sunnaragjógv. & \\
\hline 195 & 25,3 & & N. $50^{\circ}$ & & & Syd for Sunnaragjógv. & \\
\hline 196 & 26,1 & 270 & N. $100^{\circ}$ & 9 & FB & Víkará (Kvívík). & $\begin{array}{l}\text { Vestlige halvdel af gangen stærkt la- } \\
\text { melleret og breccieret. }\end{array}$ \\
\hline 197 & 26,1 & 197 & N. 120 & 5 & FFB & Breiðá (vest for Kvívík). & \\
\hline 198 & 26,1 & & N. $120^{\circ}$ & & & Vest for Kvívík. & \\
\hline 199 & 26,1 & 30 & N. $120^{\circ}$ & 1 & FFB & Víkará (Kvívík). & \\
\hline 200 & 26,1 & & N. $120^{\circ}$ & & & Gjógv mellem Kvívík og Stykkið. & \\
\hline 201 & 26,1 & 35 & N. $120^{\circ}$ & $0,3-0,4$ & FFB & Víkará (Kvívík). & \\
\hline 202 & 26,2 & 280 & N. $55^{\circ}$ & 2 & $\mathrm{~TB}$ & Breiðá, Stykkið. & \\
\hline 203 & 26,2 & & N. $30^{\circ}$ & 1 & & Syd for Rættá. & \\
\hline 204 & 26,2 & & N. $115^{\circ}$ & $3-4$ & & Nordvestsiden af Leynavatn. & \\
\hline 205 & 26,2 & & N. $115^{\circ}$ & & & $\emptyset_{\text {stsiden af Leynavatn. }}$ & \\
\hline 206 & 26,2 & & N. $95^{\circ}$ & & & Sydvestsiden af Leynavatn. & \\
\hline 207 & 26,2 & & N. $180^{\circ}$ & $2-3$ & FB & $\emptyset_{\text {st }}$ for Fremstiryggur. & \\
\hline 208 & 26,2 & & N. $95^{\circ}$ & $3-4$ & & Nordvest for Sátan. & \\
\hline 209 & 26,2 & & N. $120^{\circ}$ & 10 & ТВ & Navagjógv. & \\
\hline 210 & 26,3 & 230 & N. $110^{\circ}$ & $3-4$ & & Sjóvará. & \\
\hline 211 & 26,6 & 242 & N. $20^{\circ}$ & 3 & & Syd $\varnothing$ st i Dyllan. & \\
\hline 212 & 26,6 & & N. $40^{\circ}$ & 1 & FFB & Mosgil. & \\
\hline
\end{tabular}


Streymoy (Str.)

\begin{tabular}{|c|c|c|c|c|c|c|c|}
\hline Nr. & M 1) & Højde i m & Retning & Bredde i m & Type ${ }^{2)}$ & Lokalitet & Bemærkninger \\
\hline 213 & 26,6 & 160 & N. $10^{\circ}$ & 3 & FFB & V. Hórisg фta. & \\
\hline 214 & 26,6 & 253 & N. $135^{\circ}$ & 8 & $\mathrm{~TB}$ & Øst for Hundsarabotnur. & \\
\hline 215 & 26,6 & 420 & N. $120^{\circ}$ & 4 & $\mathrm{FB}$ & Trantur. & Opløses i apofyser. \\
\hline 216 & 26,5 & & N. $130^{\circ}$ & $3-5$ & FFB & Ravnagjógv. & \\
\hline 217 & 26,5 & & N. $140^{\circ}$ & 8 & $\mathrm{~TB}$ & Vest for Klettsgjógv. & \\
\hline 218 & 26,5 & & N. $40^{\circ}$ & 5 & $\mathrm{~TB}$ & Marknagil. & $\begin{array}{l}\text { Horisontal forkastning (Str. 219, 220), } \\
\text { noget usikker. }\end{array}$ \\
\hline 219 & 26,5 & & N. $40^{\circ}$ & $2-3$ & $\mathrm{~TB}$ & Heimaragjógv. & $\begin{array}{l}\text { Horisontal forkastning (Str. 218), } \\
\text { noget usikker. }\end{array}$ \\
\hline 220 & 26,5 & & N. $25^{\circ}$ & $2-2,5$ & TB & Ytragjógv. & $\begin{array}{l}\text { Horisontal forkastning (Str. 218), } \\
\text { noget usikker. }\end{array}$ \\
\hline 221 & 26,5 & & N. $120^{\circ}$ & & FFB & Vađsteinagjógv. & \\
\hline 222 & 26,5 & & N. 95 & & & Stallagjógv. & \\
\hline 223 & 26,5 & & N. $95^{\circ}$ & & $\mathrm{TB}$ & Kollfjarðargjógv. & \\
\hline 224 & 26,9 & 300 & N. $75^{\circ}$ & 6 & $\mathrm{~TB}$ & Gjáarbotnur. & \\
\hline 225 & 31,3 & & N. $95^{\circ}$ & & TB & Dosshellugjógv. & \\
\hline 226 & 31,3 & & N. $160^{\circ}$ & & & Seyðaskor. & \\
\hline 227 & 31,3 & & N. $155^{\circ}$ & & & Nordsiden af Reipaskor. & \\
\hline 228 & 31,3 & & N. $155^{\circ}$ & & & Sydsiden af Reipaskor. & \\
\hline 229 & 31,6 & & N. $155^{\circ}$ & & & Steyrur. & \\
\hline 230 & 20,7 & & N. $35^{\circ}$ & & & Øst for bøgærdet, Hósvík. & \\
\hline 231 & 20,7 & & N. $175^{\circ}$ & & & Øst for bøgærdet, Hósvík. & \\
\hline
\end{tabular}




\begin{tabular}{|c|c|c|c|c|c|c|}
\hline Nr. & $M$ i) & Højde i m & Retning & Bredde i m & Type ${ }^{2)}$ & Lokalitet \\
\hline 1 & 36,2 & & N. $130^{\circ}$ & 2 & & Mellem Bleikhella og Tjørnunes. \\
\hline 2 & 36,6 & & N. $130^{\circ}$ & & & Hósteinsgjógv. \\
\hline 3 & 36,6 & & N. $130^{\circ}$ & & & Mellem Øksnatangi og Hósteinsgjógv. \\
\hline
\end{tabular}

Sиðитоу (Su.)

\begin{tabular}{rrrlrll}
\hline Nr. & M $\left.{ }^{1}\right)$ & Højde i m & Retning & Bredde i m & Type 2) & Lokalitet \\
\hline 1 & 43,6 & 260 & N. $135^{\circ}$ & $8-10$ & TB & Tvørgjógv. \\
2 & 44,7 & & N. $130^{\circ}$ & 8 & TB & Hamranes - Hvítanes. \\
3 & 46,3 & 170 & N. $180^{\circ}$ & 3 & TB & Trøllkonugjógv. \\
4 & 46,3 & 160 & N. $140^{\circ}$ & 12 & TB & Suðuri í Haga (sydl. gjógv). \\
5 & 46,6 & & N. $145^{\circ}$ & $1-2$ & & Nord for Middagsskarð. \\
6 & 46,6 & & N. $155^{\circ}$ & $2-4$ & & Nord for Middagsskarð. \\
7 & 46,6 & & N. $155^{\circ}$ & 1 & & Vest for Skarvgjógv. \\
8 & 47,1 & & N. $60^{\circ}$ & 2 & TB & Suðuri í Haga, sydvest for Hæddin. \\
9 & 44,7 & & N. $140^{\circ}$ & 12 & TB & Úlvsgjógv. \\
10 & 47,1 & & N. $135^{\circ}$ & & & Nordvest for Knúkaborg. \\
11 & 47,1 & & N. $135^{\circ}$ & 10 & TB & Knúkaborg-Mannagjógv. \\
12 & 47,3 & & N. $180^{\circ}$ & & & Steinsurð. \\
13 & 47,6 & & N. $180^{\circ}$ & 3 & TB & Botnsgjógv. \\
14 & 47,5 & 115 & N. $170^{\circ}$ & 3,5 & TB & Svalbarðaá. \\
15 & 47,4 & & N. $140^{\circ}$ & $3-4$ & & Nord for Varpið. \\
16 & 47,4 & & N. $140^{\circ}$ & 1 & & Nord for Varpið. \\
17 & 47,4 & & N. $135^{\circ}$ & $6-8$ & & Nord for Soyðistangi. \\
& & & & & &
\end{tabular}




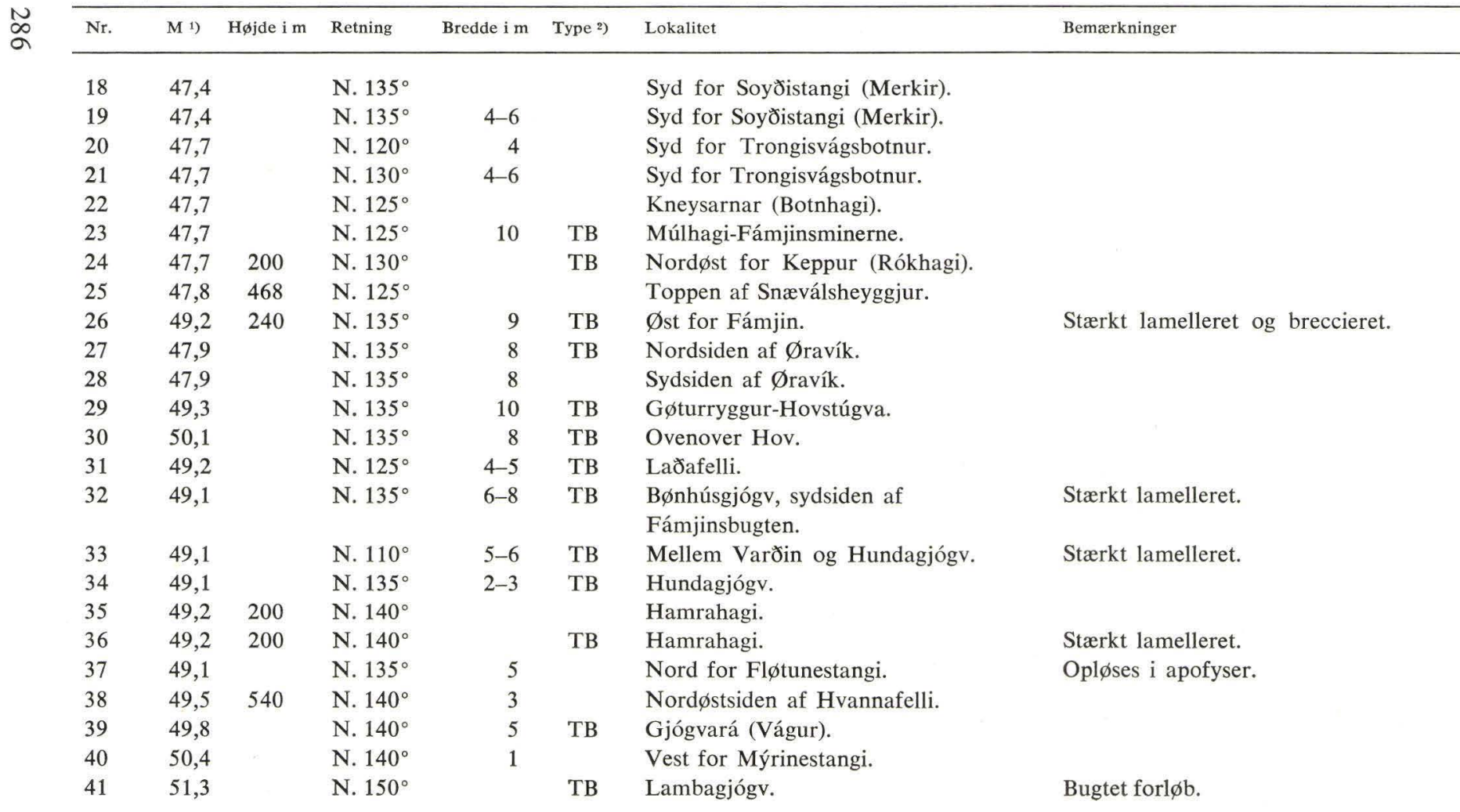




\begin{tabular}{|c|c|c|c|c|c|c|c|}
\hline Nr. & $M^{1)}$ & Højde i m & Retning & Bredde i m & Type 2) & Lokalitet & Bemærkninger \\
\hline 42 & 51,3 & & N. $145^{\circ}$ & 3 & $\mathrm{~TB}$ & Oyrnavík (Lopra). & \\
\hline 43 & 51,3 & & N. $145^{\circ}$ & 3 & & Oyrnavík (Lopra). & \\
\hline 44 & 51,6 & & N. $135^{\circ}$ & & & Hálsur. & \\
\hline 45 & 51,6 & & N. $135^{\circ}$ & & & Syd for Tindastakkur. & \\
\hline 46 & 51,6 & & N. $135^{\circ}$ & & & Trøllagjógv. & \\
\hline 47 & 52,4 & 250 & N. $140^{\circ}$ & 10 & TB & Mellem Uttarafjall og Eystarafjall. & \\
\hline 48 & 52,7 & 100 & N. $145^{\circ}$ & 5 & TB & Bielv til Áin í Dal. & \\
\hline 49 & 52,7 & & N. $145^{\circ}$ & 2 & TB & Vest for landingsstedet (Hellurók). & Bugtet forl $\varnothing$ b. Tynder ud opad. \\
\hline 50 & 52,7 & & N. $145^{\circ}$ & 20 & $\mathrm{~TB}$ & $\emptyset_{\text {st }}$ for landingsstedet, Sunnba. & \\
\hline 51 & 52,8 & & N. $125^{\circ}$ & & & Øst for Akrabyrgi. & \\
\hline 52 & 50,7 & & N. $140^{\circ}$ & $2-3$ & & Vest for Norðasti Grønutangi. & \\
\hline \multirow[t]{2}{*}{53} & 49,5 & & N. $140^{\circ}$ & 15 & TB & Botnhagi. & \\
\hline & & & & & & & St. Dimun (St. D.) \\
\hline Nr. & $M^{1)}$ & Højde i m & Retning & Bredde i m & Type 2) & Lokalitet & Bemærkninger \\
\hline \multirow[t]{2}{*}{1} & 42,8 & & N. $170^{\circ}$ & 5 & $\mathrm{~TB}$ & Dímunarkleiv. & \\
\hline & & & & & & & Sandoy (Sa.) \\
\hline Nr. & M 1) & Højde i m & Retning & Bredde i m & Type 2) & Lokalitet & Bemærkninger \\
\hline 1 & 37,4 & & N. $75^{\circ}$ & & & Svartskoragjógv. & Stærkt brecci \\
\hline 2 & 37,4 & 190 & N. $75^{\circ}$ & 4 & TB & Tungá. & Stærkt breccieret. \\
\hline
\end{tabular}


Sandoy (Sa.)

\begin{tabular}{|c|c|c|c|c|c|c|c|}
\hline Nr. & $M$ i) & Højde i m & Retning & Bredde i m & Type 2) & Lokalitet & Bemærkninger \\
\hline 3 & 37,5 & 83 & N. $85^{\circ}$ & & & Øst for Eldingin (v. gærde). & \\
\hline 4 & 37,5 & & N. $85^{\circ}$ & $7-8$ & $\mathrm{~TB}$ & Bavinsgjógv. & $\begin{array}{l}\text { Horisontal forkastning ( } \mathrm{Sa} \text { 5). } \\
\text { Stærkt breccieret. }\end{array}$ \\
\hline 5 & 37,5 & & N. $85^{\circ}$ & 4 & TB & I kysten $\varnothing$ st for Bavinsgjógv. & $\begin{array}{l}\text { Horisontal forkastning (Sa 4). } \\
\text { Stærkt lamelleret og breccieret m. } \\
\text { zeolitårer. }\end{array}$ \\
\hline 6 & 37,5 & & N. $75^{\circ}$ & & & Øst for Morðbergstangi (gjógv). & \\
\hline 7 & $37,5.6$ & & N. $130^{\circ}$ & $1-2$ & ТВ & Selgjálátur - Hestagjógv. & \\
\hline \multirow[t]{2}{*}{8} & 37,6 & & N. $130^{\circ}$ & & & Syd for Streymnev (lille kløft). & \\
\hline & & & & & & & Hestur (H.) \\
\hline Nr. & M 1) & Højde i m & Retning & Bredde i m & Type 2) & Lokalitet & Bemærkninger \\
\hline 1 & 35,7 & & N. $110^{\circ}$ & & TB & Hvíturðargjógv. & \\
\hline 2 & 35,8 & & N. $40^{\circ}$ & & & Syd for Húsagjógv. & \\
\hline \multirow[t]{2}{*}{3} & 35,8 & & N. $110^{\circ}$ & & & Streymagjógv. & \\
\hline & & & & & & & Koltur (Ko.) \\
\hline $\mathrm{Nr}$. & M 1) & Højde i m & Retning & Bredde i m & Type ${ }^{2)}$ & Lokalitet & Bemærkninger \\
\hline 1 & 34,2 & & N. $5^{\circ}$ & & TB & $\emptyset$ st for Nakkur. & \\
\hline 2 & 34,2 & & N. $15^{\circ}$ & & & $\emptyset$ st for Nakkur. & \\
\hline 3 & 34,2 & & N. $15^{\circ}$ & & & $\emptyset$ st for Krúnan. & \\
\hline 4 & 34,2 & & N. $20^{\circ}$ & & & Nord for Fleygabergstangi. & \\
\hline
\end{tabular}




\begin{tabular}{|c|c|c|c|c|c|c|c|}
\hline Nr. & $\left.M^{11}\right)$ & Højde i m & Retning & Bredde i $\mathrm{m}$ & Type 2) & Lokalitet & Bemærkninger \\
\hline 1 & 23,4 & & N. $145^{\circ}$ & 3 & ТВ & Mykineshólmur. & \\
\hline 2 & 23,2 & & N. $45^{\circ}$ & 1 & FB & Korkadalur. & Skråtstillet. \\
\hline
\end{tabular}

Vágar (Vá.)

\begin{tabular}{|c|c|c|c|c|c|c|c|}
\hline Nr. & $M^{1)} \quad I$ & Højde i m & Retning & Bredde i m & Type 2) & Lokalitet & Bemærkninger \\
\hline 1 & 17,7 & & N. $115^{\circ}$ & & & Hellisgjógv. & \\
\hline 2 & 17,8 & & N. $85^{\circ}$ & 2 & & Vest for Skarvadrangur. & \\
\hline 3 & 17,9 & & N. $85^{\circ}$ & & & Høvdagjógv. & \\
\hline 4 & 18,7 & & N. $160^{\circ}$ & 2 & & Vest for Skoranakkur. & \\
\hline 5 & 18,7 & & N. $165^{\circ}$ & 3 & TB & Øst for Grímstaðfjall. & \\
\hline 6 & 18,7 & 432 & N. $135^{\circ}$ & 2 & TB & Nordsiden af Skoradalshálsur. & \\
\hline 7 & 18,7 & & N. $140^{\circ}$ & & & Lágjógv. & \\
\hline 8 & 18,7 & & N. $110^{\circ}$ & 6 & FB & Nord for Marknará. & \\
\hline 9 & 18,7 & & N. $80^{\circ}$ & 2 & & Syd for Marknará. & \\
\hline 10 & 18,8 & & N. $100^{\circ}$ & 10 & & Barmur. & \\
\hline 11 & 24,2 & & N. $135^{\circ}$ & 1 & TB & Vest for Nevtangi. & Noget bugtet forl $\varnothing b$. \\
\hline 12 & 24,2 & & N. $175^{\circ}$ & 1 & TB & Vest for Nevtangi. & Bugtet forl $\varnothing b$. Mange apofyser. \\
\hline 13 & 24,2 & 500 & N. $105^{\circ}$ & 3 & FB & Mellem Lambagjógv og Orrtindur. & \\
\hline 14 & 24,2 & & N. $95^{\circ}$ & & & Nordl. bigjógv til Skeljagjógv. & \\
\hline 15 & 24,2 & & N. $40^{\circ}$ & 5 & TB & Skeljagjógv. & \\
\hline 16 & 24,2 & & N. $115^{\circ}$ & & FB & Eysturtindur. & \\
\hline 17 & $24,2.5$ & & N. $5^{\circ}$ & $4-5$ & TB & Jatnagarðar. & Står frem i terrænet. \\
\hline 18 & $24,2.5$ & & N. $170^{\circ}$ & & FB & Jatnagarðar. & Står frem i terrænet. \\
\hline
\end{tabular}


Vágar (Vá.)

\begin{tabular}{|c|c|c|c|c|c|c|c|}
\hline Nr. & M 1) & H $\phi$ jde i m & Retning & Bredde i m & Type 2) & Lokalitet & Bemærkninger \\
\hline 19 & 24,2 & 570 & N. $5^{\circ}$ & 1 & TB & Øst for Jatnagarðar. & \\
\hline 20 & 24,3 & 180 & N. $35^{\circ}$ & 4 & $\mathrm{~TB}$ & Tormannsgjógv. & Stærkt lamelleret og breccieret. \\
\hline 21 & 24,3 & & N. $20^{\circ}$ & 2 & TB & Húsagjógv. & \\
\hline 22 & 24,6 & 500 & N. $120^{\circ}$ & 1 & TB & Nord for Snældansfjall. & \\
\hline 23 & 24,6 & & N. $25^{\circ}$ & 2,5 & & Tungan. & \\
\hline 24 & 24,6 & 510 & N. $75^{\circ}$ & $1-2$ & TB & Myrkagjógv. & \\
\hline 25 & 24,6 & 440 & N. $35^{\circ}$ & & $\mathrm{TB}$ & Nord for Hvilvtarn $\phi v$. & \\
\hline 26 & 24,5 & & N. $155^{\circ}$ & & & Gjógv nordvest for Bóndagjógv. & \\
\hline 27 & 24,5 & & N. $160^{\circ}$ & & & Bóndagjógv. & Horisontal forkastning $8-9 \mathrm{~m}$. \\
\hline 28 & 24,5 & 514 & N. $90^{\circ}$ & $2-3$ & $\mathrm{~TB}$ & Gjógv nordøst for Berinartindur. & \\
\hline 29 & 24,5 & 220 & N. $155^{\circ}$ & 2 & FB & Mellem Berinartindur og Bøur. & \\
\hline 30 & 24,5 & & N. $15^{\circ}$ & 1,5 & $\mathrm{~TB}$ & Akranes. & Noget uregelmæssigt forløb. \\
\hline 31 & $24,5.8$ & & N. $15^{\circ}$ & 1,5 & $\mathrm{~TB}$ & Akranessker. & Noget uregelmæssigt forl $\varnothing \mathrm{b}$. \\
\hline 32 & 24,8 & & N. $160^{\circ}$ & 2 & FB & Barnagjógv. & Noget bugtet forløb. \\
\hline 33 & 24,8 & & N. $105^{\circ}$ & & & $\emptyset_{\text {st }}$ for Filpusardrangur. & \\
\hline 34 & 24,8 & & N. $30^{\circ}$ & 2 & $\mathrm{~TB}$ & Sydvest for Múlin. & \\
\hline 35 & 24,8 & & N. $20^{\circ}$ & $3-3,5$ & FB & Vest for Selvík. & \\
\hline 36 & 24,8 & 29 & N. $5^{\circ}$ & 1 & FFB & Selvíkará. & Uregelmæssigt forløb. Apofyselignende. \\
\hline 37 & $24,9.8$ & & N. $40^{\circ}$ & $1,5-2$ & FFB & Mellem Klivarnar og Selvík. & Uregelmæssigt og svingende forl $\varnothing \mathrm{b}$. \\
\hline 38 & 24,9 & & N. $50^{\circ}$ & 4 & $\mathrm{~TB}$ & Vest for Kajen, Sørvágur. & Lamelleret m. zeolit- og blegejordsårer. \\
\hline 39 & 24,9 & & N. $45^{\circ}$ & 2 & FFB & Øst for Breiðá. & Lamelleret. \\
\hline 40 & 24,9 & 420 & N. $45^{\circ}$ & 2,5 & FFB & Líðarn $\varnothing v$. & \\
\hline 41 & 24,9 & & N. $115^{\circ}$ & & TB & $\begin{array}{l}\text { I vandløb fra Húsadalsá op mod } \\
\text { Líđarnøv (gjógv). }\end{array}$ & \\
\hline 42 & 24,9 & 97 & N. $85^{\circ}$ & 70 & TB & Húsadalur. & \\
\hline
\end{tabular}




\begin{tabular}{|c|c|c|c|c|c|c|}
\hline Nr. & $M^{1)}$ & Højde i m & Retning & Bredde i m & Type 2) & Lokalitet \\
\hline 43 & 24,9 & & N. $80^{\circ}$ & 1,5 & TB & $\begin{array}{l}\text { Mellem sømærke og bøgærde, } \\
\text { S } \varnothing \text { rvágur. }\end{array}$ \\
\hline 44 & 24,9 & 114 & N. $85^{\circ}$ & & & Elven vest for bøgærdet, Sørvágur. \\
\hline 45 & 24,9 & & N. $50^{\circ}$ & $3-4$ & ТВ & Ved bøgærdet. \\
\hline 46 & 25,1 & 293 & N. $165^{\circ}$ & & $\mathrm{TB}$ & Sydvest for Tungufelli Lítla. \\
\hline 47 & 25,2 & & N. $60^{\circ}$ & & $\mathrm{TB}$ & Ørgusgjógv. \\
\hline 48 & 25,2 & & N. $125^{\circ}$ & 1 & FB & Ørgusgjógv. \\
\hline 49 & 25,2 & & N. $5^{\circ}$ & 3 & $\mathrm{FB}$ & Mellem Kloddin og Ørgusgjógv. \\
\hline 50 & 25,2 & & N. $10^{\circ}$ & 2 & $\mathrm{~TB}$ & Mellem Kloddin og Ørgusgjógv. \\
\hline 51 & 25,2 & & N. $85^{\circ}$ & 5 & FFB & Vest for Kloddin. \\
\hline 52 & 25,2 & & N. $30^{\circ}$ & $3-4$ & TB & Nord for Oyrargjógv. \\
\hline 53 & 25,3 & & N. $110^{\circ}$ & 1 & $\mathrm{~TB}$ & Nord for udløbet Breiðá. \\
\hline 54 & 25,6 & & N. $45^{\circ}$ & 1,5 & ТВ & Nord for Leypannagjógv. \\
\hline 55 & 25,6 & & N. $80^{\circ}$ & 3 & $\mathrm{FB}$ & Leypannagjógv. \\
\hline 56 & 25,6 & & N. $45^{\circ}$ & 1 & $\mathrm{~TB}$ & Nord for Hvalagjógv. \\
\hline 57 & 25,6 & & N. $155^{\circ}$ & 2 & FB & Sydsiden af Marknará. \\
\hline 58 & 25,6 & & N. $175^{\circ}$ & 3 & TB & Øst for Marknará. \\
\hline 59 & 25,6 & & N. $175^{\circ}$ & 3 & TB & Øst for Marknará. \\
\hline 60 & 25,6 & 215 & N. $25^{\circ}$ & $2-3$ & $\mathrm{~TB}$ & Bielv til Marknará. \\
\hline 61 & 25,6 & 380 & N. $60^{\circ}$ & & TB & Reynini. \\
\hline 62 & 25,6 & 420 & N. $70^{\circ}$ & & TB & Reynini. \\
\hline 63 & 25,5 & 560 & N. $65^{\circ}$ & 2 & $\mathrm{~TB}$ & Gásafelli. \\
\hline 64 & 25,5 & & N. $105^{\circ}$ & & $\mathrm{FB}$ & Nordøst for Gásafelli. \\
\hline 65 & 25,5 & & N. $55^{\circ}$ & & & Oyrargjógv. \\
\hline
\end{tabular}

Horisontal forkastning ca. $8 \mathrm{~m}$.

Lamelleret m. zeolitårer.

Lamellar sprækkedannelse m. blegejord ca. $30 \mathrm{~cm}$.

Lamelleret m. mineralisering.

Lamelleret.

Lamelleret.

Lamelleret $\mathrm{m}$. mineralisering. 


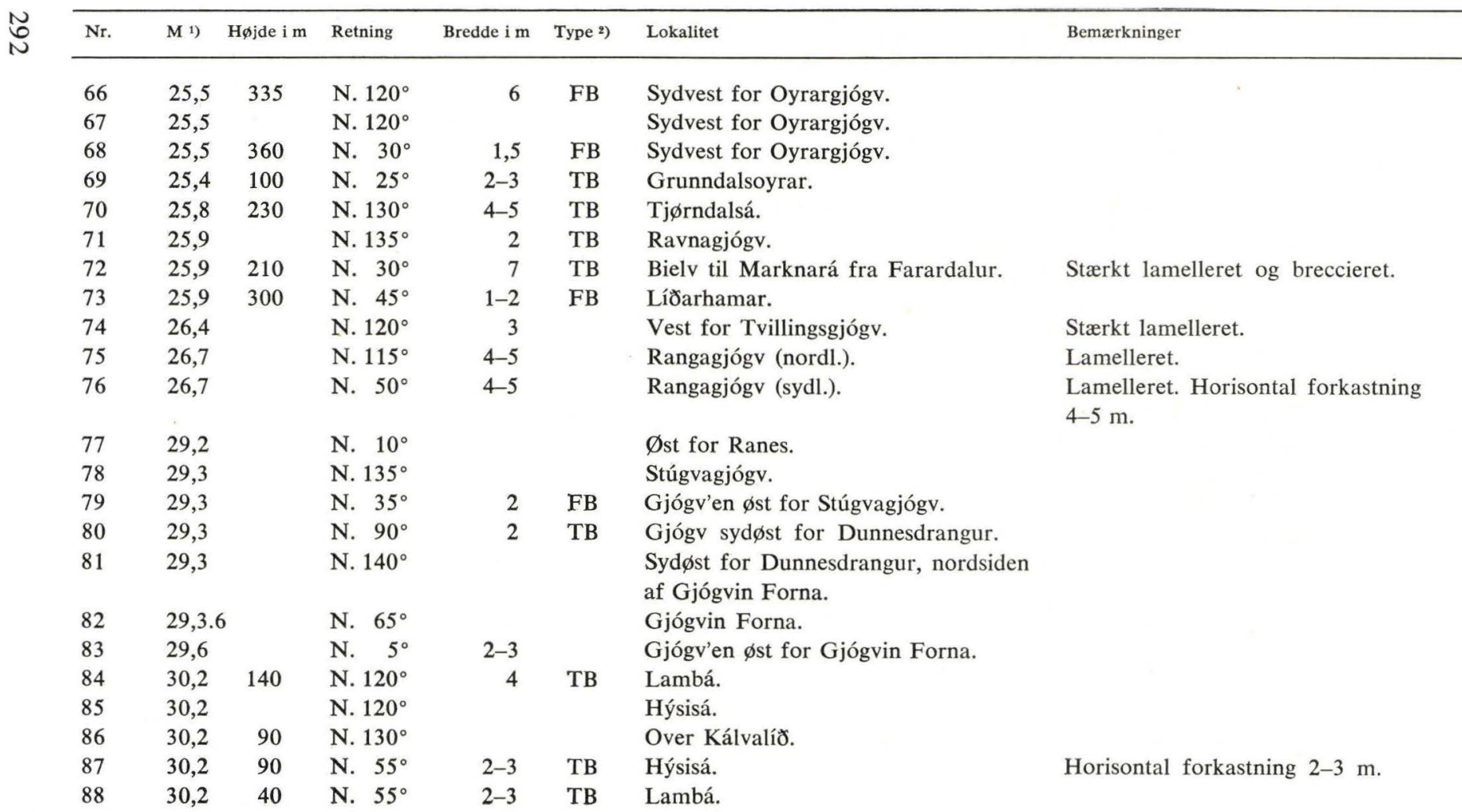




\begin{tabular}{|c|c|c|c|c|c|c|c|}
\hline $\mathrm{Nr}$. & M 1) & Højde i m & Retning & Bredde i m & Type 2) & Lokalitet & Bemærkninger \\
\hline 89 & 30,2 & 20 & N. $135^{\circ}$ & 0,6 & TB & Hýsisá. & \\
\hline 90 & 30,2 & & N. $135^{\circ}$ & 3 & $\mathrm{~TB}$ & Kysten, nordsiden af bugten. & Stærkt breccieret. \\
\hline 91 & 30,2 & & N. $25^{\circ}$ & $1-2$ & TB & Kirkjar. & \\
\hline 92 & 30,3 & 265 & N. $35^{\circ}$ & 2,5 & $\mathrm{~TB}$ & Góðansá. & \\
\hline 93 & 30,3 & 165 & N. $120^{\circ}$ & 2 & $\mathrm{~TB}$ & Fossá. & \\
\hline 94 & 30,3 & 170 & N. $120^{\circ}$ & $1-2$ & $\mathrm{~TB}$ & Fossá. & \\
\hline 95 & 30,3 & 280 & N. $135^{\circ}$ & 3,5 & TB & Fossá. & \\
\hline 96 & 30,3 & & N. $60^{\circ}$ & 10 & & Østsiden af Sandavágur. & \\
\hline 97 & 30,6 & & N. $60^{\circ}$ & $5-6$ & TB & Prestgjógv. & Lamelleret $\mathrm{m}$. mineraludskillelse. \\
\hline 98 & 30,5 & & N. $135^{\circ}$ & 3 & $\mathrm{~TB}$ & Hússá. & \\
\hline 99 & 30,5 & & N. $130^{\circ}$ & & & Sydvestsiden af Sørvágsvatn. & \\
\hline 100 & 30,5 & 60 & N. $130^{\circ}$ & 2 & TB & Sydøstsiden af Sørvágsvatn. & Lamelleret. \\
\hline 101 & 30,5 & & N. $130^{\circ}$ & & TB & Marknagjógv (Rituberg). & \\
\hline 102 & 30,5 & & N. $50^{\circ}$ & & & Lundansgjógv. & \\
\hline 103 & 30,4 & & N. $45^{\circ}$ & & & Syd for Bergliðsgjógv. & \\
\hline 104 & 30,4 & & N. $155^{\circ}$ & & & Øst for Slættabergsmúli. & \\
\hline 105 & 31,1 & & N. $45^{\circ}$ & $5-6$ & TB & Oknadalur (sydl. elvforgrening). & \\
\hline 106 & 31,1 & & N. $65-75^{\circ}$ & $3-5$ & & Oknadalsgjógv - Tvørtindur. & \\
\hline 107 & 31,1 & & N. $150-170^{\circ}$ & & & Vest for Trøllkonufingur. & \\
\hline 108 & 31,1 & & N. $150-170^{\circ}$ & & & Vest for Trøllkonufingur. & \\
\hline 109 & 31,1 & & N. $150-170^{\circ}$ & & & Vest for Tr $\phi 1 l k o n u f i n g u r$. & \\
\hline
\end{tabular}




\section{Uregelmæssige intrusive dannelser}

Således har vi valgt at betegne denne intrusionsform. Den afviger fra andre intrusionsformer gennem sin fuldstændig ubundne og uregelmæssige morfologiske afgrænsning, idet dens basalter er trængt ind $\mathrm{i}$ et så lidt modstandsdygtigt og uensartet materiale som det, der opbygger tuf-agglomeratzonen. De uregelmæssige intrusive dannelser forekommer overalt indenfor og langs denne zone, og de er intruderet i denne samt i overgangszonen mellem den kulførende serie og tuf-agglomeratzonen. De forekommer derfor kun på den nordøstlige side af Sưuroy, på Tindhólmur og på den nordvestlige del af Vágar (se s. 174).

\section{Sиみиroy}

De uregelmæssige intrusive dannelser er kun forbigående omtal i den ældre litteratur. ForCHHAMMER (1824) nævner »uregelmæssig basalt« fra Tjørnunes (Kjødenæs) på sydsiden af Hvalbiarfjørđur til Hvannhagi (Quönnahea) på nordøstsiden af Suðuroy og udtaler, at kullene i Hvannhagi må være »løsrevne og hævede«, da de efter den generelle strygning ikke skulle kunne forekomme her. Trevelyan (1823) der berejste Færøerne sammen med Forchhammer, nævner ligeledes intruderet basalt, »columnar basalt«, ved Tjørnunes. GeIKIE (1880) omtaler »intrusive basalts « langs kysten fra Hvannhagi (Kvanhauge) til Tjørnunes (Tiødenenes) samt på nordsiden af Hvalbiarfjørður og mener, at de sandsynligvis alle tilhører samme intrusive dannelse. Han nævner, ligesom Forchhammer, at kullene i Hvannhagi er dislocerede. Helland (1880) og BøGGILD $(1922,1928)$ berører kun disse forhold ganske forbigående. GEIKIE (1880) og BøGGILD (1928) anser søjlebasalterne i strandbredden ved Froðba for at være intrusive, hvilket senere undersøgelser ikke har fundet nogen begrundelse for. Fra de senere år er de uregelmæssige intrusive dannelser behandlet af RASMUSSEN (1952 og 1957).

På nordsiden af Hvalbiarfjørður ser man intrusiv basalt omtrent langs hele kyststrækningen fra den gamle landingsplads ud til Reyðibarmur. Ved den lille bugt vest for landingspladsen angiver apofyser og kontaktrester intrusionens vestlige begrænsning, og umiddelbart vest for landingspladsen danner denne underlag for anløbsbro og pakhus. Den ses igen øst for landingspladsen, hvor den optager hele forstranden, videre udad tiltager den i mægtighed 


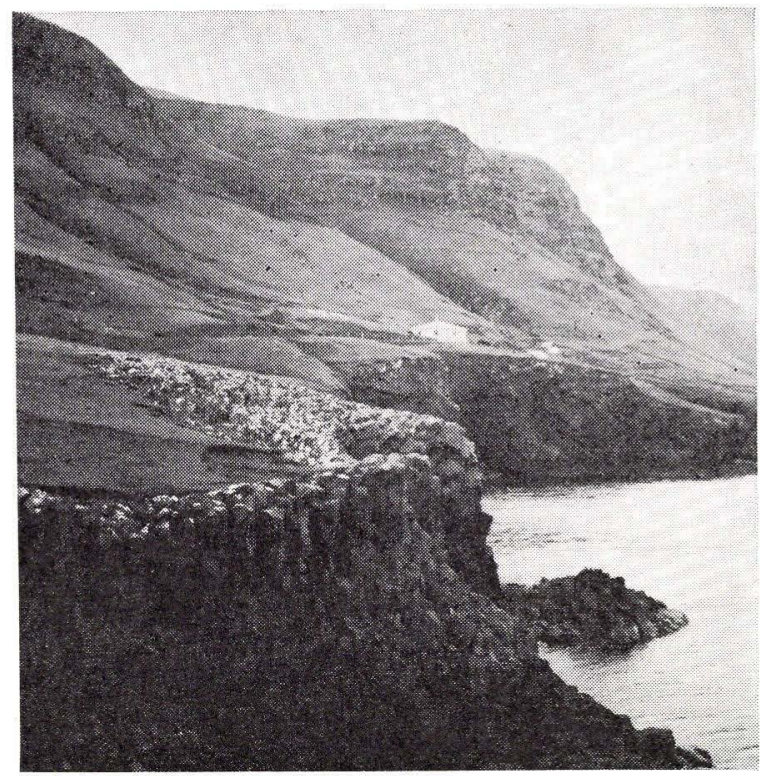

Fig. 102. Intruderet basalt i kysten på nordsiden af Hvalbiarfjørður. Óreglulig innskot norðantil á Hvalbiarfirđi.

Intrusive basalt on the coast on the north side of Hvalbiarfjorøur.

og danner en stejl skrænt, hvis højde, midt imellem den vestlige landingsplads og det nye kajanlæg, er ca. $10 \mathrm{~m}$. Derefter aftager den igen, i den lille bugt vest for Hamranes er den $\emptyset$ vre grænse for den intruderede basalt beliggende i $35 \mathrm{~m}$ h $\varnothing \mathrm{jde}$, selve kystprofilets højde er her ca. $20 \mathrm{~m}$. (Fig. 102).

Fra Hamranes synes mægtigheden igen at tage af ud mod Reyðibarmur. Kyststrækningen fra landingspladsen ud til vestsiden af Reyðibarmur er ca. 1200 m. På vestsiden af Reyðibarmur er kontaktzonen mellem de intruderede basalter og tuf-agglomeratzonen blottet, og ved selve Reyðibarmur underlejres tuf-agglomeraterne af intruderet basalt, fra hvilken der hyppigt går uregelmæssige apofyser op i disse.

Mellem Hamranes og Hvítanes ses en gang i kysten. Den gennemskærer den intruderede basalt, tuf-agglomeratzonen og den mellemste basaltserie. Den stryger NV-S $\varnothing$ og kan med mellemrum følges fra Tvфrgjógv på фens nordside til sydsiden af Hovsfjørður (Su. 1, 2, 9, 10, 11, 27, 28, 29, 30, 40) ialt en strækning på ca. $21 \mathrm{~km}$. Gangmægtigheden varierer mellem 8 og $12 \mathrm{~m}$, på nord- 
siden af Hvalbiarfjørður er den ca. 8 m. I kysten mellem Hamranes og Hvítanes, hvor gangen gennemskærer den intruderede basaltmasse, udviser gangen ikke nogen skarp kontakt til siderne, selvom der kan spores nogen termal påvirkning i selve kontaktzonen. Den er ikke typisk søjledannet, og der kan ikke spores nogen udpræget forskel i kornst $\varnothing$ rrelse fra gangmidten og ud mod kontaktzonen. I grænseområdet nærmest ved gangen ses tilnærmelsesvis vandret orienterede søjler, der efterhånden, fjernere, retter sig op i vertikal stilling. Længere oppe i kløften, hvor gangen forløber i den mellemste basaltseries lavaer, er s $\varnothing j$ lestrukturen mere veludviklet med skarpkantede søjler; der ses endvidere her skarp kontakt med sidevæggen, og der kan iagttages st $\varnothing$ rre forskel i kornst $\varnothing$ rrelse midt i gangen og i kontaktzonen. Der kan således næppe herske tvivl om, at gangen og de intrusive basalter i kysten er dannet omtrent samtidigt, og at gangen eventuelt har været tilførende til disse. (Fig. 103, 104, 105).

På sydsiden af Hvalbiarfjørður ses intrusiv basalt ved Flekksá ca. 60-100 m o. h. (fig. 45), ligeledes forekommer intruderet basalt stedvis i kysten ud mod Tjørnunes til Myrkagjógv, Tjørnunes selv består udelukkende af intruderet basalt. Her kan det umiddelbart iagttages, at den kulførende serie er gennembrudt af intrusionen.

I Lónin ligger den uregelmæssigt intruderede basalt i kysten. Hvannhólmur, holmene indenfor denne og de andre holme og skær ved Lónin udgøres af i forskellige retninger orienterede basalts $\varnothing j$ ler af intrusiv oprindelse. Den intruderede basalt kan langs kysten følges videre sydpå ind i Hvannhagi. Hvannhagi er for en meget stor del vegetationsklædt, men de intruderede basalter ses dog blottet langs kysten mellem Todnes og Stapin, stedvis sydpå gennem hele Hvannhagi og langs kysten фstpå ud mod Ribbingamúli. De antager stedvis betydelig mægtighed, således sydøstligst i Hvannhagi, hvor de ses i strandkanten og kan følges opad til ca. $60 \mathrm{~m}$ højde. Mod vest overlejrer de her den kulførende serie. Som først omtalt af ForChHAMMER (1824) må den kulførende serie, der med nordøstlig faldretning skærer havniveau ved Kolaratangi, Tjørnunes og Froðbiarnípa være disloceret, idet den findes nær kysten i Hvannhagi og Lónin. For dislocation gennem intrusion af de uregelmæssige, intruderede basalter taler endvidere, at vi ved Stapin finder rester af den kulf $\varnothing$ rende serie stærkt dislocerede og indesluttet $\mathrm{i}$ de intruderede basalter og mellem Stapin og Todnes en 4-6 m bred og ca. $30 \mathrm{~m}$ lang oprejst sedimentserie af »basaltisk 


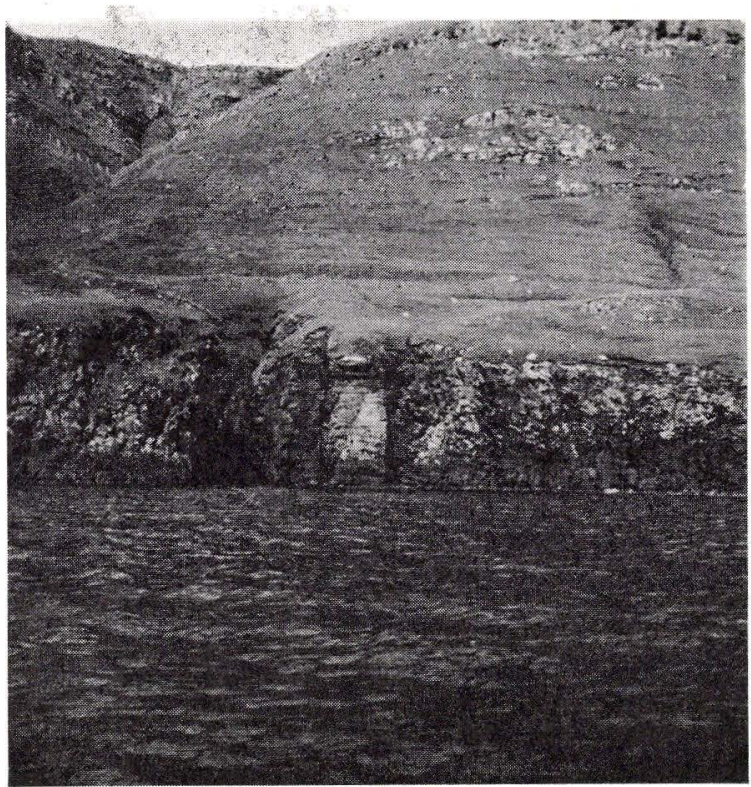

Fig. 103. Gangen mellem Hamranes og Hvítanes.

Gongin millum Hamranes og Hvitanes.

The dyke between Hamranes and Hvitanes.

sandsten «, ligeledes indesluttet i intruderet basalt. Sedimentseriens oprindelige orientering fremgår af »suncracks « på dens $\phi$ stvendte side. Midt i Hvannhagi kan den intruderede basalt ses ved Dysjarnar, delvis drkket af fjeldskred (landslide). Den kan endvidere følges fra ca. $20 \mathrm{~m}$ o. h. langs elven op i den lille hængedal med sфen (90 m o. h.) i den vestlige del af Hvannhagi. Flere steder gennembryder den hele tuf-agglomeratzonen, således umiddelbart $\varnothing$ st for Dysjarnar. Vest for Grønagjógv og særlig tydelig фst for Gásagjógv udsender den apofyser op i den mellemste basaltseries nedre del. (Fig. 46, 106, 107).

På nordsiden af Trongisvágur finder man intruderede basalter med mellemrum langs hele fjeldsiden fra området vest for Myllá til området øst for Tippisá.

Vest for Myllá ligger i ca. $150 \mathrm{~m}$ højde en basaltmasse, der utvivlsomt er intrusiv. Den kan følges tilbage til Myllá, hvor der ses apofyser, dels ved grænsen mellem agglomeratzonen og den mellemste basaltserie og dels længere nede i elven ca. $4 \mathrm{~m}$ over et gammelt mineindslag. Både her og inde i den gamle mine har 


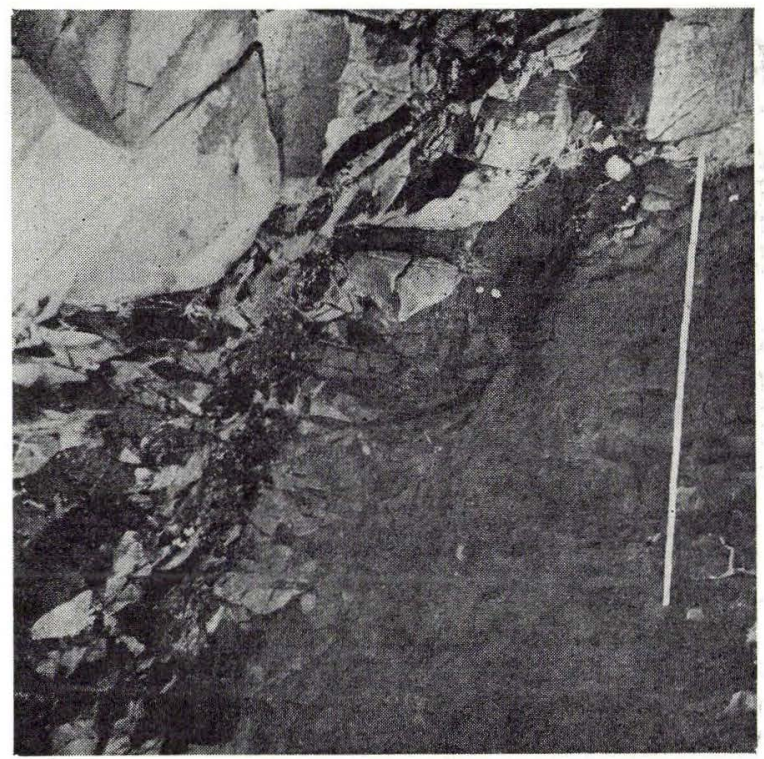

Fig. 104. Gangen mellem Hamranes og Hvítanes. Kontakt mod den intruderede basalt i kysten.

Gongin millum Hamranes og Hvitanes. Samankomingin við innskotið $\hat{\imath}$ bakkanum.

The dyke between Hamranes and Hvitanes, showing its contact against the intrusive basalt on the coast.

den intruderede basalt kontakt mod tagleret i den kulførende serie. Den intruderede basaltmasse vest for Myllá er blottet langs en strækning på ca. $180 \mathrm{~m}$, dens største mægtighed, ca. $13 \mathrm{~m}$, findes langs midterpartiet. I ca. $185 \mathrm{~m}$ højde i Myllá går en ganglignende apofyse på ca. $1 \mathrm{~m}$ bredde op i den mellemste basaltserie; den ses også at gå skråt gennem agglomeratet i kløften. På den vestlige kløftside er mægtigheden ca. $10 \mathrm{~m}$.

I $\varnothing \mathrm{kslin}$ ses intruderet basalt $\mathrm{i}$ taget af et gammelt mineindslag.

I området $\varnothing$ st for $\varnothing \mathrm{kslin}$ forekommer der flere mindre blotninger med mægtigheder på 10-15 m, som efter al sandsynlighed kan betragtes som intrusive. Kontakter eller overskæringer er ikke blevet direkte iagttaget, men efter udseende og beliggenhed i lagserien at dømme må de være intrusive.

I Tippisá og området umiddelbart øst for Tippisá ses mellem 130 og $150 \mathrm{~m} \mathrm{o.} \mathrm{h.} \mathrm{blotninger,} \mathrm{der} \mathrm{ligeledes} \mathrm{må} \mathrm{antages} \mathrm{at} \mathrm{hidrøre}$ fra de uregelmæssigt intruderede basalter. 


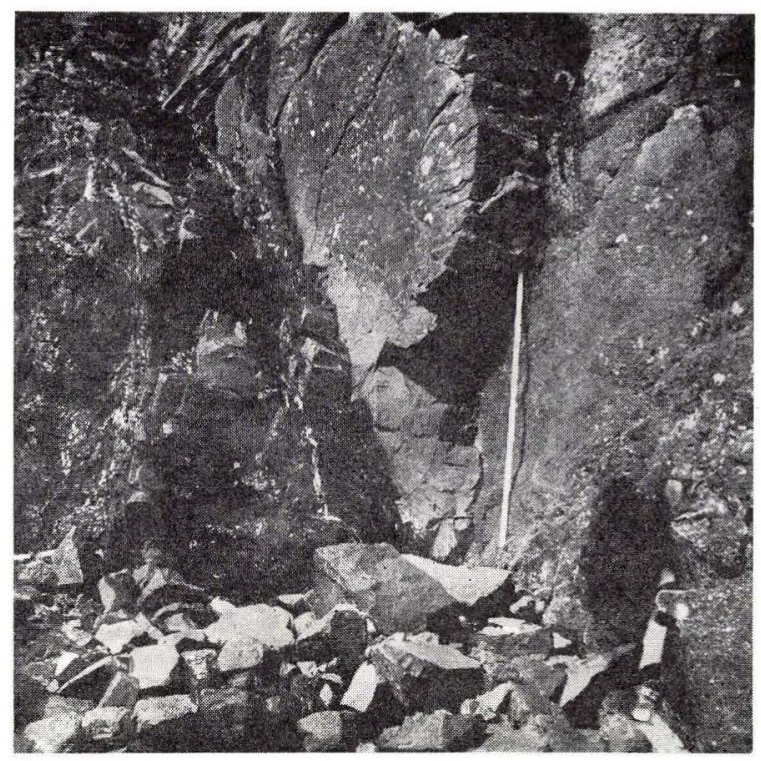

Fig. 105. Gangen mellem Hamranes og Hvítanes. Kontakt mod den mellemste basaltserie længere oppe.

Gongin millum Hamranes og Hvítanes. Samankomingin ovari, við miðfláirnar. The dyke between Hamranes and Hvitanes, showing its contact at a higher level against lavas of the middle basalt series.

På syds:den af Trongisvágur findes intruderede basalter blottet ved to gamle mineindslag i Oyrnafjall og østligere.

\section{Tindhólmur og Vágar}

Ligesom det var tilfældet på Suðuroy, forekommer de uregelmæssige intrusive dannelser også her i tilslutning til tuf-agglomeratzonen og dennes nærmeste omgivelser. ForCHHAMMER (1824) synes at have bemærket dem på Tindhólmur, men for Vágar's vedkommende ses de ikke at være nævnt i den ældre litteratur.

Tindhólmur's nordside er kun dårligt blottet, sydsiden derimod er næsten lodret og hele lagserien: nederste basaltserie, kulførende serie og tuf-agglomeratzonen med intruderede basalter samt en del af den mellemste basaltserie ses her blottet som et vertikalt snit (fig. 51).

På Vágar kan de uregelmæssigt intruderede basalter iagttages fra Akranes mellem bygderne Bøur og Gásadalur, langs kysten mod 


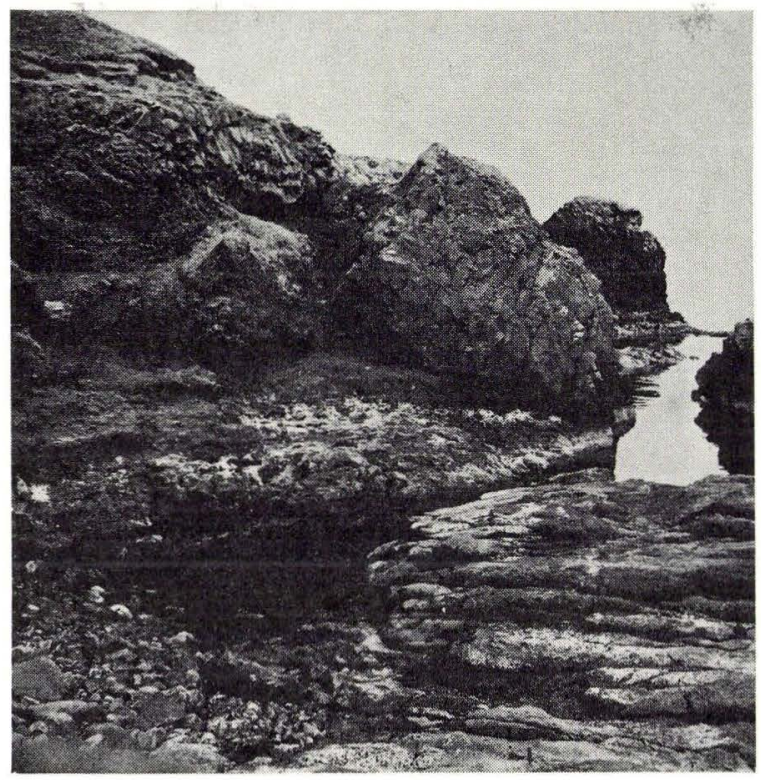

Fig. 106. Intruderet basalt med dislocerede kullag. I forgrunden agglomerat. Ved Stapin.

Innskotið blágrýti við innilokaðari leivd av kolalindini. Stapin, Hvannhagi. Intrusive basalt containing dislocated coal seams. Agglomerate in the foreground. Near Stapin, Suðuroy.

nordvest til området syd for Barðið. Akranes og Akranessker består udelukkende af intruderede basalter, og i den lille bugt $\emptyset$ st for Akranessker ses der lodret kontakt mellem de intruderede basalter og den nederste del af den mellemste basaltserie, der her veksellejrer med tuf-agglomerater. Stejlvæggen ved Akranesfossur består for langt den overvejende del af intruderet basalt med inklusioner af tuf-agglomerat og lersedimenter, der hidrører fra den kulf $\varnothing$ rende serie. Mod nordvest indtager de intruderede basalter en del af kystområdet mellem Akranessker og Gásadalur (Bíggjarurð), og ligeledes ses de i kløfter med gode blotninger fra Gásadalur til området syd for Barðið. (Fig. 48, 49, 50, 108).

Den intruderede basalt på Akranessker gennemskæres af en gang (Vá 31), den ses igen i fjeldvæggen inde på landsiden (Vá 30) og fortsætter op i den mellemste basaltserie. Gangen er kun ganske svagt søjledannet, og den termale kontakt er kun svagt udviklet. Gangforløbet er ret svingende. Såvel med hensyn til selve intru- 


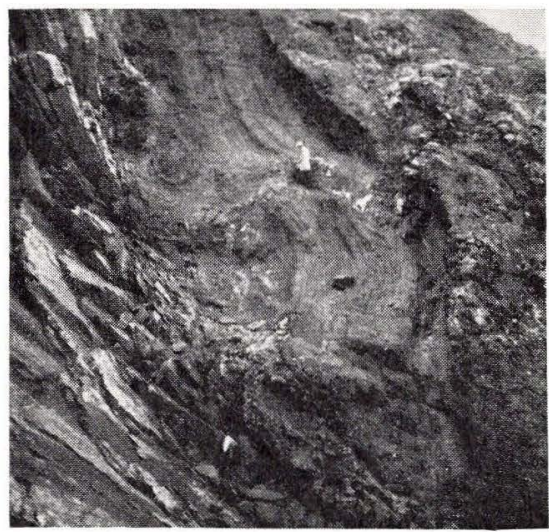

Fig. 107. Sedimentserie (»basaltisk sandsten«) indesluttet i intruderet basalt. Nord for Stapin.

Lagskipað sandgrýti innilokað i óregluliga innskotið blágrýti. Norđan fyri Stapan, Hvannhagi.

Sedimentary strata ("basaltic sandstone ) incorporated in intrusive basalt. North of Stapin.

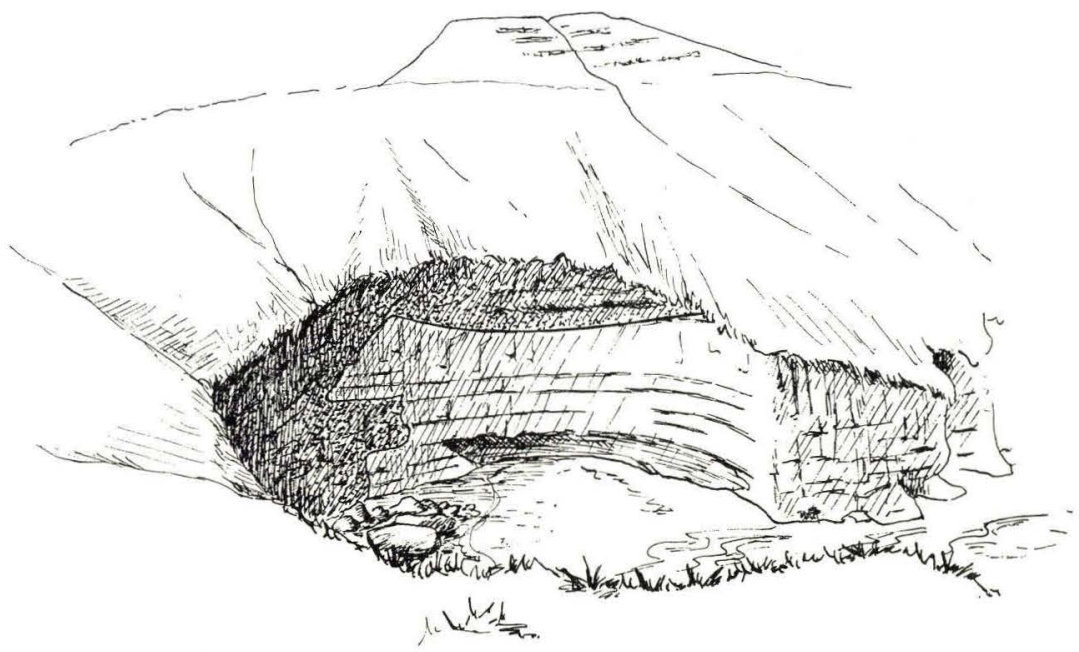

Fig. 108. Kontakt mellem intruderet basalt og den nederste del af den mellemste basaltserie $\phi$ st for Akranessker.

Samankoming millum óregluliga innskotið blágrýti og niðasta partin av miðfláunum eystan fyri Akranessker. Vágar.

Contact between intrusive basalt and the lowest part of the middle basalt series east of Akranessker. 
sionsforholdene som med hensyn til bjergartstype er der en påfaldende lighed med de forhold, der gjorde sig gældende ved gangen mellem Hamranes og Hvítanes på Suðuroy (Su. 2).

De uregelmæssige intrusivers bjergarter er repræsenteret ved pr $\varnothing$ ver fra Hvalbøur på Suðuroy og fra Akranes på Vágar; fra sidstnævnte lokalitet er der tillige set på tyndslib fra Bøggilds indsamling i 1903.

Hvalbøur: Bjergarten er i håndstykke mørk grå, mellemkornet, den fører makroskopisk synlig olivin.

Texturen er tilnærmet doleritisk. Olivinen har en gennemsnitsst $\varnothing$ rrelse af 0,2 til $0,3 \mathrm{~mm}$, enkelte individer bliver $0,4 \mathrm{~mm}$; mineralet findes som strøkorn. Olivinen er langs randen omdannet til en honninggul serpentin; serpentin optræder også i nogle individer som bånd langs gennemgangene. Plagioklaslisterne kan blive 0,5 $\mathrm{mm}$ lange, de er noget zonare. Clinopyroxenen danner individer, som er mindre, men de kan nu og da optræde klumpvis (sammensatte strøkorn), så deres fællesomrids når samme størrelse som olivinkornene. Pyroxenen er farveløs; tvillingdannelse forekommer udbredt. Malmkornene har stænglet udvikling. Der findes yderligere en lysebrun interstitialmasse med et betydeligt indhold af zeolitnåle. Centralt i st $\varnothing$ rre felter er denne masse i $\varnothing$ vrigt næsten isotrop og har åbenbart oprindelig overvejende været glasagtig; nærmere yderranden indeholder den dobbeltbrydende, men næsten ikke gennemskinnelige partier.

Mineralsammensætningen er følgende: $\mathrm{pl}=40 \%, \mathrm{cpx}=38$ $\%$, ol $=9 \%(\mathrm{ol}=6,7 \%+$ serpentin $=2,3 \%)$, malm $=5,7 \%$ og interstitialmasse $=7,3 \%$.

En kemisk analyse af bjergarten findes i tabellen. Det normative nefelinindhold skyldes antagelig zeoliterne. Klassifikatorisk betyder det, at bjergarten må betegnes som en alkali-olivinbasalt (YoDER og TILlEY 1962).

Akranes, Vágar: Bjergarten svarer i udseende nøje til dem fra Hvalbøur, også med hensyn til indholdet af makroskopisk synlig olivin.

Texturen er dog nærmest intergranular, men indeholder pletvis optrædende ofitiske фer (ophimotteled). Olivinstr $\varnothing$ kornene kan blive op til 0,4 mm lange; de er noget omdannede, især langs randen, men også nu og da langs buede gennemgange i mineralet. Nogle, enkeltliggende oliviner er helt omdannet til serpentin, der er fibr $\varnothing \mathrm{s}$ 
og enten gulligbrun eller gulliggrøn; samme farver går igen i de sekundære omdannelsesprodukter i interstitierne, disse kan være noget strålede. Plagioklaskornene kan blive $0,5 \mathrm{~mm}$ store. Clinopyroxenen er farveløs og i de ofittiske områder gennemvokset af plagioklaslister, som både her og udenfor viser tilløb til en stellar vækst. De fleste malmkorn er ækvidimensionale, men der findes også stænglede individer. Interstitialmassen kan være næsten opak på grund af bitte små malmkorn.

En, af Bøggild indsamlet, prøve er lidt mere grovkornet, den indeholder knap så megen olivin som ovennævnte, men til gengæld flere grønligtfarvede omdannelsesprodukter i interstitierne.

Mineralsammensætningen er som følger: $\mathrm{pl}=35,2 \%, \mathrm{cpx}=$ $41,5 \%$, ol $=10,8 \%(\mathrm{ol}=4,5 \%+$ serpentin $\mathrm{i}$ ol $=6,3$ $\%)$, malm $=7 \%$ og interstitialmasse $=5,5 \%$.

En kemisk analyse findes i tabellen. Bjergarten er en olivintholeiit.

Kemiske analyser af uregelmassige intrusiver (fra nedre intrusionsniveau)

\begin{tabular}{|c|c|c|c|c|c|}
\hline \multirow{2}{*}{$\mathrm{SiO}_{2}$} & 1 & 2 & \multicolumn{3}{|c|}{ Katanorm } \\
\hline & 48,15 & 48,72 & $q$ & 0 & 0 \\
\hline $\mathrm{Al}_{2} \mathrm{O}_{3}$ & 13,18 & 12,91 & or & 2,38 & 1,64 \\
\hline $\mathrm{Fe}_{2} \mathrm{O}_{3}$ & 2,67 & 2,58 & $a b$ & 26,77 & 20,91 \\
\hline $\mathrm{FeO}$ & 8,64 & 8,86 & an & 20,02 & 24,87 \\
\hline $\mathrm{MnO}$ & 0,15 & 0,14 & ne & 2,04 & 0 \\
\hline $\mathrm{MgO}$ & 8,68 & 7,98 & ap & 0,42 & 0,41 \\
\hline $\mathrm{CaO}$ & 11,33 & 12,48 & en & 0 & 10,27 \\
\hline $\mathrm{Na}_{2} \mathrm{O}$ & 3,33 & 2,27 & fs & 0 & 4,23 \\
\hline $\mathrm{K}_{2} \mathrm{O}$ & 0,40 & 0,27 & di & 28,32 & 29,91 \\
\hline $\mathrm{TiO}_{2}$ & 2,29 & 2,20 & fo & 10,32 & 1,31 \\
\hline $\mathrm{P}_{2} \mathrm{O}_{5}$ & 0,20 & 0,19 & $\mathrm{fa}$ & 3,69 & 0,54 \\
\hline $\mathrm{H}_{2} \mathrm{O}$ & 1,00 & 1,07 & $\mathrm{mt}$ & 2,82 & 2,77 \\
\hline & 100,02 & 99,67 & $\begin{array}{l}\mathrm{hm} \\
\text { il }\end{array}$ & $\begin{array}{l}0 \\
3.22\end{array}$ & $\begin{array}{l}0 \\
3.1\end{array}$ \\
\hline
\end{tabular}

1. Intrusion ved Hvalbøur, Suðuroy: Alkali-olivinbasalt. Anal. Ib Sørensen.

2. Intrusion ved Akranes, Vágar: Olivintholeiit. Anal. Ib Sørensen.

\section{Sills}

Sills eller laggange er dannet ved magmaintrusion i svaghedszoner langs lag- eller aflejringsflader i ufoldede, oprindelig vandrette lagserier. Sills er forholdsvis tynde sammenlignet med deres areale udstrækning, og deres forløb er stort set parallelt (konkor- 
dant) med den naturlige lagdeling i den omgivende bjergart. Dog ses det ikke sjældent, at en sill gennemskærer et eller flere overliggende lag og derefter fortsætter $i$ et andet niveau langs et andet plan med en anden orientering; den bliver derved transgressiv.

Et karakteristisk fællestræk for alle sills i det færøske basaltplateau er netop en påfaldende transgressivitet, et stort set konkordant intrusionsforløb i sill'ens centralområde, men stigende transgressivitet ud mod periferien (RASMUSSEN 1951). Et andet morfologisk fællestræk ved disse sills er en fremtrædende grov prismatisk s $\varnothing$ jedannelse, som er særlig iøjnefaldende i stejle fjeldskrænter. De meget regelmæssigt forekommende søjlebasalter i den nederste basaltserie er ofte blevet mistydet som sills.

I den ældre litteratur findes sills først omtalt af vON BORN (1792, 1797). Han giver en beskrivelse med ledsagende skitser, af »st $\varnothing t t e-$ basalten « på Streymoy og Eysturoy. På Eysturoy har han iagttaget disse fra Selatrað til nord for Oyri, og han forklarer, at disse »basaltst $\varnothing$ tter « danner et horisontalt lag i bjergfoden under Halgafellstindur og Reyðafellstindur. På Streymoy har von Born iagttaget »støttebasalter « i Núgvan og Skælingur.

Fra det 19. århundrede foreligger der en lang række skrifter, hvori der, for det meste kun mere eller mindre forbigånde, refereres til sills.

LANDT (1800) omtaler »st $\varnothing$ ttebasalter« på Streymoy og Eysturoy. Selvom Landts oplysninger for en stor del er hentet fra von Born, nævner han som ny iagttagelse »støttebasalter « i Sátan. AllaN (1813) nævner »columnar greenstone« ved Selatrað på Eysturoy og i Núgvan, Skælingur og Sátan på Streymoy. Trevelyan (1823) omtaler ligeledes, ganske kort med ledsagende skitser »non conforming greenstone på Streymoy og Eysturoy. Hos ForchHAMMER $(1821,1824)$ er beskrevet sills fra Streymoy, Eysturoy og Svínoy. Sammen med gangene henregner han disse til yngste afdeling af de færøske bjergarter, »den uregelmæssige trap «. GEIKIE (1880) omtaler de kendte søjlebasaltlokaliteter ved Froðba på Suðuroy som intrusive; men de forannævnte sill-lokaliteter på de nordlige фer har han ikke selv besøgt, her refererer han til Allan og Trevelyan. Lomas (1895) har iagttaget »intrusive sheets på Fugloy, Svínoy og Streymoy. Ligesom Geikie o. a. mener han, at også søjlebasalterne ved Froðba og på Mykines er intrusive. GEIKIE (1896) omtaler den store sill på Streymoy, og han mener desuden at have iagttaget sills på Kallsoy, Kunoy og andre фer. 
Heller ikke i nyere litteratur er de færøske sills nærmere behandlet, således omtaler BøGGILD $(1922,1928)$ kun kort de to største sills, Streymoysill'en og Eysturoysill'en. Simpson (1928) giver en kortfattet petrografisk beskrivelse af Streymoysill'en, og det samme g $\varnothing \mathrm{r}$ WALKER og DAVIDSON (1936), der desuden nævner sills fra Svínoy, Eysturoy, Vestmanna, Kunoy og Borðoy. Walker og Davidson mener ikke, at søjlebasalten ved Froðba er intrusiv, men at det drejer sig om »columnar lavas of Staffa type «.

Ved nærværende arbejde er der blevet karteret følgende sills:

En på Fugloy, en på Svínoy; foruden den store sill på Eysturoy endnu en mindre sill og på Streymoy foruden den store Streymoysill tre mindre sills eller sillstykker. På nordvestsiden af Kallsoy er der desuden blevet iagttaget en mindre sill højt oppe i den utilgængelige fjeldvæg (RASMUSSEN 1957).

\section{Fugloysill'en}

Fugloysill'en dækker et areal på ca. 1,25 km², dens mægtighed varierer fra 15-36 m. Den gennemskærer фen transgressivt med omtrent ret vestlig hældning og et gennemsnitligt fald på ca. $9^{\circ}$ på den sydøstlige del af øen. På sydsiden af фen ses den i havniveau mellem Skoratangi og Nevið̋ Óđa. Herfra stiger den op gennem fjeldvæggen i Grønaskor og ses som en ca. $30 \mathrm{~m}$ tyk, markant bænk over bygden Hattarvík. På den nordøstlige del af фen, mellem Kellingará og Skarðsvík, er der kun blevet iagttaget en enkelt sillblotning, men i den stejle fjeldvæg ud mod Skarðsvík ses dens forl $\varnothing \mathrm{b}$ ned gennem fjeldvæggen, $\varnothing v e r s t$ omtrent lodret og nedad med aftagende hældning mod vest, til den, hvor den når havniveau, forløber omtrent horisontalt og indtager hele strandfladen Landfles. (Fig. 109, 110).

I Grønaskor (ca. $250 \mathrm{~m}$ nord for Krossur) ligger den nedre sillgrænse ca. $120 \mathrm{~m}$ o. h., ved Húsá ca. $80 \mathrm{~m}$ o. h., mellem Húsá og Kellingará $104 \mathrm{~m}$ o. h. og ved Kellingará $110 \mathrm{~m} \mathrm{o.h.} \mathrm{Den} \mathrm{\emptyset vre}$ sillgrænse er i Grønaskor beliggende $156 \mathrm{~m}$ o. h. og ved Húsá 95 m o. h. Ved Húsá (80-95 m) er sillbjergarten en tæt, blå, temmelig finkornet basalt med en karakteristisk vertikalkløvning. Den hængende bænk er her en tæt, blå basalt med spredte zeolitter, den liggende bænk består ligeledes af en tæt, blå basalt, der $\emptyset$ verst er porøs og slagget. 


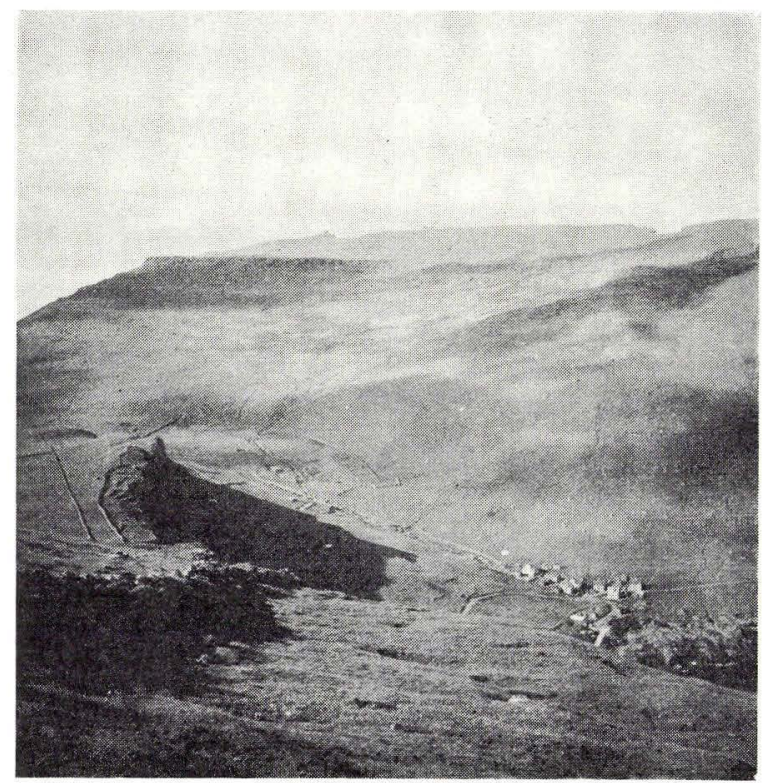

Fig. 109. Fugloysill'en over bygden Hattarvík. Fugloyarsyllin í hamrinum oman fyri Hattarvík. The Fugloy sill above the village of Hattarvik.

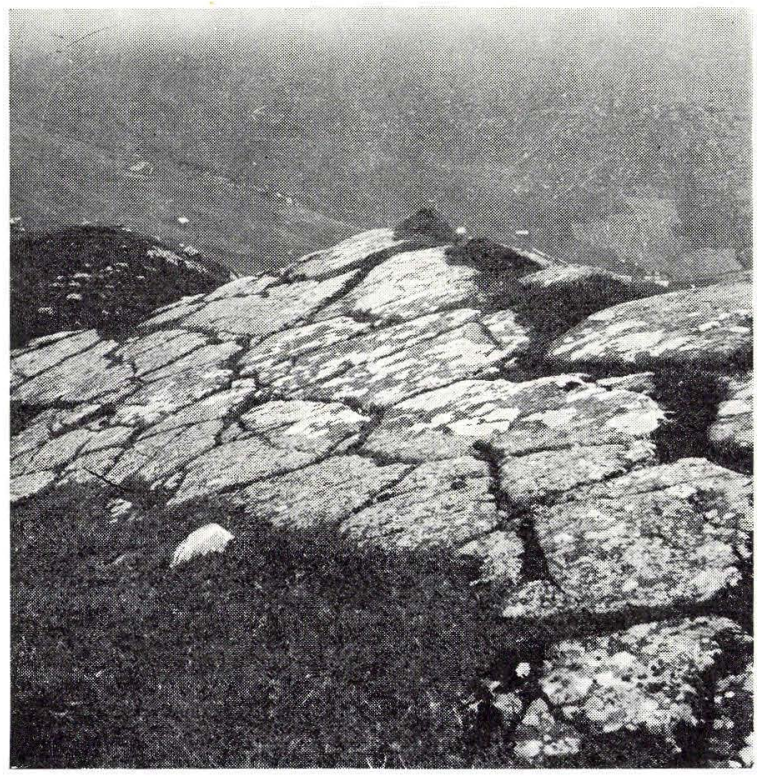

Fig. 110. Fugloysill'en over bygden Hattarvík. (Polygonale basisflader). Fugloyarsyllin i Gullheyggi, Hattarvík.

The Fugloy sill above the village of Hattarvik (polygonal basal sections of joint columns). 


\section{Svínoysill'en}

Svínoysill'en har i lighed med Fugloysill'en ıemmelig ringe udstrækning, den dækker et areal på ca. 1 km² $^{2}$. Ligesom Fugloysill'en er den transgressiv og gennemskærer den nordligste del af $\varnothing$ en med NNV hældning i den $\varnothing$ stligste del og $\mathrm{N}$ og $\mathrm{N} \varnothing$ hældning i den vestligste del. I den stejle kystklint ved Kallanes når sill'en havniveau. Herfra stiger den mod SS $\varnothing$, ca. $300 \mathrm{~m}$ syd for Kallanes ligger dens underkant ca. 75 m o. h. og ca. 700 m syd for Kallanes ca. 92 m o. h. Herefter standser dens videre forløb mod syd og den følger en $\varnothing \mathrm{V}$-gående linje i terrænet til den lille høj »Maður«. Derefter stiger den pludselig i SV retning op i Keldufjall til ca. $460 \mathrm{~m}$, hvorfra den ses at gå ned i den nordlige gjógv i Keldufjall i NNØ retning gennem Norðskor mod Selnes. (Fig. 111, 112).

Silloverfladen er kun blottet på den nordøstlige del af фen. Sill'en går ud i kystklinten ved elven vest for Kallanes, herfra kan dens $\phi$ vre grænse følges som en slynget linje mod syd, vest og derefter mod sydvest op i Keldufjall. Fra ca. $300 \mathrm{~m}$ højde og til toppen af Keldufjall kan såvel den nedre som den $\varnothing$ vre sillkontakt stedvis erkendes; afstanden i terrænet mellem de to kontakter blev i 385 m højde og nær toppen samstemmende målt til ca. $40 \mathrm{~m}$. Særdeles iøjnefaldende er Svínoysill'en i den lodrette fjeldvæg ved Selnes, hvor den kan iagttages som et sort bånd der, idet den gennemskærer basaltbænkene, stiger mod SSV op i Norðskor. Dens nedre grænse er her beliggende ca. $60 \mathrm{~m} \mathrm{o}$. h. og dens mægtighed beløber sig til ca. $30 \mathrm{~m}$, hvilket svarer til mægtigheden på фstsiden af фen.

Bjergarten i Svínoysill'en synes at være identisk med bjergarten i Fugloysill'en og ligesom ved Fugloysill'en finder vi ned mod den nedre kontaktzone en kraftig kløvning af bjergarten i små skarpkantede stykker.

Set under eet er det rimeligt at antage, at der er tale om samme intrusion, således at Fugloysill'en danner den nordøstlige transgressive flanke og Svínoysill'en ved Keldufjall en del af den sydvestlige transgressive flanke af én og samme sill.

\section{Den store Eysturoysill}

Den store Eysturoysill ligger i området mellem Reyðafellstindur, Veðranes, bygden Oyri og Nøvin. Den har en længdeudstrækning på $6,5 \mathrm{~km}$ i S $\emptyset-\mathrm{NV}$ retning, en bredde på knapt 2-3,5 km og optager et areal på ca. $16 \mathrm{~km}^{2}$. Langs kyststrækningen Veðranes - 


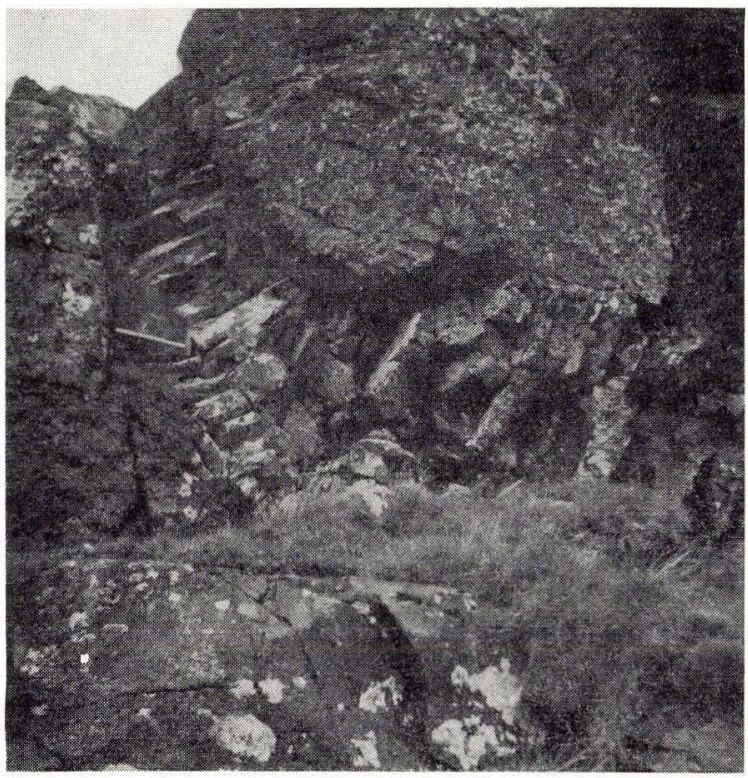

Fig. 111. Svínoysill'ens sydlige begrænsning. Suðurmarkið á Svínoyarsyllini.

Southern boundary of the Svinoy sill.

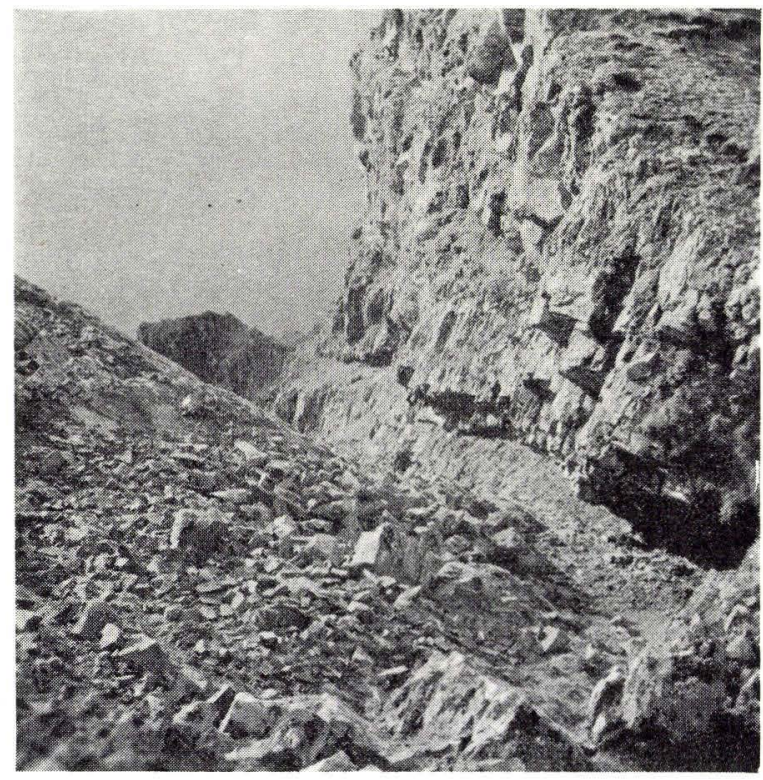

Fig. 112. Svínoysill'en i den nordlige gjógv i Keldufjall. Svínoyarsyllin á Keldufjalli, har hon fer oman í Norðskor. The Svinoy sill in the northern gjógv on Keldufjall. 
Oyri ses dens vestlige afgrænsning som en ubrudt søjledannet bænk, der ligger lavest omkring Breiðá og stiger svagt mod sydøst og nordvest. Den nedre sillgrænse findes langs denne strækning i Veðranes at være $152 \mathrm{~m} \mathrm{o}$. h., vest for Breiðá $80 \mathrm{~m}$, midt mellem Breiðá og det sydlige bøgærde ved Oyri $165 \mathrm{~m}$ og i en elv ved det sydlige bøgærde Oyri ca. 175 m o. h. Området ved Breiðá må derfor betragtes som sill'ens centralområde, herfra stiger den overalt i nordvestlig, nordlig, nordøstlig, фstlig og sydøstlig retning. (Fig. $113,114,115)$.

På sill'ens sydøstlige side kan man umiddelbart iagttage dens transgressive stigning mod $\varnothing$ st. Sillunderkanten, der ved Veðranes ligger $152 \mathrm{~m}$ o. h., er i elven фst for Argisgjógv ca. $170 \mathrm{~m}$, фst for Blásendi ca. $225 \mathrm{~m}$, ved Sandá ca. $305 \mathrm{~m}$ og ved Rókin $332 \mathrm{~m}$ o. h. Herfra stiger den brat op mod Reyðafellstindur, idet den følger en SV-N $\varnothing$ forløbende lodret linje, således at hele den stejle nordvestlige fjeldside samt fjeldtoppen, der som en spids rager op over plateauets basait og når en højde på $766 \mathrm{~m}$, dannes af sill'en, medens den sydvestlige side af fjeldet består af plateaubasalter.

Den samme bratte, transgressive stigning finder vi igen mod nord i området nordvest for Oyrargjógv og langs hele den østlige sillgrænse, således at sill'ens perifere nordlige og $\varnothing$ stlige del stedvis danner en omtrent vertikal, i terrænet ganglignende intrusion af langt ringere mægtighed end den, vi finder ved sill'ens vestlige centrale del.

Hele bunden af den store botn, der fra bygden Oyri går i nord$\emptyset$ stlig retning, udgøres af den blottede silloverflade. Denne ses på begge sider af Oyrargjógv og strækker sig op mod Oyrarskarð, gennemskåret af gjógv'en. Sill'en har her en jævn stigning mod nord og nordøst op til ca. $430 \mathrm{~m}$, hvorefter stigningen tiltager stærkt op mod Oyrarskarð og i nordlig retning op i fjeldet Nøvin. Et par hundrede meter $\emptyset$ st for trig. st. 626 i Nøvin ses en del af den blottede nordlige sillflanke som en nærmest vertikalstillet kulisse ind mod fjeldets plateaubasalt; man kan således her iagttage praktisk talt hele overgangen fra sill'ens nedre fladtliggende del til dens meget nær vertikalt stående nordlige perifere del. Dens mægtighed er her ca. 4 m. (Fig. 116, 117).

Herfra kan den følges brudstykkevis til vestsiden af Nøvin, derefter i SS $\varnothing$ retning, hvor den gennembryder basaltbænkene i ca. $600 \mathrm{~m}$ højde, ned mod mundingen til Oyrargjógv. Langs hele denne strækning fremtræder den i terrænet som en ganglignende 
Fig. 113. Længdesnit gennem Eysturoysill'en. Longdarskurður gjøgnum Eysturoyarsyllina .

Longitudinal section through the Eysturoy sill.

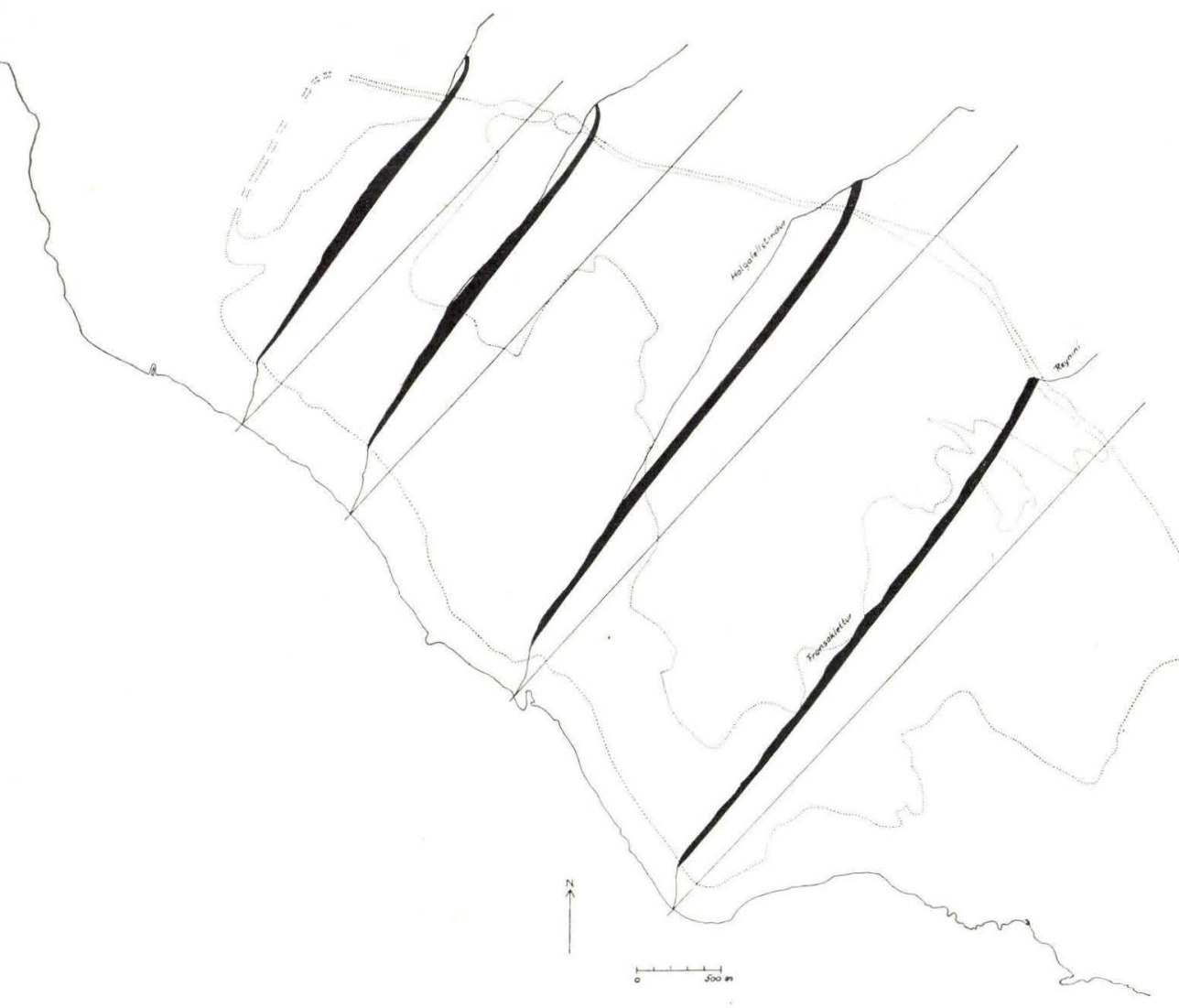

Fig. 114. Tværsnit gennem Eysturoysill'en.

Tv $\phi$ skurðir gjфgnum Eysturoyarsyllina.

Cross sections through the Eysturoy sill. 


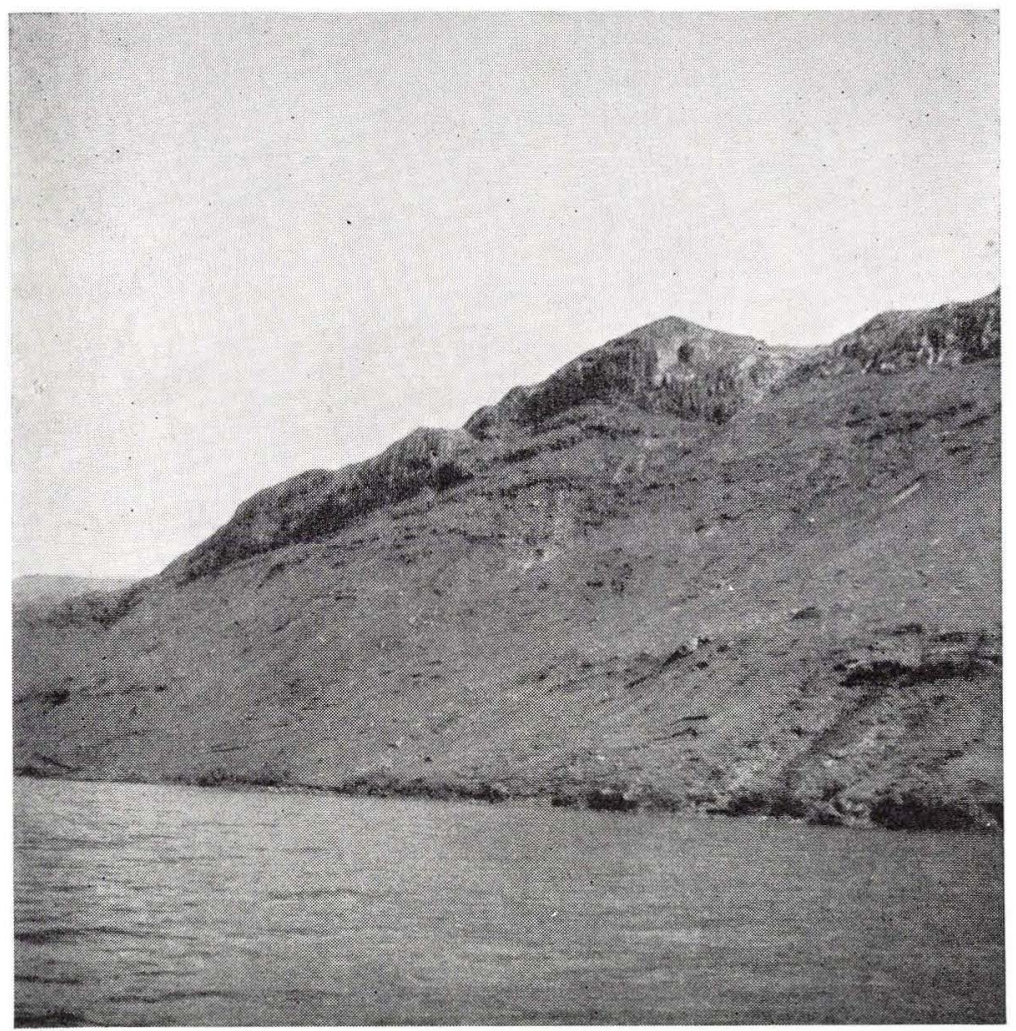

Fig. 115. Eysturoysill'en mellem Veðranes og Oyri.

Eysturoyarsyllin millum Veðranes og Oyri.

The Eysturoy sill between Veðranes and Oyri.

intrusion, varierende fra ca. 4 - ca. 8 m bredde. I området mellem Oyri og Norðskáli er der flere steder i terrænet blevet iagttaget mindre silludløbere på lavere niveau.

Den $\varnothing$ stlige sillafgrænsning kan følges fra Oyrarskarð i nord til Reyðafellstindur i syd. Ved Lágarhálsur, ovenover Skálabotnur danner sill'en en høj, lodret stejlvæg. Fra dette sted går den i SS $\varnothing$ retning op til toppen af Reyðafellstindur. NNV for Lágarhálsur gennembryder sill'en basaltbænkene vest for Halgafellstindur, mægtigheden er ca. $55 \mathrm{~m}$. Underkanten ligger i $510 \mathrm{~m}$ højde og overkanten i $565 \mathrm{~m}$ højde. Herfra stiger den i VNV retning med aftagende mægtighed, mellem Halgafellstindur og Kelduklettur er denne således kun ca. $10 \mathrm{~m}$. Langs Kelduklettur og Sandfelli er 


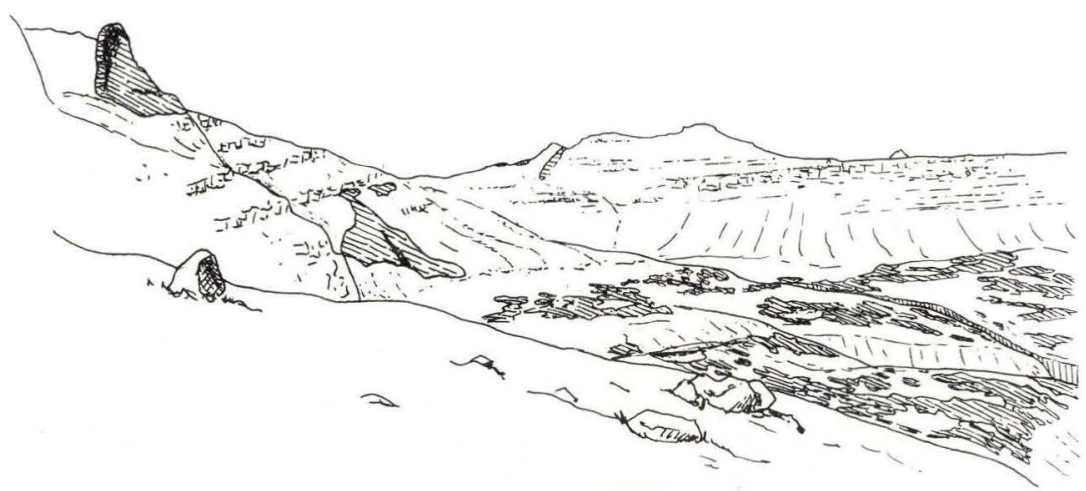

Fig. 116. Eysturoysill'en ved Oyrargjógv. Øverst i billedet (mod nord) ses den blottede sideflanke.

Eysturoyarsyllin við Oyrargjógv. Ovast á myndini sast syllarjaðarin í Nøvini. The Eysturoy sill at Oyrargjógv, viewed from the south. The exposed wall can be seen in the upper part of the figure.

sill'en igen omtrent vertikalstillet. Den har kløvning på tværs med afk $\varnothing$ lingskontakter til begge sider. Den kan på denne strækning kun iagttages stedvis, da den er dækket af løse jordarter. Ved Oyrarskarð er den afbrudt og danner »småøer « i terrænet.

Medens omtrent halvdelen af sill'en er dækket af fjeldrækken Nøvin, Sandfelli, Kelduklettur og Halgafellstindur og disse fjeldes sydvestskråninger, er silloverfladen blottet i hele området mellem Reyðafellstindur, Lágarhálsur og Veđranes og i området Veđranes, Oyrargjógv, Breiðábotnur. Den фvre sillgrænse ses sydvest for Sandfelli $415 \mathrm{~m}$ o. h., ved elven i Breiðábotnur stik syd for Sandfelli $420 \mathrm{~m}$, ved elven i forlængelse af Oyrargjógv i Breiðábotnur $430 \mathrm{~m}$ og i Sølvá $225 \mathrm{~m}$ o. h. Mægtigheden er i det sydlige område ca. $50 \mathrm{~m}$, overfladen er stærkt afslebet af isen og er fattig på vegetation; i det sydlige område er den uregelmæssig og bulet. Den oprindelige overflade af sill'en kan iagttages flere steder, bl. a. ved Fransahús og ved Blásendi, hvor der forekommer kontaktrester på de polygonale søjleender.

I Knubbagil ses en gang på ca. $3 \mathrm{~m}$ bredde (Ey. 82), den findes igen ved Ryssugil (Ey. 83), men ikke i sillområdet mellem Fransahús og Ryssugil og heller ikke i sillområdet længere mod sydøst; den er således afbrudt ved sillintrusionen. Gangen følger en NV-S $\varnothing$ gående lamelzone, der i sit oprindelige anlæg er ældre end gang- 


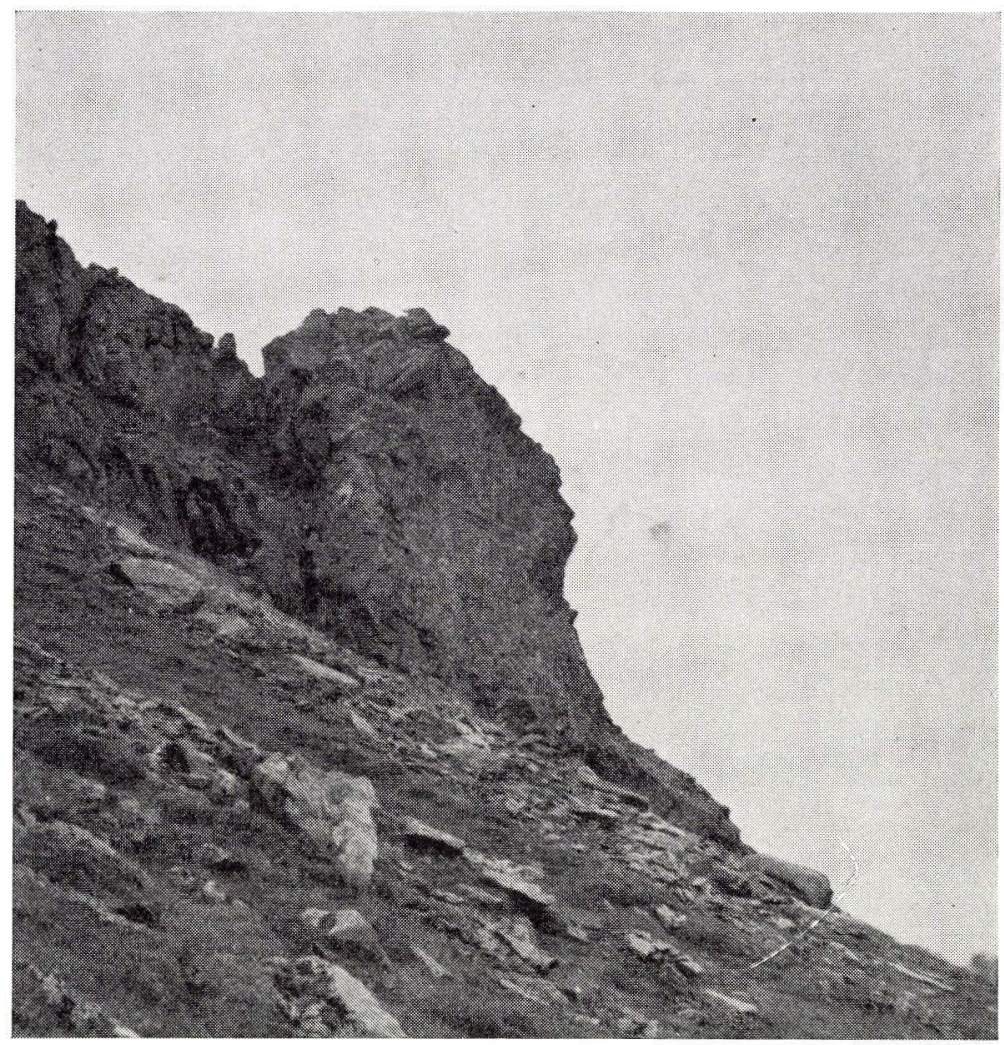

Fig. 117. Sill'ens blottede sideflanke i Nøvin.

Syllarjaðarin í Nøvini norðan fyri Oyrarskarð.

The exposed wall of the Eysturoy sill on Novin.

intrusionen, men som tillige har virket efter denne og forårsaget kløftdannelse med samme retning i sill'en.

Nordvest for Oyrargjógv (ved Oyri) ses en gang, (Ey. 202), der forl $\varnothing$ ber op langs sill'ens nordvestflanke. I ca. $250 \mathrm{~m}$ højde støder den op til og danner kontakt med sill'en. Af kontaktforholdene fremgår det tydeligt, at sill'en er intruderet senere og dermed er yngre end gangen.

\section{Den store Streymoysill}

Den store Streymoysill ligger på vestsiden af Streymoy ud mod Vágafjørður og Vestmannasund. Den hører, ligesom den store Eysturoysill, til de tidligst iagttagne og tidligst beskrevne færøske sills. 
Den strækker sig i NNV-SS $\emptyset$ retning fra fjeldet Sátan i nord til Núgvan i syd, længdeudstrækningen er ca. $9 \mathrm{~km}$ og bredden varierer fra $1-2 \mathrm{~km}$ i nord til $2-3 \mathrm{~km}$ i syd. Den dækker et areal på ca. $13 \mathrm{~km}^{2}$. Ved Skælingsskarð, mellem Sátan og Stórareyn, har erosionen været så dybtgående, at den har adskilt sill'en i en mindre nordlig del Sátan og en større sydligere del Stórareyn Núgvan (fig. 118, 119).

Streymoysill'en og Eysturoysill'en udviser påfaldende morfologiske fællestræk. Ligesom Eysturoysill'en har Streymoysill'en sin h $\varnothing$ jeste beliggenhed i nord og i syd, og ligesom denne er den desuden tiltagende transgressiv mod $\varnothing$ st, hvor den undertiden opnår så stor vestlig hældning, at dens afkølingskontakter er skiftet fra at danne gulv og loft til at danne $\varnothing$ st- og vestside.

Sill'ens vestlige begrænsning følger i store træk den normalt lejrede basaltsuccession fra Kollfjarðargjógv i nord til Reipaskor i syd, bortset fra området ved Gjáarbotnur, hvor der kan iagttages en tydelig opadgående hvælvning. Fra Kollfjarðargjógv og fra Reipaskor er dens forl $\varnothing \mathrm{b}$ derimod stærkt transgressivt, henholdsvis mod nord og mod syd.

Sillunderkantens beliggenhed er således:

Langs vestsiden. Kollfjarðargjógv 302 m, sydøsthjørnet af Sátan $227 \mathrm{~m}$, vestsiden af Skælingur $193 \mathrm{~m}$, sydsiden af Gjáarbotnur 242 m, Reipaskor 170 m (korthøjde) og Dalsnípa 315 m.

Langs midtlinjen. Sátan i nord $480 \mathrm{~m}$, Sátan i syd 337 m, Kálvadalsá $198 \mathrm{~m}$, nordsiden af Gjáarbotnur $302 \mathrm{~m}$, sydsiden af Gjáarbotnur 288 m og Áarstíggjafossur $218 \mathrm{~m}$.

Langs $\varnothing$ stsiden. Nord for Klettsgjógv $514 \mathrm{~m}$, syd for Skælingsskarð $310 \mathrm{~m}$, østsiden af Stórareyn $370 \mathrm{~m}$, vest for Trantur 375 m, Hundsarabotnur 400 m, Stallur 580 m, Bláhamar 430 m, Mjørkadalur $390 \mathrm{~m}$, sydsiden af Mjørkadalur $445 \mathrm{~m}$, nord for Núgvan $562 \mathrm{~m}$ og Núgvan $630 \mathrm{~m}$.

Den stigende transgressivitet mod nord, syd og øst er således påfaldende, bortset fra lokale variationer.

I Sátan er sill'en blottet fra Kollfjarðargjógv og nordpå til området vest for Navagjógv. Desuden består hele den nordligste del af fjeldet, Navirnar, af sill'en. Den oprindelige, fint opkløvede silloverflade kan hyppigt iagttages. Den antager ofte form efter den hængende bænks underflade og indeholder tillige brudstykker af denne. Fra Kollfjarđargjógv og sydpå er sill'en delvis skjult under løse jordlag. 
Mod syd ses den i lodret snit i den stejle fjeldvæg, jæunt stigende mod $\varnothing$ st til Klettsgjógv, hvorefter den $\emptyset$ st for Klettsgjógv pludseligt stiger således, at den mod фst danner en stejl søjlebænk med en sydvestlig hældning på ca. $15^{\circ}$. Vest for Klettsgjógv går en apofyse fra sill'en nedad, den bøjer af mod vest og gennemskærer de liggende basaltbænke. Den er ca. $2 \mathrm{~m}$ bred og har et let bugtet, uregelmæssigt forløb. Sillmægtigheden, der på vestsiden af Sátan er 30-40 m (ved Kollfjarðargjógv), er ved Navagjógv i nord ca. $20 \mathrm{~m}$, midt i stejlvæggen på sydsiden ca. $20 \mathrm{~m}$ og på фstsiden (nord for Klettsgjógv) ligeledes ca. $20 \mathrm{~m}$ (fig. 120).

Syd for Skælingsskarð er store dele af sill'en blottet ved Stórareyn, i Gjáarbotnur og på nordvestsiden af fjeldet Núgvan. Langs vestsiden af Skælingur og fjeldene syd for Gjáarbotnur kan sill'ens forl $\varnothing b$ derimod kun iagttages i en utilgængelig, stejl fjeldvæg.

Ved Stórareyn er silloverfladen kuperet og danner nøgne stenhøje med små vegetationspletter eller småsøer i lavningerne mellem de enkelte høje eller knolde. Overfladen er tydelig isafhøvlet og viser stødsider mod $\varnothing$ st og læsider mod vest. Op mod Trantur er terrænet vegetations- og grusdækket, så den $\emptyset$ vre sillkontakt ikke direkte kan iagttages.

Hele den $\emptyset$ verste del af Gjáarbotnur samt dennes sydside udgøres ligesom Stórareyn af den blottede sill. På nordsiden af Gjáarbotnur ligger den nedre sillgrænse $302 \mathrm{~m}$ og den $\emptyset$ vre $348 \mathrm{~m}$ o. h. På sydsiden findes den nedre sillgrænse $288 \mathrm{~m}$ og den $\varnothing v r e$ $340 \mathrm{~m} \mathrm{o.} \mathrm{h.} \mathrm{Mægtigheden} \mathrm{må} \mathrm{således} \mathrm{her} \mathrm{beløbe} \mathrm{sig} \mathrm{til} \mathrm{ca.} 50 \mathrm{~m}$. I lighed med området ved Stórareyn er silloverfladen kuperet og nøgen, dog med lidt vegetation i lavninger og mellem søjleenderne. På den oprindelige silloverflade ses hyppigt kontaktrester og rester af den hængende bænk. Skurestriber kan stedvis iagttages. Gennem Skælingsskor kan sill'en følges sydpå til Dosshellugjógv. Den løber her midt gennem stejlvæggen og fremtræder med skarpt afgrænsede lodretstående søjler. (Fig. 121).

Langs linjen Reipaskor (ca. 170 m) i vest, til elven midt i Mjørkadalur (ca. $360 \mathrm{~m}$ ) i $\emptyset$ st, har sill'en nået sin laveste beliggenhed. Herfra er den stærkt transgressivt stigende mod sydøst, således at dens underkant ved Dalsnípa er beliggende i 315 m højde, ved Áarstíggjafossur $218 \mathrm{~m}$ og i sydøsthjørnet af Núgvan i $630 \mathrm{~m}$ højde. Den nøgne silloverflade dækker hele Núgvans lodrette, nordvestlige fjeldside. I den $\emptyset$ vrige del af dalen Omanfyri Stígar er ter- 


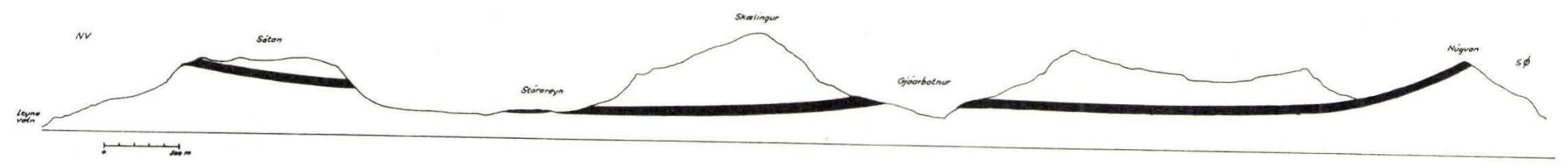

Fig. 118. Længdesnit gennem Streymoysill'en.

Longdarskurður giøgnum Streymoyarsyllina.

Longitudinal section trough the Streymoy sill. 


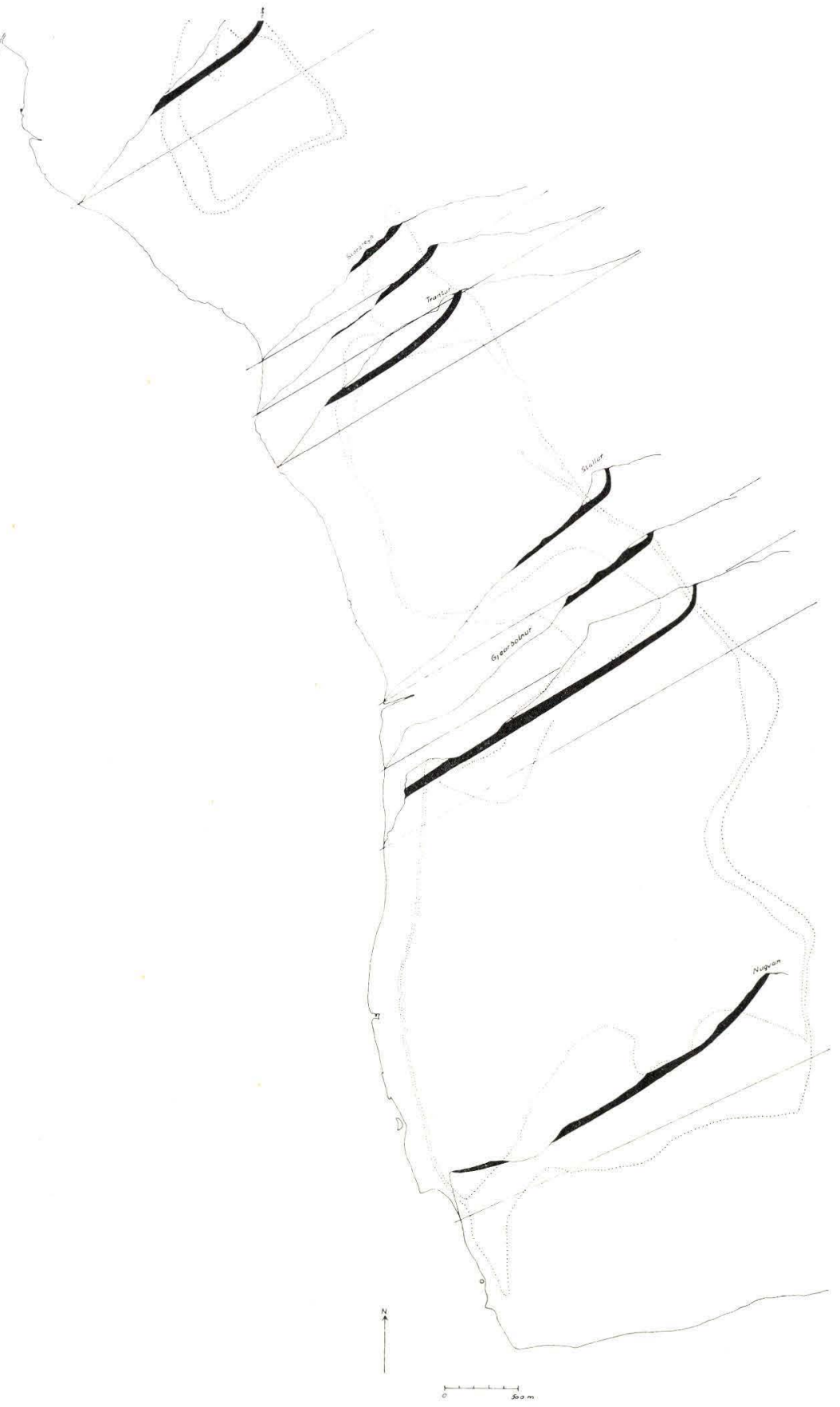

Fig. 119. Tværsnit gennem Streymoysill'en.

Tvфrskurđir gjøgnum Streymoyarsyllina.

Cross sections through the Streymoy sill. 


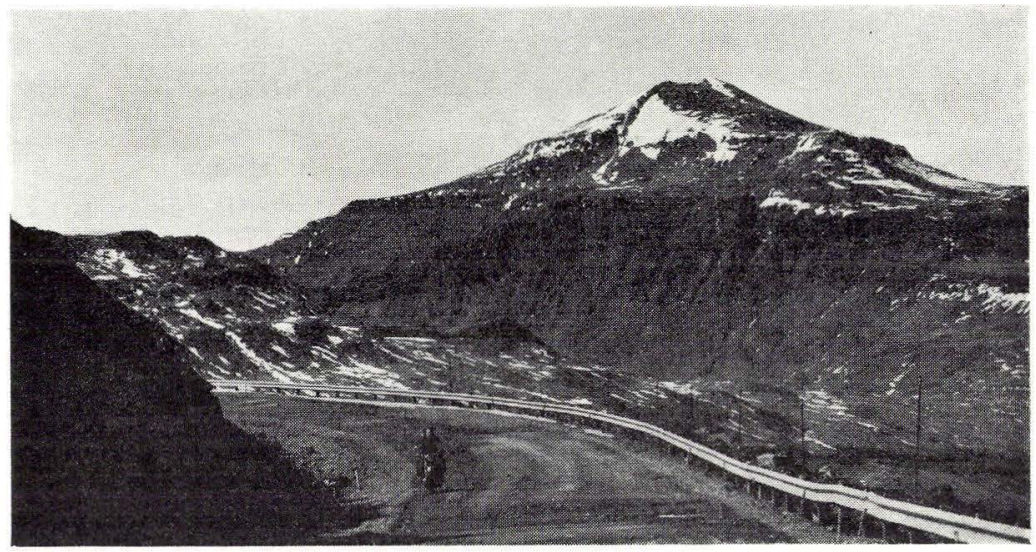

Fig. 120. Streymoysill'en i sydsiden af Sátan.

Streymoyarsyllin sunnantil í Sátuni.

The Streymoy sill on the south side of Sátan.

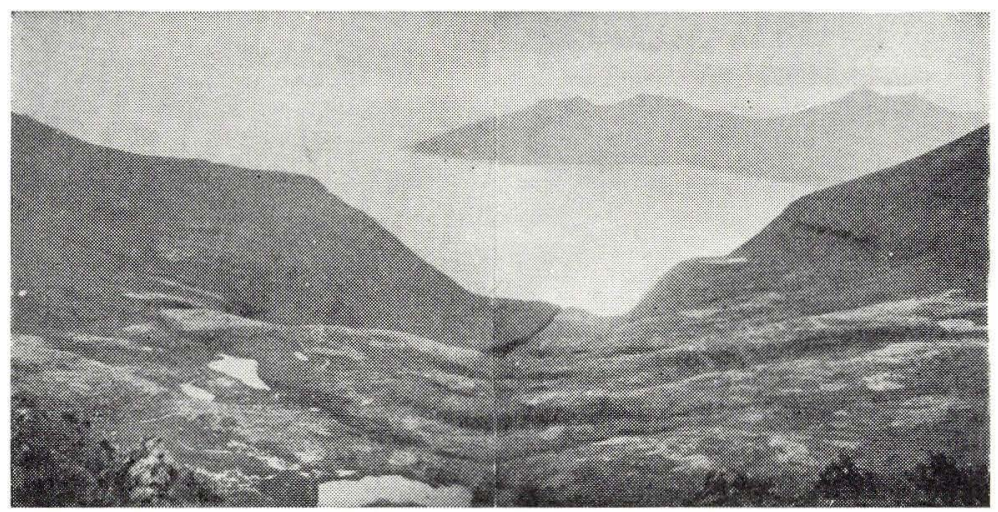

Fig. 121. Blottet sill i Gjáarbotnur, Streymoy.

Streymoyarsyllin í Gjáarbotni.

The Streymoy sill in Gjáarbotnur.

rænet jorddækket og vegetationsklædt, den $\varnothing$ vre sillgrænse kan derfor kun stedvis direkte erkendes ned langs vandl $\varnothing$ bet til de små søer i dalen. I denne er ingen iagttagelse mulig. (Fig. 122).

I nordspidsen af Stórareyn har sill'en en vestlig hældning på ca. $30^{\circ}$. Herfra kan dens $\varnothing$ stlige begrænsning følges mod sydøst til Bláhamar og derefter videre mod syd til Núgvan. Sin ringeste mægtighed når sill'en ved Hundsarabotnur, hvor den på en kortere stræk- 
ning kun er 5-7 m. Fra Stígaskarð går en stor apofyse ovenover sill'en op i nordvestlig retning samt et par mindre, bugtede apofyser ned mod Hundsarabotnur. Fra Stígaskarð stiger den brat op i Stallur og gennemskærer fjeldet; forløbet er i Stallur omtrent vertikalt, idet sill'en har en sydvestlig hældning på ca. $75^{\circ}$. Underkanten er her beliggende i $580 \mathrm{~m}$ højde, og mægtigheden beløber sig til ca. $15 \mathrm{~m}$. Fra Stallur fortsætter den med omtrent samme mægtighed, 15-20 m til Bláhamar. Den sydvestlige hældning er her så stor, at sill'en i terrænet nærmest har karakter af en gang med fint forkløftede kontaktzoner til begge sider. Ved Bláhamar tiltager mægtigheden samtidig med, at den vestlige hældning igen aftager. Omtrent hele den $\emptyset$ verste halvdel af den lodrette fjeldvæg Bláhamar består af høje, næsten vertikale søjler. Fra Mjørkadalur stiger sill'en derefter pludseligt, som foran nævnt, op i Núgvan. (Fig. 123, 124).

I Sátan ses en gang (Str. 217). Den løber i omtrent NV-S $\varnothing$ retning og kan følges over fjeldet henimod Navagjógv. I den sydlige, lodrette sillvæg vest for Klettsgjógv ses den at være gennembrudt af sill'en, og den er således ældre end denne. Gangen i Navagjógv (Str. 209) ses også at være afbrudt af sill'en. Det samme er tilfældet med gangen i Ravnagjógv (Str. 216). Denne kan følges op imod sill'en i en omtrent NV-S $\varnothing$ retning, men ses ikke inde over sillområdet, der dog er stærkt forkløftet i gangretningen. Over sill'en op mod Trantur ses gangen igen (Str. 215). Også denne gang er ældre end sill'en. I Gjáarbotnur løber en gang i omtrent $\emptyset N \varnothing$ retning op mod sill'en; den viser termal kontakt ud mod sidestenen under sill'en, men løber jævnt, uden nogen overgang, over i selve sill'en. Den kan ikke ses ovenover sill'en. Den må derfor være tilførende til denne. (Fig. 125, 126).

I Kollfjarðargjógv ses ligeledes en gang, der løber op mod sill'en i omtrent $\emptyset$ stlig retning. Den kan ikke iagttages inde i sillområdet og heller ikke længere oppe. En nærmere relation til sill'en kan imidlertid ikke sikkert erkendes, da krydsningsområdet er ras- og vegetationsdækket.

\section{Andre sills}

Sill'en i Hægstafjall, vest for Vestmanna, har kun ringe udstrækning og mægtighed. Den er kun ca. $500 \mathrm{~m}$ lang og ca. $4 \mathrm{~m}$ tyk. Mod nord er dens nedre grænse beliggende i $280 \mathrm{~m}$ og $\varnothing$ vre i $284 \mathrm{~m}$ højde, i sydvesthjørnet henholdsvis $254 \mathrm{~m}$ og $258 \mathrm{~m}$ og i sydøsthjørnet $272 \mathrm{~m}$ og $276 \mathrm{~m} \mathrm{o}$. h. 


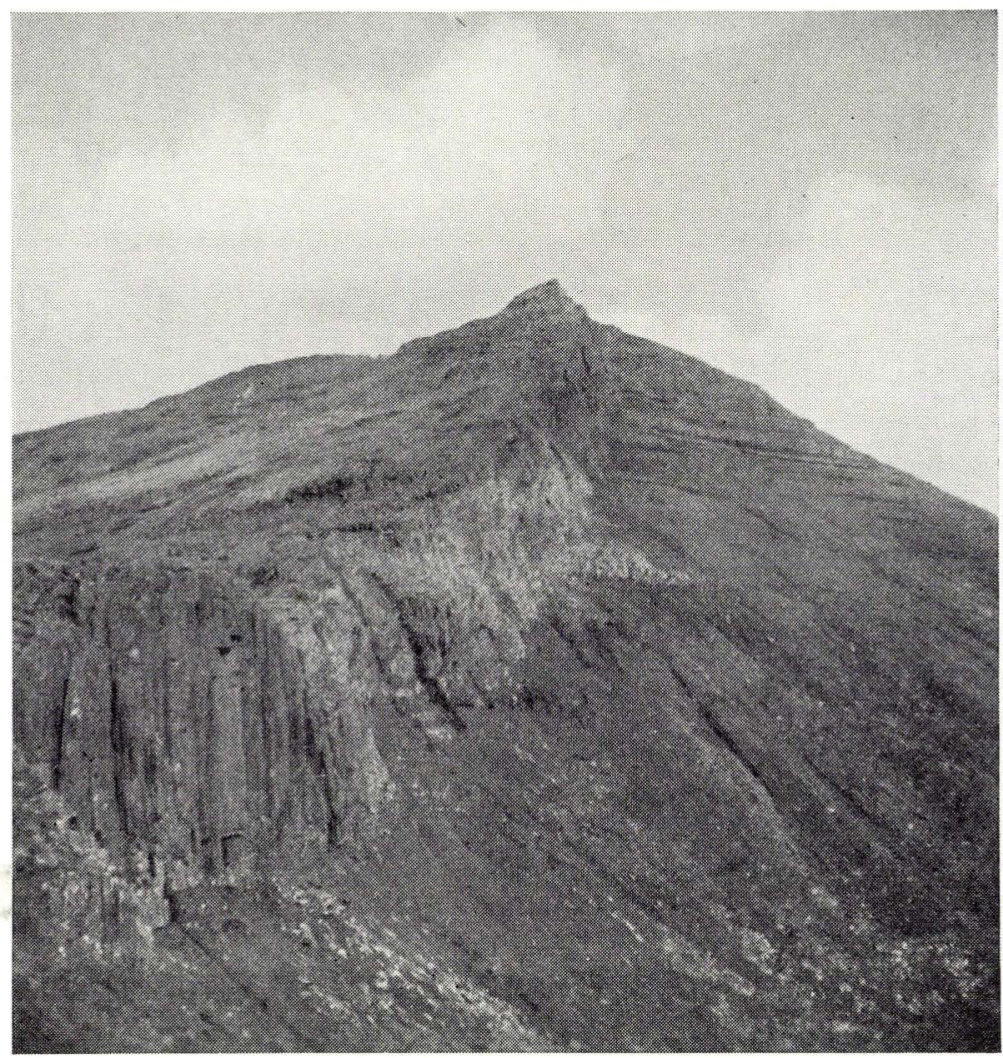

Fig. 122. Streymoysill'en i Núgvan.

Streymoyarsyllin í Núgvuni.

The Streymoy sill on Núgvan.

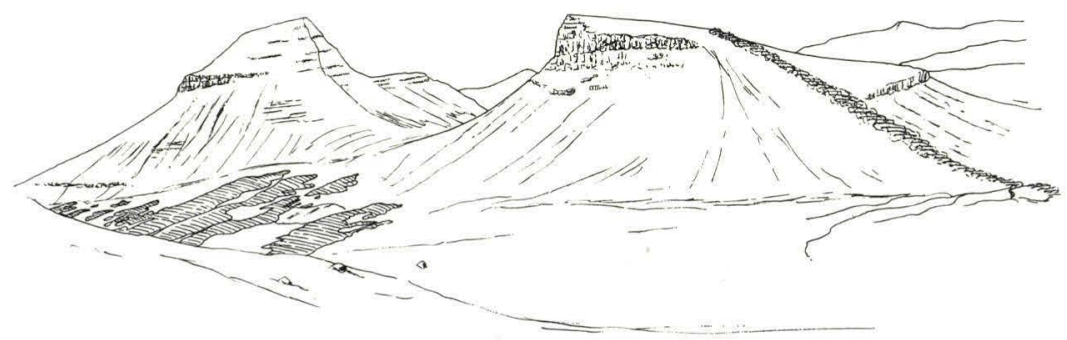

Fig. 123. Streymoysill'en i Gjáarbotnur og Stallur set mod nord.

Streymoyarsyllin i Gjáarbotni og Stalli scedd norðureftir.

The Streymoy sill in Gjáarbotnur and on Stallur looking north. 


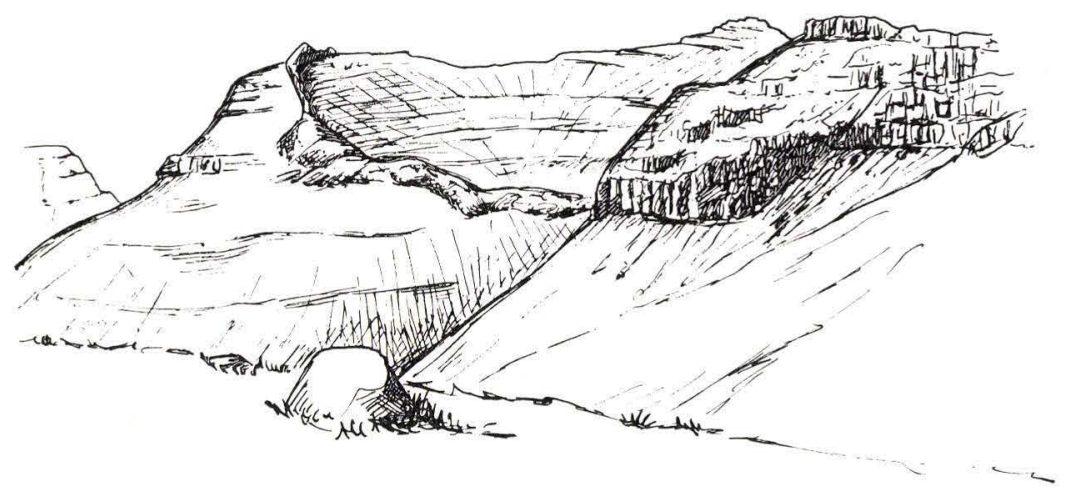

Fig. 124. Streymoysill'en Bláhamar - Núgvan.

Streymoyarsyllin Bláhamar - Núgvan.

The Streymoy sill, Bláhamar - Núgvan.

Mellem Kvívík og Vestmanna ses spredt i terrænet rester af intrusivt materiale, som ved nærmere eftersyn viser sig at hidrøre fra en sill-lignende intrusion med et ret uregelmæssigt forl $\emptyset \mathrm{b}$. Det intruderede område strækker sig over ca. $11 \mathrm{~km}^{2}$. Mest iøjnefaldende er sill'en langs $\varnothing$ stsiden af Gásafelli og ved Bornsvarði. Den nedre grænse ligger syd for Gásafelli i $314 \mathrm{~m}$ højde og nord for Gásafelli i $400 \mathrm{~m}$ højde. Mellem Bornsvarði, Egilsfjall og Gásafelli og nede i dalen mellem Egilsfjall og Gásafelli ses spredte intrusionsrester, som på grund af den dybtgående erosion nu er uden nærmere forbindelse med hinanden. Fra Bornsvarði kan denne sill følges vestpå ned gennem Hvannadalur, sydpå langs $\emptyset$ kslin ind i Gassádalur til Høgareyn og derefter igen фstpå til Kvívík. Ved Bornsvarði ligger sill'en i ca. $400 \mathrm{~m}$ højde, den går nedad mod vest. Nord for $\varnothing \mathrm{kslin}$ (ved stien) ses den i $250 \mathrm{~m}$ højde. Mægtigheden i Hvannadalur er kun 2-4 m. Inde i Gassádalur, sydpå langs Høgareyn og igen фstpå til Kvívík ses den kun stedvis. I Gassá ses den i ca. 180 m, på vestsiden af Høgareyn i ca. 220 m og ved Breiðá i ca. $190 \mathrm{~m}$ højde. Mægtigheden er kun 1-2 m langs denne strækning. I Víkará, der løber gennem bygden Kvívík, ses den nedre sillkontakt $139 \mathrm{~m}$ o. h. og den фvre $146 \mathrm{~m}$ o. h.

Fra Hórisgøta, på sydsiden af Kollafjørður og østpå til området $\emptyset$ st for Bláfossur forløber en lille sillintrusion; den er ca. $800 \mathrm{~m}$ lang og 10-20 m tyk. Apofyser ses både vest for, øst for og over hovedintrusionen. 


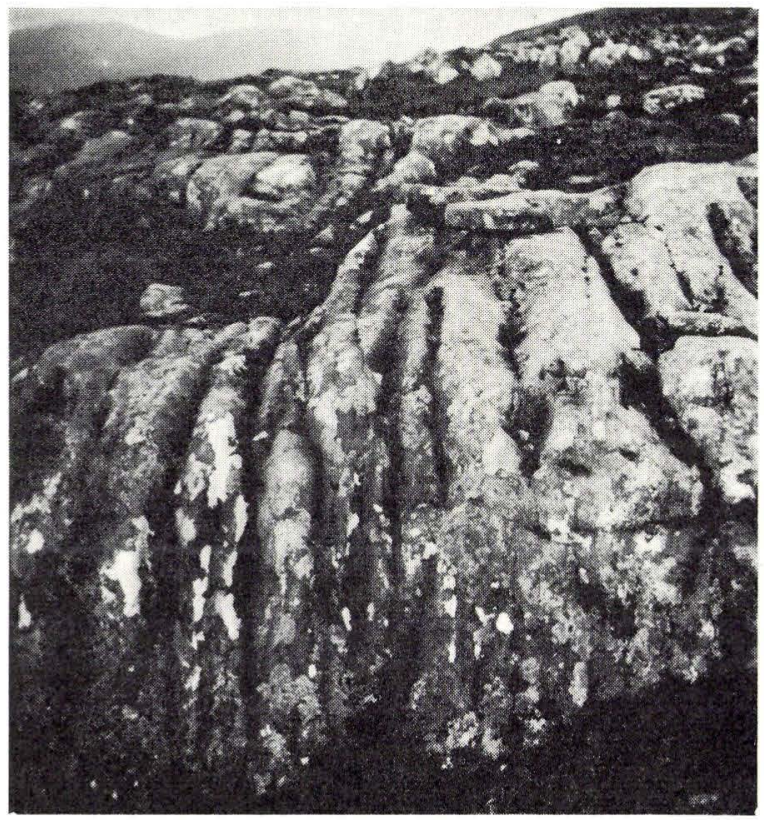

Fig. 125. Forkløftning i sill i gangretningen (Str. 216, 215).

Rivur í Streymoyarsyllini sama veg sum gongin (Str. 216, 215).

Jointing on sill surface parallel to the dyke direction. (Str. 216, 215).

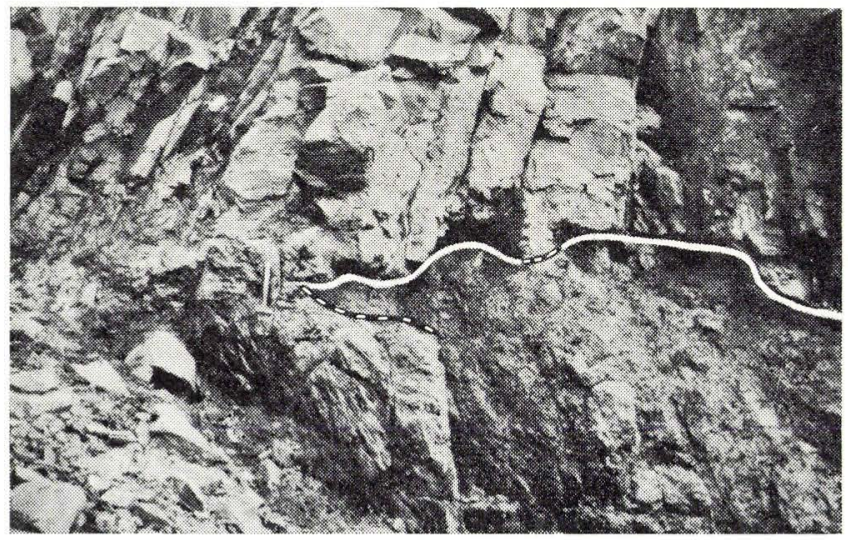

Fig. 126. Overgang mellem gang (forneden) og sill (foroven) i gjógv'en i Gjáarbotnur. Nederst til højre i billedet sidesten.

Mótið millum gong og syll í Gjáarbotni. Syll ovari á myndini. Gong niðari vinstrumegin, reguligar basaltfláir niðari á myndini høgrumegin.

Transition between dyke (below) and sill (above) in the gjógv in Gjáarbotnur. Country rock in the lower right part of the figure. 
Ved Morskranes kan en sill iagttages fra Kveistrastórá nord for Morskranes (ca. $40 \mathrm{~m} \mathrm{o.h.),} \mathrm{sydpå} \mathrm{til} \mathrm{Melheyggjur,} \mathrm{derefter} \mathrm{mod}$ $\emptyset$ st og nord, hvor den fortaber sig. Ved Melheyggjur ligger dens nedre grænse i $170 \mathrm{~m}$ og den $\emptyset$ vre i $184 \mathrm{~m}$ højde. Sill'en kan følges langs en strækning på ca. $4,5 \mathrm{~km}$.

Side 307 blev der gjort rede for, at sill'en på Fugloy og sill'en på Svínoy måtte opfattes som to partier af et og samme legeme, dette bekræftes af den petrografiske unders $\varnothing$ gelse.

Hovedbjergarten er temmelig grovkornet, texturen er ofitisk. Clinopyroxenen er mørk sandfarvet og viser ingen pleochroisme, en del individer er omtrent automorfe og omslutter næsten helt den listeformede plagioklas. $\mathrm{C} \wedge \mathrm{p}$ varierer fra $37^{\circ}-43^{\circ}, 2 \vee_{\mathrm{p}}$ fra $53^{\circ}-57^{\circ}$. Plagioklasen indeholder i gennemsnit $70 \%$ an, men varierer meget. Bjergarten indeholder en del farvel $\varnothing$ s olivin med $2 \mathrm{~V}$ nær $90^{\circ}$, den kan være næsten frisk eller noget serpentiniseret langs de buede gennemgange. Der findes en del temmelig store malmkorn, som har veludviklede krystalomrids, de kan danne sammenvoksninger med plagioklasen. Der er brun, interstitial glas til stede, lokalt findes pletter og strenge af grønne omdannelsesprodukter.

Nær kontakterne er bjergarten finkornet og indeholder små strøkorn af clinopyroxen og plagioklas samt pseudomorfoser efter olivin; malm forekommer her kun som små gryn i grundmassen, og der kan lokalt optræde et brunligt pigment af jernoxyder.

Mineralsammensætningen, målt på en prøve fra Fugloy, er: $\mathrm{pl}=$ $40,6 \%$, cpx $=32,0 \%$, ol $=11,4 \%(\mathrm{ol}=10,4 \%$, serp. $\mathrm{i}$ $\mathrm{ol}=1 \%)$, malm $=7,5 \%$, glas og grønne omdannelsesprodukter $=8,5 \%$. Bjergarten er olivintholeiitisk, en kemisk analyse findes i tabellen side 325 .

Hovedbjergarten i Eysturoysill'en er temmelig grovkornet, texturen er doleritisk. Clinopyroxenen er lys sandfarvet, den har udbredt tvillingdannelse efter (100), med såvel simple som multiple tvillinger. Plagioklasen er labrador, sammensætningen varierer fra 52-60 \% an i kernen, i zonare individer kan yderzonen gå ned til $45 \%$ an. Malmkornene er temmelig store. Bjergarten indeholder en del brunlig glas, nogle sekundære grønne omdannelsesprodukter, samt en mikrogranitisk interstitialmasse. To punkttællinger er foretaget med følgende resultat: 


$\begin{array}{lccccc} & \text { pl } & \text { cpx } & \text { ore } & \text { mikrogranit } & \text { glas + gap } \\ \text { Reyðafellstindur } & 44,4 \% & 40,9 \% & 6,1 \% & 2,6 \% & 6 \% \\ \text { Selatrað } & 40,1 \% & 27,5 \% & 8,5 \% & 0,6 \% & 23,3 \%\end{array}$

I apofyser er bjergarten finkornet og indeholder strøkorn af plagioklas, som enten ligger enkeltvis eller i småklumper, samt enkelte clinopyroxener.

En kemisk analyse af en prøve taget ved Lágarhálsur på Eysturoy findes i tabellen side 325 .

Som omtalt side 313 hører den store Streymoysill til de først iagttagne og tidligst omtalte i litteraturen.

Dens hovedområde omfatter Núgvan, Skælingur og Sátan, men der kan næppe være tvivl om, at erosionsresterne længere mod nord, helt op til den lille, isoleret forekommende sill-stump, der ligger nordfor Vestmanna tilhører samme intrusion og må være udløbere eller apofyser fra den.

Sill-bjergarten er først petrografisk beskrevet af SiMPSON (1928) fra Skælingur, senere har WALKER og DAVIDSON (1936) givet en nærmere omtale af prøver fra Núgvan. Disse forfattere tog prøver fra henholdsvis $2,5,7,13,26$ og $40 \mathrm{~m}$ over basis og fandt, at der ikke var nogen bjergartsmæssig variation at spore op gennem sill'en. Nær den nedre kontakt er bjergarten tæt og indeholder små, ca. $1 \mathrm{~mm}$ lange strøkorn af plagioklas (labrador), under mikroskop kan der yderligere skelnes små, knappenålshovedlignende korn af clinopyroxen og af sort malm; undtagelsesvis findes enkelte strøkorn af clinopyroxen.

Hovedbjergarten er en olivinførende dolerit. Feldspatkornene kan blive 3-4 mm lange, de er labradoritiske af sammensætning, og de st $\varnothing$ rste har strøkornskarakter; nu og da er anorthitindholdet i yderzonen lavere end i de omgivende, mindre grundmasseplagioklaser, der varierer fra medium til sur labrador, lokalt med en yders $\varnothing \mathrm{m}$ af andesin. Clinopyroxenen viser aldrig egne krystalbegrænsninger og er uregelmæssigt omgivet af feldspatlister, habitus er bred. Farven er bleg brunlig, eller mineralet er så godt som helt farveløst, ikke pleokroitisk og med $\mathrm{C} \wedge \gamma=44^{\circ}$. Der er lidt olivin til stede, mineralet danner afrundede eller uregelmæssige individer, som $\mathrm{i}$ en vis udstrækning er pseudomorfoseret af gr $\varnothing$ n serpentin, individerne er små, for det meste mindre end 0,2 mm lange. Olivinkornene træffes i regelen sammen med clinopyroxenen, undertiden er de indesluttet i den. Nogle få malmkorn, udvisende skeletvækst, udgør re- 
sten af mineralselskabet. Bjergarten indeholder en mindre mængde brun glas, som lokalt kan være belagt med eller fortrængt af grønlige omdannelsesprodukter.

Mineralindholdet er målt på en prøve fra $26 \mathrm{~m}$ over basis med følgende resultat: $\mathrm{pl}=57,3 \%, \mathrm{cpx}=28,7 \%$, ol (inkl. serpentin) $=6,2 \%$, malm $=3,6 \%$ og glas $=4,2 \%$.

En analyse findes i tabellen.

Kemiske analyser af sills

\begin{tabular}{|c|c|c|c|}
\hline \multicolumn{4}{|c|}{ Kemiske analyser af sills } \\
\hline & 1. & 2. & 3. \\
\hline $\mathrm{SiO}_{2}$ & 48,35 & 48,95 & 49,17 \\
\hline $\mathrm{Al}_{2} \mathrm{O}_{3}$ & 13,18 & 12,38 & 16,87 \\
\hline $\mathrm{Fe}_{2} \mathrm{O}_{3}$ & 2,28 & 5,35 & 3,61 \\
\hline $\mathrm{FeO}$ & 10,62 & 9,80 & 6,14 \\
\hline $\mathrm{MnO}$ & 0,11 & 0,23 & 0,15 \\
\hline $\mathrm{MgO}$ & 7,09 & 5,75 & 6,39 \\
\hline $\mathrm{CaO}$ & 11,50 & 11,00 & 12,93 \\
\hline $\mathrm{Na}_{2} \mathrm{O}$ & 2,65 & 2,62 & 2,20 \\
\hline $\mathrm{K}_{2} \mathrm{O}$ & 0,48 & 0,42 & 0,31 \\
\hline $\mathrm{TiO}_{2}$ & 2,01 & 1,91 & 0,80 \\
\hline $\mathrm{P}_{2} \mathrm{O}_{5}$ & 0,22 & 0,20 & 0,13 \\
\hline $\mathrm{H}_{2} \mathrm{O}$ & 0,80 & 0,86 & 0,68 \\
\hline & 99,29 & 99,47 & 99,38 \\
\hline
\end{tabular}

Katanorm

\begin{tabular}{lrrr} 
q & \multicolumn{1}{c}{0} & 2,51 & 1,02 \\
or & 2,92 & 2,59 & 1,87 \\
ab & 24,49 & 24,53 & 20,16 \\
an & 23,31 & 21,67 & 35,97 \\
ap & 0,47 & 0,44 & 0,28 \\
en & 4,82 & 7,97 & 9,50 \\
fs & 3,01 & 4,60 & 3,29 \\
di & 27,14 & 27,11 & 22,91 \\
fo & 5,23 & 0 & 0 \\
fa & 3,27 & 0 & 0 \\
mt & 2,45 & 5,81 & 3,85 \\
hm & 0 & 0 & 0 \\
il & 2,88 & 2,77 & 1,14
\end{tabular}

1. Svínoy-Fugloysill'en, Svínoy. Olivintholeiit. Anal. Ib Sørensen.

2. Eysturoysill'en, Lágarhálsur. Kvartstholeiit. Anal. Ib Sørensen.

3. Streymoysill'en, Kollafjørður. Kvartstholeiit. Anal. Ib Sørensen. 


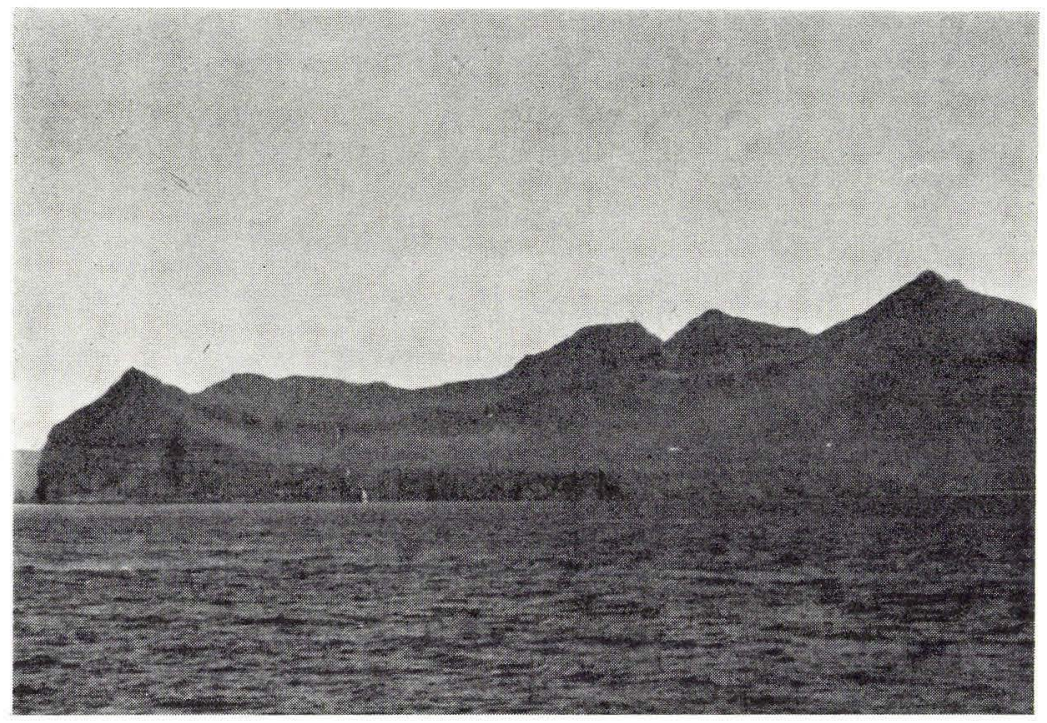

Fig. 127. Streymoysill'en mellem Dalsnípa og Núgvan, der viser stigende transgressivitet såvel mod sydøst som mod sydvest.

Streymoyarsyllin millum Dalsnípuna og Núgvuna. Syllin sker seg upp gjøgnum tar regluligu fláirnar bæoi i landsynning og í útsynning.

The Streymoy sill between Dalsnipa and Núgvan showing increasing degree of discordance to the country rocks towards south-east and south-west.

\section{Intrusionsmekanik}

Som foran nævnt er det et fællestræk ved alle de større fær$\emptyset$ ske sills, Streymoysill'en, Eysturoysill'en og Fugloy-Svínoysill'en, at de er transgressive og danner skålformede legemer, hvoraf den vestlige skålhalvdel mangler. Både Streymoysill'en og Eysturoysill'en viser tiltagende transgressivitet mod nord, syd og фst. Da vi imidlertid for den sydlige del af Streymoysill'ens vedkommende også finder stigende transgressivitet mod sydvest fra linjen Reipaskor (170 m o. h.) - Áarstíggjafossur (218 m o. h.) til Dalsnípa (315 m o. h.), er det sandsynligt, at en oprindelig vestlig skålhalvdel har eksisteret, men er blevet fjernet ved den senere fjorddannelse (fig. 127).

Af de (s. 312, 319) omtalte krydsninger mellem sills og gange fremgik, at de beskrevne sills i alle iagttagne tilfælde er yngre end gangene. I enkelte tilfælde er der iagttaget gange, som standser ved sillunderkanten og ikke ses ovenover sill'en. I ét sådant tilfælde, i 

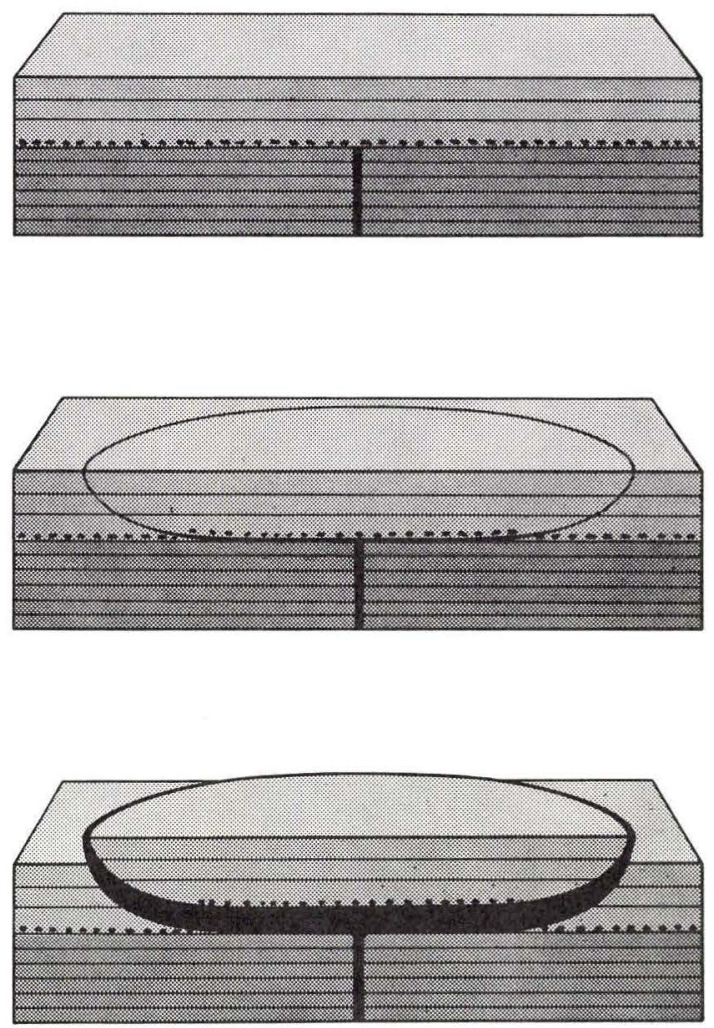

Fig. 128. Skematisk tegning af sillintrusionsforløbet. Fyrimyndartekning av syllarinnskoti.

Schematic drawing of the mechanism of sill intrusion.

Gjáarbotnur (Str. 224), var selve kontaktområdet blottet og her fandtes der jævn overgang mellem gang og sill, så det må antages, at de er blevet samtidig intruderet, og at gangen har været tilførende til sill'en (fig. 126).

Af de under de uregelmæssige intrusive dannelser omtalte intrusionsforhold vedrørende Hamranes-Hvítanes gangen (Su. 2) og Akranesgangen (Vá. 30, 31) blev det ligeledes nævnt, at kontaktforholdene var af en sådan art, at det måtte anses for sandsynligt, at intrusionen af basalterne i kysten og gangen var samtidig.

Vi må ud fra dette slutte, at såvel gange som sills og uregelmæssige intrusive dannelser stort set tilhører samme eruptionsfase. 
De svaghedszoner, som er blevet gennemtrængt ved intrusionen, er for gangenes vedkommende lodrette eller svagt hældende lamelzoner, for de uregelmæssige intrusivers vedkommende tuf-agglomeratzonen og den kulførende serie og for sill'enes vedkommende grænseområdet mellem den mellemste og den фverste basaltserie. Mindre sills på noget lavere niveau (f. eks. Vestmannasill'en og Morskranessill'en) er sandsynligvis apofyser fra henholdsvis Streymoysill'en og Eysturoysill'en.

Intrusionsforløbet må derfor antages at have været følgende: Først er gangene intruderet i de forhåndenværende lamelzoner; de er yngre end plateaubasaltdannelsen, idet de gennemsætter hele lagserien. Samtidig med gangintrusionen er der trængt magmaer ind i den meget lidt modstandsdygtige og porøse tuf-agglomeratzone. Efter at alle lamelzoner er blevet injiceret og gangene konsolideret $\mathrm{i}$ den $\emptyset$ verste del af lagserien, er magmaet ved fortsat opadrettet tryk trængt ind i grænseområdet mellem den mellemste og den фverste basaltserie. En overliggende basaltmasse er derved blevet løftet og magmaet er trængt op i de herved fremkomne, ind mod tilførselskanalen rettede revner, hvorved sill'ens transgressive perifere dele dannedes (fig. 128). 


\section{Lamelzoner, gjógv'er og forkastninger}

\section{Lamelzoner}

Den på det geologiske kort anvendte signatur for lineament omfatter nogle tydelige brudlinjer, sprækker og lamelzoner. De er dels indtegnet under karterings- og recognosceringsarbejde, dels efter luftbilleder.

Udtrykkene sprækker eller revner og lamelzoner (NOE-NYGAARD 1940) svarer stort set til de af PEACOCK (1928) anvendte benævnelser »minor joints og »master joints . (Fig. 93, 129, 130).

Lamelzoner er dannet ved gentagne trykudligninger langs samme plan i basaltplateauet som følge af ustabilitet i underlaget.

Er der først ved trykudligning dannet en sprække eller revne, vil der være en tendens til, at senere trykudligninger følger på det samme sted langs det samme plan. Der vil således ved flere på hinanden følgende tryk- eller spændingsudligninger blive dannet en svaghedszone bestående af et helt system af parallelle sprækker eller revner, en lamelzone. Ved udmodellering af lamelzoner får vi dannet ofte dybe klфfter (fær.: gjógv pl. gjáir). I bunden af en sådan gjógv vil vi tit kunne se en blottet og renvasket lamelzone; den viser sig at bestå af et ofte stort antal parallelle basaltlameller med mellemliggende knusningsmateriale og mineraliserede årer. Ikke sjældent ses tynde bånd af blegejord (montmorillonit) mellem basaltlamellerne. I de senere år har vi også haft lejlighed til at studere lamelzoner i forskellig dybde, hvortil adgangen er åbnet gennem sprængning af vandførende tunneler og vejtunneler. Med ringe tykkelse af dæklag over tunnelen er lamelzonerne, særlig når de er vandførende, ofte til stor gene for sprængningsarbejdet, idet de kan være meget løse.

\section{Gjógv'er}

Benævnelsen gjógv bliver i almindelig færøsk tale brugt om mere eller mindre dybe, smalle, ofte lange kløfter med stejle, undertiden lodrette sidevægge. Sådanne kløfter er et meget karakteristisk træk i det færøske landskab; deres forløb er gerne omtrent retlinjet eller let buet, og de forekommer hyppigt i rækker, idet de 


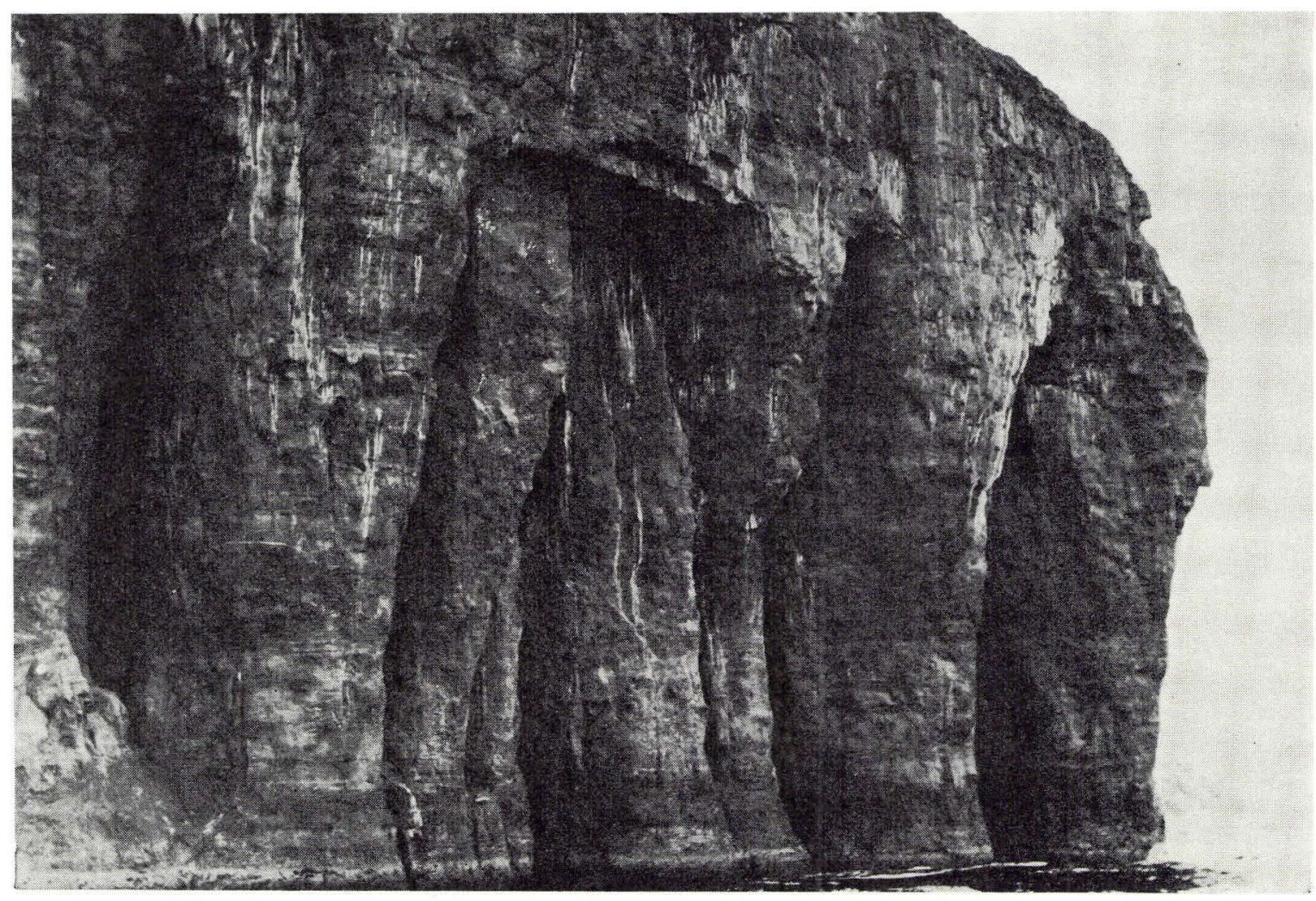

Fig. 129. Sprækkezoner vinkelret paa fjeldvæggen. Streymoy. Rivur í berginum. Streymoy.

Joints perpendicular to the coastal cliff. Streymoy. 


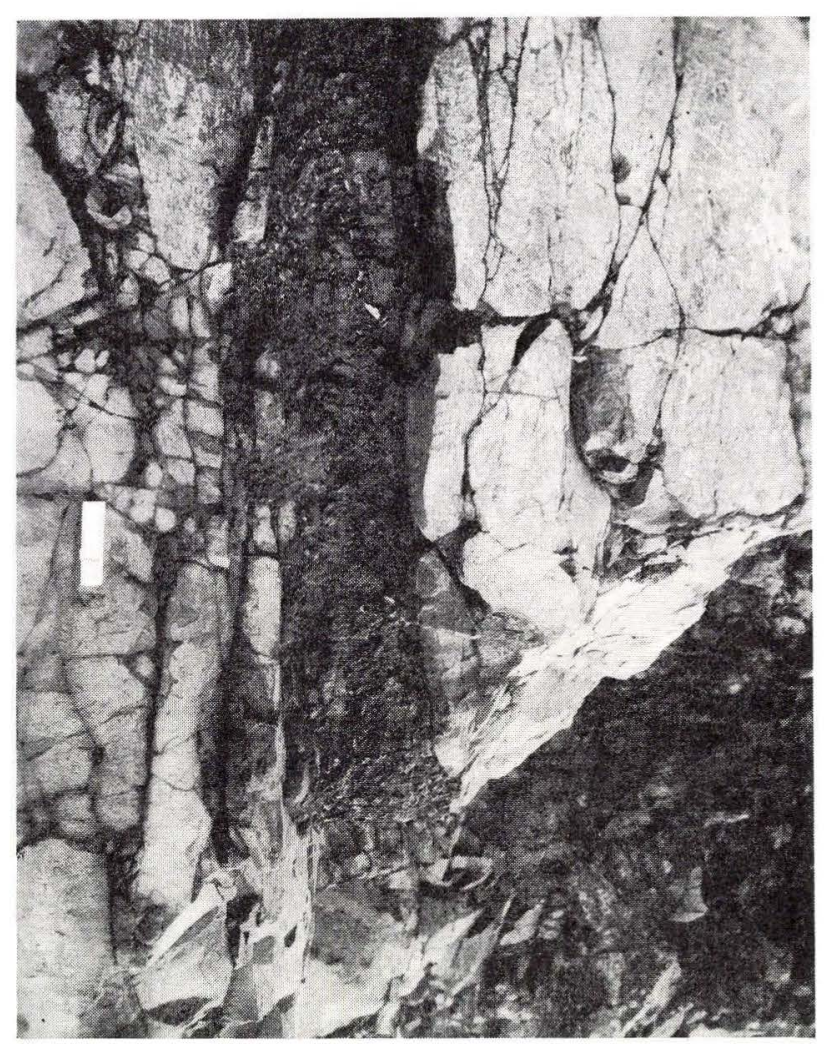

Fig. 130. Lamelzone ved Vágseiði, Suðuroy. Rivuskipan, Vágseiði, Suðuroy.

Lamellar zone at Vágseiði, Suðuroy.

følger brudlinier (lamelzoner), der kan spores som terrænlineamenter fra kløft til kløft. Som eksempel på en gjógvrække skal nævnes gjógvrækken, der strækker sig fra Gøtugjógv på фstsiden af Eysturoy til Saksun på nordvestsiden af Streymoy. Den omfatter godt en halv snes større og mindre gjógv'er fra ca. $2 \mathrm{~km}$ længde (Gøtugjógv) til mindre end $100 \mathrm{~m}$ længde ( $\varnothing$ st for Norðskáli). Det drejer sig om en strækning på ca. $25 \mathrm{~km}$, hvoraf tilsammen 5-6 km er udmodelleret til gjógv'er*.

Vi kan danne os en forestilling om antallet af gjógv'er ved at

* Udtrykket gjógv bliver dog også på færøsk brugt i anden betydning, nemlig om huler, som havet har eroderet ind $\mathrm{i}$ stejle kystfjeldvægge (våde ovne). Endvidere bliver det undertiden anvendt om en lille vig med en mere eller mindre stejl kystvæg. 


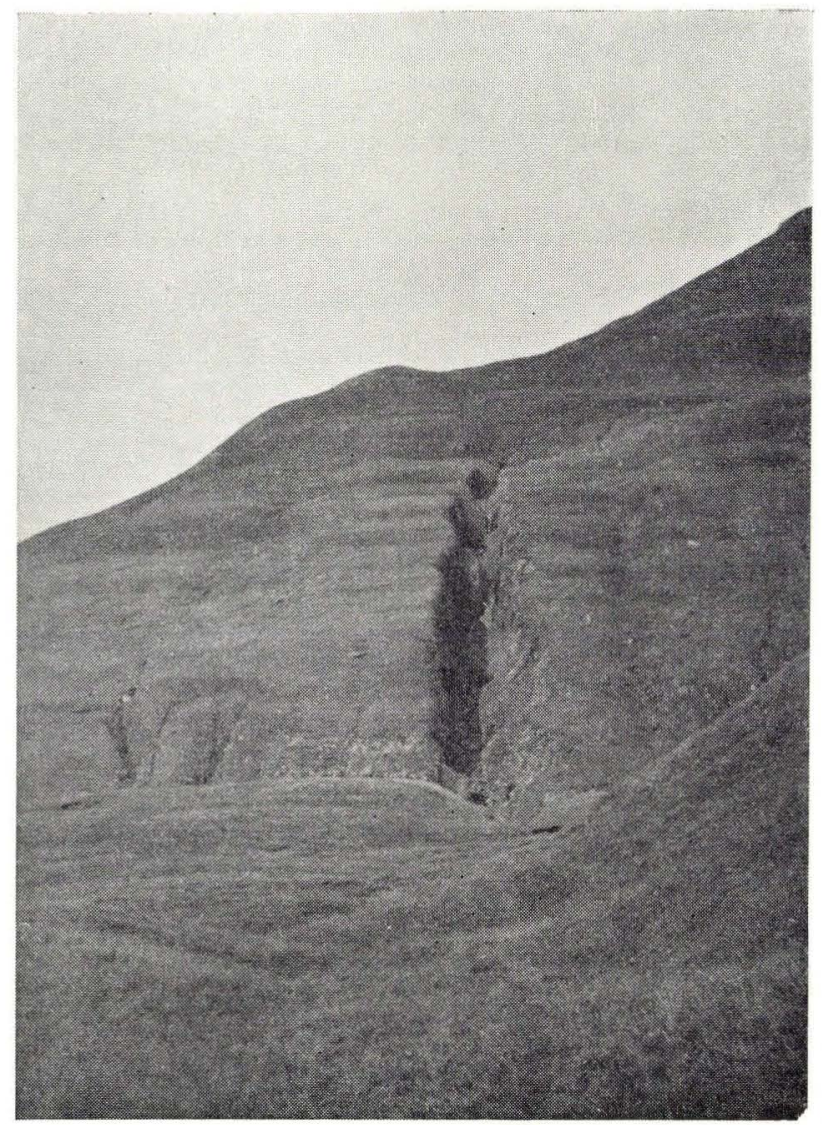

Fig. 131. Ravnagjógv, Streymoy.

tælle signaturerne for gjógv på målebordsbladene over Færøerne i 1:20.000; det giver, både større og mindre gjógv'er iberegnet, ca. 800 .

Gjógv'erne har allerede fra tidlig tid tiltrukket sig opmærksomhed, de er således omtalt og deres oprindelse diskuteret hos voN Born (1792, 1793), Landt (1800) og Mackenzie (1813); disse påviser alle, at der ofte forefindes søjleformede basalter i gjógv'erne, og Mackenzie mener desuden, at gjógv'ernes oprindelse netop skyldes nedbrydningen af de vandretliggende basaltsøjler, som derefter er blevet skyllet bort af rindende vand. Det samme mener RUDOLPHI (1913). PEACOCK (1928) påviser en tektonisk baggrund for gjógv’ernes dannelse (fig. 131). 
I de senere år er gjógv'ernes oprindelse blevet diskuteret hos Noe-NygaARd (1940) og Rasmussen (1955).

Som omtalt s. 242 ses en gang hyppigt at være horisontalt disloceret, hvor den krydses af en anden, i længderetningen lamelleret gang eller af en ikke intruderet lamelzone. Ved betragtning af kompasroserne over gange, lamelzoner og gjógv'er finder vi en ganske påfaldende overensstemmelse mellem lamelzoneretningen og gjógvretningen, medens dette ikke er tilfældet med gange og lamelzoner.

Det må derfor antages, at gangene er intruderet i et sprækkeeller lamelzonesystem, hvis oprindelse ligger umiddelbart efter plateaudannelsen, medens gjógv'erne fortrinsvis er knyttet til et lamelzonesystem, der er yngre end gangintrusionen (s. 233).

\section{Forkastninger}

På det geologiske kort er der vist en del forkastninger, som vi især har haft lejlighed til at møde ud mod de åbne kyster og i fjordene, fordi de her er bedst blottet. Et lille kvadrat på kortet angiver, hvilken side der i forhold til den anden er sænket, arabertallet i kvadratet angiver sænkningsbeløbet i meter. Den vertikale bevægelse, der kan måles ved disse forkastninger er fra under en meter til nogle meter; de største vertikale forkastningsbel $\varnothing$, vi har konstateret, overstiger kun undtagelsesvis $20 \mathrm{~m}$. Men i zoner, der rummer flere forkastninger, som f. eks. på det $S \emptyset$ Suðuroy, kan der ses en klar tendens til, at de alle viser sænkning til samme side, således at det samlede forkastningsbeløb ved opsummering bliver temmelig betydeligt; andre zoner med mange små forkastninger viser et mere uregelmæssigt mønster, således som $\mathrm{f}$. eks. et område syd for Tjørnuvík på Streymoy (NoE-NygaARD 1945).

Et billede, der ganske svarer til det, man ser i vertikale snit, kan man finde i horisontale blotninger. Man kan i disse observere forskydninger med nogle få meters forsætning af de to sider; især ses dette tydeligt i de tilfælde, hvor en gang skæres over af en forkastning. Den største horisontale forskydning, vi har observeret, ses på det geologiske kort ved Tjørnuvík, hvor to stykker af den samme gang henholdsvis sydøst og nordvest for fjorden er forskudt næsten $100 \mathrm{~m}$ i forhold til hinanden (sml. s. 242).

Vi har endvidere bemærket, at der langs et lodret forkastnings- 
plan kan ske en vipning, så at en bevæget blok er hævet i sin ene, sænket i sin anden ende i forhold til naboblokken. En særlig veludviklet forkastningszone ligger i og mellem Dalagjógv og Djúpadalsgjógv på det vestlige Streymoy, hvor et helt system af mindre forkastninger følger det samme mønster, som vises af de to store forkastninger i hovedgjógv'erne, nemlig en hævning mod vest af en trekantet, forkastningsbegrænset blok. Det tektoniske skitsekort, fig. 133 viser forkastninger, hvis vertikale og horisontale forsætninger ikke er store, men som har tydelig indvirkning på C-niveauets skæring med havspejlet, først og fremmest fordi den regionale hældning som helhed er så ringe.

De forkastninger, som vi har indtegnet på kortet, udgør kun en meget beskeden del af dem, der forekommer; forkastningsobservationerne er udført under karteringen ofte under meget usikre iagttagelsesforhold - fra båd. Der har desværre ikke været mulighed for at afse tid til at forfølge brudlinjeproblemet for dets egen skyld. En eventuelt kommende tektonisk analyse af ét eller flere af de særligt egnede områder vil utvivlsomt kunne kaste lys over selve bevægelsesmekaniken indenfor et stift basaltplateau, der er under deformation og dermed have betydning også udenfor Færøerne. 


\section{Træk af den tektoniske udvikling og geofysiske målinger}

Træk af den tektoniske udvikling

Under beskrivelsen af de 3 basaltiske hovedserier i det fær $\varnothing$ ske plateau fremgik det, at der fandtes en diskordans mellem den nederste og den mellemste serie og atter én mellem denne og den øverste. Vi må ud fra denne konstatering fastslå, at der har fundet bevægelser sted allerede medens basaltplateauet var under opbygning, eller med andre ord at dettes dannelse ikke er sket som en kontinuerlig proces.

Vi vil begynde vore betragtninger over de tektoniske forhold med at se på fig. 133, der skitsemæssigt viser nogle af hovedtrækkene.

Længst i vest, på Mykines er vist et kullag, der har sin største højde over havet i $370 \mathrm{~m}$, og som skærer havniveau efter den viste linje på kortet, de ækvidistante kurver i dette lags plan har en indbyrdes afstand på $25 \mathrm{~m}$ - det samme kurveinterval er også anvendt i alle de $\varnothing$ vrige referensflader på kortet. Kurvetætheden viser, at hældningen er temmelig stor og den ligger indenfor den nederste series basalter.

Den næste flade, vi vil betragte, er A-niveauet, som er beliggende mellem den nederste og den mellemste basaltserie på det vestligste Vágar. På kortet ses, at denne flade har meget nær den samme strygningsretning som kullaget på Mykines, men 25 m-kurverne i det mod sydøst hældende plan er langt mere åbne, fordi hældningsvinklen er mindre (ca. $3 \frac{1}{2}{ }^{\circ}$ ).

Til st $\varnothing t t e$ for kortlægningen af den mellemste basaltserie indførtes et hjælpeniveau: B-horisonten (s. 34); denne skærer havniveau i Vestmannasund ved Leynar, i Sundalagio ved Hvalvík og nord for Kollur på Eysturoy; kortet viser, at denne skæringsflade har et buet forl $\varnothing$ b. Det svagt buede plan kan forlænges bagud mod vest, kortet viser $25 \mathrm{~m}$-kurvernes forl $\varnothing \mathrm{b}$. Strygningsretningen svinger fra $\mathrm{NN} \varnothing$ over $\mathrm{N}$ til $\mathrm{NNV}$, og afviger tydeligt fra A-horisontplanets strygning, hældningsbel $\varnothing$ bet er generelt en lille smule mindre end i A-planet, først og fremmest over den svage ryg, som ses nordligst i Sundalagið. 


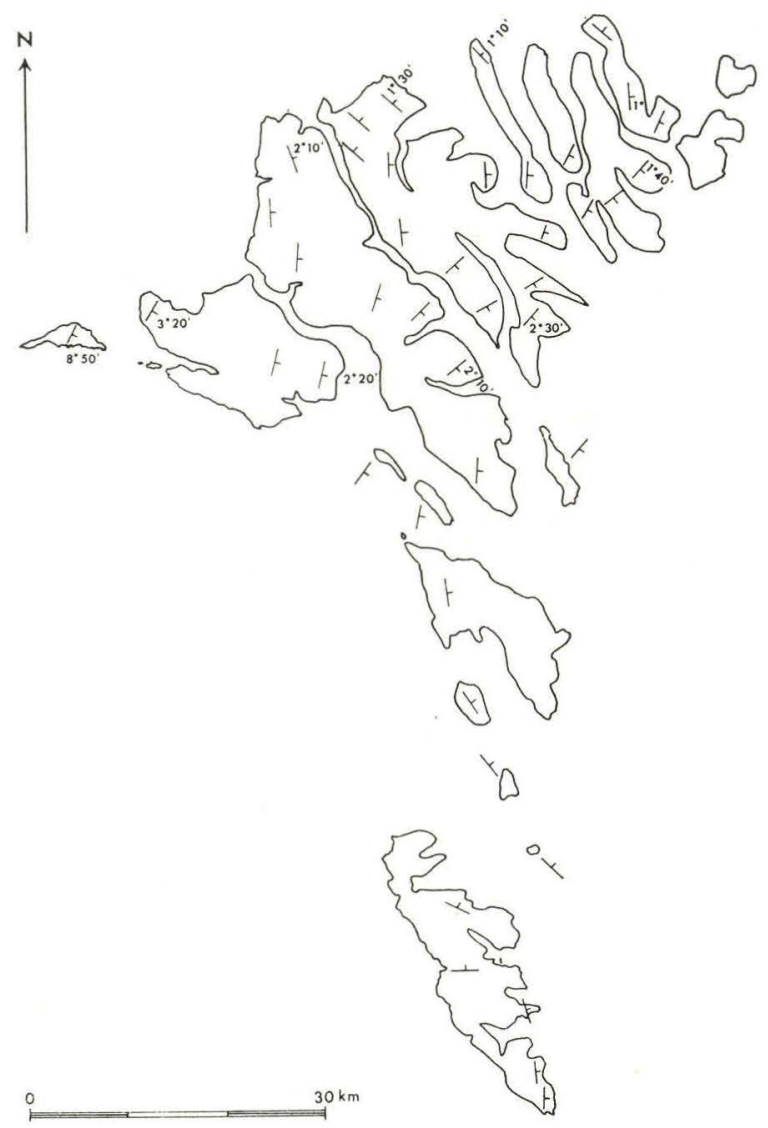

Fig. 132. Oversigtskort over strøg og fald. Yvirlitskort yvir strok og hall.

Outline map of strike and dip.

Det fjerde niveau, der er vist på kortet, er C-horisontens skæring med havniveau. Skæringslinjen ses at være afbrudt adskillige steder, men antyder i sit buede hovedforl $\varnothing$ b overensstemmelse med B-horisontens form.

De viste afbrydelser er begrænset af forkastninger, hvoraf nogle direkte er iagttaget, andre indirekte fremgår af lagstillingen. De store sillintrusioner på Streymoy, Eysturoy og Svínoy-Fugloy, som alle ligger umiddelbart i grænseområdet mellem den mellemste og den $\varnothing$ verste basaltserie (s. 328) har utvivlsomt haft indflydelse på 


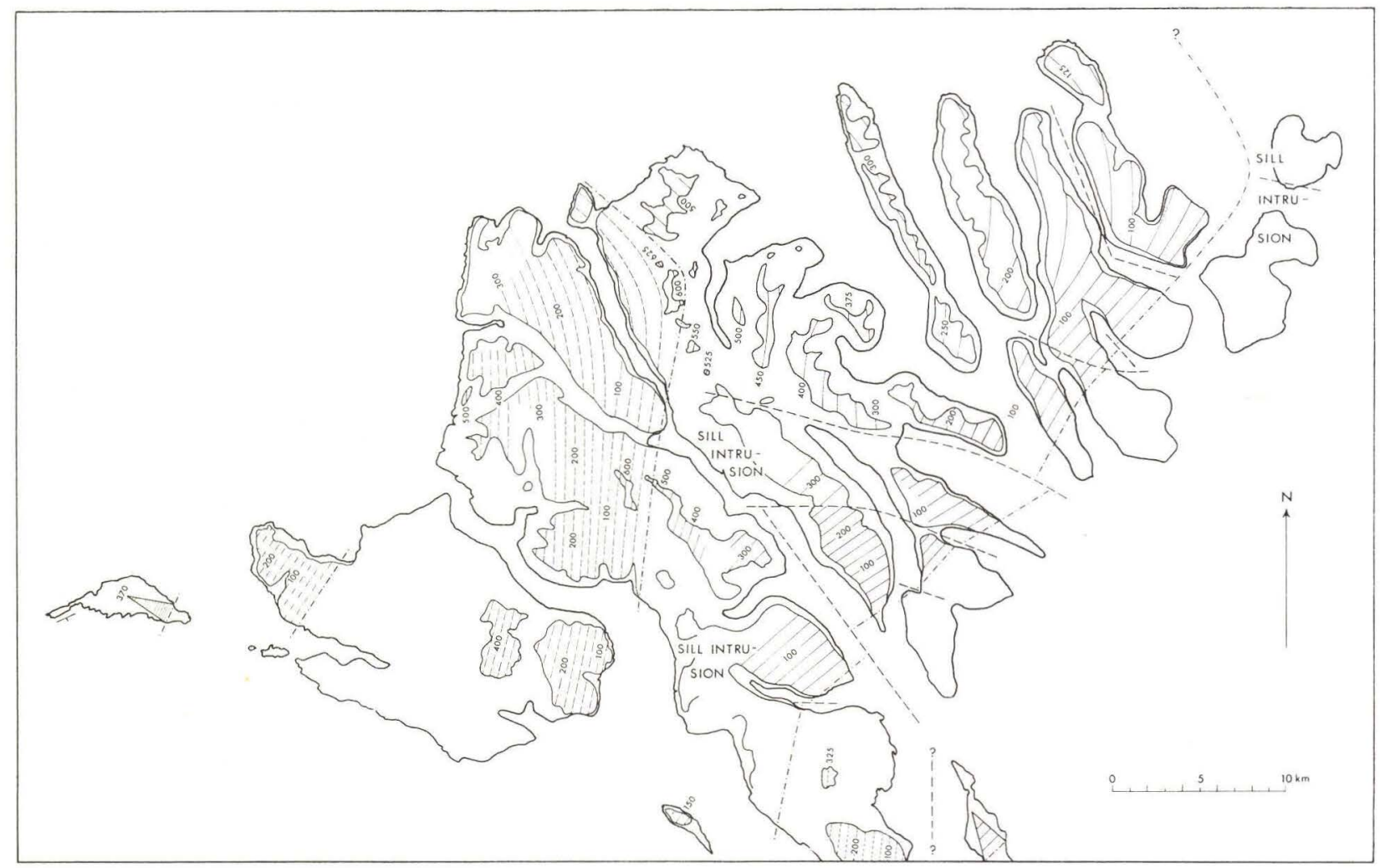

Fig. 133. Tektonisk skitsekort.

Tektonikkort - yvirlit.

Tectonic sketchmap. 
»knækkene« i C-horisontens forløb og på de hurtigt skiftende strygningsretninger på Streymoy og Eysturoy.

Som et femte referensniveau er vist en lagserie i Kirkjubøreyn på det sydlige Streymoy, syd for Tórshavn, den kaster lys over forholdene indenfor den $\varnothing$ verste serie. Hældningen er omtrent ret $\varnothing$ st og faldet ringe, strygningsretningen falder omtrent sammen med C-horisontens skæring af havniveau i dette område.

Det sjette og sidste referensniveau, der er vist på kortet, stammer fra Nólsoy, hvor man ser, at strygningsretningen er ret forskellig fra den på det sydlige Streymoy, af hvilken grund der må være forkastning mellem de to $\varnothing \mathrm{er}$.

Et detailleret tektonisk billede kan vi desværre ikke give, det ville have krævet en særlig undersøgelse med netop dette formål for $\varnothing j e$. De meget små laghældninger i grader, overvejende mellem $1^{\circ}$ og $3^{\circ}$ stiller store krav til n $\varnothing$ jagtighed; en betydelig vanskelighed er tillige, at en enkelt bænk i plateauet ikke er kontinuerlig, men kiler ud og afløses af en ny. Vi må, som forholdene er, nøjes med det, vi har.

Et hovedtræk ved kortet er, at der er en overensstemmelse i det mønster, som B- og C-horisonterne viser, nemlig en svag antiklinalstruktur med $\varnothing \mathrm{N} \varnothing$ dyk; dette viser, at de to lagserier efter deres dannelse begge har undergået én og samme, svage foldningslignende deformation. Et tilsvarende billede viser »Klakksvíklaget《 (s. 229), som ligger højt oppe i den mellemste basaltserie, fig. 134 .

Det tektoniske mønster, som vi lige har gennemgået, præges af en ejendommelig »halvhed «, der tager sig ud, som om vi kun havde den højre flanke af en større helhed, beliggende på Wyville-Thompson ryggen, bevaret oven vande. Ryggens kulmination må i så fald have ligget vest for de nuværende $\varnothing e r$, men næppe meget. Er denne betragtning korrekt, ligger det nær at antage, at denne gamle oceanryg i sin tid har opført sig på lignende måde, som de levende oceanrygge, vi finder i dag (East Pacific Rise og Mid-Atlantic Ridge). Disse viser tendens til hævning af den centrale del af ryggen. Det tektoniske billede, vi netop har tegnet af Færøerne, ville svare godt til den formodning, at der har fundet en hævning sted i vest, som er fortsat gennem den vulkanske aktivitetsperiode, men med aftagende styrke; de to diskordanser tyder på, at hævningen er sket etapevis.

Vi vil til belysning af denne model af Færøerne inddrage noget af vor nuværende viden om bjergarternes petrografi. I de moderne 

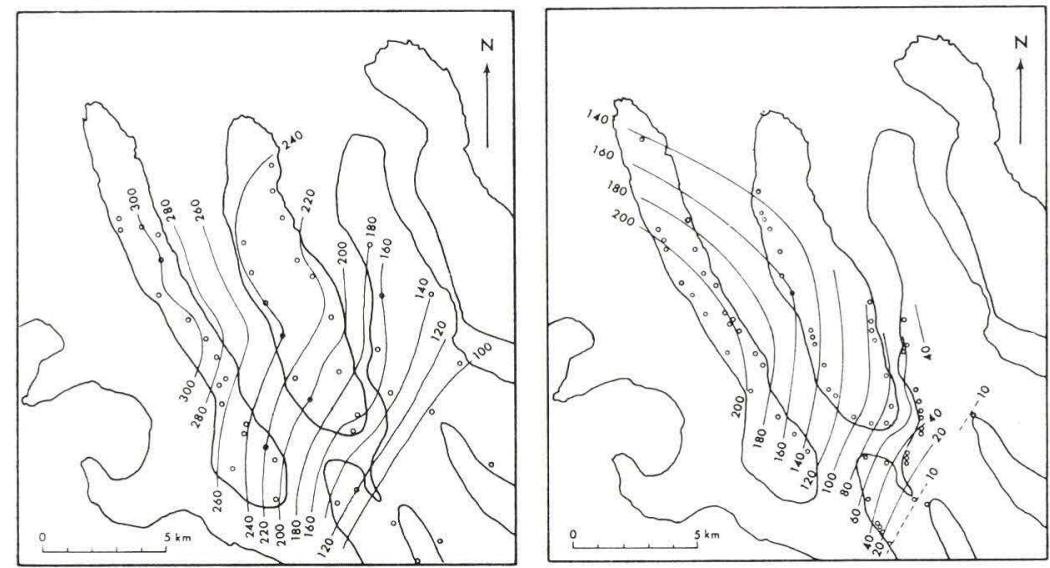

Fig. 134. $20 \mathrm{~m}$ strukturlinjerne for Klakksvíklavaen (t.h.) og C-horisonten (t.v.) $20 \mathrm{~m}$ haddarstrikur fyri C-lindina (v.m.) og eina niðari lind (h.m.)

The $20 \mathrm{~m}$ structural contour on the Klakksvíklava (right) and the $C$ horizon (left).

oceanrygge er vulkanismen i den centrale del af ryggen kvartstholeiitisk; kommer man ud på flankerne derimod, møder man olivintholeiitisk eller til og med alkali-olivinbasaltisk vulkanisme.

På Færøerne ligger geografisk de ældste lavaer længst mod vest, de yngste længst mod $\varnothing$ st.

De ældste, afyriske lavaer er kvartstholeiitiske og viser tydeligt differentiation, der findes bl. a. her lavaer af kvartsbasaltisk sammensætning og lavaer med halvstrøkorn af magnetit (NoE-NyGAARD og RASMUSSEN, 1968). De yngste lavaer er olivintholeiitiske og er de mindst differentierede. Den porfyritiske, mellemste basaltserie rummer indslag af lavaer, der er beslægtet med begge yderleddene; betragtet under ét ligger de mellem disse.

Hovedbilledet er herefter det, at de kvartstholeiitiske lavaer er dannet nærmest ved den centrale zone af ryggen, derefter følger de porfyritiske, som stadig er kvarts-normative af sammensætning, og yderst på den bevarede højre flanke følger de olivintholeiitiske lavaer.

De iagttagelser, vi har gjort over beliggenheden af de vulkanske tilførselsveje op gennem lagserien, synes at bekræfte den beskrevne model. Den rent NV-S $\varnothing$ prægede gangretning på Suðuroy markerer ligesom fjordens forl $\varnothing \mathbf{b}$ antagelig et primært træk ved den gamle oceanryg. Eksistensen af meget tykke lavastrømme længst i 
vest (s. 135) tyder på, at udbrudsstederne for den kvartstholeiitiske, nederste basaltserie ikke var langt borte.

De mange velbevarede vents og udbrudsspalter i den mellemste basaltserie, samt den store udbredelse af ganske tynde lavaenheder, der er indbyrdes svejset sammen, må betyde, at vi nu er i vulkanismens nærområde; sagt med andre ord, den vulkanske aktivitetszone har bevæget sig noget fra vest mod $\varnothing$ st.

Den $\varnothing$ verste basaltseries lavaer er transgressive, og mod vest $\mathrm{i}$ dens udbredelsesområde danner C-niveauets basaltstr $\varnothing \mathrm{m}(\mathrm{me})$ dens nederste lag; men bevæger man sig mod $\varnothing$ st, finder man, at der her, allerede under C-niveauets lavaer, findes forløbere for de olivintholeiitiske basalter, jo længere mod $\varnothing$ st, jo flere. Dette må betyde, at den $\emptyset$ verste basaltseries vulkanisme er begyndt i фstkanten, eventuelt lidt $\varnothing$ stligere, end den nuværende øgruppes landområde, og derfra er skredet frem mod vest, hvor nogle af dens senere udbrudssteder er lokaliseret (f. eks. Kunoy, Kollafjørður).

Færøernes vulkanske historie kan da antagelig skildres således: Den vulkanske aktivitet er begyndt i vest nær ryggens centrale del, derefter er den vandret mod $\varnothing$ st, hvor den en tid lang har holdt sig på flanken - omtrent midt på de nuværende фer - for endelig endnu engang at forskydes mod $\emptyset$ st bort fra ryggen, så at de sidste lavaer næsten er uden indvirkning af denne, - det er udifferentierede olivintholeiiter.

Den døende vulkanske aktivitet afspejles $i$, at de enkelte lavastrømme, d. v. s. de enkelte udbrud, bliver omtrent halverede i størrelse.

De tre basaltserier har ligget svagt diskordant ind over hinanden, da plateauet var færdigdannet, og den yngste serie har på det tidspunkt ligget vandret. Således var situationen, da intrusionen af uregelmæssige intrusiver, sills og gange fandt sted. Men hævningstendensen i oceanryggen i vest er fortsat endnu en tid lang - men afsvækket -, således at også den $\varnothing$ verste basaltseries lavaer har fået et svagt $\varnothing$ stligt fald.

Det tydelige, men dog svage »foldnings «mønster, som fremgår af fig. $133 \mathrm{og}$ som med en vis tilnærmelse genspejles i tyngdekortet kan forklares på flere måder; hvilken, der er den korrekte, kan vi endnu ikke afgøre. Vi skal angive 3 muligheder: 1. NoENyGAARD (1966) anser det for sandsynligt, at den del af Fær $\varnothing-$ plateauet, der ikke længere ses, er bygget op af submarine pillowlavaer, pillowlava-breccier og hyaloklastiter, samt at en vis uens- 
artethed i deres sammentrykkelighed kan have haft betydning for det tektoniske slutm $\varnothing$ nster. 2. Tilbagetrækningen af den termale front og den deraf følgende sammentrækning efter vulkanismens ophør kan have haft et ujævnt forløb. Jordskorpens svar på dette, kan have været det »foldnings«mønster, vi nu ser. 3. Det tektoniske mønster kan bære præg af sin formentlige beliggenhed på flanken af en ryg med et noget bugtet forløb.

\section{Geofysiske målinger}

Der er i løbet af den sidste halve snes år blevet udf $\varnothing$ rt en række geofysiske unders $\varnothing$ gelser på Færøerne; de har støttet sig til vort præliminære, strukturelle kort samt det geologiske hovedprofil, som vi har etableret under kortlægningsarbejdet (se NOE-NyGAARD og RASMUSSEN 1968).

Da de geofysiske arbejder naturligvis har betydning for den fremsatte geologiske tolkning på de foregående sider, skal vi kort referere nogle af de vigtigste resultater.

Abrahamsen og Saxov har udgivet et tyngdekort, som i noget revideret form genudgaves to år senere $(1964,1966)$. Kortets hovedtræk harmonerer godt med strukturkortet (NOE-NYGAARD 1966).

ABRAHAMSEN (1967) har ved enkel kompasmåling konstateret, at der i den nederste basaltserie på Suðuroy findes tre zoner over hinanden med forskellig magnetisering, nederst en zone med normal magnetisering, derover en med revers og atter en med normal. Over den kulførende serie skifter magnetiseringsretningen igen, og denne magnetiseringsretning synes at holde sig helt igennem såvel den mellemste som den $\emptyset$ verste basaltserie. De magnetiske forhold lader formode, at den nederste basaltserie har haft en længere dannelsestid end de to $\varnothing$ vre; men i hvert fald vises et omslag efter aflejringen af kulserien.

Tidligere indledte magnetiske arbejder fortsættes af D. H. Tarling i Newcastle-upon-Tyne. (TARLING og Gale 1968).

G. PÁlMASON (1965) har udført to refraktionsprofiler på Færфerne og derigennem fundet tre i seismisk henseende forskellige lag: Et $\emptyset$ verste med P-hastighed på $3,9 \mathrm{~km} / \mathrm{sec}$. omfattende vor $\emptyset$ verste basaltserie, et mellemste med P-hastighed på $4,9 \mathrm{~km} / \mathrm{sec}$., der omfatter vor mellemste og nederste basaltserie, og endelig derunder et nedorste med P-hastighed på $6,4 \mathrm{~km} / \mathrm{sec}$. Det fremgår således, at det færøske plateau, som helt igennem er opbygget af basalt- 
lavaer, yder to forskellige P-værdier; beskaffenheden af det tredie, nederste lag er ukendt.

Det er af betydning for den tredeling af plateaubasaltserien på Færøerne, som vi har gennemført på et rent geologisk grundlag, at bemærke, at de magnetiske målinger udskiller den nederste basaltserie som værende forskellig fra de to $\varnothing v \mathrm{vre}$, medens de seismiske unders $\varnothing$ gelser udskiller den $\emptyset$ verste basaltserie som forskellig fra de to nedre. De to helt forskellige, geofysiske målemetoder afslører tilsammen en tredeling af plateauet og angiver hver for sig beliggenheden af A- og C-niveauerne; de bekræfter dermed de resultater, vi er nået til ad geologisk vej. 


\section{Anvendte bjergarter og mineraler}

De færøske plateaubasalter er fattige på mineraler og bjergarter af nogen særlig $\varnothing$ konomisk betydning. Nedenfor skal nævnes de ting, der fra tid til anden har været gjort til genstand for udnyttelse.

Basalt. Basalten har i tidligere tid haft overordentlig stor anvendelse som bygningsmateriale (kampesten) ved bygning af gærder (marskskel), udhuse og delvis beboelseshuse. I nyere tid har den, råt tilhugget, haft nogen anvendelse i bygningsindustrien. Et aktieselskab A/S Føroya Mekaniski Grótídnaður fremstiller basaltplader til facadebeklædning, fliser og lignende, dels til indenlandsk brug, dels til eksport. Nogen større betydning har denne virksomhed dog endnu ikke fået. Ved knusning af basalten dækkes det indenlandske forbrug af skærver. Basalten til skærveproduktion brydes i åbne stenbrud. Som eksportvare ville basalt og basaltiske produkter kunne have en langt større betydning, hvis ikke fragt- og transportomkostninger trådte ind som en betydelig hindring. Bruttofaktorindkomsten af stenindustrien var i $1965 \mathrm{kr}$. 1.161.000.

Sand. Det sand, der bliver anvendt i bygningsindustrien, bliver for langt den overvejende del hentet fra bunden af fjorde og bugter. Morænesand er kun blevet anvendt i mindre grad. Bruttofaktorindkomsten var i $1965 \mathrm{kr}$. 1.470.000.

Tuf. I årene $f \varnothing r$ og efter krigen blev en hårdtbrændt, $r \varnothing d$ tufsten ved Argisfossar på Streymoy brudt og i pulveriseret tilstand anvendt

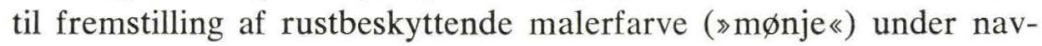
net $\gg$ Færøsit $\ll$.

Tuffoid ler. Tuf-lerarter med udpræget ionbyttende egenskaber har fundet teknisk anvendelse $\mathrm{i}$ vandfiltre til blødgøring af hårdt vand. En brydning af tuf-ler til eksport fandt sted i årene umiddelbart før krigen og i årene efter krigen til midt i 1950'erne, da den blev trængt tilbage af forskellige kunststoffer med samme anvendelse. Tuf-lerarter blev brudt på Nólsoy (Hósmøl), ved Dalur på Sandoy, forsøgsvis nord for Skálavík på Sandoy og i Gásadalur på Vágar.

T $\phi r v$. Tørv har gennem århundreder haft overmåde stor betydning som indenlandsk brændsel. Tørvemoser forekommer såvel $\mathrm{i}$ 
lavlandet, langs dalsider som oppe mellem fjeldene. De fleste moser er overrislingsmoser; tilgroningsmoser er mere sjældne. Tørvedybden er almindeligvis $1-1,5 \mathrm{~m}$. De anvendte tørv er dels kærtørv (fær.: tæðungur) dels kvisttørv (fær.: viðamógvur). I dag skæres der kun ubetydelige mængder tørv.

Kul. De færøske kul har, som allerede nævnt under den kulf $\varnothing-$ rende serie, været kendt og lejlighedsvis brudt til lokalt brug i hvert fald de sidste 2-300 år. Undertiden er brydningen foregået helt privat og undertiden ved offentlig foranstaltning. I slutningen af det 19. århundrede blev der givet en række koncessioner til kulbrydning på Suðuroy. I 1932 blev der udstedt 3 koncessioner til et fransk interessentskab »La Sociéte Miniére des Iles Feroe« på ret til 1. kulbrydning og brydning af ildfast ler på Suðuroy, 2. kobber og jernsten på Suđuroy og 3. kobber på Nólsoy. Denne koncession blev i 1936 overdraget til A/S Færø Kul, som påbegyndte en minedrift, der dog blev opgivet allerede under krigen. Efter krigen blev koncessionen overdraget Froðba sogns kommune.

Kulbrydning foregår endnu dels i det nordlige kulfelt (Prestfjall, Rókhagi) og dels i det sydlige kulfelt (Rangibotnur). Brydningen foregår på privat basis og under primitive brydningsforhold. I årene efter krigen har den dækket en væsentlig del af Færøernes behov for husholdningsbrændsel, men er nu stærkt aftagende.

I årene 1957-66 blev der produceret (ton):

$\begin{array}{lrrrrrrrrrc} & 1957 & 1958 & 1959 & 1960 & 1961 & 1962 & 1963 & 1964 & 1965 & 1966 \\ \text { R. } & 4.850 & 5.415 & 6.055 & 5.150 & 5.485 & 4.770 & 4.512 & 3.227 & 2.332 & 1.606 \\ \text { H. } & 11.682 & 11.939 & 9.450 & 9.340 & 8.578 & 6.530 & 4.736 & 5.082 & 3.842 & 1.970 \\ \text { R. = Rangibotnur. } & \text { H. = Hvalba. }\end{array}$

Bruttofaktorindkomsten af kullene var i 1965 kr. 667.000. Fors øg på at få en eksport i gang af de færøske kul er aldrig blevet kronet med held.

Ler. Der har været gjort gentagne forsøg på at udnytte de lerarter, der i ret store mængder forekommer sammen med kullene, bl. a. ildfast ler, uden at det endnu har f $\varnothing \mathrm{rt}$ til noget gunstigt resultat.

Blegejord. Blegejord (montmorillonit) forekommer i mindre mængder som lameludfyldning i gjógv'er, særlig på den sydøstlige del af Vágar ud mod Vestmannasund og i Hósteinsgjógv på Nólsoy. Det er endnu usikkert, om den vil kunne udnyttes med nogen fordel. 
Diatoméjord. Diatoméjord forekommer undertiden i ganske ubetydelig mængde under tørvemoser. Den er i enkelte tilfælde anvendt til lokalt formål.

Smykkesten. Almindeligt forekommende smykkesten er kvartsvarieteter som bjergkrystal, kalcedon, agat, onyx, karneol, jaspis samt opal. De har aldrig været gjort til genstand for $\varnothing$ konomisk udnyttelse i egentlig forstand, men har i tidligere tid været et yndet samleobjekt for indenlandske og udenlandske samlere.

Metaller. Forekomsten af kobber og jernmalm, der er indbefattet de under kul nævnte koncessioner, er så ubetydelig, at den næppe nogensinde vil få nogen praktisk betydning. 


\section{Úrtak á føroyskum}

Endamálið við tí jarðfrøðiliga kortleggingarbeiði, sum her verður borið fram, hevur í fyrsta lagi verið at finna fram til eina sundurbýting av føroysku fláaskipanini í bólkar, sum hvør sær siga frá einum tátti í upphavss $\varnothing$ gu landsins, og í фơrum lagi at vísa á korti, hvar hesir bólkar koma fyri í oyggjunum. Litirnir á yvirlitskurđinum og litirnir á kortinum svara saman og vísa somufláabólkar. Fláabólkarnir eru í skurđinum skipađir eftir aldri uppeftir, elsti bólkurin niðastur; yngst eru innskotini, sum skera seg gjøgnum tær regluligu fláirnar. Vit nevna teir einstøku bólkarnar soleiðis: Niðaru basaltfláirnar (døkt grønur litur), kolalindin (brún), gosmyrjan (miðalgrønir prikkar í ljósareyðum), miðfláirnar (miðalgrønur litur), ovaru basaltfláirnar (ljósagrønur litur), og innskot: gongir (reyðar), syllar og óreglulig innskot (ljósareyð). Á kortinum eru teir elstu bólkarnir, elstu fláirnar, vestan- og sunnantil í oyggjunum og teir yngstu eystantil, tí hallið gongur í eysturættirnar. Á kortinum er markið millum niðaru basaltfláirnar og kolalindina nevnt A-lindin, markið millum miðfláirnar og ovaru basaltfláirnar C-lindin, og niðurmarkið við ein eyðkendan hamara umleið $2 / 3$ uppi í miðfláunum hava vit nevnt B-lindina. Hesar lindir, vit kunnu nevna tær leiðarlindir, eru nýttar til at samskipa skurðir, sum mátað̋ir eru ymsastaðni í landinum, og til at meta um, hvar vit eru stødd í fláaskipanini. Á henda hátt hevur borið til at seta saman ein meginskurð (fyrimyndarskurð), umleið $3000 \mathrm{~m}$ til tjúktar, av mongum stakskurđum (I-XI á kortinum og 5. mynd) gjøgnum alla fláaskipanina.

Roynt skal nú verð̋a her at siga frá gongdini í upphavssøgu landsins í stuttum yvirliti við tilvísing til kortið og myndatilfarið í bókini. Skipanin í bókini verður bert leysliga fylgd og lættliga er farið um tað, sum ætlast má at krevja serligan forkunnleika.

Eldgos eru bundin at gosopum, sum gjøgnum goshálsar standa í samband við grótbræðingar við upploystum loftsløgum niðri í jørðini. Gosop eru stundum rundleitt ella avlong, stundum langar kluftir (goskluftir). I Íslandi eru langar beinar, stundum opnar kluftir sjónligar enn, t.d. Eldgjá. Ađ̛rar stađir, í Andesfjøllunum, í Mið- 
ameriku, á Aleutunum, í Japan og á Sundaoyggjunum (Java) siga mong gosop á rađ frá bogaskapađum rivum í jarðarskorpuni.

Føroyar eru upprunaliga vorðnar til av eldgosum, tær eru bygdar upp av grótbræðingum, sum storknađar eru flógv oman á flógv (hamrar og brýr). Gróttilfarið í Føroyum er basalt, høvuðssløgini eru blágrýti, feldspatbasalt og olivinbasalt. Basalt $\varnothing \mathrm{ki}$ bygd upp sum Føroyar nevna vit háslættabasalt. Dømi m.a. Stormberg í Suðurafriku, Deccan í Indiu, Columbia í U.S.A. og Norðuratlantska basaltøkið. Føroyar hoyra upp í Norðuratlantska basaltøkið, sum røkkur frá landnyrðingshorninum í Írlandi (Antrim) um Vesturskotland, Føroyar, Island, Jan Mayen, partar av Eystur- og Vesturgrønlandi til Baffins Land. Føroyar eru soleiðis partur av einum upprunaliga nógv størri landi og ovasti parturin av Wyville Thompson rygginum, sum gongur í landsynning - útnyrðing gjøgnum Norðuratlantshavio.

Úrslitið av Ka/Ar mátingum sigur niðaru basaltfláirnar at vera útvið 60 mill. ár. Plantuleivdir úr kolalindini benda ímóti Eocæntíðini.

ts

Eldgosini, sum bygdu upp niðaru basaltfláirnar, vóru bundin at stórum goskluftum, har grótbræđingar spríktu upp ígjøgnum. Gosini vóru ikki áhaldandi, t.e. at aftan á hvørt gosið var stytri ella longri støðgur.

Niðaru basaltfláirnar koma fyri í Suðuroy, Mykinesi, Gáshólmi, Tindhólmi og í Vágum. I Sưuroy gongur hallið $3^{\circ}-6^{\circ}$ niður í landnyrðing norðan, landnyrðing og landnyrðing eystan, so ovasti hamarin á niðaru basaltfláunum fer í sjógv eftir stroklinjuni Froðbiarnípan - Hvannhagi - Tjørnunes - Kolaratangi. I Mykinesi gongur hallið $13^{\circ}$ niơur í landsynning við Hólmgjógv og $8^{\circ}$ í landsynning eystan eystantil á oynni. Vestantil í Vágum er hallið $3^{\circ} 1$ landsynning eystan, og ovasti hamarin á niðaru basaltfláunum fer her vesturi í sjógv eftir stroklinjuni Ālkuklettur - Víkar. Á kortinum síggjast niðaru basaltfláirnar tí í Suðuroy, Mykinesi, Gáshólmi, Tindhólmi og Vágum sunnan fyri og vestan fyri tær omanfyri nevndu stroklinjurnar. Niðaru basaltfláirnar eru bygdar upp av 10-30 m tjúkkum grótfláum, stundum eru tær tynri, og tjúkkastu hamrarnir eru 50-70 m. Millum grótfláirnar er royðugrót, eyr-, sand- og leirgrýti, stundum við heilt tunnum kolalindum. Hetta sigur okkum, at støðgur hevur verið millum gosini. Grótslagið er tætt, hart blágrýti, 
ofta skapað sum stabbagrót. I Suðuroy eru serliga skilligir stabbagrýtishamrar m.a. norđantil á Trongisvágsfirđi, inni í Trongisvági, í Innarahváli, í Uttarahváli og úti í Frođba. Heilt regluligir eru stabbarnir 6 - hyrntir, men oftast eru teir óregluligir $3-4-5$ hyrntir, bogaskapaðir eru teir t.d. úti í Froðba (Kúlugjógv) og vundnir framvið Øravík - Hovsvegnum. Ovast eru tær einst $\varnothing$ ku grótfláirnar (hamrarnir) ilskukendar og poknutar. Hyggja vit inn á vesturstrondina í Suđuroy, við Beinisvørð, Rávuna og Vágseiði sunnantil á oynni (niðasti parturin av niðaru basaltfláunum), millum Vágseiði og Fámjin (miðparturin av niðaru basaltfláunum) og inn á Geitaskor og Prestskorar norðantil á oynni (ovasti partur av niðaru basaltfláunum), fáa vit eina hugmynd um, hvussu regluliga landið er bygt upp av skiftandi grót- og royðugrýtisfláum.

Umframt royðugrót er, sum frammanundan nevnt, stundum eyr-, sand- og leirgrýti viơ heilt tunnum kolalindum ella flísum at finna ímillum hamrarnar. I Suðuroy hava vit verið varir við smávegis av koli millum basaltfláirnar á hesum støðum (merkt C á kortinum): Vestantil í Grímsfjalli (50 m o. sj.), Undir Bergsleiti s. f. Hvalbiareiði (115 m o. sj.), vestan fyri Tjørnunes fram við strondini, 1 Hvannhaga vestan fyri Stapan, undir Innarahváli á Tvøroyri (76 m o. sj.), undir næstovasta hamri á Fjallinum Mikla (428 m o. sj.), undir Keppi norðan fyri Fámjin (170 m o. sj.), við Svínagjógv millum Borgina og Borgarknapp (480 m o. sj.), vestantil í Hvannafelli (520 m o. sj.), innan fyri Hovshólm, við Porkerisvegin (160 m o. sj.), við̋ Ánna Miklu í Porkeri (185 m o. sj.) og norðantil á Mýrifirð̃i.

Tey jarðfrøðiligu viðurskiftini í Mykinesi, Gáshólmi, Tindhólmi og vestasta partinum av Vágum eru meinlík teimum í Suđuroy. Tjúkkasti hamarin í Mykinesi er $70 \mathrm{~m}$, og er hann tjúkkasti hamari, sum mátaður er í Føroyum. Stabbagrót sæst mangastaðni, serliga skilligt í Korkadali, tað tey rópa steinskógir í Mykinesi. Eisini í Mykinesi eru tunnar kolalindir ímillum nið̋aru basaltfláirnar, m.a. á Mykineshólmi vestan fyri Hólmgjógv, á Fjørudalsnevi, har steinrenningar av Risafuru (Metaseqoia occidentalis) eru funnar, í berginum fyri sunnan á oynni, undir Ketilsheyggi og í Kálvadali. I Tindhólmi og í Vágum eru niðaru basaltfláirnar eins og norðantil í Suðuroy taktar av kolalindini, gosmyrjuni og miðfláunum. İ Vágum er eitt sløð av koli at síggja í royðugrýtislindum í Gásadali, í berginum vestantil á oynni og á Víkum.

I niðaru basaltfláunum er at kalla alt grótslagið tætt, hart blágrýti. 
Aftaná at eldgosini, sum bygdu upp niðaru basaltfláirnar, vóru givin, gjørdist langur støðgur, har eingi eldgos vóru. Hesin støðgur var so langur, at fasti kletturin tærdist og molnaði til leysa jørð, so gróđur festist og tók seg fram til sannan skógvøkstur. Kolalindin ber prógv um henda støðg.

Kolalindin* liggur oman á niðaru basaltfláunum og sæst í Suðuroy, Tindhólmi og í Vágum.

Í Suðuroy fevnir hon um ca. $23 \mathrm{~km}^{2}$. Eystantil á oynni fer hon í sjógv á Froðbiarnípu, í Hvannhaga og Lónini, á Tjørnunesi og á Kolaratanga. Frá Kolaratanga tekur hon seg upp suðureftir til fjøllini sunnan fyri Trongisvág, hægst er hon á Knúki n.f. Fámjin, 425 $\mathrm{m}$ o. sj. Vestantil á oynni gongur hon gjøgnum Prestskorar, Geitaskor og Rossarók.

Kolaøkið fellur i 4 sundurskildar partar:

1. Grímsfjall $\left(1,36 \mathrm{~km}^{2}\right)$.

2. Norðara kolaøki (norðanfyri Trongisvág) $(18,74 \mathrm{~km}$ ).

3. Sunnara kolaøki (sunnanfyri Trongisvág) $\left(2,60 \mathrm{~km}^{2}\right)$.

4. Kolheyggjur - Hovstúgvan $\left(0,24 \mathrm{~km}^{2}\right)$.

Kolalindin er, фll sum hon er, vanliga umleið $10 \mathrm{~m}$ til tjúktar, bæði kann hon vera tjúkkari og nógv tynri. Skurđir gjøgnum kolalindina vísa, at hon skiftir soleiðis uppeftir. Niðast er ein flógv av ljósum, grá-hvítum botnleiri, nevnt »bankin«. Omaná liggur ein niðari kolalind, »stabbin «, síð̋an kemur eitt slag av døkkum skifurleiri, »rann« og oman á rannini ein ovari kolalind, »kolbandið«. Oman á kolbandinum liggur ein fleiri metra tjúk leirflógv, í neđra nevnd »fúrstin«, í erva »takleir«. I rann, og fúrsta, eru ofta kolanýru og kolaflísar. I norðara kolaǿkinum (î Prestfjalli og Rókhaga) er stabbin vanliga tjúkkari enn kolbandið, í sunnara kolaøkinum (í Rangabotni) er kolbandið, sum har suðuri er nevnt takkol, tjúkkari enn stabbin, - sum har suð̋uri er nevndur botnstabbi -. Á mótinum millum norðara og sunnara kolaøki eru kolalindirnar ofta fleiri og fláaskipanin ikki so eyð̋end sum norðari og sunnari. Vesturi á oynni er međaltjúktin á stabbanum og kolbandinum tilsamans umleið $3 / 4 \mathrm{~m}$ roknað fyri bæði norðara og sunnara kolaøkið. Tjúkkast er kolið sunnan- og vestantil, eystur- og norðureftir tynnist tað.

* Her at skilja sum tann legugrýtislindin - kol og leir - sum skilir millum nið̌aru basaltfláirnar og miðfláirnar. 
Kortið á 33. mynd vísir kolalindina í Suđuroy; tølini á kortinum sipa til skurđir gjøgnum lindina, sum vísa fláa- ella lagskipanina á ymsum støðum. Skurđirnir 1-3 eru mátaðir í Grímsfjalli, skurðirnir 4-23 í norðara kolaøkinum, skurðirnir 24-39 í sunnara kolaøkinum og skurðirnir 40-41 í Kolheyggi.

Føroyskt kol er á markinum millum brúnkol og »bituminøst «kol. Skilt verður millum tvey sløg, nýrakol og stríput kol. Nýrakol er hart og hevur skeljut brotben, tað er reint og molnar ikki so lættliga. Тað finst ofta sum tað, teir kalla nýraskálir. Stríputa kolið er, sum navnið sigur, stríput, tað er ikki so reint sum nýrakolið og molnar skjótt, tá ið tað liggur. Hvussu lutfallið er millum nøgdirnar av hesum báđum kolasløgum, er ilt at siga, men iơ hvussu cr, er nógv minni til av nýrakoli. Brennivirði í nýrakolinum er umleið̋ $6000 \mathrm{k}$. cal., í stríputa kolinum 4-5000 k. cal. Nýrakolið hevur lítla $\varnothing$ sku, minni enn $5 \%$; $\varnothing$ skan í stríputa kolinum er nógv meiri, ofta upp ímóti $20 \%$ og stundum enn meir.

Gróðurin, sum kolið er av, hevur ikki vaksið á sjálvum staðnum, har kolalindin er, men uttan um, og er rikin við áum inn í eitt vatn og botnsett har saman viơ tí eyri, sandi og leiri, sum áirnar førdu við sær. Tær grovu eyrgrýtislindirnar bæði norðan og sunnan fyri Hvalbiareiði kundu væl miðað ímótí einum áarósa, ella einari vatnstrond har.

Eldri metingarúrslit av kolanøgdini vísa ógvuliga misjøvn úrslit. Metingarúrslitið av kolakortleggingini 1952-54 siga, at til eru upp ímóti 12 mill. tons av koli î Suðuroy, sum líkindi eru til at vinna við nøkrum fyrimuni. Kolið eysturi á oynni í norðara kolaøkinum $(7,74$ $\mathrm{km}^{2}$ ) er ikki roknađ upp í hetta talið, tí lindin tynnist munandi eystureftir, og hartil er hon skakað úr legu av yngri spreingigosum og innskotnum blágrýti.

Enn verður høgt kol bæði í norðara kolaøkinum (Prestfjall og Rókhagi) og í sunnara (Rangibotnur), men framleiðslan er nógv minkað tey seinru árini.

I Tindhólmi er eingin samanhangandi kolalind, lindin er órógvað, og kol sæst í støðum sum kolanýru og flísar. I Vágum er kolið tunt, lindin fer í sjógv á Álkukletti og á Víkum. Hægst er lindin s.f. Gilið á Dýpinum (278 m o. sj.), eisini er tjúkkasta kolið her vesturi (í Hellisgjógv). Kolið tynnist skjótt eystureftir. I Vágum eins og í Tindhólmi og eysturi á oynni í Suðuroy er kolalindin í støðum órógvað og skakað av seinri eldgosum og innskotsløgum. 
Aftaná hin langa støðgin, sum frásagt er, við ongum eldgosum, tók nú aftur at gjósa av nýggjum. Hesi gos vóru í byrjan spreingigos, t.e. knappligir brestir, har nógv tað mesta gostilfarið er leyst gostilfar, gosøska (tuff), goseyrur (lapilli) og gosbumbur, men lítið ella einki av grótbræðingum (lava). Gostilfarið legðist ikki javnt, men í dungar fram við gosopunum. Hesir dungar ella ójøvnu lindir av leysum gostilfari millum kolalindina og miðfláirnar nevna vit gosmyrju (tuf - agglomerat). Har gosmyrjan er, er tí líkt til, at vit eru nærindis einum gosopi, og so sum hon kemur fyri í Sưuroy og í Tindhólmi - Vágum, í Suðuroy eitt $2-3 \mathrm{~km}$ breitt umleið $10 \mathrm{~km}$ langt $\varnothing \mathrm{ki}$ og í Vágum eitt umleið $7 \mathrm{~km}$ langt $\varnothing \mathrm{ki}$, er líkt til, at hon liggur framvið og kanska oman á stórum goskluftum, sum gingið hava í útnyrơing - landsynning.

I Suðuroy sæst gosmyrjan norđantil á Hvalbiarfirði á sjálvum Reyðabarmi og í støðum inneftir undir miðfláunum. Sunnantil á firðinum sæst hon í Flekksá, summastađni millum Flekksá og Tjørnunes og á sjálvum Tjørnunesi. Frá Tjørnunesi sưur í Lónina sæst hon allan vegin meira og minni. I Hvannhaga er hon mangastaðni at síggja bæði uppi undir miðfláunum heilt suður móti Ribbingamúla og norðantil í Hvannhaga við Stapan niðri í fjøruni. I giljum og áum upp av Trongisvági sæst hon viơ Bláfoss og út ímóti Ranndalsá. Vituliga verður ein lind av leysum gostilfari ójavnt tjúkk, vanliga er hon 20-30 m, men mangastaðni er hon væl tjúkkari og ofta nógv tynri. Gosmyrjan er allastað̋i gjøgnumsett av innskotnum blágrýti, sum eisini sæst undir henni. I Tindhólmi kemur gosmyrjan til sjóndar sunnantil á hólminum við ójøvnum marki upp móti mið̄fláunum, og í Vágum sæst hon frá Hvalskeri út til Akranes, undir Akranesfossi, í Bíggjarurðð og aftur frá Streymnesi norður í Gilið á Dýpinum. Eins og í Suðuroy er hon gjøgnumsett og órógvađ av innskotnum blágrýti; hetta sæst sera skilliga í Bíggjarurð.

Niðast í miðfláunum skifta gosmyrja og tunnar basaltfláir sumstaðni uppeftir, so veruligur støðgur hevur eingin verið millum spreingigosini, sum framleiddu gosmyrjuna og eldgosini, sum bygdu upp miðfláirnar.

Miðfláirnar koma fyri í flestu oyggjunum, tó ikki í Mykinesi og Gáshólmi, og tað vit vita, heldur ikki í Fugloy, Svínoy og í Nólsoy. 
Á hinum oyggjunum eru tær fyri stóran part taktar av ovaru basaltfláunum, men í útnyrðingshorninum á Eysturoynni, í norđaru helvt á Streymoynni, í Tindhólmi, í Vágum og norđast í Suðuroy eru miðfláirnar allastaðni omaná.

Hvør sær eru lindirnar í miðfláunum vanliga tunnar, 1 - 2 m ella uppaftur tynri. Ovari í miðfláunum eru tær stundum tjúkkari, hendir seg upp ímóti 10 metrum. Eldgosini vóru støðugt áhaldandi alla tíðina, t. e. at lítiơ ella einki íhald var ímillum gosini. Royðugrýtislindir eru sjáldsamar og heilt tunnar niðast í miðfláunum, ovari eru tær vanligari. Líta vit at einari einstakari basaltflógv, síggja vit ofta niðast í henni hallar ella lodrættar pípur íkomnar av uppgangandi loftsløgum. Miðjan á flánni er tøtt, men ovast er hon poknut ella bløðrut, og eru hesar poknur og bløðrur íkomnar av tí luft, sum knappliga sleppur sær burtur, tá grótbræðingin kemur upp, og trýstið í henni minkar. Tílíkar pípur, poknur og bløðrur eru ofta fyltar viơ seinri úrskildum steinsløgum, sum t. d. zeolittum, kálkspat ella kvarts. Omaná er flógvin ilskukend og sæst ofta lavabørkur (ropy lava) á henni. Poknur og bløðrur eru stundum toygdar avlangar og grótslagið foyrut; av hesum sæst, at bræðingin hevur runnið, meðan hon storknaði.

Tað er fyrr nevnt, at gosopini í niðaru basaltfláunum vóru stórar goskluftir; tey gosop, vit hava verið varir við í miðfláunum, tykjast at vera nógv minni, leivdir av teimum síggja vit mangastaðni fram við strondini í fjørðum og sundum sum dungar av gosmyrju, ið skera seg upp gjøgnum tær regluligu basaltfláirnar, tað vit nevna goshálsar (vents). Tílíkir goshálsar eru higartil sæddir sunnan fyri Marragjógv í Vágum, norđan fyri bygdina í Koltri, í Koltursnakki, frá Dalsnípuni norður í Seyðaskor, norðan fyri Lambagjógv vestantil á Kallsoynni, á Svartakletti á Borðoynni, sunnan fyri bygdina á Viðareiði, sunnantil á Viðoynni (Torvstíggjur), inni á Viðvík og eystan fyri bygdina á Kirkju í Fugloy. Goshálsar eru bara sæddir í miðfláunum, heilt upp til markið millum miðfláirnar og ovaru basaltfláirnar. Тað man tí vera beint at halda, at goshálsarnir hava verið tilførslur til miðfláirnar (73. mynd).

B-lindin samsvarar við niðurmarkið á einum hamralag av fleiri tunnum fláum við poknulindum ímillum. Undir hamralagnum er stórtinnut og omaná smátinnut feldspatbasalt. B-lindin setur einki náttúrligt mark í fláarøðini, hon er umleið 2/3 uppi í miðfláunum. Á kortinum er hon prikkað, har hamralagiơ er burtur, er longri millum prikkarnar. 
I miðfláunum er grótslagið skiftandi feldspattinnut basalt, blágrýti og olivinbasalt. Feldspattinnut basalt er vanligasta grótslagið.

Aftaná enn ein støðg, óvist hvussu langan, livnaðu gosini uppaftur fyri triðju ferð og bygdu upp ovaru basaltfláirnar. Eins og í niðaru basaltfláunum var nú aftur íhald millum gosini, tey vóru ikki støðugt áhaldandi.

Ovaru basaltfláirnar eru ikki í Suđuroy, Mykinesi, Gáshólmi, Tindhólmi ng Vágum, heldur ikki í norðaru helvt á Streymoynni og í útnyrðingshornnum á Eysturoynni. Á hinum oyggjunum liggja tær oman á miðfláunum uttan har, sum firðir og dalar eru máađir niður gjøgnum tær. Eystantil í oyggjunum, úr Sandoy til Fugloyar eru tær so at siga allastaðni.

Tær einstøku fláirnar í ovaru basaltfláunum eru vanliga tjúkkari, enn tær eru í miðfláunum, men ikki so tjúkkar sum í niðaru basaltfláunum, međaltjúktin er 8-10 m. Henda ymiska fláatjúktin eyðkennir eisini sjálvt landslagið í niðaru basaltfláunum, miðfláunum og ovaru basaltfláunum. Summastaðni, serliga í norðastu oyggjunum, síggjast lindir samansettar av mongun tunnum fláum líkum teimum í miðfláunum, millum hamrarnar í ovaru basaltfláunum. Stabbagrót sæst, men er ikki so vanligt og ikki so skilligt sum í niðaru basaltfláunum. Ymisliga litt royðugrót og royðuleirgrýti er vanligt millum hamrarnar. Hesar lindir kunna vera heilt tunnar, ofta $1-2 \mathrm{~m}$ og stundum fleiri metrar. Tað hendir seg meira enn so, at funnar verða trýstmyndir av plantuleivdum í royðugróti, men aloftast eru tær so óskilligar, at ikki ber til at greina tær. I Nólsoy, Sandoy og í Gásadali hevur royðugrót og royðuleirgrýti verið útflutt og nýtt sum tilfar til málingagerð og í sílur at úrkálka vatn við. Fláarøðin við C-lindina er soleiðis uppeftir: stórtinnut feldspatbasalt; royðugrót; ein, tveir, tríggir stundum fleiri blágrýtishamrar við poknu- ella tunnum royðugrýtislindum ímillum; smátinnut feldspatbasalt. Sjálv C-lindin samsvarar við niðurmarkið á blágrýtishomrunum. C-lindin skilir millum miðfláirnar og ovaru basaltfláirnar. Markið er flestustaðni eyðkent og skilligt í landslagnum, oman fyri markið skifta hamrar og royðugrýtis- ella poknulindir, regluliga; niðan fyri markið eru hamrar ikki so vanligir, tær tunnu fláirnar eru ofta samansjóðaðar og landslagið meira javnt avbrýnt. Frávik eru kortini, har markið ikki er so greitt; nevnt kann vera í berginum vestantil á Koltri og Hesti, 
um Søltuvíkarleiðina og suðureftir vestantil á Sandoynni og norðast og sunnast á Viðoynni. C-lindin er á kortinum avmerkt sum svørt strika, í støðum, har tað hevur verið torført ella ógjørligt at eygleiða hana, er hon avmerkt sum brotin strika og har blágrýtishamrarnir eru burtur, er hon prikkað.

I ovaru basaltfláunum er grótslagiơ eins og í miðfláunum skiftandi feldspattinnut basalt, blágrýti og olivinbasalt, sum her er vanligasta grótslagið.

$$
\text { is }
$$

Táið eldgosini, sum bygdu upp niðaru basaltfláirnar, gosmyrjuna, miðfláirnar og ovaru basaltfláirnar, vóru givin med alla, kom spenni í hin umleið $3000 \mathrm{~m}$ tjúkka basaltháslættan, við tað at undirstøðið undir honum sveik og gav ójavnt eftir. Spenniơ vaks seg so stórt, at grótfláirnar stukku, rivur settu upp ígjøgnum, og grótbræðingar komu einaferð enn upp úr neð̋ra. Fyrru ferð̈irnar komu tær heilt upp, storknaðu og løgdust flógv oman á flógv, men hesa ferð settu tær upp í tær íkomnu rivurnar og inn ímillum fláirnar, har veikast var fyri, og storknaðu har sum gongir, óreglulig innskot og syllar, tað vit tilsamans nevna innskot.

Gongir eru skotnar upp í lodrættar ella hallar rivur og skera seg tí tvørtur ígjøgnum tær regluligu basaltfláirnar. Tær síggjast vanliga í landslagnum sum beinar ella eitt sindur bognar stabbagrýtislindir, har stabbarnir liggja tvørturum (tvørgrýtislindir). Gongirnar eru einfaldar, fleirfaldar ella samansettar. Einføld er ein gong, tá bert ein grótbræđing hevur skotiơ seg upp í eina rivu. Fleirfald er ein gong, tá tvær ella fleiri grótbræđingar av sama slag hava skotið seg upp, og samansett er ein gong, tá grótbræð゙ingarnar eru tvær ella fleiri av ymiskum slag. Gongirnar eru á kortinum avmerktar sum tjúkkar reyðar strikur, fleirfaldar og samansettar gongir viơ svartari striku í miðjuni. Gongirnar, ella rættari tær einst $\varnothing \mathrm{ku}$ gongeygleiðingarnar, eru á kortinum merktar viơ einum tali, sum vísir til gongtalvuna, har tær verða gjøllari lýstar. Longsta gongin er meira enn 20 $\mathrm{km}$ long, breiðasta gongin er $20 \mathrm{~m}$ breið, men vanliga eru tær nógv smalri, stundum bara brotpartin av 1 metri, meðalbreiddin av teimum $\varnothing$ llum er umleið $4 \mathrm{~m}$. I berginum sæst stundum, at gongirnar tynnast uppeftir burtur í einki; hetta sæst eisini úti við endarnar á einari gong. Er grótslagiơ til liðirnar á einari gong moyrari enn tilfarið í gongini sjálvari, týnist tað skjótari, og gongin verður standandi uppúr sum ein garđur, t. d. Jatnagarðar í Vágum. Týnist gongin 
skjótari enn grótslagiơ uttan um (t. d. tá gongin er rivut longdarvegin), verður ein kluft ella ein gjógv. - I Vágum, Streymoy og Eysturoy ganga gongirnar nakað javnt í allar ættir, í Norðoyum meira í landnyrðing norðan, landnyrðing - útsynning sunnan, útsynning. I Suðuroy ganga tær allarflestu í umleið útnyrðing - landsynning. (97., 98., 99., 100., 101. mynd). Grótslagið í gongunum er tað sama sum í basaltfláunum. Við samankomingarnar úti við liðirnar, har grótbræðingin kólnaði knappliga, er grótið tættari enn í miðjuni á gongini, har kølingin var meira líðandi. Ofta síggjast útúrgerðir úr gongunum inn í tær regluligu basaltfláirnar við liðirnar á gongini.

Tey óregluligu innskotini eru skotin inn í gosmyrjuna og í takið á kolalindini. Tilfariơ í gosmyrjuni og í kolalindini er ójavnt til fastleika og hevur stađið ymist ímóti ymsar vegir, táið bræđingin trođkað̛i seg inn, tí eru hesi innskot púra óreglulig í skapi, ofta stabbar, sum venda ymsar vegir. Tey óregluligu innskotini koma fyri í norðaru helvt av Sư̛uroy, í Tindhólmi og í vestara parti av Vágum har í nánd, sum gosmyrjan er.

Tađ̛ mesta av vegnum frá gomlu lendingini í Hvalba og út á Reyð゙abarm síggjast óreglulig innskot framvið sjónum, summastaðni, t. d. á Hamranesi, sum høgur bakki. Sunnantil á firðinum síggja vit tey í støðum frá Flekksá og út á Tjørnunes, sum er av innskotnum blágrýti alt sum tað̋ er. Ur Tjørnunesi aftur, meira og minni, suður móti Lónini, inni á Lónini og í Hvannhaga. I Hvannhaga ganga tey óregluligu innskotini summastaőni upp gjøgnum alla gosmyrjuna, upp í miđfláirnar. Norðantil á Trongisvági koma tey til sjóndar eystan fyri Myllá og javnliga úteftir eystur um Tippisá.

I Tindhólmi síggjast óregluligu innskotini sunnantil á hólminum, í Vágum frá Akranesi gjøgnum Bíggjarurð til Gásadals og mangastaðni norðureftir millum Gásadal og Barðið.

Bæði eystantil í Suðuroy, í Tindhólmi og í Vágum er kolalindin skakað og lyft úr legu av innskotunum.

Tað er líkt til, at gongin millum Hamranes og Hvítanes í Hvalba og gongin á Akranesi í Vágum báđar eru tilførslur til tey óregluligu innskotini.

Syllar eru innskotnar á mótinum millum miðfláirnar og ovaru basaltfláirnar. Eyðkent er fyri tær føroysku syllarnar, ið hvussu er tær stóru syllarnar, at tær eru samlagdar (fylgja teimum regluligu fláunum) í miðuni, og at tær verða meira og meira mislagdar (skera seg upp gjøgnum tær regluligu fláirnar) út móti syllajađaranum. Tær koma tí í skapi at vera líkar einari skál, har onnur helvtin (hin vest- 
ara, út ímóti sundunum) vantar. Syllarnar eru vanliga tjúkkastar um miðjuna og tynnast úteftir. Syllagrýti stendur í stabbum, hetta hevur gjørt, at stabbarnir í niðaru basaltfláunum stundum hava verið mistiknir fyri at vera syllar. Syllar eru sæddar í Fugloy, í Svínoy, á Eysturoynni og á Streymoynni. Ein lítil syll uppi í berginum norðantil á Kallsoynni er ikki atkomandi. Smærri syllalík innskot á Eysturoynni og á Streymoynni undir teimum stóru syllunum (í Hægstafjalli, millum Kvívík og Vestmanna, við Morskranes og við Hórisgøtu) eru helst útúrgerðir niður úr teimum stóru syllunum, har veikt hevur verið fyri.

Tað̋ tykist sum Fugloyarsyllin og Svínoyarsyllin eru teir misløgdu útjaðararnir av somu syll. Grótslagið er átøkt í báđum, tætt blágrýti, sum við niðaru samankomingina ofta sprotnar í tunnar flísar (eggjasteinur). Fugloyarsyllin er 1,25 km². Hon fer í sjógv millum Skoratanga og Nevið Óða, tekur seg upp gjøgnum Grønuskor og Bergið, gongur eystur í Guliheyggj, í hamaran oman fyri bygdina Hattarvík og í Kellingará, har niðara samankomingin er 110 m o. sj. Hađani sæst lítið og einki til hennara fyrr enn norðuri á Skarđsvík, har hon fer niður gjøgnum bergið og út í Landfles. Svínoyarsyllin er 1 $\mathrm{km}^{2}$ og sker seg eins og Fugloyarsyllin á skák gjøgnum oynna. Hon sæst niðri við sjógvin á Kallanesi, tekur seg upp suður- og vestureftir upp í Keldufjall (462 m), haðani hon sæst fara oman í norðaru gjónna niður í Norđskor og eystur móti Selnesi, har hon sæst skilliga 1 berginum umleið $60 \mathrm{~m}$. o. sj.

Eysturoyarsyllin er $16 \mathrm{~km}^{2}$. Til longdar er hon $6,5 \mathrm{~km}$ og $2-3,5$ $\mathrm{km}$ breið. Hon røkkur úr Reyðafellstindi, har hon gongur heilt upp (766 m) norður í Nøvina (umleið $600 \mathrm{~m}$ upp) og sæst vestantil, út ímóti Sundalagnum, sum høgur stabbagrýtishamari. Hon er hægst í Reyðafellstindi og í Nøvini, lægst út ímóti Sundalagnum (niðara samankomingin vestan fyri Breiðá $80 \mathrm{~m}$ o. sj.) og tekur seg upp eystureftir (niðara samankomingin norđan fyri Lágarháls $510 \mathrm{~m}$ ). Syllin er ber, t. v. s. at ovaru stabbaendarnir koma undan, millum Reyðafellstind, Lágarháls og Veđranes og í lendinum millum Veđrranes, Oyrargjógv og Breiðábotn. Eystantil liggur fjallarøðin Nøvin, Sandfelli, Kelduklettur og Halgafellstindur oman á syllini.

Streymoyarsyllin er $13 \mathrm{~km}^{2}$. Hon gongur úr Sátani suður í Núgvuna, er umleið $9 \mathrm{~km}$ long og $1-3 \mathrm{~km}$ breið. Hon er hægst í Sátuni (niðara samankomingin er $480 \mathrm{~m}$ o. sj.) og í Núgvuni (niðara samankomingin er $630 \mathrm{~m}$ o. sj.), lægst út ímóti Vestmannasundi (niðara samankomingin í Reipaskor umleið $170 \mathrm{~m}$ ), og hon tekur seg upp 
eystureftir, har hon, eins og Eysturoyarsyllin, stundum sæst sum brattur stabbagrýtishamari, t. d. í Bláhamri, og stundum er so reyst, at hon er lík einari gong. Á Skælingsskarð̋i er lendið so djúpt niðurmáađ, at Streymoyarsyllin er í tveimum, ein norðari partur, Sátan, og ein sunnari partur, Stórareyn - Núgvan. Vestantil í Sátuni, á Stórareyni, í Gjáarbotni og Oman fyri Stígar liggur syllin ber víða um, eystanfyri gongur hon undir fjøllunum. Líkt er til, at gongin í gjónni í Gjáarbotni er tilførsla til Streymoyarsyllina.

Viðvíkjandi innskotsaldri, so eru gongirnar yngri enn sjálvur basaltháslættin, tí tær seta ígjøgnum hann allan, sum hann er. Óregluligu innskotini eru skotin inn samstundis sum gongirnar, og syllarnar seinast. Syllarnar vóru skotnar inn á mótinum millum miðfláirnar og ovaru basaltfláirnar, tá allar gongbræđingarnar vóru storknaðar í erva, so at tætt var fyri. Av syllainnskotinum var fláarøðin omaná lyft upp, og bræđingin troðkaði seg út ímillum fláirnar og upp í tær nýliga íkomnu rivurnar.

Á kortinum á 74. mynd síggja vit, at goskluftirnar í niðaru basaltfláunum ganga í útnyrðing - landsynning, í somu ætt sum firðirnir. Eisini síggja vit, at gashálsarnir í miðfláunum liggja inni á og fram við fjørðunum. Líkt er tí til, at eldgosini, sum bygdu upp basaltháslættan, hava verið bundin at frammanundan íkomnum rivum í Wywille Thompson rygginum, og at upprunin til firð̈irnar eisini stendur í sambandi við hesar rivur, sum gingið hava í útnyrðing - landsynning.

Á Botnskarði í Suðuroy umskarast niðaru basaltfláirnar umleið 10 m upp og niður, og er hetta hent, áđrenn miðfláirnar løgdust omaná. I Vágum eru misløgur millum niðaru basaltfláirnar og miðfláirnar. Eisini eru misløgur at síggja millum miðfláirnar og ovaru basaltfláirnar, t. d. norðast í Hesti og Norðuri undir Síđu millum Kaldbaksfjørð og Kollafjørð.

Tær rivur og rivuskipanir, sum nú eru mest sjónskar í landslagnum, eru avmerktar á kortinum sum brotin strika. Tær eru íkomnar av spenni í basaltháslættanum, aftan á at gongirnar vóru innskotnar, tí mangastađni umskarast gongir tvørtur við teimum. Eitt tílíkt spenni verður ikki javnað út eftir einari ferð, men í smáum, og mangar rivur koma tí at liggja tætt upp at hvørji aðrari, tað vit nevna eina rivuskipan. Tær regluligu basaltfláirnar umskarast eisini tvørtur 
við ella upp og niður fram við rivum og rivuskipanum. Táið tær umskarast upp og niður, eru tær avmerktar á kortinum sum brotin strika við prikkum ímillum, ferhyrningurin vísir hvørjumegin og hvussu nógvar $\mathrm{m}$ fláirnar tí megin eru niđari.

Av tí sum her er sagt, skilja vit, at røringar hava verið í basaltháslættanum, og at hesar roringar ikki bara vóru virksamar aftan á at basaltháslættin var liðugur, men eisini međan hann enn stóð í gerð.

Hyggja vit eftir í gjáunum, síggja vit, at tær eru tætt rivutar eftir botninum, og eru gongir í teimum, eru eisini tær rivutar longdarvegin. I gjáunum eru sjónlig merki eftir røringum, sk $\emptyset$ vur og rivumyrja. Ofta ganga fleiri gjáir á rađ eftir somu rivuskipan, og á 97., 98., 99., 100., 101. mynd sæst, at gjáir og rivuskipanir ganga í somu ættir. Hildið verður tí, at gjáir eru niðurmáðaðar rivuskipanir. 


\section{English Summary}

The present memoir on the pre-Quaternary geology of the Faeroe Islands is meant to serve as a supplement to the accompanying geological map on 1:50.000.

The main text is in Danish, as are similar papers treating regions in Denmark proper. The Faeroese and English summaries differ from one another in content. The English summary is intended to be a brief outline of the geology of the island group for geologists interested in regional geology. Geologists interested in the petrology of the basalts are referred to our recent paper: Petrology of a 3000 metre sequence of basaltic lavas in the Faeroe Islands ("Lithos", 1968).

The legend to the map is given in Danish, Faeroese and English.

The Faeroe Islands have a total area of $1400 \mathrm{~km}^{2}$ and an average height of about 300 metres. They consist exclusively of flood basalt lavas which were poured out subaerially in the earliest Tertiary, and which form a pile three kilometres thick.

There were few examples of systematic geological mapping of plateau basalts for us to follow when we started our work. We soon found it absolutely necessary to establish marker horizons in the rather uniform series in order to build up a reliable stratigraphy. These horizons form the backbone of the geological map.

The heights of the marker horizons at various localities have been indicated on the map, and a short description of each of the localities is given on page 38 in the text. The main marker horizons are named A and C; $\mathrm{A}$ is the lower boundary of a coalbearing sequence, the only continous stratigraphic unit in the islands, which marks the boundary between the lower and the middle lava series, and $\mathrm{C}$ marks the boundary between the middle and the upper lava series, where the change from dominantly porphyritic to dominantly olivine tholeiitic lava occurs. The difference in the colours used on the geological map shows clearly the positions of the $\mathrm{A}$ and $\mathrm{C}$ horizons. Auxiliary marker horizons have also been used, the most important of which is the B horizon, about two thirds of the way up through the middle lava series. It, too, is indicated on the map. 
In the table, beginning on p. 38, the headings are as follows: $\mathrm{A}, \mathrm{B}$ or $\mathrm{C}$ horizon is marked above the upper line, as is the name of the island on which the observations were made. In the second line the first column $=$ height in metres, second column $=$ number of the map sheet (Geodetic Institute, Copenhagen) and number of ninths into which the map sheet has been divided by us (see fig. 6), third column $=$ locality and fourth column $=$ remarks .

Using the main horizons, A, B and C, and auxiliary marker horizons we succeeded in linking up a considerable number of sections to form a stratigraphically correct main profile through the whole lava pile (p. 36).

The simplest way of making this main profile would have been to have measured it from west to east, i. e. from bottom to top, along a single line. This was attempted, but on Mykines, the westernmost island, accessible outcrops are so scarce that the sampling became too scattered to give a reliable picture of the lower lava series. Consequently, we have taken the lower part of the profile, i. e. the portion below the coal-bearing sequence, sections I, II and III, from Suðuroy where the same rocks are much better exposed. The rest of the profile, sections IV to XI, crosses the main group of islands from west to east.

The main profile is thus composite and composed of 11 partial profiles linked laterally by recognisable horizons.

Lava sequences consist of lenticular bodies which thin out laterally, and there must therefore be variation, at least in detail, from section to section. In order to illuminate these variations we have chosen 36 auxiliary profiles, evenly distributed all over the islands, which are described in the chapter beginning on p. 71. In the accompanying tables the headings read as follows: Column $1=$ sample number; column 2 = height in metres; column $3=$ rock type; column $4=$ mineral composition (point counting of pl., cpx., ore, ol., gap.) and column $5=$ density.

The auxiliary profiles are shown on the geological map in large, circled, arabic numerals 1-36.

The headings of the chapters in the main text are as follows:

Historical outline.

Introduction.

Outline of the stratigraphy.

Stratigraphical division. 


\section{Marker horizons.}

The main profile.

Profiles.

Chemical analyses (rock samples of the main profile).

Lower basalt series.

The coal-bearing series.

Tuff-agglomerate zone.

Middle basalt series.

Upper basalt series.

Extrusive volcanism.

Minor intrusives.

Dykes.

Irregular intrusives.

Sills.

Lineaments, gjógv's and faults.

Outline of the tectonic development and geophysical measurements.

Economic geology (rocks and minerals).

We have divided the strata in the Faeroe Islands into the following members (fig. 2):

(1). The lower lava series, about 900 metres thick, consists of flows with an average thickness of about 20 metres. Columnar jointing occurs throughout, but is most pronounced near the top of the series. The lavas were produced by fissures, and there was a rhythmic pattern of activity. During periods of quiescence thin layers of interbasaltic tuff-clay sediments were laid down. The lavas are aphyric or cryptophyric and very monotonous. They are classified as quartz tholeiites. Erosion of the lower basalt series has produced typical 'trap country', with long, gently inclined slopes (figs. 28 and 29).

(2). A coal-bearing series of sedimentary strata. - The deep weathering of the lavas underlying the sedimentary strata indicates that they were deposited after an erosional interval of some length. The average thickness of the coal-bearing series is 10 metres. It consists of hardened clays with local intercalations of sand, pebblebeds and one workable coal seam. Poorly preserved plant remains have been found.

(3). The tuff-agglomerate zone. The volcanic activity that followed the deposition of the coal-bearing series began with a highly 
explosive initial phase of which tephra (bombs, lapilli and ash) was the main product. We have named the deposits of this phase the tuff-agglomerate zone. It contains fragments of the underlying, newly formed, sedimentary sequence and is very often intruded by irregular bodies of basalt belonging to the period of minor intrusions. The tuff-agglomerate zone is exposed on Suðuroy, where it forms a zone of about 10 kilometres long and 2 kilometres wide, and on Vágar.

(4). The middle lava series, about 1350 metres thick, is made up of very thin, ropy lava flows and/or flow units, rich in zeolites and with reddened upper surfaces. The thin flow units are generally welded together to form compact masses. Columnar jointing is practically absent. The rock types of the middle series show great variation, but porphyritic lavas are dominant. They are quartz tholeiitic in composition.

The volcanic activity which led to the formation of the lavas of the middle basalt series seems to have been localized in vents of limited extent. Remnants of these are found in sections along fjords and sounds, but never inland, in spite of good exposures here. They vary from 50 metres to about 1.5 kilometre in length. During the mapping ten such vents have been found. Stratigraphically they occur from a little above the middle of the series to its very top. None were found at higher levels, in the upper basalt series. As the vents all lie in the present fjords, they must be related to a system of fractures which later determined the position of the fjords.

Erosion has produced vertical, 'laminated' cliffs on the coasts (fig. 63) and smooth, convex slopes inland (figs. 52 and 53).

(5). The upper lava series, about $625 \mathrm{~m}$ thick, consists of clearly separable lava flows similar to those of the lower lava series, but, on average, only half as thick. There is a tendency for columnar jointing to occur in the thickest flows. The main rock type is a hard, bluish, often laminated, basaltic lava with small phenocrysts of olivine and plagioclase and is classified as olivine tholeiite. Intercalated plagioclase phorphyritic flows of middle series type occur in the lower part.

Erosion has produced 'trap country' with narrow steps and steep rock walls (figs. 75 and 76 ).

After the extrusive volcanism had ended and the formation of the plateau had been completed, tension developed, leading to the 
formation of cracks and fissures into which the basaltic melt rose once more as a final magmatic phase. Dykes were formed in vertical fissures, irregular bodies intruded the coal-bearing strata and the tuff-agglomerate zone, and a system of sills found their way along the boundary zone between the middle and the upper basalt series.

Dykes cut the whole plateau, most of them following a joint system which is older than the dyke injection. They are generally rectilinear or gently curved, but a few change direction abrubtly. Most of dykes are vertical. Dykes have been observed at more than 800 localities. All such localities are numbered on the map. Each island has its own system of numbers, beginning with 1 .

In the dyke table, p. 253, the following headings are used: Column 1 = dyke number; column 2 = map sheet; column $3=$ height above sea level; column $4=$ direction; column 5 = width; column $6=$ rock type $(\mathrm{TB}=$ bluish, aphyric basalt, $\mathrm{FB}=$ porphyritic basalt, $\mathrm{FFB}=$ big feldspar and $\mathrm{OB}=$ olivine-bearing basalt); column 7 = locality; column $8=$ remarks.

It has not been possible to trace any single dyke for the whole of its length, but some dykes have been followed for more than 20 kilometres.

The thicknesses of the dykes vary from a few decimetres to about 20 metres. Of 535 dykes evenly distributed all over the plateau and cutting all three basalt series, one is 20 metres thick, 19 are from 10 to 15 metres thick, 110 are from 5 to 10 metres thick and 405 are less than 5 metres thick. If the dykes in the lower and the upper basalt series are compared, the average thicknesses are 4.9 and 3.8 metres respectively. Columnar jointing is common in the dykes.

Irregular intrusive bodies (figs. 102 and 106) are encountered only in the coal-bearing strata and in the tuff-agglomerate zone above them. They are completely irregular in form and have evidently preferred this level of relatively weak rocks (p. 294). They are found on the north-eastern part of Suðuroy, on Tindhólmur and on the north-western part of Vágar only.

All the Faeroese sills lie at the same stratigraphical level, i. e. the border zone between the middle and the upper basalt series (p. 328).

In all probability the sill on Fugloy (fig. 109) and the sill on Svínoy (fig. 111) are parts of the same intrusive body, of which the Fugloy sill marks the north-eastern flank and the Svínoy sill 
part of the south-western flank. These parts of the sill are transgressive.

The thick sill on Eysturoy (figs. 113 and 114) has a length of about 6.5 kilometres in a SE-NW direction, a breadth of 2-3.5 kilometres, and covers an area of about $16 \mathrm{~km}^{2}$. Smaller outliers and isolated sill portions on Eysturoy are considered to be offshoots from the original main body.

The thick Streymoy sill, which lies on the west side of the island (figs. 118 and 119), has a length of about 9 kilometres and a breadth of 1-2 kilometres at its northern end and 2-3 kilometres at its southern end; it covers an area of about $13 \mathrm{~km}^{2}$. In Hægstafjall west of Vestmanna there is a small sill, and between Kvívík and Vestmanna there are remnants of intrusive material. These minor occurrences are likely to be offshoots from the Streymoy sill.

All the sills are transgressive, saucer-shaped bodies of which most of the western side is missing. In fig. 114 a series of cross sections of the Eysturoy sill are shown.

Where dykes and sills meet, it can be shown that the sills are younger than the dykes. A few dykes have been observed to stop at the floors of the sills and are not found above them. In one such case, at Gjáarbotnur (Streymoy sill), the dyke is continous with the sill and is inferred to have been a feeder to it.

The succession of the minor intrusions is likely to have been the following: Most of the dykes were injected into preexisting joints; they must be younger than the formation of the plateau since they cut the whole of it. The porous and weakly resistant tuff-agglomerate zone was intruded by irregular bodies at the same time. After all the dykes had been intruded and were consolidated even in the upper part of the lava sequence, the last magma, still under pressure from below, penetrated the boundary zone between the middle and the upper basalt series as sills, thereby lifting the overlying mass upwards. The mode of intrusion of the sills is shown schematically in fig. 128 .

On the geological map there is a symbol for lineaments, i. e. master joints and fault lines. In part these have been mapped during the field work, in part they have been added after interpretative work on the air photographs.

Master joints have been formed through repeated pressure adjustment along the same planes of weakness in the basalt plateau and 
take the form of lamellar zones or belts (fig. 93). They are younger than the basalt dykes.

Where master joints have been eroded out they develop into gjógvs (fig. 131). These form a very marked and characteristic feature in the landscape of the Faeroes, and have a special symbol on the map.

If the rose diagrams for dykes, master joints and gjógvs are compared, we find a marked agreement between the directions of the master joints and the gjógvs, but not between the dykes and the master joints (figs. 97 to 101).

A number of faults are shown in the map. A small square indicates the downthrown side, and the arabic numeral gives the amount of throw in metres. The throws are very rarely more than 20 metres. The largest horizontal displacement we have measured is about $100 \mathrm{~m}$, at Tjørnuvík.

The tectonic sketch map, fig. 133, shows that the vertical and horizontal displacements, although not very big, do influence the position of the line where the $\mathrm{C}$ horizon reaches sea level.

There is a weak unconformity between the lower and the middle series, and another between the middle and the upper basalt series; i. e. movements had already begun during the formation of the plateau. The tectonic map, fig. 133, shows, although not in detail, some of the main features in the development.

One important point is evident from the map, namely the parallelism of the B and C horizons, which define a weak anticline with a north-easterly plunge. This feature shows that the lava pile was weakly folded after its formation. Another horizon in the sequence gives a similar picture. About 100 metres below the $\mathrm{C}$ horizon, there is a grey, olivine-bearing lava in the area around Kallsoy Fjord. Fig. 134 shows the 20 metre structural contour on the $\mathrm{C}$ horizon and the corresponding structural contour on the lava below it; both show the same flat anticlinal structure.

The volcanic history of the Faeroe Islands can probably be summarized in the following way: The volcanic activity started in the west, near the crest of the Wyville-Thompson ridge, with aphyric, quartz tholeiitic lavas. Later it moved eastwards and for a prolonged period its location was stable on the eastern flank of the ridge, i. e. almost in the middle of the present group of islands, where it produced porphyritic quartz tholeiitic lavas. Finally it 
moved east again, away from the ridge, and produced the undifferentiated, olivine tholeiitic lavas, which are transgressive from the east. The volcanic activity was evidently diminishing during the production of the upper lava series, since the individual flows in this series are only about half as thick as the flows which constitute the lower lava series.

The three basalt series lay, with weak unconformity, upon one another when the plateau had been formed, and the upper lavas must have been horizontal when the dykes, irregular intrusives and sills were intruded.

The oceanic ridge to the west continued to rise, although only very gently, until finally the upper lava series had acquired its present weak easterly dip.

The clear, but weak, fold structure which is seen in fig. 134 and which is also indicated on the gravity maps might be explained in several ways. We suggest three possibilities:

(1) Perhaps the submerged part of the Faeroe Islands consists of submarine pillow lavas, pillow lava breccias and hyaloclastites which have different compressibilities and therefore have reacted to their load in different ways. (2) The withdrawal of the thermal front and subsequent contraction after the period of active volcanism may not have followed an even course. (3) The position of the Faeroese plateau on the right flank of an oceanic ridge with a sinous course may be significant. 


\section{Litteraturliste}

(Større utrykte arbejder er sat $i$ parentes).

Abrahamsen, N., 1967: Some paleomagnetic investigations in the Faroe Islands. - Medd. Dansk Geol. Foren. Bd. 17, s. 371-384.

Allan, T., 1813: An Account of the Mineralogy of the Faroe Islands. - Trans. of the Royal Soc. of Edinb. 7, p. 229-267.

Bergh, L., 1905: Bjergværksdrift. I: De Danske Atlanterhavsфer. Afsnit 2, s. 292-296. København.

Born, (C. L. U.) v., Captain, 1792: Om Basalt-Bierge paa Færøerne. Udtog af Brev fra Hr. Capitain Born til Hr. Etatsraad Rothe. - Skr. Nat. Hist. Selsk., København, 2, s. 198-204.

Born, (C. L. U.) v., Capitain, 1793: Fortsættelse af Brevvexlingen imellem Hr. Capit. Born og Hr. Etatsraad Rothe, om de Færøske Basalt-Bierge. Skr. Nat. Hist. Selsk., København, 3, s. 123-144.

Born, (C. L. U.) v., Capitain, 1797: Fortsættelse af Brevvexlingen fra Capitain Born til T. Rothe, om den Færøiske Basalt. - Skr. Nat. Hist. Selsk., K $\phi-$ benhavn, 4, s. 20-37.

Bøggild, O. B., 1918: Den vulkanske Aske i Moleret. - Danm. Geol. Unders. II Rk. Nr. 33.

Bøggild, O. B., 1922: Geologiske Forhold. I: Danmark Land og Folk. Færфerne, s. 9-15, København.

Bøggild, O. B., 1928: Færøerne. Oversigt over Danmarks Geologi. - Danm. Geol. Unders., række 5, 4, s. 166-169.

(Cleyndert, J., 1959-1960: Rapport beträffande möjligheterna för en rationaliserad brytning af kol och lera på Suderö, Färöarna).

Debes, L. J., 1673: Færoe et Færoa Reserata. København.

Forchhammer, J. G., 1824: Om Færøernes geognostiske Beskaffenhed. - Vid. Selsk. Skr., København, s. 159-206.

Forchhammer, J. G., 1927: Rejse til Færøerne. - Dagbog 1821. 1, 83 s. + 2, 49 s. Udg. af Ad. Clément. København.

Geikie, A., 1896: The Tertiary Basalt-plateaux of North-western Europe. Quart. Jour. Geol. Soc., London, 52, p. 331-406.

Geikie, J., 1880: On the Geology of the Færöe Islands. - Trans. of the Royal Soc. of Edinb., 30, p. 217-269.

Green, T. H., D. H. Green \& A. E. Ringwood, 1966: The origin of the HighAlumina Basalts and their relationships to Quarts-Tholeiites and AlkaliBasalts. - Earth and Planet. Sci. Lett., 2, p. 41-51.

Hartz, N., 1903: Planteforsteninger fra Færøerne. - Medd. Dansk Geol. Foren., 9, s. 61-66.

Helland, A., 1880: Om Færøernes Geologi. - Geografisk Tidsskrift 4, s. $149-179$.

(Henchel, O., 1778-1779: Underdanigst Beretning om det Arbejde og de 
Iagttagelser, som bleve gjorde under min Nærværelse paa Færøerne i Aarene 1778-1779.)

Humlum, J., 1943: Mineralproduktionen paa Færøerne. I: Humlum, J.: Danmarks Minedrift, s. 179-186. København.

Johnstrup, F., 1873: Om Kullagene paa Færøerne, samt Analyser af de i Danmark og de nordlige Bilande forekommende Kul. - Overs. over Vid. Selsk. Forh., København, s. 147-188.

Kabell, F. C., 1851: Beskrivelse af de efterhaanden foretagne Unders $\emptyset$ gelser af Steenkullene paa Færøerne, deres Drift og Betingelserne for sammes heldige Fremgang. - Optrykt i Forslag og Betænkninger afgivne af Den Færøske Landbokommission. København 1911, s. 783-796.

Kommissionsbetænkningen 1709 og 1710 angaaende Færøernes Tilstand ved Kongens Overtagelse af Enehandelen paa Færøerne. Udgivet Tórshavn 1934.

Laufeld, O., 1965: Sporomorphs in Tertiary coal from the Faeroe Islands. Geol. Fören. För. Stockholm. 87, p. 231-238.

Landt, J., 1800: Forsøg til en Beskrivelse over Færøerne, s. 4-21 + s. 92$105+$ s. 161-175. København.

Les Gisements de Houille de Suderö (Iles Feroë) 1908. 85 p. Paris.

Lindwall, G., 1923: Om kollagren paa Färöarna. Medd. Dansk Geol. Foren., $6,4 \mathrm{~s}$.

Lomas, J., 1895: Geology of the Faroe Islands. - Proceeding of the Liverpool Geol. Soc. 1894-95, p. 292-313.

MacDonald, G. A., 1967: Forms and Structures of Extrusive Basaltic Rocks. I: Hess and Poldervaart: Basalts I. The Poldervaart Treatise on Rocks of Basaltic Composition, 1, p. 1-61.

Mackenzie, Sir G. S., 1814: An Account of some Geological Facts Observed in the Faroe Islands. Trans. of the Royal Soc. of Edinb., 7, p. 213-227.

(Marstrander, H., 1950: Report on the coal position on the Faroe Islands. København.)

(Nielsen, H., 1933: Rapport over Undersøgelser af Forekomsten af de færøske Kul, de kemiske og fysiske Karakteristiker, Minedrift og Anvendelse med Henblik paa Benzinudvinding, 23 s. København.)

Nielsen, H., 1933: Danmark og Kullene paa Færøerne. - "Tilskueren ", København, 50, s. 376-388.

Noe-Nygaard, A., 1939: Sideromelantuf fra Færøerne. - Medd. Dansk Geol. Foren. 9, s. 422-425.

Noe-Nygaard, A., 1940: Om Gjógv-Systemernes Alder paa Færøerne. - Medd. Dansk Geol. Foren., 9, s. 542-547.

Noe-Nygaard, A., 1940: Planteførende Tuffer fra Færøerne. - Medd. Dansk Geol. Foren., 9, s. 548-549.

Noe-Nygaard, A., 1942: On the geology and petrography of West Greenland basalt province. - Medd. Grønland, 137 (3), 78 p.

Noe-Nygaard, A. 1945: Nogle tektoniske iagttagelser fra Færøerne. - Medd. Dansk Geol. Foren., 10, s. 541-545.

Noe-Nygaard, A., 1945: Om intrusionsforholdet hos nogle færøske Gange. Medd. Dansk Geol. Foren., 10, s. 546-547.

Noe-Nygaard, A. \& Rasmussen, J., 1957: The making of the basalt plateau of the Faröes. - Int. Geol. Congr. 20, Ses. Secc. I, 2. T., p. 399-407. 
Noe-Nygaard, A., 1966: The invisible part of the Faroes. - Medd. Dansk Geol. Foren., 16, p. 191-195.

Noe-Nygaard, A., 1967: Dredged basalt from Skagerak. - Medd. Dansk Geol. Foren., 17, p. 285-287.

Noe-Nygaard, A. \& Rasmussen, J., 1968: Petrology of a 3000 metre sequence of basaltic lavas in the Faeroe Islands. - Lithos, Vol. 1. Oslo, p. 286-304.

Noe-Nygaard, A., 1968: On extrusion forms in plateau basalts. - Jour. Sci. Iceland, 1, p. 10-13.

Nordström, N. Th., 1877: Om Færöarna. - Geografiska Sektionens Tidsskr. Stockholm, 1, 26 p.

Pálmason, G., 1965: Seismic refraction measurements of the basalt lavas of the Faeroe Islands. - Tectonophysics, 2, p. 475-482.

Peacock, M. A., 1927-28: Recent Lines of Fracture in the Færoes, in Relation to the Theories of Fiord Formation in Northern Basaltic Plateaux. Trans. Geol. Soc. Glasg., 18, p. 1-26.

Raaschou, P. E., 1937: Om Kulforekomsterne paa Færøerne. - Ingeniørvidenskabelige Skrifter B Nr. 17, 64 p.

Rasmussen, J., 1947: Nyere iagttagelser over laghældningen og de kulf $\varnothing$ rende dannelser paa Mykines (Færøerne). - Medd. Dansk Geol. Foren., 11, s. $179-188$.

Rasmussen, J., 1951: Transgressive sillintrusioner i Færøplateauet. - Medd. Dansk Geol. Foren., 12, 164 s.

Rasmussen, J., 1951: Nyere synspunkter vedrørende de færøske kullags stratigrafi. - Medd. Dansk Geol. Foren., 12, s. 164.

Rasmussen, J., 1951: Kol í Mykinesi og í Vágum. - Varđ̛in, Tórshavn, 29, s. $97-116$.

Rasmussen, J., 1952: Um Kolarannsóknir i Hvalba. - Fróðskaparrit, Tórshavn, 1, s. 131-147.

Rasmussen, J., 1952: Bidrag til forståelse af den færøske lagseries opbygning. Medd. Dansk Geol. Foren., 12, s. 275-283.

Rasmussen, J., 1955: Nøkur orơ um gjáir í Føroyum uppruna teirra og aldur. - Fróoskaparrit, Tórshavn, 4, s. 108-124.

Rasmussen, J., 1957: Yvirlit yvir innskotin grótsløg í Føroyum. - Fróðskaparrit, Tórshavn, 6, s. 61-96.

Rasmussen, J., 1958: Kolanøgdin í Suðuroy. - Fróđskaparrit, Tórshavn, 7, s. $102-144$.

Rasmussen, J., 1959: De færøske kulforekomster og deres kortlægning. Medd. Dansk Geol. Foren., 14, s. 184-188.

Rasmussen, J., 1962: Um goshálsar í Føroyum. - Fróðskaparrit, Tórshavn, s. 11.

Rasmussen, J. \& Koch, B. Eske, 1963: Fossil Metasequoia from Mikines, Faroe Islands. Fróðskaparrit, Tórshavn, 12, p. 83-96.

Rasmussen, J. \& Noe-Nygaard, A., 1966: New data on the geological age of the Faeroes. - Nature, Lond. 209, p. 1229-1230.

Rasmussen, R., 1921: Um upphav Føroya lands. - Varöin, Tórshavn, 1, s. $106-135$.

Rasmussen, R., 1925: Um skógir í Føroyum í forðum. - Varđin, Tórshavn, 5, s. $153-163$. 
(Ritson, J. A. S., 1944: Report on the coal position in the Faeroe Islands.)

Rudolphi, Hans, 1913: Die Färöer. - Zeitschr. der Ges. für Erdkunde zu Berlin, $57 \mathrm{~s}$.

Rutten, M. G., 1964: Three examples of periglacial Solifluction in the southern Plateau Central, France. - Geologie Mijnb., 43, p. 1-9.

Saxov, S. \& Abrahamsen, N., 1964: A note on some gravity and density measuring in the Faroe Islands. - Boll. di geofis Teor. ed Appl. Vol. 4, p. 249-260.

Saxov, S. \& Abrahamsen, N., 1966: Some geophysical investigations in the Faroe Islands. - Zeitschrift für Geophysik. Sonderheft, 32, p. 455-471.

Simpson, J. .B, 1928: Notes on the Geology of the Faroe Islands. - Geol. Mag., 65, p. 510-517.

Stokes, H. A., 1874: Notes upon the Coal Seam and Geology of Suderöe. Trans. of the Chesterfield and Derbyshire Institutes of Engineers, Lond., 2.

Stokes, H. A., 1880: Notes upon the Coal Found in Suderöe. - Quart. Jour. Geol. Soc. London. Vol. 36, p. 620-626.

Svabo, J. Chr., 1959: Indberetninger fra en Reise i Færöe 1781-82. Udgivet af N. Djurhuus. København.

Tarling, D. H. \& Gale, N. H., 1968: Isotopic dating and palaeomagnetic polarity in the Faroe Islands. - Nature, Lond., 218, p. 1043-1044.

Trevelyan, W. C., 1823: On the Mineralogy of the Faroe Islands. - Trans. of the Royal Soc. of Edinb., 9, p. 461-464.

Ussing, N. V., 1902: Mineralproduktionen i Danmark ved Aaret 1900. Danm. Geol. Unders., række 2, 12, s. 91-94.

Wager, L. R., 1934: Geological investigations in East Greenland. Part 1. Medd. Grønland, 105 (2), 46 p.

Walker, F. and Davidson, C. F., 1936: A Contribution to the Geology of the Faeroes. - Trans. of the Royal Soc. of Edinb., 58, p. 869-897.

Washington, H. S., 1922: Deccan Traps and other Plateau Basalts. - Bull. Geol. Soc. Am., 33, p. 785-787.

Wegmann, C. E., 1938: Geological Investigations in Southern Greenland. Part I: On the Structural Divisions of Southern Greenland. - Medd. Grønland, 113 (2), $148 \mathrm{p}$.

Yoder, H. S. \& Tilley, C. E., 1962: Origin of basalt magmas: an experimental study of natural and synthetic rock systems. - Jour. Petrology, 3, p. 342532 . 
Planche 1:

Geologisk oversigtskort over Færøerne.

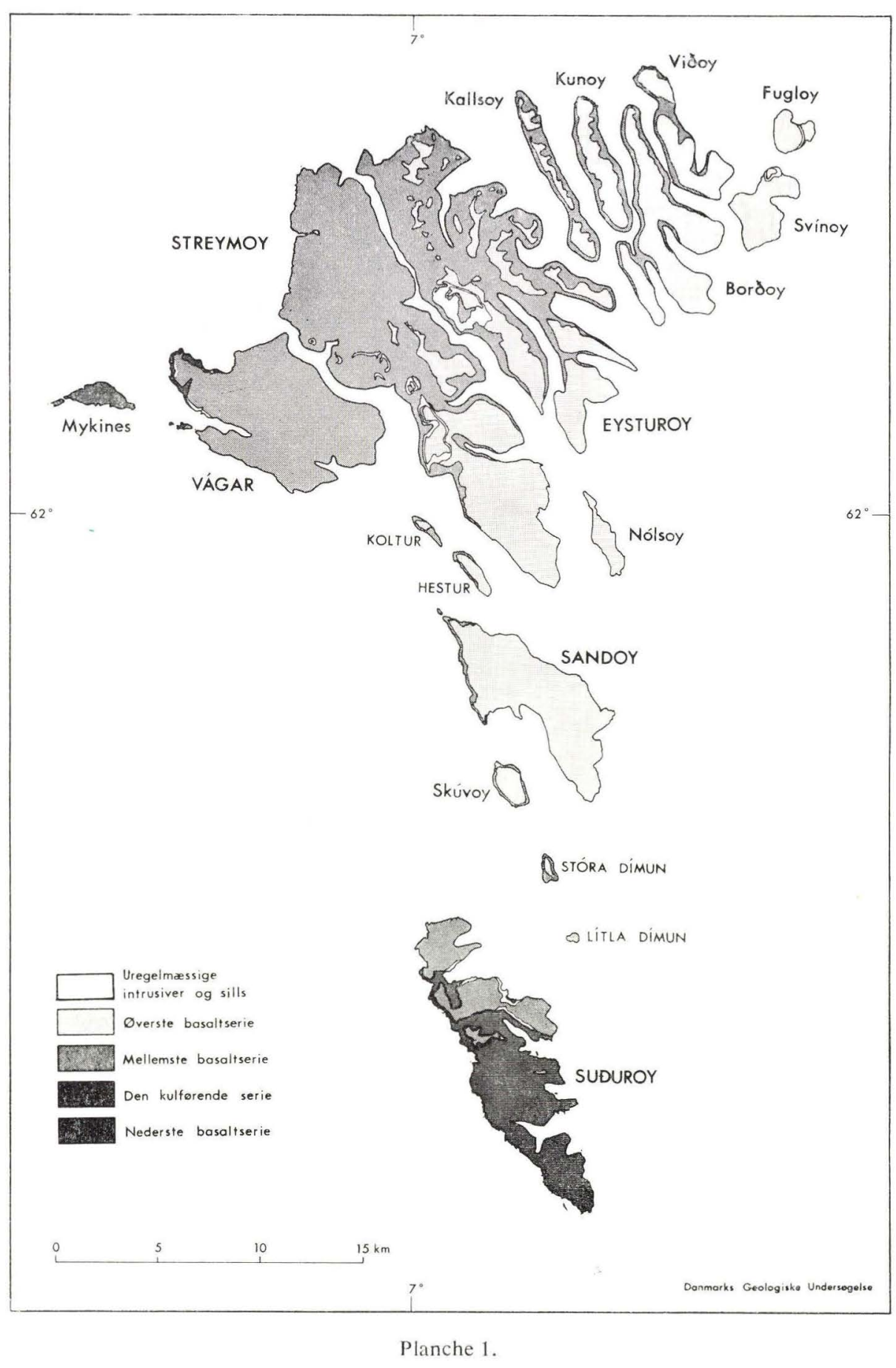



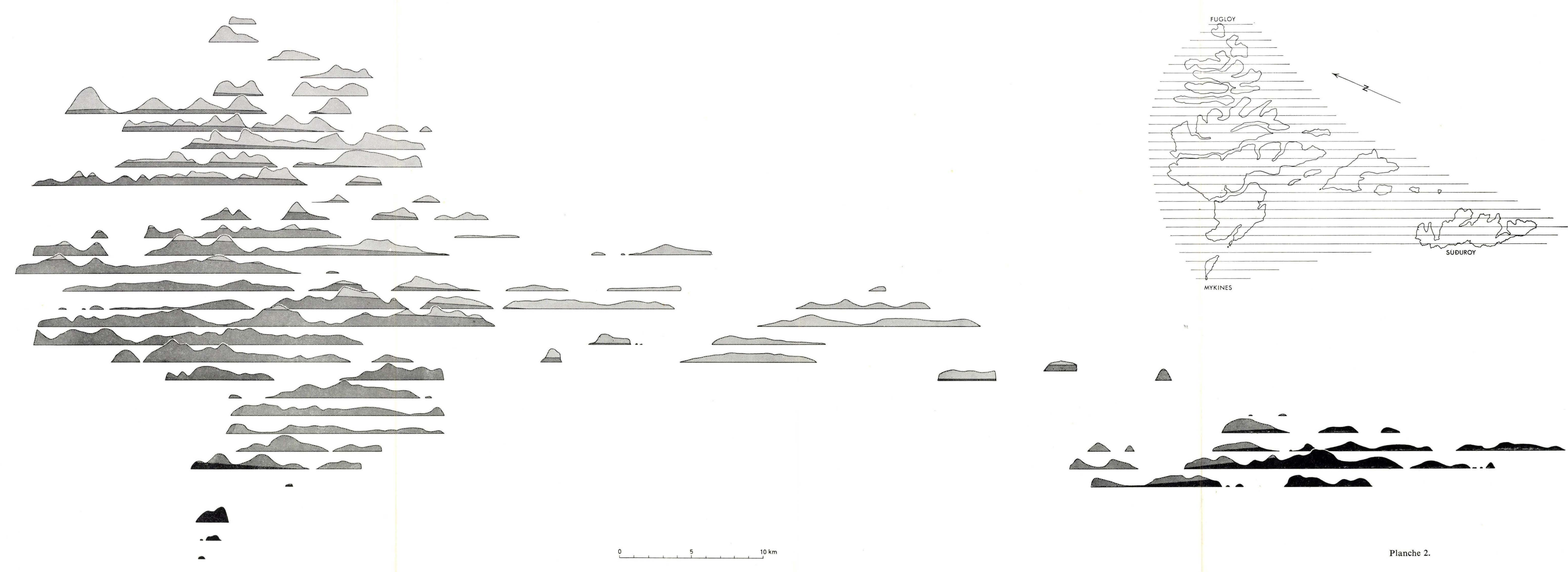